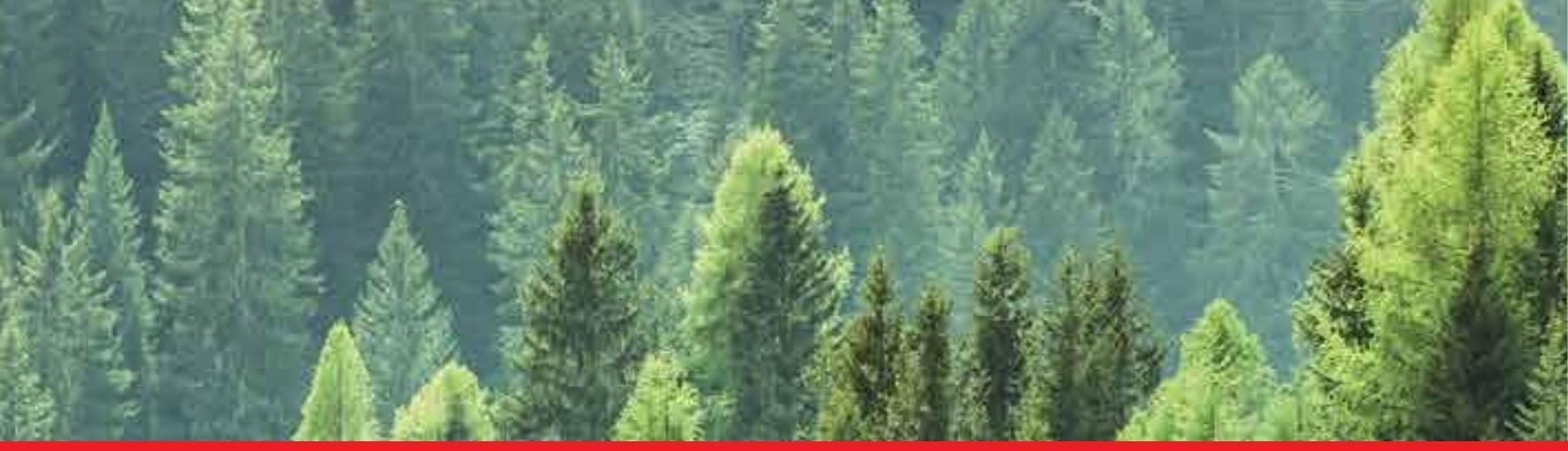

\title{
IntechOpen
}

\section{Biomass and Remote Sensing of Biomass}

\author{
Edited by Islam Atazadeh
}
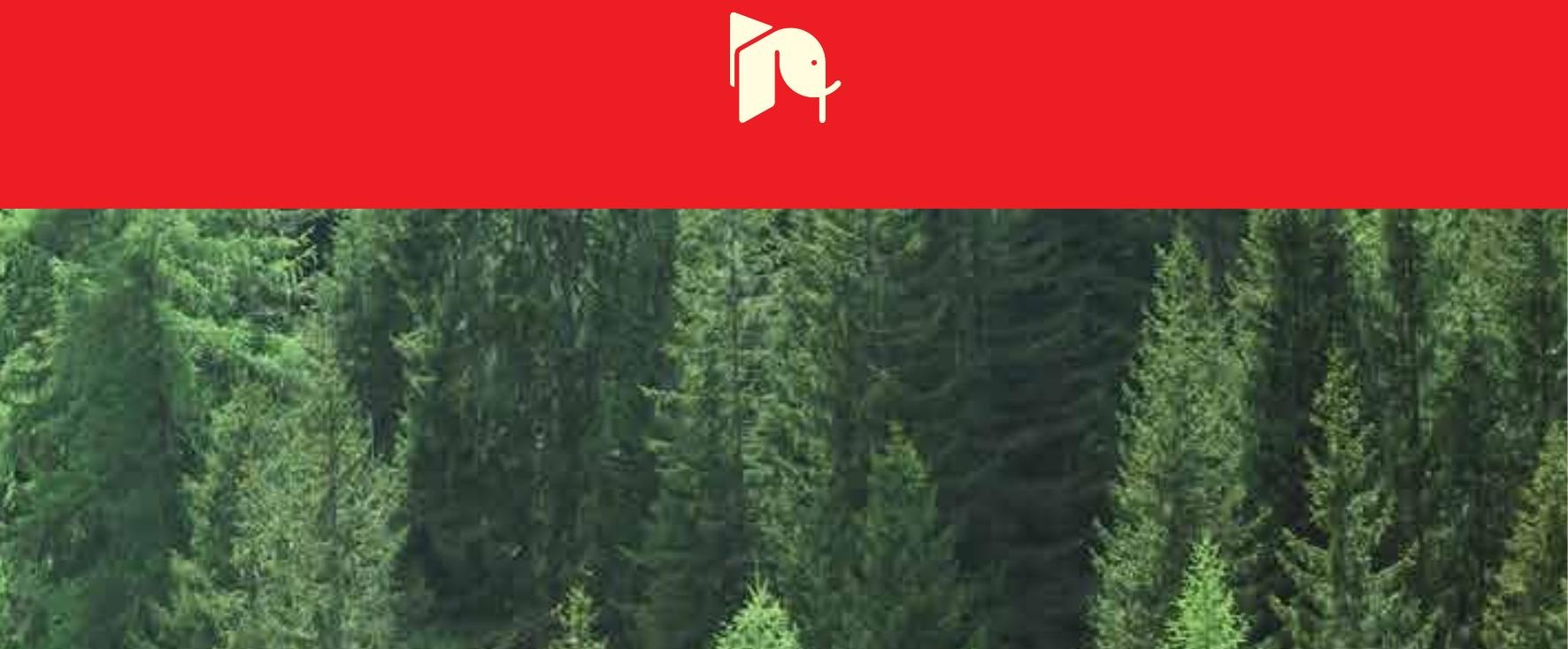



\section{BIOMASS AND REMOTE SENSING OF BIOMASS}

Edited by Islam Atazadeh 


\section{Biomass and Remote Sensing of Biomass}

http://dx.doi.org/10.5772/939

Edited by Islam Atazadeh

\section{Contributors}

Muhammad Aqeel Ashraf, Ismail Yusoff, Dato Mohd. Jamil Maah, Biljana Stojkovic, Ernesto Jose Gonzalez, Maria Leny Matos, Carlos Peñaherrera, Jiranan Piyaphongkul, Nantana Gajaseni, Anuttara Na-Thalang, Abbasi, John Kiogora Mworia, Jiri Novak, Marian Slodicak, David Dusek, Tamara Cibic, Damiano Virgilio, E. Walter Helbling, Silvana Halac, Virginia Villafane, Rodrigo Gonçalves, Laimdota Truus, Leidivan Almeida Frazão, André Mancebo Mazzetto, João Luis Carvalho, Felipe José Fracetto, Karina Cenciani, Carlos Cerri, Brigitte Feigl, Shamsollah Ayoubi, Ahmadreza Pilehvar Shahri, Parisa Mokhtari Karchegani, Kanwar L Sahrawat, Petr Mad\&Auml; ra, Diana Lopéz, Martin Šenfeldr, Pablo Luis Peri

\section{(c) The Editor(s) and the Author(s) 2011}

The moral rights of the and the author(s) have been asserted.

All rights to the book as a whole are reserved by INTECH. The book as a whole (compilation) cannot be reproduced, distributed or used for commercial or non-commercial purposes without INTECH's written permission. Enquiries concerning the use of the book should be directed to INTECH rights and permissions department (permissions@intechopen.com).

Violations are liable to prosecution under the governing Copyright Law.

\section{(cc) BY}

Individual chapters of this publication are distributed under the terms of the Creative Commons Attribution 3.0 Unported License which permits commercial use, distribution and reproduction of the individual chapters, provided the original author(s) and source publication are appropriately acknowledged. If so indicated, certain images may not be included under the Creative Commons license. In such cases users will need to obtain permission from the license holder to reproduce the material. More details and guidelines concerning content reuse and adaptation can be foundat http://www.intechopen.com/copyright-policy.html.

\section{Notice}

Statements and opinions expressed in the chapters are these of the individual contributors and not necessarily those of the editors or publisher. No responsibility is accepted for the accuracy of information contained in the published chapters. The publisher assumes no responsibility for any damage or injury to persons or property arising out of the use of any materials, instructions, methods or ideas contained in the book.

First published in Croatia, 2011 by INTECH d.o.o.

eBook (PDF) Published by IN TECH d.o.o.

Place and year of publication of eBook (PDF): Rijeka, 2019.

IntechOpen is the global imprint of IN TECH d.o.o.

Printed in Croatia

Legal deposit, Croatia: National and University Library in Zagreb

Additional hard and PDF copies can be obtained from orders@intechopen.com

Biomass and Remote Sensing of Biomass

Edited by Islam Atazadeh

p. cm.

ISBN 978-953-307-490-0

eBook (PDF) ISBN 978-953-51-6038-0 


\section{We are IntechOpen, \\ the world's leading publisher of Open Access books}

Built by scientists, for scientists

\section{$4,000+$ \\ Open access books available \\ $116,000+$ \\ International authors and editors

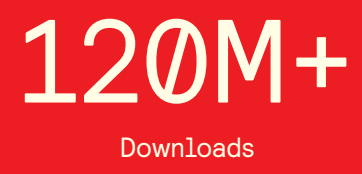

Our authors are among the

151

Countries delivered to

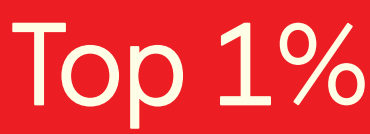

most cited scientists

Contributors from top 500 universities

$12.2 \%$

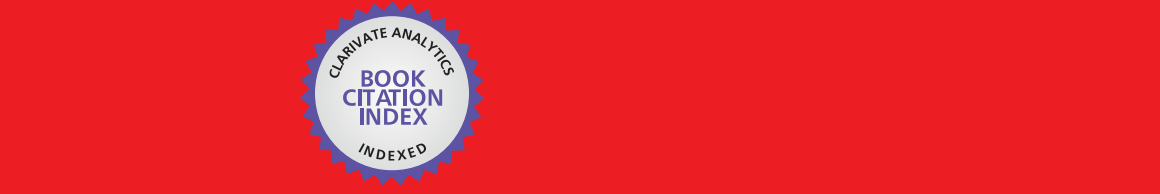

WEB OF SCIENCE ${ }^{\mathrm{M}}$

Selection of our books indexed in the Book Citation Index in Web of Science ${ }^{\mathrm{TM}}$ Core Collection (BKCI)

\section{Interested in publishing with us? \\ Contact book.department@intechopen.com}





\section{Meet the editor}

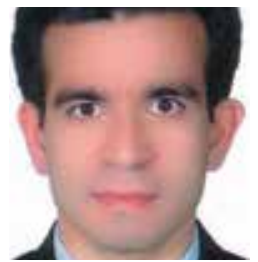

Islam Atazadeh is a researcher in Biology and Environmental Science at Razi University, Iran. He is responsible for teaching undergraduate students of plant science and environmental science. His research focuses on ecology and biology of algae, use of algae as indicator in aquatic ecosystems, water quality biomonitoring, and remote sensing for evaluation of biomass to improve

environmental sustainability. He has published several papers in international journals and other publications including Algae as Bioindicators, Lambert Academic Publishing (2010). 



\section{Contents}

Preface XI

Part 1 Biomass 1

Chapter 1 Biomass in Evolving World Individual's Point of View 3

Biljana Stojković

Chapter 2 Ecological Aspects of Biomass Removal in the Localities Damaged by Air-Pollution 21

Jiří Novák, Marian Slodičák,

David Dušek and Dušan Kacálek

Chapter 3 Invasive Plant Species

and Biomass Production in Savannas 35

John K Mworia

Chapter 4 Zooplankton Abundance, Biomass and

Trophic State in Some Venezuelan Reservoirs $\mathbf{5 7}$

Ernesto J. González, María L. Matos,

Carlos Peñaherrera and Sandra Merayo

Chapter 5 Estimation of Above-Ground Biomass of Wetlands 75

Laimdota Truus

Chapter 6 Soil Microbial Biomass Under

Native Cerrado and Its Changes After the

Pasture and Annual Crops Introduction 87

Leidivan A. Frazão, João Luis N. Carvalho,

André M. Mazzetto, Felipe José C. Fracetto,

Karina Cenciani, Brigitte J. Feigl and Carlos C. Cerri

Chapter 7 The Above-Ground Biomass

Production and Distribution in White Willow

Community During 11 Years of Primary Succession 111

Petr Maděra, Diana Lopéz and Martin Šenfeldr 
Chapter 8 Introduction to Remote Sensing of Biomass 129

Muhammad Aqeel Ashraf, Mohd. Jamil Maah and Ismail Yusoff

Chapter 9 Biomass of Fast-Growing Weeds in a

Tropical Lake: An Assessment of the Extent and the Impact with Remote Sensing and GIS 171

Tasneem Abbasi, K.B Chari and S. A. Abbasi

Chapter 10 Application of Artificial Neural Network (ANN) to Predict Soil Organic Matter Using Remote Sensing Data in Two Ecosystems 181

Shamsollah Ayoubi, Ahmahdreza Pilehvar Shahri, Parisa Mokhtari Karchegani and Kanwar L. Sahrawat

Part 3 Carbon Storage 197

Chapter 11 A Comparative Study of Carbon Sequestration Potential in Aboveground Biomass in Primary Forest and Secondary Forest, Khao Yai National Park 199 Jiranan Piyaphongkul, Nantana Gajaseni and Anuttara Na-Thalang

Chapter 12 Carbon Storage in Cold Temperate Ecosystems in Southern Patagonia, Argentina 213 Pablo Luis Peri

Part 4 Primary Productivity 227

Chapter 13 Long-Term UVR Effects Upon Phytoplankton Natural Communities of Patagonian Coastal Waters 229 Silvana R. Halac, Virginia E. Villafañe, Rodrigo J. Gonçalves and E. Walter Helbling

Chapter 14 In Situ Primary Production Measurements as an Analytical Support to Remote Sensing - An Experimental Approach to Standardize the ${ }^{14} \mathrm{C}$ Incorporation Technique 249 Tamara Cibic and Damiano Virgilio 


\section{Preface}

Generally, biomass is used for all materials originating from photosynthesis. In other words, biomass includes all plant growth, herbaceous plants, microalgae, macroalgae and aquatic plants. But biomass can equally apply to animal as well. In fact, biomass is carbon based and is composed of a mixture of organic molecules containing hydrogen, usually including atoms of oxygen, often nitrogen and also small quantities of other atoms, including alkali, alkaline earth and heavy metals.

There are various ways and methods used for evaluation of biomass. One of these ways is remote sensing. Remote sensing provides information not only about biomass but also about biodiversity and environmental factors estimation over a wide area. This information includes temporal resolution and a synopsis and digital formatting that allows for the initial processing of large amounts of data. There is a high correlation between spectral bands and vegetation parameters. The advantages of most remote sensing application for plants and phytoplankton in inland waters aim at the retrieval of the chlorophyll $a$, as this pigment is a useful proxy for the plant biomass. Although the pigment ratio provides an easily quantifiable approach to monitoring, doubts have been raised about interpretation of the results, so the method should only be used as one of several methods for monitoring. The shift in pigment ratio may be influenced by the fact that more old plant material is likely to be included in samples from sites where the organism is stressed.

The great potential of remote sensing has received considerable attention over the last few decades in many different areas in biological science including nutrient status assessment, weed abundance, deforestation, glacial features in Arctic and Antarctic regions, depth sounding of coastal and ocean depths, and density mapping.

Islam Atazadeh

Researcher in Plant Science,

Razi University,

Kermanshah,

Iran 



\section{Part 1}

\section{Biomass}





\title{
Biomass in Evolving World - Individual's Point of View
}

\author{
Biljana Stojković \\ University of Belgrade \\ Serbia
}

\section{Introduction}

For a long time, ecology has been criticized for being primarily descriptive science concentrated on the 'What' question rather than progressing further into the 'Why' and 'How' domains (O'Connor, 2000). Over the past few decades, however, ecology has moved toward dynamic mechanistic and more strongly predictive science (Kearney et al., 2010). It is becoming increasingly clear that to comprehend mechanisms underlying population dynamics, demography and ecological breadth it is necessary to regard the fact that discrete organisms, which constitute populations, might have different individual responses to ontogenetic and environmental cues (Begon et al., 1990). The challenge is, as noted by Kearney et al. (2010), "to derive an approach for studying penetrance of functional traits of individual organisms into higher, group-level phenomena".

Generally, the interdependency of population-level and individual-level processes is very complex. Although population is composed of individuals, it has emergent properties that are more than just the sum of the properties of individuals. Organisms come to life and die on particular days, but populations have birth and death rates. At any specific moment, individuals are of certain age, but populations have age structure which is very important for determining population growth. Individual characteristics, such as size, growth pattern, age at maturity, number of offspring and longevity, greatly influence population dynamics, but, on the other hand, physiology and patterns of growth and development of each organism depend both on its genotype and on population properties such as the number, sizes and spatial distribution of other individuals. Therefore, the relationship between organisms and their populations is reflexive; phenomena at one biological level are both the cause and the consequence of the phenomena on other.

This chapter is dealing with individual level processes - biomass allocation strategy, allometric growth and phenotypic plasticity. How these developmental processes may affect population dynamics will also be discussed.

\section{Individual-level phenomena}

\subsection{Allometry and allocation strategy}

Allometry (Greek allos, "other", and metron, "measure"; Huxley, 1932) is the study of sizecorrelated variations in biological forms and processes. Niklas (1994) recognizes three conceptual and methodological meanings of this term: 1) the growth of one part of an 
organism in relation to the growth of the whole organism or some other part of it, 2) the study of the consequences of size on organic form or process, and 3) any departure from geometry and shape that is conserved among a series of objects differing in size. Literally, allometry means unequal growth of organs during development of an organism. The fundamental biological principle presumes that acquisition of external resources and metabolism, producing energy and materials for all biological processes, enable organisms to grow in size (i.e., enlarge biomass). However, in biological systems, increase in absolute size always goes along with modifications in relative sizes of organismal parts. In other words, by growing larger, individuals alter their shape; growth itself is size-dependent, i.e. allometric (Weiner, 2004). This process is a consequence of inherent continuous changes in directions of biomass allocation into different structures and activities during the course of development, and reflects alterations in priorities at any point of time of individual ontogenesis. For example, early in development, after germination and emergence of radicle (part of a plant embryo which develops in a root), plants have more roots than shoots. Later, as they grow, relative allocation into aboveground structures increases and results in more 'shooty' individuals. A late fetus has a larger head and shorter legs in relation to its body length than an adult human. Alteration in growth pattern during human ontogeny accounts for later changes in body part proportions. Metabolic rates and the heat produced by metabolism increase less rapidly than total body size.

From the ecological point of view, biomass allocation strategy plays a critical role in determining organismal ability to survive and reproduce (i.e., fitness). If an ideal organism would exist, it would be mature at birth, continuously produce a large number of highquality offspring, and live forever. Such an organism, called 'Darwinian demon' (Law, 1979), would bedevil all other organisms. The same creature, named 'Hutchinsonian demon' in community ecology, would dominate in its habitat because it would be the best in colonizing new patches, utilizing all the resources, avoiding predators and resisting stresses (Kneitel \& Chase, 2004), and, eventually, it would monopolize the life on Earth. In reality, however, the existence of such an organism is impossible because: 1) the amount of resources (i.e., nutrients and energy) that an organism can acquire is finite, and 2) a proportion of the resources allocated to one activity (for example to growth, that is to somatic maintenance and survival), decreases the amount of resources that can be allocated to another (e.g., to reproduction). As noted by Stearns (1992), “allocation decisions between two or more processes that compete directly with one another for limited resources within a single individual" imply mutually exclusive allocation, or physiological trade-off.

If an increase in fitness due to a change in one trait is opposed by a decrease in fitness due to a concomitant change in the second trait, it is clear that adaptive growth strategy in one environment depends on optimal balance of biomass allocation between different organismal functions (Roff \& Fairbairn, 2007). Individuals must allocate resources in a way that make the most of their chances for contributing offspring to the next generation while simultaneously maximizing their chance of surviving to reproduce (Gurevitch et al., 2002). Among characteristics that figure directly in reproduction and survival, and are often in trade-off between each other, Stearns (1992) indicated several principal life-history traits: size at birth, growth pattern, age at maturity, size at maturity, number, size and sex ratio of offspring, age- and size-specific reproductive investments, age- and size-specific mortality schedules, and length of life. Correlations between these traits may be positive or negative (trade-offs), but eventually they combine in many different ways to produce diverse schedules and durations of key events in an organism's lifetime. Logically, natural selection 
in one environment may prioritize some capabilities at the expense of others. As a consequence, different life-histories evolve.

\subsubsection{The evolution of life-histories}

The developmental paths that describe changes in form ("ontogenetic trajectory"; Magwene, 2001) and life-history schedule are often considered to be genetically determined, i.e., species- or genotype-specific (Weiner, 2004), and/or the products of biomechanical and other physical constraints (Givnish, 1986). These assertions have been brought into question by the well documented fact that allometry itself can be plastic and trade-offs may vary with environmental variations (e.g., Cheplick, 1995; Weiner, 2004), as well as because a significant degree of variability in life-histories can exist within populations. However, they still can serve as a starting point for understanding life-history evolution. Comparative biology has demonstrated a great variety of life-histories at the level of species and higher taxonomic groups. In plants, besides tremendous variation in life-cycle patterns, from annual semelparous forms to long-lived iteroparous woody perennials, interesting variations can be found in growth architecture of clonal plants with vegetative reproduction. Lovett Doust (1981) made characterization of these clonal forms on a continuum between 'phalanx', in which vegetative clones (ramets) of one parental plant are grouped tightly together, and 'guerilla' form, which is presented with ramets dispersed like guerilla forces. Vegetative reproduction makes an interesting case on the diversity of life-histories. For example, in quaking aspen (Populus tremuloides) individual trunks, which are genetically identical to their paternal plant, live for about 50 years, while the genotype composed of many individual plants, may live for more than 10000 years. In animals, some species mature early and reproduce quickly, have small body size and a large number of eggs (e.g., many insects), whereas in other species maturation is delayed for several years, individuals are large and have a small number of offspring (e.g., some mammals). Between these extremes, a great variety of different combinations of life-history schedules and growth forms exists.

Although it is reasonable to presume that there is individual variability within each species, relations between life-history traits differ substantially more between higher taxonomic groups. Darwin elegantly explained this phenomenon - related species descended from a common ancestor and shared common evolutionary history for a long time. These 'lineagespecific effects' emphasize characteristics that are general for a group of related species or higher taxonomic levels. The comparative analyses of species, genera, families and classes demonstrate broad patterns of the evolution of allometry, trade-offs and life-history. The examples of how lineage-specific mode of growth affects metabolic and growth rates, and reproduction, can be found all over the living world. Major groups of ectothermal and endothermal organisms have different metabolisms and different growth rates per unit weight during growth, which is involved in determination of age at maturity and the cost of reproduction. For ectothermal organisms, about thirty times less energy supply is needed for the same growth rate as for endothermal (Peters, 1983). Organisms with determinate growth (e.g., annual plants, birds, mammals, and most insects) stop growing when mature, whereas allocation of energy between growth and reproduction continues through adult life for organisms with indeterminate growth, such as perennial plants, fish, amphibians, reptiles, etc. That means that 'allocation decision' between growth and reproduction is made only once for the first group, and many times for the second (Stearns, 1992). The analyses of more than 500 mammal species (Wootton, 1987) imply that body mass is positively correlated with age at first reproduction. Age at maturity is also positively correlated with 
adult lifespan within lineages of birds, mammals, some reptiles and fishes, although the relationships between the two life-history traits differ among these large groups. If corrected for body size, the data suggests that increase in longevity with delay of reproduction is the highest for birds and mammals (Charnov \& Berrigan, 1990).

The results of comparative analyses of higher taxonomic groups imply that changes in lifehistories are phylogenetically constrained in some degree, as a result of shared evolutionary history, genes and developmental pathways. However, it must be kept in mind that comparative biology provides information about boundary conditions on life-history evolution, but, within each lineage, populations and species differ and follow their own patterns of life-history adaptation to specific environment. Here, natural selection acts on life-histories to adjust biomass allocation in a way that maximizes total lifetime fitness. The genotypes (organisms) that have the ability to distribute their resources optimally for certain ecological conditions, will reach the highest fitness and their frequencies in next generations will rise. Those patterns of biomass allocation that present responses of populations to natural selection, Stearns (1992) defines as microevolutionary trade-offs. The relationship between individual-level (i.e., physiological trade-offs) and population-level (i.e., microevolutionary trade-offs) is inevitably complex. The physical division of limited materials and energy supply within an organism is a boundary condition on the evolutionary optimization of life-history strategy within a population inhabiting certain environment. However, the ability of organisms to optimally distribute their biomass and/or to alter the pattern of allocation in accordance with environmental change depends on evolutionary changes of genetic variation in a population. In other words, microevolutionary trade-offs set a trade-off structure that is a constraint for physiological trade-offs.

Intra-individual trade-offs depend on the amount of available resources and interactions between organisms, or in other words, they are plastic. To understand the nature of complex and dynamic relations between different types of trade-offs, which impose both constraints and a basis for their evolution, environmental influences on allometric patterns must be analyzed.

\subsubsection{Plastic allometry}

It is a common knowledge that the fitness of an individual depends both on its genotype and its environment. When live in variable abiotic and biotic circumstances, organisms may achieve high fitness by changing their growth and life-histories so as to match the most fit trait values for each set of environmental conditions. This property of a genotype to express different phenotypes in distinct environments is called phenotypic plasticity, and the way that trait expression varies across a range of environments for a given genotype is called its norm of reaction (Bradshaw, 1965; West-Eberhard, 1989). From the allometric point of view, plasticity can be understood as a change in allometric growth/allocation patterns in response to the environment (Schmid \& Weiner, 1993). According to the optimal allocation theory, organisms should allocate more resources to organs that capture the most limiting resource and less to organs that are involved in obtaining non-limiting resources. At the same time, as was previously noted, they must optimize biomass allocation into reproductive function in order to produce the highest possible number of quality offspring while limiting the losses for their own survival. The solution of this incredibly complex task depends on the characteristics of a population and physical environment. Besides variability in genetic background of their life-history strategies, individuals within a population may 
also differ significantly in their ability to cope with external conditions. Different genotypes may respond differently to the same environment, and this variability in reaction norm for allocation patterns accounts for the total phenotypic variation. As noted by Stearns (1992), microevolutionary trade-offs may evolve, or, in other words, population can respond to selection, if there is genetic variation for this reaction norm (i.e., for physiological trade-offs). Before we explore some examples of relations between life-histories and their plasticity, several properties of phenotypic plasticity have to be explained. As a measure of change in genotype's trait value between different environments, plasticity need not always be adaptive. Some alterations in individual appearance and function are merely unavoidable consequences of organismal physiology (Sultan, 1995). Disadvantageous (maladaptive) plasticity may results from organismal inability to maintain a constant phenotype when faced with environmental circumstances despite fitness reduction due to variation (Alpert \& Simms, 2002). For example, in low-quality environments, or under intense competition for resources, organisms are smaller compared with those in rich-environments; plants have yellow leaves when deprived of sufficient nitrogen, or have lower photosynthetic rate under low light intensity. In ecology, it is common to measure plasticity of a species as a range of ecological conditions that a species can grow in; this measure is also called species' niche (Grinell, 1917). Also, it is common to assign a species as generalist or specialist. However, it must be kept in mind that the niche of each species is determined by the sum of niches (i.e., reaction norms) of its members that may be plastic or nonplastic (Gurevitch, 2002). This is a very important remark for understanding life-history evolution - we can define life-history for each species, but its plastic responses to environmental changes give the opportunity for further evolution of life-histories.

Plasticity of trade-offs between life history traits have been demonstrated in a large number of studies and numerous taxa in laboratory and natural populations (e.g., Reznick, 1985; Sinervo \& DeNardo, 1996; Zuk, 1996; Tucić et al. 1997, 1998; Tucić \& Stojković 2001; Roff, 2002; Stojković et al. 2009). The number of possible relations between different life-history traits is great, and the ways in which they can change under various environmental conditions is, logically, much greater. Here, I present just a few examples to illustrate both the theoretical and empirical knowledge on life-history/allometry plasticity.

The allometry plasticity can be demonstrated with one of the best understood adaptive plastic systems in plants, generally termed as the 'shade avoidance' syndrome (Smith \& Whitelam, 1997). Plants are able to detect low ratio of red to far-red radiation (R:FR) in ambient light as the first signal of future competitive interactions, well before mutual shading actually occurs (Ballaré et al., 1987, 1990). Because chlorophyll preferentially absorbs red light, radiation transmitted through or reflected from a leaf canopy exhibits lower R:FR ratio than does full sunlight (Smith et al., 1990). Therefore, the R:FR ratio can be seen as an environmental, external, cue of population density. It triggers a suite of photomorphogenic plastic responses (e.g., stem elongation, branching reduction, acceleration of flowering) that enables plants to minimize effects of mutual shading by neighbours and maximize the ability to deny light to proximal plants (Aarsen, 1995). The allometric shift in plant growth form is achieved through an increased shoot extension rate coupled with a strong apical dominance (main stem dominance). In crowded conditions this growth pattern enables plants to acquire more radiant energy for photosynthesis and improve their final performance. In uncrowded situations, however, elongation of stems has more costs than benefits. More resources must be allocated into support structures rather than to flowers and seeds. That is why elongated growth form of plants is adaptive only in 
dense environment. Many experiments on plants strongly corroborated the evolutionary ecological prediction that the shade avoidance phenotype is indeed an adaptation, likely moulded by natural selection from competition for light (Dudley \& Schmitt, 1996; Schmitt, 1997; Schwinning \& Weiner, 1998; Tucić \& Stojković, 2001).

In the study on perennial clonal species Lamium maculatum, Stojković et al. (2009) have shown that genotype by environment interaction could change the proportion of biomass allocated into reproductive function. The goal of the experiment was to analyze changes in biomass allocation patterns across genetically structured populations where plants are competing for access to light. Clonal replicates of 17 genotypes were grown under three regimes: 1) control (C; low level of competition), 2) intraclonal competition (S; competition between clones of the same genotype) and, 3) interclonal competition ( $\mathrm{M}$; competition between plants of different genotypes). It was shown that the growth of these plants was sensitive to genetic identity of competitors, and that the competition between genetically

\begin{tabular}{|c|c|c|c|c|c|c|}
\hline \multirow{2}{*}{$\begin{array}{l}\text { Allometric } \\
\text { relationship }\end{array}$} & \multirow[b]{2}{*}{ Treatment } & \multirow[b]{2}{*}{$\mathrm{R}^{2}$} & \multirow[b]{2}{*}{$P$} & \multirow[b]{2}{*}{ a } & \multicolumn{2}{|c|}{$\begin{array}{l}\text { Test of isometry } \\
(\text { Ho: } \alpha=1)\end{array}$} \\
\hline & & & & & F & $P$ \\
\hline \multirow{3}{*}{$\begin{array}{l}\log F W: \\
\log (S W+L W+R W)\end{array}$} & $\mathrm{C}$ & 0.00 & 0.720 & $2.52 \mathrm{~A}$ & 105.36 & 0.000 \\
\hline & $S$ & 0.10 & 0.003 & $1.99 \mathrm{~A}$ & 52.39 & 0.000 \\
\hline & M & 0.24 & 0.000 & $1.59 \mathrm{~B}$ & 22.77 & 0.000 \\
\hline \multirow{3}{*}{$\begin{array}{l}\log S W: \\
\log (F W+L W+R W)\end{array}$} & C & 0.80 & 0.000 & $1.18 \mathrm{~A}$ & 14.02 & 0.000 \\
\hline & $S$ & 0.89 & 0.000 & $1.07 \mathrm{~A}$ & 3.37 & 0.070 \\
\hline & M & 0.89 & 0.000 & $0.99 \mathrm{~B}$ & 0.04 & 0.841 \\
\hline \multirow{3}{*}{$\begin{array}{l}\log L W: \\
\log (F W+S W+R W)\end{array}$} & C & 0.64 & 0.000 & $0.82_{\mathrm{A}(\mathrm{e})}$ & 10.92 & 0.001 \\
\hline & $S$ & 0.79 & 0.000 & $0.80_{\mathrm{B}(\mathrm{e})}$ & 22.37 & 0.000 \\
\hline & M & 0.83 & 0.000 & $0.78_{C(\mathrm{e})}$ & 33.75 & 0.000 \\
\hline \multirow{3}{*}{$\begin{array}{l}\log R W: \\
\log (F W+S W+L W)\end{array}$} & $\mathrm{C}$ & 0.68 & 0.000 & $1.41_{\mathrm{B}(\mathrm{e})}$ & 37.39 & 0.000 \\
\hline & $S$ & 0.75 & 0.000 & $1.54_{\mathrm{A}(\mathrm{e})}$ & 73.31 & 0.000 \\
\hline & M & 0.86 & 0.000 & $1.53_{\mathrm{A}(\mathrm{e})}$ & 119.84 & 0.000 \\
\hline
\end{tabular}

Table 1. Standardized major axis tests of the allometric relationship (log scaled variables) for reproductive effort (FW) and relative biomass investments to stems (SW), leaves (LW) and roots (RW) based on weight measures of L. maculatum plants grown in three experimental treatments (control - C, intraclonal - $\mathrm{S}$ and interclonal - M competition). Scaling slope $\mathrm{a}, \mathrm{R}^{2}$ and $P$ values for correlations within treatments are reported. Results of pairwise slope comparisons between treatments (based on 1000 iteration in permutation testing) are presented as letters in superscript. If differences among slopes were insignificant, pairwise tests of shift in elevation were performed and results presented as letters in subscript [(e)elevation]. Identical letters indicate insignificant difference of either slopes or elevation between treatments. Letter A points to the largest value. F statistics and $P$ values of the test of differences between observed slope within treatments and $\alpha=1$ are reported as statistics of isometry testing (Stojković et al., 2009). 
unrelated individuals was the most stressful environment for this plant species (the indices of competition intensity were the highest in this treatment, unpublished data). Analyses of allometric growth (mathematical procedure of this analysis will be explained later) revealed that in resource-rich, noncompetitive environment, where absolute fecundity is the highest, allocation to reproduction (flower weight - FW) is less determined by the size of plants than in competitive condition (insignificant correlation between flower weight and vegetative weight, $P=0.720$, Table 1 ).

On the other hand, allocation patterns into reproductive function differed considerably between S and M treatments (Table 1). First, it was shown that relationship between weights of vegetative and reproduction modules was anisometric (slope of allometric relation significantly larger than 1), indicating that relative biomass allocation to reproductive effort was greater for larger plants in competition, which achieved higher reproductive outcome. As was shown in the analyses of two treatments with different genetic identity of competitors, small individuals in intense competition (interclonal) tended to allocate larger proportion of acquired resources to reproductive organs compared with small plants in less intense competition (intraclonal). The reverse is true for larger plants suggesting that successful, big individuals in severe asymmetric interaction can balance more productively between vegetative and reproductive fitness components than smaller plants. This conclusion was based on a significantly slighter allometric slope in interclonal competition $(\alpha=1.59, P<0.000$ for $\mathrm{M} ; \alpha=1.99, P<0.003$ for $S$; Table 1, Figure 1 ).

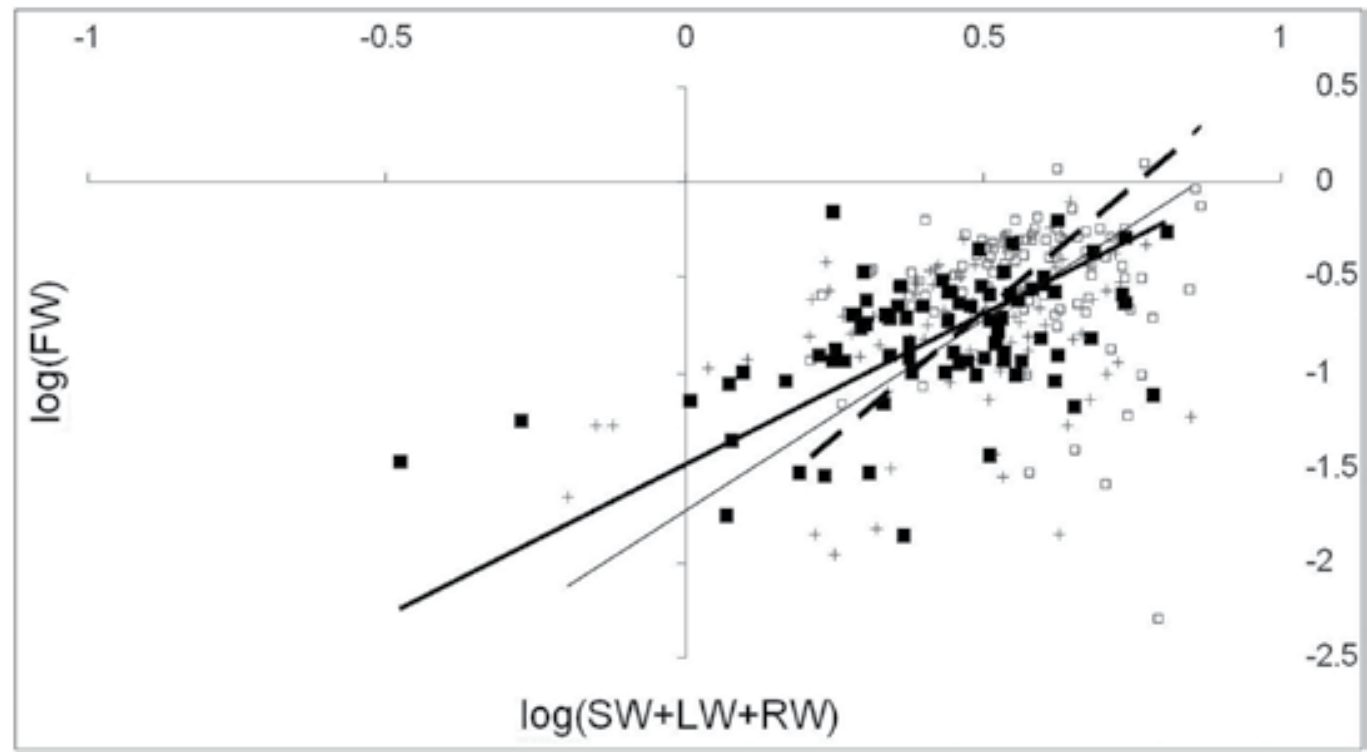

Fig. 1. The allometric relationship (log scaled variables) between reproductive effort (flower weight; FW) and allocation to vegetative modules for L. maculatum grown in three experimental treatments (control, intraclonal and interclonal competition). The SMA allometric function plotted through the individuals in control treatment (dashed line), intraclonal competition (thin line) and interclonal competition (thick line). Symbols for individuals in control (口), intraclonal (+) and interclonal (๘) competition (Stojković et al., 2009). 
Allocation analyses between other plant organs (weight of flowers, stems, leaves and roots) also suggested that in L. maculatum specific allometry strategy of smaller plants in intense competition with unrelated individuals could reflect trade-offs in favor of reproductive effort, both directly via allocation to flowers and indirectly into stems (i.e., to new plant meristems which could be committed to reproductive function). Such investment to flowers may be beneficial for smaller individuals because allocation of limited acquired biomass to extensive vegetative growth (e.g., leaves) may leave insufficient time for successful reproduction before the end of growing season (Bonser \& Aarssen, 2001). Many studies reported that plants grown in competitive environments invested relatively more in sexual reproduction (e.g., Prati \& Schmid 2000; Van Kleunen et al., 2002).

Phenotypic plasticity of correlations between life-history traits has been confirmed in many insect species. In order to analyze trade-off between the size and number of eggs, Fox et al. (1997) performed a study on seed beetle Stator limbatus. These beetles develop completely inside seeds of over 50 different host plants, and emerge from seeds as adults. In their experiments, Fox and colleagues reared beetles on acacia (Acacia greggii) which is a good host, and a palo verde (Cercidium floridum) suboptimal host on which survival of larvae is less than $50 \%$. Several presumptions from life-history theory were made: 1 ) there is a tradeoff between size and number of offspring, i.e., the same amount of resources can be allocated into large number of small offspring, or into few big ones, 2) a probability of survival for any individual offspring is an increasing function of its size, and 3) the minimum size for offspring survival is smaller on the good host. If these assumptions are correct, females of $S$. limbatus should lay larger eggs on the poor host than on the good host. The study confirmed this hypothesis - females adjusted the size of eggs to the host on which they laid, and, also, these larger eggs came at cost of fewer egg produced over a lifetime. Additionally, it was shown that the production of larger eggs was adaptive. Survival of larvae hatching from small eggs was less than $1 \%$, whereas $24 \%$ of the larvae hatching from large eggs survived to adulthood on suboptimal host. On the other hand, since the majority of larvae that developed on acacia seeds survive, higher lifetime reproductive success of females is achieved by producing more and smaller eggs. Berrigan (1991) performed metaanalysis of the relationship between egg size and number in three orders of insects and found negative correlations (i.e., trade-off) among these life-history traits.

One of the most important determinants of life-history evolution is 'age-specific selection' (Rose, 1991; Charlesworth, 1994) which is well described through several major trade-offs: between time schedules of reproduction and longevity, early and late fecundity, reproduction and growth, etc. Evolutionary changes in allocation strategy between different life-history traits have been continuously detected in laboratory evolution experiments on Acanthoscelides obtectus (Tucić et al., 1997, 1998). The methodology of experimental evolution is a valuable research tool for the study of basic mechanisms that shape individual lifehistory because it provides opportunity for testing direct and correlated responses to selection. In the laboratory of these researchers, seed beetle A. obtectus has been selected to reproduce either early (E selection line) or late in life ( $\mathrm{L}$ selection line). About 200 generations of selection for early reproduction gave rise to beetles with enhanced fitness during early life, a short life span and small body size. On the other hand, adults of both sexes selected for late-reproduction are bigger, live longer, and have increased late fecundity and total fecundity compared with beetles from the E treatment. During the course of agespecific selection on A. obtectus, at least two trade-offs were experimentally documented: the 
trade-off between late fecundity and early fecundity and among early fecundity and longevity (Tucić et al., 1997).

Clearly, the complexity and dynamic relations between life-histories of organisms and their environments suggest that allometric patterns evolve in response to numerous selection pressures and constraints. But, how these processes can influence the 'behaviour' of populations? These problems will be discussed after a short description of mathematical procedures that are currently used in the analyses of allometry.

\section{Allometry analysis}

For the adequate empirical and analytical treatment of allometric phenomena in ecological studies it is important to estimate the relationship between two variables, or, in other words, to determine how one variable scales against another. Variables represent different measures of individuals in a sample, such as weight and length of some organismal parts (organs or modules), multivariate shape or size, number of specific modules (for example, leaves, stems, flowers, roots in plants), life-history traits (e.g. life span, fecundity, growth rate, age at first reproduction), metabolic rate (e.g. activity of enzymes, hormones), etc. The main goal of this approach is to understand the allocation patterns within certain species, populations and/or environments.

The general 'allometric equation' that describes relationship between two variables is

$$
y=\gamma \cdot x^{\alpha}
$$

where $y$ and $x$ are biological variables, $\gamma$ is the 'scaling (proportionality) coefficient' and $a$ is 'scaling exponent'. $a$ and $\gamma$ parameters describe the functional (mathematical) relation between $x$ and $y$.

It can be converted into linear relationship between $x$ and $y$ if variables are log-transformed, so the above formula can be reexpressed as

$$
\log (y)=\log (\gamma)+\alpha \log (x)
$$

or

$$
Y=\beta+\alpha X
$$

where substitutions are made: $Y=\log (y), X=\log (x)$ and $\beta=\log (\gamma)$. Now, $\beta$ is the value of $Y$ where it intercepts the vertical axis, and $a$ is equal to the slope of linear function when plotted on logarithmic scale. The log transformation is useful for several reasons: 1) it allows the relationship between the two variables to be expressed as a linear relationship, 2) it puts the variables on a multiplicative or logarithmic scale, which tend to diminish differences among large numbers and accentuate differences among small numbers, 3) it may transform frequency distribution of the data into normal distribution, and 4) it reduces statistical problems resulting from a number of outlying data points.

There are several statistical procedures for finding the line of best fitting through a bivariate cloud of data - linear regression, major axis, standardized major axis and their modifications. Several authors (e.g. Niklas, 1994; Bonser \& Aarssen, 2001, 2003; Warton et al., 2006) proposed standardized major axis (SMA) method (or reduced major axis, RMA) on log-transformed variables as the most appropriate for allometry analyses. Falster et al. 
(2003) developed statistical software, (S)MATR, for application of SMA method in studies of allometry patterns.
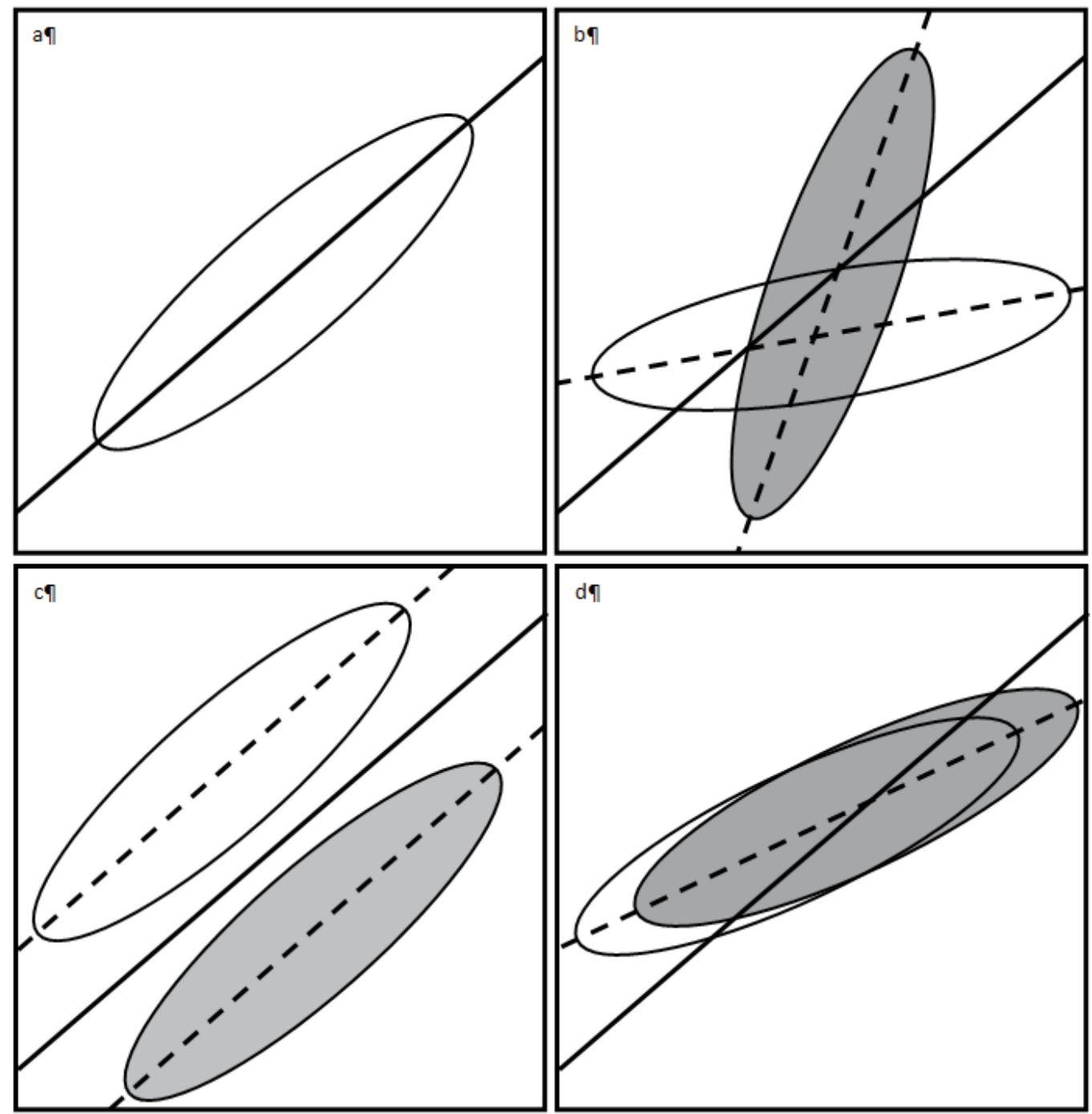

Fig. 2. Illustration of different types of allometric analyses in (S)MATR statistical software (Falster et al., 2003): (a) test of the isometry $(a=1)$; (b) testing if slopes of allometric function are different between groups; (c) testing if elevations are different between groups; (d) testing for shift along the axis. (After Falster et al., 2003)

SMA methodology is appropriate where there is error in both the $x$ and $y$ variables of the regression models and when we are not interested in prediction but to estimate the line-ofbest-fit relating two variables, which is the basic purpose of allometry estimates (Warton et al., 2006). A significant allometric relationship is indicated where the slope (a) of the relationship between logarithms of the two variables differs from isometry. An isometric relationship between biological variables $(\alpha=1)$ implies that the relative biomass allocation 
to one organ or function is proportional to the allocation to other organ or function (Figure 2a). The best way to understand isometry and allometry is to imagine that one of the variables in the allocation analysis is some measure of the size of the whole organisms (for example, total weight or height). Then, isometry suggests that relative biomass allocation to specific organ or function is constant for all individual sizes. For example, the size of adult human heads would be several times greater than it is, if the growth of human fetus would proceed in isometric fashion. If the relative allocation to some organ or biological function is greater for larger individuals, than the scaling exponent, or slope of allometric relationships between the two variables is greater than one ( $a>1$; Figure $2 b)$. On the other hand, lower relative investment into one organ during the growth of an organism is detected as a value of scaling exponent that is less than one ( $a<1$; Figure $2 b$ ). In the experiment on Lamium maculatum (Stojković et al., 2001), the biomass allocation into reproductive organs (flowers) and roots was generally greater for larger individuals, indicating that high ability of biomass acquisition was correlated with development of roots and, also, that these plants invested disproportionately high amount of energy and materials were into future offspring (Table 1, Figure 1). On the other hand, allocation of biomass into stems was shown to be isometric, i.e., directly proportional to the weight of other plant organs, whereas investment into leaves was greater for small plants (Table 1). These patterns of allocation suggested that when plants compete for the access to light, there was a difference in allometry strategy between different size classes of individuals - small plants invested more resources to organs that capture the most limiting resource (light) than larger plants. Allometry analysis gives the opportunity to answer some more questions about the nature of growth and differences between groups of organisms. For example, although the relative proportions of biomass allocated into one organ or biological function may be similar between groups (have a common allometric slope), two groups can differ in absolute values of biomass measures. Then, two groups can differ in elevation (i.e., intercepts) of their allometric function (Figure 2c), or they can diverge along a common axis (Figure 2d). In the study on $L$. maculatum, for plants with similar sum weights of flowers, roots and stems, the weights of leaves were significantly lower in competition, especially in the treatment with the most intense competition. This result indicated that plants in different competition treatment had different opportunities for acquiring resources. Although, as was noted above, an adaptive strategy of plants in competition for light (especially for small individuals) may be allocation into leaves, the difference in average absolute weights $(C>S>M)$ resulted in observed shift in elevation (Table 1).

Negative value of slope of allometric relationship is particularly important for life-history studies because it indicates the trade-off between different functions of organisms, for example between developmental rate and life span, or between fertility and longevity.

\section{Individuals versus populations}

Many ecological processes in populations and communities may be understood in terms of size and/or life-history allometric patterns. In other words, the way the individual growth and life-histories are shaped in certain environment could largely influence the demographic patterns of a population. For example, changes in life-history schedules of members of a population can change population demography parameters, such as rate of population growth and carrying capacity. The trade-off between seed size and seed number has been used as an explanation for difference in competition and colonization abilities of 
plant species. As suggested, competitive ability is enhanced by production of fewer, larger seeds, whereas colonization ability is improved by production of many small seeds (Turnbull et al., 1999; Levine \& Rees, 2002). The members of natural populations often differ in size and relatedness to each other, which may affect the division of limited resources and have consequences on reproductive success, changes in the ratio of birth rate/mortality rate, and influence population growth in different ways (Aikio \& Pakkasmaa, 2003).

Here, we explore several theoretical deductions about the relationship between individual and population level responses to competition intensity, i.e. density.

\subsection{The 'rules' in plant ecology}

"Plant growth is highly plastic, and the mass, height, number of leaves, and reproductive output of an individual plant can vary over orders of magnitude depending on growth conditions." (Gurevitch et al., 2002)

One of the regularities that were revealed in plant populations regarding competitive interaction was that the total final dry weight per unit area of all plants in a population is remarkably consistent over a wide range of densities. In other word, the average individual plant size became smaller as density increase, but this reduction is in linear relationship with increasing number of individuals per unit area (Kira et al., 1953). As a final result, total biomass will be the same for different population densities.

Regularity has been also found in the relationship between the size of a plant population (density), size of individual plant and mortality rate. For some time, this regularity has been considered as an ecological 'law' or 'first principle', and is known as '-3/2 self-thinning rule' (Yoda et al., 1963):

\section{$M=k N-3 / 2$}

According to this rule, the average individual plant biomass $(\mathrm{M})$ in a population is proportional to the $-3 / 2$ power of population density $(\mathrm{N}) ; k$ is a constant that differs among species. If $\mathrm{N}$ increases, $\mathrm{M}$ will decrease anisometrically as a consequence of density-dependent mortality, or 'self-thinning'. During the growth of seedlings, crowding becomes severe, and some individuals, usually the smallest and weakest ones, begin to die. The more plants are crowded the sooner and at smaller individual sizes mortality will begin. As a result, in less crowded plant populations, individuals may achieve larger sizes than in dense populations. Although this 'law' has been widely accepted until the 1980s, it has become clear that this scenario was not directly applicable to all populations and plants whose growth scaling is very complex. In other words, the 'law' neglects the plasticity of allocation strategy. Silvertown and Lovett Doust (1993) argued that this rule may be an upper limit of the relationship.

Another suite of empirical results and theoretical deductions comes from agronomy - the 'Law of Constant Final Yield'. This rule deals with size-dependent reproductive allocation in agricultural plant. Total crop biomass increases with density and then levels off, while reproductive output constantly decreases at higher densities. This is explained by the expected pattern according to which plants in competition allocate biomass more in competitive structures and less in reproduction.

All these rules, however, are based on the assumption that population mechanisms contribute to the maintenance of the status quo in population dynamics and demography. Numerous ecological and evolutionary models, nevertheless, explore circumstances and mechanisms by which populations do change. As noted by Gurevitch et al. (2002), mean 
plant size can be a misleading measurement in models because individual sizes in plants are generally extremely uneven as a consequence of plastic growth in asymmetric competition (Weiner, 1990; Schwinning \& Fox, 1995). Largest individuals have disproportionate large negative effects on their small neighbors, since the relative amount of resources that small individuals can acquire is less than what could be expected by their biomass. Among a group of seedlings germinating together, a small advantage in size may confer a large benefit, i.e., progressively greater inequality in competitive abilities over time. Competitive asymmetry, which leads to increased individual variability in size, has been seen as one of the major processes that secure the existence of reproductive individuals, stabilize population dynamics and assure the persistence of populations (Aikio \& Pakkasmaa, 2003). Under the assumption that there is a size-threshold for reproduction, asymmetry forces small individuals to decrease in size and to stay below the threshold. Therefore, in the presence of size-dependent mortality and reproduction, only large individuals remain in the population and reproduce, assuring population persistence. On the other hand, under symmetric competition, low variation of individual biomasses increases the possibility that either all individuals remain smaller than the size-threshold for reproduction or that all individuals exceed the threshold. This process may cause strong fluctuations in population size, destabilizes population dynamics (Lomnicki, 1988; Silvertown, 1991; Uchmanski, 2000) and increase the likelihood of extinction due to demographic stochasticity (Ripa \& Lundberg 2000). One of the causes of symmetry in competition is genetic relatedness between neighboring individuals. Relatedness reduces size variations either because superior large individuals reduce their resource consumption as an altruistic act towards their smaller relatives, which, now, exceed the size-threshold for reproduction (kin selection; Hamilton, 1964; Maynard-Smith, 1964), or because relatives have similar environmental preferences and genetic uniformity, which result in similar growth rates (Jasienski, 1988; Tonsor, 1989). All these models are strongly based on the premise that reproductive outcome is a linear function of plant size. Although it is basically true that larger individuals have more seeds, this premise does not allow for the possibility that plastic allometry may change the proportion of resources invested into reproduction. As shown in the study on L. maculatum (Stojković et al., 2009), relative allocation to reproductive effort could be enhanced in competition, leading to the decreased effect of asymmetric competition on population dynamics. Also, it was revealed that L. maculatum plants grown with genetically identical individuals had higher fitness compared with plants in unrelated patches. It seems that these relations are common for clonal plants (Donohue, 2003). In these genetically structured populations, regulation of population dynamics may include advantageous kin effects. Although there is a possibility that some kin groups may stay bellow the size-threshold for reproduction, the persistence and stability of population size could be assured via selection between kin groups.

\subsection{Life-history and population dynamics}

Using the logistic model of population growth,

$$
\frac{d N}{d t}=r N\left(\frac{K-N}{K}\right)
$$

where $N$ is the population size, $K$ is the population's carrying capacity (i.e., the population size at which the per capita birth rate equals the per capita death rate), and $r$ is intrinsic rate of population growth, MacArthur and Wilson (1967) established the ' $r$ / K selection theory'. This theoretical model, integrated with Pianka's concept of the evolution of life-history 
strategies (Pianka, 1970, 1974), proposed a relationship between density-dependent population regulation and life-history evolution. In spite of numerous critiques and limited empirical confirmations (see review in Reznick et al., 2002) this model remains one of the most influential theoretical frameworks for understanding life-history evolution. Undoubtedly, adaptive changes of life-history traits are related to the density-dependent adjustment and resource limitation that each population experience. As a consequence, under density-dependent $v$ s. density-independent selection individual fitness must be associated with different traits (Boyce, 1984; Mueller, 1997) and evolved life-history strategies should differ between populations facing distinct densities. The organisms in dense populations (i.e., close to the carrying capacity, $K$ ) are exposed to intense competition and experience density-dependent mortality, which, according to Pianka (1970), determine adaptive life-history changes toward slow development, delayed reproduction, high investment in biomass and greater competitive ability at the cost of low reproductive effort, low fecundity with large investment in each offspring, and high longevity. Contrary, in sparse populations (or populations inhabiting physically variable and unpredictable environments), where mortality factors are mainly density-independent, selection would favor individuals with rapid development, early maturity, high fecundity at the cost of investment in body size, low investment in each offspring, and shorter life span (Pianka, 1970). The later strategy, which is based on selection for traits that enhance population growth rate $(r)$, is also expected in a resource-rich, noncompetitive environment.

Although well elaborated argument for life-history strategies as long-term adaptations to the environment in a continuum from pure $r$ - to pure $K$-selection, this concept contradicts some basic assumptions about the short-term adaptive responses to competition. In other words, the plasticity of physiological trade-off may oppose long-term microevolutionary trade-offs in a population. For example, fast development is usually assumed to be associated with higher fitness because early hatching/germinated individuals benefit from more available resources compared with subsequent individuals. Also, due to higher possibilities for resource acquirement in a noncompetitive environment, one can expect overall individual performance, i.e., body mass, longevity and total fecundity, to be advanced compared with individuals in a dense population. The question is to what extent a long-term selection can limit the ability of single genotypes to plastically change their allometry strategy in response to environmental variation. Additionally, we may ask what is the consequence of these processes on population dynamics?

In the laboratory evolution experiments on Acanthoscelides obtectus two experimental lines were raised for 200 generations. The $r$ - and $K$-selected lines were derived by rearing populations at persistently low and high densities, respectively. To test the possibility that plastic responses to the contrasting environmental conditions may oppose long-term lifehistory strategies established by density-dependent selection, the samples of beetles from both lines were reared for one generation either at their common environment (i.e., low density for the $r$ - and high density for the $K$-line) or at the alternate environmental conditions (i.e., low density for the $K$ - and high density for the $r$-line). Most of Pianka's predictions on the evolution of life-history strategies under different density conditions were confirmed in A. obtectus experimental lines (Stojković \& Tucić, unpublished data; but see Tucić et al. (1997) for contrasting results on these experimental lines after only 73 generation of selection). However, preadult life-history traits (i.e., egg size, preadult viability and developmental time) were influenced by short-term density conditions. More importantly, these plastic changes induced by the novel environments (low density for the 
$K$ - and high density for the $r$-line) were in opposite directions from the course of selection for life-history traits within experimental lines. Larval experience of $r$ - females in dense conditions resulted in significant increase of investment into the egg dimension. This strategy may provide an advantage to offspring in competitive interactions. The short-term relaxation of competition in K-line enabled opportune investment into fast offspring development and increase of their viability. These plastic changes in allocation patterns in $K$ - experimental line resulted in increase of demographic parameters - intrinsic rate of population growth $(r)$ and net reproductive rate $(R o)$. It seems that amplification of per capita amount of resources at low density allowed the enlargement of carrying capacity in the K-line and, consequently, enhanced the opportunities for population growth. In population ecology it is well known that offspring born in early life-stages contribute more to the next generation (i.e., to the $r$ parameter) than offspring born later. Fertility life tables of $\mathrm{K}$-females raised for one generation at low density provided the evidence that the agespecific fecundity schedule was shifted toward earlier days of adulthood with narrow distribution of fecund days (Stojković \& Tucić, unpublished data).

The experiment on rice weevil (Calandra oryzae) revealed that variations in temperature may change intrinsic rate of population growth $(r)$ as a consequence of changes in rate of development, survival and fecundity (Birch, 1948).

Empirical data have provided excellent demonstration on how variation in survival and fecundity, as individuals vary in age, size, fecundity schedule or other life-history characteristics, affects dynamics in population demography.

\section{Conclusions}

In many ecological models populations are not perceived as being composed of individuals that vary in all aspects of their phenotype. Evolutionary biology is looking for the explanations of evolution and development of various organismal traits, but rarely explores the effects of evolutionary changes on dynamics of populations. The truth is that ecological processes provide the context for evolution, and, also, that changes in individual variability affect all population processes in a continuous feedback manner. Allometry, the study of size-correlated variations in biological form and function, may be seen as a discipline in which both theoretical programs can meet. Allometry investigates how allocation strategies evolved and how they can be changed in respect to the environment and characteristics of populations. Individuals must allocate resources in a way that make the most of their chances for contributing offspring to the next generation while simultaneously maximizing their chance of surviving to reproduce. How organisms manage to solve this complex task depends both on the evolutionary history of a population and on biotic and abiotic conditions at each point of time. Clearly, the dynamic relations between life-histories and growth architecture of organisms and their environments suggest that allometric patterns evolve in response to numerous selection pressures and constraints. At the same time, the way the individual growth and life-histories are shaped in certain environment could largely influence the demographic patterns of a population.

\section{Acknowledgement}

I gratefully acknowledge Nikola Tucić for helpful comments on the manuscript and Oliver Stojković for his help in graphic presentations. This study was supported by Ministry of Science and Technological Development of Serbia, project No. 173007. 


\section{References}

Aarssen, L.W. (1995). Hypotheses for the evolution of apical dominance in plants: implications for the interpretation of overcompensation. Oikos 74: 149-156.

Aikio, S. \& Pakkasmaa, S. (2003). Relatedness and competitive asymmetry - implications for growth and population dynamics. Oikos 100: 283-290.

Alpert, P. \& Simms, E.L. (2002). The relative advantages of plasticity and fixity in different environments: when is it good for a plant to adjust? Evolutionary Ecology 16: 285-297.

Ballaré, C.L.; Sánchez, R.A.; Scopel, A.L.; Casal J.J. \& Ghersa, C.M. (1987). Early detection of neighbor plants by phytochrome perception of spectral changes in reflected sunlight. Plant Cell Environment 10: 551-553.

Ballare, C.L.; Scopel, A.L. \& Sanchez, R.A. (1990). Far-red radiation reflected from adjacent leaves: an early signal of competition in plant canopies. Science 247: 329-332.

Begon, M.; Harper, J.L. \& Townsend C.R. (1990) Ecology: individuals, populations and communities. Blackwell, Boston, MA.

Berrigan, D. (1991). The allometry of egg size and number in insects. Oikos 60: 313-321

Birch, L.C (1948). The intrinsic rate of natural increase of an insect population. Journal of Animal Ecology 17: 15-26.

Bonser, S.P. \& Aarssen, L.W. (2001). Allometry and plasticity of meristem allocation throughout development ina Arabidopsis thaliana. Journal of Ecology 89: 72-79.

Bonser, S.P. \& Aarssen, L.W. (2003). Allometry and development in herbaceous plants: functional responses of meristem allocation to light and nutrient availability. American Journal of Botany 90: 404-412.

Boyce, M.S. (1984). Restitution of $r$ - and K-selection as a model of density-dependent natural selection. Annual Review of Ecology and Systematics 15: 427-447.

Bradshaw, A.D. (1965). Evolutionary significance of phenotypic plasticity in plants. Advances in Genetetics 13: 115-155.

Charlesworth, B. (1994). Evolution in age-structured populations. 2nd edition, Cambridge University Press, Cambridge

Charnov, E.L. \& Berrigan, D. (1990). Dimensionless numbers and life history evolution: age at maturity versus the adult lifespan. Evolutionary Ecology 4: 273-275.

Cheplick, G.P. (1995). Genotypic variation and plasticity of clonal growth in relation to nutrient availability in Amphibromus scabrivalvis. Journal of Ecology 83: 459-468.

Donohue, K. (2003). The influence of neighbor relatedness on multilevel selection in the Great Lakes sea rocket. American Naturalist 162: 77-92.

Dudley, S.A. \& Schmitt, J. (1996). Testing the adaptive plasticity hypothesis: density dependent selection on manipulated stem length in Impatiens capensis. American Naturalist 147: 445-465.

Falster, D.S.; Warton, D.I. \& Wright I.J. (2003). (S)MATR: Standardised Major Axis Tests and Routines, Version 1.0. http://www.bio.mq.edu.au/ecology/SMATR.

Fox, C.W.; Thakar, M.S. \& Mousseau, T.A. (1997). Egg size plasticity in a seed beetle: An adaptive maternal effect. American Naturalist 149: 149-163.

Givnish, T.J. (1986). Biomechanical constraints on self-thinning in plant populations. Journal of Theoretical Biology 119: 139-146.

Grinell, J. (1917). The niche-relationships of the California thrasher. The Auk 34: 427-433.

Gurevitch, J.; Scheiner, S.M. \& Fox G.A. (2002). The Ecology of Plants. Sinauer Associates Inc., Sunderland, $M A$

Hamilton, W.D. (1964). The genetical evolution of social behaviour. I \& II. Journal of Theoretical Biology 7: 1-52. 
Huxley, J.S. (1932). Problems of relative growth. MacVeagh, London.

Jasienski, M. (1988). Kinship ecology of competition: size hiearchies in kin and non-kin laboratory cohorts of tadpoles. Oecologia 77: 407-413.

Kearney, M.; Simpson, S.J.; Raubenheimer, D. \& Helmuth B. (2010). Modelling the ecological niche from functional traits. Phil. Trans. R. Soc. B. 365: 3469-3483.

Kira, T.; Ogawa, H. \& Sinozaki, K. (1953). Intraspecific competition among higher plants. 1. Competition-density-yield interrelationships in regularly dispersed populations. Journal of Institute of Polytechnic. Osaka City University D4: 1-16.

Kneitel, J.M. \& Chase, J.M. (2004). Trade-offs in community ecology: linking spatial scales and species coexistence. Ecology Letters 7: 69-80.

Law, R. (1979). Ecological determinants in the evolution of life histories. In R. M. Anderson, B. D. Turner and L. R. Taylor, eds. Population Dynamics. Blackwell Scientific, Oxford, pp. 81-103.

Levine, J.M. \& Rees, M. (2002). Coexistence and relative abundance in annual plant assemblages: the roles of competition and colonization. American Naturalist 160:452-67

Lomnicki, A. (1988). Population Ecology of Individuals. Princeton Univ. Press.

Lovett Doust, L. (1981). Population dynamics and local specialization in a clonal perennial (Ranunculus repens). I. The dynamics of ramets in contrasting habitats. Journal of Ecology 69: 743-755.

MacArthur, R. H. \& Wilson E. 0. (1967). The theory of island biogeography. Princeton Univ. Press, Princeton

Magwene, P.M. (2001). Comparing ontogenetic trajectories using growth process data. System. Biology 50: 640-656.

Maynard Smith, J. (1964). Group selection and kin selection. Nature 201: 1145-1147.

Mueller, L.D. (1997). Theoretical and empirical axamination of density-dependent selection. Annual Review of Ecology and Systematics 28: 269-288.

Niklas, K. (1994). Plant allometry: the scaling of form and process. University of Chicago Press, Chicago.

O'Connor, R.J. (2000). Why ecology lags behind biology. Scientist 14: 35.

Peters, R.H. (1983). The ecological implications of body size. Cambridge University Press, Cambridge

Pianka, E.R. (1970). On r- and K-Selection. American Naturalist 104: 592-597

Pianka, E.R. (1974) Niche Overlap and Diffuse Competition. Proceedings of Natural Academy of Science, USA. 71: 2141-2145,

Prati, D. \& Schmid, D. (2000). Genetic differentiation of life-history traits within populations of the clonal plant Ranunculus reptans. Oikos 90: 442-456.

Reznick, D.; Bryant, M.J. \& Bashey, F. (2002) r- and K-selection revisited: the role of population regulation in life-history evolution. Ecology 83: 1509-1520.

Reznick, D. (1985). Cost of reproduction: an evolution of the empirical evidence. Oikos 44:257-267.

Ripa, J. \& Lundberg, P. (2000). The route to extinction in variable environments. Oikos 90: 89-96.

Roff, D.A. \& Fairbairn D.J. (2007). The evolution of trade-offs: where are we? Journal of Evolutionary Biology 20: 433-447

Roff, D.A. (2002). Life History Evolution. Sinauer Associates, Sunderland, MA.

Rose, M. R. (1991). Evolutionary biology of aging. Oxford Univ. Press, Oxford

Schmid, B. \& Weiner, J. (1993). Plastic relationships between reproductive and vegetative mass in Solidago altissima. Evolution 47: 61-74.

Schmitt, J. (1997) Is photomorphogenic shade avoidance adaptive? Perspectives from population biology. Plant Cell Environment 20: 826-830. 
Schwinning, S. \& Fox, G. A. (1995). Population dynamic consequences of competitive symmetry in annual plants. Oikos 72: 422-432.

Schwinning, S. \& Weiner J. (1998). Mechanisms determing the degree of size asymmetry in competition among plants. Oecologia 113: 447-455.

Silvertown, J.W. \& Lovett Doust, L. (1993). Introduction to plant population biology. Blackwell, Oxford, UK.

Silvertown, J.W. (1991). Modularity, reproductive tresholds and plant population dynamics. Functional Ecology 5: 577-582.

Smith, H. \& Whitelam, G.C. (1997). The shade avoidance syndrome: multiple responses mediated by multiple phytochromes. Plant Cell Environment 20: 849-844.

Smith, H.; Casal, J.J. \& Jackson, G.M. (1990). Reflection signals and the perception by phytochrome of the proximity of neighbouring vegetation. Plant Cell Environment 13: 73-78.

Stearns, S.C. (1992). The evolution of life histories. Oxford University Press, New York.

Stojković, B.; Barišić-Klisarić, N.; Avramov, S. \& Tarasjev, A. (2009). Effect of genetic relatedness on the allometric relationship between biomass investment and sexual reproduction in clonal plant. Polish Journal of Ecology 57: 371-375.

Sultan, S.E. (1995). Phenotypic plasticity and plant adaptation. Acta Botanica Neerl. 44: 363-383.

Tonsor, S.J. (1989). Relatedness and intraspecific competition in Plantago lanceolata. American Naturalist 134: 897-906.

Tucić, B. \& Stojković, B. (2001). Shade avoidance syndrome in Picea omorika seedlings: a growth-room experiment. Journal of Evolutionary Biology 14: 444-455.

Tucić, N.; Stojković, O.; Gliksman, I.; Milanović, D. \& Šešlija D. (1997). Laboratory Evolution of Life-History Traits in the Bean Weevil (Acanthoscelides obtectus): The Effects of Density-Dependent and Age- Specific Selection. Evolution 51: 1896-1909.

Tucić, N.; Gliksman, I.; Šešlija, D.; Stojković, O. \& Milanović D. (1998). Laboratory Evolution of Life-History Traits in the Bean Weevil (Acanthoscelides obtectus): The Effects of Selection on Developmental Time in Populations with Different Previous History. Evolution 52: 1713-1725.

Uchmanski, J. (2000) Individual variability and population regulation: an individual-based approach. Oikos 90: 539-548.

van Kleunen, M.; Fischer, M. \& Schmid, B. (2002). Experimental life-history evolution: selection on the allocation to sexual reproduction and its plasticity in a clonal plant. Evolution 56: 2168-2177.

Warton, D.I.; Wright, I.J.; Falster, D.S. \& Westoby, M. (2006). Bivariate line-fitting methods for allometry. Biological Review 81: 259-291.

Weiner, J. (1990). Asymmetric competition in plant populations. Trends in Ecology and Evolution 5: 360-364.

Weiner, J. (2004). Allocation, plasticity and allometry in plants. Perspectives Plant Ecol. Evol. Syst. 6: 207-215.

West-Eberhard, M.J. (1989) Phenotypic plasticity and the origins of diversity. Annual Review in Ecology and Systematics 20: 249-278.

Wootton, J. T. (1987). The effects of body mass, phylogeny, habitat, and trophic level on mammalian age at first reproduction. Evolution 41: 732-749.

Yoda, K; Kira, T.; Ogawa, H. \& Hozumi, K. (1963). Self-thinning in overcrowded pure stands under cultivated and natural conditions. Journal of Biology, Osaka City University, 14: 107-129.

Zuk, M. (1996). Trade-offs in parasitology, evolution and behavior. Parasitology Today 12:46-47. 


\title{
Ecological Aspects of Biomass Removal in the Localities Damaged by Air-Pollution
}

\author{
Jiří Novák, Marian Slodičák, David Dušek and Dušan Kacálek \\ Forestry and Game Management Research Institute, Research Station at Opočno \\ Czech Republic
}

\section{Introduction}

Removal of above-ground biomass is connected with nutrient exclusion from the forest ecosystem. This aspect is essential mainly in the localities with damage of soil conditions, e.g in the air-polluted areas. Therefore, quantification of possible biomass removal must be based on knowledge of current soil conditions (especially forest floor) under forest stands.

We illustrate this problem with the example of the forest stands of substitute tree species, which were established in the Czech Republic on the sites where the declining spruce monocultures could not be replaced by ecologically suitable tree species due to continual air pollution impact and damaged forest soils.

One of the most heavily air-polluted areas since the 1960s of the last century is the Krušné hory Mts. (figure 1). The Krušné hory Mountains (synonym: The Ore Mts. or Erzgebirge) are located in Central Europe on the border between the Czech Republic and Saxony, Germany. These mountains are known as an area where air pollution has had a very severe impact (Šrámek et al., 2008a). Sulphur dioxide, produced mainly by coal power plants and the chemical industry, caused extensive decline of forests in the upper part of the Krušné hory Mountains during the 1970s and 1980s. Therefore, some new tree species, considered to be more resistant to air pollution, substituted the declining spruce in these areas. The substitute tree species stands occupied in this place about $36 \%$ of forest land area, i.e. about 41 thousand hectares. The largest percentage of this area is covered with birch (Betula sp.) and blue spruce (Picea pungens Engelm.) or mixtures of these two species. The third species according to covered area is European larch (Larix decidua Mill.) with more than 6.5 thousand hectares of forest land in the Krušné hory Mts.

Nowadays, substitute stands are due to air pollution decrease in good health condition and grow well. Consequently, they are now at the beginning of tree species conversion. and the questions are: Is it possible to remove aboveground biomass for chipping (with respect to their effects of forest environment, especially in these heavily disturbed localities)?

Presented chapter focuses on the results from above-ground biomass investigation in the substitute stands of blue spruce, European larch and birch located in the Krušné hory Mts. Study was completed with the results of investigation of quantity and quality of forest-floor (humus) horizons and litter-fall under these stands. Possible nutrient loss after removal above-ground biomass for chipping is discussed. 


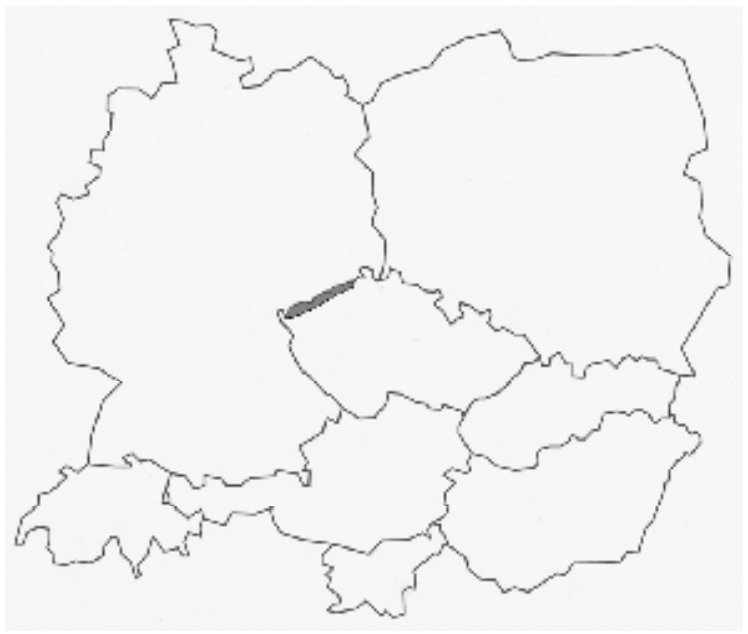

Fig. 1. Location of the Krušné hory Mts. in the frame of Central Europe

\section{Material and methods}

Presented study is based on long-term observation managed by Forestry and Game Management Research Institute (Research Station at Opocno) in the Krušné hory Mts., Czech Republic. Compilation of our previous studies was completed with unpublished data. Results from three long-term experiments (table 1) were used for presented study. These experiments were established in substitute stands of common birch (location Fláje I), blue spruce (location Fláje II) and European larch (location Kalek) in 1989, 1996 and 1999, respectively. Experiments consist of partial plots with different thinning regimes but for our study, only control plots without thinning were used. In the frame of presented study we evaluate three parts of the biomass (and consequently nutrients) cycle - above-ground biomass, biomass of forest-floor and annual litter-fall. Detailed information on experiments, observation methods and periods are mentioned below.

\subsection{History of experiments}

\subsubsection{Blue spruce - experiment Fláje II}

Blue spruce is the first of the introduced tree species used for regeneration of clearcuts induced by air pollution since 1967-1968 in the Krušné hory Mts. (Šika, 1976). In contrast with the original habitat in the West of the USA where blue spruce creates unclosed mixed stands, young monocultures (thickets) of blue spruce in the Krušné hory Mts. create closedcanopy stands with unsatisfactory stability and repeated damage by climatic factors (mainly top breaks or windfalls, frost damage, etc.). Deformations and damage of the root system are frequent as well. Furthermore, an adverse effect of blue spruce stands on the forest soil was observed (Podrázský et al., 2003). On the other hand, the present blue spruce stands comply with the main objectives of cultivation of substitute tree species stands, i.e. they create more favourable microclimatic conditions for the gradual regeneration of forest stands by target tree species (Balcar \& Kacálek, 2003).

Thinning experiment Fláje II was established in 1996 (Slodičák \& Novák 2001, 2008). The blue spruce stand is situated on a south-facing gentle slope, $770 \mathrm{~m}$ above sea level in the 
spruce $\left(8^{\text {th }}\right)$ forest vegetation zone (Piceetum acidophilum - Avenella flexuosa according to Viewegh et al., 2003, table 1). The soil type was classified as cambisol modal oligotrophic. Mean annual temperature is $5.5-6.0^{\circ} \mathrm{C}$; the mean sum of precipitation is ca $900 \mathrm{~mm}$ (for the period of 1961-2000). An experimental blue spruce stand was established by mound planting at initial spacing $2 \times 2 \mathrm{~m}-2,500$ trees per ha (figure 2).

\begin{tabular}{|c|c|c|c|c|c|c|c|c|}
\hline \multirow[b]{2}{*}{ Species } & \multirow[b]{2}{*}{ Location } & \multirow[b]{2}{*}{$\begin{array}{l}\text { Elevation } \\
\text { (m) }\end{array}$} & \multirow[b]{2}{*}{$\begin{array}{l}\text { Forest site according } \\
\text { to Viewegh et al. } \\
(2003)\end{array}$} & \multicolumn{5}{|c|}{ Mensurational characteristics of the stands } \\
\hline & & & & $\begin{array}{c}\text { Age and year } \\
\text { of } \\
\text { measurement }\end{array}$ & $\begin{array}{c}\mathrm{N} \\
\left(\text { trees.ha-1) }^{-1}\right)\end{array}$ & $\begin{array}{c}\mathrm{G} \\
\left(\mathrm{m}^{2} \cdot \mathrm{ha}^{-1}\right)\end{array}$ & $\begin{array}{c}\mathrm{d} \\
(\mathrm{cm})\end{array}$ & $\begin{array}{l}\mathrm{h} \\
(\mathrm{m})\end{array}$ \\
\hline Blue spruce & $\begin{array}{l}50^{\circ} 41^{\prime} 53^{\prime \prime} \\
13^{\circ} 37^{\prime} 52^{\prime \prime}\end{array}$ & 770 & $\begin{array}{l}\text { Piceetum acidophilum - } \\
\text { Avenella flexuosa }\end{array}$ & $\begin{array}{l}22 \text { years } \\
(2006)\end{array}$ & 2022 & 17.7 & 10.2 & 5.7 \\
\hline $\begin{array}{l}\text { European } \\
\text { larch }\end{array}$ & $\begin{array}{l}50^{\circ} 35^{\prime} 11^{\prime \prime} \\
13^{\circ} 21^{\prime} 11^{\prime \prime}\end{array}$ & 780 & $\begin{array}{l}\text { Piceeto-Fagetum oligo- } \\
\text { mesotrophicum - } \\
\text { Calamagrostis villosa }\end{array}$ & $\begin{array}{l}20 \text { years } \\
(2007)\end{array}$ & 2140 & 27.8 & 12.0 & 10.8 \\
\hline $\begin{array}{l}\text { Common } \\
\text { birch }\end{array}$ & $\begin{array}{l}50^{\circ} 41^{\prime} 38^{\prime \prime} \\
13^{\circ} 35^{\prime} 20^{\prime \prime}\end{array}$ & 800 & $\begin{array}{l}\text { Fageto-Piceetum } \\
\text { acidophilum - } \\
\text { Calamagrostis villosa }\end{array}$ & $\begin{array}{l}22 \text { years } \\
(2003)\end{array}$ & 1725 & 10.9 & 8.5 & 9.1 \\
\hline
\end{tabular}

Table 1. Basic data about long-term experiments Fláje II (blue spruce), Kalek (European larch) and Fláje I (common birch) in the Krušné hory Mts.

The experimental series consists of three comparative plots 0.1 ha in size. Ecological aspects of biomass removal were studied on the control plot without thinning. The experimental stands have been measured (diameter at breast height, height, health condition) annually since 1996. The crown area covered $91 \%$ of the stand area at the age of 16 years in 2000 . Full coverage of land by crowns (full canopy) was attained in the vegetation period 2001 (Novák \& Slodičák 2006a). During the period of investigation, the number of trees on the control plot was practically unchanged $\left(2,078-2,022\right.$ trees.ha $\left.^{-1}\right)$. Basal area on the control plot increased approximately six times during the period of observation from 2.8 to $17.7 \mathrm{~m}^{2}$.ha-1 (at the age of 12-22 years).
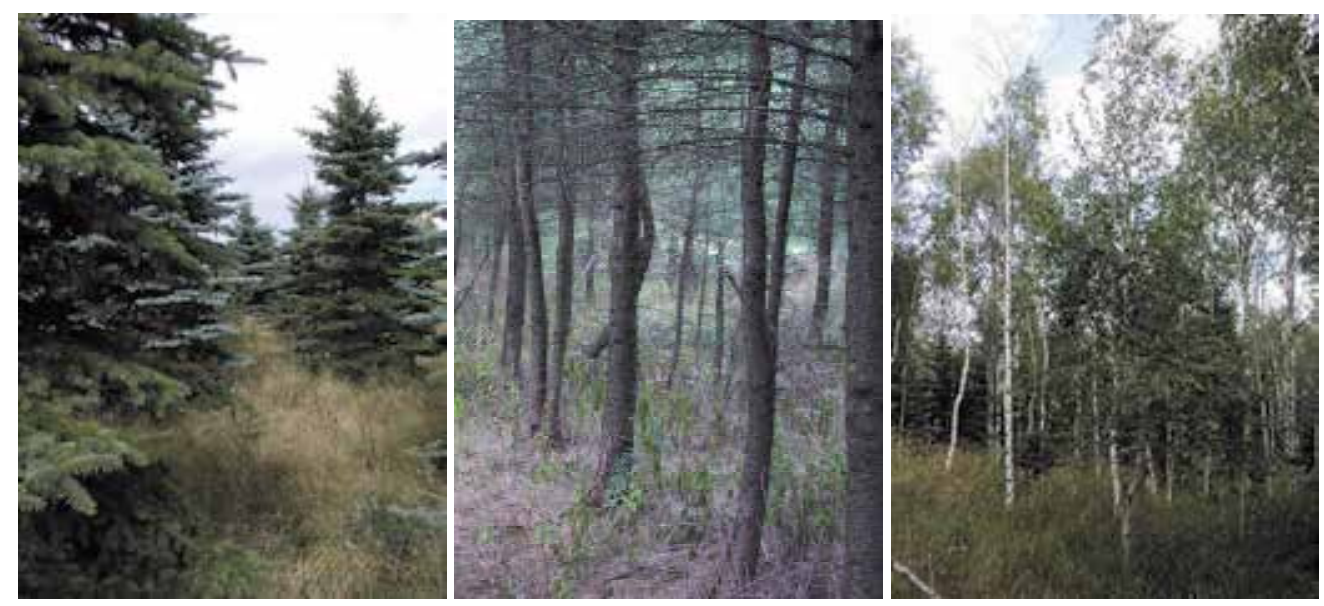

Fig. 2. Control unmanaged plots in experimental forest stands in August 2003 - blue spruce 19year-old (left), European larch 16-year-old (middle) and common birch 22-year-old (right). 
Above-ground biomass was studied in August 2006 when the stand was 22-year-old (Slodičák \& Novák 2008, table 2). Forest-floor investigation was done in October 2002 (Ulbrichová et al., 2005). Litter-fall was collected 5 years from October 2002 to October 2007 (age of 18-23 years) in this experiment.

\begin{tabular}{lcccccc}
\hline \multirow{2}{*}{ Species } & \multicolumn{5}{c}{$\begin{array}{c}\text { Abservation (sampling) } \\
\text { biomass }\end{array}$} & \multicolumn{2}{c}{ Forest-floor biomass } & Litter-fall \\
\cline { 2 - 7 } Blue spruce & 22 & Aug 2006 & 18 & Oct 2002 & $18-23$ & $\begin{array}{c}\text { Oct 2002 - } \\
\text { Oct 2007 } \\
\text { European larch }\end{array}$ \\
\cline { 2 - 7 } Common birch & 20 & Aug 2007 & 19 & Oct 2006 & $16-19$ & $\begin{array}{c}\text { Aug 2003 - } \\
\text { May 2007 } \\
\text { Sept 2003 - } \\
\text { May 2007 }\end{array}$ \\
\hline
\end{tabular}

Table 2. Summary of observations included in presented study in substitute stands of blue spruce, larch and birch in the Krušné hory Mts. *Above-ground biomass was calculated for this year and age by published equations (see methods).

\subsubsection{European larch - experiment Kalek}

In the Krušné hory Mts., larch is referred to as a target tree species in the beech with spruce $\left(6^{\text {th }}\right)$ forest vegetation zone and as a transition from target to substitute tree species in the spruce with beech (7th) forest vegetation zone. As a rule, the larch stands are not envisaged to be subjected to stand conversion and, therefore, proper attention must be paid to their tending.

Thinning experiment Kalek was established in 1999 to investigate the tending of young larch stands in the Krušné hory Mts. (Novák \& Slodičák 2006b). The stand is located in the beech with spruce $\left(6^{\text {th }}\right)$ forest vegetation zone at an elevation of $780 \mathrm{~m}$ a.s.l. in the fresh, mediumnutritive category (Piceeto-Fagetum oligo-mesotrophicum - Calamagrostis villosa according to Viewegh et al. 2003, table 1). The soil type was classified as Entic Podzol. Mean annual temperature is $5.5-6.0^{\circ} \mathrm{C}$; the mean sum of precipitation is ca $800 \mathrm{~mm}$ (for the period of 1961 2000).

An experimental larch stand was established by line planting (at initial spacing $1 \times 1.5 \mathrm{~m}-$ 6,667 trees per ha) after mechanical raking of slash to windrows (figure 2), i.e. planted area was practically without former forest-floor. The experimental series consists of four comparative plots $0.04-0.05$ ha in size. Ecological aspects of biomass removal were studied on the control plot without thinning. The experimental stands have been measured (diameter at breast height, height, health condition) annually since 1999.

In the period of investigation (2000-2007, age of 13-20 years), the number of trees decreased from 3,400 to 2,280 trees.ha-1 $(33 \%)$ by salvage cutting in control unthinned plot. Basal area in control plot increased approximately twice in the period of observation (from 14.3 to $28.6 \mathrm{~m}^{2} \cdot \mathrm{ha}^{-1}$ at the age of $13-20$ years).

Above-ground biomass was studied in August 2007 when the stand was 20-year-old (Novák et al., 2011, table 2). Forest-floor investigation was done in October 2006. Litter-fall was collected 4 years from August 2003 to May 2007 (age of 16-19 years) in this experiment. 


\subsubsection{Common birch - experiment Fláje I}

Thinning experiment Fláje I was established in 1989 to investigate the tending of substitute birch stands in the Krušné hory Mts. (Slodičák \& Novák 2001). The stand is located on the south-facing slope in the spruce with beech ( $\left.7^{\text {th }}\right)$ forest vegetation zone at an elevation of 800 $\mathrm{m}$ a.s.l. in the acid category (Fageto-Piceetum acidophilum - Calamagrostis villosa according to Viewegh et al. 2003, table 1). The soil type was classified as cambic leptosol. Mean annual temperature is $5.5-6.0^{\circ} \mathrm{C}$; the mean sum of precipitation is ca $900 \mathrm{~mm}$ (for the period of 1961 2000).

An experimental birch stand was established by seeding (figure 2). The experimental series consists of four comparative plots $0.04-0.10$ ha in size. Ecological aspects of biomass removal were studied in the control plot without thinning. The experimental stands have been measured (diameter at breast height, height, health condition) annually since 1990.

In the period of investigation (1990-2003, age of 9-22 years), the number of trees decreased from 8,825 to 1,725 trees.ha-1 $(80 \%)$ by salvage cutting in control unthinned plot. Basal area in control plot increased approximately twice in the period of observation (from 5.8 to 10.9 $\mathrm{m}^{2} \cdot \mathrm{ha}^{-1}$ at the age of $9-22$ years).

Above-ground biomass was calculated (see below) for year 2003 when the stand was 22year-old, table 2). Forest-floor investigation was done in October 2002 (Ulbrichová et al., 2005). Litter-fall was collected 4 years from September 2003 to May 2007 (age of 22-25 years) in this experiment.

\subsection{Above-ground biomass investigation}

As for blue spruce and European larch stands above-ground biomass was evaluated using previous studies (Slodičák \& Novák, 2008, Novák et al., 2011), which were done by destructive analysis directly in mentioned experiments. Above-ground biomass was observed quantitatively (dry mass - total and by particular fractions) and qualitatively (amount of nutrients). Detailed methods are described in the mentioned studies.

Birch stand was not observed by detailed study of above-ground biomass. Therefore total above-ground biomass was calculated using known diameter structure at the age of 22 years (2003) and published equations (Varik et al., 2009) for 14-year-old birch stand with similar mensurational parametres:

$$
\mathrm{Y}=121.59 \times \mathrm{d}^{2.376}
$$

where $\mathrm{Y}$ is the amount of dry mass (in $\mathrm{g}$ ) and $\mathrm{d}$ is diameter at breast height $1.3 \mathrm{~m}$ (in $\mathrm{cm}$ ). Quality of above-ground biomass (amount of nutrients) was not calculated for this tree species.

\subsection{Forest-floor investigation}

Forest-floor layers were observed directly in the experiments. Results from blue spruce and birch (sampling in October 2002) were published by Ulbrichová et al. (2005). Investigation in larch stand was done in October 2006 and the results are still unpublished. The uniform methods were used in all observed stands.

The samples were collected using steel frames $(25 \times 25 \mathrm{~cm})$ to define sampling areas at four replications in all plots. Forest-floor humus horizons $(\mathrm{L}=$ fresh litter including herbal vegetation, $\mathrm{F}=$ fermented litter and $\mathrm{H}=$ humified litter) were investigated quantitatively and qualitatively. 
All samples were dried, first under conditions of open air, later in a laboratory oven at $70^{\circ} \mathrm{C}$, and dry samples were subsequently weighed. Nutrient content was assessed from composite samples from each layer (after mineralization by mineral acids). Total Nitrogen (N) concentration was analyzed by Kjehldahl procedure and Phosphorus (P) concentration was determined colorimetrically. An atomic absorption spectrophotometer was used to determine total Potassium (K) concentration by flame emission, and Calcium (Ca) and Magnesium (Mg) by atomic absorption after addition of La. Nitrogen content was assessed from composite samples (three per treatment) after mineralization by mineral acids and analysed using Kjeldahl procedure.

\subsection{Litter-fall investigation}

Litter-fall was collected using three steel litter collectors with an individual area of $0.25 \mathrm{~m}^{2}$ (birch and larch) or $0,50 \mathrm{~m}^{2}$ (blue spruce) installed within each of observed stands. The samples were taken twice to fourth times per year during the period of observation (table 2). All samples were dried, first under conditions of open air, later in a laboratory oven at $70^{\circ} \mathrm{C}$, and dry samples were subsequently weighed. Nutrient content was assessed from composite samples from each sampling. As for forest-floor layers, the same laboratory methods for nutrient content investigation were used (see chapter 2.3). We calculate annual litter-fall (quantitatively and qualitatively) for individual stands and periods of observation.

\section{Results and discussion}

\subsection{Quantity of biomass}

\subsubsection{Above-ground biomass}

We found that 20-22-year-old substitute stands contain per hectare from 40.3 to $102.2 \mathrm{t}$ of above-ground (dry) biomass (figure 3). The lowest amount of above-ground biomass was observed in birch stand (40,270 kg.ha-1). Biomass accumulated in above-ground part of blue spruce stand was about $40 \%$ higher (56,237 kg.ha-1). The highest amount (about 154\%

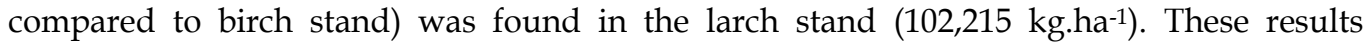
correspond with forest site classification in observed experiments. Lower vegetation zone (6 $6^{\text {th }}-$ Piceto-Fagetum $)$ in larch stand means better growth conditions compared to higher vegetation zone $\left(8^{\text {th }}-\right.$ Piceetum) in birch stand. For example, Li et al. (2003) found a relationship between aboveground biomass and elevation in larch stands, Tyrol (Austria). European larch stands (27-years-old) situated at the elevation of 1,680, 1,810 and 1,940 m showed aboveground biomass (without stumps) $135 \mathrm{t}, 61 \mathrm{t}$ and $20 \mathrm{t}$ per hectare, respectively. In literature, total aboveground biomass of larch stands ranges from 80 t.ha-1 in 50-60-yearsold stand (Young et al., 1980, as cited in Burrows et al., 2003), 158 t.ha-1 in 28-years-old stand (Komlenović, 1998) to 216 t.ha-1 in 35-36-years-old stand (Eriksson \& Rosen, 1994).

For common birch, above-ground biomass shows also a wide range of published results: 31 t.ha $^{-1}$ for 8-year-old stand (Uri et al., 2009), 20-66 t.ha-1 (on fine sand) and 31-53 t.ha-1 (on clay soil) for 12-year-old stand (Johansson, 2007) and 40 t.ha-1 $^{-1}$ for 14-year-old stand (Varik et al., 2009).

For blue spruce similar data was not published in the Czech Republic. We can compare it only with similar studies in young Norway spruce (Picea abies [L.] Karst.) stands. Results of these studies showed higher values of aboveground biomass of Norway spruce stands - 14-year-old stand ca 65 t.ha-1 $^{-1}$ (Chroust, 1993), 20-years-old stand ca 85 t.ha-1 (Chroust \& Tesařová 1985) or

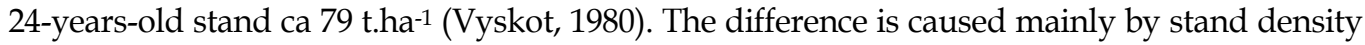


and consequently by different characteristics of mean stem. Generally, the mean stem of blue spruce stand was shorter, but thicker than the mean stem of Norway spruce.

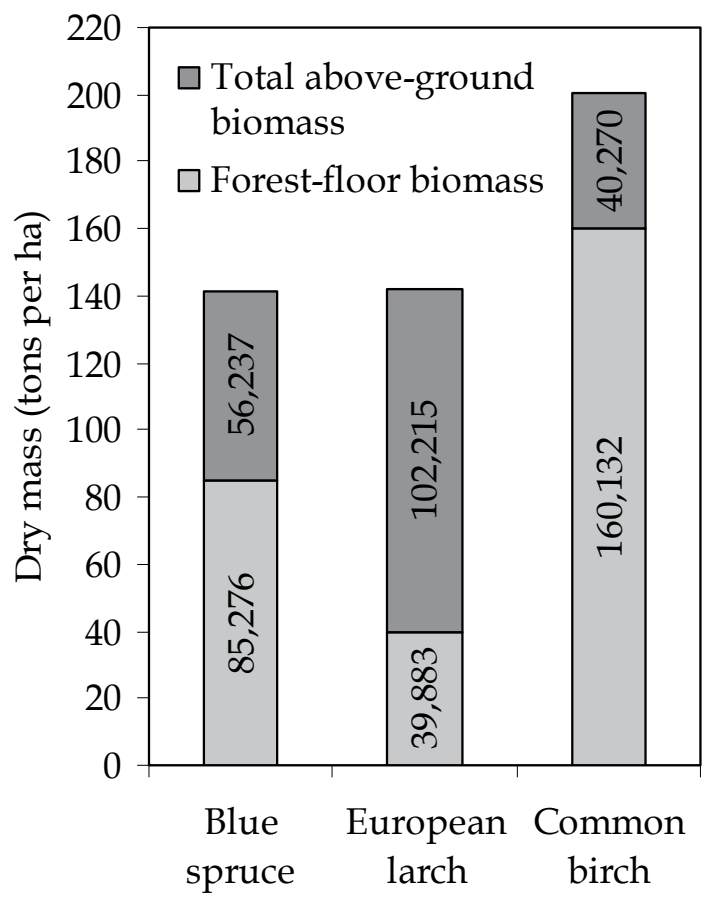

Fig. 3. Amount of above-ground and forest-floor biomass by species.

Despite the former and current air-pollution load (for all species) and raking of forest floor before planting (for larch), the amount of aboveground biomass produced by 20-22-year-old substitute stands of blue spruce, larch and birch is comparable with the results observed in corresponding stands on the other undisturbed sites.

\subsubsection{Forest-floor}

Dry-weight of forest-floor is undoubtedly influenced by history before planting (or seeding). Larch stand was planted on site without former humus layers (see methods) and consequently, amount of dry mass in humus horizons $(\mathrm{L}+\mathrm{F}+\mathrm{H})$ under 19-year-old stand was small (39,883 kg.ha-1) compared to other species (figure 3 ).

Humus horizons under 18-year-old blue spruce stand contained about $114 \%$ higher amount of dry mass $\left(85,276 \mathrm{~kg} \cdot \mathrm{ha}^{-1}\right)$ compared to larch stand. The highest amount of dry mass was observed in humus horizons under 21-year-old birch stand (160,132 kg.ha-1).

Under both blue spruce and birch stands, part of current humus layers is inherited from previous (probably Norway spruce) stands. Additionally, high stock of dry-mass in humus layers under birch may be caused by worse climatic conditions (lower temperatures) of $8^{\text {th }}$ vegetation zone, i.e. slower process of decomposition.

We can compare these results with previous studies from Norway spruce monocultures, which were common in the Krušné hory Mts. before substitute stands. Humus horizons $(\mathrm{L}+\mathrm{F}+\mathrm{H})$ under 30-35-year-old Norway spruce stands in similar growth conditions (6-7th 
forest vegetation zone) contain per hectare from $195 \mathrm{t}$ (Novák \& Slodičák, 2004) to $202 \mathrm{t}$ (Dušek et al., 2009) of dry mass. These stands were located on continually forest soil without site preparation before planting. Therefore, it mainly corresponds with results from birch stand, because of similar site and soil conditions.

\subsubsection{Litter-fall}

We found that annual litter-fall in young substitute stands reaches 2-5 t.ha-1 (figure 4). The lowest annual litter-fall was observed under 22-25-year-old birch stand (2,317 kg.ha-1). Approximately two times higher amount of annual litter-fall was found under blue spruce $\left(4,923 \mathrm{~kg} \cdot \mathrm{ha}^{-1}\right)$ and larch $\left(4,216 \mathrm{~kg} \cdot \mathrm{ha}^{-1}\right)$ stand.

There is possibility to compare these results with studies from Norway spruce monocultures. Observed values of mean annual litter-fall (2-5 t.ha-1) correspond to range of values 1.1 - 5.7 t.ha-1 $^{-1}$ reported by many authors (Bille-Hansen \& Hansen, 2001, Berg \& Meentemeyer, 2001, Novak \& Slodicak, 2004, Hansen et al., 2009).

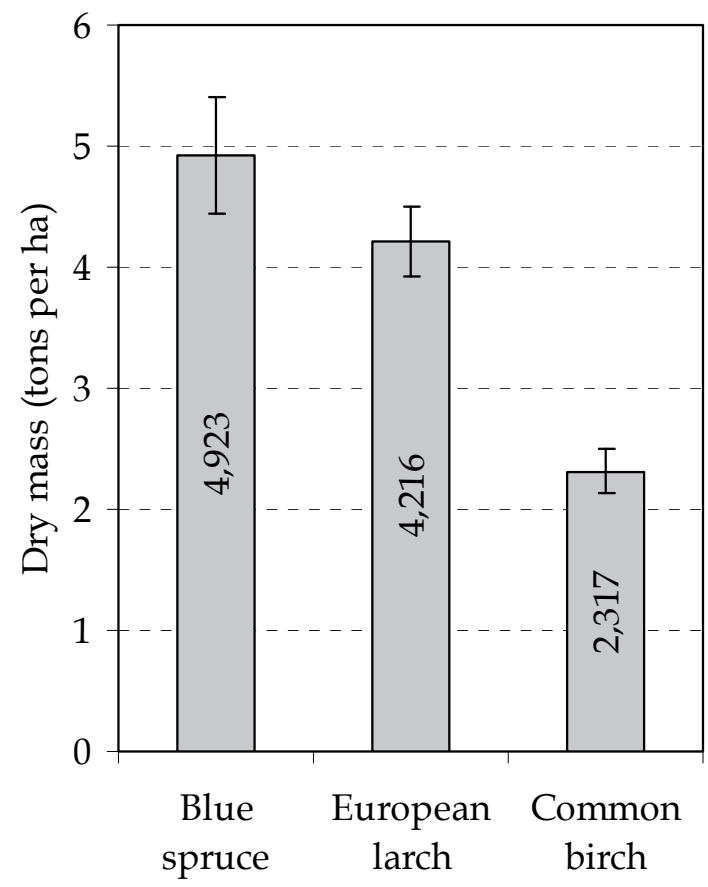

Fig. 4. Annual litter-fall in young substitute stands in the Krušné hory Mts. (means with standard deviations)

\subsection{Quality of biomass}

Amounts of main nutrients $(\mathrm{N}, \mathrm{P}, \mathrm{K}, \mathrm{Ca}, \mathrm{Mg})$ in the individual parts of biomass cycle were compared for all three observed stands (table 3 ).

\subsubsection{Blue spruce}

Under blue spruce stand forest-floor contains per hectare about 1,082 kg of N, $86 \mathrm{~kg}$ of $\mathrm{P}$, $176 \mathrm{~kg}$ of $\mathrm{K}, 22 \mathrm{~kg}$ of $\mathrm{Ca}$ and $\mathrm{Mg}$. Total amount of Nitrogen (336 kg.ha-1), Phosphorus (28 
kg.ha-1) and Pottassium (138 kg.ha-1) was lower (about 69\%, 67\% and 22\%, respectively) in above-ground biomass compared to forest-floor. On the other hand, above-ground biomass contains strongly higher amount of $\mathrm{Ca}$ (about 612\%) and $\mathrm{Mg}(28 \%)$ compared to forest-floor.

Totally $48 \mathrm{~kg}$ of N, $3 \mathrm{~kg}$ of P, $4 \mathrm{~kg}$ of K, $42 \mathrm{~kg}$ of Ca and $2 \mathrm{~kg}$ of $\mathrm{Mg}$ was returned by annual litter-fall under observed blue spruce stand. For N, P, K and Mg it represents only about 2$7 \%$ of amount accumulated in forest floor. In the case of $\mathrm{Ca}$ we found higher amount of this nutrient (about 87\%) in annual litter-fall compared to amount in forest-floor.

Thus, removal of above-ground biomass of observed blue spruce stand (totally or partly by thinning) may result in nutrient losses, especially $\mathrm{Ca}$ and $\mathrm{Mg}$ because of their low content in forest soil compared to content in above-ground biomass.

\begin{tabular}{|c|c|c|c|c|c|c|}
\hline \multirow{2}{*}{ Species } & \multirow{2}{*}{ Part of ecosystem } & \multicolumn{5}{|c|}{ Nutrients (kg per hectare) } \\
\hline & & $\mathrm{N}$ & $\mathrm{P}$ & K & $\mathrm{Ca}$ & $\mathrm{Mg}$ \\
\hline \multirow{3}{*}{$\begin{array}{l}\text { Blue } \\
\text { spruce }\end{array}$} & Above-ground biomass & 335.5 & 28.3 & 138.3 & 158.7 & 27.8 \\
\hline & Forest-floor & 1082.3 & 85.9 & 176.4 & 22.3 & 21.7 \\
\hline & Annual litter-fall & 48.0 & 2.9 & 4.4 & 41.8 & 1.5 \\
\hline \multirow{3}{*}{$\begin{array}{l}\text { European } \\
\text { larch }\end{array}$} & Above-ground biomass & 307.0 & 21.0 & 136.0 & 122.0 & 53.0 \\
\hline & Forest-floor & 383.9 & 23.4 & 195.8 & 50.3 & 135.9 \\
\hline & Annual litter-fall & 52.6 & 3.8 & 5.3 & 17.7 & 7.9 \\
\hline \multirow{3}{*}{$\begin{array}{l}\text { Common } \\
\text { birch }\end{array}$} & Above-ground biomass & \multicolumn{5}{|c|}{ No data } \\
\hline & Forest-floor & 2026.2 & 123.5 & 373.6 & 72.8 & 51.6 \\
\hline & Annual litter-fall & 39.4 & 2.2 & 2.7 & 5.5 & 1.8 \\
\hline
\end{tabular}

Table 3. Nutrient content in above-ground biomass, forest-floor and annual litter-fall by species.

\subsubsection{European larch}

Forest-floor contains per hectare about $384 \mathrm{~kg}$ of N, $23 \mathrm{~kg}$ of P, $196 \mathrm{~kg}$ of K, $50 \mathrm{~kg}$ of Ca and $136 \mathrm{~kg}$ of $\mathrm{Mg}$ under larch stand (table 3). Similarly as in blue spruce stands total amount of Nitrogen (307 kg.ha-1), Phosphorus (21 kg.ha-1) and Pottassium (136 kg.ha-1) was lower (about 20\%, 10\% and 31\%, respectively) in above-ground biomass compared to forest-floor. Amount of $\mathrm{Mg}$ (53 kg.ha-1) was obviously lower (about 61\%) in above-ground biomass compared to forest floor. On the other hand, above-ground biomass contains higher amount of Calcium (about 143\%) compared to forest-floor.

Totally $53 \mathrm{~kg}$ of N, $4 \mathrm{~kg}$ of $\mathrm{P}, 5 \mathrm{~kg}$ of $\mathrm{K}, 18 \mathrm{~kg}$ of Ca and $8 \mathrm{~kg}$ of $\mathrm{Mg}$ was returned by annual litter-fall under observed larch stand. For $\mathrm{K}$ and $\mathrm{Mg}$ it represents only about 3 and $6 \%$ of amount accumulated in forest-floor. Annual litter-fall contains about 14,16 and $35 \%$ of N, P and $\mathrm{Ca}$, respectively, compared to amount of these nutrients stored in forest-floor. 
There are two general aspects in the case of nutrient status in observed larch stand. First, in contrast to blue spruce and birch stand, larch stand was established by planting on nearly mineral soil, when former forest-floor was almost completely removed after mechanical raking of slash to rows. It means that current forest-floor is a result only of litter-fall accumulation and decomposition during the age of current stand.

Second aspect is former liming management in the Krušné hory Mts., especially where experimental larch stand is located. The dolomite with increased amount of $\mathrm{Mg}$ (minimum

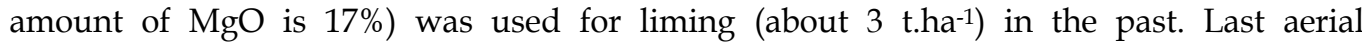
application was done in mentioned locality in 2006 (Šrámek et al., 2008b).

Whilst the amount of $\mathrm{Mg}$ is high (mainly due to previous liming) in forest floor under observed larch stand, we cannot recommend removal of above-ground biomass mainly because of possible losses of $\mathrm{Ca}$, which is highly represented in above-ground biomass and consequently in litter-fall. In the detailed study (Novák \& Slodičák, 2011) we found, that more than $50 \%$ of $\mathrm{Ca}$ amount in above-ground biomass is stored in needles and branches. Therefore, we can recommend utilisation of larch stems only for chipping in the framework of thinning. Other aboveground biomass (mainly needles and branches) should be left in a forest ecosystem for decomposition.

\subsubsection{Common birch}

Under birch stand forest-floor contains per hectare about $2026 \mathrm{~kg}$ of N, $124 \mathrm{~kg}$ of P, $374 \mathrm{~kg}$ of $\mathrm{K}, 73 \mathrm{~kg}$ of $\mathrm{Ca}$ and $52 \mathrm{~kg}$ of $\mathrm{Mg}$. Above-ground biomass for birch stand was calculated by published equations (Varik et al., 2009) by real diameter distribution because we do not have data from exact study of above-ground biomass in observed birch stand. Mentioned equation was used for dry mass calculation only because we knew that each allometric equation did not compare favourably with other equations available in the literature and we agree with the recommendation of Gower et al. (1987), who suggested that discretion must be exercised when applying regression equations to other areas than where they were developed. Thus, amount of nutrients in above-ground biomass was not calculated for this species.

Totally $39 \mathrm{~kg}$ of N, $2 \mathrm{~kg}$ of P, $3 \mathrm{~kg}$ of $\mathrm{K}, 6 \mathrm{~kg}$ of $\mathrm{Ca}$ and $2 \mathrm{~kg}$ of $\mathrm{Mg}$ was returned by annual litter-fall under observed birch stand. For $\mathrm{N}, \mathrm{P}, \mathrm{K}$ and $\mathrm{Mg}$ it represents only about $1-3 \%$ of amount accumulated in forest floor. On the other hand, annual litter-fall contains about $8 \%$ of Ca compared to amount of these nutrients stored in forest-floor.

Summary of the results from birch stand is influenced by unknown amount of nutrients in above-ground biomass. However, on the basis of forest-floor and litter-fall observations we can conclude that removal of above-ground biomass may be possible because of relatively good amount of nutrients in forest-floor, which partly consists of humus accumulated under previous (Norway spruce) stand. On the other hand dry-mass of above-ground biomass is relatively low (about 40 t.ha ${ }^{-1}$ ) and probably economically unfavourable. Furthermore, high mortality was found since 2003 in observed birch stand (Novák \& Slodičák, 2006a).

\section{Conclusion}

Management of biomass removal in forests should be connected with knowledge about nutrient cycle in the forest ecosystem mainly in the localities with damaged soils. 
This problem was illustrated by the example of the forest stands of substitute tree species (blue spruce, European larch and common birch), which were established in the Krušné hory Mts. (Czech Republic) on the sites where the declining Norway spruce monocultures could not be replaced by ecologically suitable tree species due to continual air pollution impact and damaged forest soils. On the basis of presented study we can conclude:

- Despite the former and current air-pollution load and (in the case of larch stand) raking of forest floor before planting, the amount of aboveground biomass produced by substitute 20-22-year-old blue spruce, larch and birch stands is comparable with the results observed in similar stands on the other undisturbed sites.

- Above-ground biomass represents important pool of nutrients in the frame of nutrient cycle of observed forest ecosystems.

- Forest-floor contains low amount of $\mathrm{Ca}$ and $\mathrm{Mg}$ under observed stands regardless of different history, i.e. both on sites with removal of former forest-floor before planting (larch stand) and on sites with continual forest-floor (blue-spruce and birch). Only exception was found under larch stand for content of $\mathrm{Mg}$ in forest-floor but it was probably caused by previous liming.

- Dry mass of annual litter-fall (2-5 tha $\left.{ }^{-1}\right)$ is comparable with the results observed in similar stands in other undisturbed sites. Nutrients N, P, and K from annual litter-fall represent $1-3 \%$ compared to total nutrient stock in forest-floor. In the case of larch stand creating a new forest-floor these values were higher for $\mathrm{N}$ and $\mathrm{K}$ (14-16\%). On the other hand amount of $\mathrm{Mg}$ in litter-fall represents 3-7\% compared to amount in forest-floor. For $\mathrm{Ca}$, results were different. Under birch stand about $8 \%$ of $\mathrm{Ca}$ was returned by annual litter-fall. For larch stand (removal of forest-floor before planting) this value reached $35 \%$. Under blue spruce stand, amount of Ca from annual litter-fall was even about $87 \%$ higher compared to total nutrient stock in forest-floor.

- The removal of biomass for chipping in areas previously degraded by acid deposition may result in the deficiency of $\mathrm{Ca}$ and $\mathrm{Mg}$ because of their important content in aboveground biomass (and consequently in litter-fall) and low content in forest soil.

- Thinning and removal of some parts of trees (mainly stems) for chipping could be possible way in above-mentioned stands, because thinning supports the faster growth of trees left after thinning and consequently faster biomass and nutrient accumulation.

Our results about possible risk of removal of total above-ground biomass in some formerly damaged localities can be interesting and usable in the frame of common investigation of biomass. For further investigation of the effect of biomass removal on nutrient cycle in forest ecosystems mainly in the localities with damaged soils, more detailed (and replicated) analyses are needed (especially focused on below-ground biomass and nutrient content in lower soil horizons).

\section{Acknowledgment}

This study was supported by the long-term project of the Czech Ministry of Agriculture MZE-0002070203 "Stabilisation of forest functions in anthropically disturbed and changing environmental conditions" and NAZV QH91072 "Role of tree species and silviculture measures in forest soil formation". 


\section{References}

Balcar, V. \& Kacálek, D. (2003). Výzkum optimálního prostorového uspořádání bukových výsadeb při přeměnách porostů náhradních dřevin v Jizerských horách. Zprávy lesnického výzkumu, Vol. 48, pp. 53-61, ISSN 0322-9688

Berg, B. \& Meentemeyer, V. (2001). Litter fall in some European coniferous forests as dependent on climate: a synthesis. Canadian Journal of Forest Research, Vol. 31, pp. 292-301, ISSN 1208-6037

Bille-Hansen, J. \& Hansen, K. (2001). Relation between defoliation and litterfall in some Danish Picea abies and Fagus sylvatica stands. Scandinavian Journal of Forest Research, Vol. 16, pp. 127-137, ISSN 0282-7581

Burrows, S. N.; Gower, S. T. ; Norman, J. M. ; Diak, G. ; Mackay, D. S. ; Ahl, D. E. \& Clayton M. K. (2003). Spatial variability of aboveground net primary production for a forested landscape in northern Wisconsin. Canadian Journal of Forest Research, Vol. 33, pp. 2007-2018, ISSN 1208-6037

Chroust, L. (1993). Asimilační biomasa smrku (Picea abies) a její fotosyntetický výkon. Lesnictví-Forestry, Vol. 39, pp. 265-272, ISSN 1212-4834

Chroust, L. \& Tesařová, J. (1985). Quantification of aboveground components of 20 years old Norway spruce (Picea abies (L.) Karsten). Communicationes Instituti Forestalis Čechosloveniae, Vol. 14, pp. 111-126, ISSN 1211-2992

Dušek, D.; Slodičák, M. \& Novák, J. (2009). Výchova smrkových porostů a tvorba horizontů nadložního humusu - experiment Vrchmezí v Orlických horách. Zpráoy lesnického výzkumu, Vol. 54, No. 4, pp. 293-299, ISSN 0322-9688

Eriksson, H. M. \& Rosen, K. (1994). Nutrient distribution in a Swedish tree species experiment. Plant and Soil, Vol. 164, pp. 51-59, ISSN: 0032-079X

Gower, S. T.; Grier, C. C.; Vogt, D. J. \& Vogt, K. A. (1987). Allometric relations of deciduous (Larix occidentalis) and evergreen conifers (Pinus contorta and Pseudotsuga menziesii) of the Cascade Mountains in central Washington. Canadian Journal of Forest Research, Vol. 17, pp. 630-634, ISSN 1208-6037

Hansen, K.; Vesterdal, L.; Schmidt, I. K.; Gundersen, P.; Sevel, L.; Bastrup-Birk, A.; Pedersen, L. B. \& Bille-Hansen, J. (2009). Litterfall and nutrient return in five tree species in a common garden experiment. Forest Ecology and Management, Vol. 257, pp. 21332144, ISSN: 0378-1127

Johansson, T. (2007). Biomass production and allometric above- and below-ground relations for young birch stands planted at four spacings on abandoned farmland. Forestry, Vol. 80, pp. 41-52, ISSN 0015-752X

Komlenović, N. (1998). The impact of the conifer plantations on the formation and chemical properties of the organic and humus accumulating horizon of Luvisol. Radovi Šumarskog instituta Jastrebarsko, Vol. 32, pp. 37-44, ISSN: 0351-1693

Li, M. H.; Yang, J. \& Kräuchi, N. (2003). Growth responses of Picea abies and Larix decidua to elevation in subalpine areas of Tyrol, Austria. Canadian Journal of Forest Research, Vol. 33, pp. 653-662, ISSN 1208-6037

Novák, J. \& Slodičák, M. (2004). Structure and accumulation of litterfall under Norway spruce stands in connection with thinnings. Journal of Forest Science, Vol. 50, No. 3, pp. 101-108, ISSN 1212-4834 
Novák, J. \& Slodičák, M. (2006a). Možnosti ovlivnění stability náhradních porostů smrku pichlavého (Picea pungens Engelm.), Proceedings of National Scientific Conference Lesnický výzkum v Krušných horách, pp. 347-357, ISBN 80-86461-66-1, Teplice, Czech Republic, April 20, 2006

Novák, J. \& Slodičák, M. (2006b). Development of young substitute larch (Larix decidua Mill.) stands after first thinning. Journal of Forest Science, Vol. 52, No. 4, pp. 147-157, ISSN 1212-4834

Novák, J.; Slodičák, M. \& Dušek, D. (2011). Aboveground biomass of substitute tree species stand with respect to thinning - European larch (Larix decidua Mill.). Journal of Forest Science, Vol. 57, No. 1, pp. 8-15, ISSN 1212-4834

Podrázský, V.V.; Remeš, J. \& Ulbrichová, I. (2003). Biological and chemical amelioration effects on the localities degraded by bulldozer site preparation in the Ore Mts. - Czech Republic. Journal of Forest Science, Vol. 49, pp. 141-147, ISSN 12124834

Slodičák, M. \& Novák, J. (2001). Thinning of substitute stands of birch (Betula sp.) and blue spruce (Picea pungens) in an air-polluted area of the Ore Mts. Journal of Forest Science, Vol. 47, Special Issue, pp. 139-145, ISSN 1212-4834

Slodičák, M. \& Novák, J. (2008). Nutrients in the aboveground biomass of substitute tree species stand with respect to thinning - blue spruce (Picea pungens Engelm.). Journal of Forest Science, Vol. 54, No. 3, pp. 85-91, ISSN 1212-4834

Šika, A. (1976). Růst smrku pichlavého v lesních porostech. Zprávy lesnického výzkumu, Vol. 22, pp. 8-12, ISSN 0322-9688

Šrámek, V.; Slodičák, M.; Lomský, B.; Balcar, V.; Kulhavý, J.; Hadaš, P.; Pulkráb, K.; Šišák, L.; Pěnička, L. \& Sloup, M. (2008a). The Ore Mountains: will successive recovery of forests from lethal disease be successful? Mountain Research and Development, Vol. 28, No. 3/4, pp. 216 - 221, ISSN 0276-4741

Šrámek, V.; Kulhavý, J.; Lomský, B.; Vortelová, L.; Matějka, K.; Novotný, R. \& Hellebrandová, K. (2008b). Návrh opatření k udržení a zlepšení stavu lesních půd [Proposal on the sustainability and improvement of the properties of forest soil], In: Lesnické hospodaření v Krušných horách. M. Slodičák et al. (Eds.), 13-28, Lesy České republiky, ISBN 978-80-86945-04-0, Výzkumný ústav lesního hospodářství a myslivosti 978-80-86461-91-5, Hradec Králové, Strnady, Czech Republic

Ulbrichová, I.; Podrázský, V. \& Slodičák, M. (2005). Soil forming role of birch in the Ore Mts. Journal of Forest Science, Vol. 51, Special issue, pp. 54-58, ISSN 1212-4834

Uri, V.; Lohmus, K.; Ostonen, I.; Tullus, H.; Lastik, R. \& Vildo, M. (2009). Biomass production, foliar and root characteristics and nutrient accumulation in young silver birch (Betula pendula Roth.) stand growing on abandoned agricultural land. European Journal of Forest Research, Vol. 126, pp. 495-506, ISSN $1612-4669$

Varik, M.; Aosaar, J. \& Uri, V. (2009). Biomassi produktsioon jänesekapsa kasvukohatüübi arukaasikutes. Forestry Studies/Metsanduslikud Uurimused, Vol. 51, pp. 5-16, ISSN 1406-9954 
Viewegh, J.; Kusbach, A. \& Mikeska, M. (2003). Czech forest ecosystem classification. Journal of Forest Science, Vol. 49, pp. 85-93, ISSN 1212-4834

Vyskot, M. (1980). Bilance biomasy hlavních lesních dřevin. Lesnictví, Vol. 26, pp. 849-882, ISSN 1212-4834 


\title{
Invasive Plant Species and Biomass Production in Savannas
}

\author{
John K Mworia \\ School of Biological Sciences, University of Nairobi \\ Kenya
}

\section{Introduction}

Savannas are the second largest biome accounting for c. $30 \%$ of terrestrial production. Tropical savannas are distributed largely in Africa, Australia and South America occurring between tropical forests and deserts. It is the coexistence of trees and grasses that make savannas unique. The structure of savannas or the ratio of trees to grasses which has important implications on ecosystem productivity is determined by resource availability (rainfall and soil nutrients) and disturbances (fire and herbivory) also referred to as 'drivers'. Resources influence the distribution and productivity of savanna vegetation while fire can alter vegetation structure via effects on the woody layer. Herbivory influences savannas structure and composition through its effects on nutrient cycling, seed dispersal and physical defoliation effects and may lead to expansion of the shrub layer. While ecologists agree the four drivers determine tree-grass balance the exact mechanisms are still debated with one school of thought emphasizing the importance of resources as 'primary determinants' in what are referred to as 'competition models' which basically invoke the classic niche separation mechanisms in resource acquisition. The other school of thought referred to as 'demographic bottleneck models' emphasizes the role of disturbances as the primary determinants through their effects on life history stages of trees. It's been shown however that at low levels of mean annual rainfall, precipitation governs the cover of trees and above a critical value disturbances prevent trees from forming a closed canopy.

Invasive species are considered to be non-native species that have been introduced outside their normal range and are expanding in range causing ecological and economic harm and can drastically alter the structure and composition of savannas. Most non-native species introduced in savannas were for well intended commercial and ecological purposes such as pasture and fodder improvement or rehabilitation of degraded areas. Even though patterns of invasion can not be easily generalized, a trend is that African $\mathrm{C}_{4}$ grasses such as Melinis minutiflora and Andropogon gayanus make up the most obnoxious invaders in the South American and Australian savannas while in contrast neotropical trees and shrubs are among the most successful invaders of African and Australian savannas such as Prosopis spp and Lantana camara. Ecologists have persistently attempted to answer the question 'what makes a community susceptible to invasion'? Plant characteristics of the invader is an important factor, plants introduced in savannas for improvement of pasture/fodder are generally selected for aggressiveness/competitiveness compared to native species. Selected shrubs for example tend to have fast growth, easy to propagate and often $\mathrm{N}$ fixers while grasses 
display aspects of higher resource use efficiency and greater tolerance to grazing. Ecological disturbances such as heavy grazing can destroy native vegetation and favor unpalatable invaders through effects on resource availability. Among other factors thought to enhance invasibility is climate change and its synergistic interactions with elevated $\mathrm{CO}_{2}$ since most invasive species have traits that allow them to respond strongly to elevated $\mathrm{CO}_{2}$.

Productivity levels of savannas are on a broad scale related to the relative proportion of trees to grasses while precipitation is the most important factor with an almost linear relationship to biomass production. Gaps and inconsistencies in savanna Net Primary Productivity data collected over the years make spatial and temporal comparison difficult. This paucity arises from the 'evolution' of methodologies in Net Primary Productivity (NPP) determination from the earlier commonly used 'peak biomass' methods that grossly underestimated NPP, through improvements incorporated in International Biological Programme (IBP) studies in the 1970's to further refinements in the United Nations Environmental Programme (UNEP) grassland studies that made corrections for a wide range of losses during the growth phase previously unaccounted for. Further gaps in data are because most savanna productivity studies have focused on single species within the community of study or lumped several species and rarely included both tree and grass components. Comparison of non-native and native species prior to introduction was often made through screening trials where the fodder trees were largely evaluated for productivity, digestibility, nutritional value and soil amelioration among others. Selected non-native woody species invariably had superior performance in growth parameters e.g Prosopis juliflora produced up to $188 \%$ more in aboveground biomass than the valuable indigenous Acacia tortilis in Senegal. Many screening trials also showed that despite slow growth native tree species in most trials had other positive attributes and not all were outperformed by non-natives and moreover only a small proportion of selected non-natives became invasive. African $\mathrm{C}_{4}$ grasses introduced in the neotropics and Australia on account of higher productivity have also altered fire regimes, hydrology and nutrient cycling for example Andropogon gaynus invasion in Australia which can lead to a biomass load of over $300 \%$ compared to native species but has resulted in fires eight times more intense on average. Invasive herbs just like grasses and trees can have negative impacts such as the biannual unpalatable Ipomoea hildebrandtii which depresses native grass biomass production in addition to changes in site hydrologic and nutrient dynamics patterns.

Can invasive species in savannas increase carbon sequestration? Given the rapid increase in coverage of invasive species e.g Prosopis juliflora is already estimated to cover 500,000 and 700,000 ha in Kenya and Ethiopia while vast areas in Columbia, Venezuela, Brazil and Australia are dominated by higher yielding African $C_{4}$ invasive grasses. An assessment of several studies in forests, grasslands and wetlands showed that ecosystem productivity was higher in invaded ecosystems. In savannas above ground carbon (C) stocks increases as the proportion of trees increases relative to grasses. Soil carbon constitutes over two-thirds of the global carbon found in terrestrial ecosystems. Net soil carbon stock in savannas is regulated by inputs from primary productivity and heavy losses due to herbivory and fire. It follows alteration of the $\mathrm{C}$ and $\mathrm{N}$ cycles by invasive species can vary carbon sequestration. Alteration of the $\mathrm{C}$ cycle components in savannas is attributed to differences in ecophysiological traits between the invasive and indigenous species. Some invasive species traits that lead to increased sequestration include faster relative growth, deep rooting, herbivore defense traits, faster litter decomposition and $\mathrm{N}$ fixation. However not all invasive species have these traits some decrease sequestration by depressing $\mathrm{N}$ mineralization and 
having lower litter decomposition, more studies to enable the quantification of this process in savannas are required.

\section{Savannas}

\subsection{What are savannas?}

Globally savannas the second largest biome, covering one-sixth of the land surface and accounting for c. $30 \%$ of the primary production of all terrestrial vegetation. Africa has the largest savanna occupying about $50 \%$ of the continent or about 15.1 million $\mathrm{km}^{2}$ (Grace et al., 2006). Substantial areas of savanna also cover India, Australia, Southeast Asia, Central America and Pacific islands. Tropical savannas occur in the transition between the tropical rainforests and the deserts where rainfall is inadequate to support forests. Savannas are home to about a fifth of the global human population and a large proportion of the world's ungulates both wildlife and livestock (Foxcroft et al., 2010). The term neotropics or neotropical zone includes South and Central America, the Mexican lowlands, the Caribbean islands, and southern Florida, because these regions share a large number of plant and animal groups

The climate of savannas is warm year-round, and has two distinct seasons, wet (summer) and dry (winter). Most of the rainfall is received in the summer. The length of the rainy and dry seasons generally varies with distance from the equator. In savannas near the equator the dry season is 3-4 months while closer to the desert it's longer lasting 8-9 months. The annual average rainfall in savannas ranges from 500 to $1500 \mathrm{~mm}$. Fires started are by lightning or pastoralists are a common and natural part of the savanna ecosystems.

The physiognomy of savanna vegetation consists of a diverse range of tee-grass mixtures, different species of perennial grasses and sedges, trees, woody plants and shrubs with the herbaceous cover relatively continuous and woody cover discontinuous (Frost et al., 1986). It is the coexistence and close interaction of herbaceous and woody species that makes savannas unique. Plants of the savanna biome have diverse mechanisms of adaptation to drought and fire. Some of these include drought evasion as annuals, dormancy in the dry season, small sizes, slow growth and extensive root systems. Most trees also have deep roots, thick fire-resistant barks while those in African savannas often have spines to protect them from browsing herbivores.

Its acknowledged that grazing ecosystems consisting of savannas and grasslands support more herbivore biomass than any other terrestrial habitat and that there is a long history of coevolution of plants and herbivores due to their coexistence of tens of millions of years from the late Mesozoic (Frank et al., 1998). The stability of such coexistence has been attributed to the regular migration of large ungulate herbivores in response to spatial and temporal variation in resources as well as the positive feedback of grazing intensity and fire on primary productivity and fertility (Holdo et al., 2007; Frank et al., 1998).

\subsection{South American savannas}

Savanna ecosystems in South America occur in Brazil, Venezuela, Columbia and Bolvia covering about 269 million hectares (ha.) Cerrados of Brazil are the largest (76\%), about $11 \%$ (28 million ha) form the Venezuelan Llanos and remaining Columbian Llanos (WWF, 2007). The llanos ecoregion covers a large elongated area beginning at the foothills of the Oriental Andes of Colombia and extending along the course of the Orinoco River. This ecoregion has a typical savanna climate characterized by two well-defined seasons a wet season between 
April and November and an intense drought 3 to 5 months long between December and April. The Llanos have typical savanna physiognomy consisting of an open tree layer and a continuous herbaceous layer. The ratio of trees to grasses increases with soil water availability during the dry season. The Cerrado vegetation occupies more than 2 million $\mathrm{km}^{2}$ in the central part of South America with formations ranging from open shrub savanna (campo sujo), through open savanna (campo cerrado) to tree dominated savanna (cerrado sensu stricto).

A major threat to South American savannas is conversion to croplands with most of it in the Brazilian Cerrados. Livestock production is the main activity and is responsible for changes arising from activities such as the regular use of fire and clearing of forests to increase native pasture coverage and quality. Invasive species are also an important threat especially $\mathrm{C}_{4}$ aggressive grasses introduced from Africa that include Melinis minutiflora, Hyparrenia rufa, Panicum maximum and Brachiaria mutica.

\subsection{Australian savannas}

Tropical savannas in Australia cover almost one-quarter of the continent ranging from Rockhampton on the East Coast, across the Gulf, Top End and over to the Kimberley in Western Australia (Tropical Savannas CRC). The climate consists of a distinct wet and dry season just like other savannas. The wet season occurs December to March while the dry Season is May to August. The average rainfall declines from the coastal north to the inland south.

Vegetation composition and structure is strongly associated with soil attributes such as texture, the rainfall gradient and geological factors. However in general the vegetation is dominated by Eucalyptus species in the overstorey, a shrub layer of species such as Acacia cinocarpa and an herbaceous layer of annual and perennial $C_{4}$ grasses (Setterfield, 2002). Fires are an important modifier of vegetation structure and composition in the northern savannas. This because savannas further north are inherently predisposed to regular and frequent fires due to higher rainfall which allows higher cover and height of grasses and higher litter from woodland trees all providing more fuel. Further south fires are less common due lower fuel loads due to the open landscapes, less rain fall and further reduction by grazing cattle.

The major land use of Australian tropical savannas is by the cattle industry other uses include mining, wildlife conservation and Aboriginal land. Among the major threats are invasive species including Mission grass (Pennisetum polystachion) and gamba grass (Andropogon gayanus) which have invaded vast areas, greatly increasing fuel loads and leading to more destructive fires. Changes in fire patterns in northern Australian have been linked to climate change and the spread of invasive grasses in particular Andropogon gayanus( Rossiter et al., 2003)

\subsection{African savannas}

Africa contains by far the largest area of savanna with some estimates at $65 \%$ of the continent (Huntley \& Walker, 1982). Tropical savannas form a semicircle around the western central rainforest areas, bordered by the desert zones to the north and south. Several classification systems for savannas in African have been used, mainly based on climate and physiognomy. The bioclimatic classification mainly based on Phillips (1959 quoted in Ker 1995) presented by Ker (1995) distinguishes 4 broad savanna zones and shows the importance of the rainfall gradient on savanna physiognomy (Table 1). 


\begin{tabular}{|l|l|l|l|l|}
\hline \multirow{2}{*}{$\begin{array}{l}\text { Bioclimatic } \\
\text { zone }\end{array}$} & \multicolumn{2}{|l|}{ Equivalent ecological region } & Mean annual \\
\cline { 2 - 4 } & West Africa & $\begin{array}{l}\text { Eastern and } \\
\text { southern Africa }\end{array}$ & $\begin{array}{l}\text { Length of growing } \\
\text { season (days) }\end{array}$ \\
\hline Arid savanna & $\begin{array}{l}\text { Southern } \\
\text { Sahelian }\end{array}$ & Acacia woodland & $300-600$ & $60-90$ \\
\hline $\begin{array}{l}\text { Subarid } \\
\text { savanna }\end{array}$ & Sudanian & $\begin{array}{l}\text { Southern miombo } \\
\text { woodland }\end{array}$ & $600-900$ & $90-140$ \\
\hline $\begin{array}{l}\text { Subhumid } \\
\text { savanna }\end{array}$ & $\begin{array}{l}\text { Northern } \\
\text { Guinean }\end{array}$ & $\begin{array}{l}\text { Northern miombo } \\
\text { woodland }\end{array}$ & $900-1200$ & $140-190$ \\
\hline $\begin{array}{l}\text { Humid } \\
\text { savanna }\end{array}$ & $\begin{array}{l}\text { Southern } \\
\text { Guinean }\end{array}$ & Derived savanna & $1200-1500$ & $190-230$ \\
\hline
\end{tabular}

Note: Adapted from Ker(1995)

Table 1. The bioclimatic zones of African savannas

In the context of invasion ecology African savannas show variation in two attributes from those of South America and Australia in respect to herbivory and its impacts. Firstly they have been characterized by high grazing intensity due to large herds of a variety of species including substantial numbers of mega-herbivores and bulk grazers in contrast to Australia where the largest indigenous grazers were the eastern grey and red kangaroos and South America which lacked large congregating grazers (Foxcroft et al., 2010; Klink 1994). As a consequence African grasses are hypothesized to have evolved traits that contribute to their higher competitive potential compared to native species of Australia or South American savannas. Some of which include greater compensatory re-growth after defoliation, higher carbon assimilation rate and nitrogen use efficiency and higher opportunistic water use (Baruch \& Jackson, 2005).

Secondly the African savannas harbor vast pastoral tribes with huge livestock populations that coexist with wildlife. This is because even though protected areas such as National parks are the main vehicles of wildlife conservation they do not encompass all wildlife and their migratory patterns. As such the largest proportion of wildlife is outside the protected areas system in what is referred to as dispersal areas. In these areas wildlife, livestock and human settlements exist in interrelationships that create complex spatial variations in disturbance patterns. For example Mworia et al. (2008a) found that in areas occupied largely the Maasai pastoralists adjacent to Amboseli and Chyulu wildlife reserves in Kenya that wildlife movement and distribution was primary determined by vegetation type and distribution of seasonal water resources while important secondary modifiers were human settlement density, livestock density and cultivation intensity. Disturbances as we shall see below increase the vulnerability of communities to invasion.

\subsection{Determinants of savanna structure}

We have seen that savannas are characterized by two contrasting life forms, trees and grasses. How do they coexist without one eliminating the other? Ecologists agree that resources (rainfall and nutrients) and disturbances (fire and herbivory) are the key determinants or 'drivers' of savanna structure and function (Sankaran et al., 2004). But the mechanisms by which these drivers regulate tree-grass mixtures are still debated some theories emphasize the role of competition in niche separation for limiting resources. Others 
models highlight the role of demographic mechanisms where dissimilar effects of the drivers on life-history stages on trees allow the persistence of tree-grass mixtures. As we shall see below the ratio of trees to grasses greatly influences savanna ecosystem productivity.

Rainfall determines the supply of water, but the amount that is subsequently available to plants is subject to aspects of drainage and storage such soil texture and compaction, topography, vegetation cover and losses due to evaporation and evapotranspiration. Spatial and temporal variation of rainfall in savannas is high and increases with aridity with many areas experiencing regular droughts which can be a primary cause of vegetation compositional changes (Ellis \& Swift, 1988). In general linear relationships have been found between biomass and precipitation and productivity and days of water stress (House \& Hall, 2001). Years of high rainfall favor tree recruitment and growth over grasses while drought periods limit tree recruitment and growth (Sankaran et al., 2004)

Soil nutrients are generally limiting since most tropical savanna soils are derived from old, highly-weathered acid crystalline igneous rock leading to leached sandy soils with low fertility and CEC. In particular Low nitrogen and phosphorous availability constrain many savanna ecosystems (House \& Hall, 2001). Soil water influences the availability of nutrients to plants in that nutrient mineralization, transport and root uptake are all dependent on soil water content.

Fire has been traditionally used by pastoralists and ranchers as a management tool in savannas to increase pasture and combat bush encroachment. This is because woody meristems within the flame zone $(<5 \mathrm{~m})$ are generally more exposed to fire damage than grass meristems and the latter can recover more efficiently in the short term (Trollope, 1974 quoted in Scholes \& Archer, 1997). Frequent fires therefore favour grasses and suppress the recruitment of mature woody plants. Fire and grazing can have interactive effects on savanna structure whereby low grazing pressure allows the accumulation of high grass biomass which can affect tree biomass and population by fueling intense fires. Heavy browsing helps to keep woody plants within the flame zone thus a strong grazer-browserfire interaction influences tree-grass mixtures (Scholes \& Archer, 1997).

Herbivory consists of grazing and browsing by wildlife and domestic herbivores. Herbivores influence structure and composition through selective feeding and physical effects of defoliation. Heavy browsing pressure especially by mega herbivores such the elephant may compromise the viability of some woody plant populations, resulting in community changes coupled with a possible loss of species diversity and structural diversity. On the other hand herbivory plays a significant role in nutrient cycling, seed dispersal and creation of microsites and space thus enhancing shrub recruitment.

\subsection{Models to explain savanna structure}

Ecologists have hypothesized several models through which resources (moisture and nutrients) and disturbances (fire and herbivory) regulate savanna structure. Models that explain the co-existence of trees and grasses in savannas can broadly be divided into 'competition models' and 'demographic bottleneck models'. Competition-based models apply the classic niche-separation mechanisms of coexistence whereby differences in the resource-acquisition potential of trees and grasses is the fundamental process structuring savanna communities. Importantly in competition models the resources (water and nutrients) are considered the 'primary determinants', while the disturbances (fire and grazing) represent 'modifiers'. Some competition models include; the root niche separation 
model, the phenological niche separation model and the balanced competition model. The root niche separation model is the classic equilibrium model of savannas proposed by Walter (1971). It assumes that water is the primary limiting factor and trees and grasses have differential access with trees having an almost exclusive access to that in the lower soil horizons due to deep roots while grasses have more access to that near surface. This model therefore predict trees should be advantaged on sandy soils of low water-holding capacity and under wetter climates grasses would be favoured on soils of high water-retention such clays and arid environments.

In demographic bottleneck models disturbances are the primary focus unlike competition models. The direct effects of these disturbances on germination, mortality and demographic transition in trees determine the structure rather than any post-disturbance competitive interactions. Effects of savanna drivers; herbivory, fire and moisture variability are incorporated in most demographic models with differences only in how the model results have been interpreted. For example one views the savannas as transitional 'disequilibrium' systems where pure grasslands or forests are believed to be the only equilibrium states with disturbances such as fire and grazing permitting savannas to persist in a disequilibrium state preventing complete shifts to either state (Jeltsch et al., 2000). An alternate view interprets savanna structure to be driven by rainfall variation where trees are assumed to be limited by drought at the seedling stage and by fires at the sapling stage (Higgins et al., 2000)

In comparing the models empirical studies show that support for and against both competitive and demographic mechanisms leaving definitive conclusion on the relative importance of resource limitation versus disturbances in controlling savanna structure unresolved (Scholes \& Archer, 1997; Jeltsch et al., 2000; Sankaran et al., 2004). However using very extensive data on African savannas Sankaran et al. (2005) showed that rainfall was the most important factor in tree-grass balance below annual mean of $650 \mathrm{~mm}$ with woody component increasing linearly with rainfall. Above a mean annual rainfall of $650 \mathrm{~mm}$ disturbances played a greater role in the balance by preventing the woody canopy from closing and therefore allowing grasses to coexist.

\section{Invasive plant species in savannas}

\subsection{Definition and distribution in savannas}

Physical barriers such as oceans, river valleys and mountains present boundaries to the movement of individuals of the same species populations. This eventually led to the formation of unique species from the separated populations through drift and selection thus the emergence of native populations. However since human beings developed the ability to move across continents they have enabled species breach geographical barriers hence introduced species. The history and socio-economic development of mankind is strongly associated with human-aided movement of plants and animals.. Many of the crops that sustain the human race today are introduced species. In general most plant species have been introduced intentionally with good intentions such as food crops, medicinal plants, livestock fodder, forestry or agro-forestry species. Most of these species depend on humans for their continued propagation after introduction however some have become pests or invaders.

The term 'non-native' species is used for species that have been moved outside their normal geographic range regardless of their impact to native ecosystems. Non-native species also 
includes those that have expanded beyond their native range via human actions even though still in their native continents but sometimes cause substantial harm to ecosystems they enter (Lockwod et al., 2007). The term 'invasive species' describes non-native species introduced from a different area, often a different continent which becomes established, increases in density and expands rapidly across the new habitat (Myers \& Bazely, 2003) causing ecological and economic harm or what some scientists describe as 'large environmental impacts' (Davis et al., 2000). In invasion ecology literature several and often confusing terms are frequently used interchangeably such as non-indigenous, exotic and alien to refer to non-native species.

Over the course of human civilization thousands of plant species have been moved across geographic barriers however only a very small proportion of these non-native species have become invasive. Most non-native species depend on humans for their continued propagation after introduction while others have become naturalized. Naturalized species refers to non-native species that reproduce consistently and maintain their populations over many life cycles without direct intervention of by humans but do not necessarily invade natural ecosystems or become overly abundant and damaging (Richardson et al.,2000; Myers \& Bazely, 2003). To illustrate the huge numbers of introduced plant species across the globe literature shows that 2100 or $50 \%$ in New Zealand are introduced, in South Africa 8750 or $46 \%$ are introduced, in Chile 690 or $15 \%$ are introduced to give just but a few examples from Myers \& Bazely (2003). Most of these introduced species have spread very little, if at all, beyond their point of introduction and it can therefore not be said that all introduced species are potentially harmful. Indeed it has been estimated that only about $1 \%$ of introduced species become invasive (Groves, 1986 quoted in Binggeli et al., 1998).

While patterns of invasion in savannas can not be definitively drawn, a general trend is that African $\mathrm{C}_{4}$ grasses are among very successful invaders of tropical savannas of Australia and South America. Conversely neotropical shrubs and trees are highly successful invaders of tropics and sub-tropics including savannas of Africa, Australia and pacific islands.

It is noted that in Africa with an exception of South Africa reports and publications on invasive species are few despite the range of potentially invasible habitats, many forms of anthropogenic landuse and high levels of frequent disturbances (Foxcroft et al., 2010). This is partly due to lack of extensive and intensive research and surveys of invasive species.

\subsection{Factors that enhance invasibility in savannas}

Generally the success of a non-native species in establishing and spreading in a new community has been related to its propagule pressure, existence of ecological and anthropogenic disturbances, biological characteristics of the invader and role of climate change(Lockwod et al., 2007; Myers \& Bazelly, 2003). In savannas we noted above that the key determinants of structure are the disturbances fire and herbivory and the resources moisture and nutrients. It is therefore conceivable that a complex interaction is these factors determine the success of an invader in savannas.

Propagule pressure is an indicator that combines the propagule size (number of individuals released), the number of release events and physiological condition of released individuals. The probability of establishment of the invader increases as propagule pressure increases. The importance of this factor is particularly evident where non-native species are introduced in large scale agroforestry, fodder or pasture improvement programmes as compared to limited introduction for example in a botanical garden. High propagule 


\section{WOODY SPECIES}

Lantana camara

Prosopis juliflora, P. glandulosa, P. veltuna

Acacia nilotica

Cecropiap peltata

Chromolaena odorata

Leucaena leucocephala

Maesopsis eminii

Miconia calvescens

Mimosa pigra

Pinus patula

Psidium guajava

\section{GRASS SPECIES}

Melinis minutiflora

Hyparrenia rufa

Panicum maximum

Brachiaria mutica

Andropogon gayanus

Cenchrus ciliaris

Pennisetum polystachion

Themeda quadrivalvis

\section{Life form Native region}

Shrub

Neotropics

Tree

Tree

Tree

Shrub

Neotropics

Africa-India

Neotropics

Small tree Central America

Tree

Africa

Small tree Neotropics

Small tree Neotropics

Tree Neotropics

Small tree Neotropics

$\begin{array}{ll}\text { Grass } & \text { Africa } \\ \text { Grass } & \text { Africa } \\ \text { Grass } & \text { Africa } \\ \text { Grass } & \text { Africa } \\ \text { Grass } & \text { Africa } \\ \text { Grass } & \text { Africa } \\ \text { Grass } & \text { Africa } \\ \text { Grass } & \text { Africa }\end{array}$

Invaded region

All tropics

Africa, Australia, Asia

Australia

Africa, Asia

Africa, Asia

Pacific islands

East Africa

Pacific islands

Australia, Africa

East Africa

Africa, Pacific Islands

South America

South America

South America

South America

Australia, Neotropics

Australia

Australia

Australia

* Adapted from Binggeli et al., 1998, Foxcroft et al.,2010

Table 2. Some of the most invasive species in tropics and sub-tropics

pressure is thought to have been one of factors contributing the invasive success of African $\mathrm{C}_{4}$ grasses introduced in Australia (Lonsdale, 1994) as well as Columbia, Venezuela and Brazil (Williams \& Baruch, 2000) where in both cases they were used pasture improvement. Propagule pressure across habitats in an ecosystem can be enhanced if the invasive species has multiple dispersal agents. For example Mworia et al. (2011) observed that the invader Prosopis juliflora was dispersed by several wildlife and livestock species within the savanna of the upper Tana River floodplain resulting in a significant association between habitat type and disperser type indicating the importance of habitat preference and livestock herding patterns.

Characteristics of non-native species can be an indicator of its potential invasiveness in the new community. Scientists have attempted to find differences in biological characteristics between native and non-native invasive taxa in particular floras. In savannas and tropics in general most introduced plants have a commercial value mainly improvement of pasture and fodder and tend have a general set of characteristics. For example (Binggeli et al.,1998) in an assessment of woody plants introduced in tropics found to them to have fast growth, easy to propagate, often nitrogen fixers and resistant to a variety of biotic and abiotic agents such as pests, drought and fire. Grasses introduced in Australia were generally selected for aggressiveness (Lonsdale, 1994). Even though characteristics that distinguish invasive from 
non-invasive plant are not totally consistent, some patterns are observed; for example fitness over a wide range environments, phenotypic plasticity to exploit new environments, efficient competitors for limiting resources, small and numerous seeds, small genome size, good dispersal ability and no specific mutualisms (Lockwod et al., 2007). In grazing ecosystems of savannas characteristics such as unpalatability, formation of thickets, production of spines and thorns, allelopathy, toxicity to animals and fire tolerance may confer particular advantages.

Ecological disturbance is an event that disrupts the ecosystem and communities leading to changes in resource availability or physical environment (Lockwod et al., 2007). In the 'fluctuating resources hypothesis' by Davis et al., (2000) disturbances may make a community more susceptible to invasion by causing an increase in the amount of unused resources such as light, nutrients, water or space. Fluctuation in resources could be due to a large influx of resources (e.g. unusually rainy years) or reduction in use by resident species (e.g heavy grazing of native species). It is important to note that disturbances create opportunities for both natives and non-natives and for the prevalence of non-natives to increase there must a source of non-native propagule (Lockwod et al., 2007). Lets again take the example of the Prosopis juliflora in savanna floodplain of upper Tana River in Kenya where Mworia et al. (2011) found that ecological disturbance manifested by rested crop fields not only enhanced the establishment of the invader but also had a positive effect on indigenous woody species. Rested crop fields have vegetation and soil disturbance and represent early stages of plant succession. Enhancement of regeneration in native woody species and the invasive Prosopis juliflora in rested and abandoned farms in floodplains in savannas has been reported however the invader eventually becoming dominant (Muturi et al., 2009; Stave et al., 2003; Oba et al., 2002).

Fire is a key ecological disturbance in savannas which can play a role either in suppressing potential invasive plant species that are not tolerant or promoting those that are tolerant. For example Masocha et al. (2010) found that in a long term burning experiment in the mesic savanna of Zimbabwe more non-native plant species became established in plots that had a higher frequency of burning. In the tropical savannas of northern Australia the increased incidence of destructive fires has increased over the last century as result of changes in fire regimes have been partly attributed to climate change and the spread of invasive species such Gamba grass which accumulates high fuel loads (Rossiter et al., 2003). This in turn reduces the recruitment and cover of woody plants and native grass species enhancing its further spread. Herbivory is also a determinant of savanna structure. Herbivory especially at high intensities creates soil disturbances characterized by negative shifts both in soil physical and hydrologic attributes and leads not only to compositional shifts of native plant species but may also increase invasibility by non-native species especially unpalatable ones (Mworia et al., 2008b ).

Climate change promoted by increased atmospheric $\mathrm{CO}_{2}$ is another factor thought to have the potential to enhance the proliferation of invasive species (Sala et al., 2000). The implications of changes in global heat balance on the hydrological cycle include increase in the frequency of heavy rainfall events in terrestrial precipitation, increased variability in relation to individual weather systems such has in El Nino-Oscillation (ENSO) whereby the warm episodes of ENSO have become more frequent, persistent, and intense (Grantz, 2000). This is of particular importance in tropical savannas since many are influenced by the ENSO regime. In East Africa for example the frequency of droughts is predicated to increase (Adger et al., 2003). Of concern to scientists is the possible interactive and synergistic effects 
of climate change and elevated $\mathrm{CO}_{2}$ in promoting the invasion and spread of invasive species (Sala et al., 2000). This is because invasive plants possess traits which allow them to respond strongly to elevated $\mathrm{CO}_{2}$ creating the potential for enhanced dominance and range expansion (Smith et al., 2000 in Lovejoy and Hannah, 2006). Indeed Baruch \& Jackson (2005) found that elevated $\mathrm{CO}_{2}$ increased the competitive potential of invader African $\mathrm{C}_{4}$ grasses (Hyparrhenia rufa and Melinis minutiflora) in relation to germination, seedling size and relative growth rate compared to the dominant native grass Trachypogon plumosus in northern South America.

\section{Biomass productivity}

\subsection{Factors that influence savanna productivity}

We have seen that certain factors referred to as drivers in savannas govern the proportion of tree to grass cover. It follows then that the structural diversity and different mixture of tree and grasses will influence overall ecosystem productivity. Studies in agroecosystems have shown that different combination of multi-species affects the level of NPP. It therefore conceivable that the same applies to savannas especially given that trees and grasses have access to different resources both spatially and seasonally.

The productivity of savannas is, largely attributed water availability occasioned by the generally low precipitation, with pronounced and prolonged dry season. Rainfall determines the amount of water received however infiltration hence the amount eventually available to plants depends on a number of factors including; the slope which is function of topography, soil texture which determines the drainage and water storage capacity, and vegetation cover which determines runoff following rains.

The relationships between biomass and precipitation in savannas, have been found to be almost linear (Scholes et al., 2002) just as that between productivity and days of water stress (House \& Hall, 2001) although from place to place productivity will be strongly affected by biomass burning (Frost, 1996). Rainfall is mostly received in short durations with high intensity. Furthermore as aridity increases its variability also increases making it prime driver of vegetation compositional change. Indeed Ellis \& Swift (1988) argued that in such rangelands also characterized by pastoral herd mobility, droughts are more important in triggering compositional change than herbivore pressure.

Soil attributes in particular the nutrient level and texture has also been related to variability in productivity. However nutrients have been found to account for greater variation in productivity while texture was related to the proportion of productivity related to variation in functional types. In coarse soils forbs and shrubs made up a larger proportion of total productivity as compared to fine-textured sites. Thus across a regional precipitation gradient, soil texture may play a larger role in determining community composition than in determining total ANPP (Lane et al., 1998)

\subsection{Paucity in ecosystem productivity data}

Net primary productivity (Pn) is the total photosynthetic gain, less respiratory losses, of plant matter by vegetation occupying a unit area. Over any one period, this must be equal the change in plant biomass $(\Delta \mathrm{W})$ plus any losses through death $(\mathrm{L})$, both above- and belowground formula: $\mathrm{Pn}=\Delta \mathrm{W}+\mathrm{L}$. Thus $\mathrm{Pn}$ is the measure of amount of plant matter available to consumer organisms. Net primary productivity can be estimated at species or ecosystem level. Historically techniques for estimating biomass and productivity in savannas have 
undergone refinement with time by an enhancement in the number of parameters taken into consideration to improve accuracy. The technique employed can lead to almost five-fold variation in the estimate of tropical grassland production (Long et al, 1989).

The bulk of studies especially prior to the extensive International Biological Programme (IBP) studies of the 1970's (Sigh \& Joshi, 1979) based estimations of net above-ground production on the peak standing dry matter alone and can be referred to as 'peak biomass' methods. The peak biomass method grossly underestimates NPP because it does not account for below ground production neither does it make corrections for mortality during the growing season, growth after peak standing-crop and effects of grazing and trampling. The peak biomass method therefore assumes that no carry over of biomass from one growing season to the next. Milner \& Hughes (1968 quoted in Long et al.,1989) proposed a method for the IBP which measures positive increments in aboveground live biomass referred to as the 'IBP standard method. Similarly in the 'minimum-maximum' approach the residual live material ( $R$ ) which is measured before growth resumes after a dormant period, is subtracted from peak biomass ( Bmax) thus accounting for carry over of biomass $(\mathrm{Pn}=\mathrm{Bmax}-\mathrm{R})$. However like the previous method no correction is made for mortality and disappearance of biomass during the growing season and $\mathrm{Pn}$ is therefore underestimated. To account for the assumptions in both the peak biomass and IBP methods the UNEP study (Long et al., 1992) made corrections for change in biomass for losses due to death, decomposition, root exudation and herbivory. It is evident use of different approaches will lead to quite different estimates of Pn. For example Kinyamario \& Imamba (1992) taking into account mortality and decomposition obtained an NPP $\left(\mathrm{g} \mathrm{m}^{-2} \mathrm{y}^{-1}\right)$ of 1292 and found that the 'standard IBP method' and the 'maximum-minimum' methods both underestimated productivity by 52 and $69 \%$ respectively.

Further gaps in the estimation of savanna ecosystem biomass and productivity arise from the fact that most studies have focused on a single species or have not attempted to separate contributions of various species and few have measured both tree and grass components (House \& Hall, 2001). This may be partly attributed to the difficult nature of conducting harvest based productivity experiments at ecosystem level. However in recent years advances in technology have eased the rigours of ecosystem productivity estimation for example the use of carbon isotopes to estimate the relative contributions of woody and herbaceous vegetation to savanna productivity (Lloyd et al., 2008). This is possible because while most savanna trees have a $C_{3}$ photosynthetic pathway, savanna grasses have mainly of the $\mathrm{C}_{4}$ photosynthetic pathway allowing the comparison carbon isotopic compositions of the plant and carbon pools. Further paucity in ecosystem biomass and productivity data is due to the large heterogeneity in savanna types even within the same region due the wide range in soils and climatic conditions.

\subsection{Ecosystem productivity of savannas}

Approximately $20 \%$ of the world's land surface is covered with savanna vegetation and this biome is responsible for almost $30 \%$ of global net primary production (NPP) and up to $35 \%$ if considered as a grassland- savanna system (Grace et al., 2006). It is apparent from the estimates of total NNP compiled by Grace et al (2006) that tropical savanna and grassland ecosystems constitute the second most productive biome after tropical forests (Table 3). 


\begin{tabular}{|c|c|c|c|c|}
\hline Biome & $\begin{array}{l}\text { NPP (t C ha- } \\
1 \text { year- } 1)\end{array}$ & $\begin{array}{l}\text { Area } \\
\text { (million km2) }\end{array}$ & $\begin{array}{l}\text { Total carbon } \\
\text { pool (Gt C) }\end{array}$ & $\begin{array}{l}\text { Total NPP } \\
\text { (Gt C year-1) }\end{array}$ \\
\hline Tropical forests & 12.5 & 17.5 & 553 & 21.9 \\
\hline Temperate forests & 7.7 & 10.4 & 292 & 8.1 \\
\hline Boreal forests & 1.9 & 13.7 & 395 & 2.6 \\
\hline Artic tundra & 0.9 & 5.6 & 117 & 0.5 \\
\hline Mediterranean shrubs & 5 & 2.8 & 88 & 1.4 \\
\hline Crops & 3.1 & 13.5 & 15 & 4.1 \\
\hline Tropical savanna and grasslands & 7.2 & 27.6 & 326 & 19.9 \\
\hline Temperate grasslands & 3.8 & 15 & 182 & 5.6 \\
\hline Deserts & 1.2 & 27.7 & 169 & 3.5 \\
\hline
\end{tabular}

*Data adapted from Grace et al., 2006,

Table 3. Variation in carbon fixed by vegetation of different biomes, as net primary productivity (NPP). The total C pool includes vegetation and soil organic matter.

So what makes the biomes vary in productivity? Churkina and Running (1998) quantified the relative importance of environmental factors (temperature, water availability and radiation) on NNP of various biomes using a modeling approach with ecosystem process model BIOME-BGC. They found that in the high latitudes temperature appeared to be the primary control on NPP while in the middle latitudes a combination of either temperature and radiation or temperature and water availability limited NPP. In the low latitudes where savannas fall, water availability became more dominant than the other environmental factors. LeBauer and Treseder (2008) found N limitation on NNP to be widespread among biomes except deserts. This is not surprising since climatic variables such as temperature and precipitation also influence nutrient availability through $\mathrm{N}$ mineralization rates and plant $\mathrm{N}$ demand through effects on enzyme activity.

Changes in savannas globally characterized by declining cover due to conversion to agriculture as result of increasing human pressure and encroachment of bush in many grasslands has significant implications on NNP trends. It is therefore surprising that a lot of attention and monitoring (both satellite and ground) is devoted to forests with very little to savannas despite their importance in global NNP (Grace et al., 2006).

\subsection{Comparison of invasive and indigenous species productivity}

Many plant species are introduced into savannas to enhance the nutritional plane of pasture and fodder so as to increase livestock production the main form of land use. Other reasons include provision of fuelwood/charcoal, building material, soil conservation, windbreak, organic manure and others. Various fodder trees play an important role in human food security through their function as animal-feed resources, especially as drought reserves. A major drive to improve pastoral production systems in savannas in 1970-80's by introduction of high yielding fodder tree species aimed at providing a more permanent feed supply over seasons (Nair, 1989). This was informed by the observation that while grasses in savannas produce more edible plant material for livestock they are extremely variable in their production as a result of seasonal fluctuations in rainfall. Extensive trials especially of Prosopis and Leucacena species were subsequently carried in Africa and Australia. The screening of tree species for introduction was normally based on comparative studies between combinations of introduced species and native species for biomass productivity, nutritional value, digestibility, 
soil amelioration and resource requirements. A review of comparative studies consistently indicated the superior performance of South American trees in African and Australia in terms of biomass production. Two examples of trials of non-indigenous and indigenous trees in African savannas are discussed below to illustrate the point.

Deans et al. (2003) working in semi-arid site in Senegal compared 10 year old indigenous and non-indigenous species with some of their provenances being included while Jama et al. (1989) compared growth rates of 29 multipurpose fodder species both indigenous and nonindigenous at 6 year old in a semi-arid savanna climate in Kenya (Table 4).

Species

Senegal trials ${ }^{\mathrm{a}}$

Prosopis juliflora

Acacia aneura

Azadirachta indica

Eucalyptus camaldulensis

Acacia tortilis ssp. raddiana

Acacia nilotica

Prosopis cineuria

Acacia tortilis
Origin

South America

Australia

India

Australia

Native

Native

Australia

Native

Kenya trials ${ }^{b}$

Grevillea robusta

Leucaena leucocephala (Peru)

Casuarina equisetifolia

Acacia saligna

Acacia holosericiceae

Prosopis juliflora

Acacia albida

Acacia salicana

Acacia stulmanii

Zizyphus mauritania

Tamarindus indica

Balanites aegyptica

Acacia tortlilis

Prosopis nigra

Prosopis pallida
Australia

South America

Australia

Australia

Australia

South America

Native

Australia

Native

Native

Native

Native

Native

South America

South America

\section{Leaves $(\mathrm{kg}) \quad$ biomass $(\mathrm{Kg})$}

Total above-ground

\section{2}

141

14.3

15.1

10.7

\section{Height $(\mathrm{cm}) \quad$ Diameter $(\mathrm{dbh}$ in $\mathrm{cm})$}

\section{1}

5.3

4.4

3.9

3.4

3.4

2.9

2.6

2.3

2.3

1.5

1.4

1.3

1.3

1.3

\section{8}

5.2

Data adapted from;

a Senegal data adapted from Deans et al. (2003). Only species for which above ground and leaves biomass was available were included

${ }^{b}$ Kenya data adapted from Jama et al. (1989). Only woody perennials and one provenance of leucanea leucocephala were included

Table 4. Estimated growth parameters for trials on native and non-indigenous species in Senegal and Kenya 
From their results a number of conclusions can be drawn.

a. Non-native species largely neotropical ones had superior performance in growth parameters (above ground biomass, height, bole volume, and leaf biomass) than the indigenous ones tested. As shown by the higher above ground biomass of Prosopis juliflora, Acacia aneura and Azadirachta indica as compared to native Acacia tortililis, Acacia raddiana and Acacia nilotica in Senegal while in Kenya the non-native Grevillea robusta, leucanea leucocephala and Casuarina equesitifolia attained the highest maximal height and the indigenous species such as Acacia tortilis, Balanites aegyptica and Tamarindus indica showed the minimal growth

b. Not all non-native species out perform native species, for example the Prosopis cineuria and Prosopis pallida in Senegal and Kenya respectively. This could be due unsuitable ecological conditions thus even though Prosopis. pallida is regarded to be amongst the most productive species in arid and semi-arid zones in biomass (Pasiecznik 2001) the Kenya site was way above its altitude and rainfall range.

c. Despite slow growth some native species had some positive qualities in comparison to non-native e.g. the indigenous Acacia tortilis and Acacia raddiana had the highest concentrations of $\mathrm{N}$ in their leaves while the non-native species Eucalyptus camaldulensis and Acacia aneura had the least

d. Only a small fraction of non-native species are actually invasive, e.g. of the species tried in these two examples only Prosopis juliflora and Prosopis pallida are invasive.

African grasses introduced in the South American and Australian savannas and turned invasive have altered biomass production patterns, fire regimes, hydrology, nutrient cycling, native community composition and structure. Ecological disturbances that minimize the competitive ability of native grasses or cause soil disturbances are important at some stage of invasion in most cases. Non-native gasses can depress biomass and cover of native species if they have rapid growth thus diminishing light at the soil surface and consequently reducing the photosynthetic ability of competitors. Efficient water use is also another way non-native grass species can out compete native grasses while others have also been shown to compete effectively with native species for soil nutrients (D'Antonio \& Vitousek, 1992). For example the non-native gamba grass (Andropogon gayanus) in northern Australia tropical savannas grows faster, forms taller and denser stands than native grasses resulting in an accumulation of biomass to the range of 11-15 tonnes/ha and may be as high as 30 tonnes/ha compared to 2-4 tonnes/ha of native species (Rossiter et al., 2003; Williams et al., 1998). This indicates a more than $300 \%$ production by the invasive species compared to native species. This high biomass accumulation greatly alters the fire regimes supporting fires that are about 8 and almost 25 times more intense in the early dry season and late dry season respectively (Rossiter et al., 2003). More intense fires have consequences on native species composition and abundance. In South America cerrado region the African grass, Melinis minutiflora, a $\mathrm{C}_{4}$ stoloniferous grass, is one of the most problematic aggressive invaders forming dense mats that exclude many other herbaceous species. A manipulative experiment by Barger et al (2003) to test effects of disturbance showed that soil disturbance strongly enhanced its growth increasing biomass 7 fold while clipping to simulate grazing increased biomass 13 fold.

It is not only invasive grasses that depress biomass production of local grasses, in Africa Mworia et al. (2008b) found that the invasive herb Ipomoea hildebrantii led to a decline of $47 \%$ in absence of grazing and $28 \%$ in the presence of grazing. Invasibility by Ipomoea hildebrandtii increases when lowered competition from indigenous grasses was accompanied by 
increases in soil resources. Hence establishment of Ipomoea hildebrandtii was higher in conditions of low indigenous grass biomass, high soil moisture at a depth of $30 \mathrm{~cm}$ and higher soil $\mathrm{N}$ nitrification (Mworia et al., 2008b). Therefore in both the successful establishment of invasive grasses in South America and the invasive herb in Africa the important role of disturbance, grazing and resource supply changes are evident alluding to the applicability of the resource fluctuation hypothesis.

\section{Carbon sequestering potential of invasive species}

Carbon sequestering is the process of removing carbon from the air into reservoirs such as such as terrestrial ecosystems via photosynthesis. When carried out deliberately carbon sequestration it is a strategy for long-term storage of carbon dioxide released mainly by burning of fossil fuels hence mitigate or deferring global warming mainly. Invasive species have spread to large areas of savanna ecosystems and increased plant density and biomass in some degraded or disturbed areas and even in some cases undisturbed communities. For example in East Africa Prosopis juliflora is already estimated to cover 500,000 and 700,000ha in Kenya and Ethiopia, respectively in mainly the arid and semi-arid savannas while in Venezuelan savannas invasive African grasses have increased biomass by up to $50 \%$ (Brooks et al., 2004). In Columbia, Venezuela and Brazil 4 million $\mathrm{km}^{2}$ were transformed to pasture by using, to a large extent, African $C_{4}$ grasses (Williams \&Baruch 2000). The question that arises is 'can invasive species in savannas play a role in carbon sequestering?'

The tropical savannas are important in carbon sequestration at the global scale because not only are they remarkably productive being responsible for almost $30 \%$ of global net primary production (NPP), they are also the second largest biome of the world extending over $15 \times 106 \mathrm{~km}^{2}$ (Grace et al., 2006; Long et al., 1989). The carbon sequestered in savanna ecosystems is estimated to average $7.2 \mathrm{t} \mathrm{C} \mathrm{ha-1}^{-1}$ year-1. The carbon sequestration rate reflected by the net ecosystem productivity may average $0.14 \mathrm{t} \mathrm{C}^{-1}$ year-1 $^{-1}$ or $0.39 \mathrm{Gt} \mathrm{C}$ year-1.

The above ground carbon stocks in savannas is strongly influenced by the ratio of grasses to trees, the higher the tree cover the higher the sequestered carbon with a range of $1.8 \mathrm{t} \mathrm{C} \mathrm{ha-1}$ where trees are absent, to over $30 \mathrm{t} \mathrm{C} \mathrm{ha-1}^{-1}$ where there is substantial tree cover (Grace et al., 2006). The ratio of grasses to trees is subject to the rainfall gradient and modified by the herbivory, fire, soil nutrients and texture. Plant traits also have a bearing on carbon stocks since they differ in growth rate and lifespan as a result of evolutionary trade-offs between acquisition and conservation of resources in stressful environments such as low nutrients and precipitation (Deyn et al., 2008)

Soil carbon constitutes over two-thirds of the global carbon found in terrestrial ecosystems or c. $2100 \mathrm{Gt}$, with the savannas biome soils estimated to have $200-300 \mathrm{Gt}$ or or $10-30 \%$ of the world soil carbon (Scurlock\& Hall, 1998). Furthermore native savanna soils on global average contain at least as much carbon as that stored in above- and below-ground biomass (Scholes \& Hall, 1996).Soil carbon pools are the balance between carbon input from primary productivity, and output processes such as decomposition processes, leaching of organic compounds and erosion losses. Net soil carbon input in savannas is mainly limited by low water availability and large carbon losses to herbivory and fire. Plant traits determine the amount of soil pool carbon sequestered mainly by altering overall primary productivity and belowground carbon allocation. Plant traits that may promote soil carbon sequestration comprise deep rooting, production of woody structures and herbivore defense traits. A particularly important trait in savannas is N-fixation which enhances plant productivity thereby increasing carbon input to 
soil. These are some of traits found in invasive species such as Prosopis juliflora (Pasiecznik, 2001). Furthermore many of the woody species found in the savanna have ligno-tubers and deep roots, enhancing the root : shoot ratio while tropical grasses generally have a high capacity to accumulate below-ground carbon(Scholes \& Hall, 1996).

Losses mainly through burning and soil erosion also determine the amount of carbon sequestered. As discussed above fire is an integral driver and determinant of tropical savanna function and structure with large areas seasonally burnt resulting in an efflux of carbon in the range of $2.4-4.2 \mathrm{Gt} \mathrm{C}$ year- ${ }^{-1}$ or $42 \%$ of global burned phytomass and as high as 5-8 Gt C year-1 if other losses such as management for grazing and land-use change are taken into account (Hall \& Scurlock, 1991) may influence the regional and possibly global energy. Plant traits that reduce carbon loss include fire resistance manifested by thick bark, dense wood and high lignin concentration others include fire resilience traits such as fire tolerant seeds and resprouting.

From the foregoing invasive species will significantly alter carbon pools depending on whether they have large enough effects on flux variables such as above-ground net primary production and litter decomposition, fire regimes, resources such as water and nutrients, this will depend on their traits of the invader. By alteration of the components of the Carbon $(\mathrm{C})$ and nitrogen $(\mathrm{N})$ cycles which are fundamental ecosystem functioning and processes invasive plants influence sequestration. Do introduced plant species that turn invasive have traits that augment carbon sequestration?

Many studies have shown that ecosystem net primary production (NPP) to have increased and $\mathrm{C}$ and $\mathrm{N}$ stocks to be higher in the invaded ecosystems relative to the native ecosystems (Ehrenfeld et al., 2001). However due to the wide range of effects of invasive plants on C and $\mathrm{N}$ processes and stocks the overall direction and magnitude of such alterations are poorly quantified. Liao et al (2007) using a meta-analysis approach of 94 experimental studies to quantify the changes found that plant invasion enhanced $\mathrm{C}$ and $\mathrm{N}$ pool sizes in plants, soils and soil microbes and stimulated ANPP by $83 \%$ in invaded ecosystems compared with native ecosystems grouped into forests, grasslands and wetlands. This attributed to ecophysiological differences between native and invasive species that lead to greater ANPP, plant and litter biomass, higher plant $\mathrm{N}$ concentration, and higher litter $\mathrm{N}$ concentration and lower litter $\mathrm{C}: \mathrm{N}$ ratio.

In savannas Archer et al. (2002) reported that in southern Texas bush encroachment by mainly the leguminous tree Prosopis glandulosa resulted $\mathrm{n}$ higher root biomass, increased SOC and total $\mathrm{N}$ with a linear increase in SOC storage rate with tree age. Similarly in sodic soils Kaur et al (2002) found trees planted in silvopastoral systems the total net productivity was highest in those consisting of the invader Prosopis juliflora even though grass productivity was lowest in such mixtures. Increased ANPP leading to higher C sequestration has been attributed to differences in ecophysiological traits such as specific leaf area and net photosynthetic rate between native and invasive species. In addition invaded ecosystems in general have $117 \%$ higher litter decomposition rate in comparison with native ecosystems, explained by higher plant and litter $\mathrm{N}$ concentration, lower litter $\mathrm{C}$ : $\mathrm{N}$ and lignin : $\mathrm{N}$ ratio than the native species (Liao et al., 2007). Where woody plants invade grass dominated savannas they tend be more productive above- and belowground and hence deliver more organic matter into soils, are seldom browsed by livestock or wildlife, suggesting high concentrations of secondary compounds hence a large fraction of the foliar biomass goes into the soil pool directly as litter, more lignified roots of shrubs also promote $\mathrm{C}$ and $\mathrm{N}$ accumulation compared to that of grass roots and shoots (Archer et al., 2000) 
However not all studies have noted increased $\mathrm{C}$ and $\mathrm{N}$ sequestering, some have shown plant invasion can have negative effects. For example Jackson et al. (2002) observed a C loss from a grassland ecosystem invaded by woody plants. In a Kenyan savanna Mworia et al (2008b) found N mineralization was significantly lower under the canopy of the invasive herb Ipomoea hildebrandtii as compared to locally dominant grass Chloris roxburghiana even though it was higher than bare ground/eroded areas. Ipomoea hildebrandtii is non-legume that is unpalatable and generally compounds that reduce plant palatability also reduce litter decomposition rate which may explain the reduced nitrification.

In conclusion plant invasions have led to increased $\mathrm{C}$ and $\mathrm{N}$ pools with responses attributed to differences in ecophysiological traits between invasive and native species related to ANPP, plant $\mathrm{N}$ concentration and litter biomass. Also sequestering is higher for invasive Nfixing than for nonN-fixing plants and invasive woody than for herbaceous species.

\section{Conclusions}

Savannas are an important biome given their high total NPP which is second only to forests, $3^{\text {rd }}$ highest sequestered carbon pool, highest ungulate herbivore populations and habitation of pastoral peoples. Savannas consist of mixtures of trees and grasses with the ratio largely determined by factors precipitation, herbivory, fire and soil nutrients however the mechanisms by which they operate is still debated with some ecologists emphasizing the role of competition for resources and others the effect disturbances regulating tree populations. There is need for continued research in savanna dynamics incorporating aspects of changing climate and land use patterns.

Over the history of human development large numbers of plant species have been moved across physical barriers for a wide range of reasons such as food, forage and ornamental, many have been naturalized and only a small proportion have become invasive. Ecologists have put great effort in trying to understand factors that make plant communities susceptible to invasion. Important factors identified are the characteristics of the invader mainly traits that allow greater resource use efficiency, ease of propagation and faster growth, secondly the vulnerability of communities to invasion largely ecological disturbances leading to resource fluctuations. There are still several gaps and grey areas in our understanding of invasive species in savannas. Firstly the implications of the current rapid land use changes in savannas and their interaction with the climate change effects such as increased frequency of ENSO induced drought on invasive species proliferation and impacts is poorly understood. Secondly given the importance of plant characteristics on successful invasion of a non-native species there is inadequate information on the distribution of non-native species in savannas, their autoecology and to the dynamics of host savannas in relation to variation of disturbances in time and space. In some savannas such as in Africa with an exception of South Africa few comprehensive surveys and studies on invasive species have been conducted.

The productivity of savannas is mainly regulated by rainfall and soil nutrients whose variability leads gradients of production and compositional change in savannas while soil attributes such as texture have larger effects on functional group composition rather than production. The spatial and temporal comparison and monitoring of productivity in savannas has been hampered by the wide array of methods historically used with many underestimating NPP or focusing on single species or life-form. In general savannas have been accorded far less attention in research, monitoring and database development as 
compared to forests which are regularly censured using ground and satellite imagery methods which is a conundrum given their almost equal total NPP.

\section{References}

Adger, W.N.; Huq, S.; Brown, K.; Conway, D. \& Hulme M. (2003). Adaptation to climate change in the developing world. Progress in Development Studies, Vol. 3, No.3, pp. 179-195

Archer, S.; Boutton T.W. \& Hibbard K.A.. 2002. Trees in grasslands: biogeochemical consequences of woody plant expansion, In: Global Biogeochemical Cycles in the Climate System, S.P. Schulze; Harrison, M.H.; Holland, E.A.; Lloyd, J.; Prentice, I.C. \& D. Schimel, (Eds) . Academic Press, San Diego

Barger, N.N.; D’Antonio, C.M.; Ghneim, T. \& Cuevas. E. (2003). .Constraints to colonization and growth of the African grass, Melinis minutiflora, in a Venezuelan savanna. Plant Ecology, Vol.167, pp.31-43.

Baruch, Z. \& Jackson RB.(2005). Responses of tropical native and invader $\mathrm{C}_{4}$ grasses to water stress, clipping and increased atmospheric $\mathrm{CO}_{2}$ concentration. Oecologia, Vol.145. pp.522-532.

Binggeli, P.; John B.H. \& Healey, J.R.. (1998). An overview of invasive woody plants in the tropics. School of Agricultural and Forest Sciences. Publication Number 13,University of Wales, Bangor

Brooks, M..; D’Antonio, CM.; Richardson, D.M.; Grace, J.B.; Keeley, J.E.; Di Tomaso, J.M.; Hobbs, R.J. \& Pyke, P.M. D.(2004) Effects of invasive alien plants on fire regimes. Bioscience, Vol. 54, pp.677-688

Churkina, G. \& Running, S.W. (1998). Contrasting Climatic Controls on the Estimated Productivity of Global Terrestrial Biomes. Ecosystems , Vol. 1, pp.206-215

D'Antonio M. C. \& Vitousek, P.M.(1992). Biological invasions by exotic grasses, the grass/fire cycle and global change. Annu. Rev. Ecol. Syst, Vol. 23, pp.63-87

Davis, M.A.; Grime, J.P. \& Thompson, K.(2000). Fluctuating resources in plant communities: a general theory of invasibility. Journal of Ecology, Vol. 88 pp. 528-534.

Deans, J.D.; Diagne, O.; Nizinski, J.;. Lindley, D. K.; Seck M.; Ingleby. K. \& Munro, R. C. (2003). Comparative growth, biomass production, nutrient use and soil amelioration by nitrogen-fixing tree species in semi-arid Senegal. Forest Ecology and Management Vol. 176, Issues 1-3, 17 pp. 253-264

De Deyn, G.B.; Cornelissen,.JH.C. \& .Bardgett, R.D. (2008). Plant functional traits and soil carbon sequestration in contrasting biomes. Ecology Letters Vol.11, pp. 516-531

Ehrenfeld, J.G.; Kourtev, P. \& Huang, W.Z. (2001). Changes in soil functions following invasions of exotic understory plants in deciduous forests. Ecological Applications Vol.11, pp. 1287-1300.

Ellis, J.E. \& Swift, D.M. (1988). Stability of African pastoral ecosystems: alternative paradigms and implications for development. Journal of Range Management, 41, 450459

Foxcroft, LC.; Richardson, D.M.; Rejmanek. M. \& Pysek, P. (2010). Alien plant invasions in tropical and sub-tropical savannas: patterns, processes and prospects. Biol Invasion, Vol. 12 pp.3913-3933

Frank, D.A.; McNaughton, S.J. \& Tracy B F.(1998). The Ecology of the Earth's Grazing Ecosystems. BioScience, Vol. 48, No. 7, pp.513-521 
Grace J.; Jose, J.S.; Meir, P.; Miranda, H.S. \& Montes, R.A.(2006). Productivity and carbon fluxes of tropical savannas. Journal of Biogeography, Vol.33, pp. 387-400

Grantz, M. (2000). Currents of change: Impacts of El Nino and La Nina on society (2nd Edition). Cambridge, UK Cambridge University Press.

Hall, D.O. \& Scurlock, J.M. (1991). Climatic change and productivity of natural grasslands. Annals of Botany, Vol.67, pp.49-55.

Higgins, S.I.; Bond, W.J. \& Trollope, W.S.W. (2000). Fire, resprouting and variability: a recipe for grass-tree coexistence in savanna. Journal of Ecology, Vol.88, pp.213-229.

Holdo, R.M.; Holt, R.D.; Coughenour, M.B. \& Ritchie, M.E. (2007). Plant productivity and soil nitrogen as a function of grazing, migration and fire in an African savanna. Journal of Ecology, Vol. 95, pp. 115-128

House, J.I. \& Hall, D.O. (2001). Productivity of tropical savannas and grasslands. Terrestrial global productivity: past

Huntley, B.J. \& Walker BH (eds) .(1982). Ecology of tropical savannas. Ecological studies 42. Springer, Berlin

Jama, B.; Nair, P.K.R \& Kurira, P.W. (1989). Comparative growth performance of some multipurpose trees and shrubs grown in Machakos, Kenya. Agroforestry Systems, Vol. 9, No.1, pp. 17-29

Jeltsch, F.; Weber, G.E. \& Grimm V. (2000). Ecological buffering mechanisms in savannas: a unifying theory of long-term tree-grass coexistence. Plant Ecology. Vol.161, pp.161171.

Kaur, B.S.; Gupta, R. \& Singh, G. (2002). Carbon storage and nitrogen cycling in silvopastoral systems on a sodic soil in northwestern India. Agroforestry Systems, Vol.54, pp. 21-29.

Ker, A. (1995). Farming systems of the African savanna A Continent in Crisis. IDRC .

Kinyamario, J.I. \& Imamba, S.K.( 1992). Savanna at Nairobi National Park. In: Primary Productivity of Grass Ecosystems of the Tropics and Sub-tropics. Long, S.P.; Jones, M.B. \& Roberts, M.J. (Eds) pp 25-69 Chapman \& Hall, London, UK..

Klink, C.A. (1994). Effects of clipping on size and tillering on native and African grasses of the Brazilians savannas ( the cerrado). Oikos, Vol. 70, pp. 365-376.

Lane, D.R.; Coffin, D.P. \& Lauenroth, W.K. (1998). Effects of soil texture and precipitation on above-ground net primary productivity and vegetation structure across the Central Grassland region of the United States. Journal of Vegetation Science, Vol.9, pp.239-250.

Liao, C.; Peng, R.; Luo, Y.; Zhou, X.; Wu, X.; Fang, Chen, C. J. \& Li B. (2008). Altered ecosystem carbon and nitrogen cycles by plant invasion: a meta-analysis. New Phytologist, Vol.177, pp.706-714

Lloyd, J.; Bird, M.I.; Vellen, L.; Miranda, A.C.; Veenendaal, E.M.; Djagbletey, G.; Miranda, H.S.; Cook, G \&. Farquhar, G.D. (2008). Contributions of woody and herbaceous vegetation to tropical savanna ecosystem productivity: a quasi-global estimate. Tree Physiology, Vol. 28, pp.451-468

Lockwood, J.L.; Hoopes, M.F. \& Marchetti, M.P. (2007). Invasion Ecology. Malden: Blackwell Publishing.

Long, S.P.; Garcia, M.E.;, Imbamba, S.K.; Kamnalrut, A.; Piedade, M.T.; Scurlock, J.M.; Shen, Y.K. \& Hall, D.O. (1989). Primary productivity of natural grass ecosystems of the tropics, a reappraisal. Plant and Soil, Vol.115, pp.155-166. 
Lonsdale, W. M. (1994), Inviting trouble: Introduced pasture species in northern Australia. Australian Journal of Ecology, 19: 345-354.

Lovejoy, T.E. \& Hannah L (eds). 2006. Climate change and biodiversity. Yale University Press

Masocha, M.A.; Skidmore, K.; Poshiwa, X \& Prins, H.H.T. (2010). Frequent burning promotes invasions of alien plants into a mesic African savanna. Biological Invasions. DOI 10.1007/s10530-010-9921-6, open access at Springerlink.com

Muturi, G.M.; Mohren, G.M.J. \& Kimani, J.N. (2009). Prediction of Prosopisspecies invasion in Kenya using geographical information system techniques. African Journal of Ecology, Vol. 48, pp. 628-636.

Mworia, J.K.; Kinyamario, J.I. \& Githaiga, J.M. (2008a). Influence of cultivation, settlements and water resources on wildlife distribution and habitat selection in south-east Kajiado, Kenya. Environmental Conservation, Vol. 35, No. 2, pp. 117-124

Mworia J.K.; Wambua, J.K.; Omari, J. K. \& J.I. Kinyamario. (2011). Patterns of seed dispersal and establishment of the invader Prosopis juliflora in the upper floodplain of Tana river, Kenya. African Journal of Range and Forage Science, Vol. 28, No. 1, pp.35-41.

Mworia, J.K.; Kinyamario, J.I.; \& John, E.A. (2008b). Impact of the invader Ipomoea hildebrandtii on grass biomass, nitrogen mineralization and determinants of its seedling establishment in Kajiado, Kenya. African Journal of Range and Forage Science, Vol.25, pp. 11-16.

Myers, J.H. \& Bazely, D.R. (2003). Ecology and Control of Introduced Plants. Cambridge: Cambridge University Press.

Nair, P.K.R .(ed). (1989). Agroforestry systems in the tropics. Kluwer Academic Publishers

Oba, G.; Stenseth, N.C. \& Weldaji, R.B. (2002). Impacts of shifting agriculture on a floodplain woodland regeneration in dryland, Kenya. Agriculture, Ecosystems \& Environment, Vol. 90, pp.211-216.

Pasiecznik, N.M.; Felker, P.; Harris, P.J.C.; Harsh, LN.; Cruz, G.; Tewari, J.C.; Cadoret, K. \& Maldonado, LJ. (2001). The Prosopis juliflora - Prosopis pallida Complex: A Monograph. HDRA, Coventry, UK. Academic Press, San Diego, CA.

Richardson, D.M.; Pysek, P.; Rejmanek, M.; Barbour, M.I.G.; Panetta, F.D. \& West, C.J. (2000). Naturalization and invasion of alien plants: concepts and definition. Diversity and Distributions, Vol.6, pp. 93- 107

Rossiter, N.A.; Setterfield, S.A.; Douglas, M.M. \& Hutley, L.B. (2003). Testing the grass-fire cycle: exotic grass invasion in the tropical savannas of northern Australia. Diversity and Distributions, Vol. 9, pp. 169-176.

Sala, O.E.; Chapin, F.S.; Armesto, J.J.; Berlow, E.; Bloomfield, J.; Dirzo, R; Huber-Sanwald, E.; Huenneke. L.F.; Jackson, R.B.; Kinzig, A.; Leemans, R.; Lodge, D.M.; Mooney, H.A.; Oesterheld, M.; Poff, N.L; Sykes, M.T.; Walker, B.H.; Walker, M. \& Wall, D.H. (2000). Global biodiversity scenarios for the year 2100. Science, Vol. 287, pp.17701774

Sankaran M. (2005).Determinants of woody cover in African savannas. Nature Vol. 438, No. 8, pp. $846-849$

Sankaran, M.; Ratnam, J. \& Hanan, N.P. (2004). Tree grass coexistence in savannas revisited-insights from an examination of assumptions and mechanisms invoked in existing models. Ecol. Letters, Vol. 7, pp.480--490.

Scholes, R.J. \& Archer, S.R.(1997). Tree--grass interactions in savannas. Annu. Rev. Ecol. Syst. Vol.28, pp.517--544. 
Scholes, R.J. \& Hall, D. (1996). The carbon budget of tropical savannas, woodlands and grasslands. In: Global change, effects on coniferous forest and grasslands. SCOPE (Eds) Breymeyer A.I., I.D. Hall, J.M. Melillo and G.I. Agren, pp. 69-100. John Wiley, New York.

Scholes, R.J.; Dowty, P.R.; Caylor, K.; Parsons, D.A.B.; Frost, P.G.H. \& Shugart, H.H. (2002). Trends in savanna structure and composition along an aridity gradient in the Kalahari. Journal of Vegetation Science, Vol.13, pp.419-428.

Scurlock, J.M.O. \& Hall, D.O. (1998) The global carbon sink, a grassland perspective. Global Change Biology, Vol.4, pp.229-233.

Setterfield, S.A. (2002). Seedling establishment in an Australian tropical savanna: effects of seed supply, soil disturbance and fire. Journal of Applied Ecology Vol.39, pp.949-959

Singh, J.S. \& Joshi, M.C. (1979). Tropical grasslands primary production, In: Grassland Ecosystems of the World, IBP Vol. 18, . RT. Coupland (ed) .Cambridge University Press, Cambridge.

Smith, S.D.; Huxman, T.E.; Zitzer, S.F; Charlet, T.N.; Housman, D.C.; Coleman, J.S.; Fenstermakerk, L.K.; Seemann, J.R. \& Nowak, R.S. (2000). Elevated $\mathrm{CO}_{2}$ increases productivity and invasive species success in an arid ecosystem. Nature, Vol. 408, pp. 79-82

Stave, J.; Oba, G.; Bjora, C.S.; Mengistu, Z.; Nordal, I. \& Stenseth, N.C. (2003). Spatial and temporal woodland patterns along the lower Turkwel River, Kenya. African Journal of Ecology, Vol. 41, pp.224-236.

Walter, H. (1971) Ecology of tropical and subtropical vegetation. Oliver and Boyd, Edinburgh.

Williams, D.G. \& Baruch, Z. (2000). African grass invasion in the Americas: ecosystem consequence and the role of ecophysiology. Biological Invasions, Vol. 2, pp.123-140

Williams, R..; Gill, A.M. \& Moore, P.H.R. (1998). Seasonal changes in fire behavior in a tropical savanna in northern Australia. International Journal of Wildland Fire, Vol.8, pp.227-239.

World Wildlife Fund. (2007). Llanos, In: Encyclopedia of Earth, Retrieved January 23, 2011, Available from http:/ / www.eoearth.org/article/Llanos 


\title{
Zooplankton Abundance, Biomass and Trophic State in Some Venezuelan Reservoirs
}

\author{
Ernesto J. González, María L. Matos, \\ Carlos Peñaherrera and Sandra Merayo \\ Universidad Central de Venezuela, Instituto de Biología Experimental, Caracas, \\ Venezuela
}

\section{Introduction}

The zooplankton community in freshwater bodies is composed principally of protozoa (flagellates and ciliates; from just a few to hundreds of micrometres), rotifers (from $30 \mu \mathrm{m}$ to $1 \mathrm{~mm}$ ) and crustaceans (copepods and cladocerans, some hundreds of $\mu \mathrm{m}$ up to $1 \mathrm{~cm}$ ), as well as insect larvae (such as Chaoborus), freshwater jellyfish (Craspedacusta), ostracods (Cypria), aquatic mites (Hydracarina), fish larvae and even trematode cercariae (Infante, 1988; Lampert \& Sommer, 1997; Rocha et al., 1999; Conde-Porcuna et al., 2004). This community represents a vital component in the food web of aquatic ecosystems (López et al., 2001). Especially in dammed rivers, information on the zooplankton community is important for the analysis of the functioning of these ecosystems and for the establishment of management policies for water use.

The density of zooplankton, expressed as the number of organisms per unit of area or volumen, does not necessarily provide exact information about the actual biomass of this community, since this consists of a huge variety of taxa with a wide size range (MatsumuraTundisi et al., 1989). Zooplankton biomass is also an important and necessary parameter for calculating the secondary production of this community (Melão \& Rocha, 2004). Thus, the estimation of the dry weight of zooplankton species is a more useful variable for the study of trophic structure in aquatic ecosystems than density, especially considering its relationship with the trophic states of the water bodies (Rocha et al., 1995).

In Venezuela, there is little data on the dry weight of zooplankton or their biomass (González et al., 2008). Although this country has over 100 operating reservoirs (MINAMB, 2007), information on the ecological aspects of zooplankton is only available for about $20 \%$ (López et al., 2001). In this study we aimed to establish the relationships between the abundance and biomass of the zooplankton with phytoplankton biomass (estimated as chlorophyll $a$ ) and the trophic states of reservoirs, using data collected from 13 of these water bodies.

\section{Study areas}

We collected plankton samples from the following reservoirs, distributed in the northeastern and north central regions of Venezuela: 1) Agua Fría, 2) Taguaza, 3) Lagartijo, 4) Clavellinos, 5) Tierra Blanca, 6) El Pueblito, 7) El Cigarrón, 8) El Cují, 9) El Andino, 10) La Mariposa, 11) La Pereza, 12) Quebrada Seca and 13) Suata (Figure 1). 


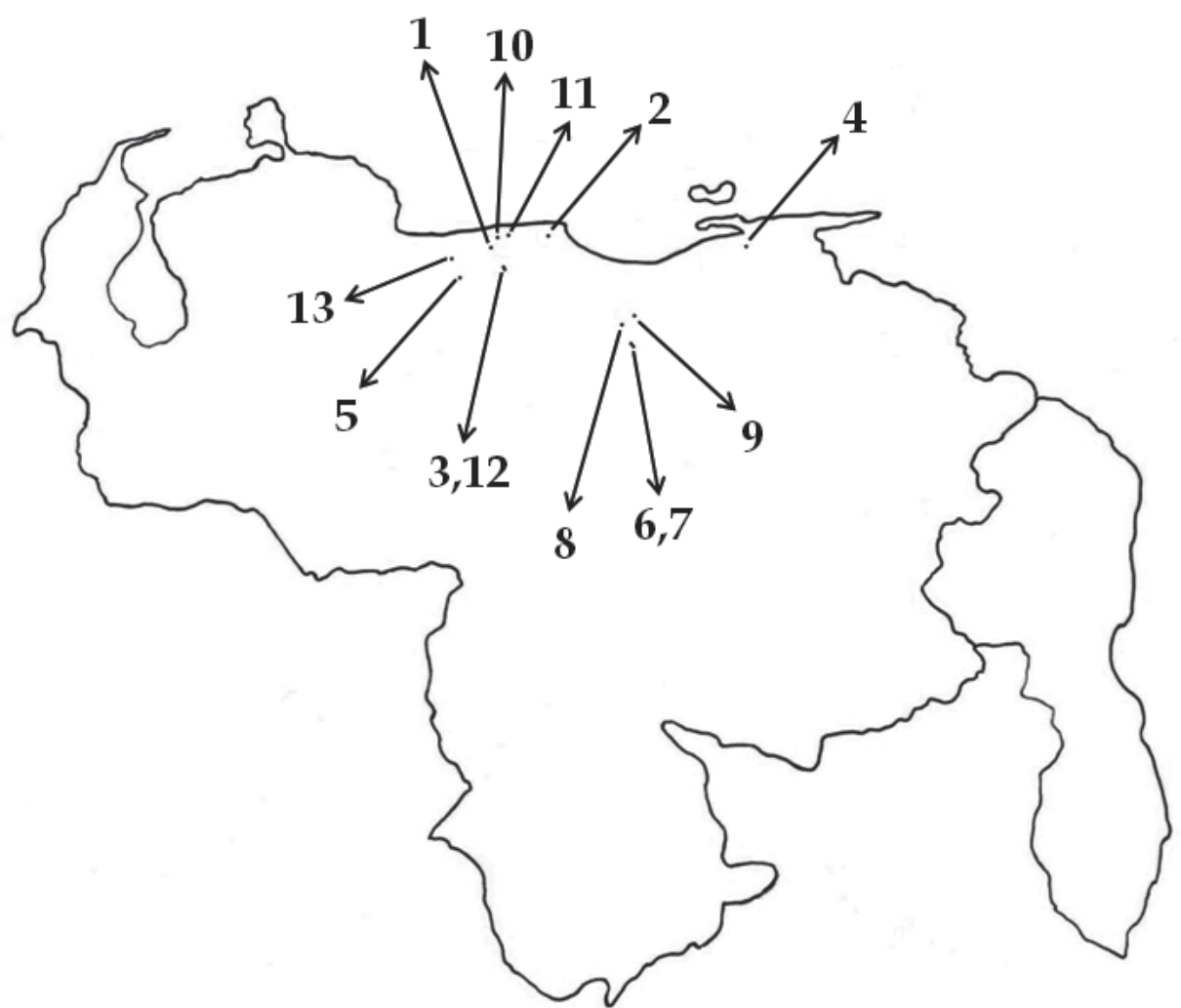

Fig. 1. Map of Venezuela, showing the relative locations of the reservoirs studied. For reservoir names, see numbers in text.

Some of the main morphometric features of the reservoirs surveyed are shown in Table 1.

\begin{tabular}{|lccccc|}
\hline Reservoir & $\begin{array}{c}\text { Mean depth } \\
(\mathrm{m})\end{array}$ & $\begin{array}{c}\text { Area } \\
\left(\mathrm{m}^{2}\right)\end{array}$ & $\begin{array}{c}\text { Volume } \\
\left(\mathrm{m}^{3}\right)\end{array}$ & $\begin{array}{c}\text { Residence time } \\
(\mathrm{d})\end{array}$ & $\begin{array}{c}\text { Location } \\
\text { Agua Fría }\end{array}$ \\
\hline 13.2 & 440,000 & $5,800,000$ & 38 & $10^{\circ} 23^{\prime} \mathrm{N}-67^{\circ} 10^{\prime} \mathrm{W}$ \\
Taguaza & 20.6 & $6,490,000$ & $134,000,000$ & 40 & $10^{\circ} 10^{\prime} \mathrm{N}-66^{\circ} 26^{\prime} \mathrm{W}$ \\
Lagartijo & 17.7 & $4,510,000$ & $80,000,000$ & 243 & $10^{\circ} 11^{\prime} \mathrm{N}-66^{\circ} 43^{\prime} \mathrm{W}$ \\
Clavellinos & 12.5 & $10,500,000$ & $131,000,000$ & 106 & $10^{\circ} 21^{\prime} \mathrm{N}-63^{\circ} 36^{\prime} \mathrm{W}$ \\
Tierra Blanca & 12.5 & 400,000 & $5,000,000$ & 144 & $9^{\circ} 58^{\prime} \mathrm{N}-67^{\circ} 25^{\prime} \mathrm{W}$ \\
El Pueblito & 6.4 & $49,500,000$ & $315,000,000$ & 152 & $9^{\circ} 12^{\prime} \mathrm{N}-65^{\circ} 34^{\prime} \mathrm{W}$ \\
El Cigarrón & 4.9 & $50,500,000$ & $246,000,000$ & 158 & $9^{\circ} 12^{\prime} \mathrm{N}-65^{\circ} 40^{\prime} \mathrm{W}$ \\
El Cují & 3.9 & $12,720,000$ & $49,310,000$ & 375 & $9^{\circ} 37^{\prime} \mathrm{N}-65^{\circ} 14^{\prime} \mathrm{W}$ \\
El Andino & 7.9 & $1,780,000$ & $14,000,000$ & 167 & $9^{\circ} 32^{\prime} \mathrm{N}-65^{\circ} 09^{\prime} \mathrm{W}$ \\
La Mariposa & 13.0 & 540,000 & $7,000,000$ & 12 & $10^{\circ} 24^{\prime} \mathrm{N}-66^{\circ} 33^{\prime} \mathrm{W}$ \\
La Pereza & 14.2 & 562,500 & $8,000,000$ & 12 & $10^{\circ} 27^{\prime} \mathrm{N}-66^{\circ} 46^{\prime} \mathrm{W}$ \\
Quebrada Seca & 7.9 & 950,000 & $7,500,000$ & 17 & $10^{\circ} 13^{\prime} \mathrm{N}-66^{\circ} 43^{\prime} \mathrm{W}$ \\
Suata & 5.1 & $8,498,00$ & $43,540,000$ & 84 & $10^{\circ} 12^{\prime} \mathrm{N}-67^{\circ} 23^{\prime} \mathrm{W}$ \\
\hline
\end{tabular}

Table 1. Mean morphometric features of the studied reservoirs. 


\section{Methods}

The data analyzed was taken from the results of 6-12 monthly sampling periods at each reservoir. Samples for estimating phytoplankton biomass (as chlorophyll $a$ ) were collected using an opaque van Dorn bottle (3 - 5 liters) from the euphotic layer of reservoirs and preserved in cold and dark conditions until their analysis in the laboratory. Chlorophyll $a$ concentration was estimated by extraction of the photosynthetic pigments with ethanol after filtering with Whatman glass-fiber filters (Nusch \& Palme, 1975). Zooplankton samples were obtained from the limnetic zone of the water bodies using vertical trawls in the oxygenated strata with a plankton tow net $(77 \mu \mathrm{m}$ mesh). Samples were preserved in $4 \%$ formaldehyde (final concentration). Abundance was determined by counting animals in Sedgwick-Rafter chambers (1ml), according to Wetzel \& Likens (2000) and biomass was estimated as dry weight (d.w.) after desiccation at $60^{\circ} \mathrm{C}$ for about $20-24 \mathrm{~h}$, according to Edmondson \& Winberg (1971). Parametric correlations were determined using the PAST program (Hammer et al., 2001).

\section{Results}

\subsection{Description of reservoirs and phytoplankton biomass}

- Agua Fría (AFR): Located within a protected area (Macarao National Park, Miranda State). Used to supply drinking water to the city of Los Teques (population approximately 172,000). This reservoir shows low nutrient concentrations, but the water level has declined over the years due to the increase in the demand for drinking water. Meromictic with a tendency to warm monomictic, following Lewis' (1983) criteria; shows hypolimnetic anoxia during the rainy season (González et al., 2004).

- Taguaza (TAG): Located within a protected area (Guatopo National Park, Miranda State). Used to supply drinking water to areas surrounding the city of Caracas (population approximately 4 million). Shows low nutrient concentrations. Meromictic with a tendency to warm monomictic and with permanent hypolimnetic anoxia (González et al., 2002).

- Lagartijo (LAG): Located within a protected area (Guatopo National Park, Miranda State). Used to supply drinking water to the city of Caracas (population approximately 4 million). Shows low nutrient concentrations, but due to the increasing demand for water by the metropolitan area of Caracas, water is pumped to the reservoir from the Tuy river (a highly contaminated river) after sedimentation and chlorination, although this pumped water only affects a small part of the water body. Meromictic with a tendency to warm monomictic and with nearly permanent hypolimnetic anoxia (Infante et al., 1992; Infante \& O. Infante, 1994; Ortaz et al., 1999).

- Clavellinos (CLA): Located in Sucre State and used to supply drinking water to the town of Carúpano and Nueva Esparta State (population 512,366) as well as for irrigation. High nitrate concentrations were detected in its waters, possibly from the use of fertilizers on the surrounding land. Warm monomictic; shows anoxic conditions in the hypolimnion during the rainy season (Merayo \& González, 2010).

- Tierra Blanca (TBL): Situated in Guárico State and used to supply drinking water to the city of San Juan de Los Morros (population 85,000); it is also used for recreational purposes. Its drainage basin is partially protected, although this is limited by free public 
access. Its water level fluctuates strongly due to demand. Meromictic with a tendency to warm monomictic and with nearly permanent hypolimnetic anoxia (González, 2006).

- El Pueblito (EPU): Located in Guárico State and used for flood control, subsistence agriculture, irrigation and recreation. Shows moderate nutrient concentrations. Classified as warm monomictic according to the criteria of Hutchinson (1957) and Lewis (1983), with hypolimnetic anoxia during the rainy season (González, 2000a).

- El Cigarrón (ECI): Located in Guárico State and used for flood control, subsistence agriculture and irrigation. Shows high nutrient concentrations due to the use of fertilizers in the surrounding areas. Warm monomictic; with hypolimnetic anoxia during the rainy season (Unpublished data).

- $\quad$ El Andino (EAN): Located in Anzoátegui State. Used for subsistence agriculture and irrigation. Shows moderate nutrient concentrations due to the use of fertilizers in the surrounding areas. Warm monomictic; with hypolimnetic anoxia during the rainy season (Infante et al., 1995; González, 2000b).

- $\quad$ El Cují (ECU): Situated in Anzoátegui State and used for the supply of drinking water to the towns of Onoto and Zaraza, as well as for flood control and irrigation. Warm monomictic; with hypolimnetic hypoxia and anoxia during the rainy season (Infante et al., 1995).

- La Mariposa (LMA): This is an urban reservoir, located $8 \mathrm{~km}$ from the city of Caracas (population approximately 4 million) and used to supply drinking water as well as for recreation. The catchment area is highly intervened and its waters show high nutrient concentrations, which has recently produced excessive growth of the macrophyte Eichhornia crassipes. In spite of low residence time, its waters show thermal stratification during the rainy season, when hypoxic conditions may also be detected in the hypolimnion (Ortaz et al., 1999).

- La Pereza (LPE): Located in Miranda State and used for recreational purposes and the supply of drinking water to areas surrounding Caracas (population approximately 4 million). Its waters show high nutrient concentrations, which come from nearby pig and chicken farms, as well as waste waters from a galvanized steel factory. Warm monomictic; with anoxic conditions in the hypolimnion during the rainy season (Ortaz et al., 1999).

- $\quad$ Quebrada Seca (QSE): Located in Miranda State and used for purifying untreated water from the Tuy river before pre treating and pumping it to the Lagartijo reservoir, from which it is used to supply drinking water to Caracas. Its catchment area is highly intervened, with surrounding rural communities that discharge their wastewaters directly into the reservoir. It mixes only once a year (warm monomictic) and shows hypolimnetic anoxia during the rainy season (Ortaz et al., 1999).

- Suata (SUA): Located in Aragua State and used to supply water for subsistence agriculture and cattle ranching. This reservoir is fed by the Aragua river which collects the wastewaters of several populations along its course that are then deposited into the reservoir without prior treatment. It is polymictic, due to the shallowness of its waters (González et al., 2009).

The reservoirs represent a gradient of different trophic states, from ultra-oligotrophic (Agua Fría and Taguaza) to hypertrophic (Quebrada Seca, La Mariposa and Suata), according to their total phosphorus concentration following Salas \& Martinó (1991), and determined by the authors cited for each reservoir description. Phytoplankton biomass, estimated as the 
concentration of chlorophyll $a$ in the euphotic zone of each water body, also reflects the trophic state of the reservoirs (Table 2). The mean values of both total phosphorus and chlorophyll $a$ for the euphotic zone of these reservoirs varied between 4 and more than 1500 $\mu \mathrm{g} / 1$ and between 2.16 and $92.89 \mu \mathrm{g} / \mathrm{l}$, respectively, for Agua Fría (the most oligotrophic) and Suata (the most eutrophicated) reservoirs.

\subsection{Zooplankton abundance and biomass}

The variation intervals of the abundance and biomass of the zooplankton for each of the reservoirs surveyed are shown in Table 3. The dominant zooplankton taxa for each water body are also specified.

Copepods were the dominant group in 8 of the 13 reservoirs sampled (Agua Fría, Taguaza, Lagartijo, Clavellinos, El Pueblito, El Cigarrón, El Cují and La Mariposa) and second in numeric abundance in the El Andino reservoir, where rotifers were the most dominant. Ostracods dominated in the Tierra Blanca and Suata reservoirs and protozoa showed the highest relative abundances in La Pereza and Quebrada Seca. The relative proportions of the different zooplankton taxa are shown in Figure 2. It can be appreciated that copepods were the dominant group in all of the ultra-oligotrophic and oligotrophic reservoirs, but as the trophic state of the water bodies increased other taxa became more abundant.

\begin{tabular}{|cccc|}
\hline Reservoir & $\begin{array}{c}\text { Total P } \\
(\mu \mathrm{g} / \mathrm{l})\end{array}$ & $\begin{array}{c}\text { Chlorophyll } a \\
(\mu \mathrm{g} / \mathrm{l})\end{array}$ & Trophic state \\
\hline Agua Fría & 6.57 & 2.27 & Ultra-oligotrophic \\
Taguaza & 8.63 & 4.67 & Ultra-oligotrophic \\
Lagartijo & 17.08 & 5.78 & Oligotrophic \\
Clavellinos & 9.60 & 15.41 & Oligotrophic \\
Tierra Blanca & 23.11 & 11.66 & Oligo-mesotrophic \\
El Pueblito & 21.31 & 8.46 & Oligotrophic \\
El Cigarrón & 37.21 & 6.71 & Mesotrophic \\
El Cují & 23.58 & 11.05 & Oligo-mesotrophic \\
El Andino & 25.60 & 26.10 & Mesotrophic \\
La Mariposa & 136.83 & 41.92 & Hypertrophic \\
La Pereza & 94.64 & 44.36 & Eutrophic \\
Quebrada Seca & 121.25 & 62.71 & Hypertrophic \\
Suata & 1616,43 & 92.89 & Hypertrophic \\
\hline
\end{tabular}

Table 2. Mean values of total P, chlorophyll $a$ and trophic state in the studied reservoirs.

It can be observed that in general, as the trophic state of the reservoir increases, the mean abundances of the zooplankton also seem to increase. This can be seen from Figure 3, where the abundance and biomass of the zooplankton were ordered according to the mean concentrations of chlorophyll $a$ in the water bodies. Thus, the lowest phytoplankton biomass values (as chlorophyll $a$ ) and the lowest abundance and biomass values of the zooplankton are found in the ultra-oligotrophic reservoirs (24 individuals/1 and $48.51 \mu \mathrm{g} \mathrm{d.w.} / 1$ in Agua Fría, and 86 individuals/1 and $28.71 \mu \mathrm{g}$ d.w./1 in Taguaza), whilst the highest 


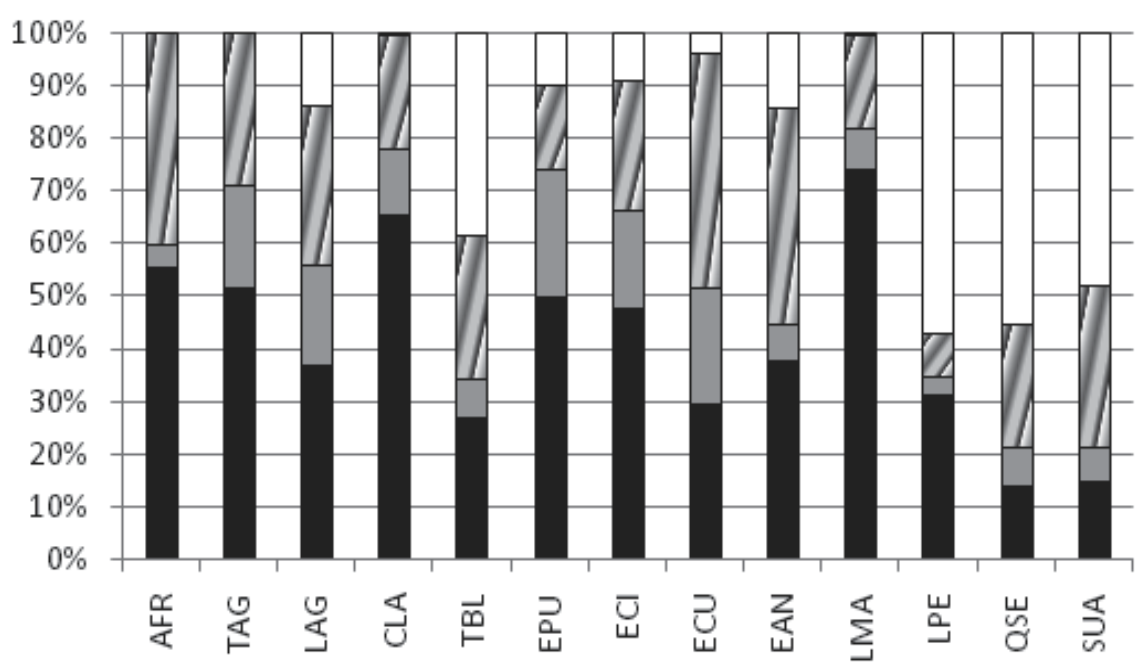

\section{- Copepods $\square$ Cladocerans $\square$ Rotifers $\square$ Others}

Fig. 2. Relative proportion of zooplankton groups in the studied reservoirs. AFR: Agua Fría, TAG: Taguaza, LAG: Lagartijo, CLA: Clavellinos, TBL: Tierra Blanca, EPU: El Pueblito, ECI: El Cigarrón, ECU: El Cují, EAN: El Andino, LMA: La Mariposa, LPE: La Pereza, QSE: Quebrada Seca, SUA: Suata.

phytoplankton biomass values and the highest mean abundance and biomass values of the zooplankton are found in the hypertrophic reservoirs (1130 individuals/1 and $1127.26 \mu \mathrm{g}$ d.w./1 in Quebrada Seca, and 753 individuals/1 and $2026.14 \mu \mathrm{g}$ d.w./1 in Suata).

Given the associations found between the phytoplankton and zooplankton, we explored the relationships between phytoplankton biomass, zooplankton abundance and zooplankton biomass in greater detail using a further set of graphs: 1) Chlorophyll $a$ vs zooplankton abundance (Figure 4), 2) chlorophyll a vs zooplankton biomass (Figure 5) and 3) zooplankton abundance vs zooplankton biomass (Figure 6). The relationships between these parameters are presented using both the raw and logarithmically transformed data, in order to see which gives a better fit.

From Figure 4 we can see that there is a good fit between the mean chlorophyll $a$ values of the water bodies and the mean abundance of the zooplankton, either when the raw data were used (Figure 4a) or after logarithmic transformation (Figure $4 \mathrm{~b}$ ). In both cases the relationship best fitted to a straight line, and the linear regression coefficients were higher than 0.60 and statistically significant $(p<0.05)$.

Figure 5 shows another good fit, this time between the mean chlorophyll $a$ values and mean zooplankton biomass, either when using the raw (Figure 5a) or logarithmically transformed (Figure $5 b$ ) data. In both cases, as for the relationship between phytoplankton biomass and zooplankton abundance, the association was linear; although the linear regression coefficients were lower, they remained statistically significant $(p<0.05)$.

Figure 6 shows that the relationship between the abundance and biomass of the zooplankton can also be described linearly, both with the raw (Figure 6a) and logarithmically transformed (Figure 6b) data. 


\begin{tabular}{|c|c|c|c|}
\hline Reservoir & $\begin{array}{c}\text { Abundance (Ind./l) } \\
\text { Min. - Max. } \\
\text { (Mean } \pm \text { S.D.) }\end{array}$ & $\begin{array}{l}\text { Biomass }(\mu \mathrm{g} / 1) \\
\text { Min. - Max. } \\
\text { (Mean } \pm \text { S.D.) }\end{array}$ & $\begin{array}{c}\text { Dominant zooplankton } \\
\text { group }\end{array}$ \\
\hline Agua Fría & $\begin{array}{c}9.68-39.41 \\
(23.91 \pm 8.98)\end{array}$ & $\begin{array}{l}11.56-123.44 \\
(48.51 \pm 32.08)\end{array}$ & Copepods \\
\hline Taguaza & $\begin{array}{l}43.86-150.00 \\
(85.58 \pm 29.79)\end{array}$ & $\begin{array}{c}3.82-55.03 \\
(28.71 \pm 15.91)\end{array}$ & Copepods \\
\hline Lagartijo & $\begin{array}{c}34.00-373.00 \\
(155.64 \pm 128.34)\end{array}$ & $\begin{array}{c}82.43-863.78 \\
(251.31 \pm 218.53)\end{array}$ & Copepods + Rotifers \\
\hline Clavellinos & $\begin{array}{c}30.48-99.94 \\
(61.84 \pm 22.33)\end{array}$ & $\begin{array}{c}97.40-1406.29 \\
(504.28 \pm 351.84)\end{array}$ & Copepods \\
\hline Tierra Blanca & $\begin{array}{c}131.80-688.67 \\
(309.16 \pm 187.14)\end{array}$ & $\begin{array}{l}100.08-2307.10 \\
(607.21 \pm 571.54)\end{array}$ & Ostracods \\
\hline El Pueblito & $\begin{array}{c}73.00-218.00 \\
(123.17 \pm 41.17) \\
\end{array}$ & $\begin{array}{c}69.80-228.10 \\
(127.25 \pm 49.77) \\
\end{array}$ & Copepods \\
\hline El Cigarrón & $\begin{array}{c}35.00-272.00 \\
130.00 \pm 69.66)\end{array}$ & $\begin{array}{c}40.00-360.00 \\
(164.67 \pm 103.86)\end{array}$ & Copepods \\
\hline El Cují & $\begin{array}{c}125.50-330.60 \\
(228.05 \pm 145.03)\end{array}$ & $\begin{array}{c}141.37-1643.14 \\
(1092.40 \pm 546.93)\end{array}$ & Copepods \\
\hline El Andino & $\begin{array}{c}8.80-616.40 \\
(287.89 \pm 201.36)\end{array}$ & $\begin{array}{c}402.98-634.67 \\
(381.72 \pm 169.46)\end{array}$ & Rotifers + Copepods \\
\hline La Mariposa & $\begin{array}{c}111.00-669.00 \\
(423.33 \pm 182.13) \\
\end{array}$ & $\begin{array}{l}154.83-1297.77 \\
(787.42 \pm 355.74)\end{array}$ & Copepods \\
\hline La Pereza & $\begin{array}{c}32.00-643.00 \\
(278.40 \pm 262.17)\end{array}$ & $\begin{array}{c}20.09-184.18 \\
(121.77 \pm 79.50) \\
\end{array}$ & Protozoans \\
\hline Quebrada Seca & $\begin{array}{c}98.00-2472.00 \\
(1129.80 \pm 871.30)\end{array}$ & $\begin{array}{c}259.46-1833.49 \\
(1127.26 \pm 710.50)\end{array}$ & Protozoans \\
\hline Suata & $\begin{array}{l}133.76-2518.47 \\
(752.93 \pm 678.60)\end{array}$ & $\begin{array}{c}305.73-13853.50 \\
(2026.14 \pm 3757.81)\end{array}$ & Ostracods \\
\hline
\end{tabular}

Table 3. Zooplankton abundance, biomass and dominant groups in the studied reservoirs. 

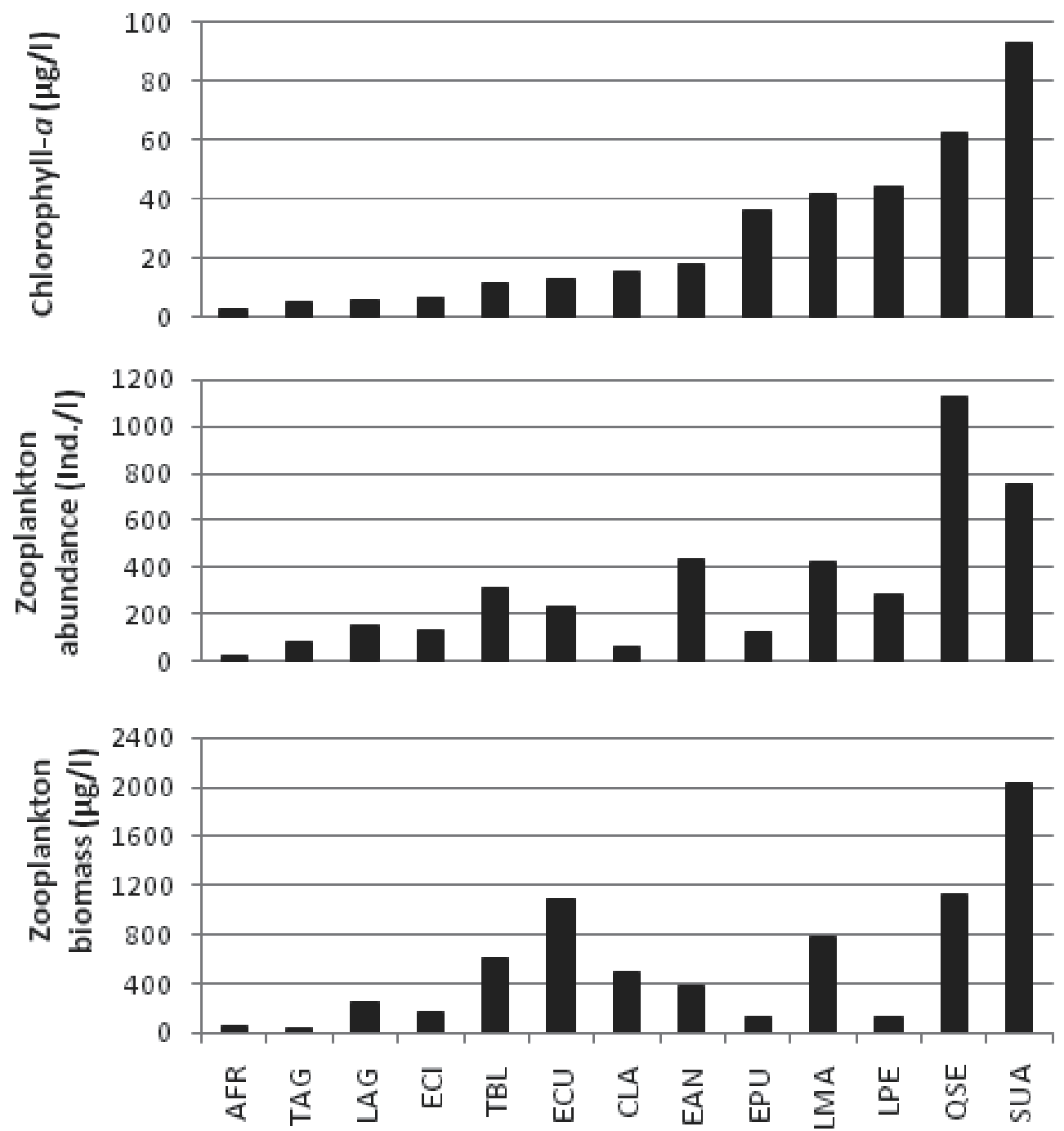

Reservoirs

Fig. 3. Mean values of chlorophyll $a$, zooplankton abundance and biomass in the studied reservoirs. AFR: Agua Fría, TAG: Taguaza, LAG: Lagartijo, CLA: Clavellinos, TBL: Tierra Blanca, EPU: El Pueblito, ECI: El Cigarrón, ECU: El Cují, EAN: El Andino, LMA: La Mariposa, LPE: La Pereza, QSE: Quebrada Seca, SUA: Suata. 

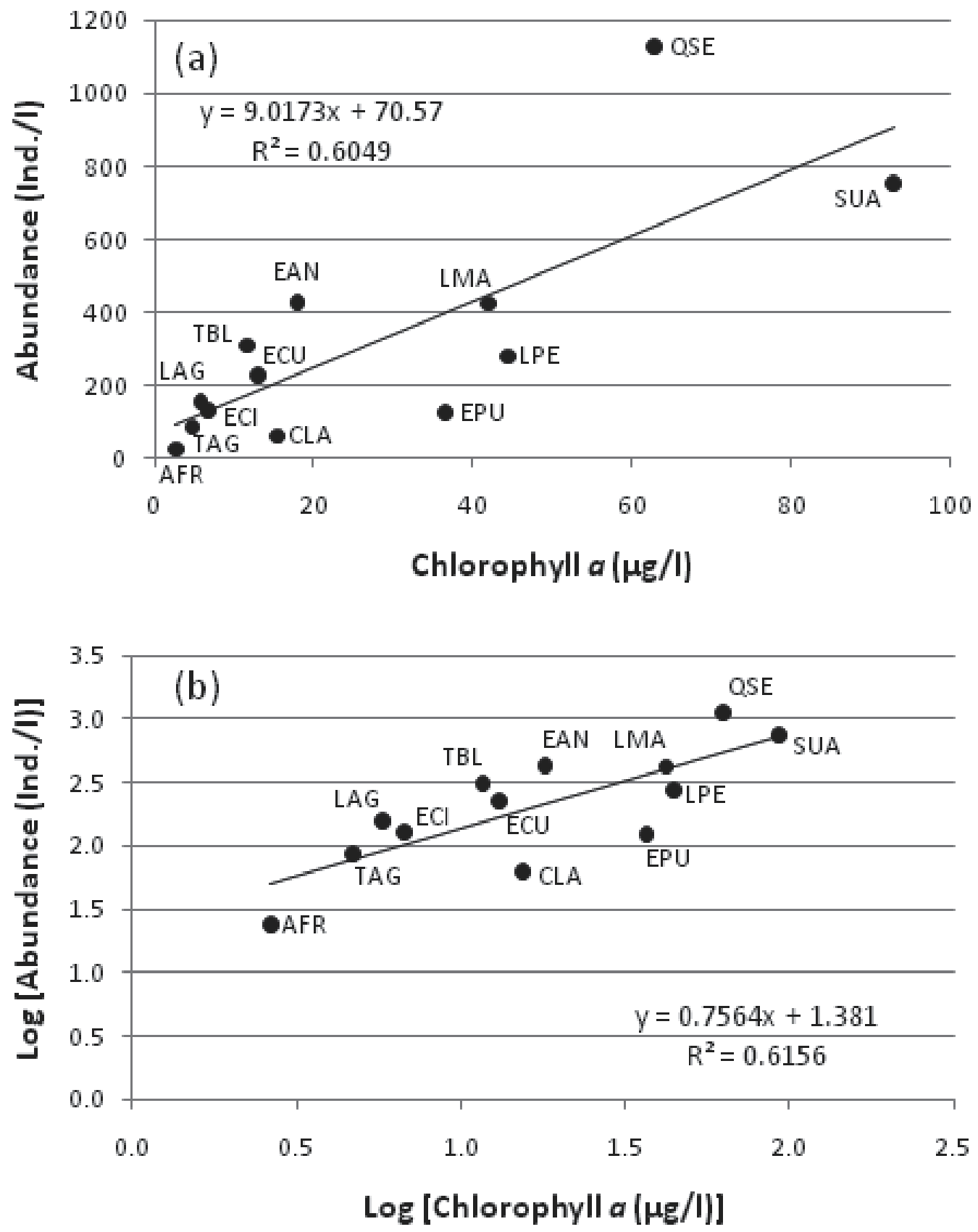

Fig. 4. Relationship between chlorophyll $a$ and zooplankton abundance: a) Raw data, b) logarithmically transformed data. For reservoir names, see Figures $2 \& 3$. 

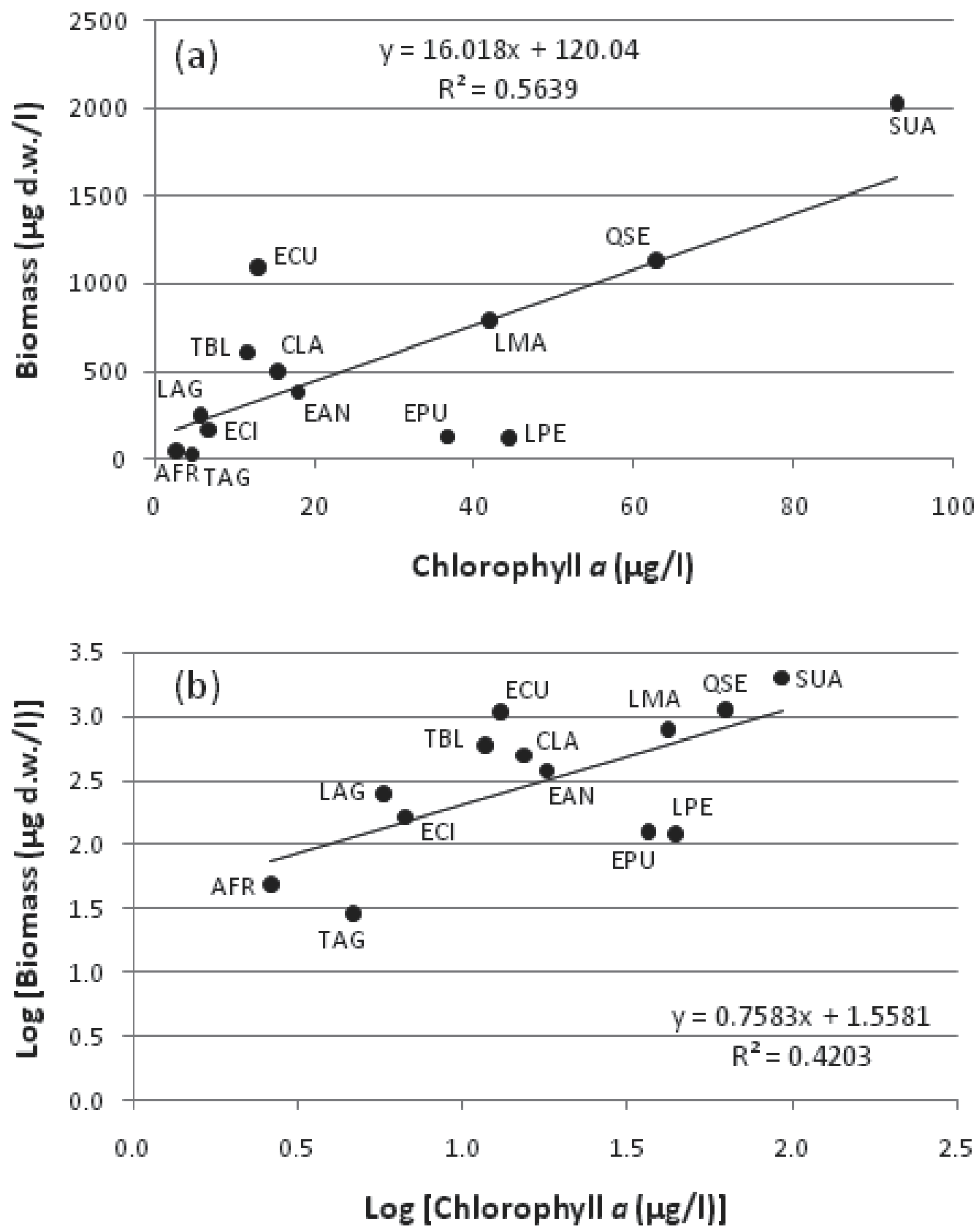

Fig. 5. Relationship between chlorophyll $a$ and zooplankton biomass: a) Raw data, b) logarithmically transformed data. For reservoir names, see Figures $2 \& 3$. 

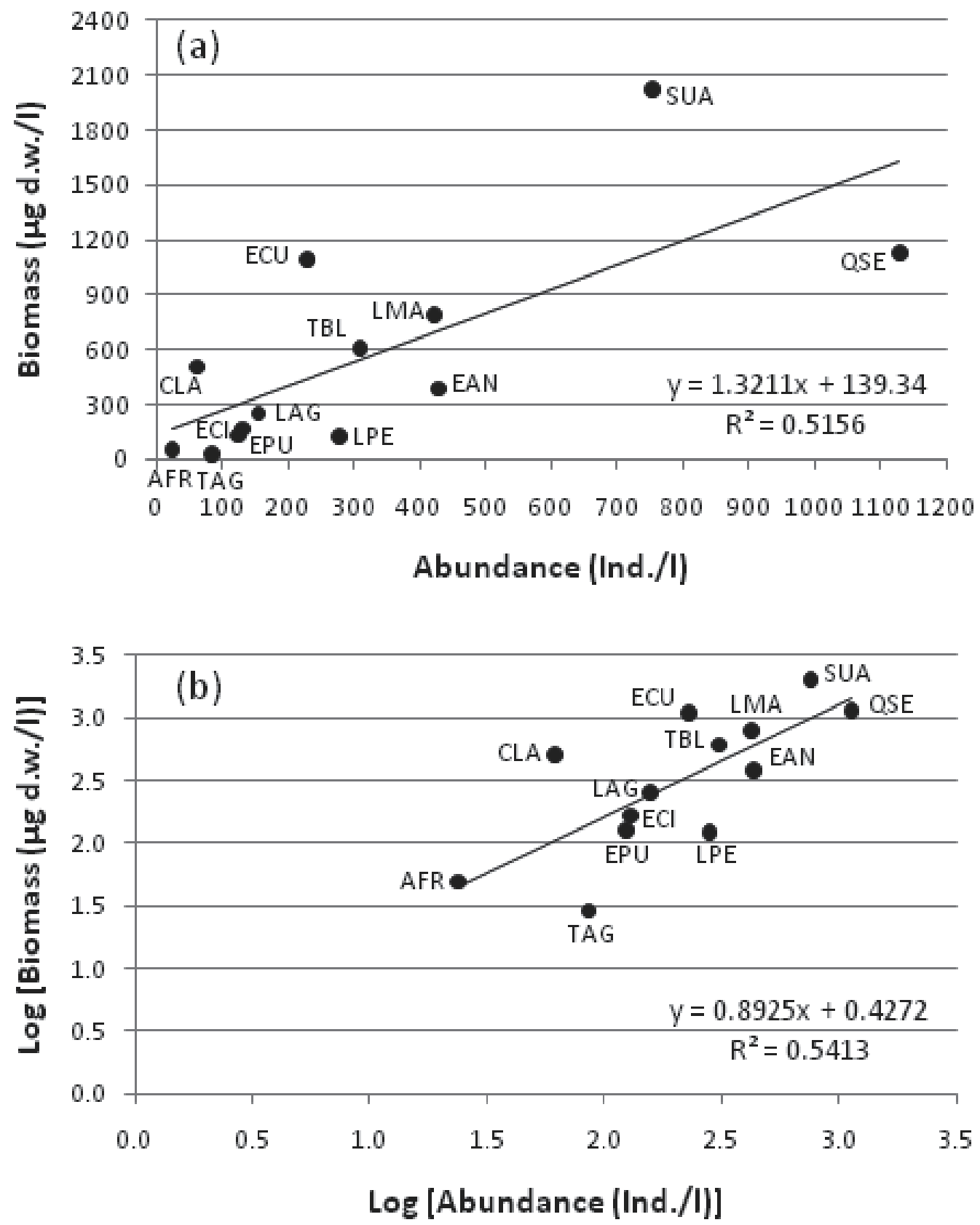

Fig. 6. Relationship between zooplankton abundance and biomass: a) Raw data, b) logarithmically transformed data. For reservoir names, see Figures $2 \& 3$. 
As for the associations shown in Figures 4 and 5, the linear regression coefficients for zooplankton abundance vs biomass were also statistically significant $(p<0.05)$ and higher than 0.51 .

The linear correlation coefficients $(\mathrm{r})$ between these variables were also calculated and were also statistically significant $(\mathrm{p}<0.05)$, as was to be expected from the linear regressions obtained:

- Chlorophyll $a$ vs. zooplankton abundance; $\mathrm{r}=0.778$.

- Chlorophyll $a$ vs. zooplankton biomass; $\mathrm{r}=0.718$.

- Zooplankton abundance vs. zooplankton biomass; $\mathrm{r}=0.751$.

\section{Discussion and final considerations}

The majority of the reservoirs included in this study show a tight linear relationship between total phosphorus and the concentration of chlorophyll $a$; thus these variables are good predictors of their trophic state (González, 2008; González \& Quirós, submitted). Reservoirs whose drainage basins are protected or in areas with low anthropogenic impact show the lowest total phosphorus and chlorophyll values, whilst those found in degraded catchment areas give the highest values.

As regards the zooplankton, Matsumura-Tundisi (1997) suggests that an understanding of the population dynamics of the different groups constitutes a useful tool for the management of reservoirs, since the composition, abundance and spatial distribution of the zooplankton communities are strongly related to their trophic state and the degree of biological interactions that occur within them, and that furthermore, the prevalence of certain species could indicate of the trophic state of the ecosystem.

According to Esteves (1998), an increase in phytoplankton primary production due to eutrophication has immediate effects on heterotrophic organisms, considerably increasing their production. As for phytoplankton, the specific composition of zooplankton and the relative density of each species changes with eutrophication (Esteves, 1998; Pinto-Coelho et al., 2005; Leitão et al., 2006; Landa et al., 2007; Tundisi et al., 2008). Thus many species either reduce in abundance or disappear completely, and are substituted by others that take over as the dominant zooplankton taxa. For example, Infante \& Riehl (1984) suggested that pelagic cladocerans, such as Ceriodaphnia cornuta, Diaphanosoma sp. and Moina micrura, may be more susceptible to the proliferation of cyanobacteria than copepods and rotifers in highly eutrophicated systems. In most cases, cyanobacteria negatively affect zooplankton (Zhao et al., 2008).

As far as we are aware this is the first comparative analysis of the relationships between the abundance and biomass of the zooplankton and phytoplankton biomass in reservoirs with different trophic states in Venezuela that takes into account the mean annual cycles of these three variables. Several previous studies only consider fluctuations in the abundance and biomass of zooplankton with respect to physicochemical changes and phytoplankton abundance and biomass (Infante, 1993; Infante et al., 1995; Mendoza, 1999; Carrillo, 2001; González et al., 2002; Gavidia, 2004; González, 2006; Cabrera, 2009; Merayo \& González, 2010). In some of these investigations, statistically significant correlations between phytoplankton and zooplankton were not found, especially in eutrophic systems, where links between the two communities may be weakened by the proliferation of microalgae that are not the preferred food of zooplankton (McQueen et al., 1986). In these cases, zooplankton dynamics were registered as being principally determined by environmental 
fluctuations, although some of the abundance and biomass peaks coincided with peaks of chlorophyll $a$ concentrations. In contrast, in several oligotrophic systems, such as the Agua Fría and Taguaza reservoirs in this study (González et al., 2002; González, 2006) and the Jucazinho reservoir in Brazil (Mélo-Júnior et al. 2007), significant correlations between phyto- and zooplankton have been reported.

From the analyses done in this study, it seems common that in water bodies with a higher degree of eutrophication, zooplankton abundance and biomass are higher compared to oligotrophic reservoirs. This relationship has been reported in other comparative studies of these variables in water bodies with contrasting trophic states in both Venezuela and Brazil (González et al., 2002; González, 2006; Sendacz et al., 2006; Blettler \& Bonecker, 2007), the only countries in which these types of investigations have been done within the South American tropics (González et al., 2008).

From this study it can be observed that the association between phytoplankton biomass and the abundance and biomass of the zooplankton is not perfect (see Fig. 3). The explanation for this is indicated by Fig. 2, however, which gives the relative proportions of the different zooplankton groups, as well as the information given in Tables 2 and 3.

As has already been mentioned, copepods dominate in the oligotrophic environments considered in this study, but as the trophic state increases, the relative abundances of other groups also increase. Thus, the lack of association between the variables could be due to the dominance of zooplankton taxa with small sized species, which contribute little in terms of weight to the total zooplankton biomass. In contrast, copepods contribute more to total zooplankton biomass in many fresh water bodies due to their larger sizes and heavier dry weights (Infante, 1993; Infante et al., 1995; Castilho-Noll \& Arcifa, 2007; González et al, 2008; Merayo \& González, 2010).

Sendacz et al. (2006) affirm that rotifers tend to dominate zooplankton communities in tropical and sub-tropical lakes and reservoirs, independently of their trophic state, but due to their small size and light weight, often contribute little to total zooplankton biomass. This could explain the lack of a perfect association between zooplankton abundance and biomass in the Venezuelan reservoirs studied.

In contrast to that indicated by Sendacz et al. (2006), the zooplankton community in most Venezuelan reservoirs seems to be dominated by copepods (López et al., 2001). This agrees with our results where copepods were the dominant group in 8 out of the 13 Venezuelan reservoirs studied. This could be promoted by high water residence times that favor species with relatively long development cycles (Santos-Wisniewski \& Rocha, 2007). The dominance by groups other than copepods in Venezuelan systems could be related to factors such as temperature, the quantity and quality of available food, species genotypes, climatic periods and differences in habitat conditions, among others (Gavidia, 2004; Sendacz et al., 2006; Mustapha, 2009; Merayo \& González, 2010).

In spite of the lack of a perfect fit between phytoplankton biomass and the abundance and biomass of zooplankton, strong linear relationships between the annual means were found. Thus, in the same way as for the strong linear relationships found between nutrients and phytoplankton biomass in Venezuelan reservoirs (González, 2008; González \& Quirós, submitted), a strong linear association was also found between zooplankton abundance and biomass, between each of these and phytoplankton biomass (estimated as chlorophyll $a$ ), and between all these variables and the trophic state of the reservoirs. 
Due to the fact that zooplankton dynamics are associated with the effects of anthropogenic activities in the drainage basins of these fresh water bodies (Infante, 1993), the identification of the dominant taxa (composition), and estimates of their abundance and biomass provide us with valuable tools for the determination of the trophic state, and thus should be taken into account when designing policies for the adequate management of reservoirs in Venezuela.

\section{Acknowledgments}

The authors would like to thank the Organization of American States, Fondo Nacional de Ciencia y Tecnología (Project S1-98-1361), Consejo de Desarrollo Científico y Humanístico UCV (Projects 03.33.4728.2000 and 03.00.6495.2006), Hydrological Companies HIDROVEN, HIDROCAPITAL, HIDROCARIBE and HIDROPAEZ, Ministerio del Ambiente for logistic and financial support. We also thank Mario Ortaz for field and laboratory assistance and discussions on zooplankton. We would also like to thank the Coordinación de Investigación, Ciencias - UCV and Frances Osborn who helped with the translation of the manuscript into English.

\section{References}

Blettler, M.C.M. \& Bonecker, C.C. (2007). Longitudinal distributions of microcrustacean biomass in three tropical reservoirs (Paraná State, Brazil). Acta Scientiarum Biological Sciences, Vol. 29, No. 3 (September 2007), pp. 293-304. ISSN 1679-9283.

Cabrera, A. (2009). Variaciones espaciales y temporales de la comunidad zooplanctónica en dos localidades del embalse Suata (Estado Aragua, Venezuela). Universidad Central de Venezuela, Thesis, Caracas.

Carrillo, V. (2001). Distribución espacial del zooplancton en el embalse La Mariposa (Distrito Capital) de julio a diciembre de 2000. Universidad Central de Venezuela, Thesis, Caracas.

Castilho-Noll, M.S.M. \& Arcifa, M.S. (2007). Length-weight relationships for zooplanktonic species of a tropical Brazilian lake: Lake Monte Alegre. Acta Limnologica Brasiliensia, Vol. 19, No.1 (June, 2007), pp. 93-100. ISSN 0102-6712.

Conde-Porcuna, J.M., Ramos-Rodríguez, E., \& Morales-Baquero, R. (2004). El zooplancton como integrante en la estructura trófica de los sistemas acuáticos lénticos. Ecosistemas, Vol. 13, No. 2 (May 2004), pp. 23-29. ISSN 1697-2473.

Edmondson, W.T. \& Winberg, G.G. (1971). A manual of methods for the measurement of secondary productivity in fresh waters. International Biological Programme Handbook $\mathrm{N}^{\mathrm{o}}$ 17, ISBN 0-632-00610-1, Oxford.

Esteves, F.A. (1998). Fundamentos de Limnologia (2nd edition), Editorial Interciencia, ISBN 857193-008-2, Rio de Janeiro.

Gavidia, J. (2004). Variaciones de abundancia y biomasa del zooplancton en dos localidades del embalse Tierra Blanca (Edo. Guárico, Venezuela). Universidad Central de Venezuela, Thesis, Caracas.

González, E.J. (2000a). Caracterización limnológica del embalse El Pueblito (Estado Guárico, Venezuela). Trabajo de Ascenso a la Categoría de Profesor Agregado. Universidad Central de Venezuela, Monograph, Caracas. 
González, E.J. (2000b). Nutrient enrichment and zooplankton effects on the phytoplankton community in microcosms from El Andino reservoir (Venezuela). Hydrobiologia, Vol. 434, No. 1 (September 2000), pp. 81-96. ISSN 0018-8158.

González, E.J. (2006). Caracterización limnológica de los embalses Agua Fría (Estado Miranda) y Tierra Blanca (Estado Guárico). Universidad Central de Venezuela, Technical Report, Proyecto S1 - 98001361, Caracas.

González, E.J. (2008). Eutrofización de embalses en Venezuela. Memorias del Instituto de Biología Experimental, Vol. 5, No. 1 (May 2008), pp. 169-172. ISSN 0034-7507.

González, E.J. \& Quirós, R. (Submitted). Eutrophication of reservoirs in Venezuela: Relationships between nitrogen, phosphorus and phytoplankton biomass. Oecologia Australis.

González, E.J., Matsumura-Tundisi, T., \& Tundisi, J.G. (2008). Size and dry weight of main zooplankton species in Bariri Reservoir (SP, Brazil). Brazilian Journal of Biology, Vol. 68, No. 1 (February 2008), pp. 69-75. ISSN 1519-6984.

González, E.J., Carrillo, V.M., \& Peñaherrera, C. (2004). Características físicas y químicas del embalse Agua Fría (Parque Nacional Macarao, Estado Miranda, Venezuela). Acta Científica Venezolana, Vol. 55, No. 3 (October 2004), pp. 225-236. ISSN 0001-5504.

González, E.J., Álvarez, M., Barrero, M., \& Finol, H. (2009). Limnología y efecto de los impactos antrópicos sobre los peces de interés comercial del embalse de Suata (Estado Aragua) y del Lago de Valencia (Estados Aragua y Carabobo). Universidad Central de Venezuela, Technical Report, PG 03.00.6495.2006, Caracas.

González, E.J., Ortaz, M., Matos, M.L., Mendoza, J., Peñaherrera, C., \& Carrillo, V.M. (2002). Zooplancton de dos embalses neotropicales con distintos estados tróficos. Interciencia, Vol. 27, No. 10 (October 2002), pp. 551-558. ISSN 0378-1844.

Hammer, Ø., Harper, D.A.T., \& Ryan, P.D. (2001). PAST: Paleontological Statistics software package for education and data analysis. Paleontologia Electronica, Vol. 4, No. 1 (June 2001), pp. 1-9. ISSN 1094-8074.

Hutchinson, G.E. (1957). A treatise on Limnology. 1. Geography, Physics, and Chemistry. Wiley \& Sons, ISBN 04-7142-570-2, New York.

Infante, A. (1988). El plancton de las aguas continentales. Secretaría General de la Organización de los Estados Americanos, Serie de Biología, Monografía No 33, ISBN 0-8270-27362, Washington DC.

Infante A. (1993). Vertical and horizontal distribution of the zooplankton in Lake Valencia. Acta Limnologica Brasiliensia, Vol. 6, No. 1 (June 1993), pp. 97-105. ISSN 0102-6712.

Infante, A. \& Infante, O. (1994). Limnological studies in a tropical man-made lake (Lagartijo Reservoir), Venezuela. Internationale Revue der Gesamten Hydrobiologie und Hydrographie, Vol. 79, No. 1 (March 1994), pp. 17-25. ISSN 0020-9309.

Infante, A. \& Riehl, W. (1984). The effect of Cyanophyta upon zooplankton in a eutrophic tropical lake (Lake Valencia, Venezuela). Hydrobiologia, Vol. 113, No. 1 (June 1984), pp. 293-295. ISSN 0018-8158.

Infante, A., Infante, O., \& González, E.J. (1995). Caracterización limnológica de los embalses El Cují y El Andino, Venezuela. Proyecto Multinacional de Medio Ambiente y 
Recursos Naturales. Technical Report. Organización de los Estados Americanos, Universidad Central de Venezuela, Caracas.

Infante, A., Infante, O., \& Vegas, T. (1992). Caracterización limnológica de los embalses Camatagua, Guanapito y Lagartijo, Venezuela. Proyecto Multinacional de Medio Ambiente y Recursos Naturales. Technical Report. Organización de los Estados Americanos, Universidad Central de Venezuela, Caracas.

Lampert, W. \& Sommer, U. (1997). Limnoecology. The ecology of lakes and streams. Oxford University Press, ISBN 0-19-509592-8, Oxford.

Landa, G.G., Barbosa, F.A.R., Rietzler, A.C., \& Maia-Barbosa, P.M. (2007). Thermocyclops decipiens (Kiefer, 1929) (Copepoda, Cyclopoida) as indicator of water quality in the State of Minas Gerais, Brazil. Brazilian Archives of Biology and Technology, Vol. 50, No. 4 (July 2007), pp. 695-705. ISSN 1516-8913.

Leitão, A.C., Freire, R.H., Rocha, O., \& Santaella, S.T. (2004). Zooplankton community composition and abundance of two Brazilian semiarid reservoirs. Acta Limnologica Brasiliensia, Vol. 18, No. 4 (October 2006), pp. 451-468. ISSN 0102-6712.

Lewis, W.M. (1983). A revised classification of lakes based on mixing. Canadian Journal of Fisheries and Aquatic Sciences, Vol. 40, No. 10 (October 1983), pp. 1779-1787. ISSN 1205-7533.

López, C., Villalobos, M., \& González, E.J. (2001). Estudio sobre el zooplancton de los embalses de Venezuela: Estado actual y recomendaciones para futuras investigaciones. Ciencia, Vol. 9, No. 2 (April 2001), pp. 217-234. ISSN 1315-2076.

Matsumura-Tundisi, T. (1997). Composition and vertical distribution of zooplankton in Lake Dom Helvécio - MG, Brazil, In: Limnological studies on the Rio Doce valley lakes, Brazil, J.G. Tundisi \& Y. Saijo (Eds.), pp. 309-326, Brazilian Academy of Sciences, University of São Paulo, ISBN 85-85761-07-5, Rio de Janeiro.

Matsumura-Tundisi, T., Rietzler, A., \& Tundisi, J.G. 1989. Biomass (dry weight and carbon content) of plankton crustacea from Broa reservoir (São Carlos, S.P. - Brazil) and its fluctuation across one year. Hydrobiologia, Vol. 179, No. 3 (July 1989), pp. 229-236. ISSN 0018-8158.

McQueen, D.J., Post, J.R., \& Mills, E.L. (1986). Trophic relationships in freshwater pelagic ecosystems. Canadian Journal of Fisheries and Aquatic Sciences, Vol. 43, No. 8 (August 1986), pp. 1571-1581. ISSN 1205-7533.

Melão, M.G.G. \& Rocha, O. (2004). Life history, biomass and production of two planktonic cyclopoid copepods in a shallow subtropical reservoir. Journal of Plankton Research, Vol. 26, No. 8 (April 2004), pp. 909-923. ISSN 0142-7873.

Mélo-Júnior, M., Santos-Almeida, V.L., Nogueira-Paranaguá, M., \& Nascimento-Moura, A. (2007). Crustâceos planctônicos de um reservatório oligotrófico do Nordeste do Brasil. Revista Brasileira de Zoociências, Vol. 9, No. 1 (June 2007), pp. 19-30. ISSN 1517-6770.

Mendoza, J. (1999). Variaciones de abundancia del plancton y de las bacterias en el embalse La Mariposa (Dtto. Federal, Venezuela): Período noviembre 1998 - mayo 1999. Universidad Central de Venezuela, Thesis, Caracas. 
Merayo, S. \& González, E.J. (2010). Variaciones de abundancia y biomasa del zooplancton en un embalse tropical oligo-mesotrófico del norte de Venezuela. Revista de Biología Tropical, Vol. 58, No. 2 (June 2010), pp. 603-619. ISSN 0034-7744.

Ministerio del Ambiente (MINAMB). (2007). Rehabilitación de presas a nivel nacional. Organización para la rehabilitación y mantenimiento de embalses. Ministerio del Poder Popular para el Ambiente (MINAMB). Technical Report. Serie de Informes Técnicos, DGEA/IT/864. No. X-002/P-129/02 Rev. B. Caracas.

Mustapha, M.K. (2009). Zooplankton assembalge of Oyun reservoir, Offa, Nigeria. Revista de Biología Tropical, Vol. 57, No. 4 (December 2009), pp. 1027-1047. ISSN 0034-7744.

Nusch, E.A. \& Palme, G. (1975). Biologische Methoden für der Praxis der Gewässeruntersuchung, Bestimmung des Chlorophyll- $a$ und Phaeopigment-gehaltes in Oberflachenwäser. GWF-Wasser/Abwässer, Vol. 116, No. 2 (May 1975), pp. 562-565. ISSN 6601-8628.

Ortaz, M., González, E.J., Manduca, J., Peñaherrera, C., \& Montes, E. (1999). Características limnológicas de los embalses La Pereza, Lagartijo, La Mariposa y Quebrada Seca y preservación del zooplancton como controlador de microalgas, mediante técnicas de biomanipulación. Hidroimpacto C.A., Hidrocapital, Universidad Central de Venezuela, Technical Report, Caracas.

Pinto-Coelho, R.M., Bezerra-Neto, J.F., \& Morais-Jr., C.A. (2005). Effects of eutrophication on size and biomass of crustacean zooplankton in a tropical reservoir. Brazilian Journal of Biology, Vol. 65, No. 2 (May 2005), pp. 325-338. ISSN 1519-6984.

Rocha, O., Sendacz, S., \& Matsumura-Tundisi, T. (1995). Composition, biomass and productivity of zooplankton in natural lakes and reservoirs of Brazil, In: Limnology in Brazil. J.G. Tundsi, C.E.M. Bicudo, \& T. Matsumura-Tundisi (Eds.), pp. 151-165, Brazilian Academy of Sciences, Brazilian Limnological Society, ISBN 85-7093-003-8, Rio de Janeiro.

Rocha, O., Matsumura-Tundisi, T., Espíndola, E.L.G., Roche, K.F., \& Rietzler, A.C. (1999). Ecological theory applied to reservoir zooplankton, In: Theoretical reservoir ecology and its applications. J.G. Tundisi \& M. Straškraba (Eds.), pp. 457-476, Brazilian Academy of Sciences, International Institute of Ecology, Backhuys Publishers, ISBN 90-5782-034-X, São Carlos.

Salas, H. \& Martinó, P. (1991). A simplified phosphorus trophic state model for warm-water tropical lakes. Water Research, Vol. 25, No. 3 (March 1991), pp. 341-350. ISSN 00431354.

Santos-Wisniewski, M.J. \& Rocha, O. (2007). Spatial distribution and secondary production of Copepoda in a tropical reservoir: Barra Bonita, SP, Brazil. Brazilian Journal of Biology, Vol. 67, No. 2 (May 2007), pp.223-233. ISSN 1519-6984.

Sendacz, S., Caleffi, S., \& Santos-Soares, J. (2006). Zooplankton biomass of reservoirs in different trophic conditions in the state of São Paulo, Brazil. Brazilian Journal of Biology, Vol. 66, No. 1b (February 2006), pp. 337-350. ISSN 1519-6984.

Tundisi, J.G., Matsumura-Tundisi, T., \& Abe, D.S. (2008). The ecological dynamics of Barra Bonita (Tietê River, SP, Brazil) reservoir: Implications for its biodiversity. Brazilian Journal of Biology, Vol. 68, No. 4 (Supp.) (November 2008), pp. 1079-1098. ISSN 15196984. 
Wetzel, R. \& Likens, G.E. (2000). Limnologycal analyses (3 ${ }^{\text {rd }}$ edition), Springer, ISBN 0-38798928-5, New York.

Zhao, J., Ramin, M., Cheng, V., \& Arhonditsis, G.B. (2008). Plankton community patterns across a trophic gradient: The role of zooplankton functional groups. Ecological Modelling, Vol. 213, No. 3-4 (May 2008), pp. 417-436. ISSN 0304-3800. 


\title{
Estimation of Above-Ground Biomass of Wetlands
}

\author{
Laimdota Truus \\ Institute of Ecology at Tallinn University \\ Estonia
}

\section{Introduction}

Despite global importance of wetlands, estimations of their production and biomass have received little attention (Campbell et al., 2000). This chapter concentrates on analysis of the composition and above-ground biomass of floodplain grasslands and fen vegetation in the Northern forest zone. Both vegetation types were extensively used for hay and/or grazing up to the middle of the 20th century, and abandoned later.

Systematic biomass estimations were conducted in the 1970s-1980s (Estonian data from 1977-1980; most data from Canada from 1972-1978 (Campbell et al., 2000)) when they were feasible for agricultural use. Papers on vegetation production and above-ground biomass of wetlands are quite scarce nowadays. Biomass has sometimes been measured for developing community structure theories, e.g. Zobel \& Liira (1997) included some wet grasslands into analysis of richness vs biomass relationship. Still, some thorough reviews can be found like an overview of biomass of rich fen types in South England and Wales by Wheeler \& Shaw (1991). New interest in the subject has risen in the context of biomass use for bioenergy production (e.g. Rösch et al., 2009).

Many plant species cannot survive without special accommodation to wetland conditions. The composition of wetland vegetation is mostly controlled by the wetland water level (WL) (Bootsma \& Wassen, 1996; Hájková et al., 2004; Barry et al., 2008). Wilcox \& Nichols (2008) and Ilomets et al. (2010) found that the diversity and habitat value of plant communities depend on the wetland WL and the water level amplitude between dry and wet seasons (WLA). In fens with a constantly high WL rhizome-spreading graminoids and herbs dominate, while drainage and fluctuating WL support high tussock-forming graminoids.

A specific feature of both floodplain grassland and fen vegetation is high patchiness due to variations in WL and WLA caused by microtopography (Liira et al., 2009). Tussocks, formed by herbaceous plants or tree stumps, locally increase the habitat variability even more (Liira et al., 2009; Ilomets et al., 2010).

Total biomass of wetland vegetation is significantly affected by three main factors: the N:P ratio, total nutrient supply and morphological and physiological traits of plants (Güsewell, 2005). Biomass variations are higher on moister sites such as wet floodplain grasslands (Truus \& Puusild, 2009) and fens (Ilomets et al., 2010). The height and coverage of tussocks increases with denser or deeper drainage. About $52 \%$ of the vascular plant species variance occurs due to four environmental variables: amplitude of WL (between spring flooding and midsummer dry period), midsummer WL, mire water $\mathrm{pH}$ and electrical conductivity (Ilomets et al., 2010). 
Truus \& Puusild (2009) found strong relation of the above-ground biomass with the management regime but not with the variations in site conditions on wet and moist floodplain grasslands. Wilson \& Keddy (1986), Moore \& Keddy (1989) and Garica et al. (1993) detected general hump-back relationship between species richness and biomass, but it has also been shown that a high number of factors can complicate prediction of species richness from community biomass (Gough et al., 1994).

\section{Factors affecting wetland productivity and species richness}

\subsection{Relationship between species richness and biomass}

The relation between plant species richness and biomass was first discussed by Grime (1973, 1979) and Al-Mufti et al. (1977) when describing general hump-back relationship between species density and community biomass. According to these authors, maximum species richness can be found at medium values of biomass. Later, this relation has been approved (Wheeler \& Giller, 1982) or denied (Gough et al., 1994). In the development of this theory Zobel \& Liira (1997) attributed species richness to the plant ramet density.

Gough et al. (1994) established correlation between environmental conditions and species richness but not between biomass and environmental conditions. Therefore, the influence of environmental conditions on species richness could not be assumed strictly from biomass. Wheeler \& Giller (1982), Boyer \& Wheeler (1989) and Wheeler \& Shaw (1991) recorded differences in biomass- species richness relation between community types (low-sedge lowproductive fen, productive tall-sedge and reed fen, and fertile site communities with strong domination of Filipendula ulmaria or Molinia cerulea).

According to Gough et al. (1994), two types of processes operate in the species richnessproductivity relation on wetlands:

- At low levels of productivity, species richness is primarily limited by the ability of the species to survive the abiotic conditions. In this range increase in productivity reflects a decrease in the harshness of the environment.

- At higher levels of community productivity, the decline in richness is believed to be related in some way to a greater degree of competitive exclusion with increasing productivity. For wetlands this relation was revealed by Wheeler \& Giller (1982). Examining herbaceous fen vegetation, they found that species richness was negatively correlated to above-ground biomass.

Wet meadows are poorer in species than those on mineral soil. Two reasons could be pointed out:

- Hard environmental stress that excludes several plant species.

- The absence of management leading to domination of tall plants and accumulation of dead biomass on soil surface (Truus, 1998).

Strong correlation has been found in fens between the height and coverage of the tussockforming graminoid Molinia cerulea in fens with fluctuating WL and midsummer WL minimum (Ilomets et al., 2010).

In general, relationship of species richness and above-ground biomass is complex and hardly predictable, especially for wetlands.

\subsection{Limitations of productivity}

2.2.1 Flood, water level and water level amplitude

On floodplain meadows the duration and intensivity of flooding serve as environmental determinants of plant species selection. Riverine floodwater pulses provide water, nutrient- 
rich material and sediments to floodplain wetlands, but flood pulses also act as a natural disturbance by removing biomass, scouring sediments and delivering turbid waters (Bayley \& Guimond, 2009). Riparian ecosystems are among the most diverse systems on the world's continents (Nilsson et al., 1997). The intensity of natural processes taking place on floodplains is variable, depending on the properties of the river and shore. Estonian rivers are usually small and floodplains narrow. Thereby most riverborn nutrients settle on the 50 $\mathrm{m}$ wide belt close to the river channel ${ }^{1}$ where productive high-growing vegetation develops. An exception is South Estonia where luxorious sandy sediments form rapidly desiccating low-productivity dry floodplain meadows.

The species composition of spring fen communities is mainly influenced by groundwater chemistry, especially $\mathrm{pH}$, electrical conductivity and mineral richness (Hájek et al., 2002). It is unknown whether these factors affect species richness and the amount of above-ground biomass (Hájkova \& Hájek, 2003).

\subsubsection{Water and soil chemistry and nutrient availability}

Water and soil chemistry and nutrient availability to plants are among the important factors controlling the diversity of wetland vegetation.

Floods bring extra nutrients to floodplain grasslands. Thus there is no $\mathrm{N}$ and P deficit and vegetation is luxorious. Management of grasslands removes nutrients from soil and biomass production decreases. Without management, however, annual biomass production increases.

Fens are characterized by high concentrations of cations in soil and water. The concentration of $\mathrm{Ca}, \mathrm{Fe}, \mathrm{N}, \mathrm{P}$ and $\mathrm{K}$ in plants varies along the poor-rich fen vegetation gradient from poor Sphagnum-fens to calcareous fens, and from sedge-moss fens to forb-rich wet meadows (Rozbrojová \& Hájek, 2008). The same study showed that the fertility gradient was largely independent of the poor-rich $(\mathrm{pH} /$ calcium) gradient. Nutrient limitations of fens are complicated: species in one community can have different limitations (Rozbrojová \& Hájek, 2008). Low-productivity fen communities that support more rare species (Wassen et al., 2005) are rather P- or K- (co)limited, or limited by different environmental conditions (Rozbrojová \& Hájek, 2008).

\subsubsection{Management}

Due to nutrient supply by floodwater, the soil of floodplain meadows is rich in nutrients and biomass productivity is high. The amounts of nutrients brought by floods is comparable to quantities taken away with the harvest or/and cattle grazing. Clipping increase species richness and shoot density but decrease above-ground biomass, thus creating more favourable conditions for more plant species. Bakker (2007) demonstrated that cutting reduces the vigour of tall competitive species, allowing smaller species coexist. Nowadays most of the floodplain meadows are left unmanaged. Hay is mown only in restricted areas for the purposes of environmental protection.

In comparison with other meadow types above-ground biomass production is lower on dry floodplain meadows and higher on floodplain marshes. Productivity is variable in all floodplain meadow community types depending on species composition (Table 1). On wet meadows the site moisture conditions are greatly responsible for plant ecological traits. On

1 Pork, K. (1984). Jõeluhtade looduslikus seisundis säilitamisest. In: Looduskaitse ja põllumajandus. Kumari, E., Randalu, I. \& Hang, V. (Eds.). Academy of Sciences of the E.S.S.R, 58-70. [In Estonian] 
permanently wet sites both tussock-forming and mat-forming graminoids dominate while herbs dominate where soil WL drops down at least in summer (Fig. 1). Comparison of Estonian data from the period of regular management (Table 1) with the period of abandonment (Tables 2 and 3) showed that productivity had risen due to accumulation of plant nutrients on unmanaged meadow soils. Above-ground biomass varied threefold, depending on the management regime (Table 3). Liira et al. (2009) also noticed that management lowered canopy height but revealed differences in functional trait structure in more detail.

Falinska $(1991,1995)$ described two stages in the after-abandonment vegetation succession in Cirsium rivularis phytocoenosis on wet grassland. The initial stage of the succession lasted about 9 years: half of 142 plant species retreated but 12 species became dominant and a macroforb meadow community (Lysimachio vulgaris-Filipenduletum) meadow with mosaic structure, including species like Filipendula ulmaria, Carex cespitosa, C. acutiformis, Lythrum salicaria and Lysimachia vulgaris, was formed. During the following 15 years a specific spatial complex developed, consisting of meadow and herbaceous communities and willow shrub aggregations with the first tree species. Next the Circaeo-Alnetum woodland community appeared. The succession exhibits differentiation of the horizontal structure - increase in patchiness, and differentiation of the vertical structure - plant height started to increase immediately after management stopped and most of the above-ground biomass moved higher from the near-surface position.

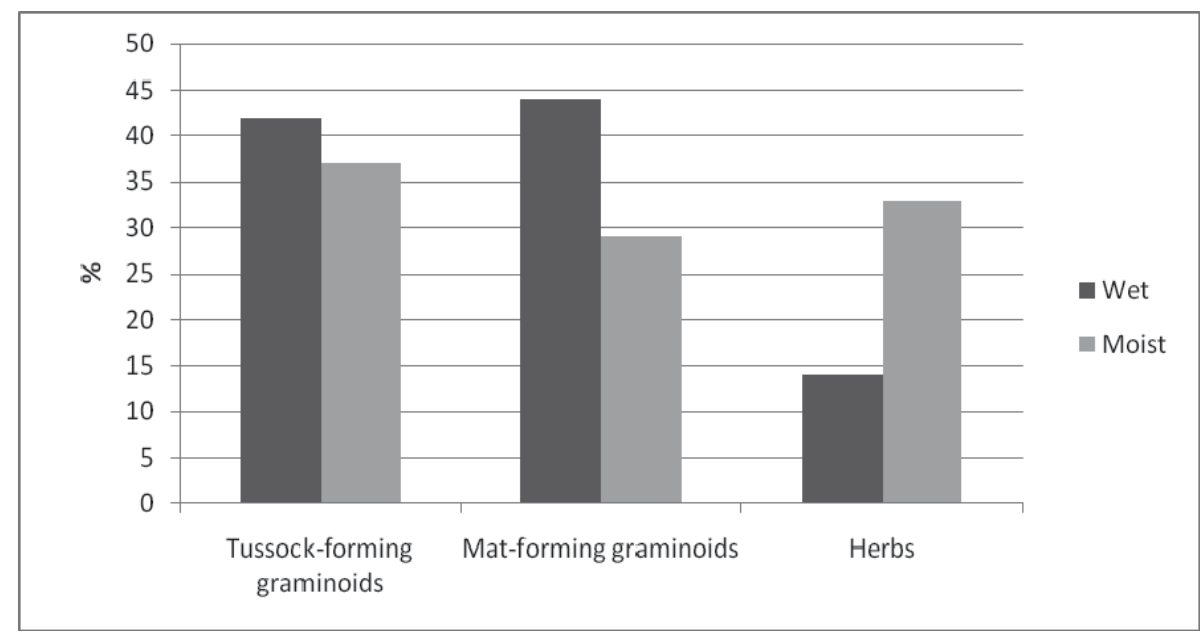

Fig. 1. Life-form distribution on Soomaa (West Estonia) wet and moist floodplain meadows

The species composition and duration of this vegetation change depend on climatic and trophic conditions and hydrology, also on the ecological trait of plants and availability of diaspores. General trends, however, are: decrease in species richness, change in species composition, increase in vegetation height and above-ground biomass, and finally replacement of the herbaceous community by woodland. Re-location of most of the biomass to a higher level in the community as described by Falinska $(1991,1995)$ takes place if herbs dominate - on wet meadows at a drier site. No comparable data about composition and biomass change are available due to abandonment of seminatural hay lands and pastures. Just general trends in vegetation change can be followed. 


\begin{tabular}{|c|c|c|c|}
\hline $\begin{array}{c}\text { Floodplain meadow } \\
\text { type } \mathbf{p}^{2} \\
\text { English description of } \\
\text { classification in Truus \& } \\
\text { Tõnisson, } 1998\end{array}$ & Plant community & $\begin{array}{l}\text { Above-ground } \\
\text { biomass } \\
\left(\mathrm{g} \mathrm{m}^{-2}\right)\end{array}$ & $\begin{array}{c}\text { Above-ground } \\
\text { biomass, mean } \\
\text { for community } \\
\text { type } \\
\left(\mathrm{g} \mathrm{m}^{-2}\right)\end{array}$ \\
\hline \multirow[t]{6}{*}{ Dry floodplain meadow } & Sesleria-Festucetum ovinaea & 150 & \multirow{6}{*}{80} \\
\hline & Seslerio-Nardetum & 40 & \\
\hline & Thymo-Festucetum & $30-100$ & \\
\hline & Sieglingo-Nardetum & $40-80$ & \\
\hline & Anthoxantho-Agrostetum & $40-100$ & \\
\hline & Galio-Agrostetum tenuis & $50-150$ & \\
\hline \multirow{3}{*}{$\begin{array}{l}\text { Moderately moist } \\
\text { floodplain meadow }\end{array}$} & Agrostetum giganteae & $150-250$ & \multirow{3}{*}{200} \\
\hline & $\begin{array}{l}\text { Deschampsio-Festucetum } \\
\text { rubrae }\end{array}$ & $100-300$ & \\
\hline & Alopecuretum pratensis & $150-380$ & \\
\hline \multirow[t]{4}{*}{ Moist floodplain meadow } & Cirsio-Polygonetum bistortae & $150-300$ & \multirow{4}{*}{230} \\
\hline & $\begin{array}{l}\text { Filipendulo-Geranietum } \\
\text { palustris }\end{array}$ & $200-400$ & \\
\hline & $\begin{array}{l}\text { Deschampsieto-Caricetum } \\
\text { caespitosae }\end{array}$ & $100-250$ & \\
\hline & $\begin{array}{l}\text { Elytrigieto-Alopecuretum } \\
\text { arundinacei }\end{array}$ & $150-300$ & \\
\hline \multirow{2}{*}{$\begin{array}{l}\text { Wet floodplain meadow } \\
\text { with tall grasses }\end{array}$} & Stellario-Deschampsietum & $80-200(300)$ & \multirow[b]{2}{*}{250} \\
\hline & Phalaroidetum & $150-500$ & \\
\hline \multirow{3}{*}{$\begin{array}{l}\text { Wet floodplain meadow } \\
\text { with tall sedges }\end{array}$} & Caricetum distichae & $200-250$ & \multirow[t]{3}{*}{260} \\
\hline & Caricetum acutae & $100-450$ & \\
\hline & Caricetum rostrato-vesicariae & $100-450$ & \\
\hline \multirow[t]{5}{*}{ Floodplain marshes } & Seslerio-Caricetum paniceae & $40-100$ & \multirow{5}{*}{125} \\
\hline & Caricetum paniceo-nigrae & $50-150$ & \\
\hline & Caricetum diandro-nigrae & $50-180$ & \\
\hline & $\begin{array}{l}\text { Caricetum cespitoso- } \\
\text { appropinquatae }\end{array}$ & $100-200$ & \\
\hline & Caricetum elatae & $80-300$ & \\
\hline
\end{tabular}

Table 1. Mean above-ground biomass of plant communities of floodplain meadows. The analyses are means for Estonia representing seminatural hay meadows in 1978-19812

Analysis of life-form distribution on Estonian floodplain meadows in periods with different management showed an increased proportion of tall herbs and graminoids instead of low herbs and graminoids in the 1960s when these areas were mostly regularly mown and the end of the 1990s when they were out of use (Fig. 2). The proportion of tall tussock-forming graminoids did not change. On floodplain grasslands these plants inhabit depressions with a higher water table and thereby were absent even in the former period.

${ }^{2}$ Krall, H., Pork, K., Aug, H., Püss, O., Rooma, I. \& Teras, T. (1980). Eesti NSV looduslike rohumaade tüübid ja tähtsamad taimekooslused, ENSV Põllumajandusministeerium IJV, Tallinn. [In Estonian] 


\section{Above-ground biomass}

\subsection{Methods for standing crop estimation}

Wheeler \& Shaw (1991) calculated above-ground biomass as the biomass increment between April and September. In regions with a dormant season for herbaceous plants in winter, above-ground biomass (that also represents production per year) is in its maximum in the middle of summer, but before abundant flowering. In wetlands different flowering times can be noticed: the sedges usually stop growing and flower in May and June (Leht, 1999) while common reed continues growing up to the August. In all cases, biomass samples were air-dried before measuring. Standing biomass measured in its maximum is usually equalized with production.

\subsection{Above-ground biomass of floodplain meadows}

In the period of regular management, mean values for above-ground biomass of Estonian floodplain meadows measured from 80 to $260 \mathrm{~g} \mathrm{~m}^{-2}$, varying largely between community types and even communities ${ }^{2}$. On unmanaged floodplain meadows those values are more than twice higher (Tables 2 and 3). Zobel \& Liira (1997) presented biomass values from 300 to $600 \mathrm{~g} \mathrm{~m}^{-2}$ for West Estonian floodplain meadows of Sauga, Vaskjõe and Kasari (the lowest value on a dry site). High standard deviation in Tables 2 and 3 shows high variability of floodplain meadows vegetation discussed earlier. For comparison, in the Czech Republic Molinio-Arrhenetheretea above-ground biomass in a moist floodplain meadow was 300-350 g $\mathrm{m}^{-2}$ (Joyce, 2001). Values of above-ground biomass from the earlier (with regular hay cutting; Table 1) and later (without management; Tables 2 and 3) periods show an increase in standing crop that can be explained as a result of management cessation. Standing biomass also varied threefold (from 263 to $763 \mathrm{~g} \mathrm{~m}^{-2}$ ) on floodplains in Soomaa, West Estonia (Truus \& Puusild, 2009).

\begin{tabular}{|l|c|}
\hline $\begin{array}{c}\text { Floodplain meadow type } \\
\text { English description in Truus \& Tõnisson, 1998 }\end{array}$ & $\begin{array}{c}\text { Above-ground biomass } \\
\text { (g m}^{-2}, \\
\text { St.Dev in parentheses) }\end{array}$ \\
\hline Dry & $458(148.6)$ \\
\hline Moderately moist & $493(240)$ \\
\hline Moist & $350(448.3)$ \\
\hline Wet & (no data) \\
\hline Wet with tall sedges & $742(70.3)$ \\
\hline Floodplain marsh & $376(100.9)$ \\
\hline
\end{tabular}

Table 2. Mean above-ground biomass on the Kloostri landscape transect, West Estonia. Previous hay-meadow, abandoned over 15 years

Truus \& Puusild (2009) studied the distribution of ecological groups (graminoids, herbs, low and tall growth-form) in relation to management cessation. The ecological group composition turned towards tussock-forming plants but the most obvious change was the increase in vegetation height (Fig. 2).

Unmanaged wetlands are dominated by powerful species (Wheeler \& Giller, 1982; Truus, 1998; Truus \& Puusild, 2009). On sites with a permanently high groundwater level Deschampsia cespitosa or Carex cespitosa form high tussocks while low-growing tussocks (Nardus stricta, Festuca ovina) spread on dry or moist managed grasslands. The abandonment 


\begin{tabular}{|l|c|}
\hline $\begin{array}{c}\text { Floodplain meadow type } \\
\text { English description in Truus \& Tõnisson, 1998 }\end{array}$ & $\begin{array}{c}\text { Above-ground biomass } \\
\text { (g } \text { }^{-2} \text {, } \\
\text { St.Dev in parentheses) }\end{array}$ \\
\hline Moist, regularly mown & $572(692.3)$ \\
\hline Moist, mown, recently abandoned & $333(167.5)$ \\
\hline Moist, unmown but mowing reintroduced & $380(178.2)$ \\
\hline Moist, unmown over 15 years & $763(627.5)$ \\
\hline Wet, regularly mown & $263(108.0)$ \\
\hline Wet, mown, recently abandoned & $516(165.9)$ \\
\hline Wet, unmown, but mowing reintroduced & $452(398.7)$ \\
\hline Wet, unmown over 15 years & $447(86.4)$ \\
\hline
\end{tabular}

Table 3. Mean above-ground biomass on moist and wet floodplain meadows with different management regimes in Soomaa, West Estonia.

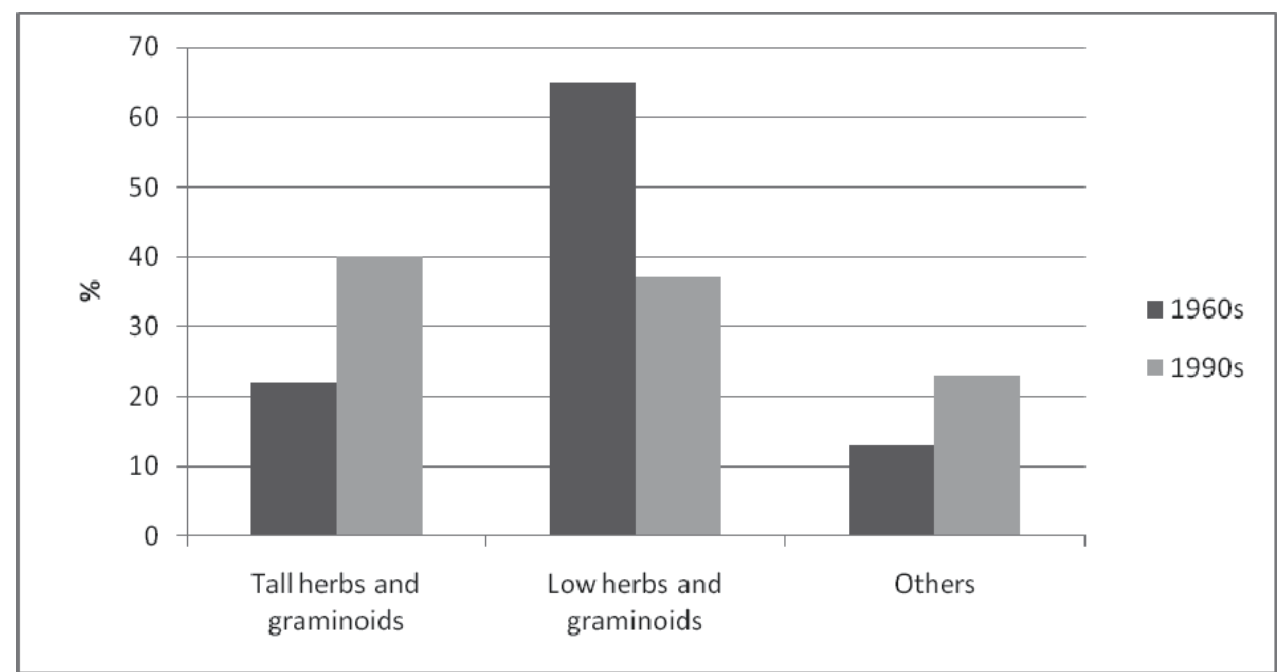

Fig. 2. Proportions of the most frequent growth-forms on floodplain meadows in periods of extensive management (first half of the 20th century) and unmanagement (end of the 1990s)

of grasslands can lead to dominance (in some cases to almost monospecies communities) of tall herbs like Filipendula ulmaria. The coverage and height of tussocks of Molinia cerulea increase on rich fen meadows (Ilomets et al., 2010).

\subsection{Biomass of fens}

Fen vegetation presented in Table 4 is highly variable and the biomass values vary between locations. The above-ground biomass values for low-growing vegetation range from 50 to $500 \mathrm{~g} \mathrm{~m}^{-2}$ and from 600 to $1750 \mathrm{~g} \mathrm{~m}^{-2}$ for both tall graminoids and tall herbs. For comparison, in Canada and adjacent USA mean above-ground biomass was $337 \pm 142 \mathrm{~g} \mathrm{~m}^{-2}$ for fens and bogs, and $924 \pm 463 \mathrm{~g} \mathrm{~m}^{-2}$ for marshes and swamps (Campbell et al., 2000).

No recent data are available on biomass production on fens in Estonia. The data from 19771980 (Table 4) gives very low values $\left(50 \mathrm{~g} \mathrm{~m}^{-2}\right)$ for above-ground biomass of fen meadows. 
The utilization of fen meadows grew in Estonia at the beginning of the 20th century. An experiment from 1922-1926 showed the yield of 140 to $450 \mathrm{~g} \mathrm{~m}^{-2}$ from unfertilized fen meadows. ${ }^{3}$. It was also mentioned that during the experiment hay production was related to weather conditions but decreased year by year (probably because of experimental hay cutting).

\begin{tabular}{|c|c|c|c|}
\hline Location & Vegetation community & $\begin{array}{l}\text { Dry } \\
\text { standing } \\
\text { biomass } \\
\left(\mathrm{g} \mathrm{m}^{-2}\right) \\
\text { St.Dev. in } \\
\text { parentheses }\end{array}$ & Reference \\
\hline England and Wales & Schoeno-Juncetum & $\sim 200$ & \multirow{12}{*}{$\begin{array}{l}\text { Wheeler \& Shaw, } \\
\text { 1991, Fig. } 1\end{array}$} \\
\hline England and Wales & Acrocladio-Caricetum & $\sim 200$ & \\
\hline England and Wales & Potentillo-Caricetum & $\sim 200$ & \\
\hline England and Wales & Peucedano-Phragmitetum & $\sim 300$ & \\
\hline England and Wales & Rich-fen meadow & $\sim 500$ & \\
\hline England and Wales & Cladio-Molinietum & $\sim 600$ & \\
\hline England and Wales & Peucedano-Phragmitetum & $\sim 700$ & \\
\hline England and Wales & Angelico-Phragmitetum & $\sim 850$ & \\
\hline England and Wales & Cicuto-Phragmitetum & $\sim 1200$ & \\
\hline England and Wales & Phragmites consociation & $\sim 1300$ & \\
\hline England and Wales & $\begin{array}{l}\text { Glyceria maxima } \\
\text { community }\end{array}$ & $\sim 1500$ & \\
\hline England and Wales & Tall herb fen & $\sim 1750$ & \\
\hline England and Wales & $\begin{array}{l}\text { Phalaris arundinacea } \\
\text { community }\end{array}$ & $900-1200$ & \multirow[t]{2}{*}{ Smith et al., 1985} \\
\hline England and Wales & $\begin{array}{l}\text { Glyceria maxima } \\
\text { community }\end{array}$ & $700-1200$ & \\
\hline Siberia, Russia & Carex-dominating fen & 200 & Pjavtšenko, 1967 \\
\hline Switzerland & Saxifraga hirculus fen & $152-231$ & $\begin{array}{l}\text { Venterink \& } \\
\text { Vittouz, } 2008\end{array}$ \\
\hline Netherlands & Molinietalia fen & $\sim 300-400$ & $\begin{array}{l}\text { Van der Hoek \& } \\
\text { Sýkora, } 2006\end{array}$ \\
\hline Estonia & Drepanoclado-Schoenetum & 50 & \multirow{2}{*}{$\begin{array}{l}\text { Data from 1977- } \\
1980^{2}\end{array}$} \\
\hline Estonia & Seslerio-Caricetum paniceae & 50 & \\
\hline
\end{tabular}

Table 4. Above-ground biomass of fens with highly variable composition in different regions

${ }^{3}$ Rinne, L. (1927). Sooheinamaa toodangu kahanemisest väetuse puudusel. Eesti Sooparanduse Seltsi teated, Vol.8\&9, 3-15. [In Estonian] 


\section{Conclusions}

Vegetation of floodplain meadows and fens varies depending on the environmental (soil, water) conditions and management regime. Both vegetation types have been in economic use but a great part of them is in the successional stage due to abandonment.

On low-productive sites plant species richness is primarily limited on abiotic conditions (WL, WLA, mineral content of soil and water, availability of plant nutrients).

The main limitation in highly productive sites is competition for light. Tall graminoids or herbs compete out low-growing plants, enabling even the development of monospecies vegetation.

The management status determines plant species richness and the above-ground biomass production. Above-ground standing biomass varied threefold due to management cessation on West Estonian floodplain grassland. Widespread cessation of management on seminatural meadows is a key for interpretation of different above-ground biomass values from different periods. Fen vegetation is probably more sensitive to above-ground biomass cutting than floodplain grassland vegetation.

It is complicated to predict species richness from community biomass, and biomass (or production) from site conditions.

Values of above-ground biomass increase from north to south but the geographical latitude (availability of photosynthetic radiation) is not as strong determinant for biomass production of wet grasslands as the local hydrological, nutritional and management status.

\section{Acknowledgement}

This research was financed by the Estonian Ministry of Education and Research (targeted funding project No. 0280009s07). The author is indebted to Anne Noor for linguistic help.

\section{References}

Al-Mufti, M.M., Sydes, C.L., Furness, S.B., Grime, J.P. \& Band, S.R. (1977). A quantitative analysis of shoot phenology and dominance in herbaceous vegetation. J. Ecol., Vol.65, 759-791, ISSN 10.2307/i313577

Barry, M.J., Andreas, B.K. \& De Szalay, F.A. (2008). Long-term plant community changes in managed fens in Ohio, USA. Aquat. Conserv., Vol.18, 392-407, ISSN 1099-0755

Bayley, S. E. \& Guimond, J.K. (2009). Aboveground biomass and nutrient limitation in relation to river connectivity in montane floodplain marshes. Wetlands, Vol.29, No.4, 1243-1254, ISSN 0277-5212

Bootsma, M.C. \& Wassen, M.J. (1996). Environmental conditions and fen vegetation in three lowland mires. Vegetatio, Vol.127, 173-189, ISSN 1385-0237

Boyer, M.L.H. \& Wheeler, B.D. (1989). Vegetation patterns in spring-fed calcareous fens: calcite precipitation and constraints on fertility. J. Ecol., Vol.77, 597-609, ISSN 10.2307/i313577

Campbell, C., Vitt, D.H., Halsey, L.A., Campbell, I.D., Thormann, M.N. \& Bayley, S.E. (2000). Net primary production and standing biomass in northern continental wetlands. 
Information report NOR-X-369. Canadian Forest Service, Northern Forestry Centre, ISSN 0704-7673, Canada

Falinska, K. (1991). Plant demography and vegetation succession. Kluwer Academic Publishers, ISBN 0-7923-1060-8, Dordrecht, Boston, London

Falinska, K. (1995). Genet disintegration in Filipendula ulmaria: consequences for population dynamics and vegetation succession. J. Ecol. Vol.83, 9-21, ISSN 10.2307/i313577

Garcia, L.V., Maranon, T., Moreno, A. \& Clemente, L. (1993). Above-ground biomass and species richness in a Mediterranean salt marsh. J. Veg. Sci., Vol.4, 417-424, ISSN 1100-9233

Gough, L., Grace, J.B. \& Taylor, K.L. (1994). The relationship between species richness and community biomass: the importance of environmental variables. Oikos, Vol.70, 271279, ISSN 0030-1299

Grime, J.P. (1973). Competitive exclusion in herbaceous vegetation. Nature, Vol.242, 344-347, ISSN 0028-0836

Grime, J.P. (1979). Plant strategies and vegetation processes. Wiley \& Sons Ltd, ISBN 04719920, Chichester, U.K.

Güsewell, S. (2005). Responses of wetland graminoids to the relative supply of nitrogen and phosphorus. Plant Ecol., Vol.176, 35-55, ISSN 1385-0237

Hájek, M., Hekera, P. \& Hájkova, P. (2002). Spring fen vegetation and water chemistry in the West Carpathian flysh zone. Folia Geobot., Vol.37, 205-224, ISSN 1211-9520

Hájkova, P. \& Hájek, M. (2003). Species richness and above-ground biomass of poor and calcareous spring fens in the flysh Weat Carpathians, and their relationship to water and soil chemistry. Preslia, Vol.75, 271-287, ISSN 0032-7786

Hájková, P., Wolf, P. \& Hájek, M. (2004). Environmental factors and Carpathian spring fen vegetation: the importance of scale and temporal variation, Ann. Bot. Fenn., Vol.41, 249-262, ISSN 0003-3847

Ilomets, M., Truus, L., Pajula, R. \& Sepp, K. (2010). Species composition and structure of vascular plants and bryophytes on the water level gradient within a calcareous fen in North Estonia. Est. J. Ecol., Vol.59, No.1, 19-38, ISSN 1736-7549

Joyce, C. 2001. The sensitivity of a species-rich flood-meadow plant community to fertilizer nitrogen: the Lužnice river floodplain, Czech Republic. Plant Ecol., Vol.155, 47-60, ISSN 1385-0237

Leht, M. (Ed.). (1999). Eesti taimede määraja. EPMÜ ZBI, Eesti Loodusfoto, ISBN 9985-830-27$\mathrm{X}, \mathrm{Tartu}$, Estonia (In Estonian)

Liira, J., Issak, M., Jõgar, Ü., Mändoja, M. \& Zobel, M. (2009). Restoration management of a floodplain meadow and its cost-effectiveness - The results of a 6-year experiment. Ann. Bot. Fen., Vol.46, 397-408, ISSN 0003-3847

Moore, D.R.J. \& Keddy, P.A. (1989). The relationship between species richness and standing crop in wetlands: The importance of scale. Vegetatio, Vol.79, 99-106, ISSN 1406-0914

Moore, D.R.J., Keddy, P.A., Gaudet, C.L. \& Wisheu, I. (1989). Conservation of wetlands: do infertile wetlands deserve a higher priority? Biol. Conserv., Vol.47, 203-217, ISSN 0006-3207 
Nilsson, C., Jansson R. \& Zinko, U. (1997).Long-term responses of river-margin vegetation to water-level regulation. Science, Vol.276, 798-800, ISSN 00368075

Pjavtšenko, N.I. (1967). O produktivnosti bolot Zapadnoi Sibiri. Rastitelnõje Resursõ. Vol.3, No.4, 523-533, ISSN 0033-9946 (In Russian)

Rozbrojová, Z. \& Hájek, M. (2008). Changes in nutrient limitation of spring fen vegetation along environmental gradients in the West Carpathians. J. Veg. Sci., Vol.19, 613-620, ISSN 1100-9233

Rösch, C., Skarka, J., Raab, K., Stelzer, V. (2009). Energy production from grassland Assessing the sustainability of different process chains under German conditions. Biomass and Bioenergy, Vol.33, 689-700, ISSN 0961-9534

Smith, S.J., Ridge, I. \& Morris, R.M. (1984). The biomass potential of seasonally flooded wetlands. In: Proceedings of Bioenergy' 84 World Conference, 15-21 June 1984 in Goteborg, Sweden, The Bioenergy Council, 190-195, ISBN 9780853343516, Stockholm, Sweden

Zobel, K. \& Liira, J. (1997). A scale-independent approach to the richness vs biomass relationship in ground-layer plant communities, Oikos. Vol.80, 325-332, ISSN 00301299

Truus, L. \& Puusild, E. (2009). Species richness, biomass production and recent vegetation changes of Estonian floodplain grassland. Pol. J. Ecol., Vol.57, No.1, 33-45, ISSN 15052249

Truus, L. \& Tõnisson, A. (1998). The ecology of floodplain grasslands in Estonia. In: European Wet Grasslands: Biodiversity, Management and Restoration, C.B. Joyce \& P.M. Wade, (Eds.), 49-60, John Wiley \& Sons Ltd, ISBN 0-471-97619-9, Chichester, U.K.

Truus, L. (1998). Influence of management cessation on reedbed and floodplain vegetation on the Kloostri floodplain meadow in the delta of the Kasari River, Estonia. Proc. Estonian Acad. Sci. Biol. Ecol., Vol.47, No.1, 58-72, ISSN 1406-0914

Van der Hoek, D. \& Sýkora, K.V. (2006). Fen-meadow succession in relation to spatial and temporal differences in hydrological and soil conditions, Appl. Veg. Sci., Vol.9, 185194, ISSN 1402-2001

Wassen, M.J., Barendregt, A., Palczynski, A., De Smidt, J.T. \& De Mars, H. (1990). The relationship between fen vegetation gradients, groundwater flow and flooding in an undrained valley mire at Biebrza, Poland, J. Ecol., Vol.78, 1106-1122, ISSN 10.2307/i313577

Wassen, M.J., Venterink, H.O., Lapshina, E.D. \& Tanneberger, F. (2005). Endangered plants persist under phosphorus limitation, Nature, Vol.437, No.22, 547-550, ISSN 00280836

Venterink, O.H. \& Vittoz, P. (2008). Biomass production of the last remaining fen with saxifraga hirculus in Switzerland is controlled by nitrogen availability, Botanica Helvetica, Vol.118, 165-174, ISSN 02531453

Wheeler, B.D. \& Shaw, S.C. (1991). Above-ground crop mass and species richness of the principal types of herbaceous rich-fen vegetation of lowland England and Wales, $J$. Ecol., Vol.79, 285-301, ISSN 10.2307/i313577 
Wheeler, B.D., Giller, K.E. (1982). Species richness of herbaceous fen vegetation in Boardland, Norfolk in relation to the quantity of above-ground plant material, J. Ecol., Vol.70, 79-200, ISSN 10.2307/i313577

Wilcox, D.A. \& Nichols, S.J. (2008). The effect of water-level fluctuations on vegetation in a Lake Huron wetland, Wetlands, Vol.28, No.2, 487-501, ISSN 0277-5212

Wilson, S.D. \& Keddy, P.A. (1986). Species competitive ability and position along a natural stress/disturbance gradient, Ecology, Vol.67, 1236-1242, ISSN 0012-9658 


\title{
Soil Microbial Biomass Under Native Cerrado and Its Changes After the Pasture and Annual Crops Introduction
}

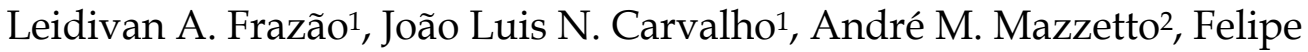 \\ José C. Fracetto ${ }^{1}$, Karina Cenciani ${ }^{2}$, Brigitte J. Feigl ${ }^{2}$ and Carlos C. Cerri ${ }^{2}$ \\ 1 Universidade de São Paulo/Escola superior de Agricultura "Luiz de Queiroz" \\ ${ }^{2}$ Centro de Energia Nuclear na Agricultura \\ Brazil
}

\section{Introduction}

The Brazilian savanna (Cerrado) soils were incorporated into the agricultural production process in the 1970's. Soils were initially occupied by pastures, and later used for cropping (Ferreira et al., 1997). An area of over 12 million hectares is cultivated with annual crops under different systems of soil management (Bayer et al., 2004). The introduction of pastures and/or annual crops utilizing different management systems promoted changes in the dynamics of soil organic matter (SOM).

The SOM improves the soil structure and regulates its biological activity, as well as being directly linked with the ability to accumulate water and maintain the soil fertility. The introduction of agricultural systems in the Cerrado soils, with intensive land use, has brought direct consequences for the chemical, physical and biological properties of soil, with losses in its quality. Continued land use for the cultivation of grains, fibers and cultivated pastures can generate a rapid process of degradation, loss of organic matter, biological processes and imbalance in the flow of nutrients.

The conversion of Cerrado into pastures and croplands made by the slash-and-burn process which causes major impacts on soil fertility. In order to improve the soil conservation, maintain and increase crop productivity, a number of practices were introduced, such as the elimination of crop residues caused by burning, the adoption of conservation tillage, and the management of crop residues (Mielniczuk et al., 1983). As a consequence, SOM increased not only due to the reduction of losses caused by biological decomposition and erosion but also due to the increase of plant residues on soil surface (Bayer et al., 2000).

It is widely known that SOM improves soil structure (Feller \& Beare, 1997) and regulates soil biological activity (Bayer \& Mielniczuck, 1999), in addition to its role in water holding capacity and soil fertility maintenance (Dick, 1983). The dynamics of SOM is different in clayey and sandy soils and it is highly influenced by different management practices and climate conditions in each region. The stocks of SOM decrease when the soil is exposed to intensive tillage systems due to increasing losses caused by water erosion and microbial oxidation (Silva et al., 1994). However, little information is available about the effects of agricultural management practices on the dynamics of SOM in the Cerrado 
region. Some studies in Oxisols showed a decrease in microbial attributes in management systems compared to the native systems (Neill et al., 1995; Roscoe et al., 2000; Matsuoka et al., 2003).

Microorganisms play a key role in SOM decomposition. When their diversity or abundance is reduced, the nutrient cycling can be highly affected (Giller et al., 1998). The soil microbial community is generally influenced by variations in soil temperature, water content and aeration, rupture of aggregates, decrease in soil cover, nutrient availability, and organic substrates. These factors can be modified by soil management systems as a function of crop residue incorporation and soil disturbance intensity (Vargas \& Scholles, 2000). Soil microorganisms present a high potential for use in soil quality assessments due to their abundance, biochemical and metabolic activity, providing faster responses to environmental changes (Araújo \& Monteiro, 2007).

In most part of the soils under agricultural practices (tillage, fertilization, liming, incorporation of pesticides and other inputs) the communities available could be affected to changes in the physical, chemical and biological characteristics. Each change represents a profound renewal of selection pressure, favoring some components of the microbial community and eliminating others, thus experiencing the reallocation of the steady state between the populations.

The soil microbial biomass (SMB), the living fraction of soil organic matter, represents 1 to $4 \%$ of the soil organic carbon (C) (Anderson \& Domsch, 1990; Sparling, 1992), 2 to 6\% of the soil total nitrogen (N) (Jenkinson, 1988), and it is an $\mathrm{N}$ reservoir for plants. Nutrient release and immobilization depends on the microbial dynamics, the quantity and quality of plant residues, on the carbon cycling and efficiency of the soil microbial community (Beaudoin et al., 2003). Management systems influence microbial $\mathrm{C}$ and $\mathrm{N}$ concentrations and conventional tillage reduces the soil microbial biomass and microbial activity (Roscoe et al., 2000; Figueiredo et al., 2007). Due to its sensitivity to changes occurring in the soil, SMB is considered to be a good soil quality indicator (Jackson et al., 2003).

The objective of this chapter is to evaluate the changes in the soil microbial attributes due to conversion of the native Cerrado into pasture and annual crops and to determine the changes related to soil management and climate seasonality.

\section{Changes in soil microbial biomass after the land-use-change in Cerrado region}

Soil microbial biomass (SMB) and its activity have been suggested as appropriate indicators of changes caused by different land uses and management systems. Kaschuk \& Hungria (2010) evaluated a hundreds of studies involving the microbial biomass carbon (MB-C) as one of the physical-chemical indicators of soil quality in the Brazilian cerrado region, confirming the benefits of the conservation tillage in the MB-C and increases of its concentration due to permanent organic agriculture. Thus, the application of pesticides and burning of the vegetation affected the soil microbial communities and reduced the MB-C in overgrazed pastures, but increased in pastures rotated with well-managed crops. However, these authors concluded that the direct relationship between $M B-C$, nutrient-cycling dynamics, microbial diversity and the soil functionality are still unclear. Further studies are needed in order to develop strategies to maximize the beneficial effects of microbial communities on soil fertility and crop productivity. 
It is important to evaluate the microbial biomass nitrogen (MB-N) when nitrogen fertilization occurs. Only between 40 to $60 \%$ of the nitrogen applied as fertilizer is absorbed by plants and $20-50 \%$ is incorporated into the soil as organic nitrogen (GamaRodrigues et al., 2005). However, little information is available about the effects caused by successive applications of nitrogen fertilizers in the SMB, especially in soils of tropical ecosystems.

There are other studies reporting that the addition of nitrogen fertilizer on the soil surface has induced changes in the amount of SMB and its activity, not only in superficial layers but also in deeper layers (Zaman et al., 2002). Taking advantage of this evaluation Coser et al. (2007) working with an Oxisol cultivated with barley studied the effect of nitrogen fertilization $\left(30,60,90\right.$ and $\left.120 \mathrm{~kg} \mathrm{ha}^{-1}\right)$ the microbial biomass nitrogen at different soil depths $(0-5,5-10,10-20$ and 20-30 cm). Results showed no increases in the MB-N in the soil under higher doses of nitrogen (90 and $120 \mathrm{~kg} \mathrm{ha}^{-1}$ ), but the MB-N decreased with depth. This clearly shows that even with addition of nitrogen an increase of SMB may not occur, but this depends increase in SMB but this depends on the type of culture evaluated.

With regard to soybean cultivation, Perez et al. (2004) quantified the microbial biomass carbon (MB-C) and the organic carbon (Corg) of cerrado soil under different systems: no tillage, disking, sub soiling and disking operations over a clayey Oxisol. Soil samples were collected at five depths $(0-5,5-10,10-20,20-30$ and 30-40 cm) and in four periods (before soil preparation, 30 days after germination, flowering and after soybean harvest). Thus, they reported that sub soiling showed the lowest value of SOC after soybean harvest, since the values of carbon in tillage remained more stable, especially at $0-20 \mathrm{~cm}$. Before planting the crop, the MB-C:Corg was higher in the Cerrado and no significant differences among the tillage systems were found. At 30 days after germination, significant differences were obtained in the values of MB-C:Corg among the types of tillage systems. The values of microbial biomass carbon under the tillage systems were more stable especially at $0-20 \mathrm{~cm}$.

Matsuoka et al. (2003) show that the population of microorganisms on the rhizosphere can be increased when the soil structure has been preserved. Carneiro et al (2008) working with Cerrado soils with soybean cultivation also noted that the maintenance of organic carbon in these soils is essential to maintain its sustainability, since it provides the structure and functioning of soil microbial activity, and contribute to increase the cation exchange capacity (CEC) of these soils.

Anyway, there are many papers studying the SMB and the most important factor that diverges at the results is the type of soil cultivation associated with the type of management and the conditions of soil treatment. In general, the soils of the surface layers contain higher input of organic matter due to increasing of the SMB. The conversion of Cerrado into pasture alters the soil microbial composition.

A permanent cover of soil is an important factor for the maintenance of microorganisms, is directly reflected in the content of microbial $\mathrm{C}$ and $\mathrm{N}$. The land use with pasture and managed over time provides high levels of microbial $\mathrm{C}$ and $\mathrm{N}$, and that detention may be similar to that observed in the native system.

Studies evaluating soil management systems with annual crops in different soil types showed reduction of microbial $\mathrm{C}$ and $\mathrm{N}$ in these systems in relation to native Cerrado. This is the most favorable conditions for microorganisms when there is native vegetation, with species diversity and favors the preservation of soil fungal hyphae. The reduction of the 
most active fraction of SOM affects various functions in the soil, for example, maintaining the production of polysaccharides fundamental to the process of aggregation.

\subsection{Soil microbial biomass after pasture and agriculture introduction in Cerrado region}

Processes of deforestation are complex and involve many factors at different scales of time and space. Initially, the main reason for deforestation was the timber exploration and the livestock (pasture). The growing demand for grains, fiber and meat for export have caused significant changes in the agricultural scenario of the Brazilian territory. Native areas are being converted to livestock and agriculture utilizing intensive management systems (Brazil, 2009).

According to Maia (2009), the cultivated area in Mato Grosso State had increased 20 times in the period between 1970 and 2002. The increase of pastureland was 2.1 times lower in the same period. Already in Rondonia State, pastureland showed an increase of 17 times, while the agricultural area increased 10.3 times. The author related a large increase in grassland classified as degraded, but also there was a significant increase in areas with improved pasture.

The land-use-change has caused modification in the dynamics of SOM as well as vegetation influences in the activity of the microbial biomass resulting in the reduction of biomass $\mathrm{C}$ as studies involving deforestation have shown. When a forest is converted to monoculture or pasture there is a severe environmental impact. The natural mechanisms of nutrient recycling and soil protection are disrupted, often resulting in degradation of the area. Modifications in the microbial community can result in changes in soil quality and fertility and in the availability of carbon $(\mathrm{C})$, nitrogen $(\mathrm{N})$, phosphorus $(\mathrm{P})$ and and others nutrients for plants.

The degradation of SOM is a property of all heterotrophic microorganisms and its rate is commonly used to indicate the soil microbial activity. Thus, it is possible to better understand the process of mineralization and verify the intensity of energy flows (Ingran et al., 2005). The microbial respiration has great potential as an indicator of soil quality in degraded areas, related to the loss of organic $\mathrm{C}$ from the soil-plant system to the atmosphere.

\subsubsection{Study areas}

This study focuses on the Southwestern Amazonian states of Rondônia ( $R O$ ) and Mato Grosso (MT), a transitional region between the Amazon Basin and the highlands of the Brazilian Central Plateau. Located at latitude $7^{\circ}$ and $18^{\circ}$ South and longitude $50^{\circ}$ and $67^{\circ}$ West, the region represents the water divisor between two large basins: the Amazon on the North and the Paraná on the South. It is also one of the largest agricultural frontiers in the world, comprising an area of approximately 1,128,000 km².

The regional climate varies according to latitude and can be characterized as a humid tropical regime with short dry seasons. The pluviometric regime has very defined seasons: a rainy and a dry season (or low rainy season) with mean annual precipitation ranging from 1400 to 2500 $\mathrm{mm}$. The types of soil in this region, as described by Mello (2007), are Oxisols, Ultisols and Entisols, comprising $40 \%, 20 \%$ and $15 \%$, respectively, of the total area of both states.

The research sites were selected to cover the main bio and geo-climatic zones of the States of Rondonia and Mato Grosso (Fig. 1), following the "Guidelines for National Greenhouse Gas Inventories" issued by the Intergovernmental Panel for Climate Changes (IPCC, 2007). The 
delimitation of the zones was performed using the Geographic Information System ArcGis 9.0 with combined information on soils, native vegetation, geology, climate and relief. This methodology allowed to obtain relatively homogeneous areas that made it possible to perform a discerning extrapolation of the microbiological parameters for the whole region. In each one of the 11 zones, two cities were randomly chosen for data collection, totaling 22 points of research sites (Maia et al., 2009).

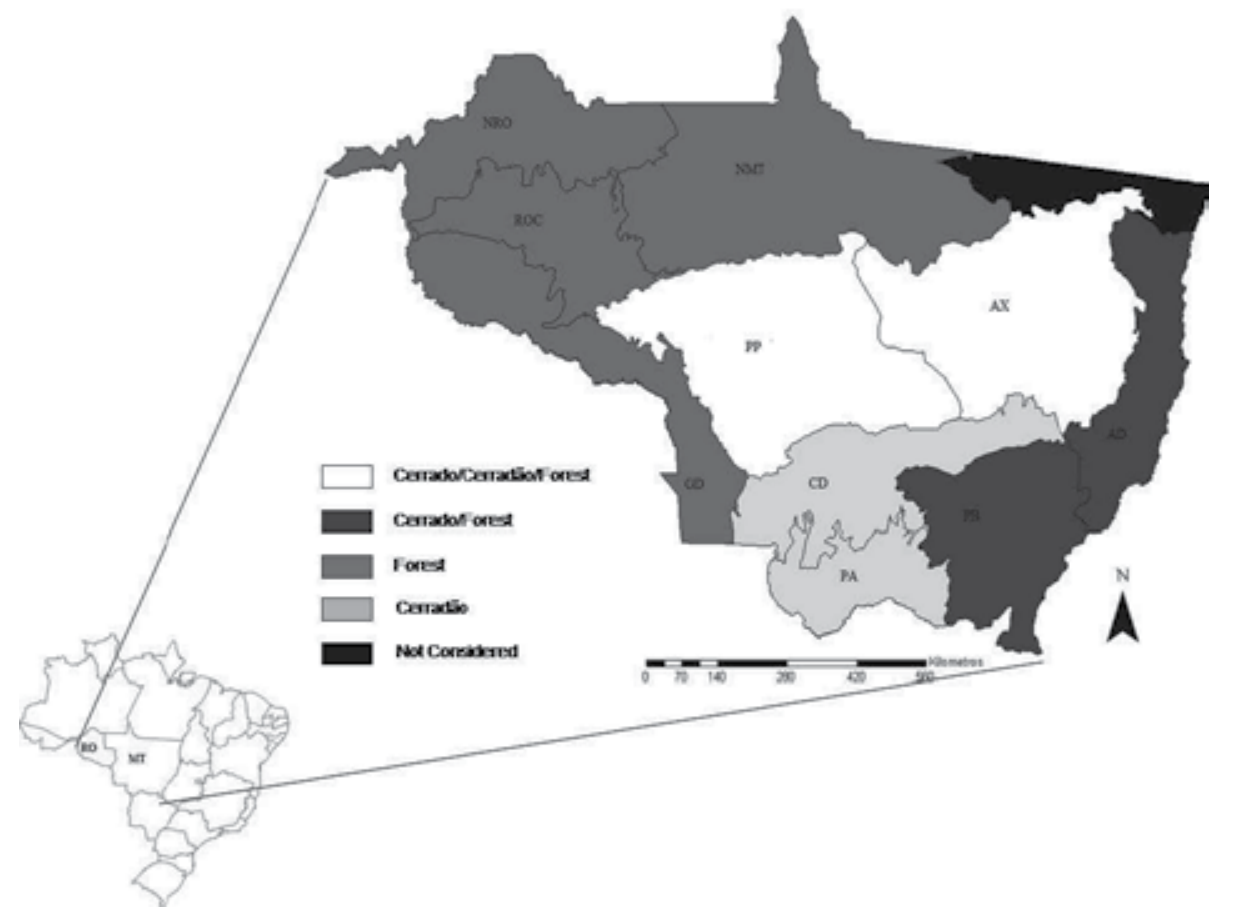

Fig. 1. Distribution of Ecoregions and native areas in study area; (AX) Alto Xingu; (PB) Parana Basin; (PP) Parecis Plateau; (AD) Araguaia Depression; (CD) Cuiabá Depression; (DG) Guaporé Depression; (NMT) North of Mato Grosso; (NRO) North of Rondônia; (PA) Pantanal; (ROC) Central Rondônia.

The follow land uses were selected for this study: native Cerrado area (CER); Agriculture (AGR) with different crops (soybean, corn, rice, etc); and Pasture area (PAS).

\subsubsection{Soil sampling and analytical procedures}

Sampling was carried out in June/July 2007 at 0-5 cm depth (15 in Cerrado area, 45 in agricultural area, and 55 in pasture area) in three replicates on each place, totaling 345 samples. Soil samples were harrowed and sifted through a $2 \mathrm{~mm}$ mesh to remove rocks and vegetation fragments.

Soil Basal Respiration (BR) was determined by $\mathrm{CO}_{2}$ evolution. Field-moist soil samples (equivalent to $5 \mathrm{~g} \mathrm{dw}$ ) were placed in $250 \mathrm{ml}$ tubes and pre-incubated at $25^{\circ} \mathrm{C}$ for 3 days. The tubes were hermetically closed and he $\mathrm{CO}_{2}$ produced from the soil after 8 hours of incubation. The samples were carried out with BD syringes $(2 \mathrm{ml})$ and analyzed utilizing an infra-red analyzer (IRGA LICOR-6262). 
Microbial biomass C (MB-C) was determined by the chloroform fumigation-extraction method (Vance et al.,1987) with field-moist samples (equivalent to $20 \mathrm{~g} \mathrm{dw}$ ). The filtered soil extracts of both fumigated and no fumigated samples were analyzed for soluble organic $\mathrm{C}$ using a total organic $\mathrm{C}$ analyser (Shimadzu TOC-5000). The MB-C was estimated on the basis of the difference between the organic $\mathrm{C}$ extracted from the fumigated soil and that from the no fumigated soil (EC). For the quantification of nitrogen in microbial biomass (MB-N), the extracts were analyzed using the Ninhydrin Method (Jorgensen and Brookes, 1990). Ten Cerrado areas, 20 agricultural areas and 20 pasture areas were selected, in three replicates on each place in field conditions and two replicates in laboratory, totaling 300 samples.

The $\left(\mathrm{qCO}_{2}\right)$ metabolic ratio (or specific respiratory rates) was calculated based on relationship between $\mathrm{MB}-\mathrm{C}$ and $\mathrm{BR}$.

\subsubsection{Results and discussion}

The results for the basal respiration between pasture and Cerrado were similar (Table 1). These results may be related to carbon stocks equivalents, while the different behavior in the agricultural areas may be related to soil management and the different types of crops that are found in the region (soybean, corn, rice, coffee, etc.).

Studies show that after some years of cultivation, the total concentration of carbon in the pasture soil is similar to the native systems (Cerri et al., 1991; Cerri, 2003; Silva, 2004) which also influences the dynamics of SMB. This fact is due to the large amount of roots present in the pasture system which allows the increase in SOM content and available substrates for microorganisms to long-term (Carneiro et al., 2008). Maia (2009) concluded that degraded pastures in the states of Mato Grosso and Rondonia may provide an increase in the soil organic $\mathrm{C}$ content and consequently promote $\mathrm{C}$ sequestration.

Jakelaitis et al. (2008) also reported the same sequence in their studies. According to Ballota et al. (1998) soil that exhibit high and low values of MB-C:Corg may represent accumulation or loss of soil carbon, respectively. Those values are consistent with the percentage proposed by Jenkinson \& Ladd (1981) who consider it normal that 1 do $4 \%$ of soil carbon corresponds to the microbial component. This ratio is reported as an indicator of the quality of SOM (Wardle, 1994), it allows to monitor the disturbances promoted by the ecological imbalance and changes in total SOM caused by management, reacting faster than the physical and chemical indicators (Alvarez et al., 1995).

Studies in different soils and regions found higher values of $\mathrm{qCO}_{2}$ in native areas (Xavier, 2004; Santos et al., 2004; Fialho et al., 2006). Assessing agroecosystem for 21 years, Mader et al. (2002) reported a high negative correlation between microbial diversity and $\mathrm{qCO}_{2}$. The lower values observed in pasture (0.76) suggest that these areas have a more efficient microbial biomass energy use, featuring more stable environment (Chaer, 2001) and also have higher microbial diversity (Mader et al., 2002). Dinesh et al. (2003) assigns higher values of $\mathrm{qCO}_{2}$ due the large amount of $\mathrm{C}$ content available for soil microbial degradation. The higher values of MB-C and MB-N observed in soils under pasture (PAS) in relation to native area (CER) is due to long time of pasture implantation in these ecoregions (10 to 25 years of establishment). Luizão et al. (1999) studied pastures 2 to 13 years in the Amazon region and assign that the $\mathrm{SMB}$ and $\mathrm{BR}$ in the soil superficial layer $(0-5 \mathrm{~cm})$ increase until five years after the pasture establishment. After that a progressive decline occurs until the eighth year. However, De Vries et al. (2007) shows a positive correlation between SMB (fungal and bacterial) and the age of pasture. 


\begin{tabular}{|c|c|c|c|c|}
\hline \multicolumn{5}{|c|}{ Basal Respiration $\left(\mathrm{ugCO} 2 \mathrm{~g}\right.$ soil h $\left.\mathrm{h}^{-1}\right)$} \\
\hline & Mean & $\mathrm{N}$ & S.D. & C.V. $(\%)$ \\
\hline AGR & $0.37 \mathrm{~b}$ & 135 & 0.08 & 21.44 \\
\hline PAS & $0.50 \mathrm{a}$ & 165 & 0.18 & 38.06 \\
\hline CER & $0.46 \mathrm{a}$ & 45 & 0.09 & 19.17 \\
\hline \multicolumn{5}{|c|}{ MB-C (g C kg soil-1-1) } \\
\hline & Mean & $\mathrm{N}$ & S.D & C.V. (\%) \\
\hline AGR & $0.53 \mathrm{~b}$ & 120 & 0.21 & 41.29 \\
\hline PAS & $0.69 \mathrm{a}$ & 120 & 0.17 & 25.29 \\
\hline CER & $0.53 \mathrm{~b}$ & 60 & 0.29 & 54.86 \\
\hline \multicolumn{5}{|c|}{ MB-N (mg C kg soil-1) } \\
\hline & Mean & $\mathrm{N}$ & S.D & C.V. (\%) \\
\hline AGR & $17.85 \mathrm{~b}$ & 120 & 16.10 & 90.19 \\
\hline PAS & $37.16 \mathrm{a}$ & 120 & 26.93 & 71.00 \\
\hline CER & $26.56 \mathrm{~b}$ & 60 & 18.74 & 70.55 \\
\hline \multicolumn{5}{|c|}{ MB-C: Corg (\%) } \\
\hline & Mean & $\mathrm{N}$ & S.D & C.V. $(\%)$ \\
\hline AGR & $2.98 \mathrm{~b}$ & 100 & 2.40 & 49.51 \\
\hline PAS & $4.08 \mathrm{a}$ & 100 & 2.50 & 33.14 \\
\hline CER & $3.45 \mathrm{a}$ & 20 & 2.31 & 67.03 \\
\hline \multicolumn{5}{|c|}{$\mathrm{qCO}_{2}\left(\mathrm{~g} \mathrm{CO}_{2} \mathrm{~h}^{-1}\right)$} \\
\hline & Mean & $\mathrm{N}$ & S.D & C.V. (\%) \\
\hline AGR & $1.01 \mathrm{a}$ & 120 & 0.49 & 97.14 \\
\hline PAS & $0.76 \mathrm{~b}$ & 120 & 0.47 & 45.09 \\
\hline CER & $1.02 \mathrm{a}$ & 20 & 0.78 & 76.52 \\
\hline
\end{tabular}

Table 1. Soil microbial attributes in different areas at Mato Grosso and Rondonia states. AGR: Agriculture; PAS: Pasture areas; CER: Cerrado; S.D.: Standard Deviation; C.V.: Coefficient of Variation.

According to Luizão et al. (1999), the biomass of fine roots is a factor that may influence the response of the microbial attributes in the pasture system, having a positive correlation with the SMB and the soil water content. The higher BR observed in degraded pastures may be related to the diversity of invasive plants which have varied root systems, resulting in greater soil aeration and oxygenation (Grimaldi et al., 1992). Moreover, there is an increase in nutrient input through litter and exudates produced by different plant species.

The greatest MB-N content in degraded pastures may indicate, indirectly, a change in taxonomic groups that compose the microbial biomass (Venzke Filho, 1999). The development of nitrifying microorganisms occurs due to different physical, chemical and nutritional properties.

Other factor that promotes the development of the SMB in pasture is an intensive livestock, resulting in an increase in MB-C and MB-N (Wang et al., 2006). The livestock waste acts as a natural fertilizer and consequently causes reactions in the dynamics of soil microorganisms (Saviozzi et al., 2001; Iyyemperumal et al., 2007). The microbial biomass is sensitive to changes in soil organic carbon related to management and land-use-change. After the 
alterations in the soil, the SMB undergoes fluctuations until a new equilibrium (Polwson et al., 1987).

To illustrate the dynamics of the microbial attributes within ecoregions, was performed a study in the Alto Xingu ecoregion. This ecoregion was chosen because it has great representation in the land-use-change in Southwestern Amazonia. The Alto Xingu is characterized by livestock and agriculture in the municipality of Sorriso, and the soil is classified as Oxisols with different clay contents (Belizario, 2008).

The improved pastures (IP) showed higher values of MB-C and BR in relation to degraded (DP) and typical pastures (TP). The SM-C (Figure 2) values were 0.84 (IP), 0.60 (DP) and 0.53

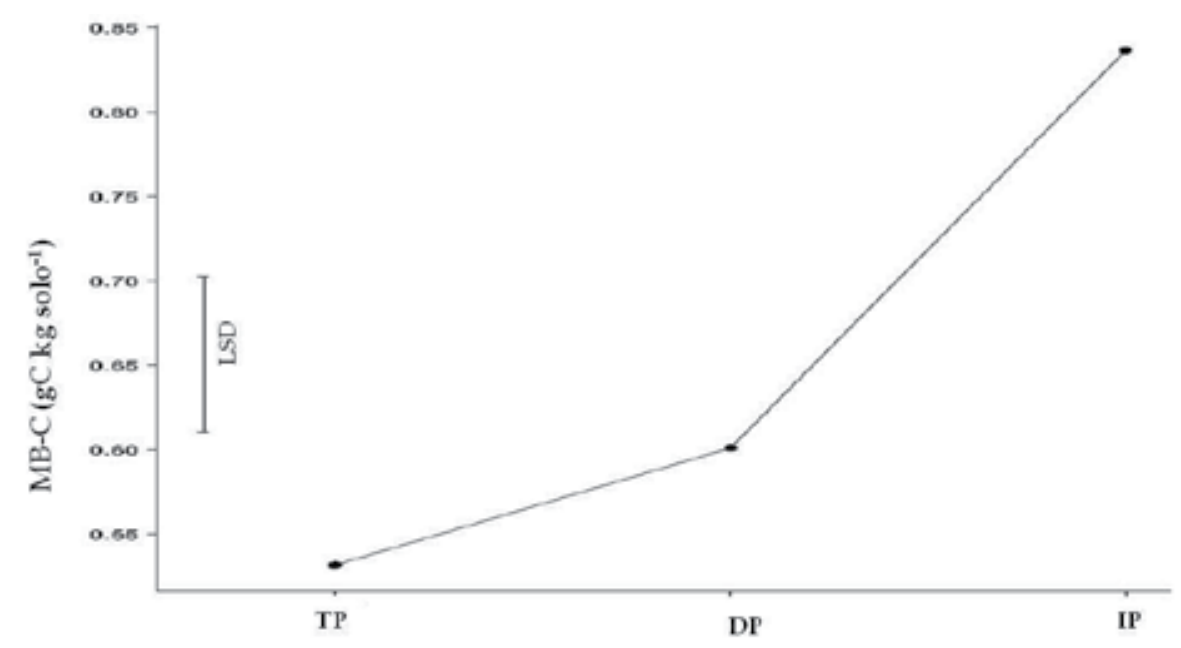

Fig. 2. Microbial biomass carbon (MB-C) in pasture areas located at Alto Xingu ecoregion. LSD, Least significant difference; TP, typical pasture; DP, degraded pasture; IP, improved pasture.

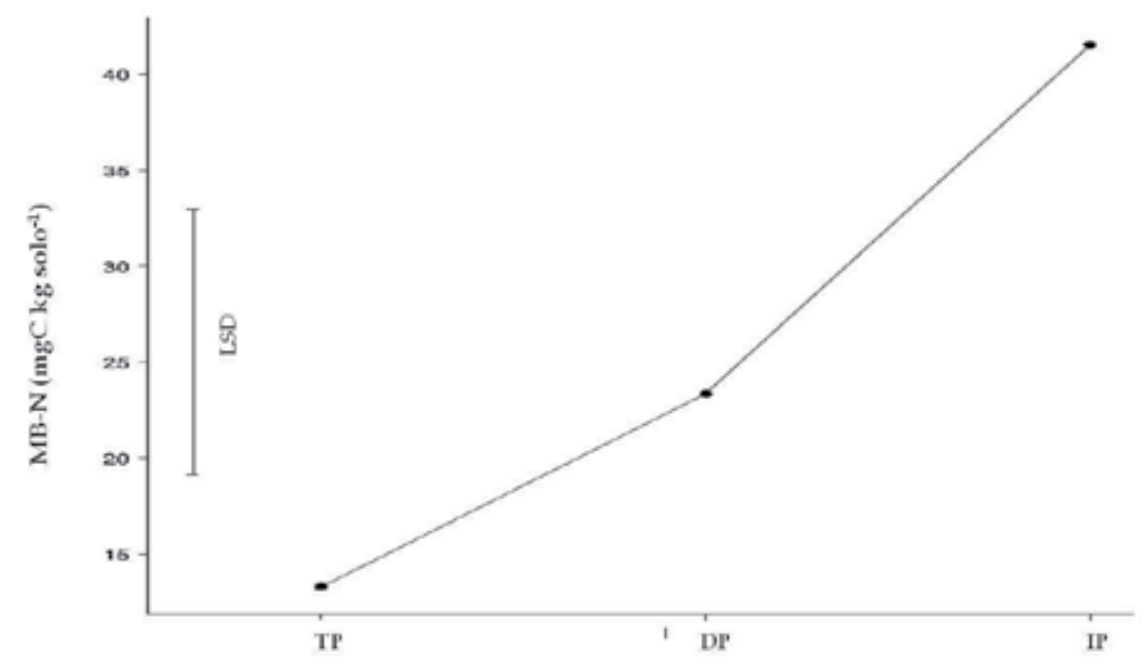

Fig. 3. Microbial biomass nitrogen (MB-N) in pasture areas located at Alto Xingu ecoregion. LSD, Least significant difference; TP, typical pasture; DP, degraded pasture; IP, improved pasture. 


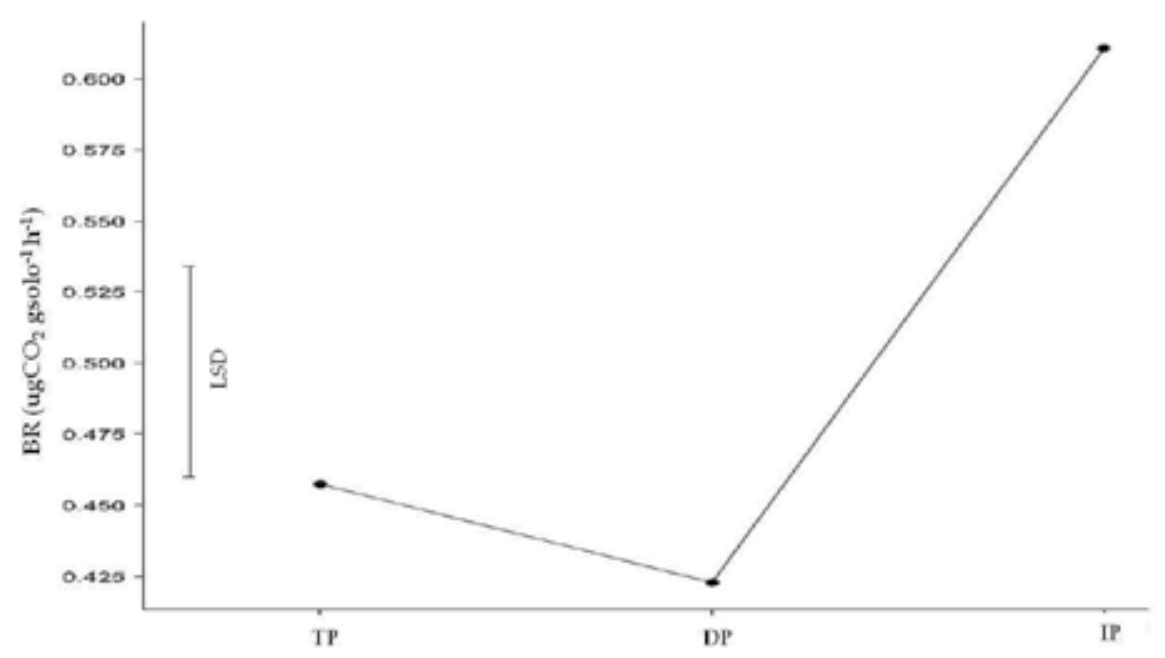

Fig. 4. Soil basal respiration (BR) in pasture areas located at Alto Xingu ecoregion. LSD, Least significant difference; TP, typical pasture; DP, degraded pasture; IP, improved pasture.

gC kg solo-1 (TP), without statistical differences between DP and TP. The MB-N (figure 3) showed higher values to IP (41.54 mgN kg solo-1), followed by DP $\left(23.36 \mathrm{mgN} \mathrm{kg} \mathrm{solo}^{-1}\right)$ and TP (13.29 $\left.\mathrm{mgN} \mathrm{kg} \mathrm{solo}^{-1}\right)$.The BR values (Figure 4) were 0.61 (IP), 0.42 (DP) and $0.46 \mathrm{ugCO}_{2}$ gsolo $^{-1} \mathrm{~h}^{-1}(\mathrm{TP})$.

The highest values of soil microbial attributes founded in IP may be related to the application of fertilizers and lime in the study area. Hatch et al. (2000) demonstrated increases in basal respiration in soils after the application of fertilizers, however, no reported increases in the MB-C, different that observed in this study.

The fertilizer can initiate a process of "priming effect" on soil, promoting an increase in the active biomass (r-strategists microorganisms) which die after the exhaustion of the substrate, or become dormant due to its inability to mineralize the SOM. In contrast, the microbial biomass of slower growth (k-strategists microorganisms) remains active and increased its population due the non-degraded fractions by r-strategists microorganisms and also the substrates provided by cell lyses (Fontaine et al., 2003). The mechanisms of priming effect are not fully elucidated yet; however competition between $r$ and $k$-strategists microorganisms can help to elucidate the dynamics observed in these study areas with pasture.

The increase in $\mathrm{pH}$ caused by the lime application promotes an impact in the composition of $\mathrm{SMB}$. High $\mathrm{pH}$ stimulates the activity of nitrifying bacteria which combined with fertilizers cause the soil acidification, mainly in the superficial layers (Giracca, 2005).

\subsection{Soil microbial biomass after the annual crops introduction in Cerrado region}

The Cerrado region was incorporated for the grain production because has weather conditions favorable to cultivate annual crops (soybean, corn, sorghum, etc). Moreover, the flat topography facilitates the soil management and harvesting of grains.

The pasture and annual crops cultivation are the first land-use-change that have occurred in large proportions and quite fast in the Amazon region. The expansion of soybean cultivation 
in the Southwestern of Amazon region has occurred mainly in the Rodonia and Mato Grosso states. The production of Brazilian soybean was $19 \mathrm{M}$ tons in 1994 and increased to $40 \mathrm{M}$ tons in 2004, and the Mato Grosso State was the largest contributor to this increase (Brasil, 2009).

It is important to report that the intensive land use reduces the quality of organic matter remaining in the soil. These changes occur, for example, in the breakdown and destruction of soil aggregates with losses to erosion, reducing the availability of nutrients to plants and the water storage capacity. These are some factors that reflect negatively on agricultural productivity, and consequently on food production and the sustainability of the soil-plantatmosphere (Lal. 2003; Six et al., 2004; Knorr et al., 2005). However, Maia (2009) in interviews with experts noted that occurred a considerable increase in the no-tillage cultivation between 1985 and 2002, and now it is the main crop system adopted in the region.

Microorganisms play an essential role for the decomposition of SOM and its reduction in the diversity or abundance may affect nutrient cycling (Giller et al., 1998). The microbial activity is affected by soil management systems, depending how the crop residue is incorporate and the degree of soil disturbance (Vargas \& Scholles, 2000). Thus, is important determine the changes in soil microbial biomass related to soil management and climate seasonality in the Cerrado region.

\subsubsection{Study areas}

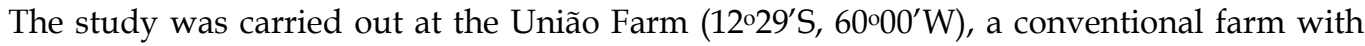
an area of 3,700 in Rondonia State, Brazil (Figure 5). The native vegetation of the region is classified as Cerrado, sub-group Cerradão of the dense vegetation type (Ribeiro and Walter, 1998). According to Köppen (1900) the climate is classified as Aw (humid tropical) with mean temperature of $23.1{ }^{\circ} \mathrm{C}$ and a minimum temperature of $18.0^{\circ} \mathrm{C}$ during the coldest month. The region has a well defined dry season (May to September) with a monthly rainfall below $10 \mathrm{~mm}$, while the mean annual rainfall is 2,170 $\mathrm{mm}$. The mean altitude of the region is $600 \mathrm{~m}$ with undulating relief. The soil was classified as an Oxisol (Typic Hapludox) with very clayey texture (730 $\mathrm{g}$ clay $\mathrm{kg}^{-1}$ of soil).

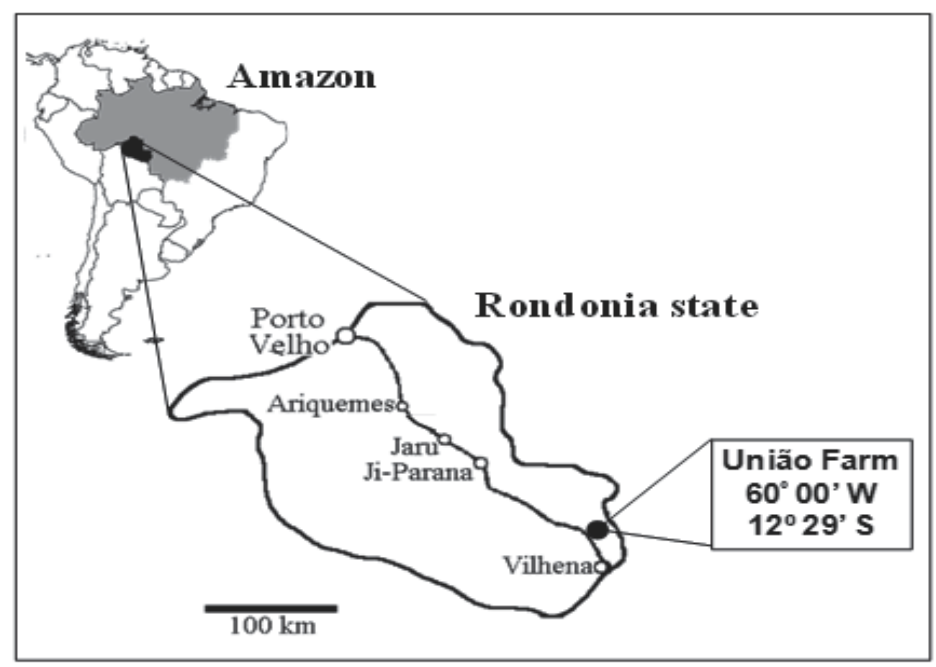

Fig. 5. Map of location of the study area in the União Farm, Rondônia State, Amazon region, Brazil. 
Areas of about 500 ha of the farm were cleared yearly for cultivation between 1999 and 2004 . (Figure 6). The clearing was done by tractor and blade at the end of the wet season (May/June). After a drying period of 20 days, aboveground biomass was burnt. Mechanical windrowing followed this operation and areas were subsequently cleaned by burning stumps and root residues and removing remaining material. For further soil preparation, a disc harrow was used to incorporate dolomite lime, which was applied to achieve $50 \%$ base saturation (V) in the $0-20 \mathrm{~cm}$ soil layer. Next, a leveling harrow was used. These initial preparation steps had been applied to all sampled areas, except for the native Cerrado (used as control).

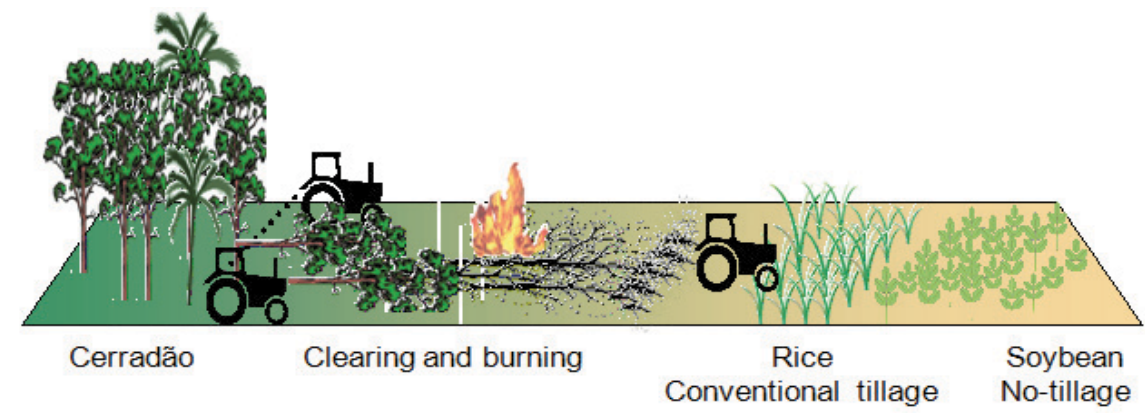

Fig. 6. Conversion of Cerradão to agriculture in União farm.

Every newly established area was cultivated with rice under CT. After two years of rice under CT and associated lime incorporation, leveling and cleaning of the soil surface, a NT system with soybean was introduced for one to three years. A chronosequence of six different sites was considered in this study: native Cerrado vegetation (CE), used as a reference area, a CT system cultivated with rice for 1 year (1CT) and 2 years (2CT), and a NT system cultivated with soybean for 1 (1NT), 2 (2NT) and 3 years (3NT), always preceded by a 2-year period of rice under CT alternating either with other crops or fallow land in the winter season (Table 2). This table also shows the crop cycles, annual application rates of lime, $\mathrm{pH} \mathrm{CaCl}$, available $\mathrm{P}$ and $\mathrm{V}$ in the $0-30 \mathrm{~cm}$ soil layer. Nitrogen fertilization rates and other nutrient additions in the study area are described in detail in Carvalho et al. (2007). The areas were located in close proximity (less than $2 \mathrm{~km}$ apart from each other), with similar topography, soil and climate conditions, differing only in the time since clearing and the setting up of the sites.

\subsubsection{Sampling and analytical procedures}

Soil sampling was carried out in July 2004 (dry season) and in January 2005 (wet season) in six areas of approximately 1 ha $(100 \times 100 \mathrm{~m})$ based on a completely randomized sampling design with five pseudo replicates in each area. We are considering those as pseudo replicates, since they came from the same evaluated areas.

Soil samples were taken from 5 profiles at 0-5, 5-10 and 10-20 cm depths in each site. After air-drying, the samples were sieved at $2 \mathrm{~mm}$. From each sample, $10 \mathrm{~g}$ were ground and sieved at $0.25 \mathrm{~mm}$ for determination of Total Organic Carbon (TOC). The determination was carried according to Nelson \& Sommers (1982) using a Carbon Analyzer - LECO ${ }^{\circledR}$ CN-2000. As samples were collected from fixed layers, the $C$ stock calculation needed to be adjusted for variations in bulk density (BD) after land use changes. Therefore, the methodology described 


\begin{tabular}{|c|c|c|c|c|c|c|c|c|}
\hline $\begin{array}{l}\text { Land } \\
\text { use }\end{array}$ & $\begin{array}{l}\text { Cultivation } \\
\text { period }\end{array}$ & $\begin{array}{l}\text { Main } \\
\text { crop }\end{array}$ & $\begin{array}{l}\text { Winter } \\
\text { crop }\end{array}$ & Lime & $\begin{array}{l}\text { Soil } \\
\text { Density }\end{array}$ & $\begin{array}{l}\mathrm{pH} \\
\mathrm{CaCl}_{2}\end{array}$ & $\begin{array}{l}\text { Available } \\
\text { P }\end{array}$ & V \\
\hline & & & & $\mathrm{Mg} \mathrm{ha}^{-1}$ & $\mathrm{~g} \mathrm{~cm}^{-3}$ & & $\mathrm{mg} \mathrm{dm}^{-3}$ & $\%$ \\
\hline \multicolumn{2}{|c|}{ Continuous Cerrado } & & & - & 0.77 & 3.8 & 4.7 & 3.6 \\
\hline $1 C T$ & $2003-2004$ & rice $(\mathrm{CT})$ & $\begin{array}{l}\text { fallow } \\
\text { land }\end{array}$ & 6 & 1.00 & 4.5 & 6.5 & 24.0 \\
\hline \multirow[t]{2}{*}{$2 C T$} & $2002-2003$ & rice $(\mathrm{CT})$ & $\begin{array}{l}\text { fallow } \\
\text { land }\end{array}$ & 2 & 0.93 & 4.5 & 5.7 & 20.1 \\
\hline & $2003-2004$ & rice $(\mathrm{CT})$ & $\begin{array}{l}\text { fallow } \\
\text { land }\end{array}$ & 4 & & & & \\
\hline \multirow[t]{3}{*}{$1 N T$} & $2001-2002$ & rice $(\mathrm{CT})$ & $\begin{array}{l}\text { fallow } \\
\text { land }\end{array}$ & 2 & 1.11 & 4.7 & 9.4 & 32.5 \\
\hline & $2002-2003$ & rice $(\mathrm{CT})$ & $\begin{array}{l}\text { fallow } \\
\text { land }\end{array}$ & 2 & & & & \\
\hline & $2003-2004$ & $\begin{array}{l}\text { soybean } \\
(\mathrm{NT})\end{array}$ & maize & 2 & & & & \\
\hline \multirow[t]{4}{*}{$2 N T$} & $2000-2001$ & rice $(\mathrm{CT})$ & $\begin{array}{l}\text { fallow } \\
\text { land }\end{array}$ & 2 & 0.98 & 5.0 & 15.4 & 39.1 \\
\hline & $2001-2002$ & rice $(\mathrm{CT})$ & $\begin{array}{l}\text { fallow } \\
\text { land }\end{array}$ & 2 & & & & \\
\hline & $2002-2003$ & $\begin{array}{l}\text { soybean } \\
(\mathrm{NT})\end{array}$ & sorghum & 1 & & & & \\
\hline & $2003-2004$ & $\begin{array}{l}\text { soybean } \\
(\mathrm{NT})\end{array}$ & millet & 1 & & & & \\
\hline \multirow[t]{5}{*}{$3 N T$} & $1999-2000$ & rice $(\mathrm{CT})$ & $\begin{array}{l}\text { fallow } \\
\text { land }\end{array}$ & 1 & 1.14 & 5.4 & 29.7 & 58.9 \\
\hline & $2000-2001$ & rice $(\mathrm{CT})$ & $\begin{array}{l}\text { fallow } \\
\text { land }\end{array}$ & 2 & & & & \\
\hline & $2001-2002$ & $\begin{array}{l}\text { soybean } \\
(\mathrm{NT})\end{array}$ & $\begin{array}{l}\text { fallow } \\
\text { land }\end{array}$ & 1 & & & & \\
\hline & $2002-2003$ & $\begin{array}{l}\text { soybean } \\
(\mathrm{NT})\end{array}$ & maize & 0 & & & & \\
\hline & $2003-2004$ & $\begin{array}{l}\text { soybean } \\
(\mathrm{NT})\end{array}$ & maize & 2 & & & & \\
\hline
\end{tabular}

Table 2. Cultivation history of the main crops (rice, soybean) and land use in the winter season in the corresponding cultivation periods under different land use practices annual lime application rates, $\mathrm{pH} \mathrm{CaCl}$, available $\mathrm{P}$ and base saturation in the $0-30 \mathrm{~cm}$ soil layer. Source: Carvalho et al. (2009). Where: 1CT and 2CT mean 1 and 2 years of rice under conventional tillage; 1NT, 2NT and 3NT mean 1, 2 and 3 years of soybean under no-tillage after a 2-year period of rice under conventional tillage; $\mathrm{V}$ means base saturation. 
in Ellert \& Bettany (1996) and Moraes et al. (1996) was used to adjust soil C stocks to an equivalent soil mass. In order to calculate $C$ stocks in an equivalent soil mass, the depth of the considered area was adjusted, i.e., the depth of the cultivated areas containing the same soil mass as the corresponding layer $(0-30 \mathrm{~cm})$ in native vegetation (the reference area).

To determine soil microbial biomass and basal respiration, subsamples were carried out using a grid pattern at five points within a $100 \mathrm{~m}^{2}$ quadrant for each treatment. The soil subsamples from each treatment were bulked and thoroughly mixed in a plastic bag, and a composite sample was taken. The composite samples, in five replicates for each treatment, were transported on ice, in a cooler, to the laboratory. Field moist soils were sieved through a $2 \mathrm{~mm}$ screen, and immediately stored in sealed plastic bags at $4^{\circ} \mathrm{C}$.

The samples used for microbial biomass and determination of soil basal respiration (BR) were adjusted to $55 \%$ of the field capacity, considered the ideal soil water content for studying microbial activity responses. The soil microbial biomass was estimated by the fumigation-extraction method proposed by Vance et al. (1987). Fumigated and nonfumigated soil samples were extracted with $0.5 \mathrm{M} \mathrm{K}_{2} \mathrm{SO}_{4}$ for $30 \mathrm{~min}$ (1:5 soil:extraction ratio), filtered, and the aliquot was analyzed. The microbial $\mathrm{C}$ concentration in the extracts was obtained by a SHIMADZU TOC 5000-A equipment. The microbial $\mathrm{N}$ was determined by the ninhydrin reactive compound quantification method (Joergensen \& Brookes, 1990) using the conversion factor $\mathrm{kEN}=0,65$ (Sparling et al., 1993).

The statistical analysis of data was performed on a completely randomized sampling design, with the assumption that the areas studied had the same topographic, edaphic and climatic conditions. Six areas with five pseudo replicates were evaluated.

Data from soil $C$ stocks under different areas were analyzed for variance (ANOVA) to determine land use effects. A Tukey test was used to test significant $(p \leq 0.05)$ differences among treatments. All statistical analyses were performed using the SAS program, version 6.

\subsubsection{Results and discussion}

In the 0-30 $\mathrm{cm}$ soil layer, the $\mathrm{C}$ stock in $\mathrm{CE}$ was $50 \mathrm{Mg}^{-1}$, significantly smaller than the stocks in 1NT and 3NT ( $<<0.05)$, in the dry season (Table 3). Corazza et al. (1999), studying a clayey Typic Hapludox under Brazilian Cerrado vegetation, measured a soil $\mathrm{C}$ stock in the 0-20 cm layer of 39.8 Mg ha-1. Resck et al. (2000) measured in a Typic Hapludox under Brazilian Cerrado a C stock of $61 \mathrm{Mg} \mathrm{C}$ ha-1 in the $0-30 \mathrm{~cm}$ soil layer. In a Rhodic Hapludox with very clayey texture under Cerrado in Dourados (Mato Grosso do Sul State, Brazil), Salton et al. (2005) measured a soil C stock of $44.5 \mathrm{Mg}^{-1}$ in the $0-20 \mathrm{~cm}$ layer. Bayer et al.

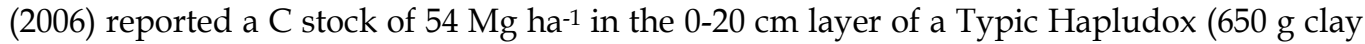
$\mathrm{kg}^{-1}$ soil) under Cerrado in Brazil. Despite the soil $\mathrm{C}$ contents were similar among the mentioned studies (ranging from 2.5 up to $3.1 \%$ comparable to the $2.9 \%$ of $\mathrm{C}$ for this research) the soil BD obtained here (weighted mean of $0.77 \mathrm{~g} \mathrm{~cm}^{-3}$ in the $0-30 \mathrm{~cm}$ soil depth) was lower than the values reported by Salton et al. (2005) and Bayer et al. (2006). Therefore, we suggest that the lower soil $\mathrm{C}$ stocks presented here are due to the lower BD compared to the last two studies cited above.

After the conversion of Cerrado into agricultural land, while the soil C stock in 1CT (47.6 Mg

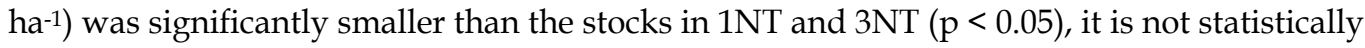
different from 2NT (Table 3).

In the wet season, six months after the first soil sampling, there were no significant differences among the areas in the $0-30 \mathrm{~cm}$ soil layer (Table 3). Average soil $\mathrm{C}$ stocks in 


\begin{tabular}{ccc}
\hline \multirow{2}{*}{ Situations } & \multicolumn{2}{c}{ Soil C Stocks $\left(\mathrm{Mg} \mathrm{ha}^{-1}\right)$} \\
\cline { 2 - 3 } & Dry season & Wet season \\
\hline CE & $50.0 \pm 7.4 \mathrm{~b}$ & $48.1 \pm 2.6 \mathrm{a}$ \\
$1 \mathrm{CT}$ & $47.6 \pm 4.9 \mathrm{~b}$ & $47.4 \pm 7.2 \mathrm{a}$ \\
$2 \mathrm{CT}$ & $55.4 \pm 8.5 \mathrm{ab}$ & $58.5 \pm 11.0 \mathrm{a}$ \\
$1 \mathrm{NT}$ & $66.5 \pm 6.5 \mathrm{a}$ & $65.6 \pm 15.4 \mathrm{a}$ \\
$2 \mathrm{NT}$ & $54.5 \pm 5.6 \mathrm{ab}$ & $47.4 \pm 7.9 \mathrm{a}$ \\
$3 \mathrm{NT}$ & $67.5 \pm 10.3 \mathrm{a}$ & $59.0 \pm 18.5 \mathrm{a}$ \\
\hline LSD(1) & 14.49 & 22.87 \\
CV\% $^{(2)}$ & 13.0 & 21.5 \\
\hline
\end{tabular}

Table 3. Soil C stocks ( $\left.\mathrm{Mg} \mathrm{ha}^{-1}\right)$ in the equivalent soil mass of $30 \mathrm{~cm}$ depth under Cerradão in the dry (July 2004) and wet (January 2005) seasons under Cerrado (CE), conventional tillage (1CT and 2CT) and no-tillage (1NT, 2NT and 3NT) in Vilhena, Rondonia State, Brazil.

Adapted from: Carvalho et al., (2009).The results are mean $(n=5) \pm$ standard deviation.

Means followed by the same letter are not significantly different according to Tukey's test at $5 \%$. (1) Least Significant Difference. (2) Coefficient of variation

the 0-30 $\mathrm{cm}$ were calculated using the data of the two evaluated sampling times (dry and wet seasons presented). When the average soil $C$ stock was considered, some significant differences were observed. The $C$ stock in $1 C T$ was significantly smaller $(p<0.05)$ than the stocks in 2CT, 1NT and 3NT.

In dry season, the MB-C in the $0-5 \mathrm{~cm}$ soil depth was higher in the $\mathrm{CE}$ area than the other situations (Table 4). However, only 1CT and 1NT were significantly lower $(p<0.05)$. In the 5$10 \mathrm{~cm}$ soil layer, was again obtained higher contents of MB-C in CE area, followed by 2CT and $1 \mathrm{NT}$. At $10-20 \mathrm{~cm}$ soil depth there were no significant differences between the situations evaluated.

The MB-C increased in January 2005. Others studies in the Amazon region (Geraldes ,1995; Frazão et al., 2010) reported modifications in SMB under different management systems and seasonal variation, with increases in the wet season.

In the rainy season the MB-C was higher in the CE situation (Table 4). At 0-5 cm, MB-C was higher in CE, followed 1NT, 1CT, 3NT, 2NT and 2CT. Cerri et al. (1985) found higher MB-C in native area in relation to cultivated areas, and this fact was linked to increased deposition of organic residues in soil and the large amount of roots with stimulate the activity of soil microorganisms, especially in the superficial layers of soil.

In both seasons studied showed the same trends of MB-C reduction with the land-usechange. Chaga (2000) studying soils in Cerrado region, did not found significant differences in MB-C values between native forest and NT system. Moreover, Hungria (1996), in study at Parana State, noted that the MB-C was 50\% higher in soil under NT compared to CT.

A possible explanation for the lower amount of MB-C in NT may be related to short time of installation this system. Souza et al. (2006) founded similar results, with lower values in NT than in CT. According to D'Andrea et al. (2001) this occurs in NT areas recently implemented, where there is initially a reduction of $\mathrm{MB}-\mathrm{C}$ and then after the stabilization of NT the result is an increase in soil MB-C. 


\begin{tabular}{|c|c|c|c|c|c|c|}
\hline \multirow{3}{*}{ Situation } & \multicolumn{6}{|c|}{ Microbial biomass carbon (mg C kg soil $\left.{ }^{-1}\right)$} \\
\hline & \multicolumn{3}{|c|}{ Dry season (July 2004) } & \multicolumn{3}{|c|}{ Wet season (January 2005) } \\
\hline & $0-5 \mathrm{~cm}$ & $5-10 \mathrm{~cm}$ & $10-20 \mathrm{~cm}$ & $0-5 \mathrm{~cm}$ & $5-10 \mathrm{~cm}$ & $10-20 \mathrm{~cm}$ \\
\hline $\mathrm{CE}$ & $713 \pm 147 a$ & $644 \pm 69 a$ & $421 \pm 118 \mathrm{ab}$ & $1262 \pm 310 a$ & $993 \pm 263 a$ & $840 \pm 212 a$ \\
\hline $1 \mathrm{CT}$ & $354 \pm 118 b$ & $342 \pm 57 c$ & $338 \pm 69 a b$ & $312 \pm 146 \mathrm{bc}$ & $467 \pm 323 b c$ & $679 \pm 217$ bc \\
\hline $2 \mathrm{CT}$ & $535 \pm 209 \mathrm{ab}$ & $521 \pm 135 \mathrm{ab}$ & $479 \pm 61 \mathrm{a}$ & $200 \pm 25 c$ & $470 \pm 103 \mathrm{bc}$ & $352 \pm 167 \mathrm{bc}$ \\
\hline $1 \mathrm{NT}$ & $367 \pm 87 b$ & $367 \pm 91 b c$ & $310 \pm 49 b$ & $543 \pm 141 b$ & $657 \pm 118 \mathrm{ab}$ & $655 \pm 250 b c$ \\
\hline $2 \mathrm{NT}$ & $465 \pm 104 \mathrm{ab}$ & $307 \pm 80 c$ & $280 \pm 116 b$ & $228 \pm 28 c$ & $307 \pm 97 c$ & $239 \pm 133 c$ \\
\hline $3 \mathrm{NT}$ & $641 \pm 183 \mathrm{ab}$ & $346 \pm 76 c$ & $299 \pm 75 b$ & $292 \pm 110 \mathrm{bc}$ & $244 \pm 93 c$ & $364 \pm 127 b c$ \\
\hline
\end{tabular}

Table 4. Microbial biomass carbon (MB-C) in the dry (July 2004) and wet (January 2005) seasons under Cerrado (CE), conventional tillage (1CT and 2CT) and no-tillage (1NT, 2NT and 3NT) in Vilhena, Rondonia State, Brazil. The results represent the mean $(n=5) \pm$ standard deviation. Means within each column of the same depth followed by the same letter are not significantly different by the Tukey test $(\mathrm{p}<0.05)$.

The content of MB-N was altered by changes in soil moisture (Table 5). Overall, the averages of MB-N tended to be higher in the CE situation. In dry season, the 0-5 cm layer showed increase in $3 \mathrm{NT}$, followed $\mathrm{CE}$ and $2 \mathrm{NT}$ situations. The lowest MB-N contents were obtained in $1 \mathrm{NT}$.

In the rainy season there was no statistical difference at $0-5 \mathrm{~cm}$ soil depth $(\mathrm{p}<0.05)$. It was observed the higher MB-N values in CE at 5-10 cm, and CE and $1 \mathrm{NT}$ at $10-20 \mathrm{~cm}$ soil depth.

\begin{tabular}{|c|c|c|c|c|c|c|}
\hline \multirow{3}{*}{ Situation } & \multicolumn{6}{|c|}{ Microbial biomass nitrogen (mg N kg soil-1 $)$} \\
\hline & \multicolumn{3}{|c|}{ Dry season (July 2004) } & \multicolumn{3}{|c|}{ Wet season (January 2005) } \\
\hline & $0-5 \mathrm{~cm}$ & $5-10 \mathrm{~cm}$ & $10-20 \mathrm{~cm}$ & $0-5 \mathrm{~cm}$ & $5-10 \mathrm{~cm}$ & $10-20 \mathrm{~cm}$ \\
\hline$\overline{\mathrm{CE}}$ & $47 \pm 16 a b$ & $32 \pm 9 \mathrm{a}$ & $27 \pm 8 \mathrm{abc}$ & $36 \pm 28 a$ & $75 \pm 19 a$ & $58 \pm 11 \mathrm{a}$ \\
\hline $1 \mathrm{CT}$ & $21 \pm 4 \mathrm{~cd}$ & $20 \pm 4 b c$ & $23 \pm 12 a b$ & $27 \pm 22 \mathrm{a}$ & $35 \pm 25 \mathrm{ab}$ & $43 \pm 22 \mathrm{ab}$ \\
\hline $2 \mathrm{CT}$ & $28 \pm 8$ bcd & $31 \pm 4 \mathrm{ab}$ & $33 \pm 4$ a & $22 \pm 10 \mathrm{a}$ & $24 \pm 25 b$ & $32 \pm 14 a b c$ \\
\hline $1 \mathrm{NT}$ & $15 \pm 4 \mathrm{~d}$ & $11 \pm 4 \mathrm{c}$ & $14 \pm 6 \mathrm{~d}$ & $44 \pm 20 \mathrm{a}$ & $42 \pm 20 \mathrm{ab}$ & $47 \pm 13 \mathrm{a}$ \\
\hline 2NT & $38 \pm 5 a b c$ & $19 \pm 5 b c$ & $20 \pm 4 \mathrm{bcd}$ & $24 \pm 26 a$ & $20 \pm 10 b$ & $18 \pm 14 b c$ \\
\hline $3 \mathrm{NT}$ & $55 \pm 17 \mathrm{a}$ & $23 \pm 8 a b c$ & $16 \pm 4 \mathrm{~cd}$ & $28 \pm 15 a$ & $22 \pm 23 b$ & $14 \pm 8 c$ \\
\hline
\end{tabular}

Table 5. Microbial biomass nitrogen (MB-N) in the dry (July 2004) and wet (January 2005) seasons under Cerrado (CE), conventional tillage (1CT and 2CT) and no-tillage (1NT, 2NT and 3NT) in Vilhena, Rondonia State, Brazil. The results represent the mean $(n=5) \pm$ standard deviation. Means within each column of th same depth followed by the same letter are not significantly different by the Tukey test $(\mathrm{p}<0.05)$.

Fernandes et al. (1998) in a study at Sete Lagoas, Minas Gerais State, founded the quantity of the soil MB-N two times higher in NT than in CT.

The ratio between microbial biomass carbon and total organic carbon (MB-C:Corg) has been considered a good indicator of changes of SOM in the evaluation of soil management systems (Sá et al., 2001) and reflects the amount of C available for the growth of microorganisms.

The MB-C:Corg ratio ranged between dry and rainy seasons, confirming the results obtained by Frazão et al (2010) in a sandy soil in the Amazon region. The MB-C:Corg ratio 
was highest at $0-10 \mathrm{~cm}$ than at $10-20 \mathrm{~cm}$ soil depth. (Figure 7). Haynes (1999) evaluated temperate soils and reported a reduction in ratio with the increase of soil depth. In dry season, considering 0-20 cm layer, the higher MB-C:Corg ratio was observed in CE $(1,6 \%)$. The values ranged between $1.4(2 \mathrm{CT})$ and $0.9 \%(1 \mathrm{NT})$ in management systems.
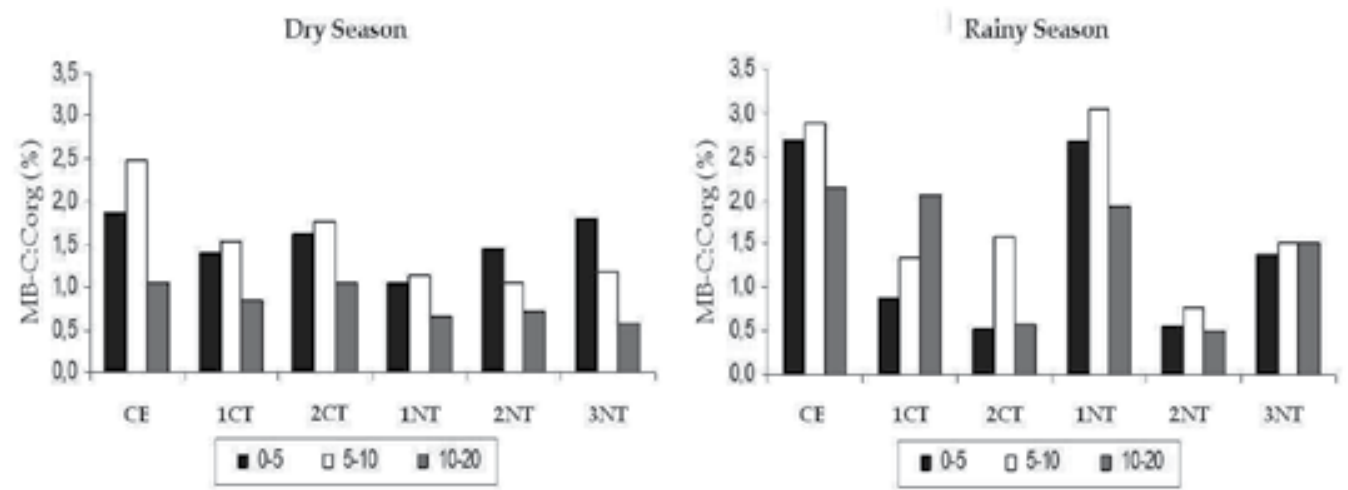

Fig. 7. MB-C:Corg ratio (\%) in dry and rainy season. Situations evaluated: Cerrado (CE), Conventional tillage (1CTand 2CT) and No-tillage (1NT, 2NT and 3NT).

In the rainy season the MB-C:Corg ratio in the 0-20 cm soil layer was 2.5, 1.6, 0.8, 2.4, 0.6 and $1.5 \%$ for $\mathrm{CE}, 1 \mathrm{CT}, 2 \mathrm{CT}, 2 \mathrm{CT}, 1 \mathrm{NT}, 2 \mathrm{NT}$ and $3 \mathrm{NT}$, respectively (figure 7 ). Anderson \& Domsh (1989) evaluated the MB-C:Corg ratio in 134 plots of agricultural experiments to long term in temperate regions and obtained values between 0.27 and $7.0 \%$.This variation was attributed to type and management of soil, type of vegetation, sampling season and analytical conditions. The authors suggested equilibrium values of $2.3 \%$ for monoculture and $2.9 \%$ for crop rotation.

However, according to Sá (2001), the MB-C:Corg ratio are lower in tropical regions than in temperate regions. Cerri et al. (1985) studying an Oxisol in the Amazon region found values of $0.73 \%$ under natural conditions and $0.04 \%$ in an area recently cleared and burned. Other study carried out in Parana State in soil cultivated with soybean under NT system found values ranging between 0.79 and $1.59 \%$ (Colozzi-Filho et al., 2005).

The MB-N:Ntotal ratio represents the mineralizable $\mathrm{N}$ fraction, i.e., it expresses the potential of inorganic $\mathrm{N}$ available in the soil for the next crop (McGill et al., 1988).

The ratio between microbial biomass nitrogen and total nitrogen (MB-N:Ntotal) varied in both seasons (Figure 8). The highest ratios were observed in 3NT, CE and 2NT. In NT situations (3NT and 2NT) the highest MB-N content were observed at 0-5 cm deep. Considering the MB-N:Norg ratio (\%) at $0-20 \mathrm{~cm}$, the values were 1.5 for CE area, 1.1 for $1 \mathrm{CT}$ and $2 \mathrm{CT}$ area, 0.6 for $1 \mathrm{NT}, 1.2$ for $2 \mathrm{NT}$ and 1.3 for $3 \mathrm{NT}$ (Figure 8). In all situations were observed a reduction in the MB-N:Norg ratio at $10-20 \mathrm{~cm}$ compared to the superficial layers.

In the rainy season were founded the highest contribution of theMB-N into the $\mathrm{N}$ stocks. However, there was oscillation between the situations in the dry season. The MB-N:Ntotal ratio (\%) at $0-20 \mathrm{~cm}$ in depth was 2.5 for $\mathrm{CE}, 2.0$ for $1 \mathrm{CT}, 1.1$ for $2 \mathrm{CT}, 2.9$ for $1 \mathrm{NT}, 0.8$ for $2 \mathrm{NT}$ and 1,5 for 3NT. The higher MB-N:Ntotal values in the CE and 1PD areas represent higher inorganic $\mathrm{N}$ cycling efficiency and availability in the medium term (Xavier et al., 2007). 

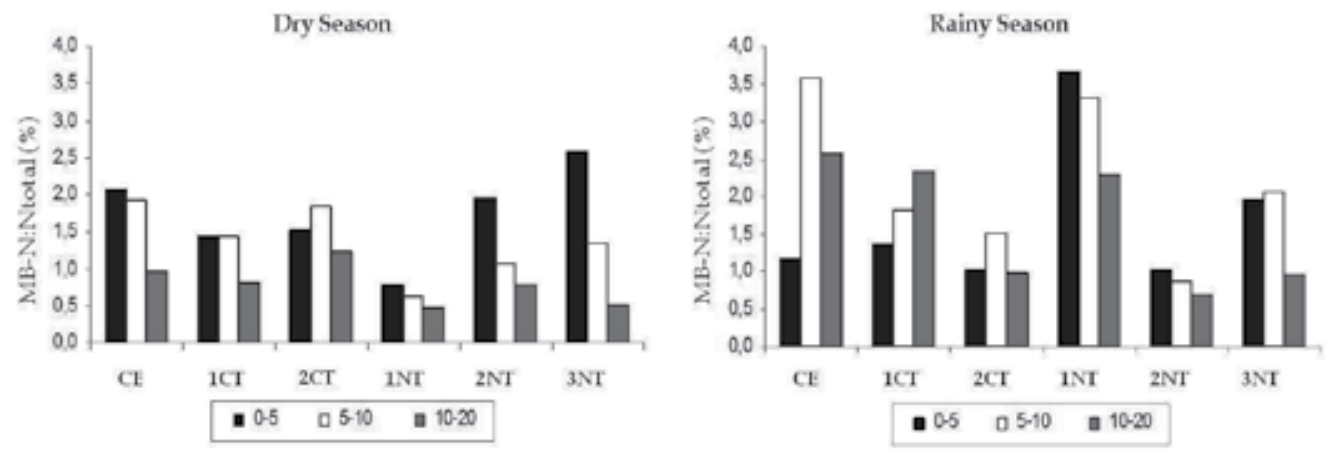

Fig. 8. MB-N:Ntotal ratio (\%) in dry and rainy season. Situations evaluated: Cerrado (CE), Conventional tillage (1CTand 2CT) and No-tillage (1NT, 2NT and 3NT).

\section{Conclusions}

The land-use-change in the Cerrado region for pasture and agricultural purposes using different soil management systems promote alterations in the microbial components of soil.

The highest values of MB-C and MB-N were found in the Cerrado and pasture areas. The permanent soil cover and the lack of soil disturbance with the absence of agricultural practices produced more favorable conditions for microbial development in those systems.

The largest variations in the agricultural systems can be attributed more to climatic seasonality than to differences in the management systems.

In general, it is possible to conclude that soils under native system and agriculture with minimal disturbance of soil contribute to development and maintenance of soil microbial attributes.

\section{Acknowledgments}

The authors thank FAPESP - Fundação de Apoio a Pesquisa do Estado de São Paulo (The State of São Paulo Research Foundation) and CNPq - Conselho Nacional de Desenvolvimento Cientifico e Tecnológico (National Council for Scientific and Technological Development) for concession of scholarships and financial resources.

\section{References}

Alvarez, R., Diaz, R.A., Barbero, N., Santanatoglia, O.J., Balotta, L.(1995) .Soil organic carbon, microbial biomass and $\mathrm{CO} 2-\mathrm{C}$ production from tree tillage systems. Soil $\mathcal{E}$ Tillage Research, Vol. 33, pp. 17-28, ISSN 0167-1987

Anderson, T.H., Domsch, K.H., 1990.Application of eco-physiological quotients (qCO2 and qD) on microbial biomasses from soils of different cropping histories. Soil Biology EBiochemistry, Vol. 22, pp. 251-255, ISSN 0038-0717 
Anderson, T.H., Domsch, K.H. (1989). Ratios of microbial biomass carbon to total carbon in arable soils. Soil Biology EBiochemistry, Vol. 21, pp. 471-479, ISSN 0038-0717

Araújo, A.S.F., Monteiro, R.T.R. (2007). Indicadores biológicos de qualidade do solo. Bioscience Journal, Vol. 23, pp. 66-75, ISSN 1516-3725

Ballota, E. L.; Colozzi-filho, A.; Andrade, D. S.; Hungria, M. (1998). Biomassa microbiana e sua atividade em solos sob diferentes sistemas de preparo e sucessão de culturas. Revista Brasileira de Ciência do Solo, Vol. 22, pp. 641-649, ISSN 0100-0683

Beaudoin, N., Saad, J.K., van Laethem, C., Machet, J.M., Maucorps, J., Mary, B. (2005). Nitrate leaching in intensive agriculture in Northern France: effect of farming practices, soils and crop rotations. Agriculture Ecosystems \& Environment, Vol. 111, pp. 292-310, ISSN 0167-8809

Bayer, C. Martin-Neto, L.; Mielniczuk, J., Pavinato, A. (2004). Armazenamento de carbono em frações lábeis da matéria orgânica de um Latossolo Vermelho sob plantio direto. Pesquisa Agropecuaria Brasileira, Vol. 39, pp. 677-683, ISSN 0100-204X

Bayer, C., Martin-Neto, L., Mielniczuk, J., Pavinato, A., Dieckow, J. (2006). Carbon sequestration in two Brazilian Cerrado soils under no-till. Soil \& Tillage Research, Vol. 86, pp. 237-245, ISSN 0167-1987

Bayer, C., Mielniczuk, J. (1999). Dinâmica e função da matéria orgânica, In: Fundamentos da matéria orgânica do solo: ecossistemas tropicais e subtropicais, G.A Santos; F.A.O.Camargo (Ed.), pp. 9-26, Gênesis, ISBN 987-43-3175-5, Porto Alegre, Brazil

Bayer, C., Mielniczuk, J., Martin-Neto, L. (2000). Efeito de sistemas de preparo e de cultura na dinâmica da matéria orgânica e na mitigação das emissões de $\mathrm{CO}_{2}$. Rev. Brasileira de Ciência do Solo, Vol. 24, pp. 599-607, ISSN 0100-0683

Belizario, M. H. (2008). Mudanças no estoque de carbono do solo devido ao uso agrícola da terra no Sudoeste da Amazônia, MSc. Thesis, Escola Superior de Agricultura "Luiz de Queiroz", Piracicaba, São Paulo, Brazil.

Brazil. Ministério da Agricultura, Abastecimento e Agropecuária, (2009), Date of access: May 20 2009, Available from: <http://www.agricultura.gov.br/>

Carneiro, M..C.; Assis, P.C.R; Melo, L.B.C.; Pereira, H.S.; Paulino, H.B.; Silveira Neto, A.N. (2008). Atributos bioquímicos em dois solos de Cerrado sob diferentes sistemas de manejo e uso. Pesquisa Agropecuária Tropical, Vol. 38, pp. 276-283, ISSN 15176398

Carvalho, J.L.N.; Cerri, C.E.P.; Cerri, C.C.; Feigl, B.J.; Piccolo, M.C.; Godinho, V.; Herpin, U. (2007). Changes of chemical properties in an Oxisol after clearing of native Cerrado vegetation for agricultural use in Vilhena, Rondonia State, Brazil. Soil $\mathcal{E}$ Tillage Research, v. 96, pp. 95-102, ISSN 0167-1987

Carvalho, J.L.N.; Cerri, C.E.P.; Feigl, B.J.; Piccolo, M.C.; Godinho, V.P.; Cerri, C.C. (2009). Carbon sequestration in agricultural soils in the Cerrado region of the Brazilian Amazon. Soil \& Tillage Research, Amsterdam, v.103, p.342-349, ISSN 0167-1987

Cerri, C. E. P.; Coleman, K ; Jenkinson, D. S. Bernoux, M. Victoria, R., Cerri, C. C. (2003). Modeling Soil Carbon from Forest and Pasture Ecosystems of Amazon, Brazil. Soil Science Society of America Journal, Vol. 67, pp.1879-1887, ISSN 1435-0661

Cerri, C.C.; Eduardo, B.P.; Piccolo, M.C. (1991). Use of stable isotopes in soil organic matter studies, Proceedings of International Symposium on the use of stable isotopes in plant 
nutrition, soil fertility and environmental studies, ISBN 9-2001-0391-X, Vienna, October 1990

Cerri, C.C.; Feller, C.; Balesdent, J.; Victoria, R.; Plenecassagne, A. (1985). Application du traçage isotopique naturel en ${ }^{13} \mathrm{C}$, à $\mathrm{l}^{\prime}$ étude de la dynamique de la matière organique dans sols. Comptes Rendu Academic Seances Paris, Vol. 9, pp. 423-428, ISSN 0764-4442

Chaer, G. M. (2001). Modelos para determinação de índice de qualidade do solo baseado em indicadores físicos, químicos e biológicos, MSc. Thesis, Universidade Federal de Viçosa, Viçosa, Brazil

Chaga, R.C.S. (2000). Alterações de parâmetros microbiológicos do solo em função do sistema de produção sob plantio direto na região dos cerrados, MSc. Thesis, Centro de Energia Nuclear na Agricultura, Piracicaba, Sao Paulo, Brazil

Colozzi-Filho, A.; Andrade, D.S.; Balota, E.L; Hungria,M. (2005). Biomassa microbiana do solo no agrossistema soja orgânica em plantio direto. Procedings of Simposio sobre plantio direto e meio ambiente, ISBN 9-78997-40583-9, Foz do Iguaçu, May 2005

Coser, T. R.; Ramos, M.L.G.; Amabile, R.F. (2007). Microbial biomass nitrogen in cerrado soil with nitrogen fertilizer application. Pesquisa Agropecuária Brasileira, Vol. 42, No. 3, ISSN 0100-204X

Corazza, E.J., Silva, J.E.D., Resck, D.V.S., Gomes, A.C. (1999). Comportamento de diferentes sistemas de manejo como fonte ou depósito de carbono em relação à vegetação de Cerrado. Revista Brasileira de Ciência do Solo, Vol. 23, pp. 425-432, ISSN 0100-0683

D'Andréa, A.F. (2001). Atributos indicadores da qualidade do solo em sistemas de manejo no sul de Goiás. MSc Thesis, Universidade Federal de Lavras, Lavras, Brazil

De Vries, S.T.; Bloem, J.; Eekeren, N.; Brusaard, L.; Hoffland, E. (2007). Fungal biomass in pastures increase with age and reduced $\mathrm{N}$ input. Soil Biology and Biochemistry, Vol. 39, pp. 1620-1630, ISSN 0038-0717

Dinesh, R.; Ghoshal Chaudhuri, S.; Ganeshamurthy, A.N.; Dey, C. (2003). Changes in soil microbial indices and their relationships following deforestation and cultivation in wet tropical forests. Applied Soil Ecology, Vol. 24, pp. 17-26, ISSN 0929-1393

Ellert, B.H.; Bettany, J.R. (1996). Calculation of organic matter and nutrients stored in soils under contrasting management regimes. Canadian Journal of Soil Science, Vol. 75, pp. 529-538, ISSN 1918-1841

Feller, C., Beare, M. H. (1997). Physical control of soil organic matter dynamics in the tropics. Geoderma, Vol. 79, pp. 69-116, ISSN 0016-7061

Ferreira, E.A.B., Resck, D.V.S., Gomes, A.C., Ramos, M.L.G. (2007). Dinâmica do carbono da biomassa microbiana em cinco épocas do ano em diferentes sistemas de manejo do solo no Cerrado. Revista Brasileira de Ciência do Solo, Vol. 31, pp. 1625-1635, ISSN 0100-0683

Fernandes, M.F.; Fernandes, R.P.M.; Anjos, J.L.; Sobral, L.F Araujo, A.S. (1998). Efeito da saturação por bases sobre a atividade de fosfatases em um solo de tabuleiro costeiro cultivado com citros. II. Constantes cinéticas das enzimas. Revista Brasileira de Ciência do Solo, Vol. 22, pp. 403-410, ISSN 0100-0683 
Fialho, J.S.; Gomes, V.F.F.; Oliveira. T.S.; Silva Júnior, J.M.T. (2006) Indicadores da qualidade do solo em áreas de vegetação natural e cultivo de bananeiras na Chapada do Apodi - CE. Revista de Ciência Agronômica, Vol. 37, pp. 250-257, ISSN 1806-6690

Figueiredo, C.C., Resck, D.V.S., Gomes, A.C., Ferreira, E.A.B., Ramos, M.L.G. (2007). Carbono e nitrogênio da biomassa microbiana em resposta a diferentes sistemas de manejo em um Latossolo Vermelho no Cerrado. Revista Brasileira de Ciência do Solo, Vol. 31, pp. 551-562, ISSN 0100-0683

Fontaine, S., Mariotti, A., Abbadie, A. (2003). The priming effect of organic matter: a question of microbial competition? Soil Biology and Biochemistry, Vol.35, pp. 837-843, ISSN 0038-0717.

Frazão, L.A. Piccolo, M.C., Feigl, B.J, Cerri, C.C.; Cerri, C.E.P. (2010) Inorganic nitrogen, microbial biomass and microbial activity of a sandy Brazilian Cerrado soil under different land uses. Agriculture, Ecosystems E Environment, Vol. 135, pp. 161-167, ISSN 0167-8809

Gama Rodrigues; Barros E.F.; Gama-Rodrigues, N.F.; Santos, A.C. (2005). Nitrogênio, carbono e atividade da biomassa microbiana do solo em plantações de eucalipto. Revista Brasileira de Ciência do Solo, Vol. 29, pp. 893-901, ISSN 0100-0683

Geraldes, A.P.A.; Cerri, C.C.; Feigl, B.J. (1995). Biomassa microbiana de solo sob pastagens na Amazônia. Revista Brasileira de Ciência do Solo, Vol. 19, pp. 55-60, ISSN 0100-0683

Giller, K.E., Witter, E., McGrath, S.P. (1998). Toxicity of heavy metals to microorganisms and microbial process in agricultural soils: a review. Soil Biology and Biochemistry, Vol. 30, pp. 1389-1414, ISSN 00380717.

Giracca, E.M.N. (2005). Efeito do calcário em atributos microbiológicos do solo. PhD. Thesis, Universidade Federal de Santa Maria, Santa Maria, Brazil

Grimaldi, M.; Sarrazin, M.; Chauvel, A.; Luizão, F.; Rodrigues, M.R. (1992). Efeitos da vegetação e da ação do homem sobre a estrutura dos latossolos argilosos da Amazônia Brasileira, Proceedings of The first International Symposium on Environmental Studies on Tropical Rainforests, Rio de Janeiro, October 1992

Hatch, D.J., Lovell, R.D., Antil, R.S., Jarvis, S.C. (2000). Nitrogen mineralization and microbial activity in permanent pastures amended with nitrogen fertilizer or dung. Biology \& Fertility Soils, Vol. 30, pp. 288-293, ISSN 0178-2762

Haynes, R.J. Size and activity of the soil microbial biomass under grass and arable management. (1999). Biology \& Fertility Soils, Vol. 47, pp. 245-251, ISSN 01782762

Ingram, L.J.; Schuman, G.E.; Stahl, P.D.; Spackman, L.K. (2005). Microbial Respiration and Organic Carbon Indicate Nutrient Cycling Recovery in Reclaimed Soils. Soil Science Society of America Journal, Vol. 69, pp. 1737-1745, ISSN 0361-5995

International Panel on Climate Change (IPCC). (2007). Guidelines for national greenhouse gas inventories. Date of Access: April 26 2008, Available from:

< http://www.ipcc- nggip.iges.or.jp/public/2006gl/index.html>

Iyyemperumal, K.; Israel, D.W.; Shi, W. (2007). Soil microbial biomass, activity and potential nitrogen mineralization in a pasture: Impact of stock camping activity. Soil Biology and Biochemistry, Vol. 39, pp. 149-157, ISSN 0038-0717. 
Jackson, L.E., Calderon, F.J., Steenwerth, K.L., Scow, K.M., Rolston, D.E. (2003). Responses of soil microbial process and community structure to tillage events and implications for soil quality. Geoderma, Vol. 114, pp. 305-317, ISSN 0016-7061

Jakelaitis, A.; da Silva, A.A.; dos Santos, J.B.; Vivian, R. (2008). Qualidade da camada superficial de solo sob mata, pastagens e áreas cultivadas. Pesquisa Agropecuária Tropical, Vol. 38, pp. 118-1127, ISSN 1517-6398

Jenkinson, D.S. (1988). Determination of microbial biomass carbon and nitrogen in soil. In: Advances in Nitrogen Cycling in Agricultural Ecosystems, J.R. Wilson, (Ed.), pp. 368386, CAB International, ISBN 0-8519-8603-X, New York, USA

Jenkinson, D. S. \& Ladd, J. N. (1981). Microbial biomass in soil. Measurement and turnover, In: Soil Biochemistry, E.A. Paul.; J.M. Ladd, (Ed.), Vol.5, pp.415-471, Dekker, ISBN 08247-11131-9, New York, USA

Joergensen, R.G; Brookes, P.C. (1990). Ninhydrin-reactive nitrogen measurements of microbial biomass in 0,5 M K2SO4 soil extracts. Soil Biology and Biochemistry, Vol. 22, pp. 1023-1027, ISSN 0038-0717

Kaschuk, G.A.; Hungria.; M. (2010). Three decades of soil microbial biomass studies in Brazilian ecosystems: Lessons learned about soil quality and indications for improving sustainability. Soil Biology and Biochemistry, Vol. 42, No. 1, January 2010, ISSN 0038-0717

Knorr, W., I.C. Prentice, J.I. House, and E.A. Holland. (2005). Long-term sensitivity of soil carbon turnover to warming. Nature, Vol. 433, pp. 298-301, ISSN 0028-0836

Koppen, W. Versucheiner Klassification der Klimate, vorzugsweise nach ihren Beziehungen zur Pflanzenwelt. (1900). Geographische Zeitschrift, Vol. 6, pp.593-611, ISSN 00167479

Lal, R. (2003). Global potential of soil carbon sequestration to mitigate the greenhouse effect. Critical Reviews in Plant Science, Vol. 22, pp. 151-184, ISSN 0735-2689

Luizão, R.C.C.; Costa, E. S.; Luizão, F. J. (1999). Mudanças na biomassa microbiana e nas transformações de nitrogênio em uma seqüência de idades de pastagens após derruba e queima da floresta na Amazônia Central. Acta Amazônica, Vol. 29, pp. 4356, ISSN 0044-5967

Mader, P.; Fliebach, A.; Dubois, A.; Gunst, L.; Fried, P.; Niggli, U. (2002). Soil fertility and biodiversity in organic farming. Science, Vol. 296, pp. 4, ISSN 1095-9203

Maia, S.M.F. (2009). Estimativas das emissões de carbono do solo devido à mudanças de uso da terra no uso da terra em Rondônia e Mato Grosso, PhD thesis, Escola Superior de Agricultura "Luiz de Queiroz", Piracicaba, São Paulo, Brazil

Matsuoka, M.; Mendes, I. C.; Loureiro, M. F. (2003). Biomassa microbiana e atividade enzimática em solos sob vegetação nativa e sistemas agrícolas anuais e perenes na região de Primavera do Leste (MT). Revista Brasileira de Ciência do Solo, Vol. 27, No. 3, pp. 425-433, ISSN 0100-0683

McGill, W.B., Dormaar, J.E., Reinl-Dwyer, E. (1988). New perspective on soil organic matter quality, quantity and dynamics on the Canadian prairies. Proceedings of 43 th Annual Meeting of the Canadian Society of Soil Science, ISBN 3-8359-5384-2, Calgary, August 1988 
Mello, F.F.C. (2007). Estimativas dos estoques de carbono dos solos nos Estados de Rondônia e Mato Grosso anteriores à intervenção antrópica, MSc thesis, Escola Superior de Agricultura "Luiz de Queiroz", Piracicaba, São Paulo, Brazil

Mielniczuk, J., Wünsche, W.A., Ferreira, T. (1983). Conservação do solo. Revista Trigo e Soja, Vol. 66, pp. 17-21, ISSN 1517-4964

Moraes, J.F.L.; Volkoff, B.; Cerril, C.C.; Bernoux, M. (1996). Soil properties under Amazon forest and changes due to pasture installation in Rondônia, Brazil. Geoderma, Vol. 70, pp. 63-81, ISSN 0016-7061

Nelson, D.W.; Sommers, L.E. Total carbon, organic carbon and organic matter. (1982). In: Methods of soil analysis, A.L. Page; R.H. Miller; D.R. Keeney (Ed.), pp. 539-579, American Society of Agronomy, ISBN 0-8911-8088-5, Madison, USA

Neill, C., Piccolo, M.C., Steudler, P.A., Melillo, J.M., Feigl, B.J., Cerri, C.C. (1995). Nitrogen dynamics in soils of forests and active pastures in the Western Brazilian Amazon Basin. Soil Biology EBiochemistry, Vol. 27, pp. 1167-1175, ISSN 0038-0717

Perez, K.S.S.; Ramos, M.L.G.; McManus, C. (2004). Carbono da biomassa microbiana em solo cultivado com soja sob diferentes sistemas de manejo nos cerrados. Pesquisa Agropecuária Brasileira, Vol.39, pp. 567-573, ISSN 0100-204X

Resck, D.V.S., Vasconcellos, C.A., Vilela, L., Macedo, M.C.M. (2000). Impact of conversion of Brazilian Cerrados to cropland and pasture land on soil carbon pool and dynamics. In: Global climate change and tropical ecosystems, R. Lal; J.M. Kimble; B.A. Stewart (Ed.), pp. 169-196, CRC Press, ISBN 9-781566-70485-4 , Boca Raton, USA

Ribeiro, J.F.; Walter, B.M.T. (1998). Fitofisionomias do bioma Cerrado. In: Cerrado: ambiente e flora, S.M. Sano; S.P. de Almeida (Ed.), pp. 89-166, EMBRAPA, ISBN 8570750080, Brasília, Brazil

Roscoe, R., Vasconcellos, C.A., Furtini-Neto, A.E., Guedes, G.A.A., Fernandes, L.A. R. (2000). Uréase activity and its relation to soil organic matter, microbial biomass nitrogen and urea-nitrogen assimilation by maize in a Brazilian Oxisol under no-tillage and tillage systems. Biology \& Fertility Soils, Vol. 32, pp. 52-59, ISSN 0178-2762

Sa, J.C.; Cerri, C.C; Dick, W.A.; Lal, R.; Venzke Filho, S.P.; Piccolo, M.C.; Feigl, B.J. (2001). Organic matter dynamics and carbon sequestration rates for a tillage chronosequence in a Brazilian oxisol. Soil Science Society of America Journal, Vol. 65, pp. 1486-1499, ISSN 1435-0661

Salton, J.C., Mielniczuk, J., Bayer, C., Fabrício, A.C., Macedo, M.C.M., Broch, D.L., Boeni, M., Conceição, P.C. (2005). Matéria Orgânica do Solo na Integração Lavoura-Pecuária em Mato Grosso do Sul, EMBRAPA, Retreived from

$<$ http://www.cpao.embrapa.br>

Santos, V,B.; Castilhos, D.D.; Castilhos, R.M.V.; Pauletto, E.A.; Gomes, A.S; Silva, D.G. (2004). Biomassa, Atividade microbiana e teores de carbono e nitrogênio totais de um planossolo sob diferentes sistemas de manejo. Revista Brasileira de Agrociência, Vol. 10, pp. 333-338, ISSN 0104-8996

Saviozzi, A.; Levi-minzi, R.; Cardelli, R.; Riffaldi, R. A (2001). Comparison of soil quality in adjacent cultivated, Forest and native grassland soils. Plant and Soil, Vol. 233, pp. 251-259, ISSN 0032-079X 
Silva. J. E., Lemainski, J., Resck, D. V. S. (1994). Perdas de matéria orgânica e suas relações com a capacidade de troca catiônica em solos da região de cerrados do oeste baiano. Revista Brasileira de Ciência do Solo, Vol. 18, pp. 541-547, ISSN 01000683

Silva, J.E.; Resck, D.V.S.; Corazza, E.J.; Vivaldi, L. (2004). Carbon storage in clayey oxisol cultivated pastures in the "Cerrado" region, Brazil. Agriculture Ecosystems $\mathcal{E}$ Environment, Vol. 103, pp. 357-363, ISSN 0167-8809

Six, J., S.M. Ogle, F.J. Breidt, R.T. Conant, A.R. Mosier, and K. Paustian. (2004). The potential to mitigate global warming with no-tillage management is only realized when practised in the long term. Global Change Biology, Vol. 10, pp. 155-160, ISSN 13541013

Souza, E. D.; Carneiro, M. A. C.; Paulino, H. B.; Silva, C. A. (2006). Frações do carbono orgânico, biomassa e atividade microbiana em um Latossolo Vermelho sob cerrado submetido a diferentes sistemas de manejos e usos do solo. Acta Scientiarum Agronomy, Vol. 28, No. 3, pp. 323-329, ISSN 1679-9275

Sparling, G. (1992). Ratio on microbial biomass carbon to soil organic carbon as a sensitive indicator of changes in soil organic matter. Australian Journal of Soil Research, Vol. 30, pp. 195-207, ISSN 0004-9573

Sparling, G.P., Grupta, V.V.R., Zhu, C. (1993). Release of ninhydrinreactive compounds during fumigation of soil to estimate microbial C and N. Soil Biology E Biochemistry, Vol. 25, pp. 1803-1805, ISSN 0038-0717

Vance, E.D.; Brookes, P.C.; Jenkinson, D.S. (1987). An extration method for measuring soil microbial biomass C. Soil Biology \& Biochemistry, Vol. 19, pp. 703-707, ISSN 00380717

Vargas, L.K., Scholles, D. (2000). Biomassa microbiana e produção de C- $\mathrm{CO}_{2}$ e $\mathrm{N}$ mineral de um solo Podzólico Vermelho-Escuro submetido a diferentes sistemas de manejo. Revista Brasileira de Ciência do Solo, Vol. 24, pp. 35-42, ISSN 0100-0683

Venzke filho, S. P. (1999). Microbiota e sua atividade em uma cronosseqüencia sob sistema de plantio direto, MSc thesis, Escola Superior de Agricultura "Luiz de Queiroz", Piracicaba, São Paulo, Brazil

Wang, K.H.; Mcsorley, R.; Bohlen, P.; Gathumbi, S.M. (2006). Cattle grazing increases microbial biomass and alter soil nematode communities in subtropical pastures. Soil Biology E Biochemistry, Vol.38, pp. 1956-1965, ISSN 0038-0717.

Wardle, D.A. (1994). Metodologia para quantificação da biomassa microbiana do solo. In: Manual de métodos empregados em estudos de microbiologia agrícola, M. Hungria; R.S. Araújo (Ed.), pp. 419-436, EMBRAPA, Retreived from < http://www.infoteca.cnptia.embrapa.br/handle/CNPAF/8927>

Xavier, F. A. S. (2004). Compartimentos da matéria orgânica do solo em sistemas agrícola convencional e orgânico na região da Chapada da Ibiapaba-CE. MSc. Thesis, Universidade Federal do Ceará, Fortaleza, Brazil

Xavier, F.A.S., Maia, S.M.F., Oliveira, T.S., Mendonça, E.S. (2007). Biomassa microbiana e matéria orgânica leve em solos sob sistemas agrícolas orgânico e convencional na Chapada da Ibiapaba - CE. Revista Brasileira de Ciência do Solo, Vol. 30, pp. 247-258, ISSN 0100-0683 
Zaman, M.; Cameron, K.C.; Di, H.J.; Inubushi, K. (2002). Changes in mineral N, microbial biomass and enzyme activities in different soil depths after surface applications of dairy shed effluent and chemical fertilizer. Nutrient Cycling in Agroecosystems, Vol. 63, pp. 275-290, ISSN 1385-1314 


\title{
The Above-Ground Biomass Production and Distribution in White Willow Community During 11 Years of Primary Succession
}

\author{
Petr Maděra, Diana Lopéz and Martin Šenfeldr \\ Department of Forest Botany, Dendrology and Geobiocoenology, \\ Faculty of Forestry and Wood Technology, Mendel University in Brno \\ Czech Republic
}

\section{Introduction}

In 1996 the water level in the studied area, the central lake of the Nove Mlyny Reservoir, was reduced by $85 \mathrm{~cm}$. The reason was the implementation of a project with the aim to remedy the negative effect of the reservoir on the biological function of the river corridor. Within the project two islands across the reservoir were to be constructed. After the water level was reduced, seedlings of White Willow appeared immediately on the uncovered sediments. The area of the Nove Mlyny Reservoir thus became a unique natural laboratory of the succession of soft floodplain forest in several dozens of hectares (Buček et al., 2004). The initial stages of the White Willow community, originating from the primary succession (Bergmann, 1999; Matic et al., 1999), prove to be highly productive ecosystems.

The aim of research was to monitor the development of the successive community not only regarding the number and growth of individuals but also other production indicators, such as the biomass of stems, branches and leaves, the LAI or the stem volume, in order to create a natural model of community succession. A natural succession model can both bring some light into the principles of community growth and be a suitable source of knowledge concerning the cultivation of fast-growing woody plants on energetic plantations.

\section{Material and methods}

\subsection{Study area}

The permanent research plot was established in 2005 in Vlckuv ostrov Island, the construction of which was finished in 2001. The middle Nove Mlyny reservoir is located approximately $40 \mathrm{~km}$ to the south of Brno (the Czech Republic), 16 $37^{\prime} \mathrm{E}$ and $48^{\circ} 55 \mathrm{~N}$, at an altitude of $170 \mathrm{~m}$ a.s.l. In the stand, aged 5 at the time, a rectangular area of $20 \times 50 \mathrm{~m}$ was set up. The initial succession stages until the age of five were studied in smaller areas because of the high population density (Konůpek, 1998; Kovářová, 2003).

The area is located in Northern Pannonian biogeographical subprovince (Culek et al., 1996); it is characterized by warm climate with low precipitation, therefore it belongs to a warm climatic region (Quitt, 1971). The soil in the research area has been artificially created. The sediments which had naturally sorted in the liquid environment were relocated from the 
reservoir bottom to the middle of the artificially created island embankments by suction dredgers. The upper horizon contains loamy particles, after $15-20 \mathrm{~cm}$ these are sandy. With the reservoir water permanent storage quota of $170 \mathrm{~m}$ a.s.l. the surface of ground water is 20 cm deep.

\subsection{Field and laboratory works}

In 2005 all trees in the research plot were numbered and their biometric characteristics - the height and the girth of the stem at breast height (using the VERTEX III altimeter and a tape) - were measured. The measuring was repeated annually, always after the end of the growing season. In 2010 individual trees were surveyed by means of the FieldMap (IFER) technology; the obtained data were used for the creation of a 3D visualization of the research plot (Fig.1), using SVS application.

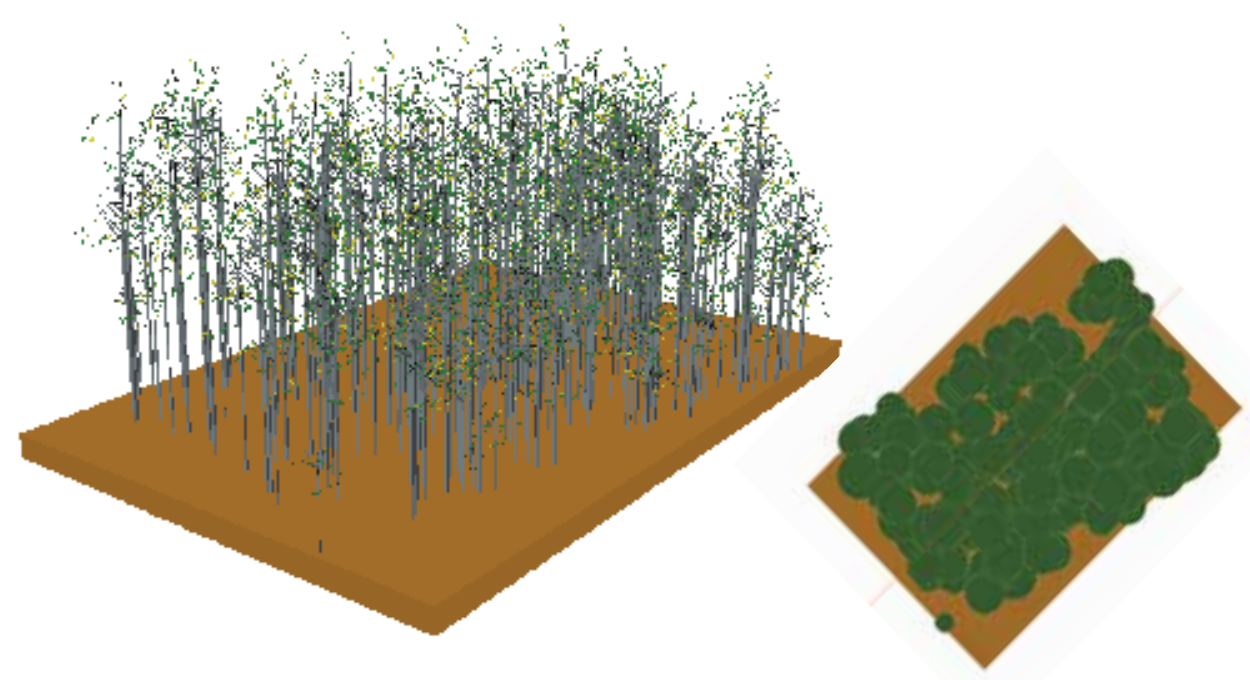

Fig. 1. 3D visualisation of research plot in age of 11 years

In order to gain production characteristic of the stand, the method published by Newbould (1967) was used in a form slightly modified by authors.

Six sample trees of different DBH (diameter at breast height) classes were destructively sampled during the research. The sample trees were taken from adjacent stands; the research plot was left for solely natural succession.

After felling, the sample trees were divided into meter sections and their leaves and branches were gradually removed. Twenty leaves were sampled in each section at random. The girth of the stem was measured each $20 \mathrm{~cm}$; a cross section was extracted from the stem basis for the tree-ring analysis; and a part of stem was extracted for the establishment of wood density.

The removed leaves and branches were dried at a temperature of $1050 \mathrm{C}$ until they reached constant weight. The series of 20 leaves from each section were scanned and their area was measured using the ImageTools application. Further, also these leaves were dried and their drymass was measured. The volume of wood samples was ascertained using a measuring cylinder, then the samples were dried again and their drymass was measured. 
The energy content accumulated in leaves, branches and wood was found out calorimetrically (Bomb Calorimeter PARR 1281).

\subsection{Data evaluation}

The annual measurement of all trees in the research plot was used to calculate:

1. Population density

2. Mortality

3. Number of sample trees in DBH and height classes

4. Mean height and DBH of stem

The drymass of leaves and branches of sample trees were added up for individual sections to gain the total drymass. The volume of stem was calculated using the formula for the blunted cone volume as the sum of volume of the $20 \mathrm{~cm}$ sections. The stem drymass was calculated from the wood density by multiplying the stem volume. Further, the average specific leaf area (SLA) for the leaves of individual sections was calculated as the quotient of a leaf drymass and its area. The SLA value was then used to calculate the area of leaves in individual sections from the total leaf drymass.

To derive the values of growth characteristics of sample trees non-linear Gompertz function was used:

$$
Y=\left(a^{*} \exp \left(-b^{*} \exp \left(-c^{*} x\right)\right)\right)-d,(1)
$$

where " $Y$ " is the mean value of biomass of sample trees in each DBH class, " $x$ " is the mean diameter at breast height in $\mathrm{cm}$ for the particular DBH class, and coefficients a, b, c, d are presented in Table 1.

\begin{tabular}{|c|c|c|c|c|c|c|}
\hline Growth quantity & \multicolumn{4}{|c|}{ Coefficients } & Regression coefficient & Mean error \\
\hline & $a$ & $\mathrm{~b}$ & c & $\mathrm{d}$ & & [\%] \\
\hline Stem volume & 595 & 5.9 & 0.0925 & 3.0 & 0.992 & 8.56 \\
\hline Stem biomass & 235 & 5.3 & 0.08 & 2.4 & 0.993 & 2.61 \\
\hline Branch biomass & 98.8 & 10.15 & 0.095 & 0.0 & 0.999 & 0.35 \\
\hline Leaf biomass & 5.5 & 8.8 & 0.16 & 0.008 & 0.993 & 0.13 \\
\hline
\end{tabular}

Table 1. Regression coefficient, mean error and the coefficients of the non-linear Gompertz function used for the processing of the biomass of White Willow sample trees

The data valid for a stand area unit ( 1 ha) were obtained by multiplying the mean values by the number of trees in each class and their summarization. The non-linear Gompertz functions were used to process the data of the White Willow biomass as they express the data very well, which is proved by the high values of regression coefficients (Table 1).

\section{Results}

\subsection{Population density development}

The community of the White Willow sprang up as a cohort on the island - all trees are of the same age and the same species. In such a community the predominating relationship is intraspecific competition, which leads to high mortality related to the growth of individuals. This process is referred to as self-thinning and it follows the $3 / 2$ rule (Slavíková, 1985). The development of the population density in the research plot (Fig. 2) complies with this ecological law. 


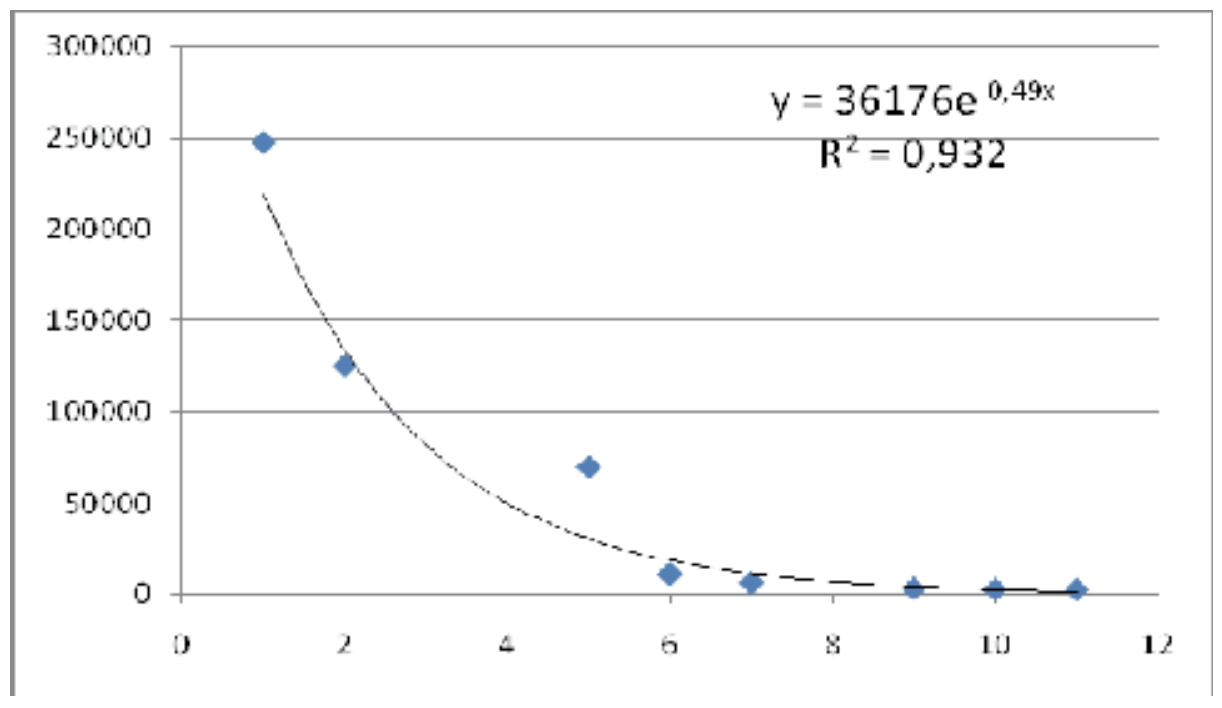

Fig. 2. Population density (No. of trees per hectar). development during succession

The gradual transition of trees from lower DBH classes to higher ones is expressed in Table 2. We can see the diversification of $\mathrm{DBH}$ values and the considerable mortality of trees in the lowest DBH classes which is caused by the lack of radiation in the lowest stand layers. With the succession of the community, the canopy closure expressed by LAI (see chapter 3.3) increases and for a light-demanding species, such as the White Willow, the amount of radiation soon drops under the value of the photosynthesis compensation point.

The mortality in the second year of succession rose to $50 \%$, then it dropped to about a third. The key moment came in the sixth year of succession when the intra-annual mortality reached $85 \%$, which was reflected in the productivity stagnation. Since this year, the intraannual mortality decreased gradually to $51 \%, 12 \%$, and $9 \%$. The total mortality after 11 years reached $99 \%$ !

\subsection{Tree size development}

The gradual development of the mean $\mathrm{DBH}$ and the mean height is presented in Figures 3 and 4 . At the age of 11, the average annual height increment was $1.4 \mathrm{~m}$ and the average annual diameter increment was $1.2 \mathrm{~cm}$. However, the maximum height of dominant trees is up to $22.6 \mathrm{~m}$ and the maximum $\mathrm{DBH}$ is $28.6 \mathrm{~cm}$. The stand now manifests a clear division into height layers. The height increment started to slow down from the age of 9 , in contrast to the diameter increment, which continues with approximately the same speed. Moreover, the increase in the mean $\mathrm{DBH}$ is more noticeable thanks to the mortality of the trees from the lowest DBH classes.

\subsection{Leaf area development}

The difference in the SLA between the leaves in the shade and the leaves in the sun was considerable. The lowest SLA value of the leaves at the crown base of subdominant trees was $0.00433 \mathrm{~g}^{*} \mathrm{~cm}^{-1}$; on the other hand, the highest SLA value measured in the sunny leaves at the crown top of dominant trees was $0.12748 \mathrm{~g}^{*} \mathrm{~cm}^{-1}$. Therefore, the same drymass of sunny leaves takes a thirty times smaller area. 


\begin{tabular}{|c|c|c|c|c|c|c|c|c|}
\hline \multirow{2}{*}{$\begin{array}{c}\text { DBH class } \\
{[\mathrm{cm}]}\end{array}$} & \multicolumn{8}{|c|}{ Succession age } \\
\hline & 1 & 2 & 5 & 6 & 7 & 9 & 10 & 11 \\
\hline I $(0.00-1.00)$ & 247600 & 46880 & 8533 & 200 & 10 & 0 & 0 & 0 \\
\hline II (1.00-2.00) & & 78160 & 27733 & 1260 & 450 & 70 & 10 & 20 \\
\hline III (2.0-3.00) & & & 20667 & 1670 & 490 & 70 & 10 & 10 \\
\hline IV (3.00-4.00) & & & 6800 & 1740 & 480 & 60 & 50 & 0 \\
\hline $\mathrm{V}(4.00-5.00)$ & & & 2400 & 1340 & 610 & 60 & 40 & 10 \\
\hline VI (5.00-6.00) & & & 2133 & 1060 & 670 & 100 & 60 & 50 \\
\hline VII (6.00-7.00) & & & 800 & 710 & 680 & 230 & 120 & 120 \\
\hline VIII (7.00-8.00) & & & 400 & 680 & 470 & 230 & 230 & 70 \\
\hline IX (8.00-9.00) & & & 267 & 380 & 410 & 250 & 180 & 140 \\
\hline$X(9.00-10.00)$ & & & & 400 & 380 & 210 & 170 & 170 \\
\hline XI (10.00-11.00) & & & & 530 & 360 & 280 & 220 & 190 \\
\hline XII (11.00-12.00) & & & & 330 & 380 & 240 & 230 & 220 \\
\hline XIII (12.00-13.00) & & & & 220 & 310 & 210 & 190 & 230 \\
\hline XIV (13.00-14.00) & & & & 200 & 230 & 300 & 240 & 240 \\
\hline XV (14.00-15.00) & & & & 70 & 170 & 120 & 160 & 130 \\
\hline XVI (15.00-16.00) & & & & 100 & 120 & 230 & 150 & 100 \\
\hline XVII (16.00-17.00) & & & & 30 & 50 & 120 & 200 & 120 \\
\hline XVIII (17.00-18.00) & & & & 30 & 60 & 110 & 110 & 200 \\
\hline XIX (18.00-19.00) & & & & & 30 & 80 & 90 & 60 \\
\hline XX (19.00-20.00) & & & & & & 80 & 130 & 100 \\
\hline XXI (20.00-21.00) & & & & & & 40 & 50 & 130 \\
\hline XXII (21.00-22.00) & & & & & & 10 & 70 & 80 \\
\hline XXIII (22.00-23.00) & & & & & & 10 & 20 & 40 \\
\hline XXIV (23.00-24.00) & & & & & & & 10 & 30 \\
\hline XXV (24.00-25.00) & & & & & & & & 0 \\
\hline XXVI (25.00-26.00) & & & & & & & & 10 \\
\hline XXVII (26.00-27.00) & & & & & & & & 0 \\
\hline XXVIII (27.00-28.00) & & & & & & & & 10 \\
\hline XXIX (28.00-29.00) & & & & & & & & 10 \\
\hline Total & 247600 & 125040 & 69733 & 10950 & 6360 & 3110 & 2740 & 2490 \\
\hline
\end{tabular}

Table 2. The numbers of trees in DBH classes during succession 


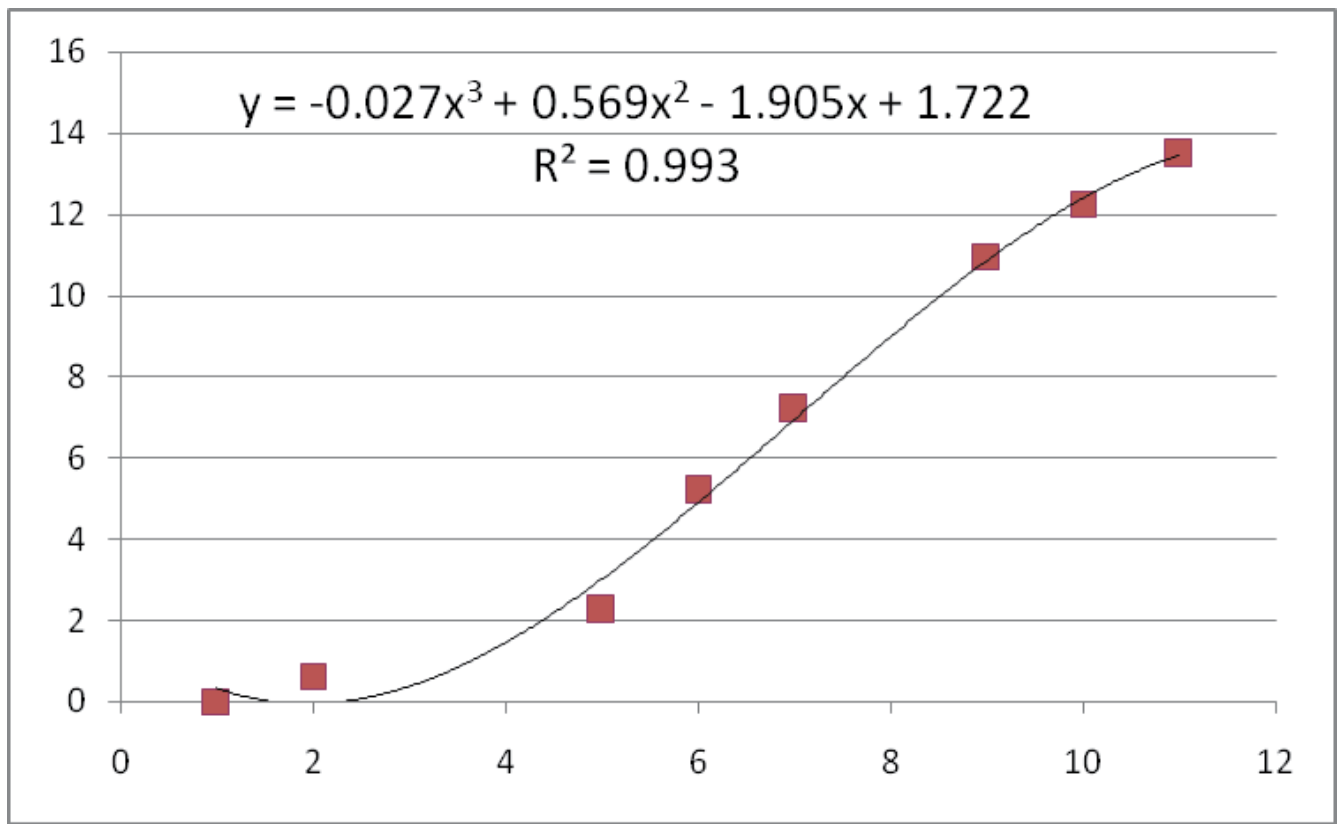

Fig. 3. The development of the stand mean diameter at breast height $[\mathrm{cm}]$ during 11 years of succession

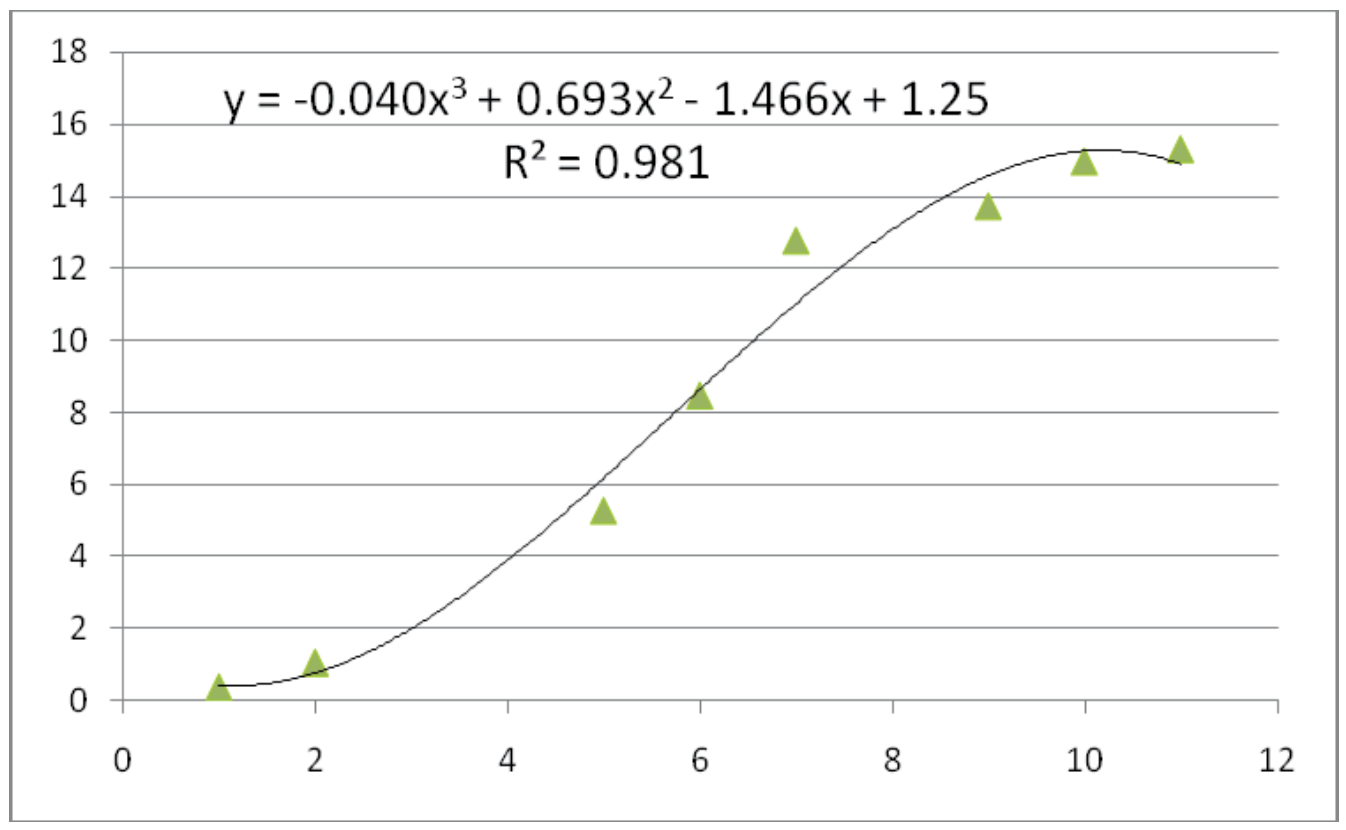

Fig. 4. The development of the stand mean height $[\mathrm{m}]$ during 11 years of succession 
The distribution of leaf area in the stand at different ages is visualized in Fig. 5 - there is an obvious shift of the crown space to higher layers or higher DBH classes and from the age of 9 the stand started to create particular layers; at the age of 11 there are three obvious layers and there are a few dominant trees.

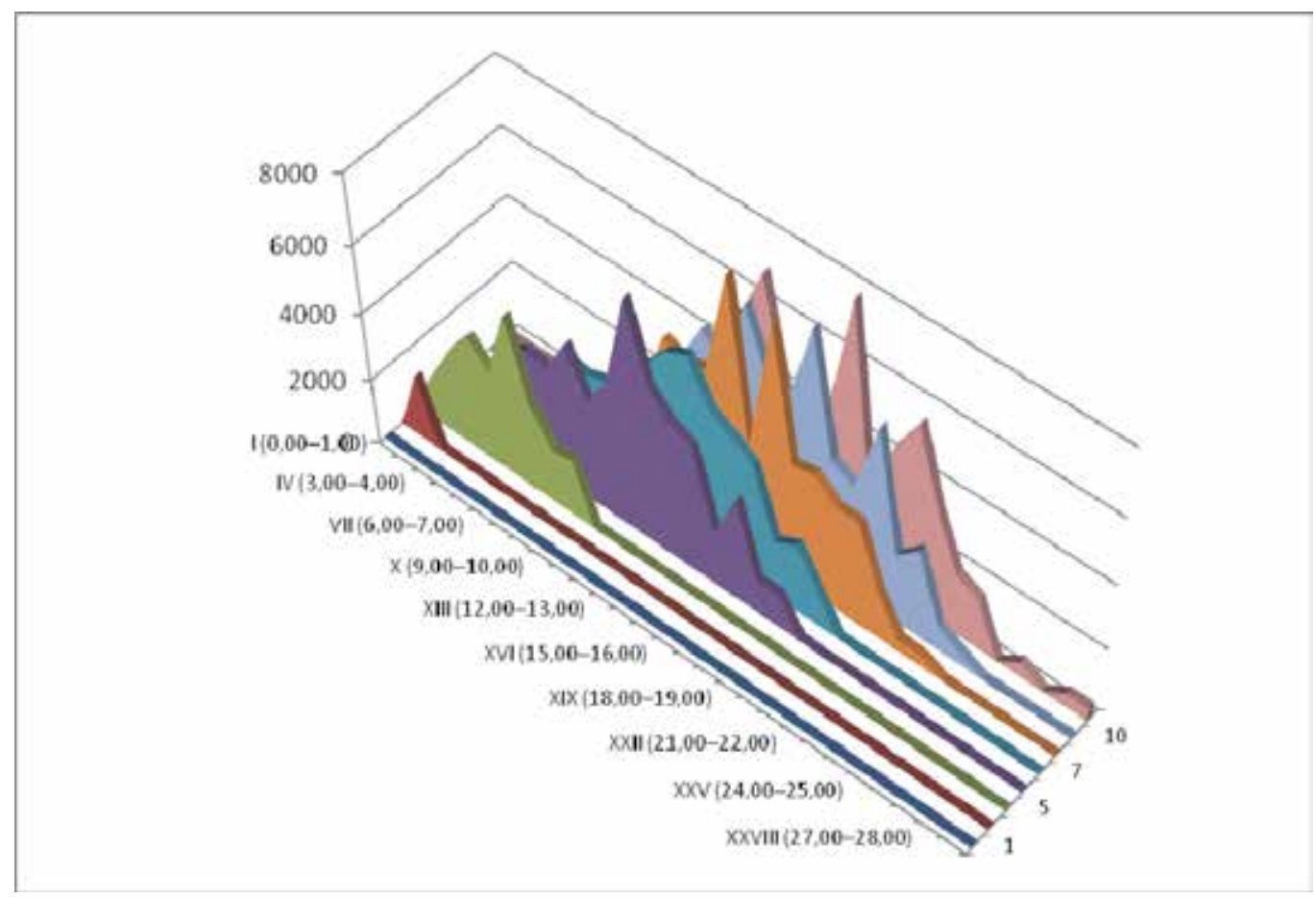

Fig. 5. The distribution of leaf area $\left[\mathrm{m}^{2}\right]$ in $\mathrm{DBH}$ classes in the White Willow stand during the succession

As regards the total leaf area, its development can be clearly shown using the leaf area index (LAI) (Fig. 6). In eleven years the initial negligible LAI values at the beginning of the succession grew up to a relatively high value of 6.6.

\subsection{Biomass production development \\ 3.4.1 Stem volume}

The stem volume is a basic production characteristic of forest stands. The development of the wood volume storage during the succession is presented in Fig. 7.

There is a clear fast increase in hectare storage during the first years of succession; from the age of 6 it decreases. The age of 6 is of key significance from the point of view of potential effectiveness of harvest. The stand had already achieved very high storage $-244.6 \mathrm{~m}^{3} . \mathrm{ha}^{-1}$ with the mean DBH $5.2 \mathrm{~cm}$ and height $8.5 \mathrm{~m}$. Moreover, the six-year-old stand reached the highest average annual increment $-40.75\left[\mathrm{~m}^{3 *} \mathrm{ha}^{-1 *} \mathrm{a}^{-1}\right]$.

Fig. 8 shows that in the first two years of succession the entire storage was concentrated in the low DBH classes (up to $2 \mathrm{~cm}$ ); at the age of 5, the core of the storage is still in the lowest $\mathrm{DBH}$ class but a considerable part is transferred to $\mathrm{DBH}$ classes up to $9 \mathrm{~cm}$. In the sixth and seventh year of the succession the storage is quite evenly distributed in DBH classes $2-19 \mathrm{~cm}$ 


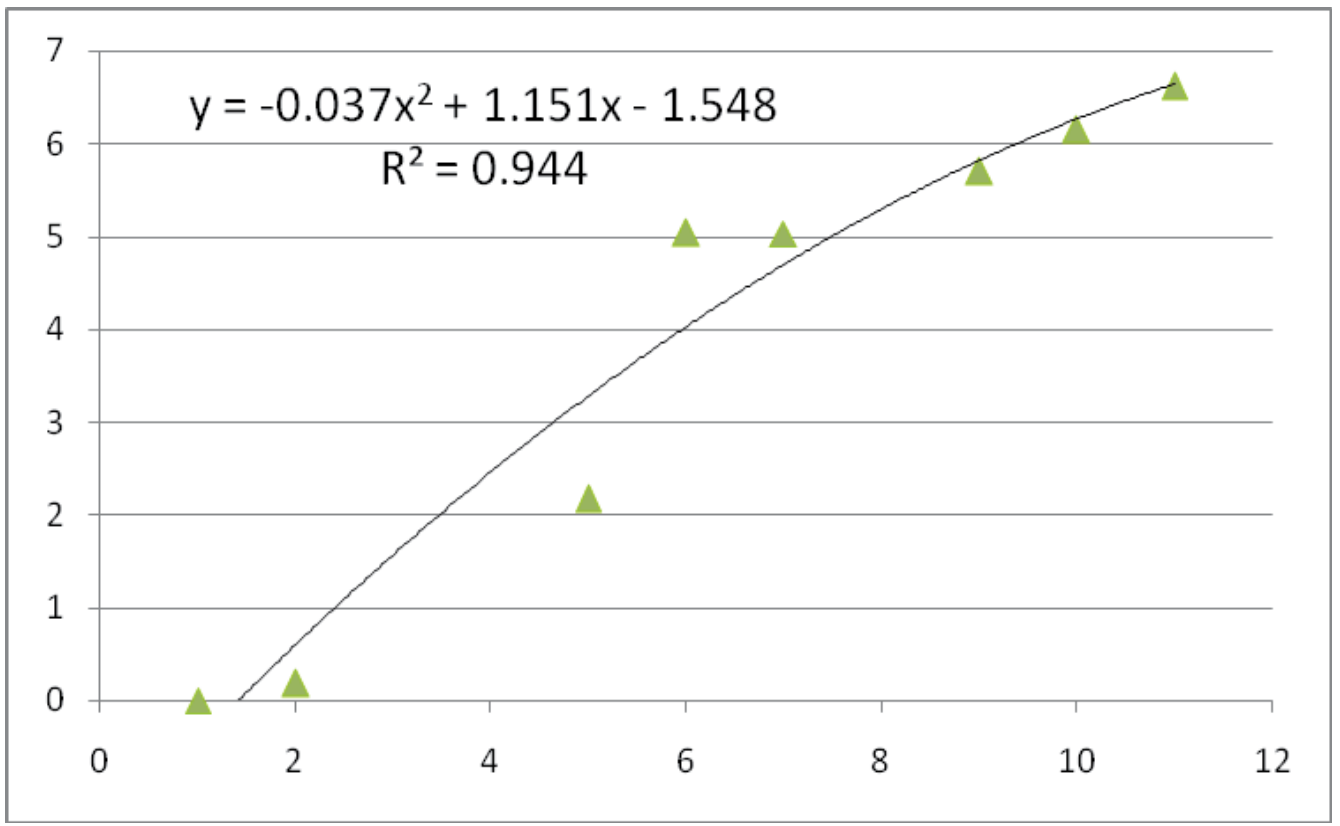

Fig. 6. The development of the leaf area index of the White Willow stand during 11 years of succession

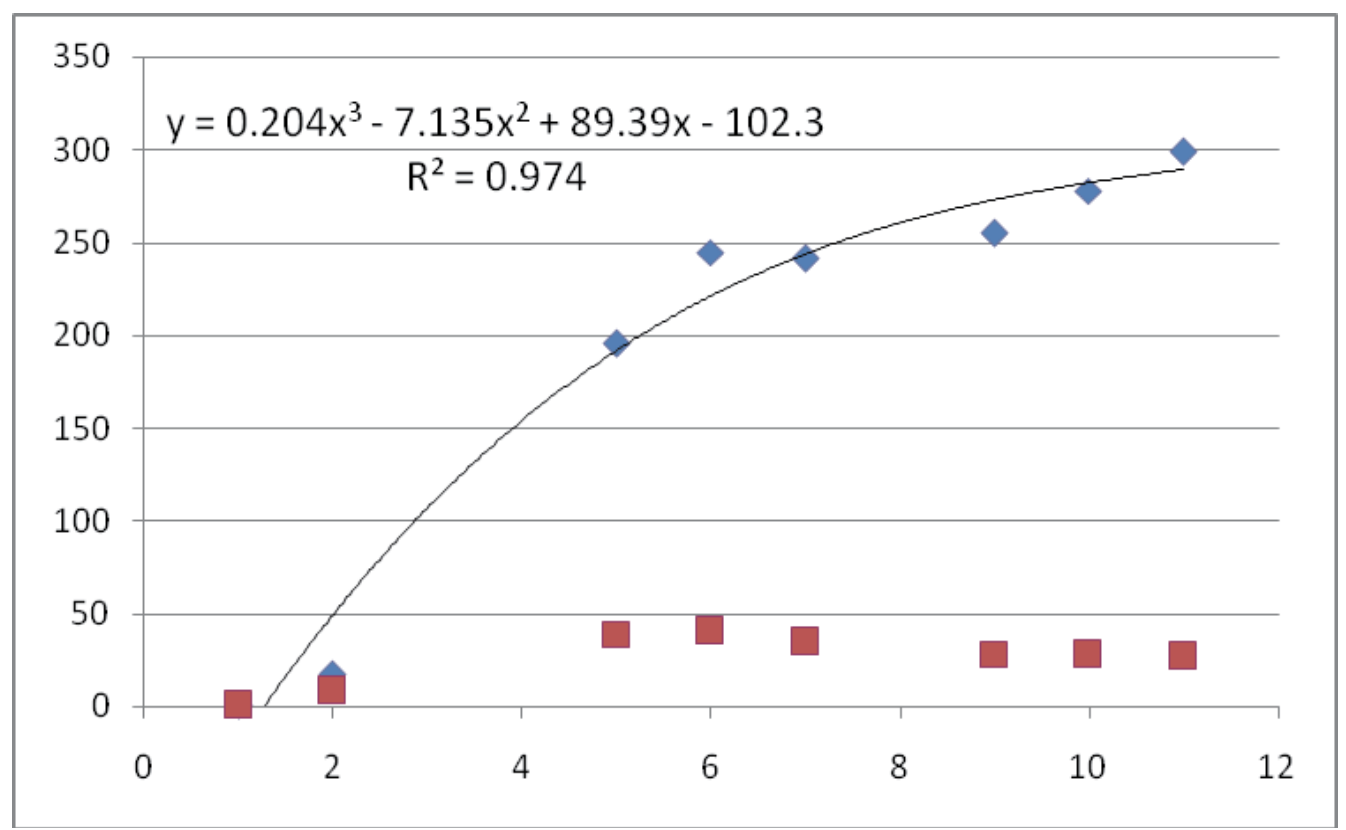

Fig. 7. The development of the wood volume storage in stems $\left[\mathrm{m}^{3} \cdot \mathrm{ha}^{-1}\right]$ during succession connected by a trend curve and the development of the average annual volume increment $\left[\mathrm{m}^{3^{*}} \mathrm{ha}^{-1^{*}} \mathrm{a}^{-1}\right]$ 
with the maximum in 10-16 cm. In the last four years of succession, the wood storage in stems is gradually moved to the higher DBH classes and divided into three groups, with the concurrent decrease in significance of the trees in the lower DBH classes, which die out due to the intraspecific competition for light. The trees with diameters from 10 to $23 \mathrm{~cm}$ become the bearers of production. This fact is important for the selection of the optimum harvesting and transport technology.

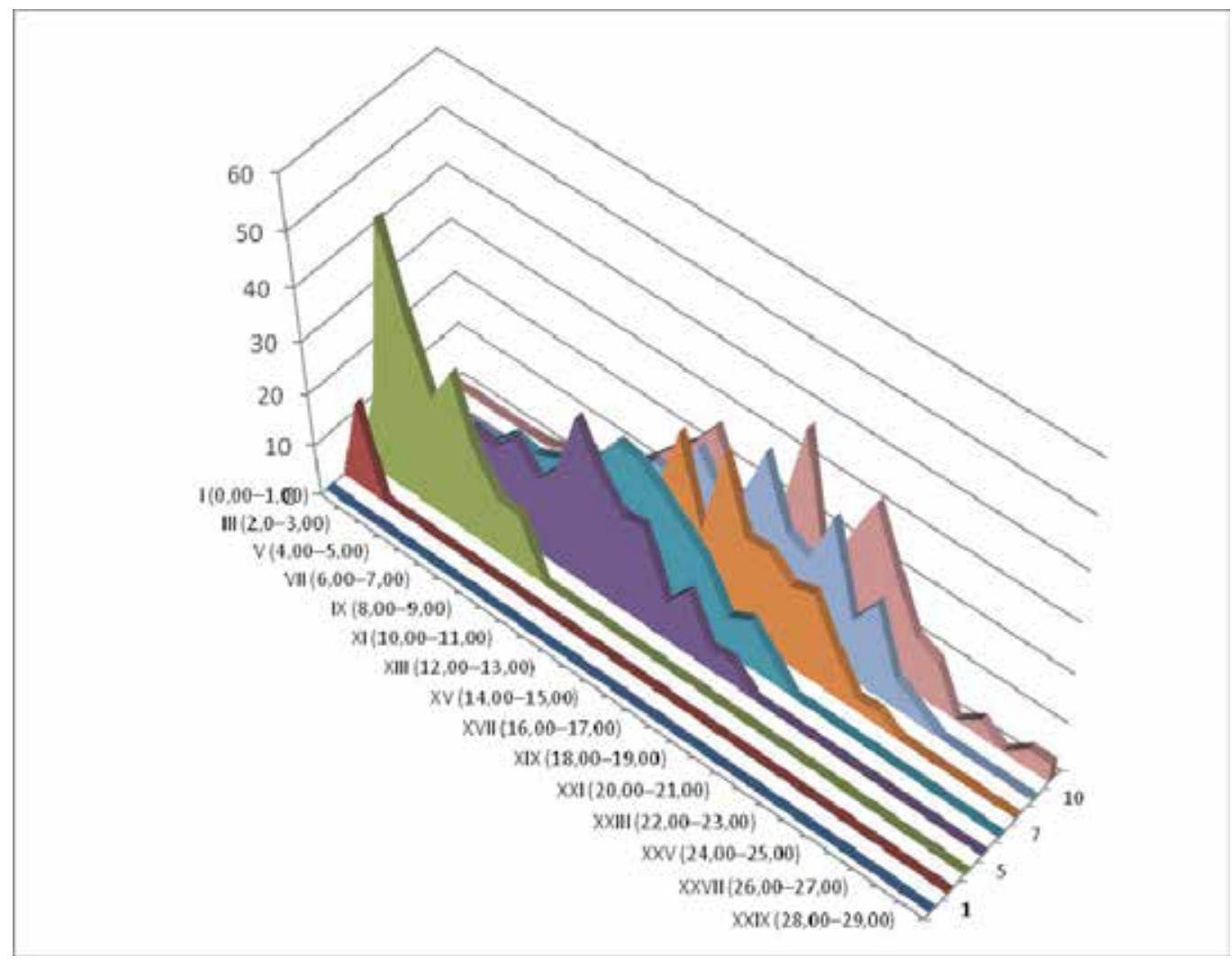

Fig. 8. The distribution of the stem volume storage $\left[\mathrm{m}^{3 *} \mathrm{ha}^{-1}\right]$ in $\mathrm{DBH}$ classes during succession

\subsubsection{Stem drymass}

The drymass stored in stems expresses the production of the community better as the wood of fast-growing woody species has a relatively low density. The density we calculated for the White Willow (as the quotient of the volume of a fresh sample and drymass) was 337 $\mathrm{kg}^{*} \mathrm{~m}^{-3}$.

The drymass accumulated in the stems is expressed in the following graph (Fig. 9). At the age of 11 , the community reached $102 \mathrm{t}^{*} \mathrm{ha}^{-1}$, but similarly to the values of stem volume, we can see the decrease in intra-annual growth starting at the age of 6 . The average annual increment at the age of 6 was $14.38 \mathrm{t}^{*} \mathrm{ha}^{-1 *} \mathrm{a}^{-1}$. 


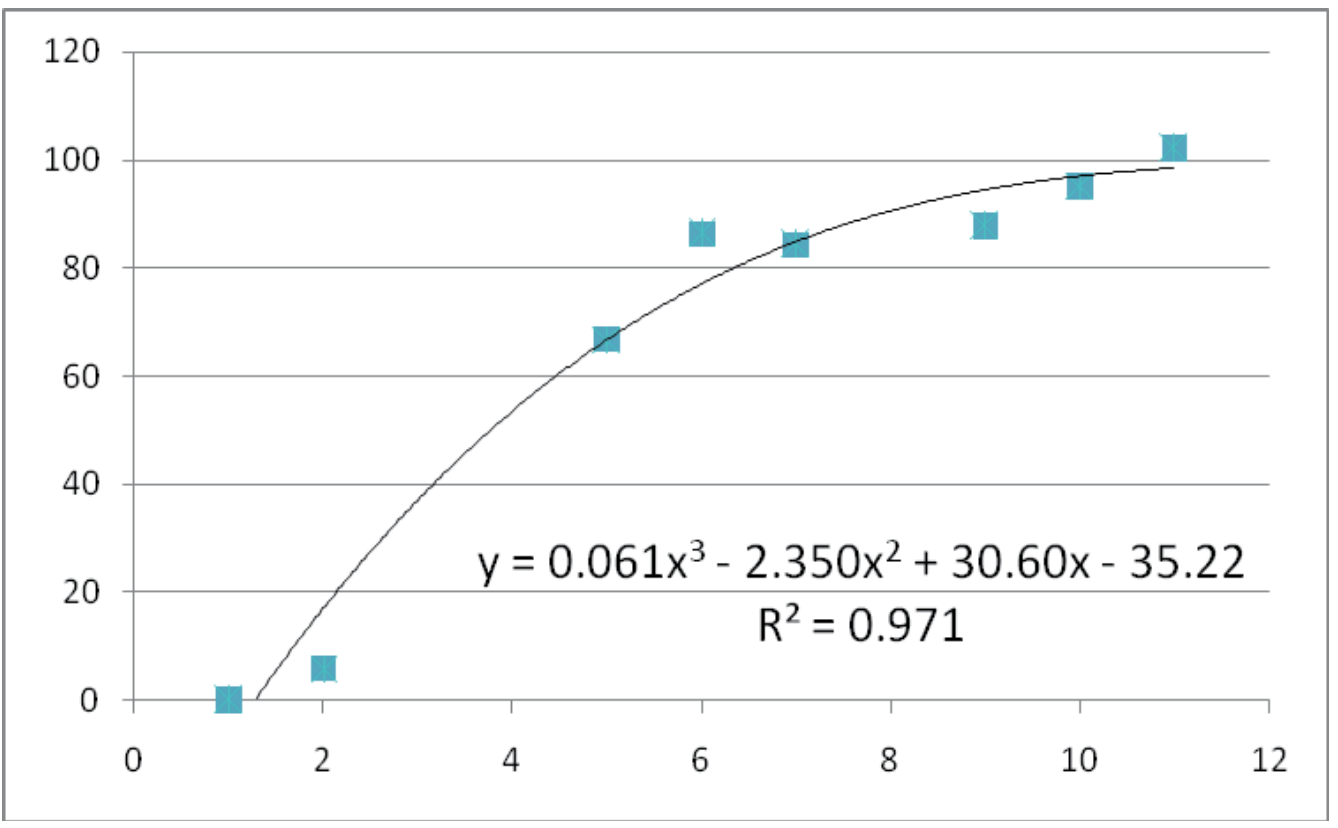

Fig. 9. The development of the total production of biomass accumulated in the stems during succession expressed in drymass [ $\left.\mathrm{t}^{*} \mathrm{ha}^{-1}\right]$

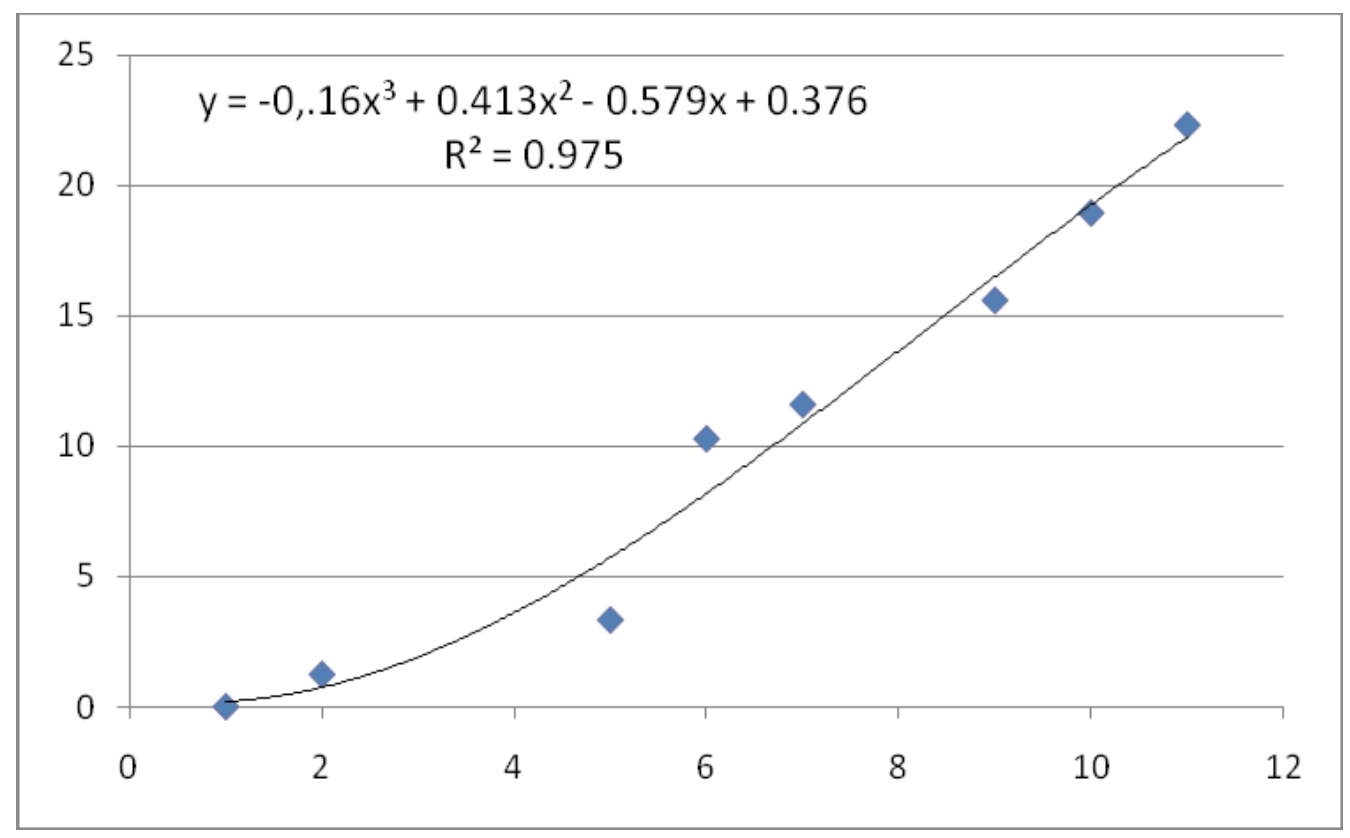

Fig. 10. The development of the total production of biomass accumulated in the branches during succession expressed in drymass [ $\left.\mathrm{t}^{\star} \mathrm{ha}^{-1}\right]$ 


\subsubsection{Branch drymass}

The branch biomass can also be used as an energy material. The drymass accumulated in the branches is visualized in Fig. 10. At the eleventh year of the community succession, the branch drymass reaches $22.29 \mathrm{t}^{*} \mathrm{ha}^{-1}$, which is considerable $17 \%$ out of the total biomass.

\subsubsection{Leaf drymass}

The development of the assimilation apparatus expressed by the leaf drymass in the individual years of succession shows an increasing production capacity of the community (Fig. 11).

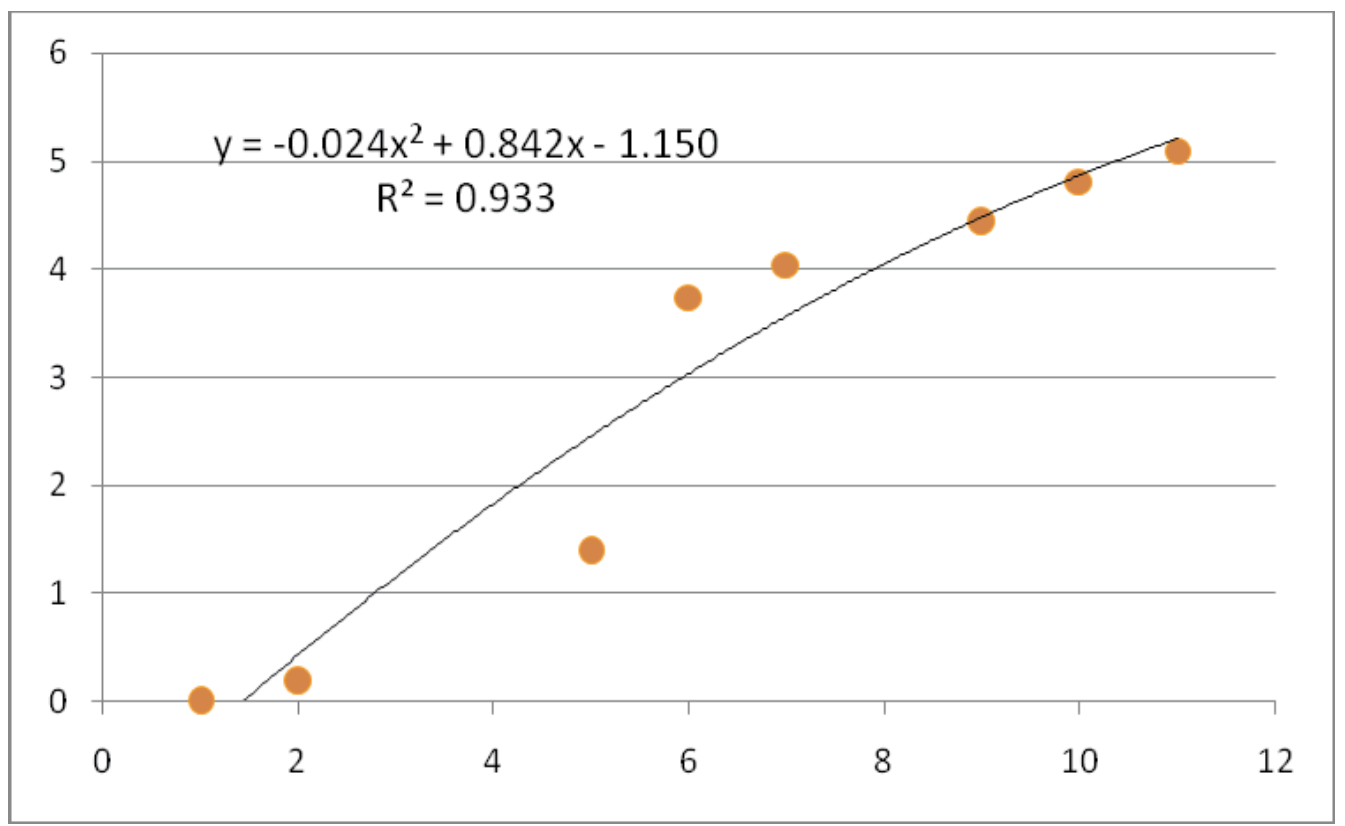

Fig. 11. The development of the total production of biomass accumulated in the leaves during succession expressed in drymass [ $\left.\mathrm{t}^{\star} \mathrm{ha}^{-1}\right]$

In the eleventh year of succession the leaf drymass exceeded $5 t^{*} \mathrm{ha}^{-1}$; it was $3.9 \%$ out of the total drymass of the above-ground biomass accumulated in the stand.

\subsubsection{Total drymass}

The total production of the above-ground biomass of the community is a sum of the drymass of the stems, branches and leaves. Its development in the individual years of the succession is presented in Fig. 12. At the age of 11 the total production of the community above-ground biomass reached $129.4 \mathrm{t}^{*}$ ha- ${ }^{-1}$.

Fig. 13 shows the relative proportions of the drymass of the stems, branches and leaves in the total drymass of the above-ground biomass. The proportion of the stem drymass in comparison with branch and leaf drymass is the lowest in the initial stages of succession $(80 \%)$. At the age of 5 the proportion of stem drymass is the highest and since this moment the proportion of branch and leaf drymass increases at the expense of the stem. Finally, in the eleventh year, the relative proportion of stem drymass is again $80 \%$. 


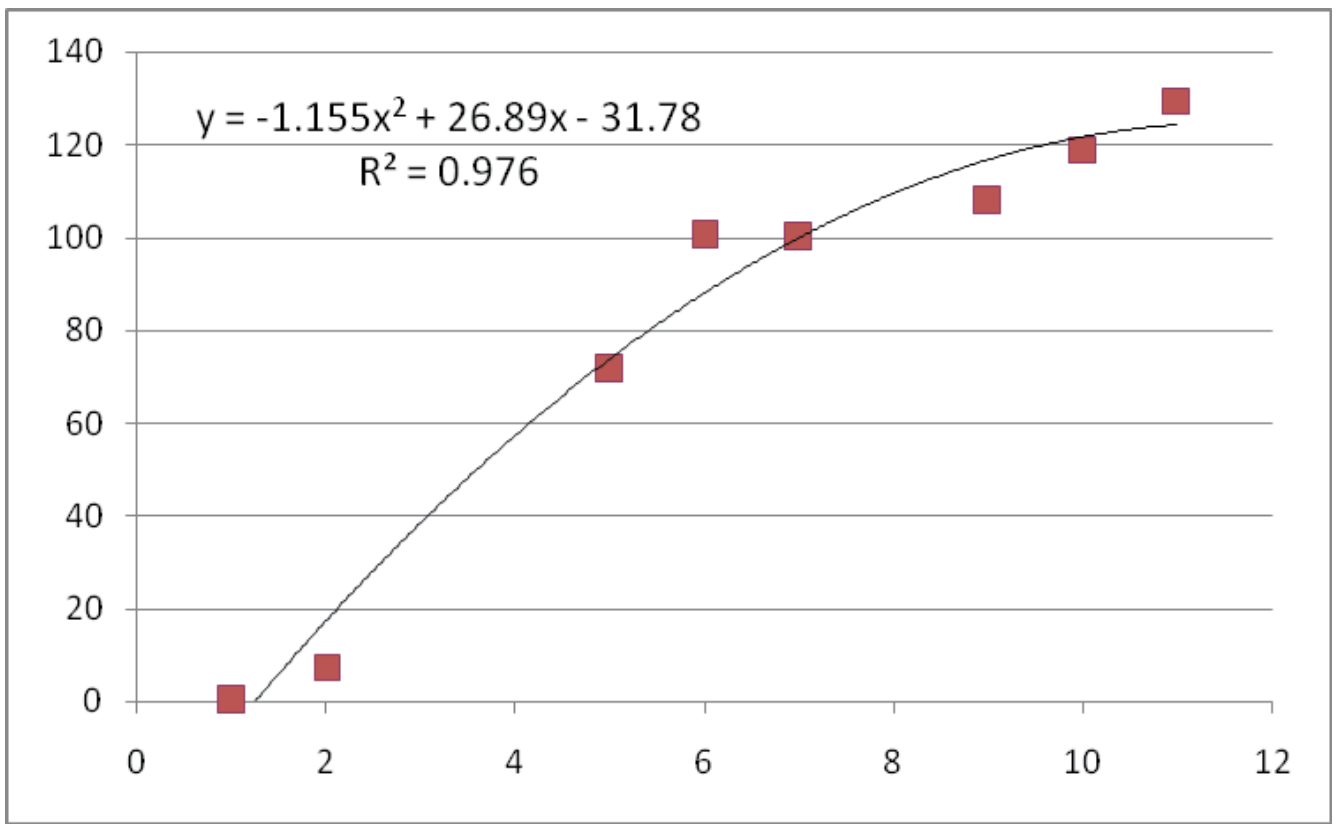

Fig. 12. The development of the total production of the community above-ground biomass during succession expressed in drymass [ $\mathrm{t}^{*} \mathrm{ha}^{-1}$ ]

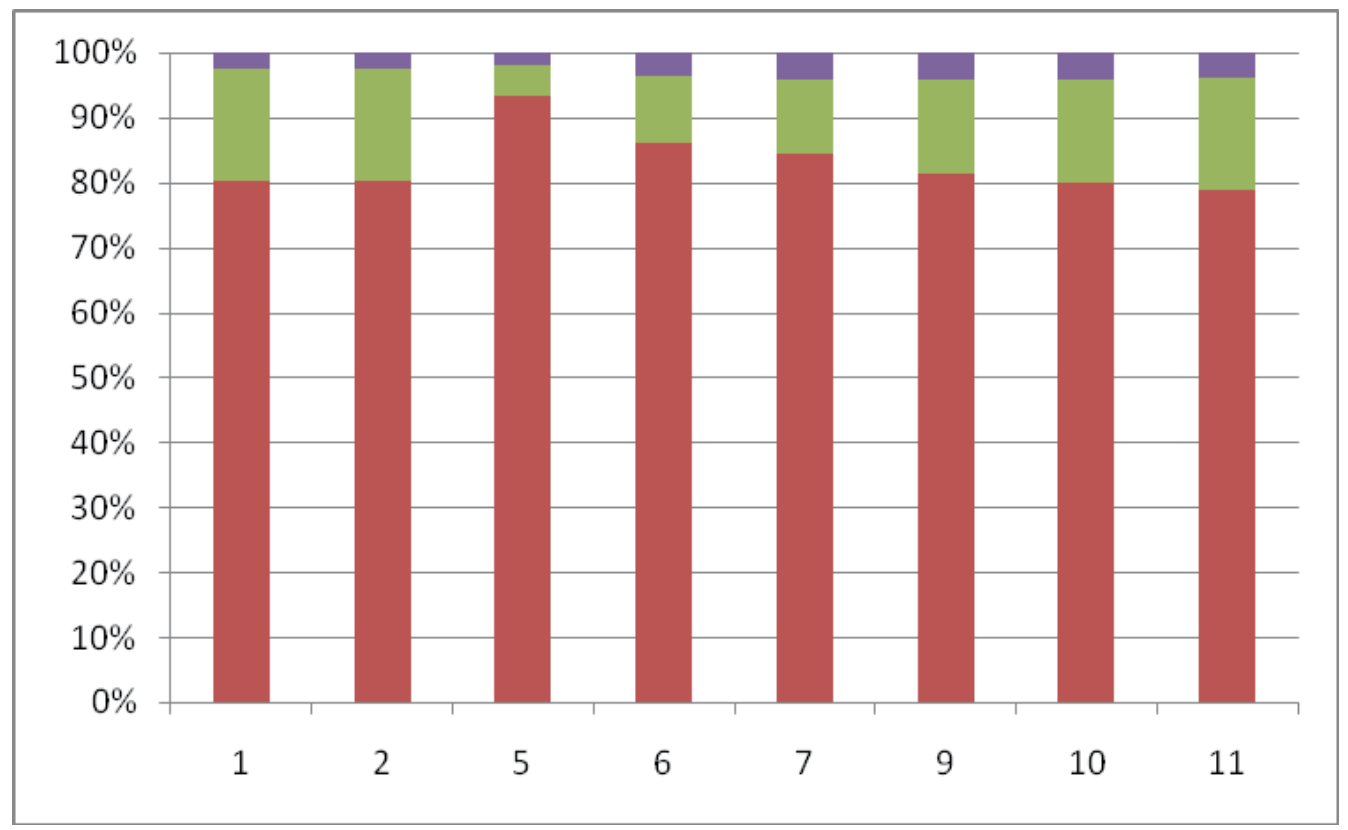

Fig. 13. The relative proportion of stem drymass (red), branch drymass (green) and leaf drymass (blue) during succession 
Another visualization of the distribution of drymass of the above-ground biomass in the stand during the succession is provided in the following graph (Fig. 14). In the initial stages of succession the lowest $\mathrm{DBH}$ classes are of the highest production significance in the community. This continues until the age of 5. Between the fifth and the sixth year of succession a significant change occurs in the structure of the stand. As the lowest DBH class trees had died, the trees of higher DBH classes gained space and their diameter increments started to increase fast. This trend, although slower, remains in the following years up to the age of 10. The eleventh year brought about another big leap of the plants into the higher DBH classes.

The average annual production of the above-ground biomass expressed in drymass reaches $11.77 \mathrm{t}^{*} \mathrm{ha}^{-1}$; however, the maximum values are ascertained for the age of 6 , when the average annual production was $16.72 \mathrm{t}^{*}$ ha ${ }^{-1}$.

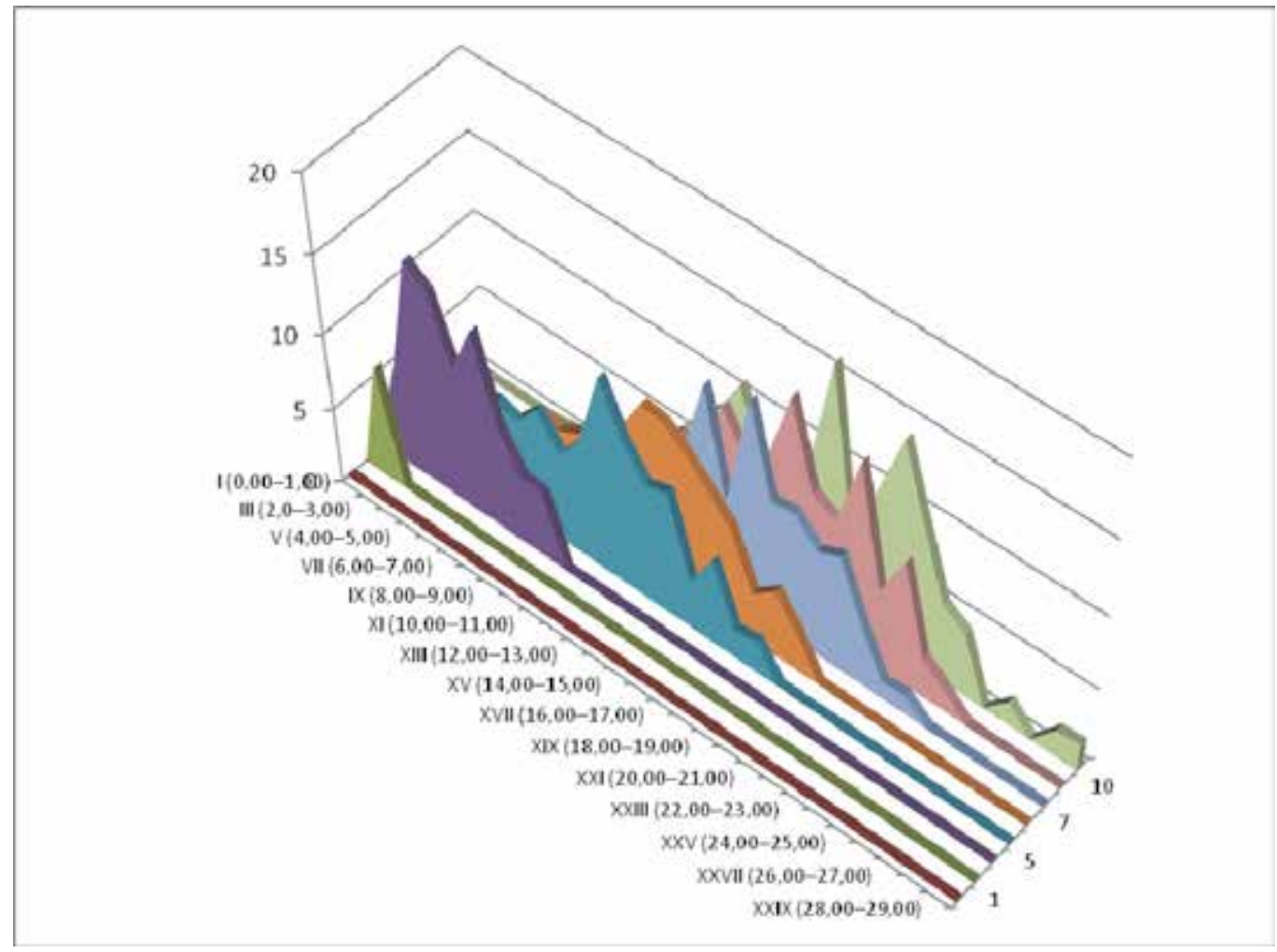

Fig. 14. The distribution of the total drymass of the above-ground biomass [ $\left.\mathrm{t}^{\star} \mathrm{ha}^{-1}\right]$ in DBH classes during succession

\subsection{Community energy output}

The content of energy accumulated in the above-ground biomass (of leaves, branches and wood) is presented in the following graph (Fig. 15). The average content of energy measured was $18.15 \mathrm{KJ}^{*} \mathrm{~g}^{-1}$ for leaves, $18.16 \mathrm{KJ}^{*} \mathrm{~g}^{-1}$ for branches and $17.83 \mathrm{KJ}^{*} \mathrm{~g}^{-1}$ for wood.

As regards the average annual content of energy accumulated in the stand above-ground biomass (Fig. 16), the highest values were reached at the age of $6-298,827 \mathrm{MJ}^{\star}{ }^{-1}{ }^{-1}$. The 


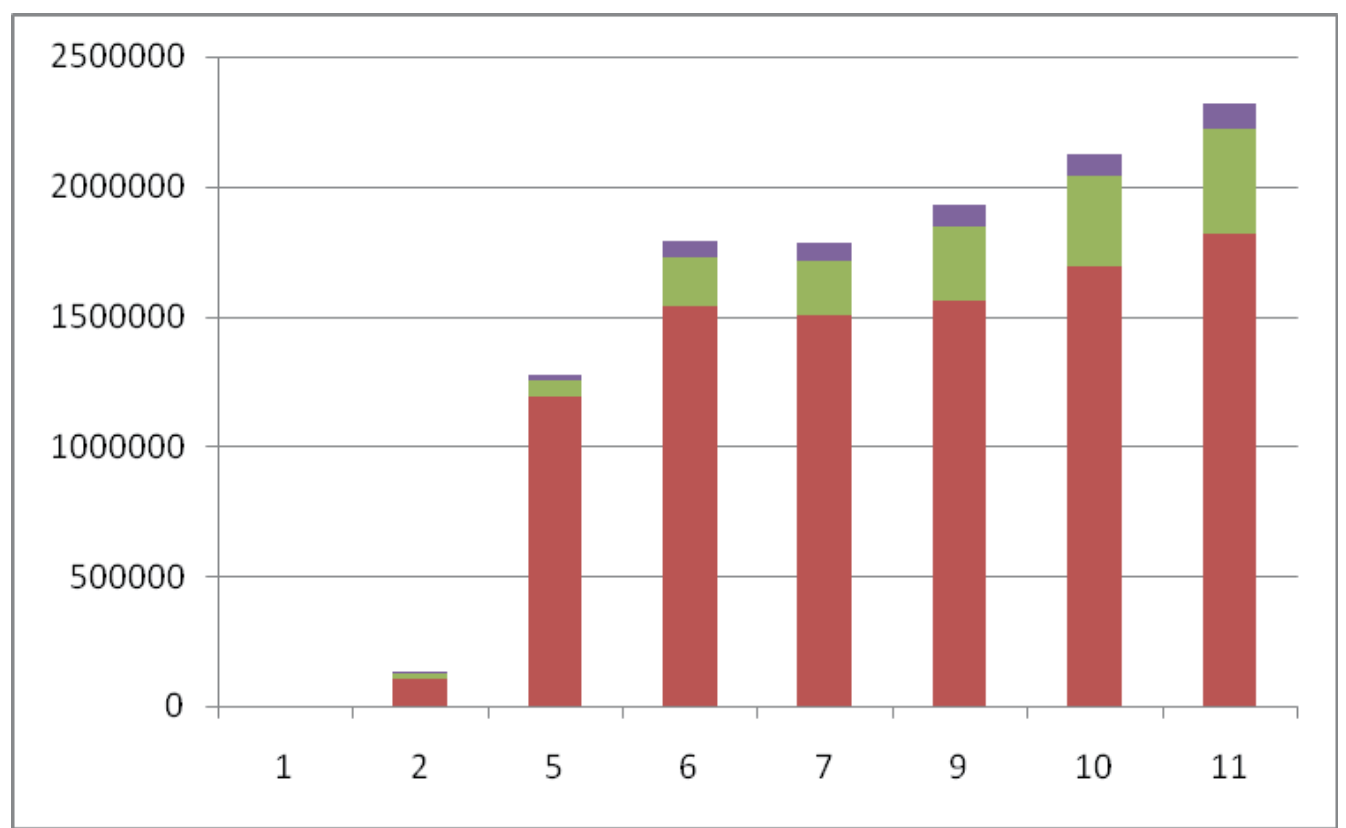

Fig. 15. The content of energy (MJ*ha-1) accumulated in stems (red), branches (green) and leaves (blue) of the stand during the succession

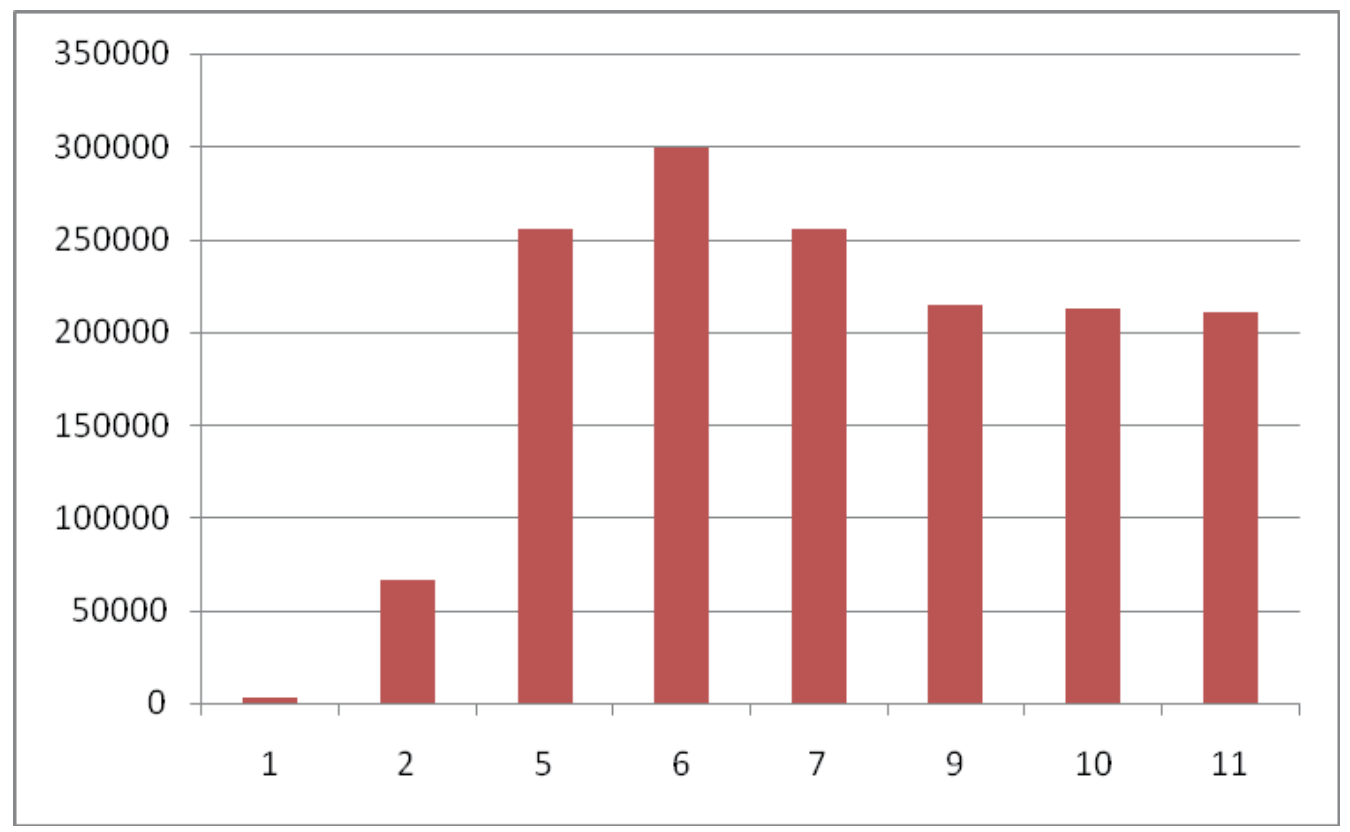

Fig. 16. The average annual content of accumulated energy [MJ'ha-1] in the stand during the succession 
values then decreased until they dropped to $214,000 \mathrm{MJ}^{\star}$ ha-1 in the ninth year; subsequently, the average annual content of accumulate energy remains more or less constant.

The same progress is also manifested by the stand output (Fig. 17), expressed in $\mathrm{kW}^{*} \mathrm{ha}^{-1}$ : the highest value, $9.48 \mathrm{~kW}^{*} \mathrm{ha}-1$, is reached at the age of 6 , and in the eleven-year-old stand the output drops to $6.68 \mathrm{~kW}^{*}$ ha-1.

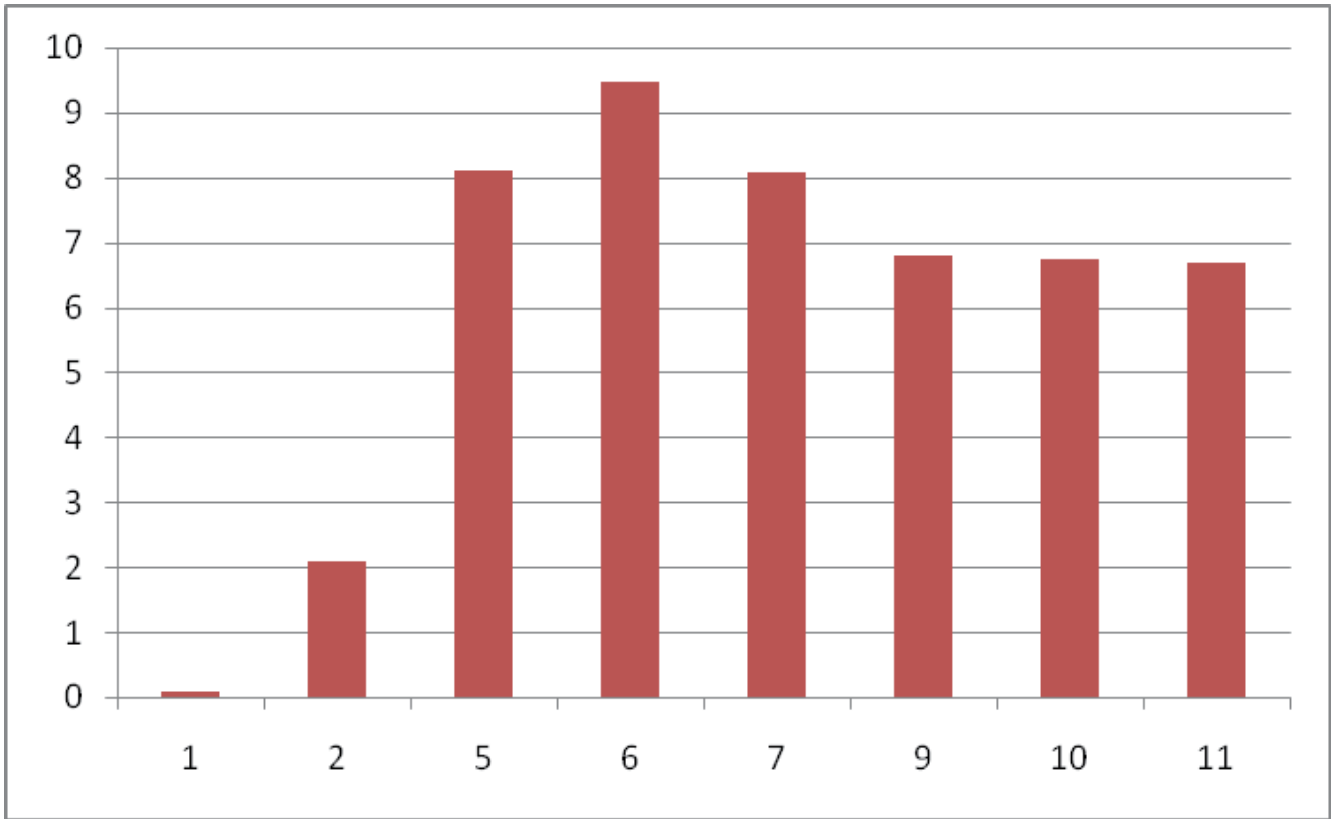

Fig. 17. The output of 1 ha of the stand during the succession $\left[\mathrm{kW}^{*} \mathrm{ha}-1\right]$

\section{Conclusion}

The paper describes selected production characteristics of a community of the White Willow which originated by means of natural oecesis on a newly constructed island in the middle of a water reservoir. The community succession was monitored for 11 years. During this period the stand developed completely naturally without any human interventions. The results were used to create a model of production properties of a natural ecosystem which can serve as a foundation for possible management rules for energy stands of the same species in similar conditions, such as bank stands or polders (Madera et al., 2009).

The results prove that the production of the above-ground biomass is very high in the monitored community of the White Willow. The highest average annual values of all monitored production characteristics were achieved at the age of 6 of the stand. The estimated value of drymass production is very favourable exceeding the majority of species which are grown for energy purposes in Central Europe. The values exceed the data measured by Bungart et al. (2000) in the region of Lusatia, Germany for 3-4-year-old stands of willows and poplars in mining areas approximately ten times. Kajba et al. (2004) mention that the overall mean DM production of all the investigated clones was 6.5 tons per hectare, the greatest production was exhibited by clones 'B44', 'V093' and 'V052' (10.2, 9.2 and 9.1 $t^{*} h^{-1}$, respectively). 
Based on the obtained results, from the perspective of production the most appropriate moment for harvest in case of energy stands of the White Willow appears to be when a stand reaches six years of age.

\section{Acknowledgment}

The study was supported by the research project MSM 6215648902 and Internal Grant Agency of Faculty of Forestry and Wood Technology Mendel University in Brno 12/2010.

\section{References}

Bergmann, J.H. (1999). The occurrence of willow in natural succession of lowlands of north eastern Germany. Beitrage für Forstwirtschaft und Landschaftsökologie, Vol.33, No.4, pp. 186-187

Buček, A.; Maděra, P. \& Packová, P. (2004). Evaluation and prediction of the geobiocoenosis development in the Nature Reserve Věstonická nádrž reservoir, Mendel University of Agriculture and Forestry, ISBN 978-80-7157-781-2, Brno

Bungart, R.; Bens, O.; Hüttl, R.F. (2000). Production of bioenergy in post-mining landscapes in Lusatia. Perspectives and challenges for alternative landuse systems. Ecological Engineering, Vol.16, Supplement 1, pp. 5-16, ISSN 0925-8574

Culek, M. (ed.), (1996). Biogeographical differentiation of the Czech Republic. Enigma, ISBN 80-85368-80-3, Prague.

Kajba, D.; Bogdan, S.; Katicic-Trupcevic, I. (2004): White willow biomass production in a short rotation clonal test Drávida. Sumarski -List, Vol.128, No.9-10, pp. 509-515, ISSN 0373-1332

Konůpek, J. (1998). Natural development dynamic of early succession stages of floodplain forest in Dyje and Svratka rivers alluvium. Thesis, Mendel University of Agriculture and Forestry, Brno.

Kovářová, P. (2003). Development of woody species communities in the supraregional biocorridor built in the middle water reservoir of Nové Mlýny. Ekológia (Bratislava), Vol.22, Supplement 2, pp. 231-142, ISSN 1335-342X

Maděra, P.; Packová, P.; Manjarrés, D.R.L.; Štykar, J. \& Simanov, V. (2009). The model of potential biomass production in Odra River basin. Ekológia (Bratislava), Vol.28, No.2, pp. 170-190, ISSN 1335-342X

Matic, S. ; Vukelic, J. \& Anic, I. (1999). Succession and sylvicultural treatments in riparian forests of the Croatian Podunavlje region. Ekológia (Bratislava), Vol.23, Supplement 1, pp. 191-204, ISSN 1335-342X

Newbould, P.J. (1967). Methods for estimating the primary production of forest. Blackwell Scientific Publications, Oxford and Edinburgh.

Slavíková, J. (1985). Plant Ecology. SPN, Prague

Quitt, E. (1971). Klimatische Gebiete der Tschechoslowakei. Studia geographica, ČSAV, Brno. 


\section{Part 2}

Remote Sensing of Biomass 



\title{
Introduction to Remote Sensing of Biomass
}

\author{
Muhammad Aqeel Ashraf ${ }^{1}$, Mohd. Jamil Maah ${ }^{1}$ and Ismail Yusoff ${ }^{2}$ \\ 1 Department of Chemistry, University of Malaya, \\ ${ }^{2}$ Department of Geology, University of Malaya, \\ Malaysia
}

\section{Introduction}

Planet Earth is distinguished from other Solar System planets by two major categories: Oceans and Land Vegetation. The oceans cover $\sim 70 \%$ of the Earth's surface; land comprises $30 \%$. On the land itself, the first order categories break down as follows: Trees $=30 \%$; Grasses $=30 \%$; Snow and Ice $=15 \%$; Bare Rock $=18 \%$; Sand and Desert Rock $=7 \%$. Remote sensing has proven a powerful "tool" for assessing the identity, characteristics, and growth potential of most kinds of vegetative matter at several levels (from biomes to individual plants). Vegetation behaviour depends on the nature of the vegetation itself, its interactions with solar radiation and other climate factors, and the availability of chemical nutrients and water within the host medium (usually soil, or water in marine environments). A common measure of the status of a given plant, such as a crop used for human consumption, is its potential productivity (one such parameter has units of bushels/acre or tons/hectare, or similar units). Productivity is sensitive to amounts of incoming solar radiation and precipitation (both influence the regional climate), soil chemistry, water retention factors, and plant type, keeping in mind that various remote sensing systems (e.g., meteorological or earth-observing satellites) can provide inputs to productivity estimation.

Remote sensing can be broadly defined as the collection and interpretation of information about an object, area, or event without being in physical contact with the object. Aircraft and satellites are the common platforms for remote sensing of the earth and its natural resources. Aerial photography in the visible portion of the electromagnetic wavelength was the original form of remote sensing but technological developments has enabled the acquisition of information at other wavelengths including near infrared, thermal infrared and microwave. Collection of information over a large numbers of wavelength bands is referred to as multispectral or hyperspectral data. The development and deployment of manned and unmanned satellites has enhanced the collection of remotely sensed data and offers an inexpensive way to obtain information over large areas. The capacity of remote sensing to identify and monitor land surfaces and environmental conditions has expanded greatly over the last few years and remotely sensed data will be an essential tool in natural resource management.

\subsection{Electromagnetic energy}

The electromagnetic (EM) spectrum is the continuous range of electromagnetic radiation, extending from gamma rays (highest frequency \& shortest wavelength) to radio waves (lowest frequency \& longest wavelength) and including visible light. 
The EM spectrum can be divided into seven different regions - - gamma rays, X-rays, ultraviolet, visible light, infrared, microwaves and radio waves.

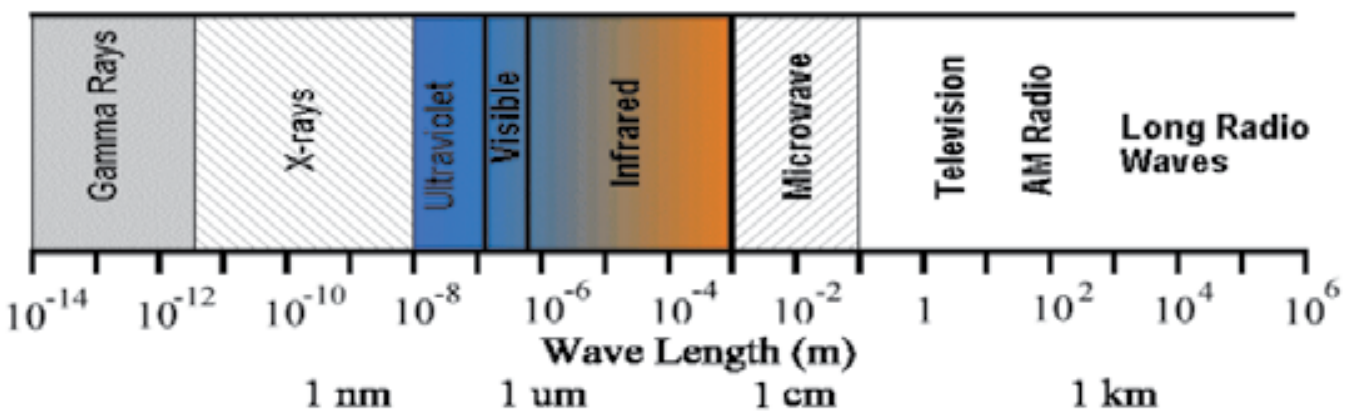

Fig. 1. Electromagnetic radiation spectrum

Remote sensing involves the measurement of energy in many parts of the electromagnetic (EM) spectrum. The major regions of interest in satellite sensing are visible light, reflected and emitted infrared, and the microwave regions. The measurement of this radiation takes place in what are known as spectral bands. A spectral band is defined as a discrete interval of the EM spectrum. For example the wavelength range of $0.4 \mu \mathrm{m}$ to $0.5 \mu \mathrm{m}(\mu \mathrm{m}=$ micrometers or $10-6 \mathrm{~m}$ ) is one spectral band. Satellite sensors have been designed to measure responses within particular spectral bands to enable the discrimination of the major Earth surface materials. Scientists will choose a particular spectral band for data collection depending on what they wish to examine.

The design of satellite sensors is based on the absorption characteristics of Earth surface materials across all the measurable parts in the EM spectrum.

\subsection{Reflection and absorption}

When radiation from the Sun reaches the surface of the Earth, some of the energy at specific wavelengths is absorbed and the rest of the energy is reflected by the surface material. The only two exceptions to this situation are if the surface of a body is a perfect reflector or a true black body. The occurrence of these surfaces in the natural world is very rare. In the visible region of the EM spectrum, the feature we describe as the colour of the object is the visible light that is not absorbed by that object. In the case of a green leaf, for example, the blue and red wavelengths are absorbed by the leaf, while the green wavelength is reflected and detected by our eyes.

In remote sensing, a detector measures the electromagnetic (EM) radiation that is reflected back from the Earth's surface materials. These measurements can help to distinguish the type of land covering. Soil, water and vegetation have clearly different patterns of reflectance and absorption over different wavelengths. The reflectance of radiation from one type of surface material, such as soil, varies over the range of wavelengths in the EM spectrum. This is known as the spectral signature of the material.

\subsection{Sensors and platforms}

A sensor is a device that measures and records electromagnetic energy. Sensors can be divided into two groups. Passive sensors depend on an external source of energy, usually the sun. The most common passive sensor is the photographic camera. Active sensors have 
their own source of energy; an example would be a radar gun. These sensors send out a signal and measure the amount reflected back. Active sensors are more controlled because they do not depend upon varying illumination conditions.

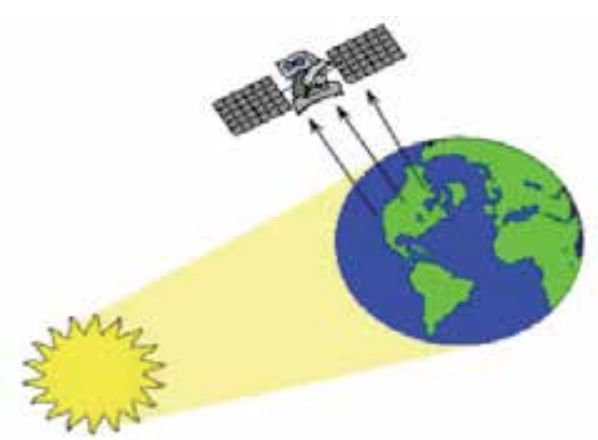

Passive sensors

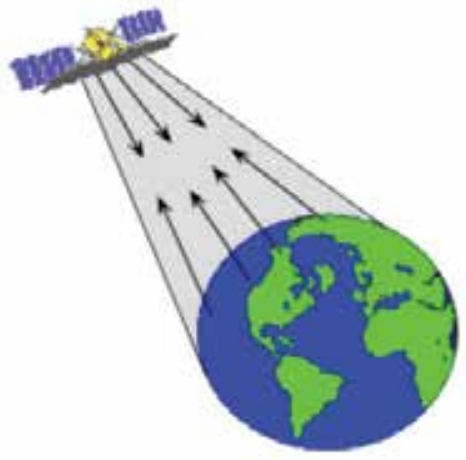

Active sensors

Fig. 2. Active and passive sensors

\subsubsection{Orbits and swaths}

The path followed by a satellite is referred to as its orbit. Satellites which view the same portion of the earth's surface at all times have geostationary orbits. Weather and communication satellites commonly have these types of orbits. Many satellites are designed to follow a north south orbit which, in conjunction with the earth's rotation (west-east), allows them to cover most of the earth's surface over a period of time. These are Near-polar orbits. Many of these satellites orbits are also Sun-synchronous such that they cover each area of the world at a constant local time of day. Near polar orbits also means that the satellite travels northward on one side of the earth and the southward on the second half of its orbit. These are called Ascending and Descending passes. As a satellite revolves around the earth, the sensor sees a certain portion of the earth's surface. The area imaged is referred to as the Swath. The surface directly below the satellite is called the Nadir point. Steerable sensors on satellites can view an area (off nadir) before and after the orbits passes over a target.

\subsubsection{Satellite sensor characteristics}

The basic functions of most satellite sensors are to collect information about the reflected radiation along a pathway, also known as the field of view (FOV), as the satellite orbits the Earth. The smallest area of ground that is sampled is called the instantaneous field of view (IFOV). The IFOV is also described as the pixel size of the sensor. This sampling or measurement occurs in one or many spectral bands of the EM spectrum. The data collected by each satellite sensor can be described in terms of spatial, spectral and temporal resolution.

\subsubsection{Spatial resolution}

The spatial resolution (also known as ground resolution) is the ground area imaged for the instantaneous field of view (IFOV) of the sensing device. Spatial resolution may also be described as the ground surface area that forms one pixel in the satellite image. The IFOV or 
ground resolution of the Landsat Thematic Mapper (TM) sensor, for example, is $30 \mathrm{~m}$. The ground resolution of weather satellite sensors is often larger than a square kilometre. There are satellites that collect data at less than one meter ground resolution but these are classified military satellites or very expensive commercial systems.

\subsubsection{Temporal resolution}

Temporal resolution is a measure of the repeat cycle or frequency with which a sensor revisits the same part of the Earth's surf ace. The frequency will vary from several times per day, for a typical weather satellite, to 8-20 times a year for a moderate ground resolution satellite, such as Landsat TM. The frequency characteristics will be determined by the design of the satellite sensor and its orbit pattern

\subsubsection{Spectral resolution}

The spectral resolution of a sensor system is the number and width of spectral bands in the sensing device. The simplest form of spectral resolution is a sensor with one band only, which senses visible light. An image from this sensor would be similar in appearance to a black and white photograph from an aircraft. A sensor with three spectral bands in the visible region of the EM spectrum would collect similar information to that of the human vision system. The Landsat TM sensor has seven spectral bands located in the visible and near to mid infrared parts of the spectrum.

A panchromatic image consists of only one band. It is usually displayed as a grey scale image, i.e. the displayed brightness of a particular pixel is proportional to the pixel digital number which is related to the intensity of solar radiation reflected by the targets in the
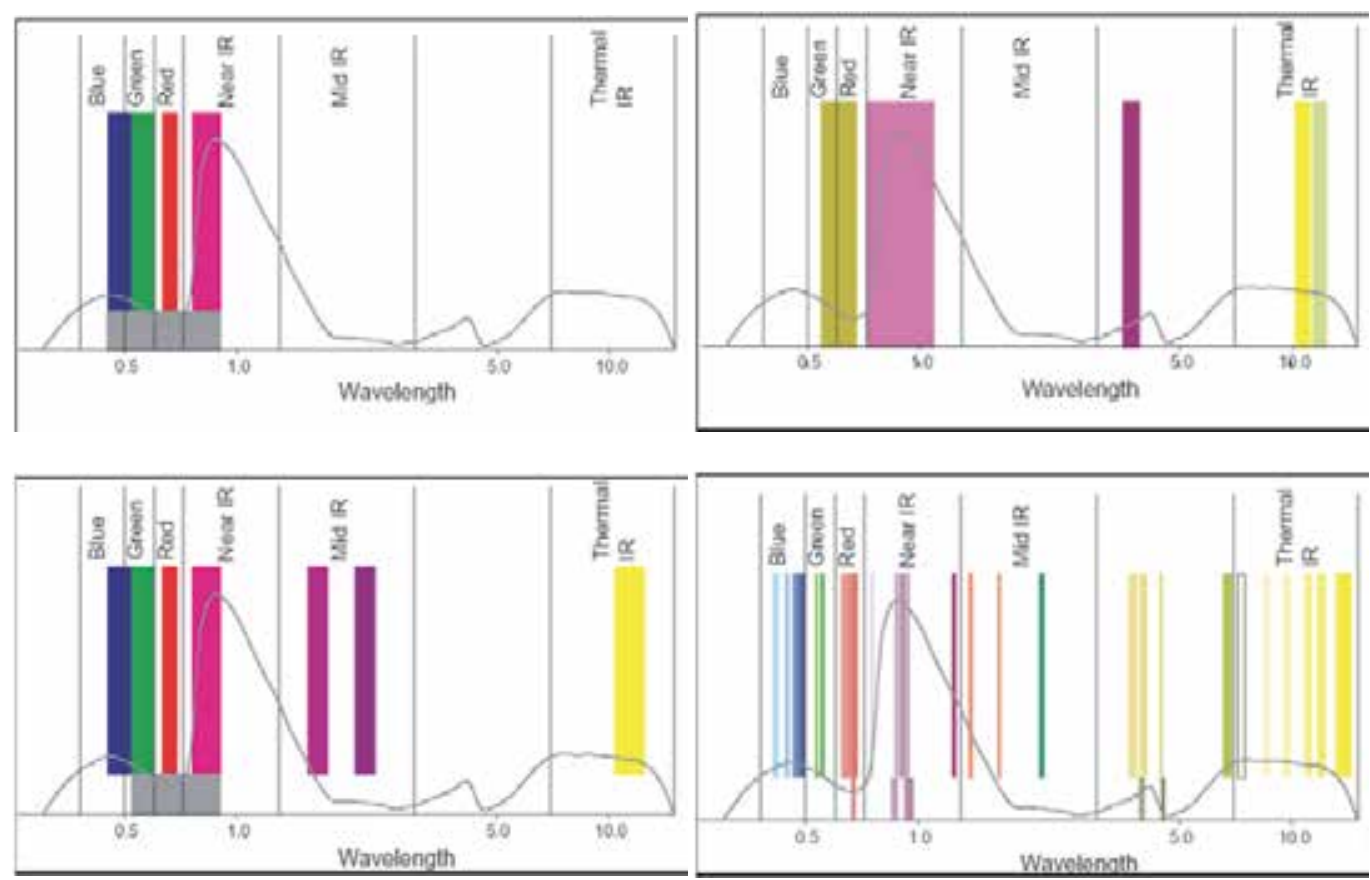

Fig. 3. Electromagnetic radiation spectrum with different resolution bands 
pixel and detected by the detector. Thus, a panchromatic image may be similarly interpreted as a black-and-white aerial photograph of the area, though at a lower resolution.

Multispectral and hyperspectral images consist of several bands of data. For visual display, each band of the image may be displayed one band at a time as a grey scale image, or in combination of three bands at a time as a color composite image. Interpretation of a multispectral color composite image will require the knowledge of the spectral reflectance signature of the targets in the scene.

\subsubsection{Platforms}

Aerial photography has been used in agricultural and natural resource management for many years. These photographs can be black and white, colour, or colour infrared. Depending on the camera, lens, and flying height these images can have a variety of scales. Photographs can be used to determine spatial arrangement of fields, irrigation ditches, roads, and other features or they can be used to view individual features within a field.

Infrared images can detect stress in crops before it is visible with the naked eye. Healthy canopies reflect strongly in the infrared spectral range, whereas plants that are stressed will reflect a dull colour. These images can tell a farmer that there is a problem but does not tell him what is causing the problem. The stress might be from lack of water, insect damage, improper nutrition or soil problems, such as compaction, salinity or inefficient drainage. The farmer must assess the cause of the stress from other information. If the dull areas disappear on subsequent pictures, the stress could have been lack of water that was eased with irrigation. If the stress continues it could be a sign of insect infestation. The farmer still has to conduct in-field assessment to identify the causes of the problem. The development of cameras that measure reflectance in a wider range of wavelengths may lead to better quantify plant stress. The uses of these multi-spectral cameras are increasing and will become an important tool in precision agriculture.

Satellite remote sensing is becoming more readily available for use in precision agriculture. The Landsat and the NOAA polar-orbiting satellites carry instruments that can be used to determine crop types and conditions, and to measure crop acreage. The Advanced Very High Resolution Radiometer (AVHRR) carried onboard NOAA polar orbiting satellites measure reflectance from the earth's surface in the visible, near infrared, and thermal infrared portions of the electromagnetic spectrum.

This spectral sensitivity makes it suitable for measuring vegetative condition and because the satellite passes overhead twice a day, it can be used to detect rapidly changing conditions. Unfortunately, its use as a precision agriculture tool is limited because the spatial resolution of the sensor is nominally $1.1 \mathrm{~km}$. A possible application of this scanner would be to use the thermal infrared sensor to estimate daily maximum and minimum temperatures. These temperature estimates could then be used to determine degree-days that will drive pest development models.

Degree-day models are an essential part of IPM programs and the enhanced spatial coverage provided by satellites would allow for assessment of spatial variability in predicted events that is not possible with data from sparsely spaced weather stations currently used for these models. Remotely sensed data can also be used to determine irrigation scheduling and adequacy of irrigation systems for uniformly wetting an entire field. The sensors aboard the Landsat satellite measures reflected radiation in seven 
spectral bands from the visible through the thermal infrared. The sensors high spatial resolution (approximately 30m) makes it useful in precision agriculture. The spectral response and higher spatial resolution make it suitable for assessing vegetative condition for individual fields but the overpass frequency is only once every 16 days. The less frequent overpass makes it difficult to use these data for assessing rapidly changing events such as insect outbreaks or water stress. New satellites with enhanced capabilities are planned and remotely sensed data will become more widely used in management support systems.

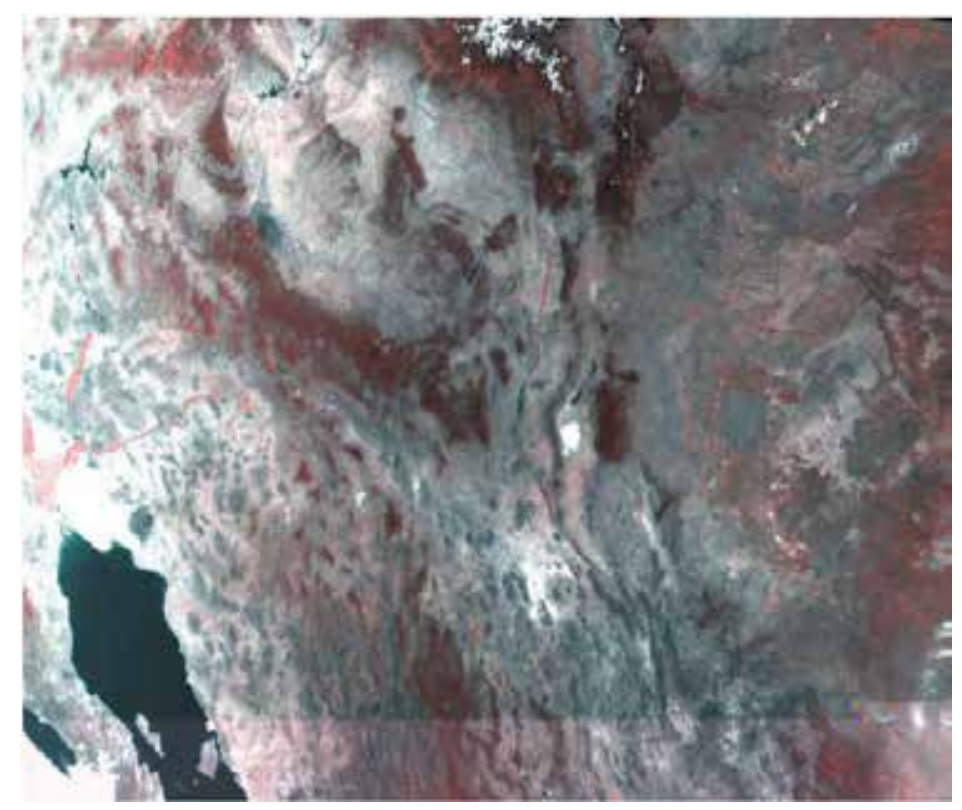

Fig. 4. Figure Advanced Very High Resolution Radiometer (AVHRR) image of the southwest Untied States. Image is centred on the Las Cruces, New Mexico.

\subsubsection{Common satellites}

\subsubsection{GOES}

5 spectral bands 1 - $41 \mathrm{~km}$ spatial resolution Geostationary

\subsubsection{NOAA AVHRR}

5 spectral bands $1.1 \mathrm{~km}$ spatial resolution 1 day repeat cycle

\subsubsection{Landsat TM}

7 spectral bands $30 \mathrm{~m}$ spatial resolution 16 day repeat cycle

\subsubsection{MODIS}

Multi- spectral bands $250-1000 \mathrm{~m}$ spatial resolution (band dependent) 1day repeat cycle

\subsubsection{IKONOS}

4 spectral Bands $4 \mathrm{~m}$ spatial resolution 5 day repeat cycle 


\subsection{Spectral signatures of natural and human-made materials}

Remote sensing makes use of visible, near infrared and short-wave infrared sensors to form images of the earth's surface by detecting the solar radiation reflected from targets on the ground. Different materials reflect and absorb differently at different wavelengths. Thus, the targets can be differentiated by their spectral reflectance signatures in the remotely sensed images.

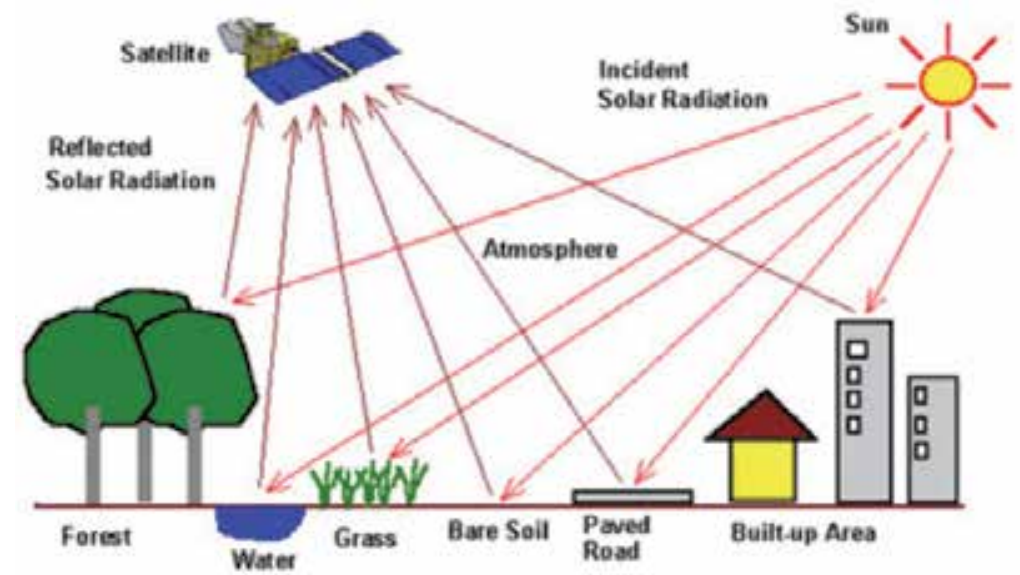

Fig. 5. Refraction and diffraction of radiations by different objects

\subsection{Spectral reflectance signature}

When solar radiation hits a target surface, it may be transmitted, absorbed or reflected. Different materials reflect and absorb differently at different wavelengths. The reflectance spectrum of a material is a plot of the fraction of radiation reflected as a fun tion of the incident wavelength and serves as a unique signature for the material. In principle, a material can be identified from its spectral reflectance signature if the sensing system has sufficient spectral resolution to distinguish its spectrum from those of other materials. This premise provides the basis for multispectral remote sensing. The following graph shows the typical reflectance spectra of water, bare soil and two types of vegetation.

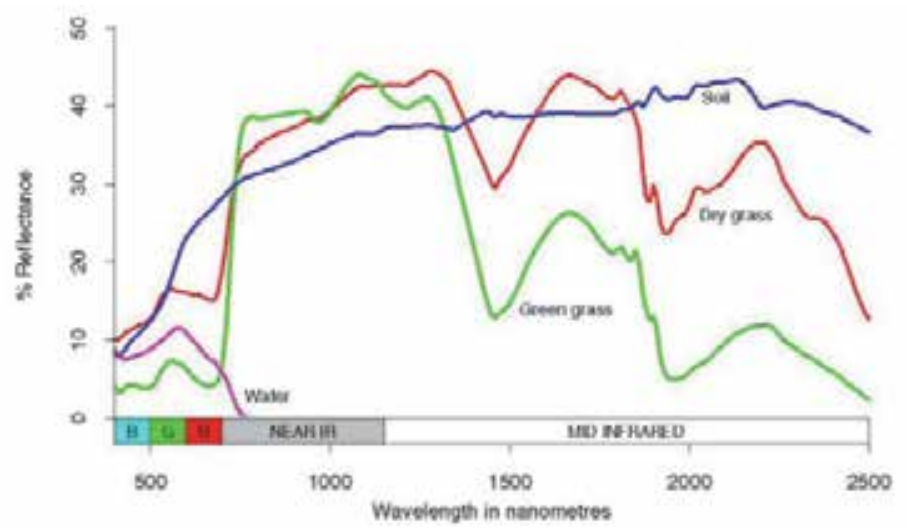

Fig. 6. Spectral resolution of different materials 
The reflectance of clear water is generally low. However, the reflectance is maximum at the blue end of the spectrum and decreases as wavelength increases. Hence, water appears dark bluish to the visible eye. Turbid water has some sediment suspension that increases the reflectance in the red end of the spectrum and would be brownish in appearance. The reflectance of bare soil generally depends on its composition. In the example shown, the reflectance increases monotonically with increasing wavelength. Hence, it should appear yellowish-red to the eye.

Vegetation has a unique spectral signature that enables it to be distinguished readily from other types of land cover in an optical/near-infrared image. The reflectance is low in both the blue and red regions of the spectrum, due to absorption by chlorophyll for photosynthesis. It has a peak at the green region. In the near infrared (NIR) region, the reflectance is much higher than that in the visible band due to the cellular structure in the leaves. Hence, vegetation can be identified by the high NIR but generally low visible reflectance. This property has been used in early reconnaissance missions during war times for "camouflage detection".

The shape of the reflectance spectrum can be used for identification of vegetation type. For example, the reflectance spectra of dry grass and green grass in the previous figures can be distinguished although they exhibit the generally characteristics of high NIR but low visible reflectance. Dry grass has higher reflectance in the visible region but lower reflectance in the NIR region. For the same vegetation type, the reflectance spectrum also depends on other factors such as the leaf moisture content and health of the plants. These properties enable vegetation condition to be monitored using remotely sensed images.

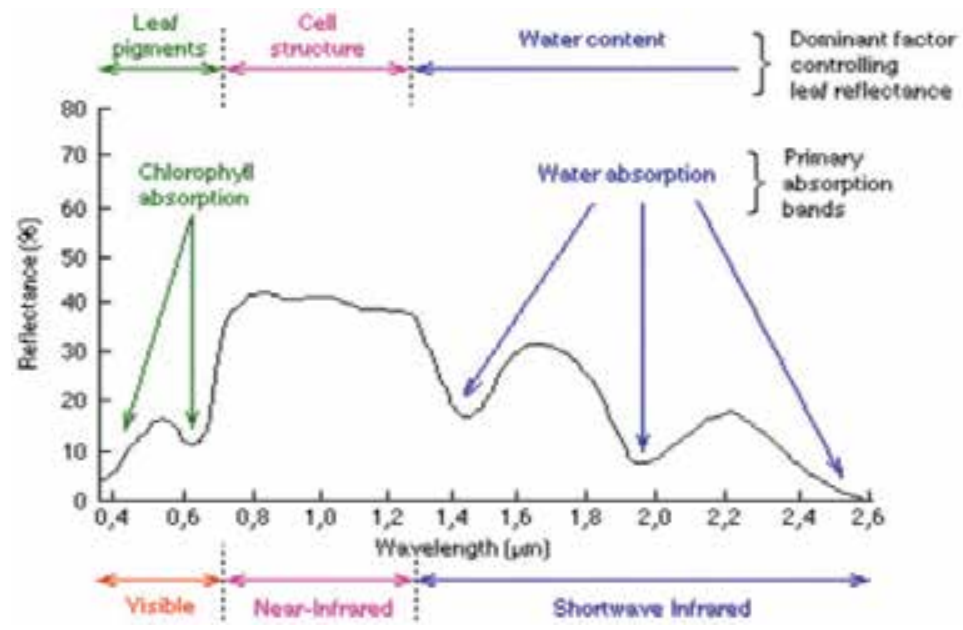

Fig. 7. Reflectance spectrum of different materials

\subsection{Geodesy, geodetic datums and map projections}

Geodesy is the branch of science concerned with the determination of the size and shape of the Earth. Geodesy involves the processing of survey measurements on the curved surface of the Earth, as well as the analysis of gravity measurements. Knowing the exact location of a pixel on the Earth's surface (its spatial location) is an essential component of remote sensing. It requires a detailed knowledge of the size and the shape of the Earth. The Earth is 
not a simple sphere. Topographic features such as mountain ranges and deep oceans disturb the surface of the Earth. The ideal reference model for the Earth's shape is one that can represent these irregularities and identify the position of features through a co-ordinate system. It should also be easy to use.

\subsubsection{Flat Earth vs curved Earth}

The "flat Earth" model is not appropriate when mapping larger areas. It does not take into account the curvature of the Earth. A "curved Earth" model more closely represents the shape of the Earth. A spheroid best represents the shape of the Earth because it is significantly wider at the equator than around the poles (Unlike a simple sphere). A spheroid, (also known as an ellipsoid) represents the equator as an elliptical shape, rather than a round circle. Surveying and navigation calculations can he performed over a large area when a spheroid is used as a curved Earth reference model.

\subsubsection{Sea level and the composition of the Earth's interior}

The surface of the sea is not uniform. The Earth's gravitational field shapes it. The rocks that make up the Earth's interior vary in density and distribution, causing anomalies in the gravitational field. These, in turn, cause irregularities in the sea surface. A mathematical model of the sea surface can be formulated; however, it is very complex and not useful for finding geographic positions on a spheroid reference model.

\subsubsection{Types of geodetic datum}

Based on these ideas, models can be established from which spatial position can be calculated. These models are known as geodetic datums and are normally classified into two types geocentric datum and local geodetic datum

A geocentric datum is one which best approximates the size and shape of the Earth as a whole. The center of its spheroid coincides with the Earth's center of mass. A geocentric datum does not seek to be a good approximation to any particular part of the Earth. A local geodetic datum is used to approximate the size and shape of the Earth's sea surface in a smaller area.

\section{Datums and GIS}

Having a standard accurate datum set becomes increasingly important as multiple layers of information about the same area are collected and analyzed. The layers are developed into geographic information systems (GIS), which enable the relationships between layers of data to be examined. In order to function effectively, a GIS must possess one essential attribute. It must have the ability to geographically relate data within and across layers. For example, if a dataset about vegetation is being examined against the data sets for topography and soils, the accurate spatial compatibility of the two datasets is critical.

\subsubsection{Map projection coordinates}

A map projection is a systematic representation of all or part of the Earth on a two dimensional surface, such as a flat sheet of paper. During this process some distortion of distances, directions, scale, and area is inevitable. There are several different types of map 
projections. No projection is free from all distortions, but each minimizes distortions in some of the above properties, at the expense of leaving errors in others. For example, the commonly used Transverse Mercator projection represents direction accurately, but distorts distance and area, especially those farthest from the equator. Greenland, for example, appears to be much larger than it really is. The Transverse Mercator projection is useful for navigation charts.

\subsubsection{Universal Transverse Mercator (UTM)}

Universal Transverse Mercator (UTM) is a global spatial system based on the Transverse Mercator projection. UTM divides the Earth into 60 equal zones, each being 6 degrees wide. Each zone is bounded by lines of longitude extending from the North Pole to the South Pole. Imagine an orange consisting of 60 segments. Each segment would be equivalent to a UTM zone. A rectangular grid coordinate system is used in most map projections. These coordinates are referred to as Eastings and Northings, being distances East and North of an origin. They are usually expressed in metres. Under the UTM system, each East and North coordinate pair could refer to one of sixty points on Earth - one point in each of the sixty zones. Because of this, the zone number needs to be quoted to ensure the correct point on Earth is being identified.

\subsubsection{Global Positioning System}

The Global Positioning System (GPS) is a satellite based system that gives real time three dimensional (3D) latitude, longitude, and height information at sub-meter accuracy. The system was developed by the United States military in the late 1970's to give troops accurate position and navigational information. A GPS receiver calculates its position on earth from radio signals broadcast by satellites orbiting the earth. There are currently twenty-four GPS satellites in this system. GPS equipment is capable of measuring a position to within centimetres but the accuracy suffers due to errors in the satellite signals. Errors in the signal can be caused by atmospheric interference, proximity of mountains, trees, or tall buildings. The government can also introduce errors in the signal for security purposes. This intentional degradation of the satellite signals is known as selective availability. The accuracy of the position information can be improved by using differential GPS. In differential GPS, one receiver is mounted in a stationary position, usually at the farm office, while the other is on the tractor or harvesting equipment. The stationary receiver calculates the error and transmits the necessary correction to the mobile receiver. GPS equipment suitable for precision agricultural cost several thousand dollars. Less expensive equipment is becoming available but the accuracy and capability is reduced.

\subsubsection{Geographic Information System (GIS)}

A Geographic Information System (GIS) is a computer-assisted system for handling spatial information. GIS software can be considered as a collection of software programs to acquire, store, analyze, and display information. The input data can be maps, charts, spreadsheets, or pictures. The GIS software can analyze these data using image processing and statistical procedures. Data can be grouped together and displayed as overlays. Overlays could be information such as soil type, topography, crop type, crop yield, pest levels, irrigation, and management information as shown. 


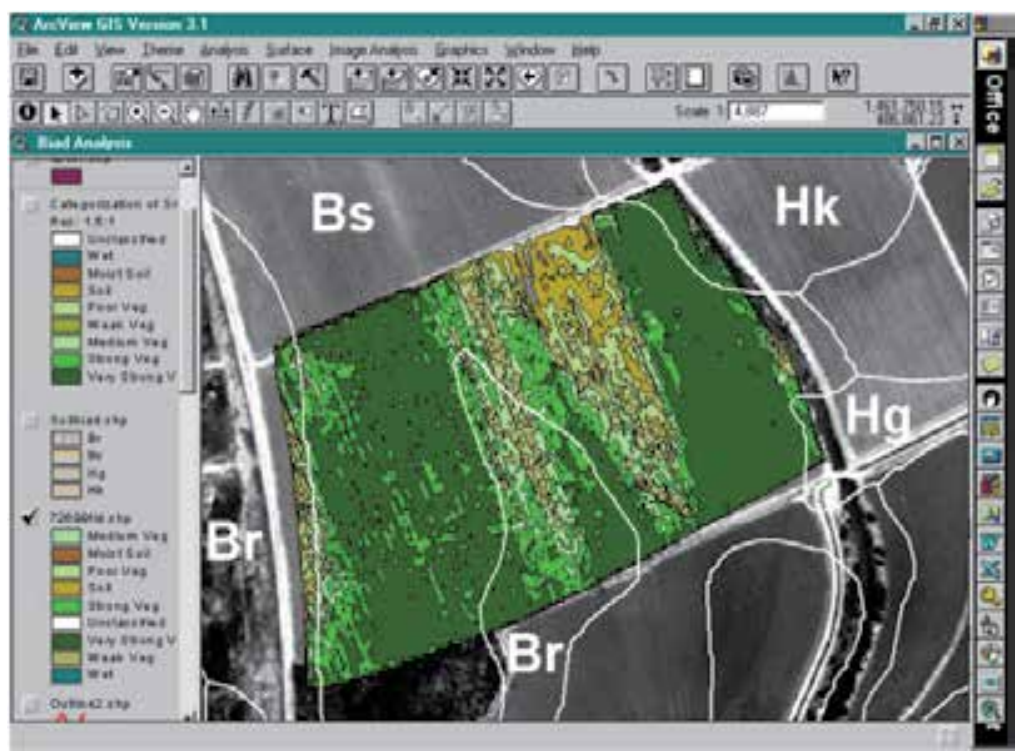

Fig. 8. Topographic GIS map of the forest area

Relationships can be examined and new data sets produced by combining a number of overlays. These data sets can be combined with models and decision support systems to construct a powerful management tool. For example, we could assess how far a field was from roads or non-agricultural crops. This information could be important in pest infestation or in planning chemical application. We could also examine crop yield relationship to soil type or other factors as show in the following figure. A number of GIS software packages are now commercially available. Spatial data for the GIS is often collected using GPS equipment but another source of spatial information is aerial and satellite imagery.

\subsubsection{Pixels, images and colours}

\subsection{Colour composite images}

In displaying a colour composite image, three primary colors (red, green and blue) are used when these three colours are combined in various proportions, they produce different colors in the visible spectrum. Associating each spectral band (not necessarily a visible band) to a separate primary colour results in a colour composite image.

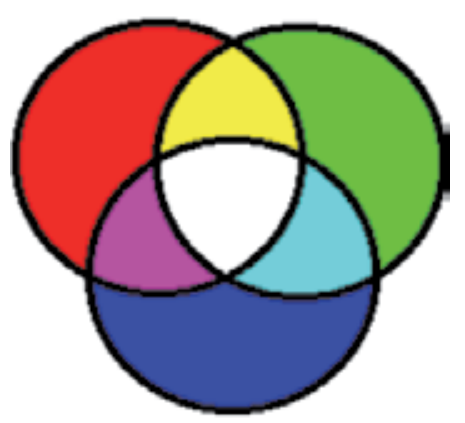

Fig. 9. Primary colour composite 
Many colours can be formed by combining the three primary colours (Red, Green, Blue) in various proportions.

\subsection{False colour composite}

The display colour assignment for any band of a multispectral image can be done in an entirely arbitrary manner. In this case, the colour of a target in the displayed image does not have any resemblance to its actual colour. The resulting product is known as a false color composite image. There are many possible schemes of producing false color composite images. However, some scheme may be more suitable for detecting certain objects in the image.

\subsection{Natural colour composite}

When displaying a natural colour composite image, the spectral bands (some of which may not be in the visible region) are combined in such a way that the appearance of the displayed image resembles a visible colour photograph, i.e. vegetation in green, water in blue, soil in brown or grey, etc. Many people refer to this composite as a "true colour" composite. However, this term may be misleading since in many instances the colours are only simulated to look similar to the "true" colours of the targets. For example, the bands 3 (red band), 2 (green band) and 1 (blue band) of a AVHRR image can be assigned respectively to the $R, G$, and $B$ colours for display. In this way, the colour of the resulting colour composite image resembles closely what the human eyes would observe.

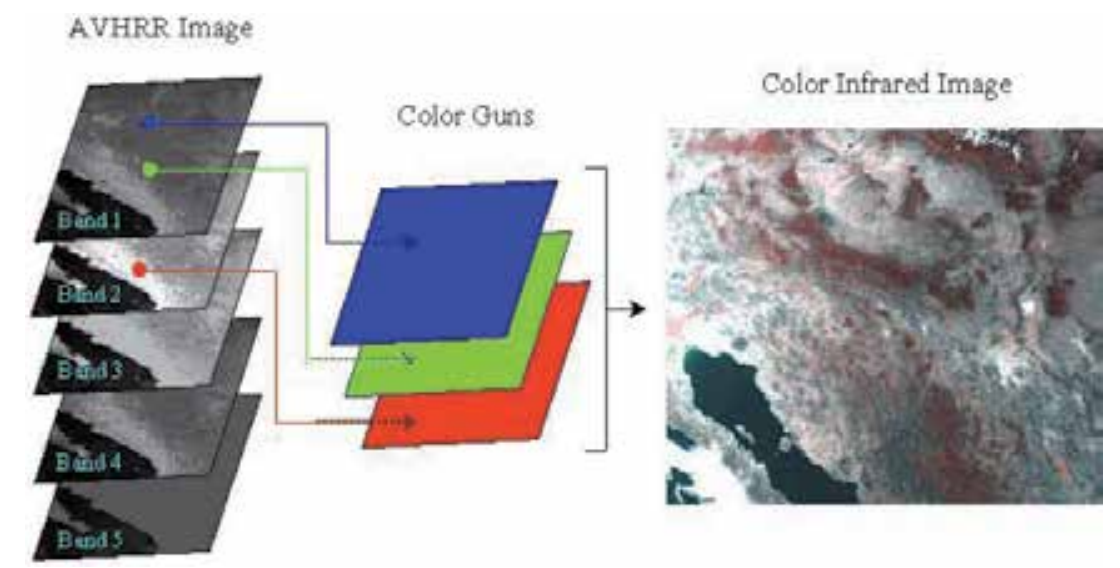

Fig. 10. Development of natural colour composite

\subsection{Image processing and analysis}

Many image processing and analysis techniques have been developed to aid the interpretation of remote sensing images and to extract as much information as possible from the images. The choice of specific techniques or algorithms to use depends on the goals of each individual project. The key steps in processing remotely sensed data are Digitizing of Images, Image Calibration, Geo-Registration, and Spectral Analysis. Prior to data analysis, initial processing on the raw data is usually carried out to correct for any distortion due to the characteristics of the imaging system and imaging conditions. Depending on the user's requirement, some standard correction procedures may be carried out by the ground station 
operators before the data is delivered to the end-user. These procedures include radiometric correction to correct for uneven sensor response over the whole image and geometric correction to correct for geometric distortion due to Earth's rotation and other imaging conditions (such as oblique viewing). The image may also be transformed to conform to a specific map projection system. Furthermore, if accurate geographical location of an area on the image needs to be known, ground control points (GCP's) are used to register the image to a precise map (geo-referencing).

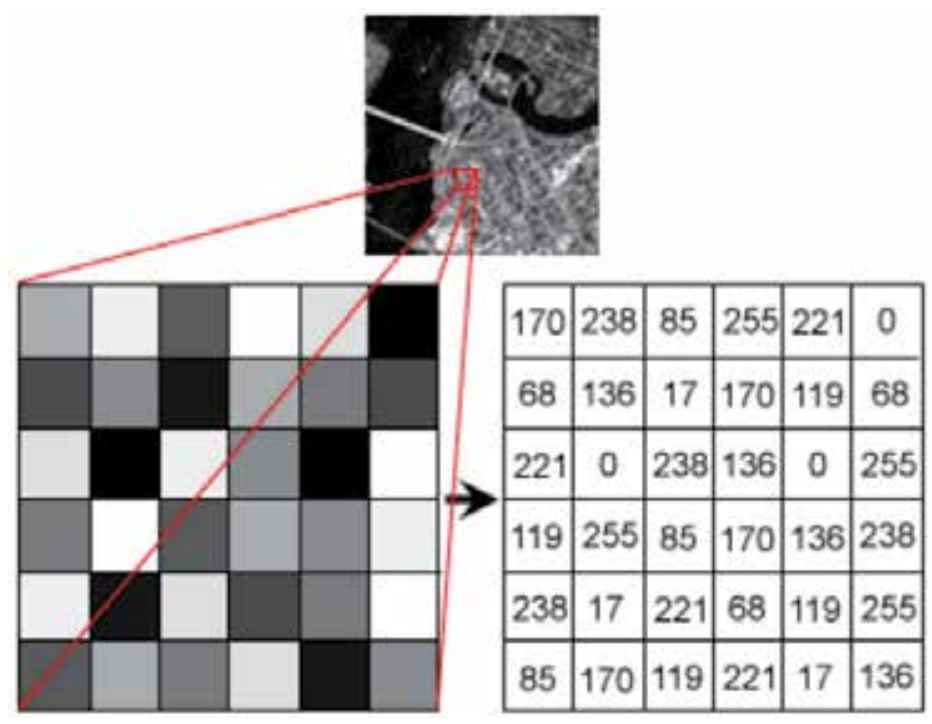

Fig. 11. Georeferencing of a map

\subsubsection{Digitizing of images}

Image digitization is the conversion of an analogue image, such as a photograph, into a series of grid cells. The value of each cell is related to the brightness, colour or reflectance at that point. A scanner is a simple way to digitize images. Many modern sensors now produce raw data in digital format.

\subsubsection{Image enhancement}

In order to aid visual interpretation, visual appearance of the objects in the image can be improved by image enhancement techniques such as grey level stretching to improve the contrast and spatial filtering for enhancing the edges. An example of an enhancement procedure is shown here.

\subsubsection{Image classification}

Different land cover types in an image can be discriminated using some image classification algorithms using spectral features, i.e. the brightness and "colour" information contained in each pixel. The classification procedures can be "supervised" or "unsupervised". In supervised classification, the spectral features of some areas of known land cover types are extracted from the image. These areas are known as the "training areas". Every pixel in the whole image is then classified as belonging to one of the classes depending on how close 
its spectral features are to the spectral features of the training areas. In unsupervised classification, the computer program automatically groups the pixels in the image into separate clusters, depending on their spectral features. Each cluster will then be assigned a landcover type by the analyst. Each class of land cover is referred to as a "theme" and the product of classification is known as a "thematic map". The information derived from remote sensing images are often combined with other auxiliary data to form the basis for a Geographic Information System (GIS). A GIS is a database of different layers, where each layer contains information about a specific aspect of the same area which is used for analysis by the resource scientists.

\subsection{Image interpretation}

\subsubsection{Vegetation indices}

Different bands of a multispectral image may be combined to accentuate the vegetated areas.

One such combination is the ratio of the near-infrared band to the red band. This ratio is known as the Ratio Vegetation Index (RVI)

\section{RVI = NIR/Red}

Since vegetation has high NIR reflectance but low red reflectance, vegetated areas will have higher RVI values compared to non-vegetated aeras. Another commonly used vegetation index is the Normalised Difference Vegetation Index (NDVI) computed by

\section{NDVI $=($ NIR - Red $) /($ NIR + Red $)$}

Table shows equations and references for several indices that can be use in vegetation monitoring.

\begin{tabular}{|l|l|l|}
\hline PARAMETER & EQUATION & REFERENCE \\
\hline $\begin{array}{l}\text { Normalized Difference } \\
\text { Vegetation Index (NDVI) }\end{array}$ & (NIR-Red)/(NIR+Red) & Rouse et al (1974) \\
\hline Water Band Index (WBI) & $900 / 970 \mathrm{~nm}$ & Pefluelas et al. $(1997)$ \\
\hline Water Moisture Index (WMI) & $1600 / 820 \mathrm{~nm}$ & Hunt and Rock (1989) \\
\hline Photosynthesis Index & $(531-570) / 531+570)$ & Gamon et al. $(1990)$ \\
\hline Nitrogen Index (RN) & $(550-600) /(800-(900)$ & Blackmer et al. $(1996)$ \\
\hline $\begin{array}{l}\text { Chlorophyll based Difference Index } \\
(\mathrm{CI})\end{array}$ & $(850-710) / 850-680)$ & Datt (1999) \\
\hline
\end{tabular}

Table 1. Equation and references for different parameters

Vegetation maps are produced by generating a normalized difference vegetation index from a infrared image and then doing a vegetation classification. Colour infrared photographs collect information in the green, red and near infrared light reflectance spectrum. Green vegetation reflects very strongly in the near infrared light range and therefore infrared images can detect stress in many crops before it is visible with the naked eye.

The Normalized Difference Vegetation Index (NDVI) is used to separate green vegetation from the background soil brightness. It is the difference between the near infrared and red reflectance normalized over the sum of these bands. 


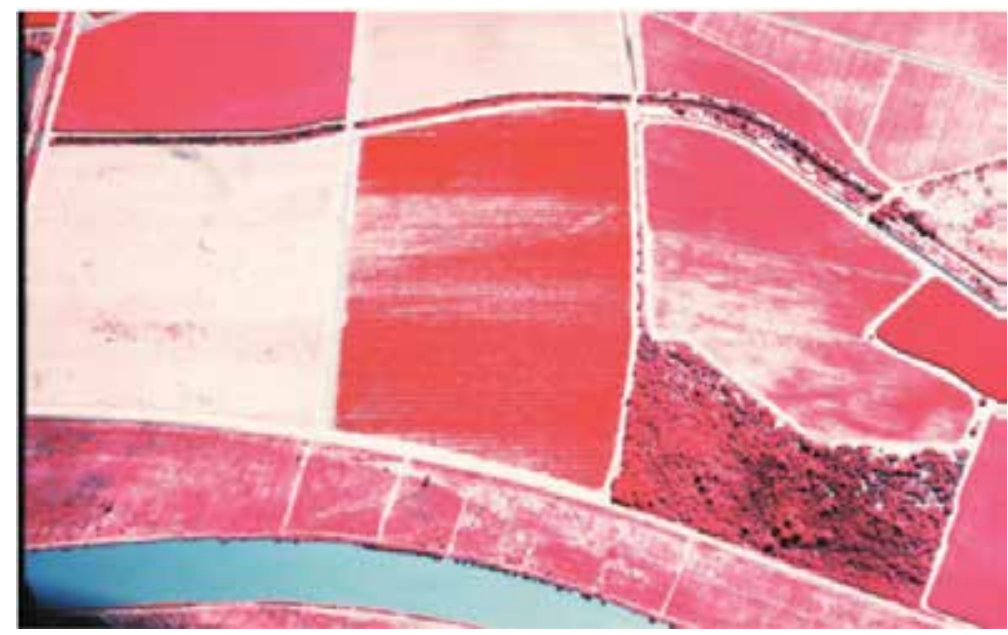

Fig. 12. Example of image processing of aerial infrared photographs to produce a vegetation map for a chile field.

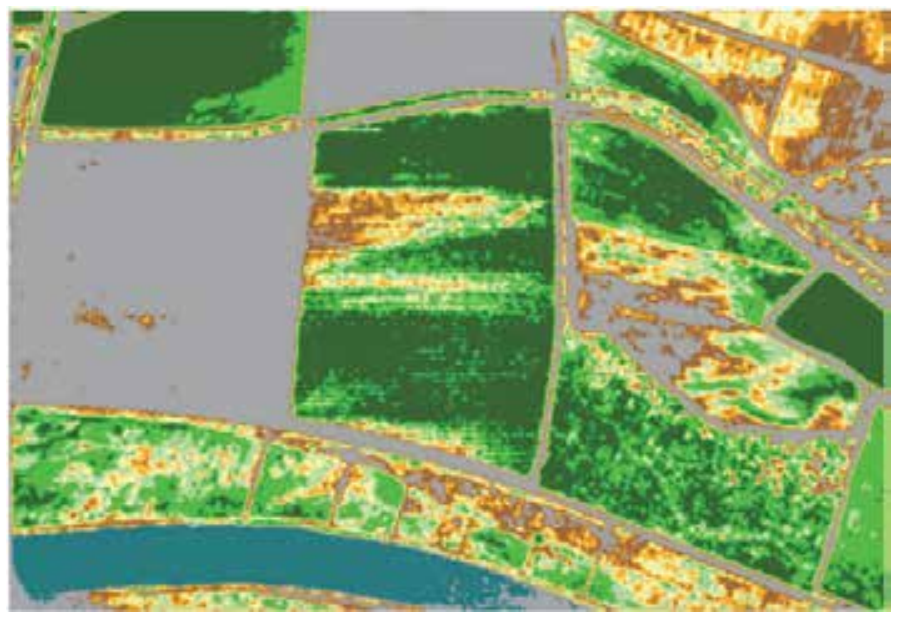

Fig. 13. Example of image processing of aerial infrared photographs to produce a vegetation map for a peddy field.

\section{NDVI $=($ IR-Red $) /(I R+R e d)$}

These NDVI maps can then be classified into vegetation categories and displayed as a vegetation maps with different colours representing different levels of vegetation. In the map on the left browns and yellow represent bare soil and shades of green represent vegetation, darker greens are stronger vegetation.

\subsection{Background on remote sensing}

\subsubsection{Remote sensing}

Remote sensing is the science and art of obtaining information about an object, area or phenomenon through the analysis of data acquired by a device that is not in contact with the object, area, or phenomenon under investigation. As the term indicates, it applies to any 
information gathering device or method where the object of observation is remote from the device.

Out of a number of devices involved in remote sensing, the most common platforms are aircraft and satellites. The sensors associated with these devices are of two types, namely passive and active sensors. In a passive system, the instrument gathers information from the radiation that happens to arrive. The main sources of radiation for such systems are either solar radiation or thermal emissions. In the active system, it is the instrument itself on board the device that is the source of radiation. It sends signals to target under investigation, and receives the return signal, having the unique characteristics of the target features. As far as satellite remote sensing is concerned, systems operating in the visible and infrared part of the electromagnetic spectrum are passive while microwave instruments are either active or passive.

Currently, satellites are the main devices in remote sensing. And the two main types of satellites are the Polar or Near-polar Orbiting and Geostationary satellites. The Polar or Near Polar orbiting satellites are Sun-synchronous i.e. the satellites keep a precise pace with the Sun's westward progress as the earth rotates so that they always cross the equator at precisely the same solar time. Examples can be Landsat and NOAA satellites. Geostationary satellites are satellites which travel with an angular velocity that matches the earth's rotation. As a result, they remain at the same point above the earth at all times. An example is Meteosat. These satellites are helpful in obtaining constant and persistent image of a particular area at fixed interval which is a great advantage in monitoring a location with high temporal resolution to capture the transient behavior of objects such as rain clouds.

Estimation of biomass production will provide guidance to energy development polices including:

- The impact of improved stoves on fuel wood and dung energy consumption.

- The potential of increasing the supply of fuel wood through the establishment of small scale "forest plantations"

- The potential of dung and other fuels for biomass energy supply.

\subsubsection{Principles involved}

\subsubsection{The photon and radiometric quantities}

Most remote sensing texts begin by giving a survey of the main principles, to build a theoretical background, mainly in the physics of radiation. While it is important to have such a framework to pursue many aspects of remote sensing, we do not delve into this complex subject in much detail at this point. Instead, we offer on this and the next several pages an outline survey of the basics of relevant electromagnetic concepts. On this page, the nature of the photon is the prime topic. Photons of different energy values are distributed through what is called the Electromagnetic Spectrum.

Hereafter in this Introduction and in the Sections that follow, we limit the discussion and scenes examined to remote sensing products obtained almost exclusively by measurements within the Electromagnetic Spectrum (force field and acoustic remote sensing are briefly covered elsewhere in the Tutorial). Our emphasis is on pictures (photos) and images (either TV-like displays on screens or "photos" made from data initially acquired as electronic signals, rather than recorded directly on film). We concentrate mainly on images produced by sensors operating in the visible and near-IR segments of the electromagnetic spectrum but also inspect a fair number of images obtained by radar and thermal sensors. 
The underlying basis for most remote sensing methods and systems is simply that of measuring the varying energy levels of a single entity, the fundamental unit in the electromagnetic (which may be abbreviated "EM") force field known as the photon. As you will see later on this page, variations in photon energies (expressed in Joules or ergs) are tied to the parameter wavelength or its inverse, frequency. EM radiation that varies from high to low energy levels comprises the ElectroMagnetic spectrum (EMS). Radiation from specific parts of the EM spectrum contain photons of different wavelengths whose energy levels fall within a discrete range of values. When any target material is excited by internal processes or by interaction with incoming EM radiation, it will emit or reflect photons of varying wavelengths whose radiometric quantities differ at different wavelengths in a way diagnostic of the material. Photon energy received at detectors is commonly stated in power units such as Watts per square meter per wavelength unit. The plot of variation of power with wavelength gives rise to a specific pattern or curve that is the spectral signature for the substance or feature being sensed.

Now, in more detail: The photon is the physical form of a quantum, the basic particle of energy studied in quantum mechanics (which deals with the physics of the very small, that is, particles and their behavior at atomic and subatomic levels). The photon is also described as the messenger particle for EM force or as the smallest bundle of light. This subatomic massless particle, which also does not carry an electric charge, comprises radiation emitted by matter when it is excited thermally, or by nuclear processes (fusion, fission), or by bombardment with other radiation (as well as by particle collisions). It also can become involved as reflected or absorbed radiation. Photons move at the speed of light: 299,792.46 $\mathrm{km} / \mathrm{sec}$ (commonly rounded off to $300,000 \mathrm{~km} / \mathrm{sec}$ or $\sim 186,000 \mathrm{miles} / \mathrm{sec}$ ).

Photon particles also move as waves and hence, have a "dual" nature. These waves follow a pattern that can be described in terms of a sine (trigonometric) function, as shown in two dimensions in the figure below.

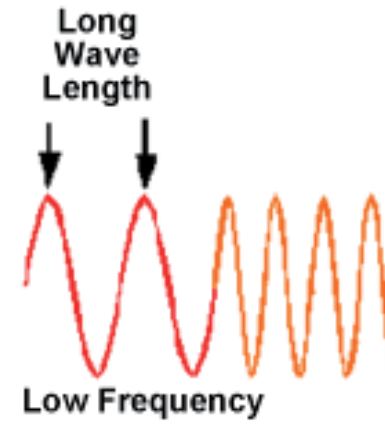

Low Energy

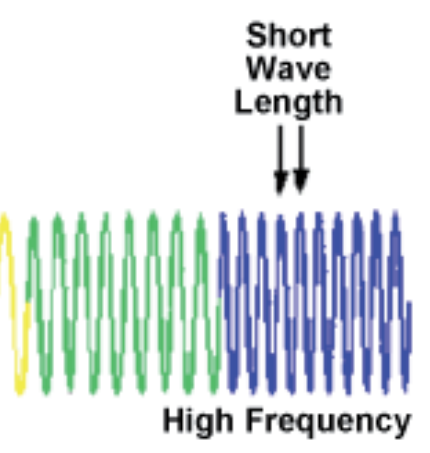

High Energy

(NOTE: Frequency refers to number of crests of waves of same wavelength that pass by a point in one second.)

Fig. 14. Movement of photon particles as sine waves

The distance between two adjacent peaks on a wave is its wavelength. The total number of peaks (top of the individual up-down curve) that pass by a reference lookpoint in a second is that wave's frequency (in units of cycles per second, whose SI version [SI stands for System International] is known as a Hertz $\left[1\right.$ Hertz $\left.=1 / \mathrm{s}^{-1}\right]$ ). 
A photon travels as an EM wave having two components, oscillating as sine waves mutually at right angles, one consisting of the varying electric field, the other the varying magnetic field. Both have the same amplitudes (strengths) which reach their maxima-minima at the same time. Unlike other wave types which require a carrier (e.g., water waves), photon waves can transmit through a vacuum (such as in space). When photons pass from one medium to another, e.g., air to glass, their wave pathways are bent (follow new directions) and thus experience refraction.

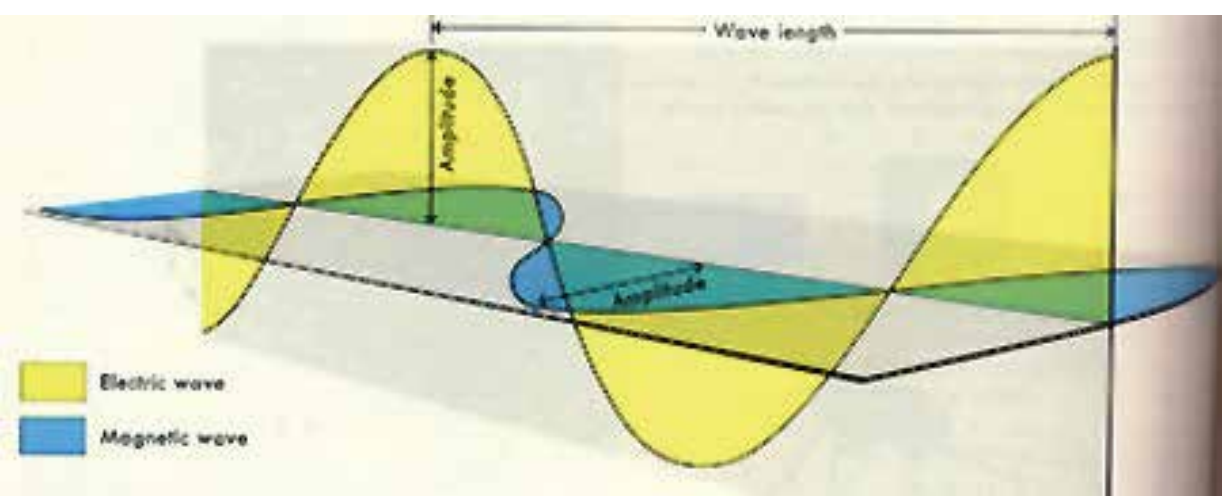

Fig. 15. Dual nature (electric and magnetic field) of photon particles

A photon is said to be quantized, in that any given one possesses a certain quantity of energy. Some other photon can have a different energy value. Photons as quanta thus show a wide range of discrete energies. The amount of energy characterizing a photon is determined using Planck's general equation:

$$
\mathrm{E}=h v
$$

where $h$ is Planck's constant $\left(6.6260 \ldots \times 10^{-34}\right.$ Joules-sec) ${ }^{*}$ and $v$ is the Greek letter, nu, representing frequency (the letter " $f$ " is sometimes used instead of $v$ ). Photons traveling at higher frequencies are therefore more energetic. If a material under excitation experiences a change in energy level from a higher level $E_{2}$ to a lower level $E_{1}$, we restate the above formula as:

$$
\Delta \mathrm{E}=\mathrm{E}_{2}-\mathrm{E}_{1}=h v
$$

where $v$ has some discrete value determined by $\left(v_{2}-v_{1}\right)$. In other words, a particular energy change is characterized by producing emitted radiation (photons) at a specific frequency $v$ and a corresponding wavelength at a value dependent on the magnitude of the change.

\subsubsection{Sources of electromagnetic (EM)- radiation}

EM radiation is the energy resulting from the acceleration of electric charges and the associated electric and magnetic fields (this study is restricted to radiation emitted from the Sun and earth's surface). EM radiation is governed by the equations:

$$
\Delta^{2} E-\frac{\partial^{2} E}{\partial t^{2}}=0
$$




$$
\Delta^{2} H-\frac{\partial^{2} H}{\partial t^{2}}=0
$$

where the speed of light $c^{2}=1 /(\mu \varepsilon)$

The energy associated with EM waves can be regarded as stream of photons travelling at speed of light, each photon having an energy hv, where $\mathrm{h}$ is Plank's constant and $\mathrm{v}$ is the frequency of the light. The EM spectrum, which is the range of wavelengths over which electromagnetic radiation extend, constitute of radio waves, micro waves, thermal infrared, infrared, visible, ultraviolet, $x$-ray, and gamma rays in decreasing order of wavelengths.

The ultimate source of energy for remote sensing is the Sun. Besides, all matter above absolute zero temperature emit radiation. Thus terrestrial objects are also sources of radiation, though it is considerably different in magnitude and spectral composition than that of the Sun. The emitted radiation from terrestrial objects is a function of temperature. From the principle of Black Body Radiation, the density of radiant energy U(v) emitted from a black body in the frequency range $\mathrm{v}+\mathrm{dv}$ and $\mathrm{v}$ is:

$$
U(v) d v=\frac{8 \hbar}{C^{3}} \frac{v^{3} d v}{\exp \left(\frac{\hbar v}{k T}-1\right)}
$$

which is the Planck distribution law. The total energy density overall frequencies is :

$$
U=\int_{0}^{\infty} U(v) d v=\frac{8 \pi^{5} k^{4}}{15 c^{3} h^{3}} T^{4}=a T^{4}
$$

where $\mathbf{a}$ is a universal constant.

The intensity emitted from an object is therefore:

$$
\mathrm{I}=\varepsilon \sigma \mathrm{T}^{4}
$$

This is the Stefan - Boltzman Law

The spectral distribution of emitted energy varies with temperature as shown in Figure 1. Meanwhile, the wavelength at which greatest energy density occurs varies inversely with temperature and is given by Wein's displacement law:

$$
\lambda_{\max } T=\frac{h c}{4.965 \mathrm{~K}}=2.898 \times 10^{-3} \mathrm{~m} \cdot \mathrm{k}
$$

\subsubsection{Energy interaction in the atmosphere}

Atmosphere can have a profound effect on the intensity and spectral composition available to any sensing system as the radiation which reaches the sensed object passes through a certain optical path length of atmospheric air. These effects are caused principally through the mechanism of atmospheric scattering and absorption.

\subsubsection{Scattering}

As stated above, the atmosphere can have a significant effect on the incoming and outgoing radiation by scattering. There are three types of scattering depending on the size of particle involved. And these are Rayleigh scattering, Mie scattering and Non-selective 
scattering where Rayleigh and Non-selective scattering are the limiting cases of Mie scattering.

For Rayleigh scattering to occur, the particle size must not be larger than about $1 / 10^{\text {th }}$ of the wavelength of the light. In a gas with $\mathrm{N}$ molecules per unit volume and refractive index $\mathrm{n}$, the Rayleigh extinction coefficient a for a wavelength is approximately:

$$
\alpha \approx \frac{32 \pi^{3}}{3 N \dagger}(n-1)^{2}
$$

Rayleigh Sc atter i $\propto \frac{1}{\dagger}$

The extinction coefficient decreases as a wavelength increases. Specifically, the amount of scattering is inversely proportional to the fourth power of wavelength.

Mie scatter occurs for particles whose diameter is approximately equal to the wavelength. In a gas containing $\mathrm{N}$ spherical particles of radius $\mathrm{R}$, the effective cross-section is given by:

$$
\sigma=\text { NAds } \mathbf{R}_{\boldsymbol{N}} \dagger
$$

where Ads - is the volume in which the gas is contained, provided that no one particle lies in the shadow of another particle. If no absorption takes place, the extinction coefficient equals to scattering extinction co-efficient. Mie extinction coefficient is given by

$$
\mathrm{a}=\mathrm{NK}_{\mathbf{n}} \mathbf{R}^{2}
$$

where $\mathbf{K}=$ the extinction factor

The ratio of scattered to incident light can be expressed as:

$$
\frac{i}{I_{o}}=-\alpha d s
$$

In this type of scattering, as the particles are of the order of wavelength, the light scattered from one part of the surface can be out of phase with coming from another part, unlike Rayleigh scattering were there is no phase difference between the light source and the scattered light. For Mie scattering, phase difference will be small for small scattering angle which gives rise to a large intensity in the forward direction and less in the reverse.

Non-selective scattering occurs when the diameter of the scattering particles is much larger than the wavelength. Water droplets, for example, cause such a scattering. They commonly have diameter in the range 5 to $100 \mathrm{~m}$ and scatter all visible wavelengths, equal quantities of blue, green, and red light are scattered, making fog and clouds appear white.

\subsubsection{Absorption}

When light pass through a certain optical path in the atmosphere, it experiences absorption in addition to scattering by the existing particles. The intensity of the light diminishes according

To the equation :

$$
I=I_{0} \exp \left(-\alpha^{1}\right)
$$

where $a$ is the absorption coefficient 
In the atmosphere, the most efficient absorbers of radiation are water vapour, carbon dioxide, and ozone.

The effect of this absorption is to leave only few regions known as atmospheric windows, in which the atmosphere transmits a substantial proportion of electromagnetic radiation. These are the only regions that can be used in remote sensing of the earth's surface.

Both scattering and absorption increase with increase in path length or with an increase in air mass.

\subsubsection{Energy interaction with the earth's surface}

When a light wave is incident on a surface, it will be reflected, transmitted, or absorbed. Furthermore, the energy of the absorbed radiation can be re-emitted as other forms of radiation. For an incident wave of intensity $\mathbf{I}_{\mathbf{0}}$ the intensity of the reflected wave is $\mathbf{r I}_{\mathbf{o}}$ and the amplitude of the rest is $(\mathbf{1} \mathbf{- r}) \mathbf{I}_{\mathbf{o}}$, where $\mathbf{r}$ is the coefficient of reflection.

When EM radiation is incident on a given surface feature, out of the three fundamental processes the reflected part is often of interest in remote sensing. (thermal emission are also often of interest). The reflected part $\left(\mathbf{r I}_{\mathbf{0}}\right)$ will be different for different earth features depending on the type of material and the condition of the material (e.g. dry or wet). Reflectivity is also dependent on the wavelength or frequency of the incoming radiation. The function which describes the dependence of reflectivity on wavelength is called the spectral reflectance function, and is given by:

$$
\rho_{2}=\frac{\text { Energy of reflected }}{\text { Energy of incident }}
$$

Different objects have very distinct spectral reflectance curves. It is the differences in spectral reflectance that allows one to distinguish different materials and objects using remotely sensed reflected radiation.

For thermal infrared wavelengths, the reflected radiation is outweighed by the emitted energy of the surface features. Hence in the thermal infrared, the radiation received from an object depends on its emissivity and temperature. Meanwhile, the temperature of an object will depend on its absorptivity (how much radiation it absorbs), its thermal conductivity (rate at which heat pass through a material), thermal capacity (ability of a material to store heat), and thermal inertia (thermal response of material to temperature change). Since our investigation focuses on non-thermal images, we will not discuss thermal remote sensing methods in detail.

\subsubsection{Data acquisition and interpretation}

Detection of EM energy can be performed either photographically or electronically. The process of photography uses chemical reactions on the surface of a light sensitive film to detect energy variation within a scene while electronic sensors generate in electrical signals that corresponds to the energy or intensity of the detected radiation. The advantage of visual (photographic) is that it is simple, it provides high good spatial detail (because of the high resolution of chemical films) and geometric integrity (geometry is not distorted). On the other hand, electronics have the advantage of broader spectral sensitivity and easier conversion of the image to digital form. 
Photographic images are interpreted visually (or scanned to convert them into digital images) whereas electronic images are interpreted digitally. The electronic image constitutes an array of pixels which vary in the level of brightness in accordance with the radiation received from the surface feature they represent. Pixel brightness is converted to a binary number. In our case pixel values are 8-bit binary numbers representing integer values from 0 to 255 . These are positive integers that result from quantizing of the original electrical signal from the sensor.

\subsection{Remote sensing of biomass production}

\subsubsection{Reflectance characteristics of green plants}

Green plants have a unique spectral reflectance curve. In the visible part of the spectrum, plants strongly absorb light in the blue $(0.45 \mu \mathrm{m})$ and red $(0.67 \mathrm{~nm})$ regions and reflect strongly in the green portion of the spectrum due to the presence of chlorophyll. In cases where the plant is subjected to stress or to a condition which hinders growth, the chlorophyll production will decrease. And this in turn leads to less absorption in the blue and red bands.

In the near infrared portion of the spectrum $(0.7-1.3 \mu \mathrm{m})$, green plant reflectance increases to $40-50 \%$ of incident light. Beyond $1.3 \mu \mathrm{m}$, there are dips in the reflectance curve due to absorption by water in the leaves.

\subsubsection{Principles of detection}

The differential reflection of green plants in the visible and infrared portion of the spectrum makes possible the detection of green plants from satellites. Other features on the earth surface don't have such a unique step-like character in the $0.65-0.75 \mu \mathrm{m}$ range of the reflectance curve. NDVI is commonly used to represent this character. It is calculated from Advanced Very High Resolution Radiometer (AVHRR) data from NOAA-8 and NOAA-9 polar orbiting satellite and is defined as:

$$
N D V I=\frac{C H N 2-C H N 1}{C H N 2+C H N 1}
$$

where CHN1 and CHN2 are reflectance in the visible (red) $(0.58-0.68 \mu \mathrm{m})$ and near infrared channels $(0.725-1.10 \mu \mathrm{m})$ respectively. NDVI is determined by the degree of absorption by chlorophyll in the red wavelengths, which is proportional to green leaf density. Therefore, NDVI correlates well with green leaf biomass, leaf area index, and other related parameters.

\subsubsection{Estimation of radiation use efficiency in plants}

Plants make use of specific energy wavelengths $(0.4-0.7 \mu \mathrm{m})$ for the process of photosynthesis. The photo-synthetically active radiation constitutes about $50 \%$ of the energy that is emitted from the sun. Out of this phot-synthetically active radiation (PAR), about $80 \%$ of the radiation incident on a plant leaf is captured by photo-synthetically active compounds. The rest is lost by reflection and absorption by non-photosynthesizing materials. A minimum of eight photons are required to produce a glucose from a single carbon-dioxide and glucose stores $28 \%$ of the captured energy in the form of chemical energy of the molecules. And finally, as the plant produces the glucose molecule it will use 
about $40 \%$ of the converted energy for dark respiration. Therefore, the maximum photosynthetic efficiency is:

$$
100 \times 0.50 \times 0.80 \times 0.28 \times 0.60=6.70
$$

This result applies to $c_{4}$ plants (so-called because their first product of photosynthesis is 4carbon sugar). For $c_{3}$ plants, like wheat and rice, the efficiency is lower due to photorespiration effects.

\subsection{Remote sensing of radiation intensity}

1.11.1 Solar constant

The average solar irradiance received outside the earth atmosphere is called Solar Constant. The intensity of solar radiation above the earth's atmosphere has nearly constant value unlike irradiance received at the ground. It's average value is $1367 \mathrm{~W} / \mathrm{m}^{2}$ though it shows some variation due to variations in solar activity. Annual fluctuations due to Earth-Sun distance give rise to a variation of $\pm 3.4 \%$ of the extra-terrestrial irradiance and are given by

$$
\mathrm{E}_{\mathrm{o}}=\left\langle\mathrm{E}_{0}>\left(1+0.0167 \cos \left((2 / 365)^{*}(\mathrm{D}-3)\right)\right)^{2}\right.
$$

where $\left\langle\mathrm{E}_{0}\right\rangle$ is the mean value of solar constant, $\mathbf{D}$ is the Julian days.

\subsubsection{Radiation reflected and received by the ground}

Radiation received at the ground surface is a combination of direct radiation, which comes from the sun after passing through a path length in the transparent atmosphere, and diffuse radiation which is radiation reflected by clouds and scattered by atmosphere in general. The contribution of diffuse radiation to irradiance received by ground depends on the atmospheric thickness, moisture content, cloud frequency, turbidity of the atmosphere, and angle of zenith.

The radiation that is reflected from the ground is very small compared to that reflected from the clouds. Its value depends on the reflectance of different earth surface features. In many cases, surface albedo is taken to be uniform (0.15) across the land.

\subsubsection{Atmospheric effects}

Atmosphere plays a major role at attenuation and reflection of light that pass through it. Their main effects are reflection, absorption, and scattering, depending on the wavelength and air mass ratio.

\subsubsection{Air mass ratio}

Air mass ratio is defined as the ratio of the path length of the radiation through the atmosphere at a given angle of a reference path length. The reference path length is that obtained by light traveling to a point at sea level straight through the atmosphere (vertically). The air mass ratio depends on the angle of zenith and the height above sea level of the observer. For small angles, the ratio is expressed as;

$$
\mathbf{m}=\sec \theta_{\mathrm{z}}
$$

where $\theta_{\mathbf{z}}$ is the zenith angle. As the angle of zenith increases, the air mass ratio increases i.e., the attenuation increases. 


\subsubsection{Atmospheric absorption and reflection}

Light passing through the atmosphere experiences absorption, scattering and reflection. Absorption causes heating and eventual re-emission of the absorbed energy as long wavelength radiation. Scattering is a wavelength dependent change in a direction. On the average $30 \%$ extra-terrestrial irradiance is reflected to outer space mainly due to cloud.

\subsubsection{Irradiance variation}

Irradiance received at a given location may differ in magnitude from hour to hour, day to day, month to month, and season to season depending on air mass, turbidity, moisture content, cloud frequency, and angle of zenith. The seasonal variation give rise to a significant amount of fluctuations in the irradiance received. This fluctuation in irradiance is due to variation in the declination angle from season to season. The declination angle ( $\boldsymbol{\delta})$ that the earth posses with respect to the sun varies from season to season. In the middle of march and september the declination angle, $\delta$, is zero $\left(0^{\circ}\right)$, where as $\delta=23.5^{\circ}$ and $\delta=-23.5^{\circ}$ in the middle of June and December respectively. Analytically, the declination angle is expressed as :

$$
\delta=23.5^{\circ} \sin \left(360 \frac{(284+D)}{365}\right)
$$

where $\mathbf{D}$ is the Julian days.

Depending on the latitude, for a given declination angle, the irradiance increases or decreases. Moreover, irradiance varies with latitude. Irradiance variation due to seasonal variation is great at high latitudes. Variation in the earth sun distance also contributes to the variation in irradiance received although its contribution is very small.

\section{Applications}

\subsection{Forestry applications}

Satellite imagery is used to identify and map: -

- The species of native and exotic forest trees.

- The effects of major diseases or adverse change in environmental conditions.

- The geographic extent of forests.

This application of satellite imagery has led to the extensive use of imagery by organizations that have an interest in a range of environmental management responsibilities at a state and national level.

\subsubsection{Greenhouse gases - sinks and sources}

Forests are often referred to as carbon sinks. This description is used because during photosynthesis, carbon dioxide, the major greenhouse gas, is taken from the atmosphere and converted into plant matter and oxygen.

Climate change has serious implications for Malaysia and overseas countries alike. Sustainable v land management is essential for effective greenhouse gas management; hence, it is important to acquire data on land cover in Malaysia. Remotely sensed land cover changes are used in calculations of our national emission levels, and data collected on a national scale will enable governments to develop responses to land clearing. 


\subsubsection{Vegetation health}

Vegetation can become stressed or less healthy because of a change in a range of environmental factors. These factors include lack of water, concentration of toxic elements/herbicides and infestation by insects/viruses. The spectral reflectance of vegetation changes according to the structure and health of a plant. In particular, the influence of chlorophyll in the leaf pigments controls the response of vegetation to radiation in the visible wavelength. As a plant becomes diseased, the cell structure of a plant alters and the spectral signature of a plant or plant community will change. The maximum reflection of electromagnetic radiation from vegetation occurs in the near infrared wavelengths. Vegetation has characteristically high near-infrared reflectance and low red reflectance. Air-borne scanners using narrow spectral bands between 0.4 urn and 0.9 urn can indicate deteriorating plant health before a change in condition is visible in the plant itself.

\subsubsection{Biodiversity}

Vegetation type and extent derived from satellite imagery can be combined, with biological and topographic information to provide information about biodiversity. Typically, this analysis is done with a geographic information system.

\subsubsection{Change detection}

Satellite imagery is not always able to provide exact details about the species or age of vegetation. However, the imagery provides a very good means of measuring significant change in vegetation cover, whether it is through clearing, wildfire damage or environmental stress. The most common form of environmental stress is water deficiency.

\subsection{Geology}

Remote sensing is useful for providing information relevant to the geosciences. For example, remote sensing data are used in:

- Mineral and petroleum exploration,

- Mapping geomorphology, and

- Monitoring volcanoes.

\subsection{Land degradation}

Imagery can be used to map areas of poor or no vegetation cover. A range of factors, including saline or sodic soils, and overgrazing, can cause degraded landscapes.

\subsection{Oceanography}

Remote sensing is applied to oceanography studies. Remote sensing is used, for example, to measure sea surface temperature and to monitor marine habitats.

\subsection{Meteorology}

Remote sensing is an effective method for mapping cloud type and extent, and cloud top temperature. In many of the applications identified above remotely sensed data are used with a range of other Earth science data to provide information about the natural environment. This analysis of Earth science data from a range of sources is usually done in a geographic information system (GIS). 


\subsection{Applications in agriculture, forestry, and ecology}

\subsubsection{General principles for recognizing vegetation}

Planet Earth is distinguished from other Solar System planets by two major categories: Oceans and Land Vegetation. The oceans cover $\sim 70 \%$ of the Earth's surface; land comprises $30 \%$. On the land itself, the first order categories break down as follows: Trees $=30 \%$; Grasses $=30 \%$; Snow and Ice $=15 \%$; Bare Rock $=18 \%$; Sand and Desert Rock $=7 \%$. We have already seen in previous Sections and in the Overview that in false colour imagery the remote sensing signature of vegetation is a bright red. The landscape shown in this first image could almost be on Mars except for the presence of this bright red sign of vegetation. This is the Ouargla Oasis in the Sahara Desert of southern Algeria, a concentration of trees and plants where groundwater reaches the surface:

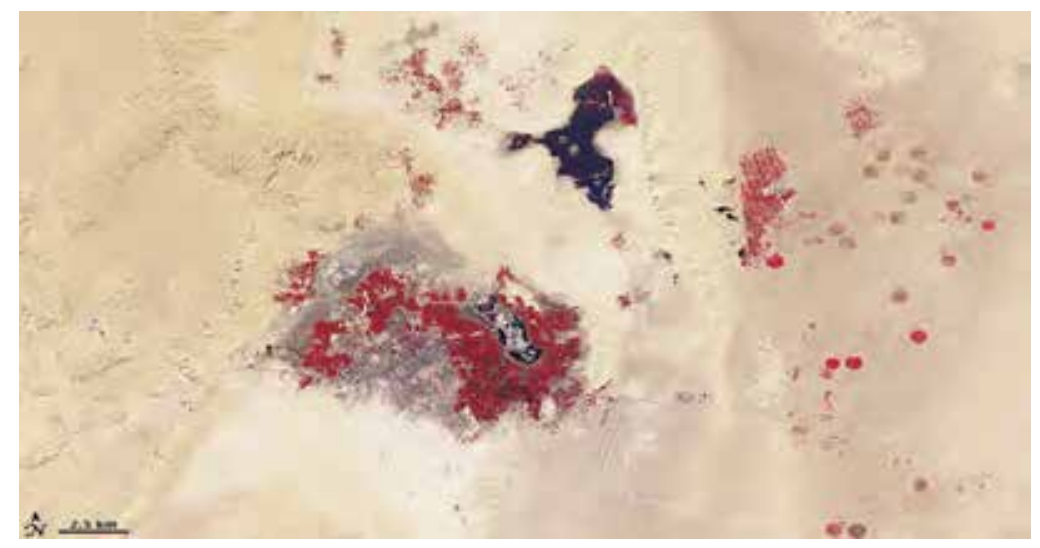

Fig. 16. Image of the Ouargla Oasis in the Sahara Desert of southern Algeria

On Earth, the amount of vegetation within the seas is huge and important in the food chain. But for people the land provides most of the vegetation within the human diet. The primary categories of land vegetation (biomes) and their proportions is shown in this pie chart:

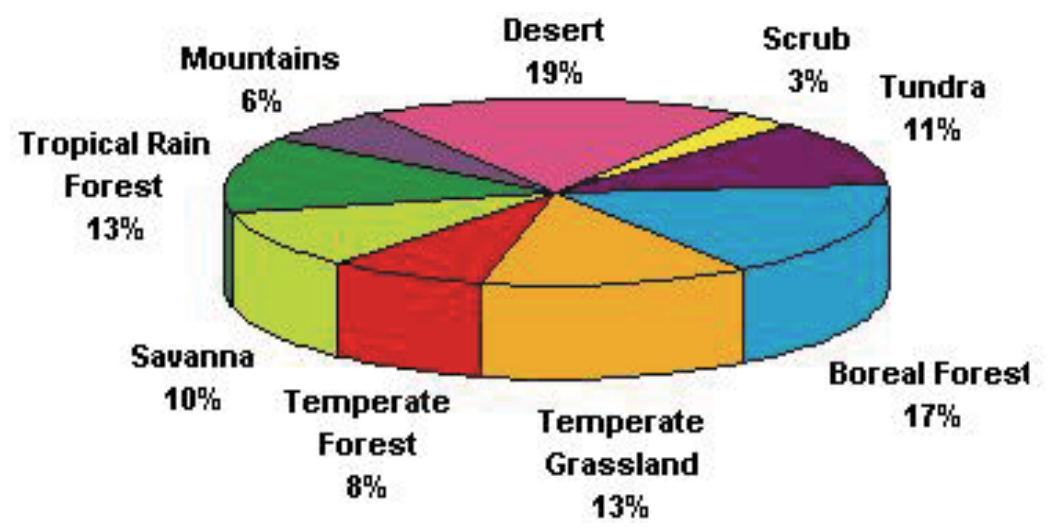

Fig. 17. Pie chart for land vegetation (biomes) and their proportions

These biomes are defined in part by the temperature and precipitation controls that differentiate them: 


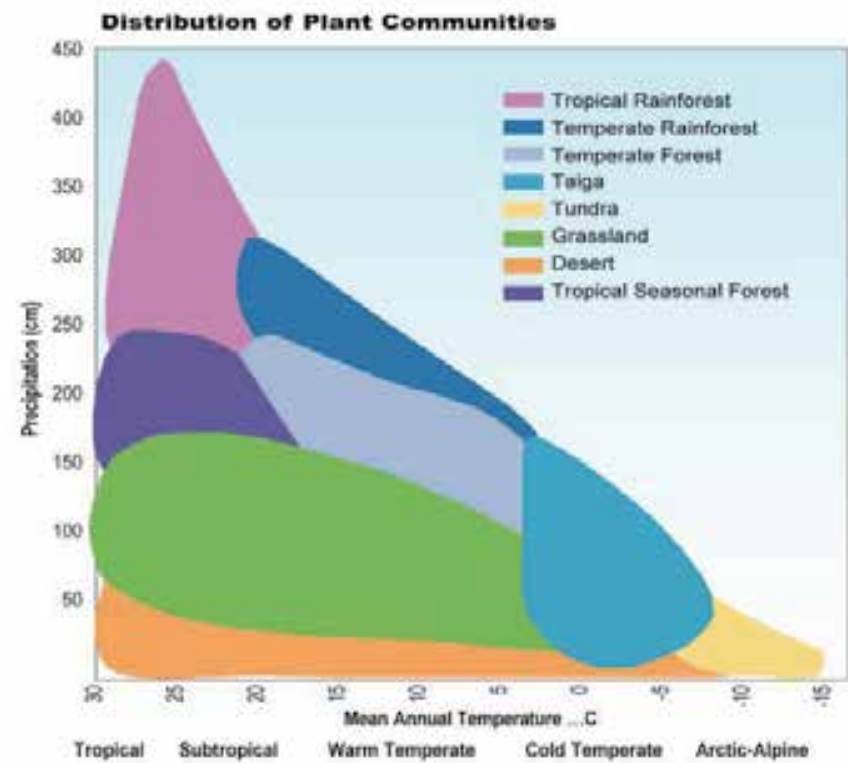

Both temperature and precipitation limit the dis. tribution of plant communities. The climate temperature and precipitation) zones of some of the major plant communities (such as tem. perate forests. grasslands, and deserts) in the US are shown in this fipure. Note that grasslands' zone encloses a wide range of environments. This zone can include a mixture of woody plants with the grasus. The shrublacods and woodlands of the Wost are examples of arass/woody vegetation mixes that oceur in the rone designated as granslands

With climate change, the areas occupied by these zones will shift relative to their current distribution. Plant species are expected to shif with their climate zones. The new plant communities that result tram these shifis are likely to be diflerent from current plant communities because individual species will very likely migrate at diflerent rates and have different degrees of success in eatablishing themselves in new places.

Fig. 18. Distribution of land vegetation by temperature and precipitation controls

Global maps of vegetation biomes on the continents show this general distribution:

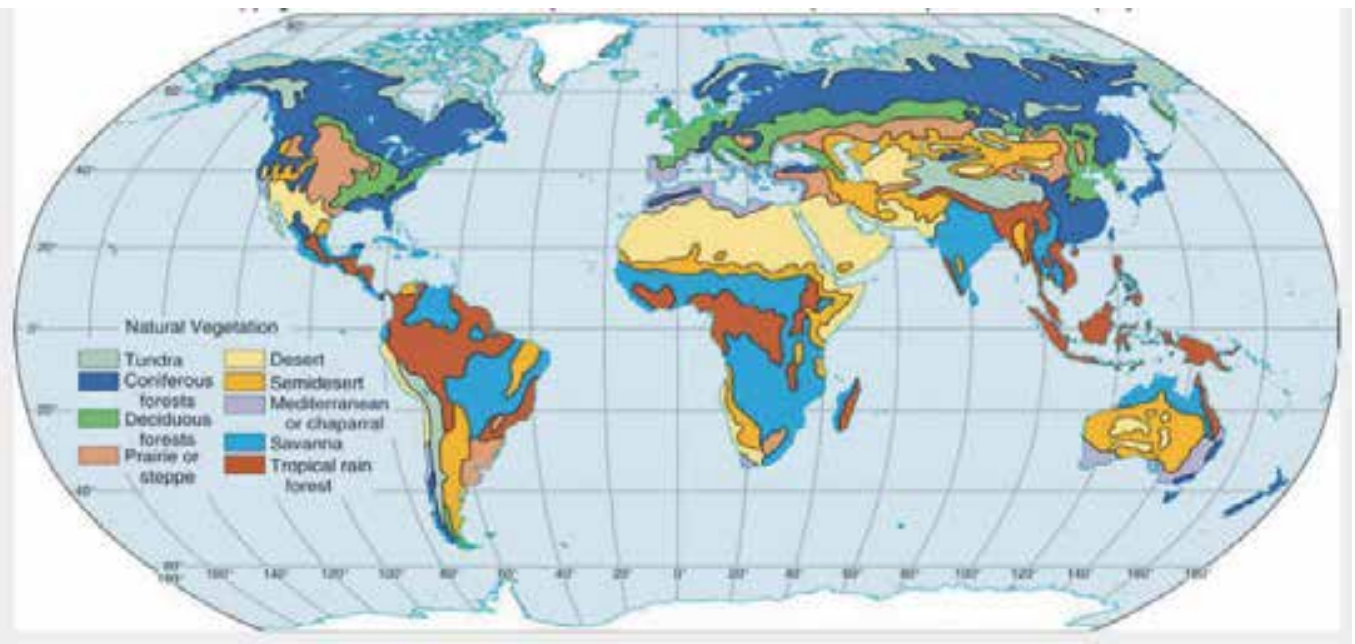

Fig. 19. Global maps of land vegetation (biomes)

A fair number of global vegetation maps have been published. These usually show slight to moderate differences, depending in part with the types and numbers of classes established in the classification. There also exists a notable correlation between vegetation classes and climate. Remote sensing has proven a powerful "tool" for assessing the identity, characteristics, and growth potential of most kinds of vegetative matter at several levels (from biomes to individual plants). Vegetation behaviour depends on the nature of the vegetation itself, its interactions with solar radiation and other climate factors, and the 
availability of chemical nutrients and water within the host medium (usually soil, or water in marine environments). A common measure of the status of a given plant, such as a crop used for human consumption, is its potential productivity (one such parameter has units of bushels/acre or tons/hectare, or similar units). Productivity is sensitive to amounts of incoming solar radiation and precipitation (both influence the regional climate), soil chemistry, water retention factors, and plant type. Examine the diagram below to see how these interact, keeping in mind that various remote sensing systems (e.g., meteorological or earth-observing satellites) can provide inputs to productivity estimation:

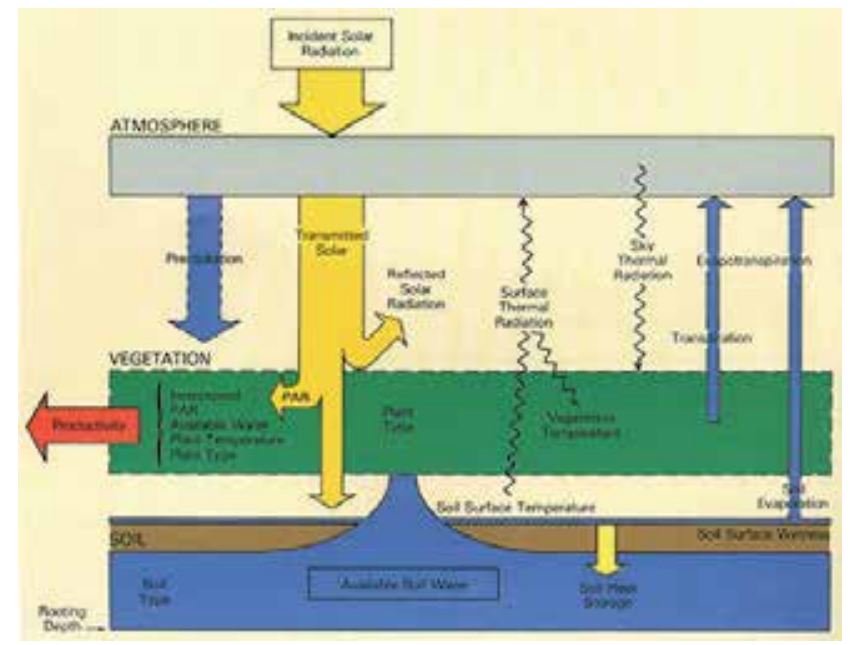

Fig. 20. Interaction between productivity and solar radiations

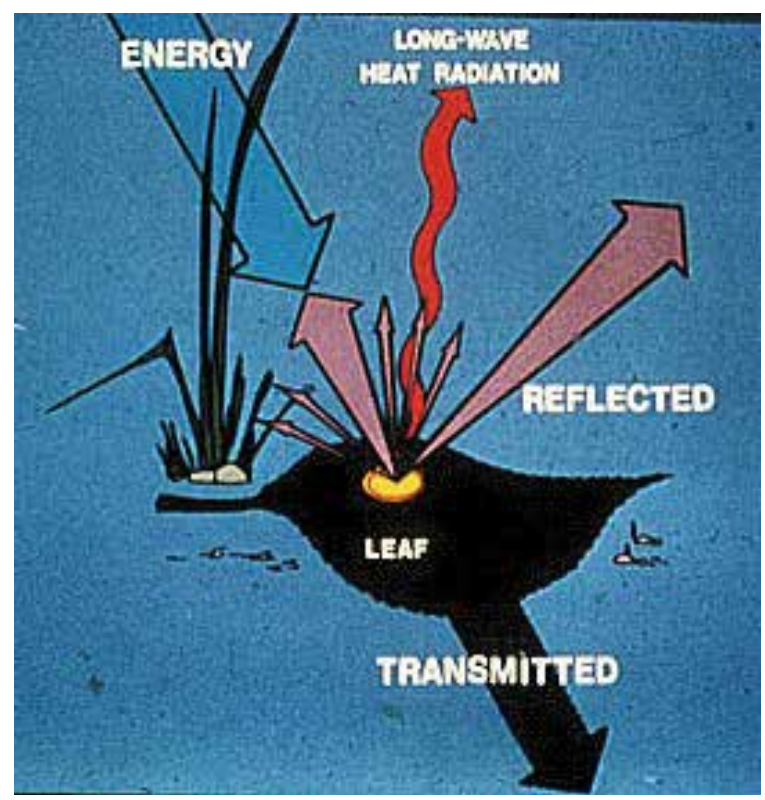

Fig. 21. Reflection and absorption of radiations through biomass 
Because many remote sensing devices operate in the green, red, and near infrared regions of the electromagnetic spectrum, they can discriminate radiation absorption and reflectance properties of vegetation. One special characteristic of vegetation is that leaves, a common manifestation, are partly transparent allowing some of the radiation to pass through (often reaching the ground, which reflects its own signature). The general behaviour of incoming and outgoing radiation that an act on a leaf is shown in figure 21.

Now, consider this diagram which traces the influence of green leafy material on incoming and reflected radiation.

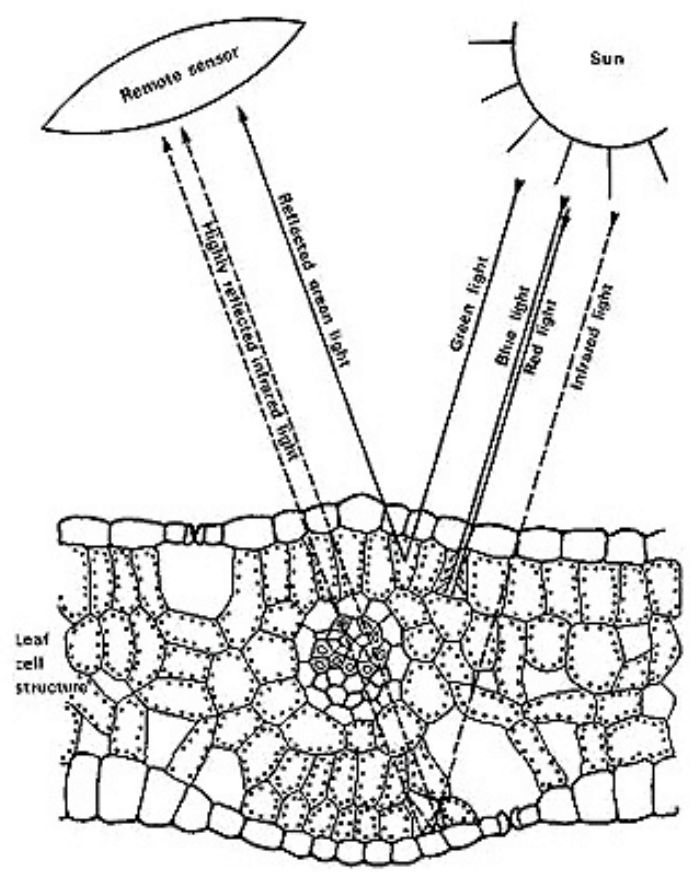

Fig. 22. The influence of green leafy material on incoming and reflected radiation.

Absorption centred at about $0.65 \mu \mathrm{m}$ (visible red) is controlled by chlorophyll pigment in green-leaf chloroplasts that reside in the outer or Palisade leaf. Absorption occurs to a similar extent in the blue. With these colours thus removed from white light, the predominant but diminished reflectance of visible wavelengths is concentrated in the green. Thus, most vegetation has a green-leafy colour. There is also strong reflectance between 0.7 and $1.0 \mu \mathrm{m}$ (near IR) in the spongy mesophyll cells located in the interior or back of a leaf, within which light reflects mainly at cell wall/air space interfaces, much of which emerges as strong reflection rays. The intensity of this reflectance is commonly greater (higher percentage) than from most inorganic materials, so vegetation appears bright in the near-IR wavelengths (which, fortunately, is beyond the response of mammalian eyes). These properties of vegetation account for their tonal signatures on multispectral images: darker tones in the blue and, especially red, bands, somewhat lighter in the green band, and notably light in the near-IR bands (maximum in Landsat's Multispectral Scanner Bands 6 and 7 and Thematic Mapper Band 4 and SPOT's Band 3). 
Identifying vegetation in remote-sensing images depends on several plant characteristics. For instance, in general, deciduous leaves tend to be more reflective than evergreen needles. Thus, in infrared colour composites, the red colours associated with those bands in the 0.7 $1.1 \mu \mathrm{m}$ interval are normally richer in hue and brighter from tree leaves than from pine needles.

These spectral variations facilitate fairly precise detecting, identifying and monitoring of vegetation on land surfaces and, in some instances, within the oceans and other water bodies. Thus, we can continually assess changes in forests, grasslands and range, shrub lands, crops and orchards, and marine plankton, often at quantitative levels. Because vegetation is the dominant component in most ecosystems, we can use remote sensing from air and space to routinely gather valuable information helpful in characterizing and managing of these organic systems.

This discrimination capability implies that one of the most successful applications of multispectral space imagery is monitoring the state of the world's agricultural production. This application includes identifying and differentiating most of the major crop types: wheat, barley, millet, oats, corn, soybeans, rice, and others. This capability was convincingly demonstrated by an early ERTS-1 classification of several crop types being grown in Holt County, Nebraska. This pair of image subsets, obtained just weeks after launch, indicates what crops were successfully differentiated; the lower image shows the improvement in distinguishing these types by using data from two different dates of image acquisition:

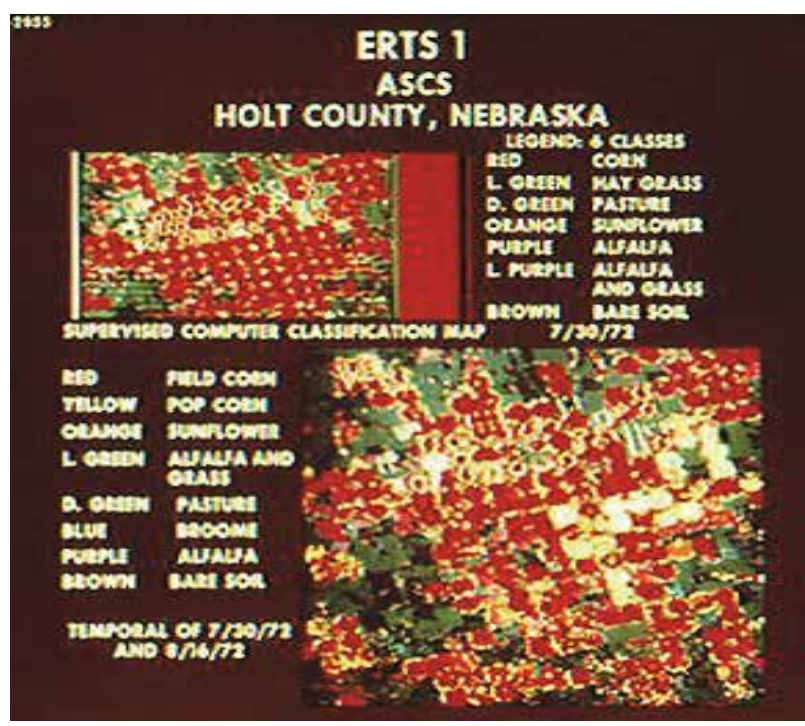

Fig. 23. ERTS-1 classification of several crop types being grown in Holt County, Nebraska

This is a good point in the discussion to introduce the appearance of large area croplands as they are seen in Landsat images. We illustrate with imagery that covers the two major crop growing areas of the United States. The scene below is a part of the Great or Central Valley California, specifically the San Joaquin Valley. Agricultural here is primarily associated with such cash crops as barley, alfalfa, sugar beets, beans, tomatoes, cotton, grapes, and peach and walnut trees. In July of 1972 most of these fields are nearing full growth. Irrigation from the Sierra Nevada, whose foothills are in the upper right, compensates for the sparsity or 
rain in summer months (temperatures can be near $100^{\circ} \mathrm{F}$ ). The eastern Coast Ranges appear at the lower left. The yellow-brown and blue areas flanking the Valley crops are grasslands and chapparal best suited for cattle grazing. The blue areas within the croplands (near the top) are the cities of Stockton and Modesto.

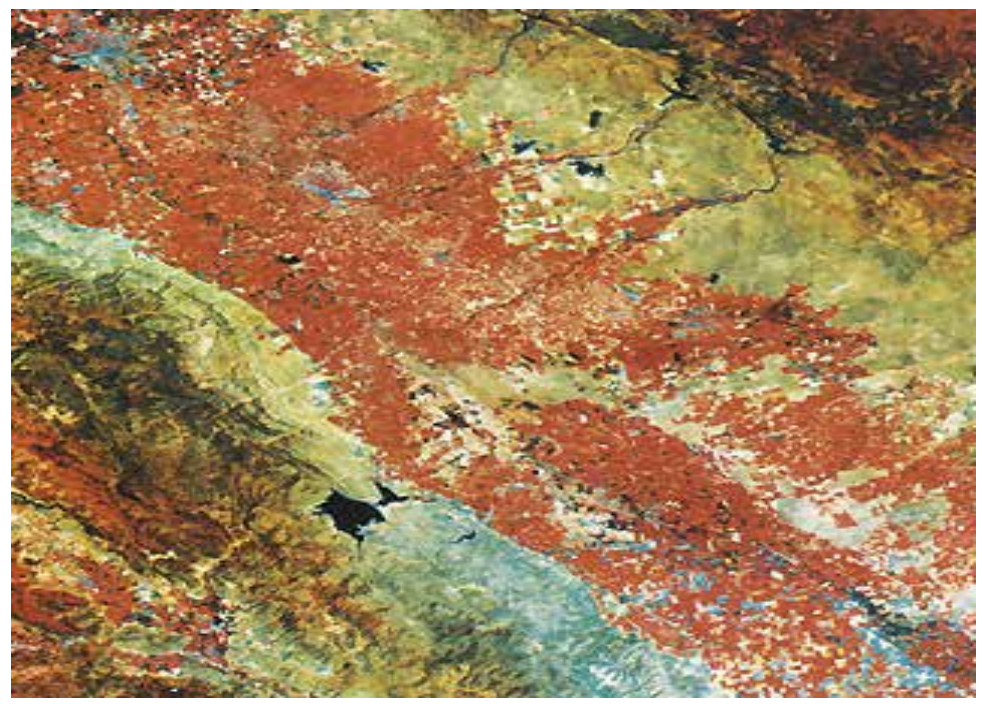

Fig. 24. Landsat imagery of Great or Central Valley of California.

Many factors combine to cause small to large differences in spectral signatures for the varieties of crops cultivated by man. Generally, we must determine the signature for each crop in a region from representative samples at specific times. However, some crop types have quite similar spectral responses at equivalent growth stages. The differences between crop (plant) types can be fairly small in the Near-Infrared, as shown in these spectral signatures (in which other variables such as soil type, ground moisture, etc. are in effect held constant).

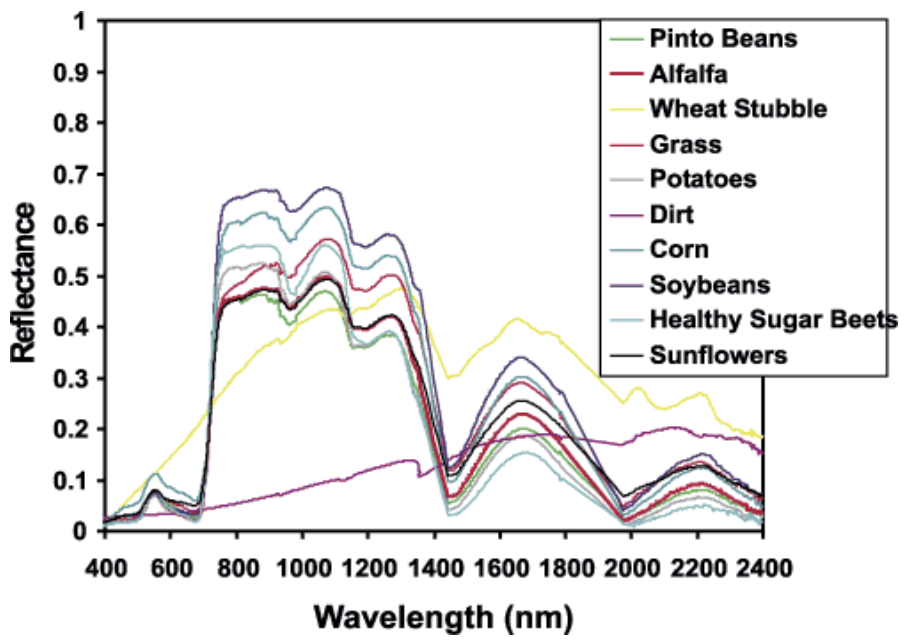

Fig. 25. Spectral responses of different crops 
The shape of these curves is almost identical when each crop type is compared with the others. The big difference is in the percent reflectance. The similarity in shape is explained by the fact, discussed earlier, that most vegetation matter has the same basic cell structure and similar content of chlorophyll. Yet remote sensing is reasonably effective at distinguishing and identifying different crop types.

\subsubsection{Factors affecting spectral signatures of field crops}

Read the answer to this question - it is important. The list is incomplete, but the main factors are discussed. But with so many variables involved, it is difficult to claim that each crop has a specific spectral signature. This means that, in order to identify the several crops usually present in agricultural terrain in any particular area, the most efficient course is to establish training sites, spectral characteristics are one means of identifying and classifying features in a scene. We will see how reliable this is by itself as this Section unfolds. Shape and pattern recognition are valuable inputs in determining what a feature is. The geometric shape of a field of crops sometimes is helpful in determining the actual crop itself. But field shapes tend to vary both within regions of large countries like the U.S. and in different parts of the world. This variation is evident in the illustration below

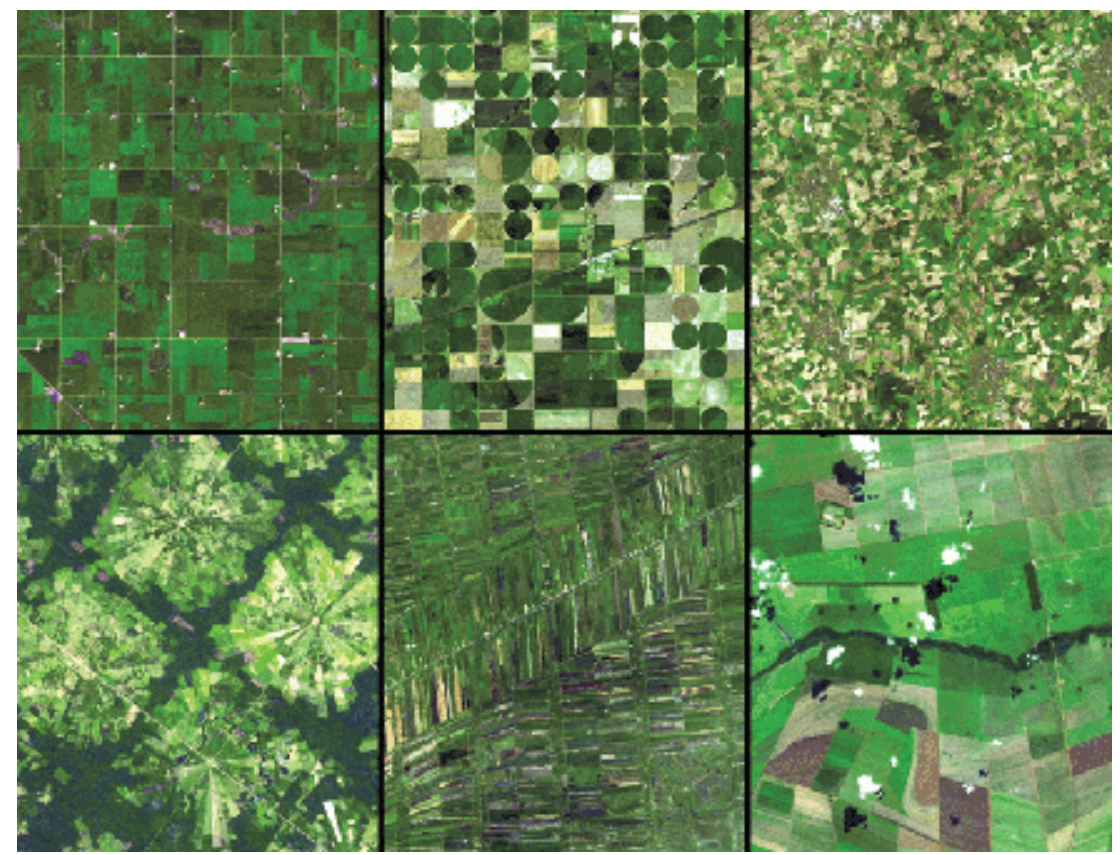

Fig. 26. Landsat image showing the geometric shape of a field of different crops

Through remote sensing it is possible to quantify on a global scale the total acreage dedicated to these and other crops at any time. Of particular import is the utility of space observations to accurately estimate (goal: best case 90\%) the expected yields (production in bushels or other units) of each crop, locally, regionally or globally. We can do this by first computing the areas dedicated to each crop, and then incorporating reliable yield assessments per unit area, which agronomists can measure at representative ground-truth sites. Reliability is enhanced by using the repeat coverage of the croplands afforded by the cyclical satellite orbits assuming, of course, cloud cover is sparse enough to foster several 
good looks during the growing season. Usually, the yield estimates obtained from satellite data are more comprehensive and earlier (often by weeks) than determined conventionally as harvesting approaches. Information about soil moisture content, often critical to good production, can be qualitatively (and under favourable conditions, quantitatively) appraised with certain satellite observations; that information can be used to warn farmers of any impending drought conditions.

Under suitable circumstances, it is feasible to detect crop stress generally from moisture deficiency or disease and pests, and sometimes suggest treatment before the farmers become aware of problems. Stress is indicated by a progressive decrease in Near-IR reflectance accompanied by a reversal in Short-Wave IR reflectance, as shown in this general diagram:

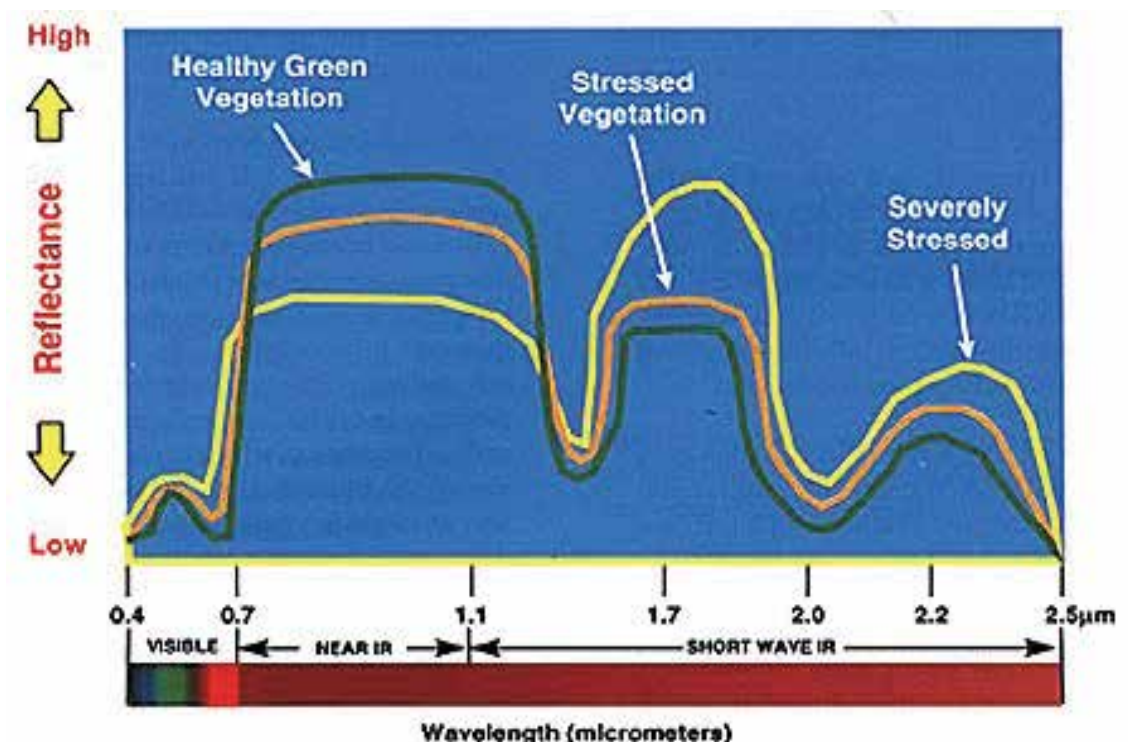

Fig. 27. Crop stress by high and low reflectance

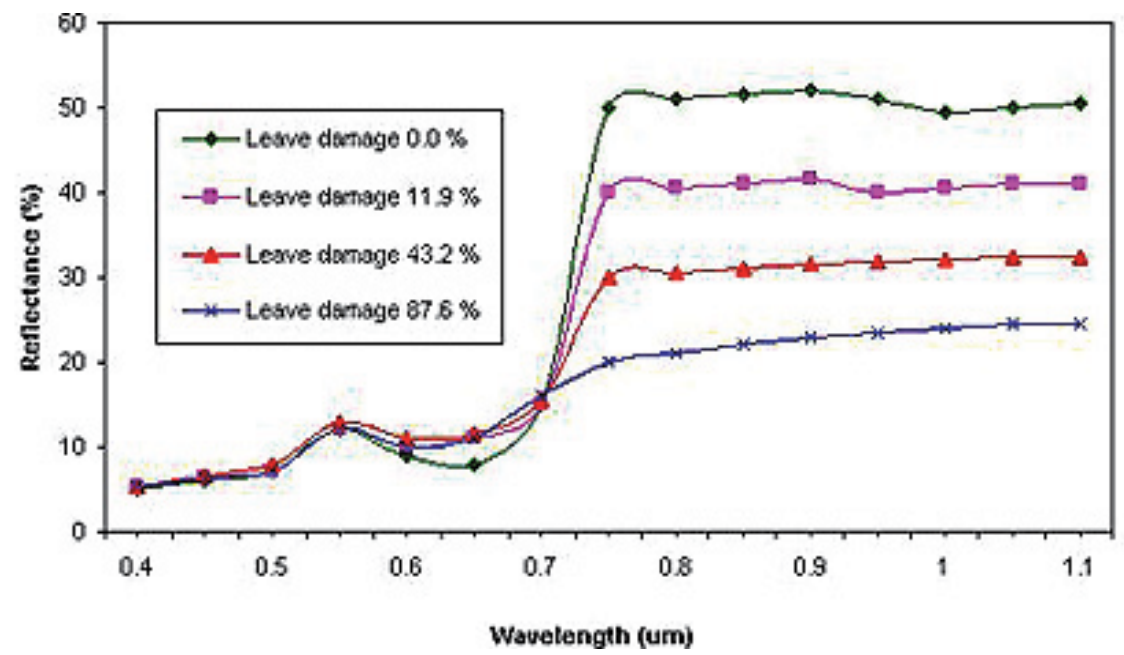

Fig. 28. Soybean plant leaves indicating patterns of high and low reflectance 
This effect is evidenced quantitatively in this set of field spectral measurements of leaves taken from soybean plants as these underwent increasing stress that causes loss of water and breakdown of cell walls.

For the soybeans, the major change with progressive stress is the decrease in infrared reflectances. In the visible, the change may be limited to color modification (loss of greenness), as indicated in this sugar beets example, in which the leaves have browned:

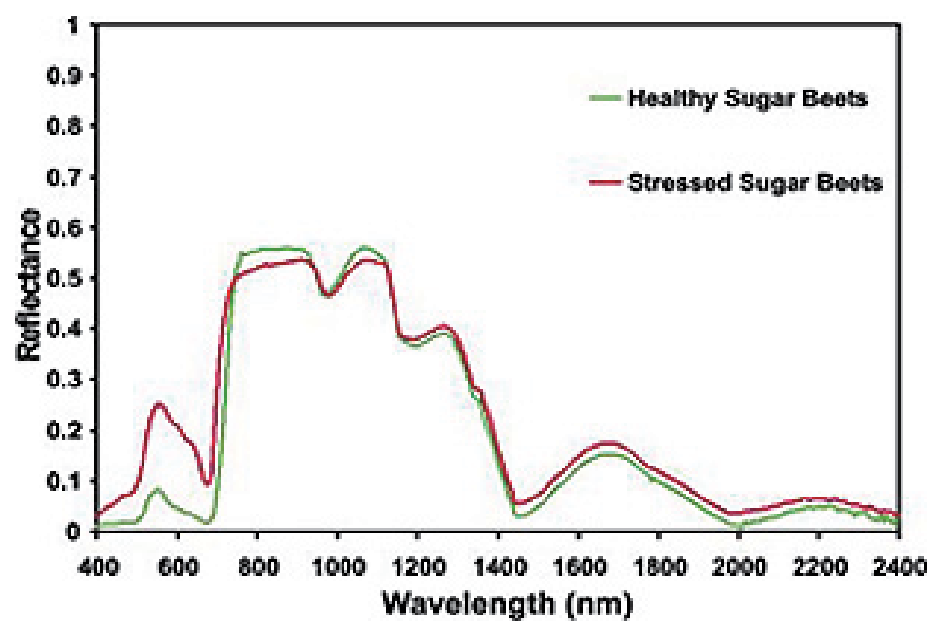

Fig. 29. Sugar beets indicating patterns of high and low reflectance

Differences in vegetation vigour, resulting from variable stress, are especially evident when Near Infrared imagery or data are used. In this aerial photo made with Colour IR film shows a woodlands with healthy trees in red, and "sick" (stressed) vegetation in yellow-white (the red no longer dominates):

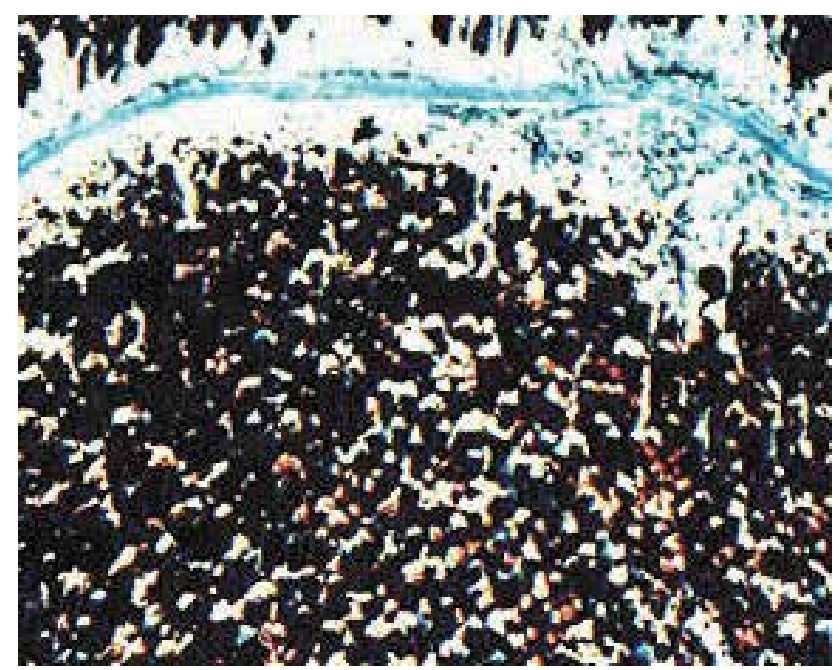

Fig. 30. Colour IR film of woodland showing high and low stress 
For identifying crops, two important parameters are the size and shape of the crop type. For example, soybeans have spread out leaf clumps and corn has tall stalks with long, narrow leaves and thin, tassle-topped stems. Wheat (in the cereal grass family) has long thin central stems with a few small, bent leaves on short branches, all topped by a head containing the kernels from which flour is made. Other considerations are the surface area of individual leaves, the plant height and amount of shadow it casts, and the spacing or other planting geometries of row crops (the normal arrangement of legumes, feed crops, and fruit orchards). The stage of growth (degree of crop maturity) is also a factor. For example during its development wheat passes through several distinct steps such as developing its kernelbearing head and changing from shades of green to golden-brown.

Another related parameter is Leaf Area Index (LAI), defined as the ratio of one-half the total area of leaves (the other half is the underside) in vegetation to the total surface area containing that vegetation. If all the leaves were removed from a tree canopy and laid on the ground, their combined areas relative to the ground area projected beneath the canopy would be some number greater than 1 but usually less than 10. As a tree, for example, fully leaves, it will produce some LAI value that is dependent on leaf size and shape, the number of limbs, and other factors. The LAI is related to the the total biomass (amount of vegetative matter [live and dead] per unit area, usually measured in units of tons or kilograms per hectare [2.47 acres]) in the plant and to various measures of Vegetation Index. Estimates of biomass can be carried out with variable reliability using remote sensing inputs, provided there is good supporting field data and the quantitative (mathematical) models are efficient. Both LAI and NDVI are used in the calculations.

Satellite remote sensing is an excellent means of determining LAI on a regional or sub continental scale. In principal, actual LAI must be determined on site directly by stripping off all leaves, but in practice it can be estimated by statistical sampling or by measuring some property such as reflectance. Thus, remote sensing can determine an LAI estimate if the reflectance are matched with appropriate field truth. For remotely sensed crops, LAI is

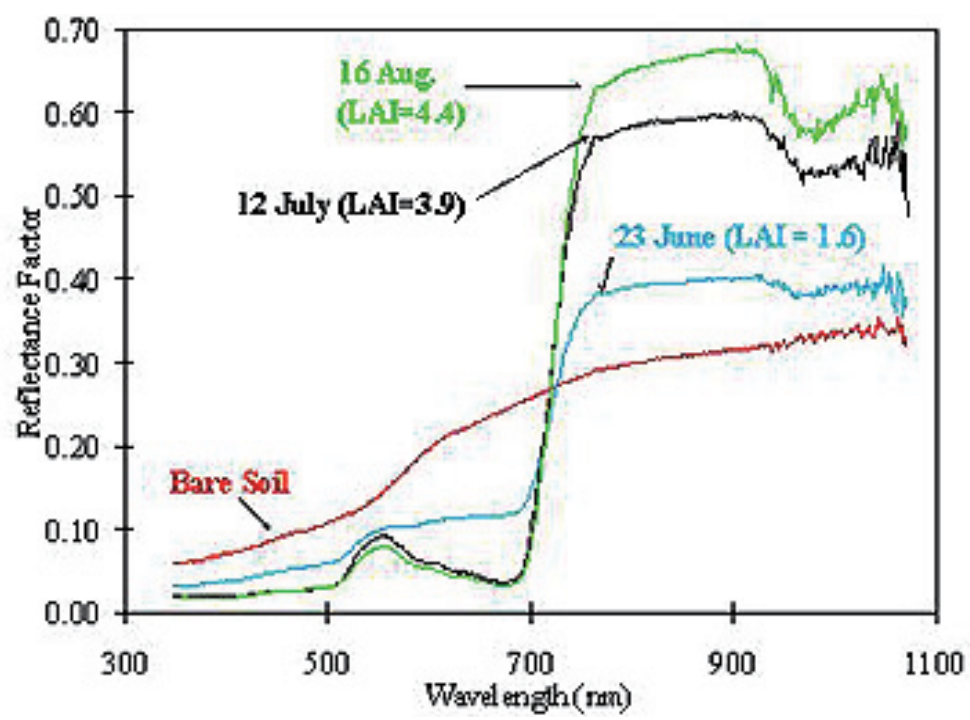

Fig. 31. IR reflectance of corn and soil with LAI 
influenced by the amount of reflecting soil between plant (thus looking straight down will see both corn and soil but at maturity a cornfield seems closely spaced when viewed from the side). For the spectral signatures shown below, the Near IR reflectances will increase with LAI. This change in appearance and extent of surface area coverage over time is the hallmark of vegetation as compared with most other categories of ground features (especially those not weather-related). Crops in particular show strong changes in the course of a growing season, as illustrated here for these three stages - bare soil in field (A); full growth (B); fall senescence $(\mathrm{C})$, seen in a false colour rendition:

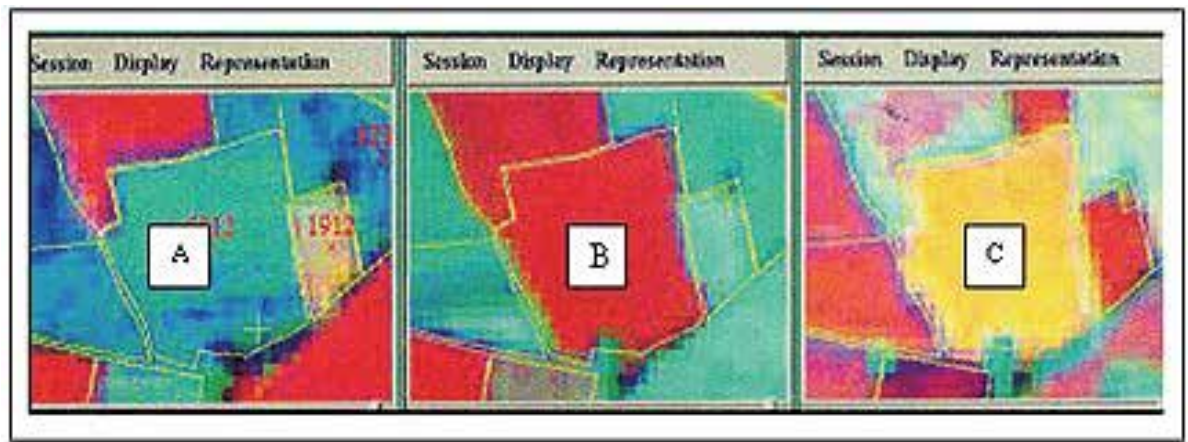

Fig. 32. Land sat image of the field showing three stages - bare soil in field (A); full growth (B); fall senescence (C)

\subsubsection{Detection of dead vegetation by Landsat}

The study of vegetation dynamics in terms of climatically-driven changes that take place over a growing season is called phenology. A good example of how repetitive satellite observations can provide updated information on the phenological history of natural vegetation and crops during a single cycle of Spring-Summer growth is this sequence of

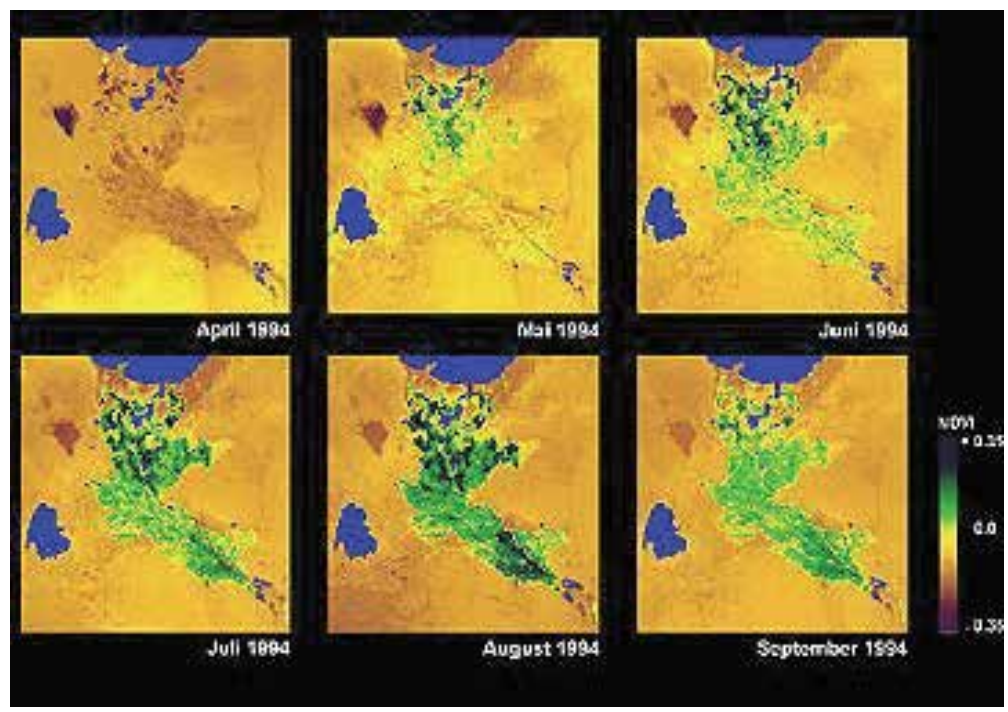

Fig. 33. AVHRR images of the Amu-Dar'ja Delta, south of the Aral Sea in Ujbekistan 
AVHRR images of the Amu-Dar'ja Delta just south of the Aral Sea in Ujbekistan (southcentral Asia).The amount of vegetation present in the delta (a major farming district for this region) is expressed as the NDVI. The Aral Sea - a large inland lake - is now rapidly drying up. More generally, seasonal change appears each year with the "greening" that comes with the advent of Spring into Summer as both trees and grasses commence their annual growth. The leafing of trees in particular results in whole regions becoming dominated by active vegetation that is evident when rendered in a multispectral image in green tones. The MODIS sensor on Terra has several vegetation-sensitive bands used to calculate a variation of the NDVI called the Enhanced Vegetation Index (EVI).

Now, to emphasize the variability of the spectral response of crops over time, we show these phonological stages for wheat in this sequential illustration:

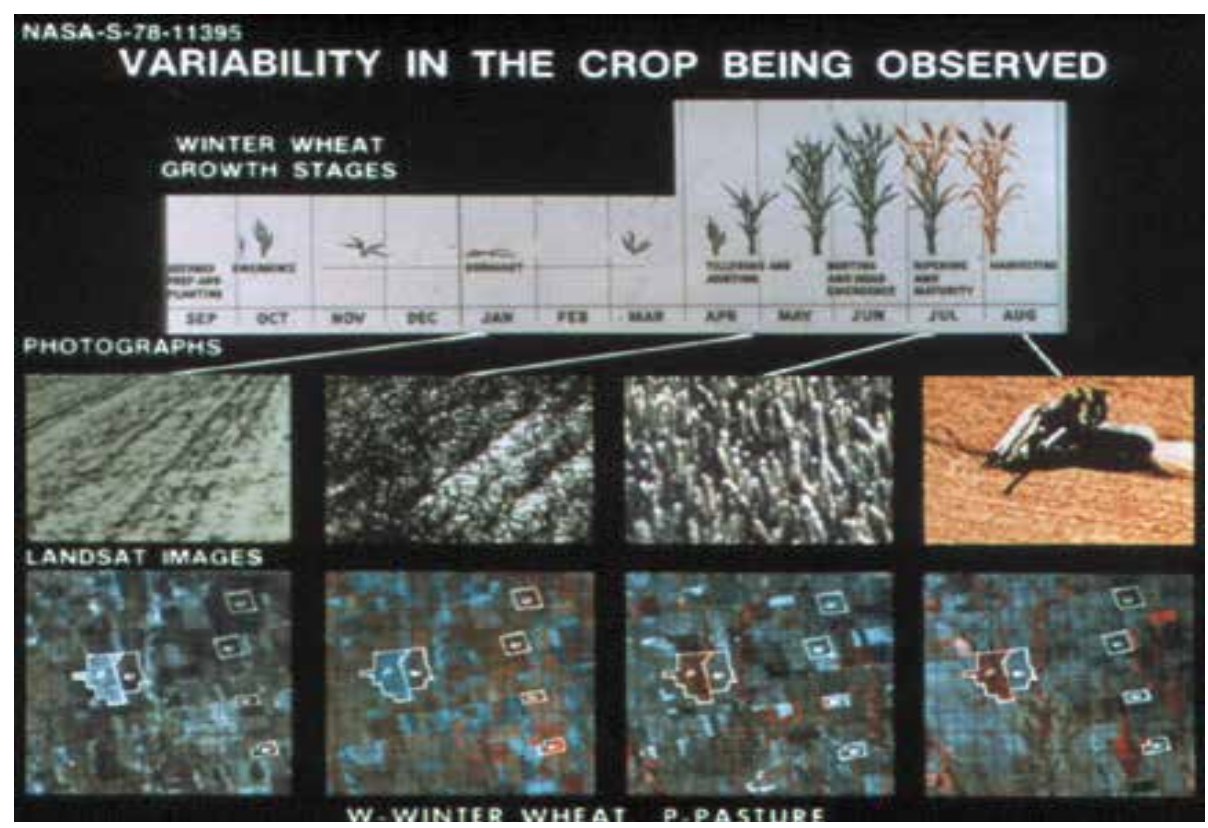

Fig. 34. Enhanced Vegetation Index (EVI) showing variability of the spectral response of crops over time

Note that, in the Landsat imagery, the wheat fields (particularly the light-blue polygon in the far-left image) show their brightest response in the IR (hence red) during the emergent stage but become less responsive by the ripening stage. The grasses and alfalfa that make up pasture crops mature (redden) much later.

\subsubsection{Usage of specific crop types as training sites identified (determined)?}

With this survey of the role of several variables in determining crop types, let us look now at one of the most successful classifications reported to date. These are being achieved by hyper spectral sensors such as AVIRIS and Hyperion. The Hyperion hyper spectral sensor on NASA's EO-1 has procured multichannel data for the Coleambally test area in Malaysia. This image, made from 3 narrow channels in the visible-Near IR, shows how the fields of corn, rice, and soybeans changed their reflectance during the (southern hemisphere) growing season: Notice the pronounced differences in crop shapes which is a big factor in 
producing the reflectance differences (as said above, healthy leaf vegetation generally has a spectral response that does not vary much in percent reflectance from one plant type to others, so that differences in crop shape become the distinguishing factor).

\section{Time Sequence of Hyperion Images}

Coleambally Irrigation Area Farm 33

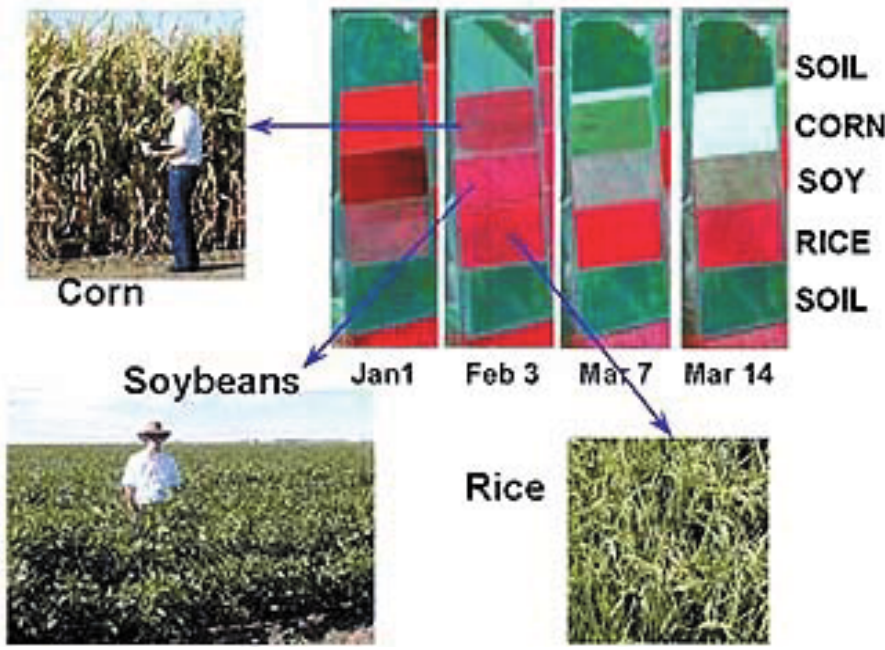

Fig. 35. Visible-Near IR image showing reflectance changing in the fields of corn, rice, and soybeans during the growing season

The multichannel data from Hyperion were used to plot the observed spectral signatures for the soil and three crops, as shown here (the curves identified in the upper right [the writing is too small to be decipherable on most screens] are, from top to bottom, soil, corn, rice, and soybeans):

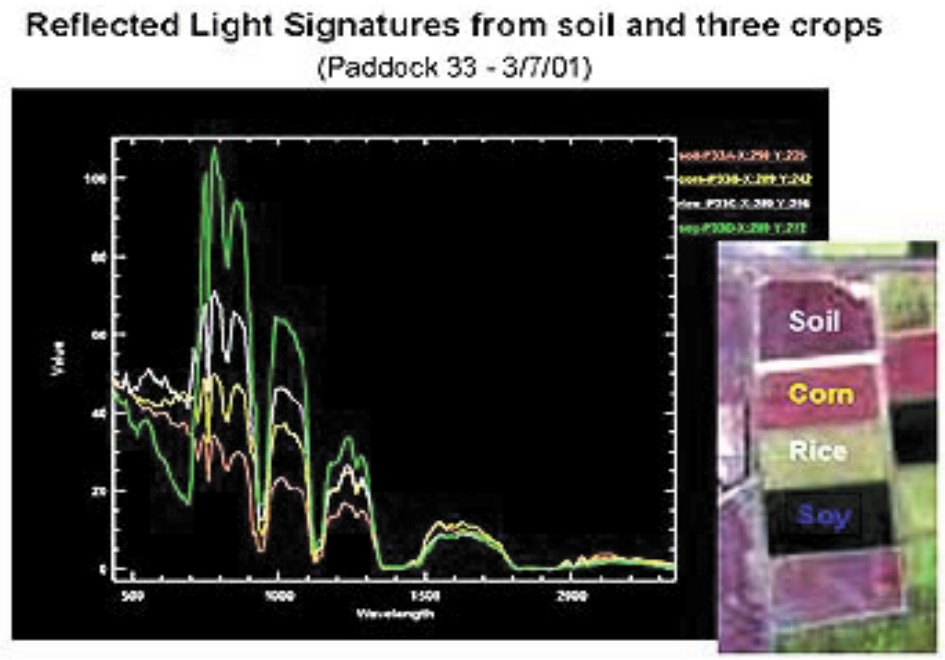

Fig. 36. Reflected light signatures from soil and three crops 
Using a large number of selected individual Hyperion channels, this supervised classification of the four classes in the sub scene was generated; this end result is more accurate than is normally achievable with broad band data such as obtained by Landsat:

Active microwave sensors, or radar, can use several variables to recognize crop vegetation and even develop a classification of crop types. Here is a SIR-C (Space Shuttle) image of farmland in the Netherlands, taken on April 4, 1994. The false colour composite was made with L-band in the $\mathrm{HH}$ polarization mode = red; $\mathrm{L}-$ band $\mathrm{HV}=$ green; and $\mathrm{C}-$ band $\mathrm{HH}=$ blue.

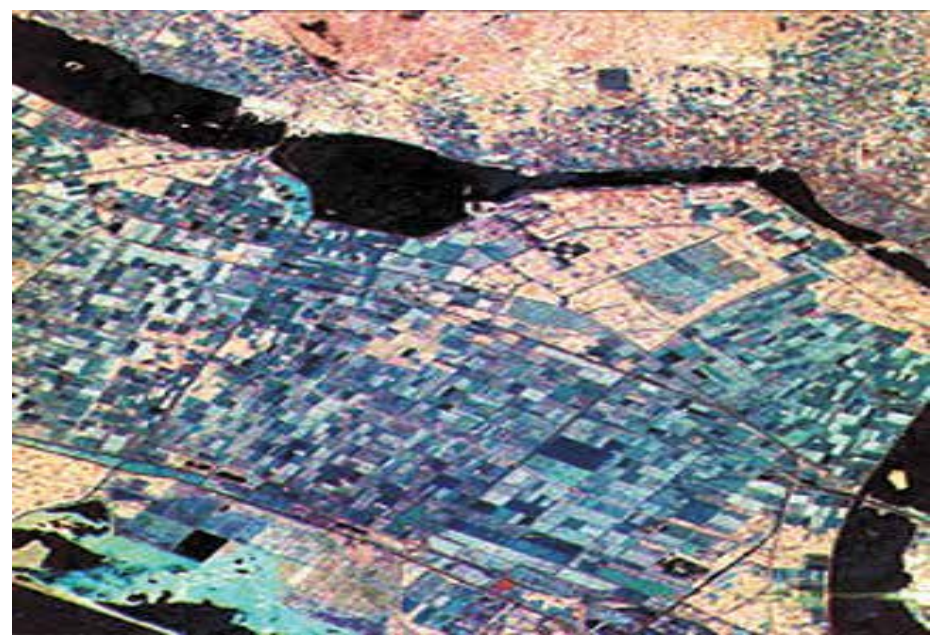

Fig. 37. SIR-C (Space Shuttle) image of farmland in the Netherlands

An additional image variable is the crop's background, namely the nurturing soil, whose colour and other properties can change with the particular soil type, and whose reflectance depends on the amount of moisture it holds. Moisture tends to darken a given soil colour; this condition is readily picked up in aircraft imagery as seen in this pair of images:
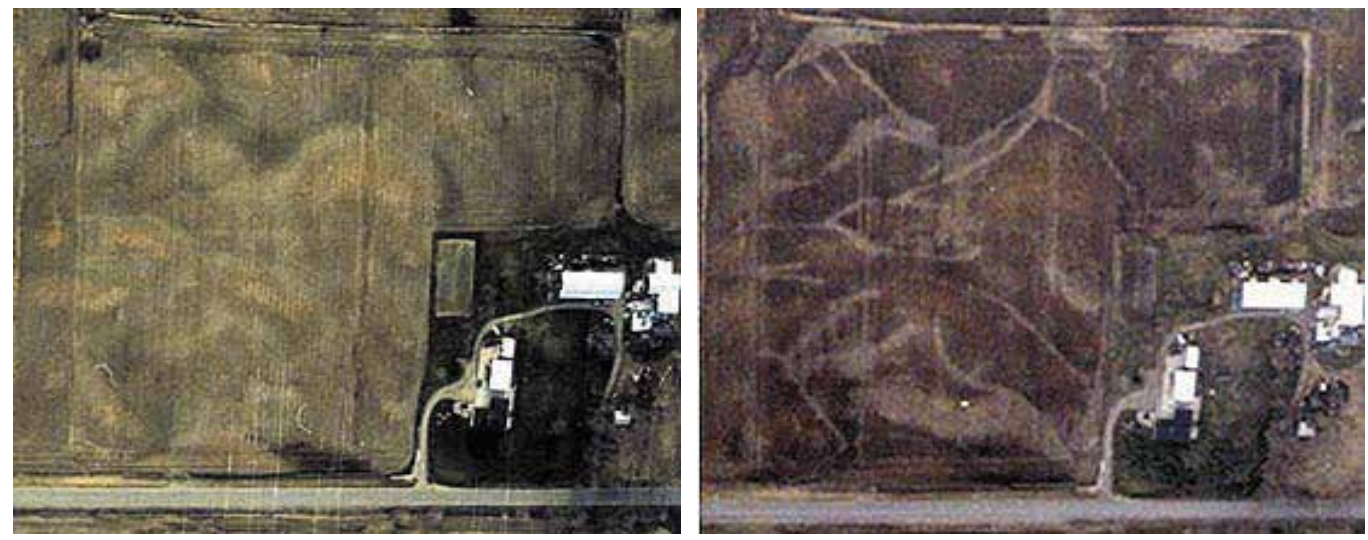

Fig. 38. Aircraft imagery showing different colours due to moisture pickup

Often, the distribution of moisture, as soil dries differentially, is variable in an imaged barren field giving rise to a mottled or blotchy appearance. Thermal imagery brings out the 
differential soil moisture content by virtue of temperature variations. The amount of water in the crop itself also affects the sensed temperature (stressed [water deficient] or diseased crop material is generally warmer). Soil water variations are evident in this image made by an airborne thermal sensor of several fields, where high moisture correlates with blue and drier parts of the fields with reds and yellows:

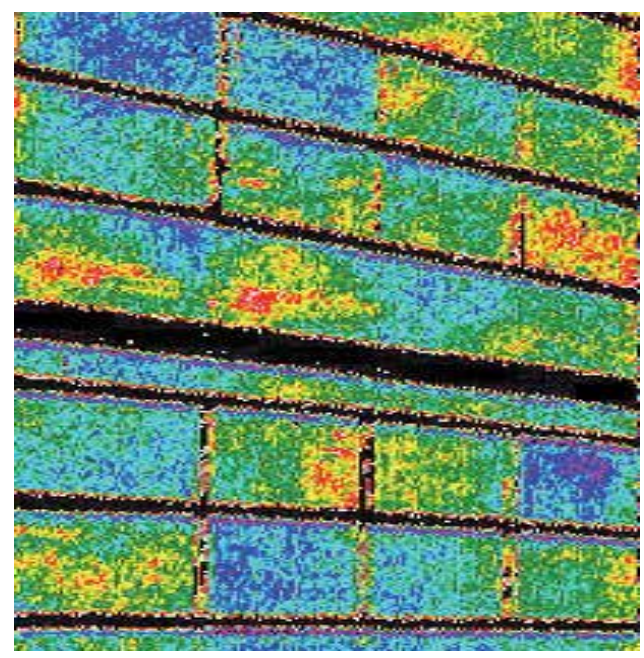

Fig. 39. Image made by an airborne thermal sensor of several fields showing the soil water variations

A combination of visible, NIR, and thermal bands can pick up both water deficiency and the resulting stress on the crops in the fields. This set of three images was made by a Daedalus instrument flown on an aircraft. In the top image, yellow marks unplanted fields and those in blue and green are growing crops. The center image picks up patterns of water distribution in the crop fields. The bottom image shows levels of stress related in part to insufficient moisture.
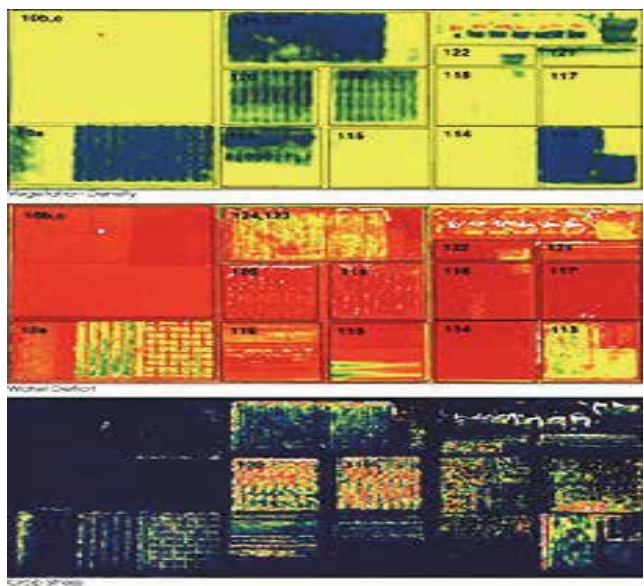

Fig. 40. Image showing levels of stress related in part to insufficient moisture 
A passive microwave sensor also picks up soil moisture. Cooler areas appear dark in images of fields over flown by a microwave sensor - although other factors, such as absence or presence of growing crops (and their types) besides moisture can account for some darker tones.

\section{References}

Bankert, R.L., and P.M. Tag, 1998: Using SSM/I Data and Computer Vision to Estimate Tropical Cyclone Intensity. Proceedings, 9th Conference on Satellite Meteorology and Oceanography, American Meteorological Society, Boston, MA, pp. 226-229.

Baum, B.A., V.Tovinkere, J.Titlow, and R.M. Welch, 1997: Automated Cloud Classification of Global AVHRR Data Using a Fuzzy Logic Approach. Journal of Applied Meteorology, 36, 1519-1540.

Baumgardner, M. F., Silva, L. F., Biehl, L. L. And Stoner, E. R. (1985) Reflectance properties of soils, Advances in Agronomy, 38, 1-44.

Bojinski, S., Schaepman, M., Schaepfer, D. And Itten, K. (2003) SPECCHIO: a spectrum database for remote sensing applications, Computers and Geosciences, 29: 27-38.

Boochs, F., Kupper, G., Dockter, K. and Kuhbauch, W. (1990) Shape of the red edge as vitality indicator of plants, International Journal of Remote Sensing, 11 (10), 1741-1753.

Campbell, J. B. (1996) An Introduction to Remote Sensing (2nd Ed), New York, The Guilford Press.

Clark, R. N., King, T. V. V., Ager, C. and Swayze, G. A. (1995) Initial vegetation species and senescence/stress mapping in the San LuisValley, Colorado, using imaging spectrometer data, Proceedings: Summitville Forum 1995,

Clark, R.N., Swayze, G.A. Gallagher, A.J., King, T.V.V. and W.M. Calvin (1993) The U. S. Geological Survey, Digital Spectral Library, Version 1: 0.2 to 3.0 microns, U.S. Geological Survey Open File Report 93-592, 1340 pages.

Collins, W. (1978) Remote Sensing of Crop Type and Maturity, Photogrammetric Engineering and Remote Sensing, 44, 43-55.

Curran, P. J. (1989) Remote sensing of foliar chemistry, Remote Sensing of Environment, 30, 271-278.

Curtiss, B. and Goetz, A. F. H. (2001) Fiel Spectrometry: techniques and instrumentation, Analytical Spectral Devices Inc,

Datt, B. (2000) Identification of green and dry vegetation components with a crosscorrelogram spectral matching technique, International Journal of Remote Sensing, 21, 2133-2139.

Deering, D. W. (1989) Field measurements of bidirectional reflectance: In Theory and Applications of Optical Remote Sensing, G. Asrar (Ed.), New York, Wiley and Sons, 14-61.

Duggin, M. J. and Philipson, W. R. (1982) Field Measurement of Reflectance: some major considerations, Applied Optics, 21 (15), 2833-2840.

Goetz, F. H. and Rowan L., C. (1981) Geologic Remote Sensing. Science, 211, 781-791

Grove, C. I., Hook, S. J. and Paylor II, E. D. (1992) Laboratory Reflectance Spectra of 160 Minerals, 0.4 to 2.5 Micrometers, Jet Propulsion Laboratory Pub, 92-2.

Hapke, B. (1993) Theory of Reflectance and Emittance Spectroscopy, UK, Cambridge University Press.

Hooker, S.B. and McClain, C.R. (2000) The calibration and validation of SeaWiFS data. Prog. Oceanogr., 45(3-4), 427-465.

Hunt, G. R., Salisbury, J. W. and Lenhoff, C. J. (1971a) Visible and Near-Infrared spectra of minerals and rocks: III Oxides and Hydroxides, Modern Geology, 2, 195-205.

Hunt, G. R. (1979) Near-infrared (1.3-2.4 $\mathrm{m})$ spectra of alteration minerals - Potential for use in remote sensing, Geophysics, 44, 1974- 1986. 
Irons, J.R., Weismiller, R.A. and Peterson, G.W. (1989) Soil reflectance In Theory and Applications of Optical Remote Sensing, G. Asrar (Ed), New York, Wiley and Sons, 66-106.

King, T. V. V., Clark, R. N., Ager, C. and Swayze, G. A. (1995) Remote mineral mapping using AVIRIS data at Summitville, Proceedings: Summitville Forum 1995, Posey, H. H., Pendelton, J. A. and Van Zyl, D., (Eds.), Colorado Geological Survey Special Publication 38: 59-63.

Krasnopolsky, V. M and W.H. Gemmill,, 2000, Neural network multi-parameter algorithms to retrieve atmospheric and oceanic parameters from satellite data., Proceedings, Second Conference on Artificial Intelligence, AMS, Long Beach, CA, 9-14 January, 2000, pp. 73-76

May, D.A., J. Sandidge, R. Holyer, and J.D. Hawkins, 1997: SSM/I Derived Tropical Cyclone Intensities. Proceedings, 22nd Conference on Hurricanes and Tropical Meteorology, American Meteorological Society, Boston, MA, pp. 27-28.

Milton, E. J., Rollin, E. M. and Emery, D. R. (1995) Advances in Field Spectroscopy, In Danson, F. M. and Plummer, S. E. (1995) Advances in Environmental Remote Sensing, UK: John Wiley and Sons.

Nicodemus, F., Richmond, J. Hsia, J., Ginsberg, I. And Limperis, T. (1977) Geometrical Considerations and Nomenclature for Reflectance, NBS Monograph 160, US Department of Commerce.

Pearson, Robert A. and Donald D. Bustamante, 1999. "Improving Error Structure in Temperature Profile Retrievals from Satellite Observations", 6th International Conference on Neural Information Processing (ICONIP'99), November 16-20, Perth, Australia.

Pfitzner, K., Bartolo, R.E., Ryan, B. and Bollhöfer, A. (2005). Issues to consider when designing a spectral library database, Spatial Sciences Institute Conference Proceedings 2005, Melbourne, Spatial Sciences Institute, ISBN 0- 9581366

Pfitzner, K., Bollhöfer, A. and Carr, G (2006) Protocols for measuring field reflectance spectra. Supervising Scientist Report, In Press, Supervising Scientist for the Alligator Rivers Region, Canberra.

Pidwirny, M. (2006). "Introduction to Geographic Information Systems". Fundamentals of Physical Geography, 2nd Edition.

Posey, H. H., Pendelton, J. A., and Van Zyl, D., (Eds.), Colorado Geological Survey Special Publication 38, 64-69.

Rees, W. G. (2001) Physical Principles of remote sensing, 2nd Edition, UK, Cambridge University Press.

Rollin, E.M., Emery, D.R. and Milton, E.J. (1995) The design of field spectroradiometers, a user's view, In Proceedings of the 21st Annual Conference of the Remote Sensing Society, Nottingham, UK, 555-562.

Salisbury, J. W. (1998) Spectral Measurements Field Guide, Earth Satellite Corporation, April 23 1998, Published by the Defence Technology Information Centre as Report No. ADA362372.

Satterwhite, M. B. and Henley, J. P. (1990) Hyperspectral Signatures (400-2500 nm) of Vegetation, Minerals, Soils, Rocks, and Cultural Features: Laboratory and Field Measurements, U.S. Army Corps of Engineers, Engineer Topographic Laboratories, Fort Belvoir, Virginia 22060-5546.

Schaepman, M. E. (1998) Calibration of a Field Spectroradiometer. Calibration and Characterisation of a non-imaging field spectroradiometer supporting imaging spectrometer validation and hyperspectral sensor modelling, Remote Sensing Laboratories, Department of Geography, University of Zurich, 1998.

Silva (1978) Radiation and instrumentation in remote sensing, In Swain et al., (Ed.): Remote sensing - the quantitative approach, McGraw \& Hill, 121-135. 


\title{
Biomass of Fast-Growing Weeds in a Tropical Lake: An Assessment of the Extent and the Impact with Remote Sensing and GIS
}

\author{
Tasneem Abbasi, K.B Chari and S. A. Abbasi \\ Centre for Pollution Control \& Environmental Engineering \\ Pondicherry University \\ India
}

\section{Introduction}

The Oussudu watershed is situated at $11^{\circ} 57^{\prime}$ North and $77^{\circ} 45^{\prime}$ East on either side of the border separating the Union Territory of Puducherry and the Indian state of Tamil Nadu (Figure 1). Apart from playing a crucial role in recharging the ground water aquifers, the Oussudu watershed also harbors rich flora and fauna (Chari and Abbasi, 2000; 2002; 2005). This watershed supports Puducherry's largest inland lake Oussudu which is also called Ousteri (a Tamil language hybrid of Oussudu and eri, meaning Oussudu lake) with a surface area of $8.026 \mathrm{Km}^{2}$ and shore line length of $14.71 \mathrm{Km}^{2}$. Oussudu lake is such an important wintering ground for migratory birds that it has been identified as one of the heritage sites by IUCN (Interactional Union for Conservation of Nature) and has been ranked among the most important wetlands of Asia (Scott 1989).

In the recent past, Oussudu lake and its watershed have been subject to enormous pressures due to the increasing population, industrialization and urbanization. The resultant inputs of pollutants - rich in nitrogen and phosphorous - has provided aquatic weeds an opportunity to grow uncontrollably in the lake to the exclusion of other flora. This has led to a defacing of the lake by large patches of ipomoea (Ipomoea carnia) and other weeds.

\section{Methodology}

\subsection{Biomass estimation}

The biomass estimation was done using the total harvest method as per APHA (2005). Brass rings of $31 \mathrm{~cm}$ diameter and $0.5 \mathrm{~m}$ length were used as a sampling units. These rings were placed at 5 representative sites (Figure 2). All the macrophytes that were within the circumference of the rings were then harvested, segregated, identified, packed in polythene covers and labeled appropriately. Some of the samples included grossly decayed plant material which had become unidentifiable. Such biomass was recorded as 'mixed phytomass'.

The samples were washed under the running tap to remove the debris and silt and were placed in a cloth bag. To this bag a piece of strong thread was tied and the bag was swirled till all the excess water was removed by the centrifugal force due to the swirling action. At 

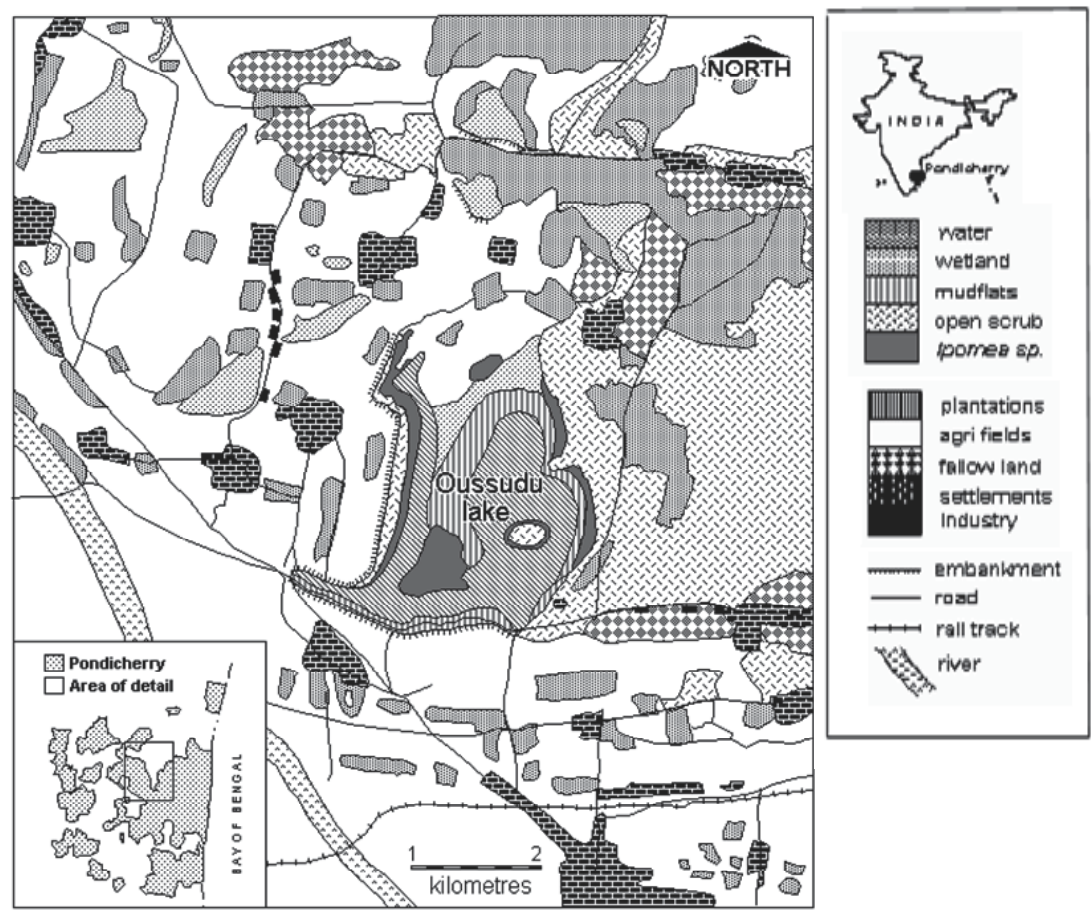

Fig. 1. Location and land use/land cover of the Oussudu catchment

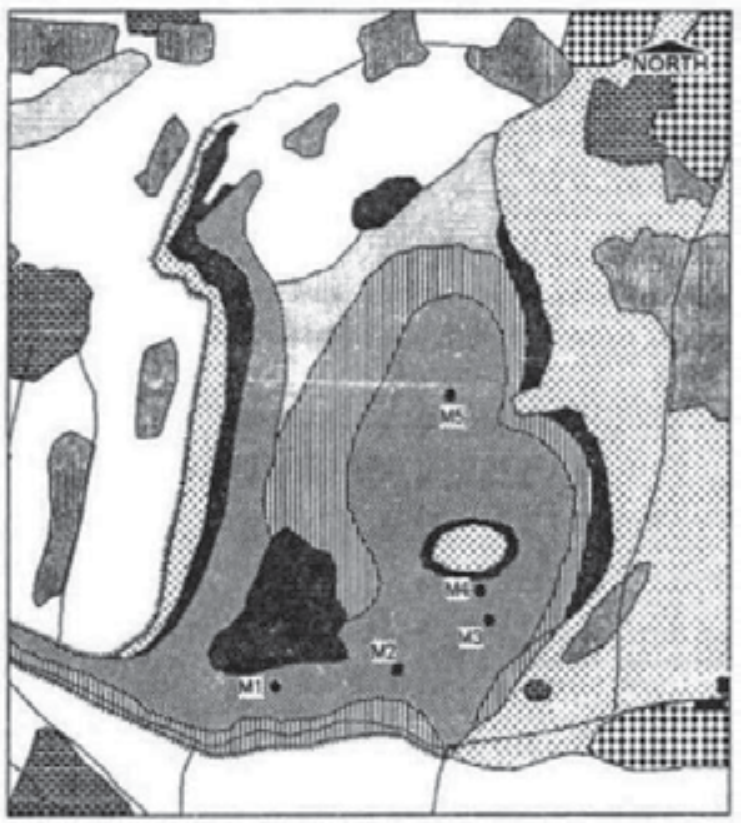

Fig. 2. Location of the sampling stations (MI, M2, M3, M4, MS) for estimating biomass in Oussudu lake 
this point the samples were weighted for their fresh weight, also called the wet weight. The samples were then oven dried at $105^{\circ} \mathrm{C}$ to a constant weight, and their dry weight was taken The moisture content was calculated as follows:

$$
\text { Moisture, } \%=\frac{(\text { Fresh weight }- \text { dry weight }) \times 100}{\text { Fresh weight }}
$$

\subsection{Remote sensing and GIS}

The area covered by Ipomoea was estimated using remote sensing and GIS. A satellite imagery, IRS-ID L1SS Ill, was processed using the image processing software Image Analyst 8.2 and the GIS software MapInfo Professional 5.5 (Abbasi and Abbasi, 2010a). The image (Figure 1) was then classified for the land cover / land use categories as per the system adopted from Avery and Berline (1992).

The classified image was interpreted by means of visual observation (on-site verification). Five locations were chosen for biomass essay on the basis of achieving representativeness in terms of a) lake depth, b) extent of infestation, and c) proximity to population clusters.

\section{Results and discussion}

The dominant phytomass species at each of the five locations and the overall biomass density at each location are presented in Table 1. Lake-wise averages, computed on this basis, are presented in Table 2. This data, as well as visual observations indicate that Oussudu lake is heavily infested with Ceratophyllum demersum and Hydrilla verticillata - two of the world's most dominant submersed weeds. The weeds form such dense mats in some parts of the lake that it is impossible to cast dragnets for capturing fishes there (Chari and Abbasi, 2005).

\begin{tabular}{|c|c|c|c|c|c|c|}
\hline Site & $\begin{array}{l}\text { Depth } \\
(m)\end{array}$ & $\begin{array}{l}\text { Seechi } \\
\text { depth (m) }\end{array}$ & Dominant macrophyte & $\begin{array}{l}\text { Fresh weight } \\
\mathrm{g} \mathrm{m}^{-2}\end{array}$ & $\begin{array}{l}\text { Dry weight } \\
\mathrm{g} \mathrm{m}^{-2}\end{array}$ & $\begin{array}{l}\text { Moisture } \\
\text { content (\%) }\end{array}$ \\
\hline \multirow[b]{2}{*}{ M1 } & \multirow[b]{2}{*}{0.48} & \multirow[b]{2}{*}{0.34} & Ceratophyllum sp. & 2576 & 317 & $87.7 \%$ \\
\hline & & & Hydrilla sp. & 5 & 1 & $85.6 \%$ \\
\hline \multirow[b]{2}{*}{ M2 } & \multirow[b]{2}{*}{0.62} & \multirow[b]{2}{*}{0.59} & Ceratophyllum sp. & 268 & 31 & $88.4 \%$ \\
\hline & & & Hydrilla sp. & 676 & 74 & $89.1 \%$ \\
\hline \multirow[t]{2}{*}{ M3 } & 0.29 & -- & Ceratophyllurn sp. & 864 & 97 & $88.7 \%$ \\
\hline & & & Mixed phytornass & 555 & 61 & $89.1 \%$ \\
\hline M4 & 0.45 & 0.39 & Ceratophyllum sp. & 439 & 47 & $89.4 \%$ \\
\hline M5 & 0.06 & -- & Cera tophyllum sp. & 849 & 117 & $86.2 \%$ \\
\hline
\end{tabular}

Table 1. Biomass density in Oussudu lake at five locations

The species, Ceratophyllum, is the most widespread and present at all the sites (Table 1, Figure 3). The fresh weight of this species varies between $268 \mathrm{~g} \mathrm{~m}^{-2}$ and $2576 \mathrm{~g} \mathrm{~m}^{-2}$, with an average of $999 \mathrm{~g} \mathrm{~m}^{-2}$. The dry weight varies between $31 \mathrm{~g} \mathrm{~m}^{-2}$ and $317 \mathrm{~g} \mathrm{~m}^{-2}$, with an average of $122 \mathrm{~g} \mathrm{~m}^{-2}$ (Table 2, Figure 3). The moisture content, with respect to fresh weight, varies between $89.4 \%$ and $87.67 \%$, with an average of $88.1 \%$ (Table 2, Figure 5). 


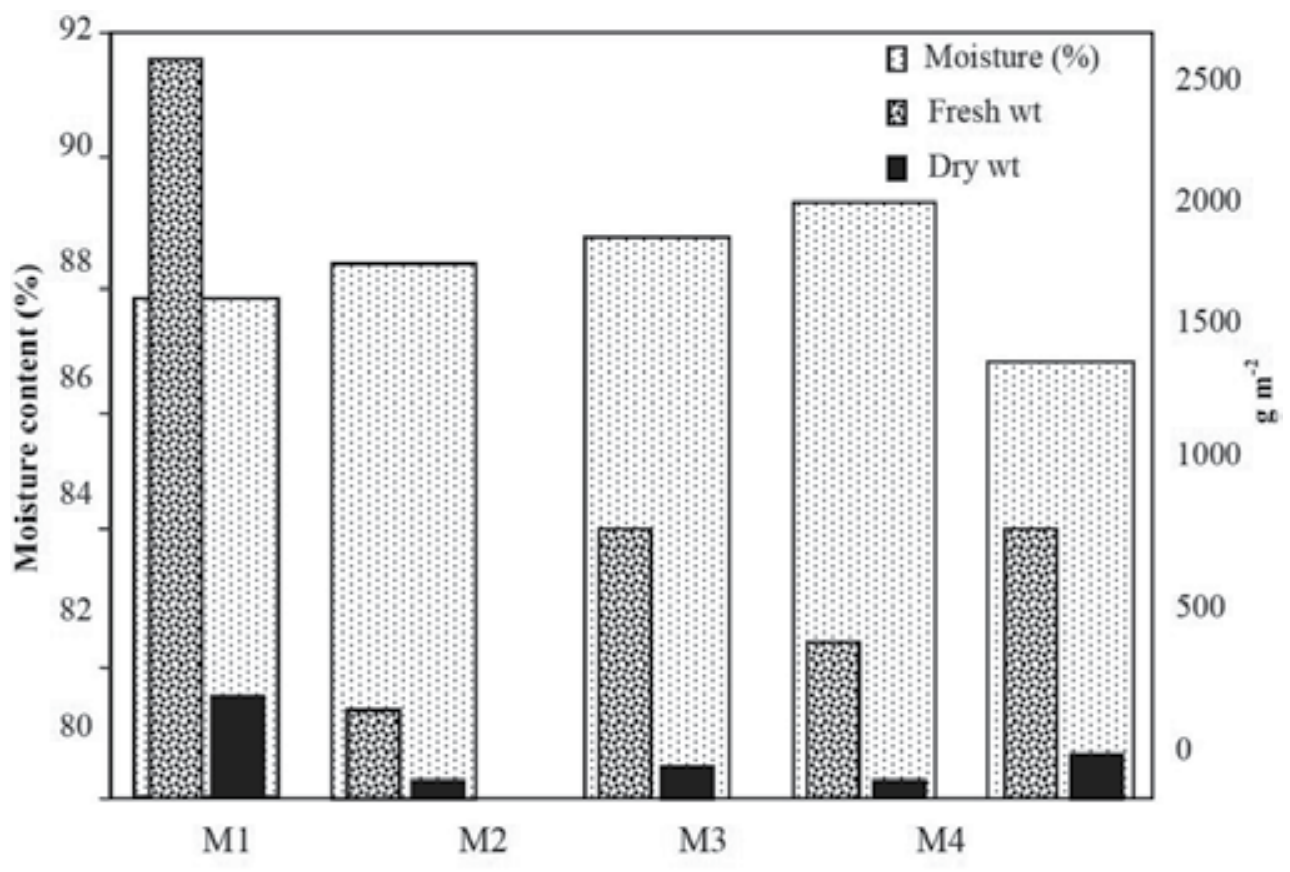

Sampling stations

Fig. 3. Distribution of biomass of Ceratophyllum demersum at various locations in Oussudu lake

\begin{tabular}{|l|c|c|c|}
\hline Phytomass species & $\begin{array}{c}\text { Average fresh weight } \\
\left(\mathrm{g} \mathrm{m}^{-2}\right)\end{array}$ & $\begin{array}{c}\text { Average dry weight } \\
(\mathrm{g} \mathrm{m}-2)\end{array}$ & $\begin{array}{c}\text { Average moisture } \\
\text { content }(\%)\end{array}$ \\
\hline Ceratophyllum $\mathrm{sp}$. & 999 & 122 & 88.1 \\
\hline Hydrilla sp. & 340 & 38 & 87.3 \\
\hline Mixed phytornass & 555 & 61 & 89.1 \\
\hline
\end{tabular}

Table 2. The average fresh weight, dry weight and moisture content of phytomass in Oussudu lake.

Like Ranuncules, Nymphea, and Vallisneria, Ceratophyllum is known to precipitate lime. Also, this species is capable of utilizing bicarbonate ions as a source of carbon (Gupta, 1987).

The other aquatic weed, Hydrilla verticillata, is found at the sites MI and M2 (Table I, Figure 4). The fresh weight of the species varies between $5 \mathrm{~g} \mathrm{~m}^{-2}$ and $676 \mathrm{~g} \mathrm{~m}^{-2}$, with an average of $340 \mathrm{~g} \mathrm{~m}^{-2}$. The dry weight varies between $0.75 \mathrm{~g} \mathrm{~m}^{-2}$ and $74 \mathrm{~g} \mathrm{~m}^{-2}$, with an average of $37 \mathrm{~g} \mathrm{~m}^{-2}$ (Table 2, Figure 4) . The moisture content, with respect to fresh weight varies between $85.6 \%$ and $89.07 \%$, with an average of $87.3 \%$ (Table 2, Figure 5).

Hydrilla, due to its low light compensation (10 - 12 Einsteins $\left.\mathrm{m}^{-2} \mathrm{sec}^{-1}\right)$, is known to grow even at depths where most other plants can't thrive in the aquatic habitats (Gupta, 1987). Indeed the spread of Hydrilla shows a positive correlation with the water depth of the lake (Figure 6).

The mixed phytomass sample collected at site M3, weighed $555 \mathrm{~g} \mathrm{~m}^{-2}$ when fresh, and $61 \mathrm{~g} \mathrm{~m}^{-2}$ when oven-dried. The moisture content measured $89 \%$ of the fresh weight (Table 2, Figure 4). 


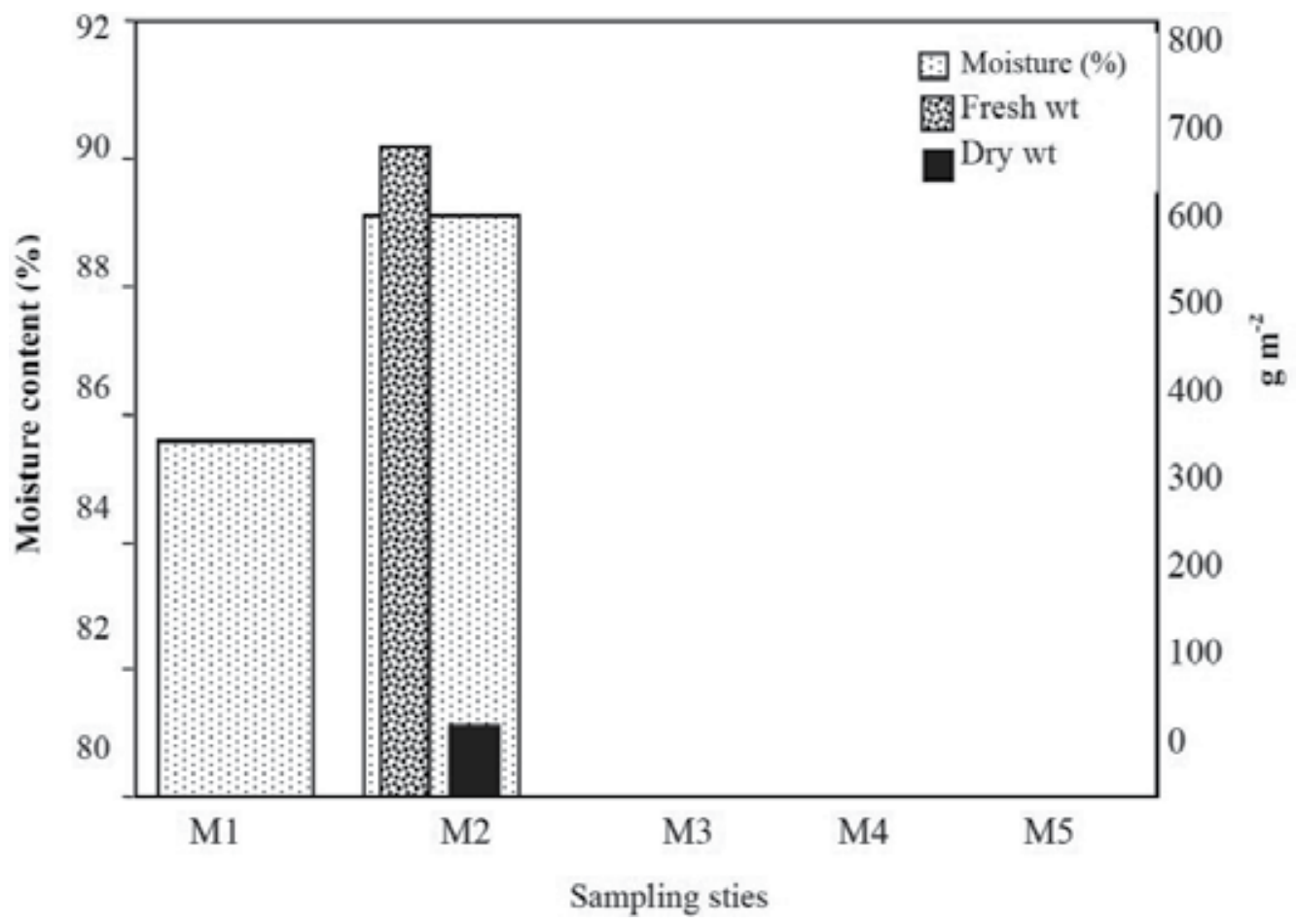

Fig. 4. Biomass of Hydrilla verticillata at the sampling sties

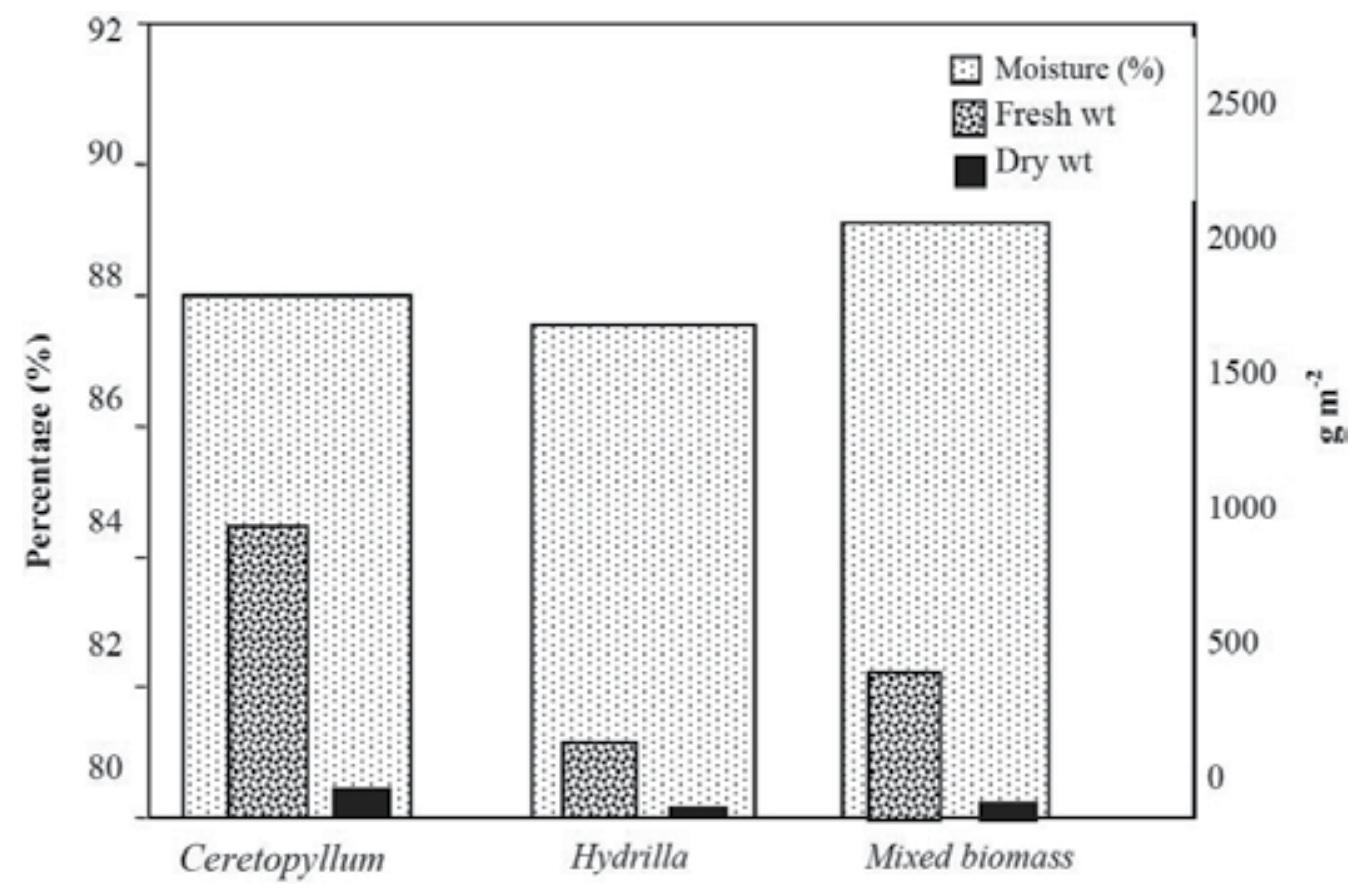

Fig. 5. The average fresh weight, dry weight and moisture content of the macrophytes 


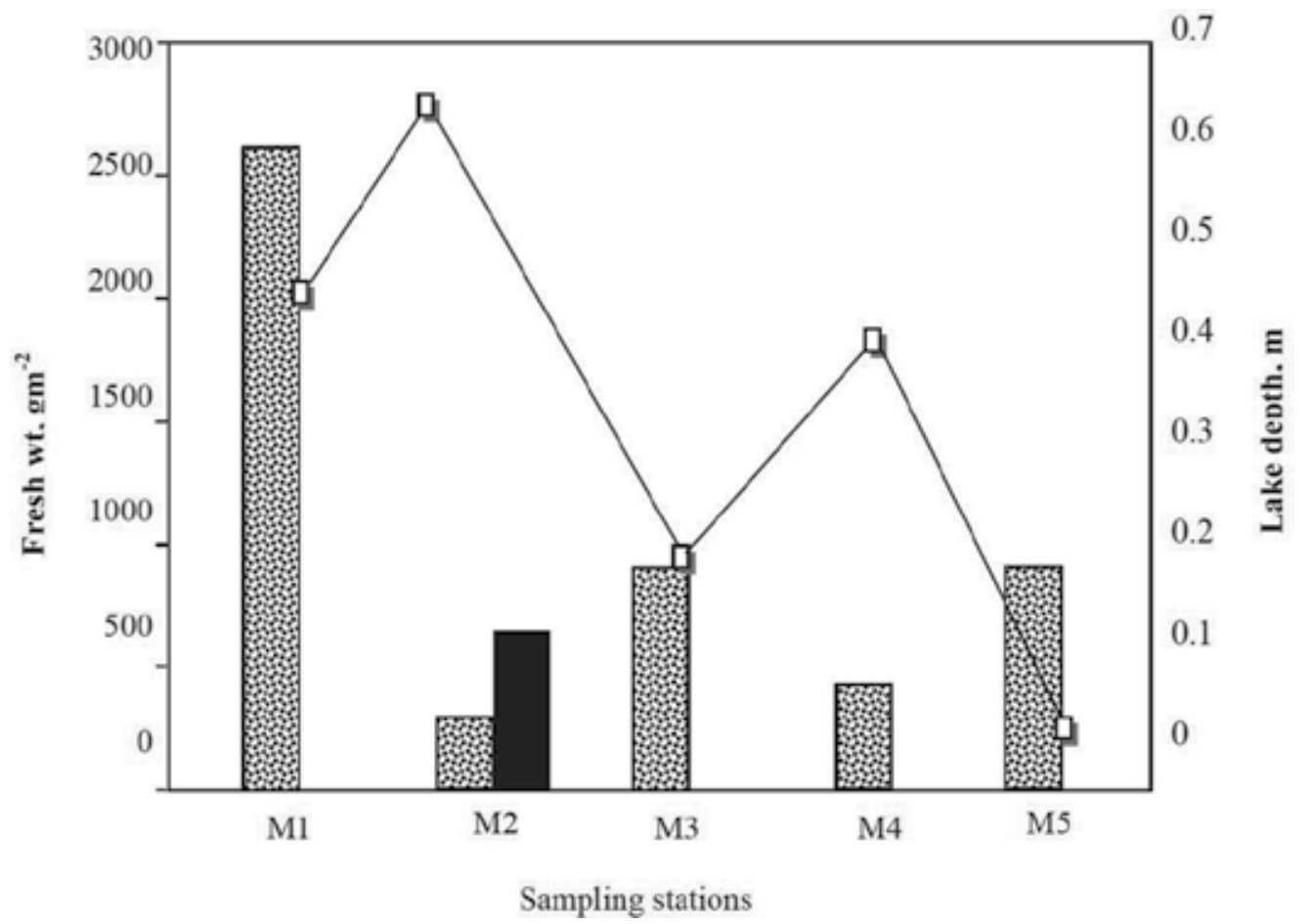

Fig. 6. The distribution of macrophytes at various sites as a function of lake water depth

\subsection{Areal coverage}

According to the remote sensing and GIS studies carried out by the authors, Ipomoea covered an area of $1.16 \mathrm{Km}^{2}$, which is as much as $14 \%$ of the water-spread of Oussudu lake. Huge islands of ipomoea can be seen at the shallower portions of the lake, presenting an unseemly sight and seriously jeopardizing the beauty and recreational value of the lake, besides exacerbating the environmental degradation of the lake as elaborated in the following section.

The presence of rampaging mats of terrestrial and aquatic weeds in Oussudu indicates that the lake is highly polluted and is, as a result, becoming eutrophic or 'obese' (Abbasi and Chari, 2008; Abbasi and Abbasi, 2010 b; Figure 7).

\subsection{Impact on the lake ecosystem}

Colonization of Oussudu by aquatic weeds threatens to upset the lake ecosystem in several ways. These include the following:

i. The thick mats of the weeds prevent sunlight from reaching the submerged flora and fauna, thereby cutting off their energy source. This situation would disfavor several species leading to dwindling of their populations and causing loss of diversity.

ii. Once weeds colonize a water body due to pollution, they deteriorate the water quality further (Abbasi and Nipaney, 1993; Abbasi and Abbasi 2000; Abbasi and Abbasi 2010c). The decaying of the weeds adds to the depletion of dissolved oxygen, and increases the BOD, COD, nitrogen and phosphorus. This also encourages growth of various pathogens which may be harmful to humans. 

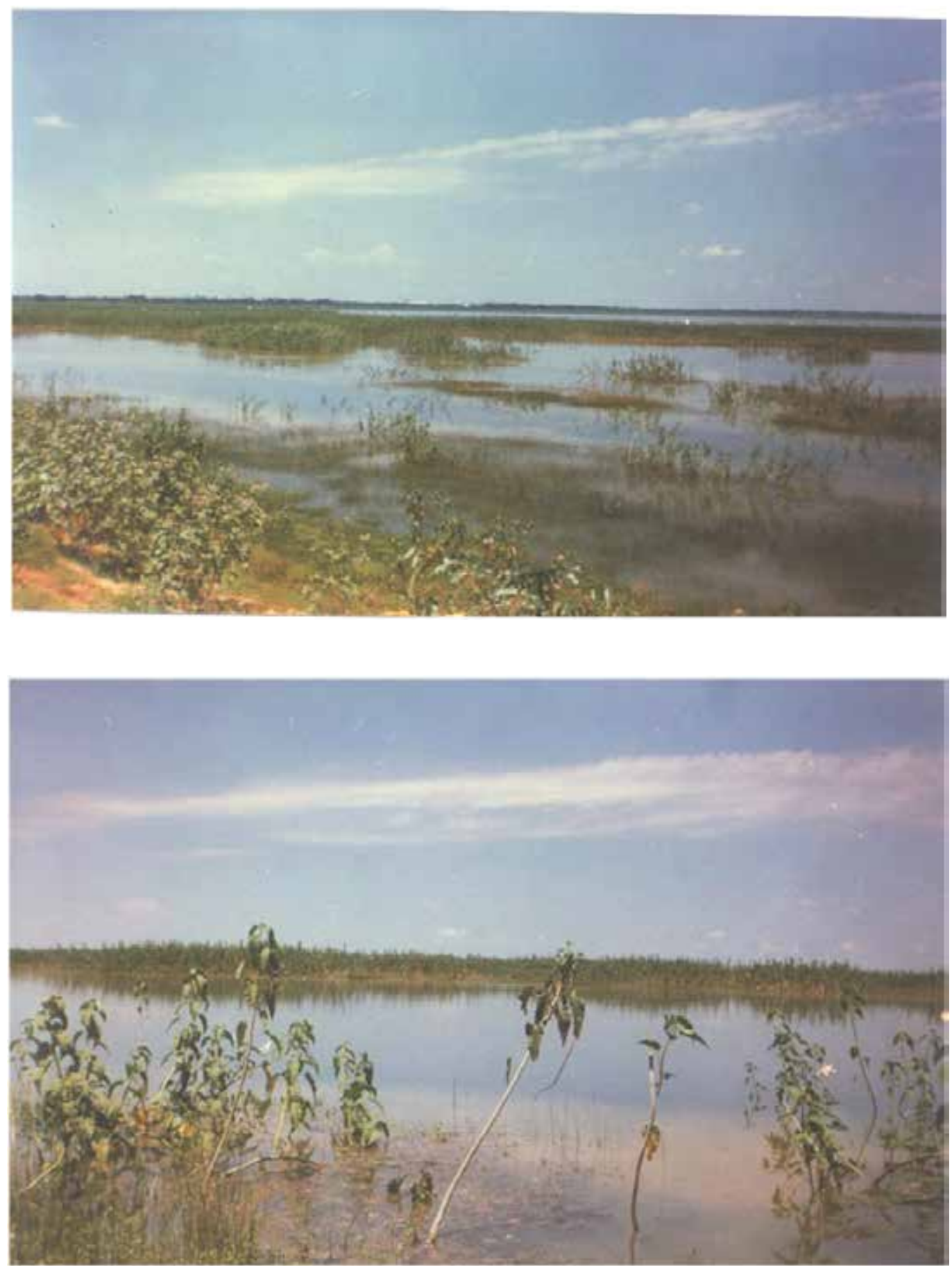

Fig. 7. Ipomoea in Oussudu lake (above) and a closer view of the weed (below) 
iii. The spread of weeds in the lake reduces the area available to fishes and hinders their mobility. The depletion of dissolved oxygen may result in mass fish kills or may favor only certain kinds of fishes, (which can tolerate low oxygen levels), thereby eroding the piscian diversity.

iv. The profuse growth of weeds breaks natural water currents. Consequently the water becomes stagnant, favoring the breeding of mosquitoes and other disease causing vectors.

v. Ipomoea is known to give off exudates which are toxic to certain animals and plants. The extracts of decaying leaves and rhizomes of several aquatic weeds are known for their phytotoxicity (Sankar Ganesh et al., 2008).

vi. Weeds provide ideal habitat for the growth of molluscs, which in turn choke water supply systems (canals and pipes) and impart undesirable taste and odour to water. Mollusks such as snails, are primary hosts to blood and liver flukes the human disease causing pathogens. These mollusks seek shelter, multiply, and find sustenance among the roots of the weeds.

Many of the abovementioned impacts have been documented (Abbasi et al., 2008; 2009).

\section{Remedial measures}

The very high net biomass production in Oussudu lake may hasten the process of wetlandto-land succession, sounding the death-knell for the lake. Hence measures to control the weeds while at the same time blocking further ingress of pollutants in the lake are both very urgent requirements. Several methods of controlling the aquatic macrophytes have been suggested and field-tested for their effectiveness; these have been summarized in Table 3. Of these methods, the one based on weed foraging by the diploid grass carp (Ctenopharyngdon idella, white amur) is the most effective at controlling the growth of aquatic macrophytes and filamentous algae (Cooke et. al., 1996). Hence, using the grass carp would not only control the aquatic weeds but also the filamentous algae of Oussudu lake.

\begin{tabular}{|l|l|l|l|l|}
\hline $\begin{array}{l}\text { Treatment } \\
\text { (one application) }\end{array}$ & $\begin{array}{l}\text { Short-term } \\
\text { effectiveness }\end{array}$ & $\begin{array}{l}\text { Long-term } \\
\text { effectiveness }\end{array}$ & Cost & $\begin{array}{l}\text { Chance of negative } \\
\text { effects }\end{array}$ \\
\hline Sediment removal & E & E & P & F \\
\hline Drawdown of water & G & F & E & F \\
\hline Sediment covers & E & F & P & L \\
\hline Grass Carp & P & E & E & F \\
\hline Insects & P & G & E & L \\
\hline Harvesting & E & F & F & F \\
\hline Herbicides & E & P & F & H \\
\hline
\end{tabular}

$E=$ Excellent $; F=$ Fair $; G=$ Good $; P=$ Poor $; H=H i g h ;$ and $L=$ Low

Table 3. Comparison of lake restoration and management techniques for the control of aquatic weeds (Olem and Flock, 1990) 
The species - C.idella - was earlier introduced by Puducherry's Department of Fisheries in Oussudu lake, but is no longer present now. The triploid variant of this species, which is genetically derived from the diploid grass carp, would preclude any possibility of the spread of the species.

Apart from C. idella, Tilapia zilli and T. aurea also feed voraciously on the macrophytes and the filamentous algae. Introduction of those would help in the reduction of phytomass and speed up the recovery of the lake.

\section{Acknowledgement}

Authors thank the Ministry of Water Resources. Government of India, for financial support.

\section{References}

Abbasi S.A. and Nipaney (1993), Worlds Worst Weed- Impact and Utilization, International book distributors, Dehradun.

Abbasi S.A., Abbasi N., (2000), The likely adverse environmental impacts of renewable energy sources, Applied Energy, 65, (1-4) 121-144.

Abbasi, T., and Abbasi, S.A., (2010a), Remote Sensing, GIS and Wetland Management, Discovery Publishing House, New Delhi vii+411 pages.

Abbasi, T., and Abbasi, S.A., (2010b), Pollution Control, Climate Change and Industrial Disasters, Discovery Publishing House, New Delhi viii+301 pages.

Abbasi, T., and Abbasi, S. A., (2010c), Production of clean energy by anaerobic digestion of phytomass-New prospects, for a global warming amelioration technology, Renewable and Sustainable Energy Reviews,14, 1653-1659.

Abbasi, T., Chari, K.B., and Abbasi, S. A., (2008), Oussudu lake, Pondicherry, India: A survey on socio-economic interferences, The Indian Geographical Journal, 83(2), 149162.

Abbasi, T., Chari, K.B., and Abbasi, S. A., (2009), Spatial and temporal patterns in the water quality of a major tropical lake - Oussudu, Pollution Research, 28 (3), 353-365.

APHA, (2005), Standard Methods for the Examination of Water and Waste Water, American Public Health Association, Washington DC.

Avery T.E., Berline G.L. (1992), Fundamentals of Remote Sensing and Air-photo Interpretation, MacMillan Publishing Company, New York.

Chari, K.B., \& Abbasi S.A. (2000). Environmental Conditions of Oussudu Watershed, Pondicherry, India: An Integrated Geographical Assessment, The Indian Geographical Journal, 75 (2) 81-94.

Chari K. B. and Abbasi S.A. (2002) Application fo GIS and remote sending in the environmental assessment of Oussude Watershed, Hydrology Journal, 25(4) 13-30.

Chari K.B., Abbasi S.A. (2005), A study on the fish fauna of Oussudu - A rare freshwater lake of South India, International Journal of Environmental Studies, 62, (2) 137-145.

Gupta O.P. (1987), Aquatic Weed Management - a Text Book and Manual, Today and Tommorrow's Printers and Publishers, New Delhi.

Olem, H., and G. Flock (eds) (1990), The lake and Reservoir Restoration Guidance Manual, EPA 440/4-90-00 6, USEPA. Washington DC. 
Sankar Ganesh P., Sanjeevi R., Gajalakshmi S., Ramasamy E.V., Abbasi S.A. ( 2008), Recovery of methane-rich gas from solid-feed anaerobic digestion of ipomoea (Ipomoea carnea), Bioresource Technology, 99, (4) 812-818.

CV7 Biomass fast-growing_GIS 27.12.10 


\title{
Application of Artificial Neural Network (ANN) to Predict Soil Organic Matter Using Remote Sensing Data in Two Ecosystems
}

\author{
Shamsollah Ayoubi ${ }^{1}$, Ahmahdreza Pilehvar Shahri ${ }^{1}$, \\ Parisa Mokhtari Karchegani ${ }^{2}$ and Kanwar L. Sahrawat ${ }^{3}$ \\ ${ }^{1}$ Department of Soil Science, College of Agriculture, \\ Isfahan University of Technology, Isfahan, \\ ${ }^{2}$ Department of Soil Science, College of Agriculture, \\ Islamic Azad University, Khorasgan Branch, Isfahan \\ ${ }^{3}$ International Crops Research Institute for the Semi Arid Tropics \\ (ICRISAT), Patancheru, Andhra Pradesh \\ 1,2Iran \\ India
}

\section{Introduction}

\subsection{Importance of soil organic matter prediction}

Concern over global problems induced by rising $\mathrm{CO}_{2}$ has prompted attention on the role of forests and pastures as carbon 'storage' because forests and pastures store a large amount of carbon in vegetation biomass and soil. Soil organic matter (SOM) plays a critical role in soil quality and has the potential to cost-effectively mitigate the detrimental effects of rising atmospheric $\mathrm{CO}_{2}$ and other greenhouse gas emissions that cause global warming and climate change(Causarano-Medina, 2006).

$\mathrm{SOM}$, an important source of plant nutrients is itself influenced by land use, soil type, parent material, time, climate and vegetation (Loveland \&Webb, 2003). Important climatic factors influencing SOM include rainfall and temperature. Within the same isotherm, the SOM content increases with increase in rainfall regime. For the same isohyet, the SOM content increases with decrease in average annual temperature. Within the same landscape unit, the SOM pool rises with increase in clay content and available water-holding capacity in the root zone (Lal, 2001). SOM is also one of the important factors affecting soil quality, sustainability of agriculture, soil aggregate stability and crop yield (Loveland \&Webb, 2003). Dynamic soil properties such as organic carbon as well as static soil properties need to be monitored and managed (Sullivan et al., 2005). The application of quantitative soillandscape modeling (McKenzie et al., 2000), precision agriculture (Thomasson et al., 2001), and global soil carbon monitoring (Post et al., 2001) necessitate more affordable (Lu et al., 1997), accurate (Blackmer \&White, 1998), and simple methods to estimate SOM concentration. Study in environmental monitoring, modeling need good quality soil data generated in a cost-effective manner to develop, rapid and cost-effective methods of soil C 
analysis. There is need to develop methods that use the minimum number of soil analysis to reduce and minimize cost for preparing SOM maps to support precision agriculture (Wetterlind et al., 2008), quantitative soil-landscape modeling (McKenzie et al., 2000) and global soil C monitoring (Post et al., 2001).

\subsection{SOM and remote sensing}

High resolution secondary information such as RS could be used to provide greater details as an alternative to less extensive soil measurements like SOM (Causarano-Medina, 2006). It is hypothesized that RS imagery may play a role in aiding the detection of SOM variability in natural landscapes through the relationship between SOM and forage growth conditions, since the latter has been shown to be highly correlated with RS data

Recent research has suggested that spectral bands are correlated with soil properties and could minimize the cost of prediction of soil physical, chemical and biological characteristics (e.g. Roy et al., 2006). SOM plays a critical role in influencing chemical and physical processes in the soil environment; and SOM also affects the shape and nature of a soil reflectance spectrum. Generally, soils with higher in organic matter appear darker. It is proposed that correlation among reflectance in spectral bands and soil properties could provide cost effective prediction of SOM (Ladoni et al., 2010).

The wide spectral range proposed by different workers to estimate SOM content suggests that SOM is an important soil component across the entire spectrum. Soil minerals, organic matter, and moisture are the major components of soils, with distinct spectral features in the visible and near-infrared regions (Henderson et al., 1992). The essential characteristics related to various constituents of SOM generally occur in the mid to thermal-infrared range (2500-25, 000nm), but their feeble overtones and combinations of these essential vibrations due to the curving of $\mathrm{NH}, \mathrm{OH}$ and $\mathrm{CH}$ groups dominate the NIR (700-2500 $\mathrm{nm}$ ) and the VIS (400-700 nm) portions of the electromagnetic spectrum(Shepherd \&Walsh, 2002). In the VIS range, important bands for the prediction of SOM are around 410, 570,660and 520, 540 and $550 \mathrm{~nm}$ (Brown et al., 2006). Organic matter decreases the reflectance in the range 550-700 $\mathrm{nm}($ Galvao \&Vitorello, 1998) or it results in a concave curve for larger OM contents and a convex one for smaller amounts of OM in the 500-1300 nm range (Huete \&Escadafal, 1991). Henderson et al. (1992) found that reflectance of organic matter extracted from four Indiana agricultural soils strongly correlated with organic $C$ content and significantly responded to the concentrations of $\mathrm{Fe}$ and $\mathrm{Mn}$ oxides in the visible range for soils developed from the same parent material. A portable near-infrared spectrophotometer designed by Sudduth and Hummel (1993) was used to predict soil organic matter $\left(R^{2}=0.85\right)$, moisture $\left(R^{2}=0.94\right)$, and CEC $\left(\mathrm{R}^{2}=0.85\right)$ in soils from Illinois (Sudduth \&Hummel, 1993); and it concluded that the prediction of these soil properties became less accurate as the geographic range of samples increased .

Recently, NIR technique was developed for in-field analysis of soil properties (Christy et al., 2003). Near-infrared spectra are produced by weak overtones and combinations of fundamental vibrational bands for $\mathrm{H}-\mathrm{C}, \mathrm{H}-\mathrm{N}$, and $\mathrm{H}-\mathrm{O}$ bonds from the near- and midinfrared region (Christy et al., 2003; Sorenson \&Dalsgaard, 2005). Since organic matter in the soil mainly consists of $\mathrm{C}, \mathrm{H}, \mathrm{O}$ and $\mathrm{N}$ elements, the NIR measurements are greatly affected (Sorenson \&Dalsgaard, 2005). Christy et al. (2003) showed that NIR spectra were related to soil carbon in agricultural fields of central Iowa and Kansas. Suchenwirth et al. (2010) modeled the distribution of organic carbon stocks in floodplain soils with remote sensing data and additional geoinformation. 
Chen et al. (2005) examined the relationship between SOM content in the upper $15 \mathrm{~cm}$ of the soil profile and selected parts of the spectrum from the image by two different methods. In the first method, an equation was used to calculate the surface SOM concentrations for each pixel with the resulting values grouped into one of eight classes. In the second method, the image was classified into 20 groups and the above equation was applied to the classified result. Finally, the original 20 groups were sub-grouped further into eight classes. There was good agreement between the measured and the predicted values for both the methods in all of the images (Chen et al., 2005).

\subsection{Artificial neural network modeling}

ANNs provide a method to characterize synthetic neurons to solve complex problems in the same manner as the human brain does. For many years, especially since the middle of the last century, an interest in studying the brain's mechanism and structure has been increasing. This growing research interest has led to the development of new computational models, connectionist systems or ANNs, based on the biological background, for solving complex problems like pattern recognition, and fast information processing and adaptation (Huang, 2009).

Neural networks use machine learning based on the concept of self-adjustment of internal control parameters. An artificial neural network is a non-parametric attempt to model the human brain. Artificial neural networks are pliable mathematical structures that are capable of identifying complex non-linear relationships among input and output data sets. The principal differences between the various types of ANNs are arrangement of neurons and the many ways to assess the weights and functions for inputs and neurons (training).

Application of statistical methods, in SOM estimation, has been limited, because of oversimplification, illiteracy of complex nonlinear interactions. Another approach in dealing with nonlinear systems is to use non-linear methods such as ANN. ANN has been successfully used in the classification and prediction (Zhang \&McGrath., 2004). The potential benefits of this method include greater prediction credibility, cost-effective estimation and solving complex problems involving nonlinearity and uncertainty.

There are a variety of ANN architectures, such as multi-layer perceptron. The multilayer perceptron (MLP) neural network has been designed to function well for non-linear phenomena. A feed forward MLP network consists of a layer of input neurons and output layer with selected number of input and output neurons, respectively with one or more hidden layers in between the input and the output layer with some number of neurons on each (Melesse, 2005).

\subsection{Objective}

No investigation has been made in the semiarid regions to use non-linear and intelligent models to predict surface SOM using imagery data. Therefore, the objectives of this study were to (i) predict SOM in the hilly regions using an ANN and multiple linear regression (MLR) modeling, (ii) compare the efficacy of two models to predict SOM using remotely sensed data, and (iii) identify the most important bands and ratios for explaining the variability of SOM based upon the ANN modeling using sensitivity analysis at two selected sites under rangeland and forested land in central and western Iran, respectively. 


\section{Methods and materials}

\subsection{Description of the studied sites}

This study was conducted at two sites in the hilly region. One site was under natural rangeland and located in Semirom region, Isfahan province, Central Iran (site1), the second site was under natural forested land located in Lordegan region in the Charmahal and Bakhtirai province, west of Iran (site 2) (Fig.1). General description of the selected sites is presented in Table 1. Soil temperature and moisture regimes of the selected sites were mesic and xeric for site 1 , and thermic and xeric for site 2, respectively.

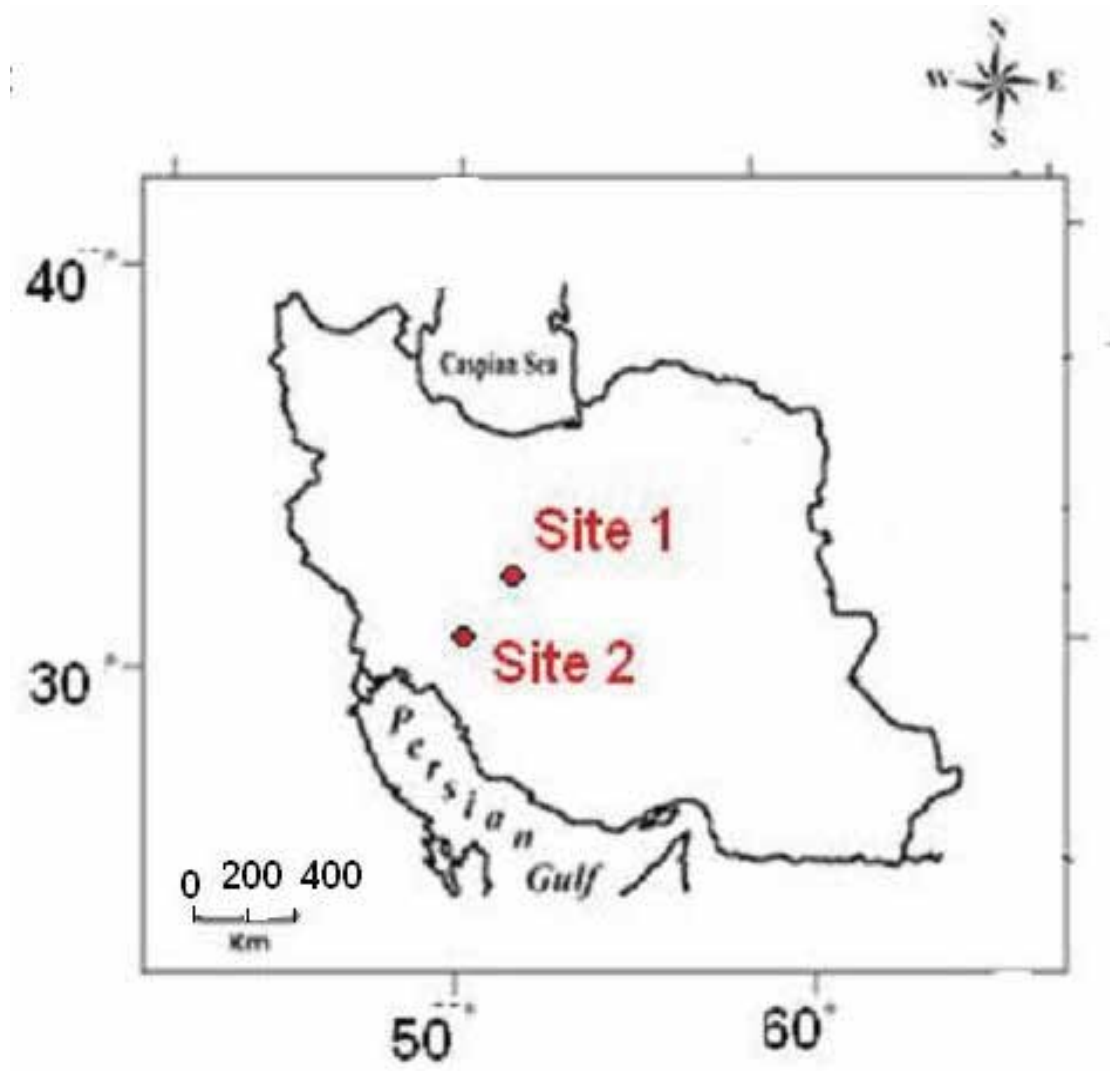

Fig. 1. Location of the sites studied in western and central Iran

\begin{tabular}{|c|c|c|c|c|c|c|c|c|c|}
\hline Site & $\begin{array}{l}\text { Land } \\
\text { use }\end{array}$ & Long. & Lat. & $\begin{array}{c}\text { Elevation } \\
\text { (a.s.l) } \\
\text { (m) }\end{array}$ & $\begin{array}{c}\text { Mean } \\
\text { annual } \\
\text { temperature } \\
\left({ }^{\circ} \mathrm{C}\right)\end{array}$ & $\begin{array}{c}\text { Mean } \\
\text { annual } \\
\text { precipitation } \\
(\mathrm{mm})\end{array}$ & $\begin{array}{c}\text { Lateral } \\
\text { slopes } \\
(\%)\end{array}$ & $\begin{array}{c}\text { Soil } \\
\text { classifications } \\
\text { (USAD, 2008) }\end{array}$ & $\begin{array}{l}\text { Parent } \\
\text { material }\end{array}$ \\
\hline 1 & $\begin{array}{l}\text { Range } \\
\text { land }\end{array}$ & 39 & ${ }^{\circ} 18^{\prime} \mathrm{N}$ & 2500 & 10.6 & 350 & $20-30$ & $\begin{array}{c}\text { Typic } \\
\text { Calcixerepts }\end{array}$ & $\begin{array}{c}\text { Quaternary } \\
\text { deposits }\end{array}$ \\
\hline 2 & Forest & $50^{\circ} 32^{\prime}$ & $32^{\circ} 03^{\prime} \mathrm{N}$ & 1800 & 15 & 600 & $20-40$ & $\begin{array}{c}\text { Typic } \\
\text { Calcixerept }\end{array}$ & $\begin{array}{c}\text { Quaternary } \\
\text { deposits }\end{array}$ \\
\hline
\end{tabular}

Table 1. General description of the two selected sites in central and west of Iran 


\subsection{Soil sampling and laboratory analysis}

A total of 125 soil samples were collected from the study site1 in October 2008 following grid sampling strategy on a regular $350 \times 350 \mathrm{~m}$ grid, and a total of 108 soil samples were collected at site 2 in September 2009 following a randomly stratified sampling scheme (Fig. 2). Prior to analyses for physical and chemical characteristics, the soil samples were air-dried for two weeks and ground to pass through a $2 \mathrm{~mm}$ sieve to remove stones, roots and large organic residues. Soil organic carbon was determined using a wet combustion method (Nelson \& Sommers, 1982).
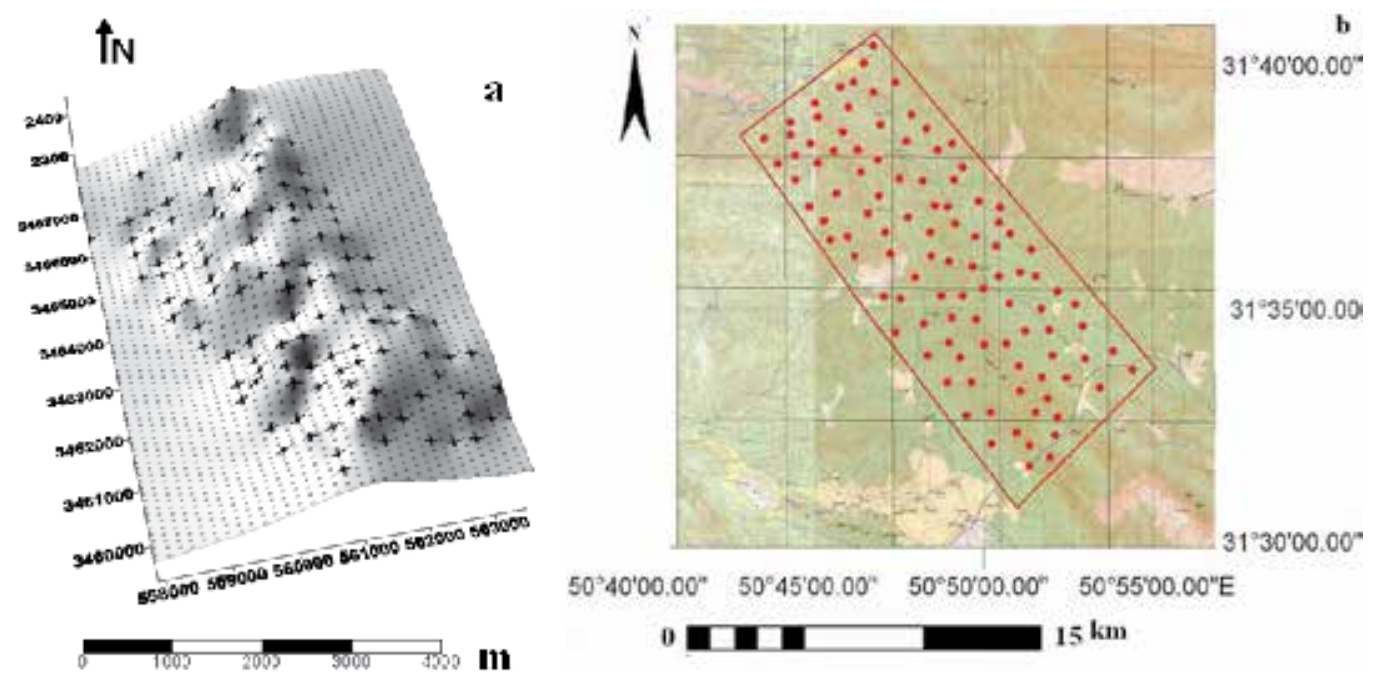

Fig. 2. Spatial distribution of the sampling points within the landscapes (a): Hilly range lands in Semiroum region, central Iran, (b): hilly forest Querqus in Lordegan region, western Iran.

\subsection{Descriptive statistical analysis}

Descriptive statistics such as means, minimum, maximum, coefficient of variation (CV) and skewness were determined (Wilson \&Gallant, 2000). The coefficient of variation was utilized to explain the variability in soil organic carbon.

\subsection{Remote sensing data}

The remote sensing data used to build the model in this study included the Landsat ETM band 1, 2, 5 and band 7 and combination of bands 3 and 4 for the calculation of NDVI, with spatial resolution of $30 \times 30 \mathrm{~m}$. The acquisition date of the image was 22 June 2001 . The subset image covering the study area was then geometrically corrected using the landform map of Iran 1:25000 scale as the reference. All image processing was performed using ILLWIS software.

The spectral characteristics used in this study consisted of single band data (i.e. the digital number of band 1, 2, 5 and 7) and vegetation index (NDVI). These data were then used as inputs in ANN modeling.

The NDVI is known to be closely related to biophysical crop characteristics, such as absorption of photosynthetic active radiation and productivity (Rondeaux, 1996; Pettorelli, 
2005) and its values range between -1 and +1 . High positive values usually reveal the occurrence of dense green vegetation, pointing to an optimum state of water and nutrient supply. Low NDVI values express limited photosynthetic activity and negative ones correspond to sparse ground coverage (Huete, 1994). NDVI was calculated as the reflectance ratio from near-infrared (NIR) and red channel (R) of satellite or airborne sensors as follows:

$$
N D V I=\frac{N I R-R}{N I R+R}
$$

\subsection{Artificial neural network development}

In this research, MLP with back propagation learning rule was used. The MLP network (Fig.3) is the most commonly used network in engineering problems relative to non-linear mapping (Haykin, 1994). Back propagation was developed by Rumelhart et al. (1986) and is one of the widely implemented of all neural network paradigms. It is based on a multilayered feed forward topology with supervised learning. Back propagation uses a type of gradient descent method, following the slope of the error surface downwards toward its minimum (Rumelhart, 1986; Melesse, 2005).

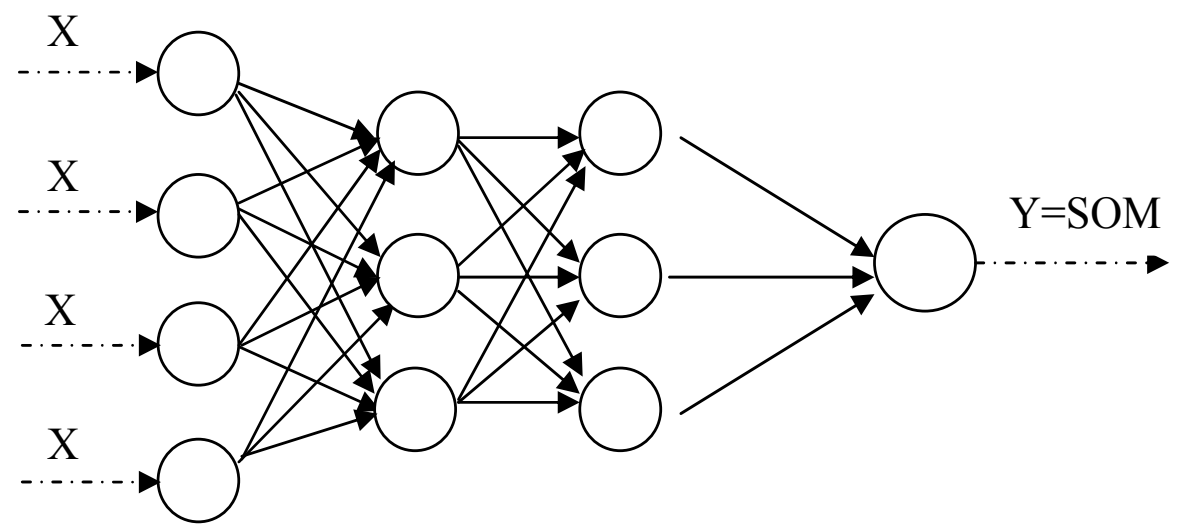

Input layer Hidden layer Output layer

Fig. 3. Multilayer perceptron neural network used for the estimation of SOM

The learning process is performed using the well known back propagation (BP) algorithm, which is based on the delta learning rule (Rumelhart, 1986). Two main processes are implemented in a BP algorithm, a forward pass and a backward pass. In the forward pass, an output pattern is presented to the network and its effect propagated through the network, layer by layer. For each neuron, the input value is calculated as follows (Haykin, 1994): 


$$
n e t_{i}^{n}=\sum_{j=1}^{m} w_{j i}^{n} \cdot O_{j}^{n-1}
$$

where

$n e t_{i}^{n}$ is the input value of $i^{\text {th }}$ neuron in $n^{\text {th }}$ layer;

$w_{j i}^{n}$ is the connection weight between $i^{\text {th }}$ neuron in $n t h$ layer and $j^{\text {th }}$ neuron in the $(n-1)^{\text {th }}$ layer;

$O_{j}^{n-1}$ is the output of $j^{\text {th }}$ neuron in the (n-1) th layer;

$m$ is the number of neurons in the $(\mathrm{n}-1)^{\text {th }}$ layer.

In each neuron, the value calculated from Eq. (2) is transferred by an activation function. The common function for this purpose is the sigmoid function, and is given by:

$$
\operatorname{Sig}\left(n e t_{j}^{n}\right)=1 /\left(1+\operatorname{Exp}\left(-n e t_{j}^{n}\right)\right)
$$

The output of each neuron computed and propagated through the next layer until the last layer. Then, the final computed output of the network is prepared to compare with the target output. In this regard, an appropriate objective function such as the root mean square error (RMSE) is calculated as follows (Degroot, 1986).

$$
R M S E=\sqrt{\frac{\sum_{i=1}^{n_{p}} \sum_{j=1}^{n_{o}}\left(T_{p j}-O_{p j}\right)^{2}}{n_{p} \cdot n_{o}}}
$$

where

$T_{p j}$ is the jth element of the target output related to the pth pattern;

$O_{p j}$ is the computed output of $\mathrm{jth}$ neuron related to the pth pattern;

$n_{p}$ is the number of patterns;

$n_{o}$ is the number of neurons in the output layer.

After calculating the objective function, the second step of the BP algorithm, i.e. the backward process is started by back propagation of the network error to the previous layers. Using the gradient descent technique, the weights are adjusted to reduce the network error by performing the following equation (Rumelhart, 1986):

$$
\left.\Delta w_{j i}^{n}\right|_{(m+1)}=\eta \frac{\partial(E)}{\partial w_{j i}^{n}}+\left.\alpha \Delta w_{j i}^{n}\right|_{(m)}
$$

where,

$\left.\Delta w_{j i}^{n}\right|_{(m+1)}$ is the weight increment at the $(\mathrm{m}+1)$ th iteration (Epoch);

$\eta$ is the learning rate

$\alpha$ is the momentum term $(0 \leq \eta, \alpha \leq 1)$.

This process was continued until the allowable network error was obtained. For designing the artificial neural network, the measured field data were used. The data set was shuffled; $60 \%$ of them were used for the learning process, $20 \%$ sets were used for testing, and the remaining $20 \%$ sets were used for verification, respectively. The data sets for learning, testing, and verification processes were selected randomly at different points on the landscape in the field to avoid bias in estimation. In this study, ANN modeling was 
performed using MATLAB software package (MATLAB. 2008). The number of neurons in input and output layers depend on the independent and dependent variables, respectively. The network was designed with 5 parameters (i.e. the digital number of band 1, 2, 5 and 7 and NDVI) as input pattern and SOM as the output parameters.

The number of hidden layers, number of neurons in the hidden layers, the parameter $\alpha$, and the number of iterations were selected by calibration through several test runs and trial and error (Marquardt Levenberg learning rule). Various activation functions were tested for MLP neural networks and the tansigmoid function presented the best results.

\subsection{Sensitivity analysis}

Sensitivity analysis was performed so that a better understanding of the importance of each input on the output could be examined. Thus, sensitivity analysis was performed to investigate a behavior of input variables. In order to identify the most important band of $\mathrm{ETM}+$ and vegetation index explaining the variability of SOM, sensitivity analysis was done using the StatSoft method(StatSoft, 2004).

A sensitivity ratio was calculated by dividing the total network error when the variable was treated as being not variable by the total network error when the actual values of the variable were used. A ratio greater than 1.0 implied that, then, the variable made an important contribution to the variability in soil organic matter. The higher the ratio, the more important the variable (StatSoft, 2004; Miao, 2006).

\subsection{Multivariate statistical regression}

Multivariate statistical regression was selected to model the relationships of selected variables with soil organic matter concentration. Multivariate statistical regression concentrated to find the combination, which is called as the linear discriminate function against the variables and the discriminate score. The linear expression is as follows:

$$
D=B_{0}+B_{1} X_{1}+B_{2} X_{2}+\ldots+B_{n} X_{n}
$$

where $D$ is a discriminate score

$B_{0}$ is an estimated constant

$B_{n}$ are the estimated coefficients

$X_{n}$ are the variables

\subsection{Performance of the methods}

Two statistical parameters were used for performance analysis: coefficient of determination $\left(R^{2}\right)$ and root mean square error (RMSE). RMSE is one the most commonly used statistical parameters, which expresses the mean differences between estimated and observed values (Uno et al, 2005, Douaoui et al. 2006). The data set for comparison of two approaches (MLR and ANN) was selected similarly. In addition, the performance of each model was evaluated by plotting the estimated value against the actual value and by testing the statistical significance of regression parameters

\section{Results and discussions}

\subsection{Descriptive statistics}

The descriptive statistics and variation in SOM are given in Table 2. The SOM content in site 1 under natural range land varied from 0.33 to $2.2 \%$, whereas in the site 2 under forest it 
varied from 1.5 to $5.4 \%$. It is obvious that significant increase in SOM is attributed to greater precipitation and higher biomass production in site 2 under forest than in site1. The remote sensing data and SOM, were normally distributed as confirmed by the KolmogorovSmirnov (K-S)) test and the values on skewness. SOM had moderate variability ( $\mathrm{CV}=34 \%$ for site 1 and $\mathrm{CV}=32 \%$ for site2) for the two sites studied. It seems that this variability in SOM depends on the landscape position, causing differential accumulation of water at different positions of landscape (over the landscape), resulting in variability in SOM content.

\begin{tabular}{lllllllll}
\hline Variable & Unit & No & Min & Max & Mean & CV\% & Skewness & Range \\
\hline SOM(Site 1) & $\%$ & 125 & 0.33 & 2.20 & 0.81 & 34 & 0.29 & 1.87 \\
SOM(Site 2) & $\%$ & 108 & 1.50 & 5.40 & 2.33 & 32 & -0.54 & 3.90 \\
\hline
\end{tabular}

Min: Minimum; Max: maximum; CV: Coefficient of variation; SOM: soil organic matter

Table 2. Descriptive statistics of SOM variability in the two sites studied

The correlation coefficients among variables (Table 3) showed that the correlation coefficients between SOM with band 1, 2, 5 and 7 were negative, and correlation between SOM and NDVI was significantly positive, $(\alpha=0.010)$.

\begin{tabular}{lllllll}
\hline Site & Variable & Band1 & Band2 & Band5 & Band7 & NDVI \\
\hline 1 & SOM & $-0.47^{* *}$ & $-0.48^{* *}$ & $-0.28^{*}$ & $-0.44^{* *}$ & $0.45^{* *}$ \\
2 & SOM & $-0.23^{*}$ & $-0.20^{*}$ & $-0.21^{*}$ & $-0.32^{* *}$ & $0.78^{* *}$ \\
\hline
\end{tabular}

**Significant at $99 \%$ probability *Significant at $95 \%$ probability

Table 3. Pearson correlation coefficients of SOM with remote sensing data variables at the two sites studied, in Iran

The soil generally has reflectance spectra in the $1100-2500 \mathrm{~nm}$ range, containing three distinct absorption peaks around 1400, 1900 and $2200 \mathrm{~nm}$ with a few small absorption peaks between 2200 and $2500 \mathrm{~nm}$ (Chang \&Laird, 2002). Chen et al. (2000) related surface organic matter content to image intensities in the red, green, and blue bands of the visible spectrum and discovered a good agreement between the measured and the predicted values with $\mathrm{R}^{2}$ varying from 0.97 to 0.98 (Chen, 2000).

\subsection{Multiple linear regression analysis}

The results of the multivariate linear regression are presented in Table 4. In these data, SOM denotes the soil organic matter concentration and Band 1 and 2 present digital numbers of ETM, NDVI present the normalized difference vegetation index.

The results revealed a moderate relationship between the measured SOM contents and the predicted ones with the $\mathrm{R}^{2}$ of 0.54 , implying that we can predict the soil organic matter concentration at $54 \%$ confidence with $\pm 26 \%$ error (e.g. soil organic matter of 0.5 would be predicted to vary from 0.37 to 0.63 ). The results showed that the MLR models explained 54 $\%$ of the total variability in SOM at the rangeland site. On the other hand, MLR model could explain $77 \%$ of variability in SOM at the forested site. This means that SOM content can be explained through independent variables band 1, 2 and NDVI by 54 and 77 percent for rangeland and forested sites respectively, whereas 46 and $23 \%$ left might be explained by other variables not used in the model, and the results also indicated the existence of nonlinear interactions between variables. 


\begin{tabular}{llccc}
\hline Site & Regression model & $\mathrm{R}^{2}$ & $\mathrm{MAE}$ & $\mathrm{RMSE}$ \\
\hline 1 & $\mathrm{SOM}(\%)=2.433-0.011(\mathrm{Band} 2)+3.872(\mathrm{NDVI})$ & 0.54 & 0.18 & 0.26 \\
2 & $\mathrm{SOM}(\%)=1.3766+4.78(\mathrm{NDVI})-0.012(\mathrm{Band} 1)$ & 0.77 & 0.09 & 0.13 \\
\hline
\end{tabular}

SOM: Soil organic matter; . MAE: Mean absolute error, RMSE: Root mean square error. NDVI: Normalized difference vegetation index.

Table 4. Stepwise linear regression parameters used to estimate SOM at the two selected sites in Iran.

When five independent variables were used in stepwise regression analysis, the output showed that the frequency of band2 and NDVI for site 1 and NDVI and band1 for site 2 . Band 2 and 1 have negative relationship and NDVI has positive relationship with soil organic matter content as shown by the regression model. In these formulations, the SOM content increases with decrease in band 2 and band 1 and SOM pool rises with increase in NDVI.

Multivariate statistics has widely been used to exploit the relationships between spectral characteristics and SOM content. For exmaple, Mc Carty and Reeves (2006) predicted SOM using multivariate analysis and spectral response in the near infrared (NIR) regions of the electromagnetic spectrum

\subsection{ANN's structure optimization}

The data on best structure having optimum parameters (Table 5) of the final selected ANN model could be used to predict the SOM. Finding the optimum number of hidden neurons in the hidden layer is an important step in developing MLP networks. The hidden-layer nodes were determined to be 10 for the two sites studied. Also, the optimum iteration learning rates were determined as 10000 and 12000 for SOM in rangeland and forested land, respectively.

\begin{tabular}{llllll}
\hline Sites & ANN structure & $\begin{array}{l}\text { Transfer } \\
\text { function }\end{array}$ & Iteration & $\begin{array}{l}\text { Number of } \\
\text { hidden layers }\end{array}$ & $\begin{array}{l}\text { Number of } \\
\text { hidden neurons }\end{array}$ \\
\hline 1 & $5-10-1$ & Tangsigm & 10000 & 1 & 10 \\
2 & $5-10-1$ & Tangsigm & 12000 & 1 & 10 \\
\hline
\end{tabular}

Table 5. Optimum parameters of ANN model for predicting soil organic matter using ETM data at sites 1 and 2 in Iran

\subsection{Comparison of MLR and ANN models to estimate SOM in two ecosystems}

The relationship between measured and predicted values of SOM using MLR model are shown in Fig. $4 \mathrm{a}$ and $4 \mathrm{~b}$ for rangeland and frosted area, respectively. As shown, MLR in forested land explained greater variability of SOM than in the rangeland. It seems that NDVI index as a indicator of vegetation cover plays a greater role in explaining the variability in SOM in the hilly region than in the rangeland area with lower variation in NDVI .Normalized predicted data versus normalized observed data for testing data set are shown in Fig 4c and 4d for rangeland and forested area, respectively; and the coefficients of determination $\left(\mathrm{R}^{2}\right)$ were determined.

Moreover the MAE and RMSE values were calculated to be 0.18 and 0.26 for MLR model for SOM in rangeland and 0.09 and 0.13 for forested area using MLR. On the other hand, ANN 
model improved the MAE and RMSE, which were 0.09 and 0.12 for rangeland and 0.01 and 0.09 for forested land, respectively. Overall, the ANN models explained greater variability and had higher capacity to predict SOM because these models use the non-linear relationships among inputs and output variables.

The developed ANN model for predicting the soil organic matter in the present study explained $84 \%$ and $91 \%$ of the total SOM variability in the rangeland and forest landscapes receptively. Overall, the results implied that the ANN modeling was successful in identifying most of the remote sensing data, which influence soil organic matter. However, our results also suggest that this methodology used for analyzing the data has wider applicability and can be applied to other sites.
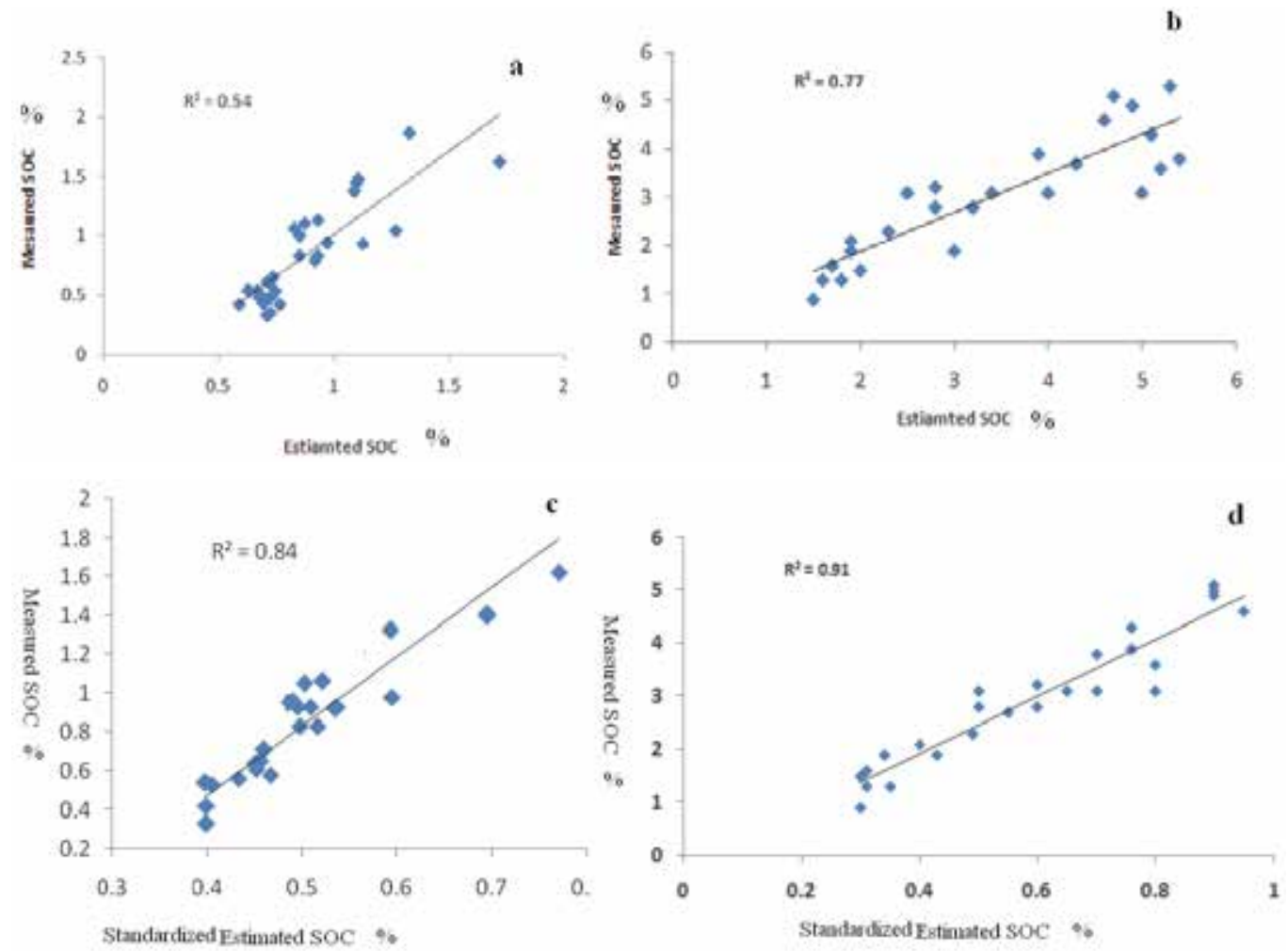

Fig. 4. Scatter plot displaying the relationships between measured and estimated value of the SOM in MLR and ANN models at the two sites studied in west and central Iran. (a): MLR for rangeland (b): MLR for forested land (c): ANN for rangeland, (d):ANN for forested land.

\subsection{Determining the most important bands for explaining variability in SOM}

The results on the relative importance of digital numbers and vegetation index using sensitivity analysis based upon coefficients of sensitivity of the ANN model for soil organic matter are shown in Fig. 5. The variables with high values made contributions to explain the variability in SOM.

Band 1 of ETM was identified as the most important band for detecting SOM variability in the study area of rangeland (Fig. 5a). Other important factors for predicting SOM, included 
band 2 and 5 with relative coefficients of sensitivity ranking as 1.21 and 1.06, respectively. Two other selected variables included band 7, and the NDVI showed sensitivity coefficient of less than 1, implying that they make lower contribution in predicting SOM in the rangeland site.

In the ANN analysis for SOM variability in forested land, the NDVI was identified as the most important and other digital numbers were also identified. NDVI, a widely used indicator in remote sensing showing abundance of vegetation cover. Spatial distribution of the NDVI was strongly influenced by the relief, which controls the movement of water and nutrients along the hillslopes. The distribution of vegetation could be controlled the variability in SOM within the landscape, and the reflectance of soil surface in red and infrared spectrums can determine the presence of different amounts of SOM. (Liu et al., 2004). The NDVI indicates the greenness cover on the land surface and shows a well documented relationship with crop and vegetation productivity (Pettorelli, 2005). LozanoGarcia et al. (1991) reported on the correlations between NDVI and soil properties. Li et al. (2001) found that the NDVI between red and infrared wavelengths was cross-correlated with soil water content, sand, clay and elevation. However, a composed and complex index such as NDVI, which mostly reflects biomass status, indicates soil-dependent site quality (Sommer, 2003).
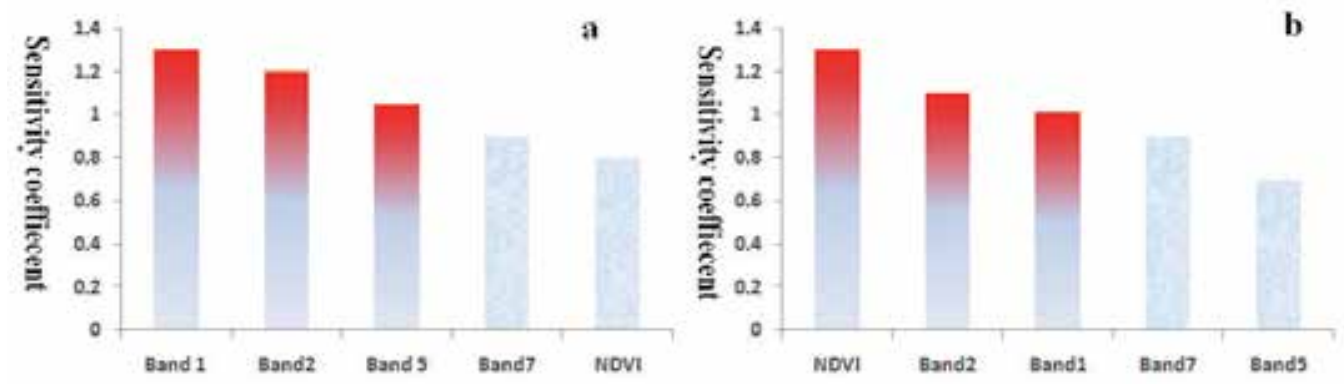

Fig. 5. Histogram displaying the results on sensitivity analysis, relative sensitivity coefficients of remote sensing data for the SOM. NDVI: normalized difference vegetation index.(a): Rangeland of Semiroum; (b): Forested land of Lordegan

Independent variable Landsat ETM digital numbers of bands 1, 2, 5 and 7, which may have been influenced by the presence of vegetative cover, were identified as important factors for the variability in SOM. Band 1 is useful for soil/vegetation differentiation and in distinguishing the forest types. Band 2 detects green reflectance from healthy vegetation. The two mid-IR red bands on TM ( bands 5 and 7) are useful for vegetation and soil moisture studies (Lillesand \&Kieffer, 1987).

Moreover, SOM has been related to reflectance in data collected over agricultural fields in several studies (Coleman et al., 1991; Henderson, 1992; Chen, 2000) and it has been reported that visible wave-lengths $(0.425$ to $0.695 \mathrm{~mm}$ ) (Bands 1 to 3 ) had a strong correlation with SOM for soils with the same parent material. The use of middle infrared bands (Band 5 of ETM) improved the prediction of SOM content when the soils were from different parent materials (Henderson, 1992). Chen et al. (2000) were able to accurately predict SOM using true color imagery of a 115-ha field with the use of locally developed regression relationships. 
Organic matter influences soil optical properties. Organic matter may indirectly affect the spectral influence, based on the soil structure and water retention capacity. High organic matter in soil may produce spectral interferences for band characteristics of mineral like manganese oxide and iron oxide (Coleman et al., 1991). The relationships of surface SOM concentration with the pixel intensity values, with data ranging from 0 to 255 for each band, were not linear (Chen, 2000). Therefore, non-linear regression analyses were developed.

Stamatiadis et al. (2005) observed that the red and NIR regions are more sensitive to matterates in soils. The results of this study also showed that in samples that contain high amounts of matterates, the visible bands showed higher correlation (Stamatiadis et al., 2005). These results are similar to those reported by Fox and Sabbagh (2002) who found the strongest correlation of SOM with reflectance in red band, but their results did not confirm the result reported by Sullivan et al. (2005) and Agbu et al. (1990), who showed that reflectance in green band was more strongly correlated with SOM than the reflectance in red band. Krishnan et al. (1980), reported that no absorption climax was caused by organic matter in the NIR region (800-2400 $\mathrm{nm}$ ), and SOM content was better measured with visible bands than NIR bands.

Overall, organic matter is the factor that influences soil optical properties. Organic matter may indirectly affect the spectral influence, based on the soil structure and water retention capacity. High organic matter in soil may produce spectral interferences for band characteristics of minerals such as manganese and iron oxides.

The developed ANN models for predicting the SOM in the present study by ETM-Landsat explained $84 \%$ and $91 \%$ of the total SOM variability within the two selected landscapes. A part of the unexplained variability is probably due to the management practices such as grazing and deforestation in some parts that influenced the plant density over the landscape. Moreover, as reported by other researchers (Kaul et al., 2005), it is important to compare the results of the ANN models with those obtained by other statistical approaches for determining the precision of the model under development. Hence the learning rate, number of hidden layer, number of hidden nodes and the training tolerance need to be determined accurately for developing models for SOM prediction. However, the performance of the ANN models as compared to other approaches suggest that ANN models have better realistic chance to predict SOM, especially when complex non-linear relationships exist among factors. In such cases, the correlation study may provide inaccurate and even misleading results about the relationships (Liu et al., 2001).

\section{Conclusions}

In this study, the potential of remote sensing data for the estimation of within-field variability of SOM was explored for hillslopes in the semiarid region under rangeland and forested uses. Multivariate statistical techniques and ANNs were employed for model development to explore the potential of remote sensing data. To achieve a nonlinear function relating soil organic matter to remote sensing data in hilly region of the semiarid region of central and western Iran, the results of this study indicated that the designed ANN models was able to establish the relationship between the remote sensing data and SOM content. Some of remote sensing data such as band 1, band 2 and NDVI were identified as the important factors that explained the variability in SOM content at the sites studied both in in rangeland and forested areas. The results showed that the MLR and ANN models explained 54 and $84 \%$ of the total variability in SOM, respectively, in the rangeland site. 
On the other hand, the MLR and ANN models explained 77 and 91\% of the total variability of SOM in forested area using remotely sensed data.

The calculated MAE and RMSE values were 0.18 and 0.26 for the MLR model for SOM in rangeland and 0.09 and 0.13 for the forested area using MLR. On the other hand, ANN improved the MAE and RMSE to 0.09 and 0.12 for rangeland and 0.01 and 0.09 for forested land, respectively. Therefore, the ANN model could provide superior predictive performance when compared with the MLR model developed.

Our results also suggest that the future research should consider soil properties which are used as factors in the equation, because soil reflectance properties depend on numerous soil characteristics such as mineral composition, texture, structure and moisture content in the use of remote sensing imagery to achieve a high accuracy in research.

\section{References}

Agbu, P. A.; Fehrenbacher, D. J. \& Jansen, I. I. (1990). Soil property relationships with SPOT satellite digital data in East Central Illinois. Soil Science Society of America Journal, $54,807-812$.

Blackmer, A. M. \& White, S. E. (1998). Using precision farming technologies to improve management of soil and fertilizer nitrogen. Australian Journal of Agricultural Research, 49, 555-564.

Brown, D. J.; Shepherd, K. D.; Walsh, M. G.; Dewayne Mays, M. \& Reinsch, T. G. (2006). Global soil characterization with VNIR diffuse reflectance spectroscopy. Geoderma, 132, 273-290.

Caudill, H. J. (2006). Management and landscape influences on soil organic carbon in the southern piedmont and coastal plain. the Graduate Faculty of Auburn University, 152.

Chang, C. W. \& Laird, D. A. (2002). Near-infrared reflectance spectroscopic analysis of soil C and N. Soil Science, 167, 110-116.

Chen, F.; Kissel, D. E.; West, L. T. \& Adkins, W. (2000). Field-scale mapping of surface soil organic carbon using remotely sensed imagery. Soil Science Society of America Journal, 64, 746-753.

Chen, F.; Kissel, D. E.; West, L. T.; Rickman, D.; Luvall, J. C. \& Adkins, W. (2005). Mapping surface soil organic carbon for crop fields with remote sensing. Journal of soil and water Conservation, 60, 51-57.

Christy, C. D.; Drummond, P. \& Laird, D. A. (2003). An on-the-go spectral reflectance sensor for soil. American Society of Agricultural Engineers Meeting, 3, 10-44.

Coleman, T. L.; Agbu, P. A.; Montgomery, O. L.; Gao, T. \& Prasad, S. (1991). Spectral band selection for quantifying selected proper-ties in highly weathered soils. Soil Science, 151 (5), 355-361.

Fox, G. A. \& Sabbagh, G. J. (2002). Estimation of soil organic matter from red and nearinfrared remotely sensed data using a soil line Euclidean distance technique. Soil Science Society of America Journal, 66, 1922-1929.

Galvao, L. S. \& Vitorello, I. (1998). Role of organic matter in obliterating the effects of iron on spectral reflectance and colour of Brazilian tropical soils. International Journal of Remote Sensing, 19, 1969-1979.

Haykin, S. (1994). Neural Networks: A Comprehensive Foundation. Macmillan, New York, NY. 
Henderson, T. L.; Baumgardner, M. F.; Franzmeier, D. P.; Stott, D. E. \& Coster, D. C. (1992). High dimensional reflectance analysis of soil organic matter. Soil Science Society of America Journal, 56, 865-872.

Huang, Y. (2009). Advances in Artificial Neural Networks - Methodological Development and Application. Algorithms, 2, 973-1007.

Huete, A. R. \& Escadafal, R. (1991). Assessment of biophysical soil properties through spectral decomposition techniques. Remote Sensing of Environment, 35, 149-157.

Huete, A. R., Liu, H.Q. (1994). An error and sensitivity analysis of the atmosphericcorrecting and soil-correcting variants of the NDVI for the modis-eos. IEEE Trans. Geosci. Remote Sensing, 32, 897-905.

Kaul, M.; Hill, R. \& Walthall, C. (2005). Artificial neural networks for corn and soybean yield prediction. Agricultural Systems, 85, 1-18.

Krishnan, P.; Alexander, J. D.; Butler, B. J. \& Hummel, J. W. (1980). Reflectance technique for predicting soil organic matter. Soil Science Society of America Journal, 44, 12821285.

Ladoni, M.; Bahrami, H. A.; Alavipanah, S. K. \& Norouzi, A. A. (2010). Estimating soil organic carbon from soil reflectance: A review. Precision Agriculture, 11, 82-100.

Lal, R. (2001). Soils and the greenhouse effect, Soil Science Society of America Special pub.

Lillesand, T. M. \& Kieffer, R. W. (1987). Remote sensing and image ineroretation, New York: John Wiley and Sons.

Liu, J.; Goering, C. E. \& Tian, L. (2001). A neural network for setting target yields. American Society of Agricultural and Biological Engineers, 44, 705-713.

Liu, C. W.; Huang, H.C.; Chen, S.K. \& Kuo, Y.M. (2004). Subsurface return flow and ground water recharge of terrace fields in northern Taiwan. J. Am. Water Resources Assoc, 40, 603-614.

Loveland, P. \& Webb, J. (2003). Is there a critical level of organic matter in the agricultural soils of temperate regions: a review. soil Till Res, 70, 1-18.

Lozano-Garcia, D. F.; Fernandez, R.N. \& Johannsen, C.J. (1991). Assessment of regional biomass-soil relationships using vegetation indexes. IEEE Trans. Geosci. Remote Sensing, 29, 331-339.

Lu, Y. C.; Daughtry, C.; Hart, G. \& Watkins, B. (1997). The current state of precision farming. Food Reviews International, 13, 141-162.

McKenzie, N. J.; Cresswell, H. P.; Ryan, P. J. \& Grundy, M. (2000). Contemporary land resource survey requires improvements in direct soil measurement. Soil Science and Plant Analysis, 31, 1553-1569.

Melesse, A. M. \& Hanley, R. S (2005). Artificial neural network application for multiecosystem carbon flux simulation. Ecological Modelling, 189, 305-314.

Miao, Y.; Mulla, D.J. \& Robert, P.C. (2006). Identifying important factors influencing corn yield and grain quality variability using artificial neural networks. Precision Agriculture, 7, 117-135.

Nelson, D. W. \& Sommers, L.E. (1982) . Total carbon, organic carbon, and organic matter.

Pettorelli, N.; Vik, J.O.; Mysterud, A.; Gaillard, J.M.; Tucker, C.J. \& Stenseth, N.C. (2005). Using the satellite-derived NDVI to assess ecological responses to environmental change. Trends Ecol. Evol., 20, 503-510.

Post, W. M.; Izaurralde, R. C.; Mann, L. K. \& Bliss, N. (2001). Monitoring and verifying changes of organic carbon in soil. Climate Change, 51, 73-99. 
Roy, S. K.; Shibusawa, S. \& Okayama, T. (2006). Textural analysis of soil images to quantify and characterize the spatial variation of soil properties using a real-time soil sensor. Precision Agriculture, 7, 419-436.

Rumelhart, D. E. \& McClelland, J.L. (1986). Parallel Recognition in Modern computers. Explorations in the Microstructure of Cognition, 1. Foundations(MIT Press/ Bradford Books, Cambridge, MA.).

Shepherd, K. D. \& Walsh, M. G. (2002). Development of Reflectance Spectral Libraries for Characterization of Soil Properties. Soil Science Society of America Journal, 66, 988998.

Sommer, M.; Wehrhan, M.; Zipprich, M.; Weller, U.; Castell, W.Z.; Ehrich, S.; Tandler, B. \& Selige, T. (2003). Hierarchical data fusion for mapping soil units at field scale. Geoderma, 112, 179-196.

Sorenson, L. K. \& Dalsgaard, S. (2005). Determination of clay and other soil properties by near infrared spectroscopy. Soil Science Society of America Journal, 69, 159-167.

Stamatiadis, S.; Christofides, C.; Tsadilas, C.; Samaras, V.; Schepers, J. S. \& Francis, D. (2005). Groundsensor soil reflectance as related to soil properties and crop response in a cotton field. Precision Agriculture 6, 399-411.

StatSoft (2004). Electronic Statistics Textbook (Tulsa, OK). http:/ / www.statsoft.com/textbook/stathome.html.

Suchenwirth, L.; Kleinscmit, B. \& Forster, M. (2010). Modelling the distribution of organic carbon stocks in floodplain soils with VHSR remote sensing data and additional geoinformation. Proceedings of the remote sensing and photogrammetry society conference remote sensing and the carbon cycle, Burlington House, London, 5th, 14.

Sudduth, K. A. \& Hummel, J. W. (1993). Potable, near-infrared spectrophotometer for rapid soil analysis. Trans. ASAE, 36, 185-193.

Sullivan, D. G., Shaw, J. N., Rickman, D., Mask, P. L., \& Luvall, J. C. (2005). Using remote sensing data to evaluate surface soil properties in Alabama ultisols. Soil Science, 170 954-968.

Thomasson, J. A.; Sui, R.; Cox, M. S. \& Al-Rajehy, A. (2001). Soil reflectance sensing for determining soil properties in precision agriculture. Transactions of ASAE, 44, 1445-1453.

Wetterlind, J.; Stenberg, B. \& Soderstrom, M. (2008). The use of near infrared (NIR) spectroscopy to improve soil mapping at the farm scale. Precision Agriculture, 9, 57-69.

Wilson, J. P. \& Gallant, J. C. (2000). Terrain analysis. New York, Wiley \& Sons.

Zhang, C. \& McGrath., D. (2004). Geostatistical and GIS analyses on soil organic carbon concentrations in grassland of southeastern Ireland from two different periods. Geoderma, 119, 261-275. 


\section{Part 3}

Carbon Storage 



\title{
A Comparative Study of Carbon Sequestration Potential in Aboveground Biomass in Primary Forest and Secondary Forest, Khao Yai National Park
}

\author{
Jiranan Piyaphongkul ${ }^{1}$, Nantana Gajaseni ${ }^{2}$ and Anuttara Na-Thalang ${ }^{3}$ \\ ${ }^{1}$ Faculty of Liberal Arts and Science, Kasetsart University, \\ ${ }^{2}$ Faculty of Science, Chulalongkorn University, \\ ${ }^{3}$ BIOTEC Central Research Unit, The National Science and Technology Development, \\ Thailand
}

\section{Introduction}

Climate change is a topic that has been widely discussed and debated over recent decades. Scientists have reached a general agreement that the lower atmosphere and the Earth's surface are definitely getting warmer. The Intergovernmental Panel on Climate Change (IPCC) reported that a gradual but accelerating increase of atmospheric greenhouse gases has occurred since 1750 as result of human activities and among the anthropogenic greenhouse gases, $\mathrm{CO}_{2}$ is the most important. The global atmospheric concentration of $\mathrm{CO}_{2}$ has increased from a pre-industrial value of about $280 \mathrm{ppm}$ to $379 \mathrm{ppm}$ in 2005 (Alley et al., 2007). Temperature has risen by about $0.3-0.6{ }^{\circ} \mathrm{C}$ since the late $19^{\text {th }}$ century. If $\mathrm{CO}_{2}$ emissions were maintained at 1994 levels, its concentration would increase to about $550 \mathrm{ppm}$ by the end of the $21^{\text {st }}$ century (Chakraborty et al., 2000). Thailand is a member of the United Nation Framework Convention on Climate Change (UNFCCC), which is negotiated by the nations of the world in June 1992 (Michaelowa and Rolfe, 2001). The targets of the UNFCCC is to reducing $\mathrm{CO}_{2}$ emissions from the rate reported for 1990 during the five-year period from 2008 - 2012. This agreement is called the Kyoto Protocol which Thailand has ratified since August 28, 2002. There are two alternatives to reduce $\mathrm{CO}_{2}$, these include decreasing fossil fuel consumption and increasing carbon sink through forestry activities. According to Article 3.3 of the agreed Kyoto Protocol, some $\mathrm{CO}_{2}$ sources and sinks of forests shall be used to meet the commitments (UNFCCC, 1997). The sources and sinks to be used were measured as verifiable changes in carbon stocks in each commitment period (Terakunpisut et al., 2007; Forest research, 2011).

Forestry sectors are known as an important natural brake on climate change since they play an important role in the global both as a carbon sink and source because of their large biomass per unit area of land (Gibbs et al., 2007). The carbon in forests originates from the atmosphere and is accumulated in terms of the organic matter of soil and trees, and it continuously cycles between forests and the atmosphere through the decomposition of dead organic matter (Alexandrove, 2007). Thus, changing carbon stocks in forests can affect the amount of carbon in the atmosphere. If more carbon accumulates in forest through 
photosynthetic process, the forest will be a sink of atmospheric carbon. If the carbon stocks in forests decrease and release carbon into the atmosphere, the forests will become a source of atmospheric carbon. The carbon stocks of forests can change in two ways, on the one hand as a result of changes in forest area and on the other hand as a result of changes in carbon stocks on the existing forest area. Broadmeadow and Matthews (2003) report that approximately $1.6 \mathrm{GtC}$ per year have released into the atmosphere as $\mathrm{CO}_{2}$ from deforestation during 1990s, but at the same time forest ecosystems is believed to have absorbed between $2-3 \mathrm{GtC}$ per year.

Tropical forests have an importan role for carbon sequestration in a much higher quantity than any other biome (Gorte, 2009) and also as a main carbon source to the atmoshere in areas that have undergone deforestation or unsustainable management (Malhi et al., 2006). The amount of carbon storage in the world's tropical forests which cover $17.6 \times 10^{6} \mathrm{~km}^{2}$ are approximately $4.28 \times 1011$ tonne $C$ in vegetation and soils (Lasco, 2002). Figure 1 shows the total world's tropical forests. In Asia, tropical forests are accounted for about 15.3 per cent in the world (UNCTAD Secretariat, n.d.). However, these forest ecosystems are facing the problem from deforestation and forest degradation in the tropics and Southeast Asia has been no exception. Lasco (2002) indicates that in 1990 deforestation rate in Southeast Asia was around 2.6x106 ha/ year. In addition there is liitle information on the carbon sequestration in natural forest ecosystems in Southeast Asia. To understand carbon sources and sinks, it is essential to estimate the biomass for these forests. Thus, the aim of this study was to estimate and compare the aboveground biomass and carbon stock between primary forest and secondary forest in the area of Khao Yai National Park.

\section{Materials and methods}

\subsection{Study areas}

This study was carried out at Khao Yai National Park. It covers a large complex area in Nakhon Ratchasima, Saraburi, Prachinburi and Nakhon Nayok Provinces. This National

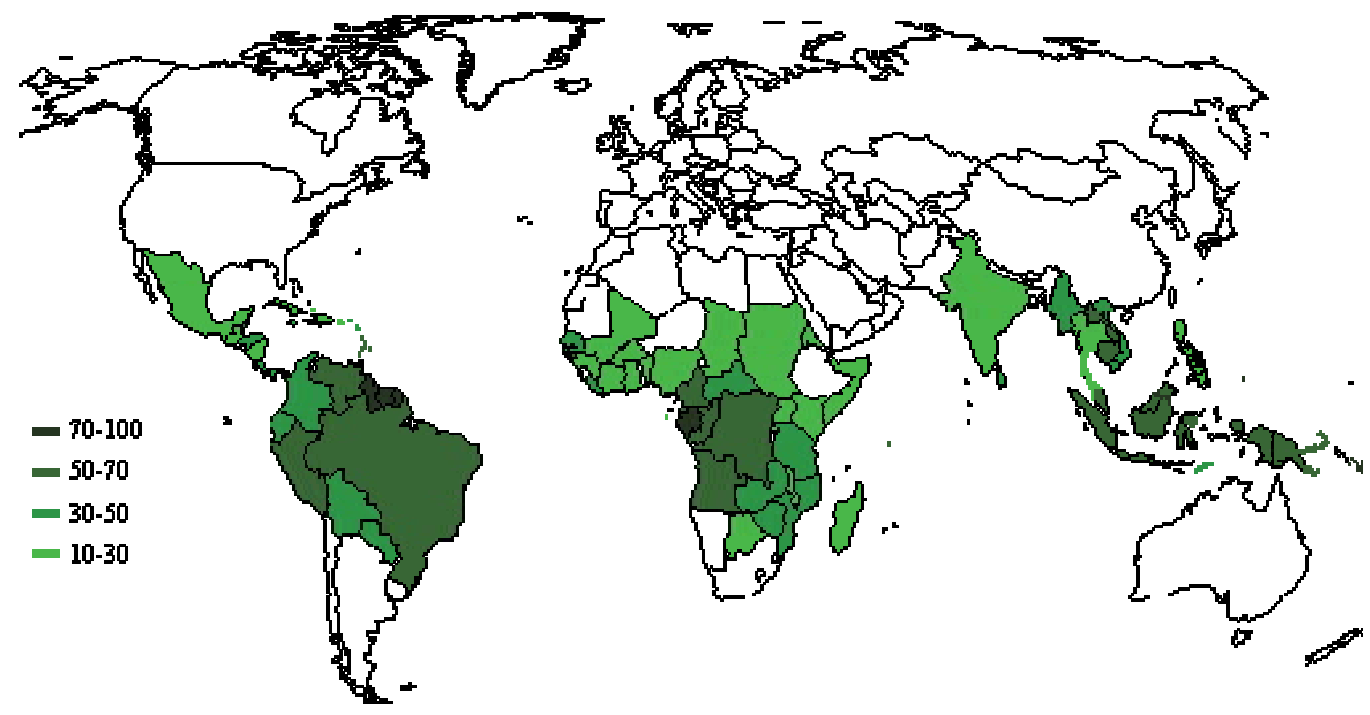

Fig. 1. The distribution of the world's tropical forest area in 2000 from UNCTAD Secretariat (n.d.) 
Park is also part of the Dong Phaya Yen . The Dong Phayayen-Khao Yai Forest Complex is an important pool of biodiversity and complex terresstrial habitats not only in region, but also at global level. It was granted as a UNESCO Natural World Heritage Site on 14 July 2005 (Kekule, 2009). The climatological data was recieved from Khao Yai station, Department of Meteorology provied 25 years from 1982 - 2006. The annual temperature in the area varied from $30-33^{\circ} \mathrm{C}$ and the area recieved the annual mean precipitation of $1,123.48 \pm 165.08 \mathrm{~mm}$. The selected study areas were carried out in Nakhon Ratchasima Province as shown in Figure 2. The sites were selected based on anthropogenic disturbance. The primary forest was classified as non or least disturbed forested area and the main area characteristic was classified as the tropical rain forest. On the other hand, the secondary forest was disturbed from anthropogenic activities in the past and described as dry evergreen and mixed deciduous forest types. All sampling plots were in the permanent plot of Professor Emeritus Warren Y. Brockelman under the project : foraging and ranging behavior of gibbons in Khao Yai National Park.

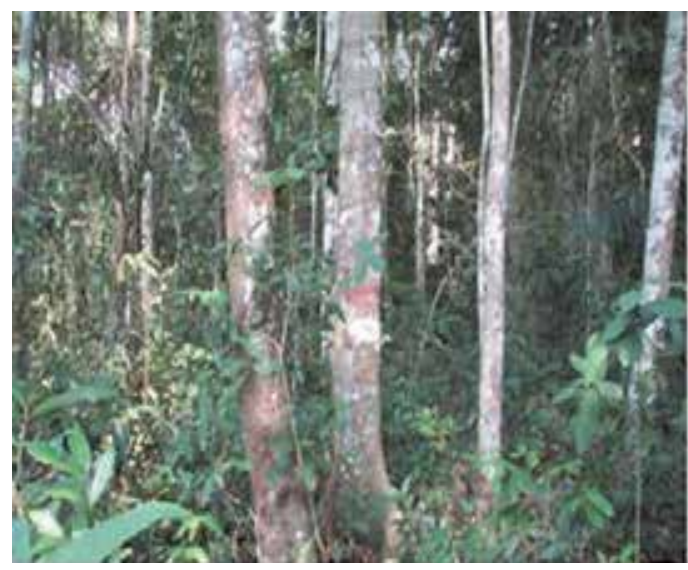

(a) The sampling plot in the primary forest

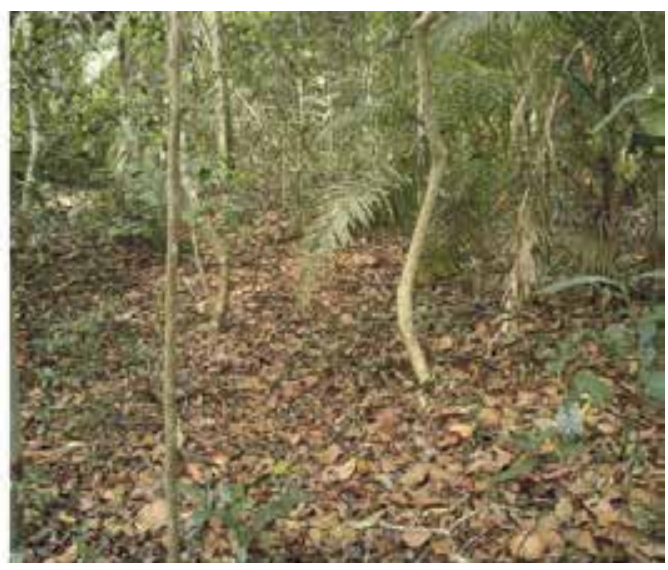

(b) The sampling plot in the secondary forest

Fig. 2. The study sites in Khao Yai National Park

\subsection{Data collection and analysis}

A randomly 1 ha sampling plot $(100 \mathrm{~m} \times 100 \mathrm{~m})$ in each forest type was established. To reveal the tree composition and biomass, all live trees with a diameter $\geq 4.5 \mathrm{~cm}$ were recorded. The diameter was measured at breast height ( $\mathrm{DBH}, 1.3 \mathrm{~m}$ height from the ground) to estimate biomass and the size class distribution of trees as well as species diversity in a sampling plot. All supported botanical data were represented by the species in terms of taxonomic classification identifie into Genera or Species, providing both local and scientific names by Aunttara Na-Thalang, a researcher at BIOTEC central research unit and a coresearcher of this project. In case of irregularities of trunk tree, the measurement was taken at the nearest lower point where the stem was cylindrical, or above the buttresses on large trunks. DBH was measured by used of diameter tape. Trees with multiple stems connected near the ground were counted as single individuals and bole circumference was measured separately. Tree height was recored by using a measuring pole. Figure 3 displayed primary data record and field measurement. 


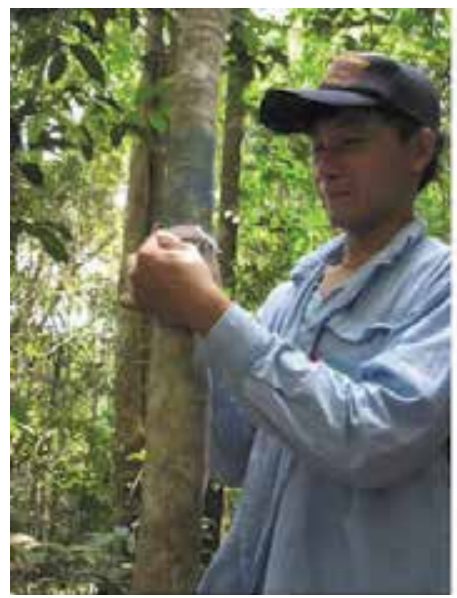

(a) Trees $\geq 4.5$ cmwere measured

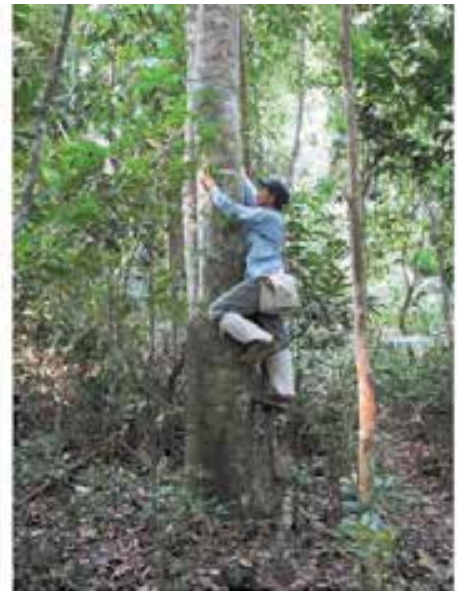

(b) DBH was measured above the buttress root

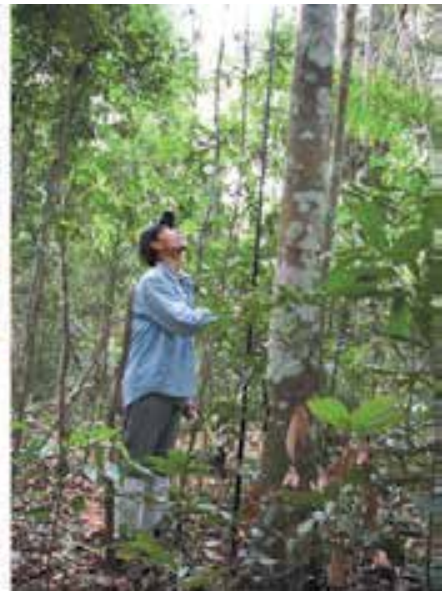

(c) Tree height was recorded

Fig. 3. Field measurement

\section{Data analysis}

\subsection{Species diversity and Important Value Index (IVI)}

It was widely believe that species diversty related to the level of disturbance (Mackey and Currie, 2001). Thus, species diversity was evaluated by using the Shannon - Wiener index method (see Equation 1) in this study to compare between primary forest and secondary forest. It was assumed that all species represented in the sampling plot were randomly sampled. In this method, the proportion of number of individuals of a species to the overall number of individuals in the sample plots was used to express the diversity of species in the studied ecosystem (Krebs, 1999).

$$
H^{\prime}=-\sum_{i=1}^{s}\left(p_{i}\right)\left(\log _{2} p_{i}\right)
$$

Where:

$$
\begin{gathered}
H^{\prime}=\text { Index of species diversity } \\
\mathrm{s}=\text { Species number in the sample } \\
p_{i}=\text { Proportional abundance of theith species }=\left(\mathrm{n}_{\mathrm{i}} / \mathrm{N}\right)
\end{gathered}
$$

To investigate the structural role of tree in the sampling plots, the importance value index (IVI) of each species was calculated using the percentage of relative abundance (R.A.), relative dominance (R.D.) and relative frequency (RF) (see Equation 2)

$$
\text { I.V. = R.A. + R.D. + R.F .....Whittaker (1970) }
$$

Where: 
I.V. = Important value index of each species

$$
\begin{aligned}
& \text { R.A. }=\text { Relative abundance }=\frac{\text { total number of each species } \times 100}{\text { total nuber of all species }} \\
& \text { R.D. }=\text { Relative dominance }=\frac{\text { basal area of each species } \times 100}{\text { basal area of all species }} \\
& \text { R.F. }=\text { Relative frequency }=\frac{\text { chance to find each species } \times 100}{\text { chance to find all of species }}
\end{aligned}
$$

To test the significance of the difference between categories, one way analysis of variance (ANOVA) was carried out using the SPSS Statistics 17.0 software. Data on species distribution in two forest types were analyzed by correspondence analysis using the same software. We used correspondence analysis (CA) as the ordination method to examine the differences in the distribution of tree species using the same software.

\subsection{Aboveground biomass and carbon sequestration}

To estimate aboveground biomass in the study areas by non - destructive methods, we had to collect data such as diameter at breast height (DBH) and height of all trees. SILVIC Program was used to predict the mean total tree height in the sampling plots. It was developed from the relationship between $\mathrm{DBH}$ and tree height $(\mathrm{Ht})$ by hyperbolic equation (see Equation 3) or D - H curve (Ogawa, Yoda and Kira, 1961). Forty trees in different sizes in the sampling plots were observed to analyse their height and DBH relationships. Ogawa (1969) showed that $\mathrm{H}$ was approximately equal to one for most mature forests. Assuming that $\mathrm{h}$ equaled one, the other coefficients, $\mathrm{A}$ and $\mathrm{H}^{*}$ for each stand were calculated by using the non - linear least square method. These constant values were used to predict tree height in this study.

$$
1 / \mathrm{H}_{\mathrm{t}}=1 / \mathrm{A}(\mathrm{DBH})^{\mathrm{h}}+1 / \mathrm{H}^{*}
$$

Where

$\mathrm{Ht}=$ height of tree $(\mathrm{m})$

$\mathrm{DBH}=$ diameter at breast height $(\mathrm{cm})$

$\mathrm{A}, \mathrm{h}, \mathrm{H}^{*}=$ constant

The next step was the aboveground biomass evaluation by non-destructive assessments. The biomass regression equations on the basis of $\mathrm{DBH}$ and $\mathrm{Ht}$ which derived from in tropical forests were applied for calculating the aboveground biomass and the size class analysis will evaluate the status of forest ecosystem. The primary forest used the equation developed by Tsutsumi et al. (1983) (see Equation 4) and the equation developed by Ogawa et al. (1965) was used for the secondary forest (see Equation 5).

$$
\begin{aligned}
\text { Stem }(W S) & =0.0509^{*}\left(\mathrm{D}^{2} \mathrm{H}\right)^{0.919} \\
\text { Branch }(\mathrm{WB}) & =0.00893^{*}\left(\mathrm{D}^{2} \mathrm{H}\right)^{0.977}
\end{aligned}
$$




$$
\text { Leaf }(\mathrm{WL}) \quad=0.0140^{*}\left(\mathrm{D}^{2} \mathrm{H}\right){ }^{0.669}
$$

and

$$
\begin{gathered}
\text { Stem }(\mathrm{WS}) \quad=0.0396^{*}\left(\mathrm{D}^{2} \mathrm{H}\right)^{0.9326} \\
\text { Branch }(\mathrm{WB})=0.003487^{*}\left(\mathrm{D}^{2} \mathrm{H}\right)^{1.027} \\
\text { Leaf }(\mathrm{WL}) \quad=((28.0 / \mathrm{WS}+\mathrm{WB})+0.025)^{-1}
\end{gathered}
$$

Where

Ws $=$ stem mass $(\mathrm{kg} /$ individual tree $)$

$\mathrm{Wb}=$ branches mass $(\mathrm{kg} /$ individual tree $)$

$\mathrm{Wl}=$ leaf mass $(\mathrm{kg} /$ individual tree $)$

$\mathrm{Ht}=$ height of tree $(\mathrm{m})$

$\mathrm{DBH}=$ diameter at breast height $(\mathrm{cm})$

Total carbon content was estimated from aboveground biomass by converted from biomass to carbon stock. From the reports (Atjay et al., 1979; Brown \& Lugo, 1982; Iverson et al., 1994; Dixon et al., 1994; Cannell \& Milne, 1995 and Terakunpisut et al., 2007), carbon content would be about fifty percent of the amount of aboveground biomass. To compare the potential of carbon sequestration between primary forest and secondary forest, frequency distribution of total aboveground biomass in a range of $\mathrm{DBH}$ size classes were considered to assess the potential of the forests across their size classes and age.

\section{Results and discussion}

\subsection{Species diversity}

Across sampling sites, tree species varried with forest types. Primary forest had greater species richness (75 species/ ha) than secondary forest (47 species/ ha). It probably implied that the study site in primary forest was more complexity in a community and species interaction. Since number of species compositions indicated the degrees of energy transfer through foodweb. In this case, the level of energy transfer in primary forest was stronger than secondary forest in order to support the higher total number of individuals of all species. This meant that the productivity in primary forest was also higher than another. In addition, the greater number of species compositions were most in ecosystems that have long time evolution, because organisms may develop mechanisms to conserve or more efficiently acquire any of the other limiting resources by certain physical or abiotic factors of the environment such as temperature, precipitation, light and soil.

From the species diversity $(H)$ measurement, The results showed that the overall plant species diversity of primary forest was higher than secondary forest, with the ShannonWiener indexes being 3.46 and 2.03 respectively. In practical, species diversity has been used to indicate the stability of the ecosystem. It meant that the high species diversity can exist in the spatially heterogeneous environment where the disturbances influence to the species in different degree. The species diversity index values measured and calculated from different forest ecosystems in Thailand had been listed and compared with this study as shown in Table 1. The species diversity values in primary forest and secondary forest were not much different from others study. The main conclusion was clearly demonstrated that the highest species diversity was from primary forest (tropical rain forest) because there were rich in 
resource such as diverse of habitat types and a large extent on food available in the tropical rain forest more than in other forest types.

\begin{tabular}{|c|c|c|}
\hline Forest ecosystem & $\begin{array}{c}\text { Shannon - Wiener diversity } \\
\text { index }\end{array}$ & References \\
\hline The primary forest & 3.46 & This study \\
The secondary forest & 2.03 & Terakunpisut et al., 2007 \\
\hline Tropical rain forest & $3.48-3.52$ & $\begin{array}{c}\text { Terakunpisut et al., 2007 } \\
\text { Sahunalu et al., 1979 }\end{array}$ \\
\hline Dry evergreen forest & 3.62 & Terakunpisut et al., 2007 \\
& $3.5-4.9$ & Sahunalu et al., 1979 \\
\hline Mixed deciduous forest & 3.09 & 3.9
\end{tabular}

Table 1. A comparison of species diversity index under different forest ecosystems in Thailand among this study and the others.

This study also identified the dominant species according to the important value index (IVI). The result represented in Figure 4, which ranked from the highest value to lower value. The result indicated that common species in the primary forest were Ardisia nervosa (127 tree/ ha, IVI = 56.08) followed by Mastixia pentandra, Gonocaryum lobbianum, Dipterocarpus gracilis, Cinnamomum subavenium and Aglaia elaeagnoidea. The contribution of the dominant species in the secondary forest was Schima wallichii (505 trees/ ha, IVI = 71.94) and 2 co-dominant species were Machilus odoratissima and Eurya nitida.

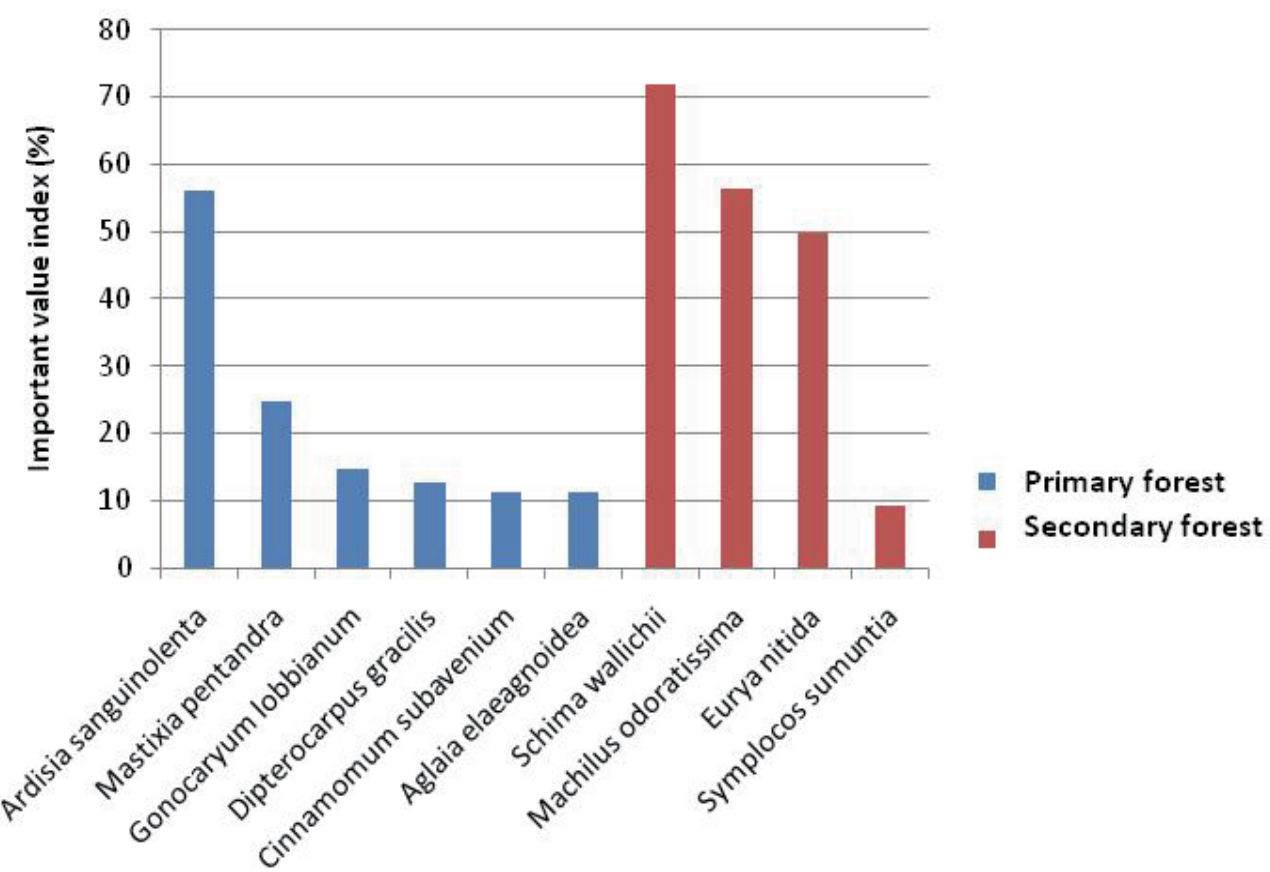

Fig. 4. Important value index of tree species $(\mathrm{DBH} \geq 4.5 \mathrm{~cm})$ in the primary forest and the secondary forest 
The correspondence analysis revealed the pattern of the species distribution tree distribution in the study areas (see Figure 5). A correspondence map displayed two of the dimensions to relate the distribution of tree species with forest types. It showed that some plant species had high potential distribution. Thus, there were overlapped in their distribution between the different forest types. For example, Aquilaria crassna, Bridelia insulana, C. subavenium, Cleistocalyx operculatus, D. gracilis, Eurya nitida, Garcinia benthamii, G. lobbianum, Helicia formosana, Ilex chevalieri, Litsea umbellata, M. pantandra, Phoebe lanceolata, Syzygium grande, S. siamensis and S. Syzygiodes occurred in both forest types and the pattern indicated links to both forests. Because of the similarity of climate such as annual precipitation and annual temperature, the species compositions of each forest type had features in common and only a few rare species were specific to a single forest type. The analysis of variance showed that tree species did not significantly differ across the two forest types in terms of species richness, $F(1,120)=2.328, p=0.130$. This was due to several species were found in both forests.

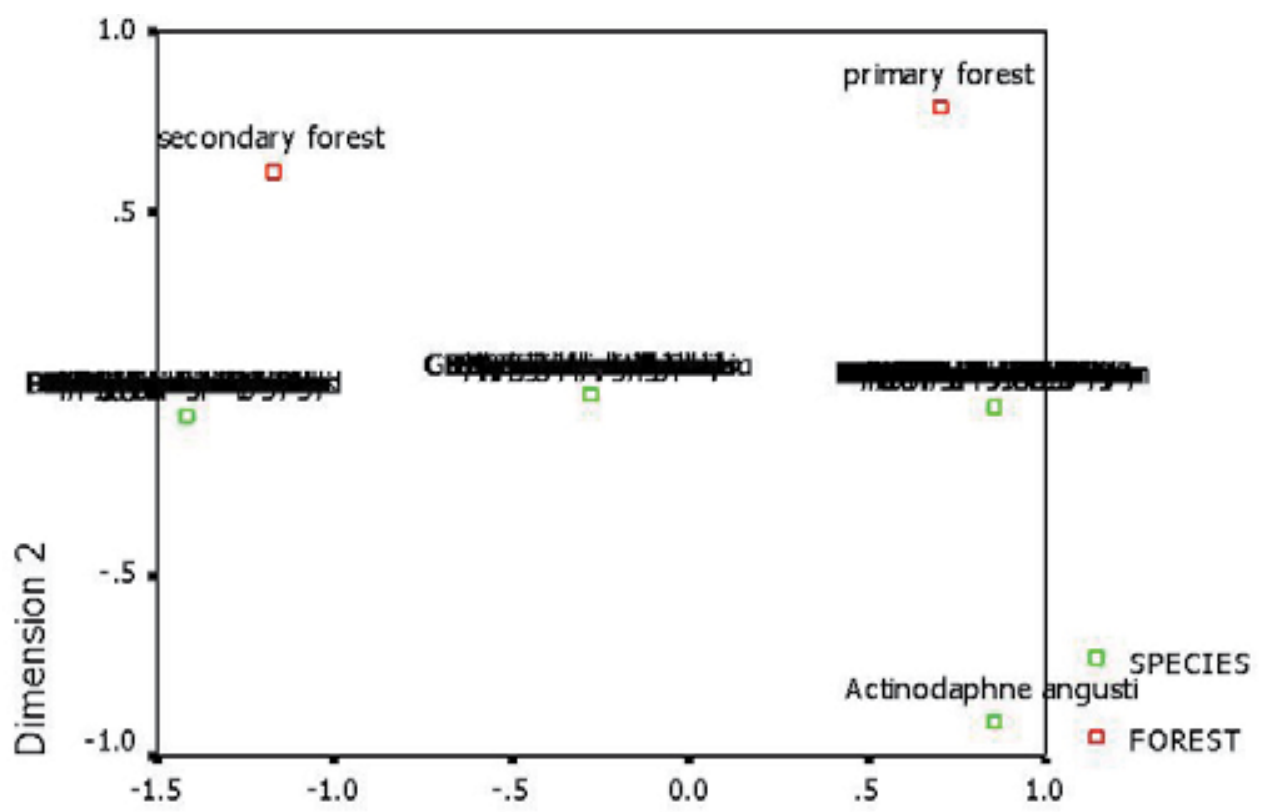

\section{Dimension 1}

Fig. 5. Species distribution and forest types. Tree compositions in both forests were not significantly different across groups, $F(1,120)=2.328, p=0.130$

Figure 6 showed the DBH size class distribution on two sampling plots. The density of plants with $\mathrm{DBH} \geq 4.5 \mathrm{~cm}$ in secondary forest was 1,249 trees/ ha due to lots of small tree sizes. While tree density in primary forest was only 919 trees/ ha since the main tree size class in this area was medium to large tree sizes at DBH $>40-60 \mathrm{~cm}$ and $60-80 \mathrm{~cm}$. It was cler that the frequency distribution curves of DBH were all L- shaped in both forests. The density of trees was the highest at the left end of the graph and decreased afterward. Up to $>20-40 \mathrm{~cm}$, the distribution curves of primary forest and secondary forest were similar, 
although the amount of trees in secondary forest were much higher, especially in DBH size class $\geq 4.5-20 \mathrm{~cm}$. The main differences between primary forest and secondary forest were in the number of trees in medium size class at DBH $>40-60 \mathrm{~cm}$ and $>60-80 \mathrm{~cm}$ which were greater amount in primary forest. The analysis of variance showed that there was significant difference of tree density between primary forest and secondary forest, $F(1,120)$ $=4.393, p=0.038$.

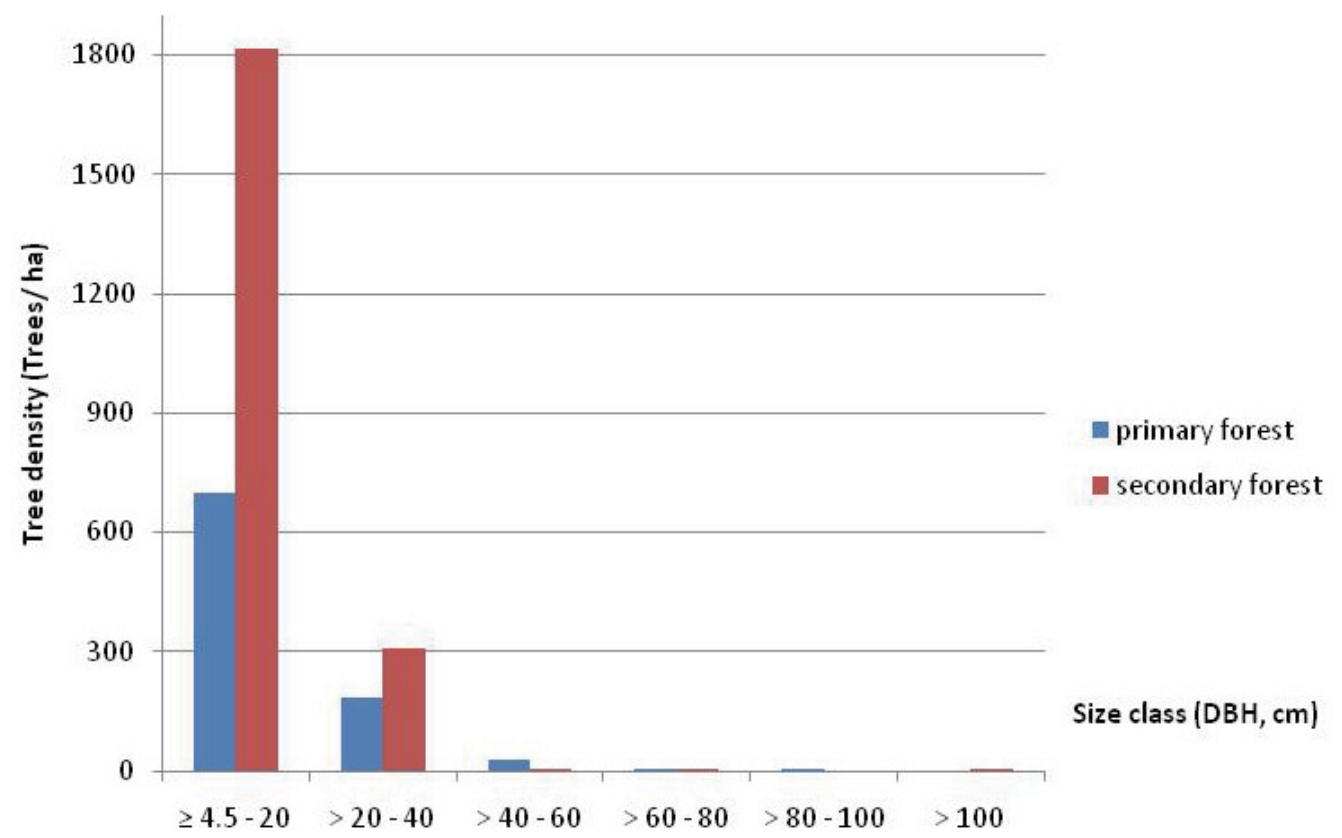

Fig. 6. A trend of tree density distribution in different DBH size classes

\subsection{Aboveground biomass and carbon sequestration}

Aboveground biomass distribution and carbon storage in different DBH size classes were compared between primary forest and secondaryforest in Khao Yai National Park (see Figure 7). It was remarkable that total aboveground biomass accumulation in primary forest (684.76 tonne/ ha) was higher than seconday forest (198.20 tonne/ ha). Although the number of trees were significantly greater in secondary forest, but the highest tree density were in the group of small tree size classes at $\mathrm{DBH} \geq 4.5-20$ and $20-40 \mathrm{~cm}$ which had lowest individual volume and biomass. On the other hand, the most aboveground biomass accumulation was found in big trees of size class at $>60-80,>80-100$ and $>100 \mathrm{~cm}$ that were dominant tree groups in primary forest. Because these trees were highest stem volume and large diameter, although they were the smallest group of tree densities. The analysis of variance revealed a significant difference in terms of median total aboveground biomass between primary forest and secondaryforest, $F(1,3046)=29.189, p=0.000$.

In comparison with other tropical forests, the range of aboveground biomass in this study both areas were similar (see Table 2). The result in Primary forest was compared to tropical rain forest, while data in secondary forest was compared with the biomass in dry evergreen forest and mixed deciduous forest. 


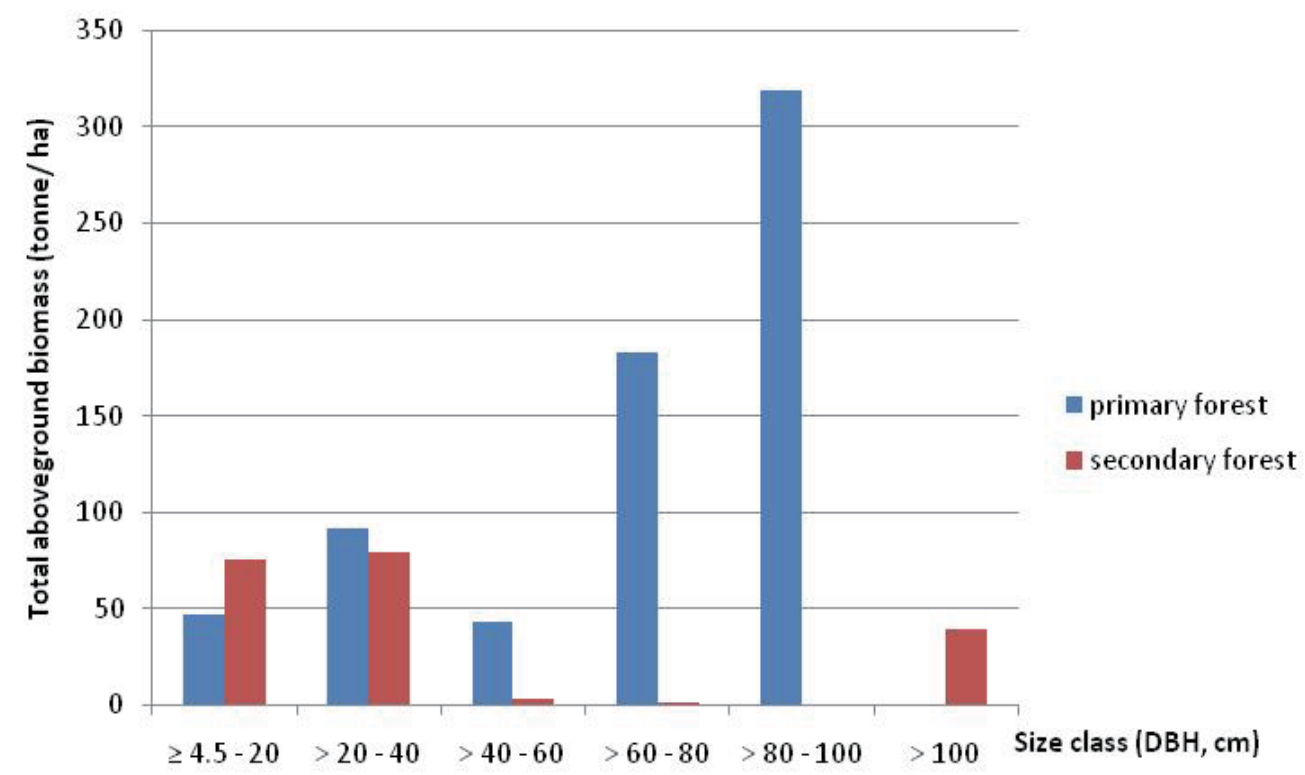

Fig. 7. Frequency distribution of total aboveground biomass in a range of DBH size classes between the primary forest and the secondary forest

\begin{tabular}{|c|c|c|}
\hline Forest ecosystem & $\begin{array}{c}\text { Aboveground biomass } \\
\text { (tonne/ ha) }\end{array}$ & References \\
\hline $\begin{array}{c}\text { The primary forest } \\
\text { Tropical rain forest }\end{array}$ & 684.76 & $\begin{array}{c}\text { This study } \\
\text { Yamakura et al., 1986 }\end{array}$ \\
\hline The secondary forest & 509.00 & $\begin{array}{c}\text { This study } \\
\text { Dry evergreen forest } \\
\text { Dry evergreen forest }\end{array}$ \\
Mixed deciduous forest & 198.20 & $\begin{array}{c}\text { Mani and Parthasarathy, 2007 } \\
\text { Terakunpisut et al., 2007 } \\
\text { Terakunpisut et al., 2007 }\end{array}$ \\
\hline
\end{tabular}

Table 2. A comparison of total aboveground biomass in this study and the others.

The percentage data of tree density and carbon sequestration were presented in Table 3 . The total carbon sequestration in primary forest and secondary forest were equal to 342 and 99.10 tonne C/ ha, respectively. The results showed that the distribution of DBH size classes and the total carbon storage in each size class varied between the forest types. About 80 per cent of the carbon stock was presented in DBH size class at $\geq 4.5-20 \mathrm{~cm}$ and $>20-40 \mathrm{~cm}$ in secondary forest but contributed only 20 per cent of total carbon stock in primary forest. The carbon storage was highest in DBH size class at $>60-80 \mathrm{~cm}$ and $>80-100 \mathrm{~cm}$ in primary forest.

However, the highest potential size class to sequester $\mathrm{CO}_{2}$ from the atmosphere in primary forest and secondary forest were $\mathrm{DBH}$ size class at $>60-80 \mathrm{~cm}$ and $>20-40 \mathrm{~cm}$, respectively. Since number of trees in these size classes were lower than other, but the 
amount of carbon storage were greater than other groups which had higher tree density. For example, in secondary forest; trees in the size class at $\geq 4.5-20 \mathrm{~cm}$ were five times more tree density than trees in the size class at $>20-40 \mathrm{~cm}$, but the amount of carbon storage were similar. Likewise primary forest, trees in the size class at $>60-80 \mathrm{~cm}$ were found only 0.44 per cent, but the amount of carbon storage was nearly four times of trees in the size class at $\geq 4.5-20 \mathrm{~cm}$.

\begin{tabular}{|c|c|c|c|c|}
\hline \multirow{2}{*}{$\begin{array}{c}\text { size class } \\
(\mathrm{DBH}, \mathrm{cm})\end{array}$} & \multicolumn{2}{|c|}{ The primary forest } & \multicolumn{2}{c|}{ The secondary forest } \\
\cline { 2 - 5 } & Tree density (\%) & Carbon stock (\%) & Tree density (\%) & Carbon stock (\%) \\
\hline$\geq 4.5-20$ & 76.20 & 6.93 & 85.30 & 38.18 \\
\hline$>20-40$ & 20.00 & 13.43 & 14.37 & 39.96 \\
\hline$>40-60$ & 3.04 & 6.37 & 0.19 & 1.48 \\
\hline$>60-80$ & 0.44 & 26.73 & 0.05 & 0.62 \\
\hline$>80-100$ & 0.33 & 46.53 & - & - \\
\hline$>100$ & - & - & 0.09 & 19.75 \\
\hline
\end{tabular}

Table 3. A comparison of the percentage of tree density and carbon sequestration potential between the primary forest and the secondary forest

In summary, the distribution pattern of aboveground biomass had been related to past disturbance history the forests. Total aboveground biomass in the primary forest was about triple that of the secondary forest. However, both study areas had high carbon sequestration potential in the future due to presence of large number of trees belonging to small DBH size classes. These trees in size class at $\geq 4.5-20 \mathrm{~cm}$ were in the youth phase and their growth rate was accelerating to reach maturity. It meant that at the present these smaller trees are not the highest carbon sequestration potential, but in the near future they can sequester $\mathrm{CO}_{2}$ from the atmosphere through photosynthesis to form their structure till senescent phase. Broadmeadow and Matthews (2003) suggested the option to reserve carbon in the forests by minimal intervention, with a gradual long - term increase in carbon stocks.

\section{Conclusions}

The number of tree species occurring on the sample area in the primary forest and the secondary forest were 75 and 47 species, respectively. To conclude the correspondence analysis and ANOVA, it was found that there were many species in common between primary forest and secondary forest. So each forest type had not a distinctive of species distribution. From the results, it was found that the tree density was counted in the secondary forest as 2,129 trees/ ha due to lots of saplings and small trees, while the tree density in the primary forest was found only 919 trees/ ha since the main tree size class in this area was medium to large tree size at $>60-80 \mathrm{~cm}$.

The primary forest and secondary forest of Khao Yai National Park had carbon stocks 342.29 and 99.10 tonne $\mathrm{C} / \mathrm{ha}$, respectively. The total aboveground carbonstorage in the primary forest was significantly greater than the secondary forest. Although the young trees belonging to the size class at $\mathrm{DBH} \geq 4.5-20 \mathrm{~cm}$ dominated both forests in terms of tree density, the carbon sequestration potential was greater in the size class at DBH $>20-40 \mathrm{~cm}$ in secondary forest and in the size class at DBH $>60-80 \mathrm{~cm}$ in primary forest. Both forests were very important for carbon sequestration because there were typically high carbon 
stocks. Moreover, the result also implied that the potential was considerably high to sequester carbon in both forest areas in the near future due to lots of small trees in the areas. We hope that the results of this study on aboveground biomass and carbon sequestration will be useful to conserve these forest areas under sustainable management.

\section{Acknowledgements}

The authors express their sincere gratitude to Kasetsart University Research and Development Institute (KURDI) for financial support of this project and wish to thank Kasetsart University for support in publishing. The authors also thank the Biodiversity Research and Training Program (BRT) to support young sciencetists. The authors are thankful to Professor Emeritus Warren Y. Brockelman, for his support valuable data use in this article and giving permission to carry out field work in the permanent plot under the project: foraging and ranging behavior of gibbons in Khao Yai National Park. The author also thanks the staff of Professor Emeritus Warren Y. Brockelman's project and a team of undergraduade students from the Faculty of Liberal Arts and Science, Kasetsart University for help in the field survey. A big thank you also goes out to Dr. Taeng-on Prommi, a lecturer at Faculty of Liberal Arts and Science for help in the application process of publishing grant. Also thank Megan Combs for always improving the language of this paper.

\section{References}

Alexandrove, G.A. (2007). Carbon Stock Growth in a Forest Stand: the Power of Age, Carbon Balance and Management, Vol. 2 (4), pp. 1 - 5.

Alley, R., Berntsen, T., Bindoff, N.L., Chen, Z., Chidthaisong, A., Friedlingstein, P., Gregory, J., Hegerl, G., Heimann, M., Hewitson, B., Hoskins, B., Joos, F., Jouzel, J., Kattsov, V., Lohmann, U., Manning, M., Matsuno, T., Molina, M., Nicholis, N., Overpeck, J., Qin, D., Raga, G., Ramaswamy, V., Ren, J., Rusticucci, M., Solomon, S., Somerville, R., Stocker, T.F., Stott, P., Stouffer, R.J., Whetton, P., Wood, R.A. \& Wratt, D. (2007). The Fourth Assessment Report of the Intergovernmental Panel on Climate Change: Climate Change 2007: the Physical Science Basis, Geneva, Switzerland, Intergovernmental Panel on Climate Change.

Atjay, G.L., Ketner, P. \& Duvignead, P. (1979). Terrestrial Primary Production and Phytomass. In B. Bolin, E.T. Degens, \& S. Kempe, (Eds.), The Global Carbon Cycle, Wiley and Sons, New York, pp. 129 - 182,

Broadmeadow, M. \& Matthews, R. (2003). Forests, Carbon, and Climate Change: the UK Contribution, Information Note, June 2003. Available from http://www.forestry.gov.uk/pdf/fcin048.pdf/\$FILE/fcin048.pdf

Brown, S. \& Lugo, A.E. (1982). The Storage and Production of Organic Matter in Tropical Forests and Their Role in the Global Carbon Cycle, Biotropica Vol 14, pp. 161 - 187.

Cannell, M.G.R. \& Milne, R. (1995). Carbon pools and sequestration in forest ecosystems in Britain, Forestry Vol 68, pp. $361-378$.

Chakraborty, S., Tiedemann, A.V. \& Teng, P.S. (2000). Climate Change: Potential Impact on Plant Diseases, Environmental Pollution Vol.108, pp. 317-326.

Dixon, R.K., Brown, S., Solomon, R.A., Trexler, M.C. \& Wisniewski, J. (1994). Carbon Pools and Flux of Global Forest Ecosystems, Science Vol 263, pp. 185 - 190. 
Forest Research. (2011). Kyoto Protocol and UK forests, Climate Change Mitigation, Available from http://www.forestry.gov.uk/website/forestresearch.nsf/ByUnique/INFD62VEK3.

Gibbs, H.K., Brown, S., Niles, J.O., \& Foley, J.A. (2007). Monitoring and Estimating Tropical Forest Carbon Stocks: Making REED a Reality, Environ. Res. Lett. Vol. 2, pp. 1 - 13.

Gorte, R.W. (2009). Carbon Sequestration in Forests. CRS Report for Congress, Congressional Research Service, August 6, 2009.

Iversion, L. R., Brown, S., Prasad, A., Mitasova, H., Gillespie, A.J.R. \& Lugo, A.E. (1994). Use of GIS Estimating Potential and Actual Forest Biomass for Continental South and Southeast Asia. In W. Dale, (Ed.), Effect of Land-Use Change on Atmospheric $\mathrm{CO}_{2}$ Concen-tration, Springer - Verlag, New York, pp 67 - 116.

Kekule, L.B. (2009). Khao Yai: Thailand's First and Most Famous National Park. In: Bangkok Post, August 31, 2009, Available from http://brucekekule.com/the_northeast/aworld-heritage-treasure-in-the-north-east/

Lasco, R.D. (2002). Forest Carbon Budgets in Southeast Asia following Harvesting and Land Cover Change, Science inChina Vol. 45, pp. 55-64.

Leith, H.F.H. (1975). Primary Productivity in Ecosystems: Comparative Analysis of Global Patterns. In W.H. Van Dobben \& R. H. McConnell, (Eds.), Unifying Concepts in Ecology, The Huge, Wageningen, pp $67-87$.

Mackey, R.L. \& Currie, D. (2001). The Diversity - Disturbance Relationship: Is It Generally Strong and Peaked?, Ecology Vol 82(12), pp. 3479-3492.

Malhi, Y., Wood, D., Bakers, T.R., Wright, J., Phillips, O.L., Cochrane, T., Meir, P., Chave, J., Almeida, S., Arroyo, L., Higuchiss, N., Killeen, T.J., Laurance, S.G., Laurance, W.F., Lewiss, S.L., Monteagudo, A., Neill, D.A., Vargas, P.N., Pitman, N.C.A., Quesadas, C.A., Salomao, R., Silva, J.N.M., Lezama, A.T., Terborgh, J., Martinez, R.V. \& Vinceti, B. (2006). The Regional Variation of Aboveground Live Biomass in OldGrowth Amazonian Forests, Global Change Biology Vol 12, pp. 1-32.

Mani, S. \& Parthasarathy, N. (2007). Above-ground biomass estimation in ten tropical dry every forest sites of peninsular India, Biomass and Bioenergy, Vol 31, pp. 284-290.

Michaelowa, A. \& Rolfe, C. (2001). Early Action to Reduce Greenhouse Gas Emissions before the Commitment Period of the Kyoto protocol: Advantages and Disadvantages, Environmental Management Vol 28, pp. 281-292.

Ogawa, H. 1969. An attempt at classifying forest types based on the relationship between tree height and DBH. In T. Kira (ed.), Comparative study of primary productivity of forest ecosystem, pp. 3 - 17.

Ogawa, H., Yoda, K. \& Kira, T. (1961). A Preliminary Survey on the Vegetation of Thailand, Natural and Life in Southeast Asia Vol 1, pp. 21-157.

Ogawa, H., Yoda, K., Ogino, K. \& Kira, T. (1965). Comparative Ecological Studies on Three Main Type of Forest Vegetation in Thailand II. Plant Biomass, Nature and Life in Southeast Asia Vol 4, pp. 49 - 80.

Mackey, R.L. \& Currie, D.J. (2001). The Diversity - Disturbance Relationship: Is It Generally Strong and Peaked?, Ecology Vol. 82 (12), pp. 3479-3492.

Sahunalu, P., Chamreanpruk, M., Puriyakorn, B., Dhanmanonda, P., Suwannapin, W. \& Prachaiyo, B. 1979. Structure of three forest types in the Prom Basin, Chaiyaphum Province. Faculty of Forestry: Kasetsart University. 
Terakunpisut , J., Gajaseni, N. \& Ruankawe, N. (2007). Carbon Sequestration Potential in Aboveground Biomass of Thong Pha Phum National Forest, Thailand, Applied Ecology and Environmental Research Vol.2, pp. 93-102, ISSN 1589-1623

Tsutsumi, T., Yoda, K., Sahunalu, P., Dhanmanonda, P. \& Prachaiyo, B. (1983). Forest: Felling, Burning and Regeneration, In K. Kyuma \& C. Pairintra, (Eds.), Shifting cultivation, Tokyo, pp. 13-62.

UNCTAD secretariat. (n.d.). Trends in Tropical Forest Area. Tropical Timber [Online], Available from http://www.unctad.org/infocomm/anglais/timbertrop/crop.htm

UNFCCC. 1997. Kyoto Protocol to the United Nations Framework Convention on Climate Change Available from:

http:/ / www.unfccc.de/resource/ index.html

Whittaker, R.H. (1970). Communities and Ecosystem, Toranto, Macmillian.

Yamakura, T., Hagihara, A., Sukardjo, S. \& Ogawa, H. (1986). Aboveground biomass of tropical rain forest stands in Indonesian Borneo, Plant Ecology Vol. 68 (2), pp. 71-82. 


\title{
Carbon Storage in Cold Temperate Ecosystems in Southern Patagonia, Argentina
}

\author{
Pablo Luis Peri \\ Universidad Nacional de la Patagonia Austral (UNPA)- Instituto Nacional \\ de Tecnología Agropecuaria (INTA) EEA Santa Cruz-CONICET \\ Argentina
}

\section{Introduction}

Recently there has been an increasing interest of research related to improve the understanding of carbon (C) sequestration mainly under Article 3.4 of the Kyoto Protocol of the United Nations Framework Convention on Climate Change where countries can count this sequestration as a contribution to reduce greenhouse gas emission (IPCC, 2001). Data on $\mathrm{C}$ storage in forests, grasslands and shrublands are essential for understanding the importance of rapidly increasing level of $\mathrm{CO}_{2}$ in the atmosphere and its potential effect on global climate change. In South America, mean annual temperature is predicted to increase by $3-4{ }^{\circ} \mathrm{C}$ in both summer and winter between $30^{\circ}$ and $55^{\circ}$ SL (Manabe \& Wetherald, 1987). Such an increase would have significant effects on Patagonian ecosystems. In this context, secondary indigenous forests are considered efficient $\mathrm{C}$ sink ecosystems. Nothofagus antarctica (ñire), one of the main deciduous native species in the Patagonian region (Argentina), covers 751.643 hectares over a wide latitudinal (from $36^{\circ} 25^{\prime}$ to $54^{\circ} 53^{\prime} \mathrm{SL}$ ) and altitudinal (near sea level to 2000 m.a.s.l.) distribution. These forests occur naturally in different habitats such as poorly drained sites at low elevations, exposed windy areas with shallow soils, depressions under cold air influence, or in drier eastern sites near the Patagonian steppe (Veblen et al., 1996). These forests provide a range of wood products including poles, firewood and timber for rural construction purposes. Site quality for $N$. antarctica ranges from tall trees up to $15 \mathrm{~m}$ in dominant height on the best sites to shrubby trees of $2 \mathrm{~m}$ tall on rocky, xeric and exposed sites, and also in poorly drained sites. Previous research has highlighted the importance of stand age on the magnitude of $\mathrm{C}$ pools in both forest biomass and forest floor pools (Silvester \& Orchard, 1999; Davis et al., 2003). Largescale canopy disturbance in $N$. antarctica forests may occur as a result of blowdown, snow avalanches or fire. This results in abundant regeneration $(100,000$ seedlings ha-1 less than 1 $\mathrm{m}$ tall, up to 20 years of age) followed by self thinning due mainly to light competition resulting in a final stand density of 200-350 trees ha-1 at mature stages (more than 180 years of age). It is important to emphasize that many researchers have only focused on aboveground carbon sequestration (Davis et al., 2003). However, roots in forest ecosystems can contribute up to two times more biomass than above-ground components in young growth phases (Peri et al., 2006, 2008). There are few studies of above- and below-ground pools of C 
storage in Patagonian Nothofagus forests that provide an understanding about ecosystem functionality (Peri et al., 2004, 2005) and the consequences of different disturbance and management regimes. In this context, forest ecosystem pools and fluxes of $C$ are strongly affected by forest management (Finér et al., 2003). Peri et al. (2010) showed that $C$ storage in tree components (leaves, stems, branches, roots) and forest floor change as a result of different forest structure determined by the proportion of crown classes, development stages (age) and the site quality where trees grow.

The steppe ecosystem, mainly characterised by the presence of tussock, short grasses and shrubs, covers $85 \%$ of the total area. Grazing has modified the structure of Patagonian ecosystems by reducing vegetation cover, increasing bare areas, and changing floristic composition. Erosion and degradation processes have occurred in several areas of Patagonia due to an overestimation of the carrying capacity of these rangelands, inadequate distribution of animals in very large and heterogeneous paddocks, and year-long continuous grazing (Golluscio et al., 1998). In Patagonia, most of the actual knowledge about the environmental factors that affect net primary production of grasslands at regional level derives from the importance of mean annual precipitation, radiation and temperature (Jobbágy \& Sala, 2000). However, data on C accumulation in both above- and belowground components of plant functional types are essential for evaluating the impacts of grazing on $\mathrm{C}$ cycle and long -term effects on the $\mathrm{C}$ balance of grasslands. Global estimates of the relative amounts of $C$ in different vegetation types suggest that grasslands approximately contribute more than $10 \%$ of the total biosphere store (Nosberger et al., 2000). Also, it has been demonstrated that most temperate grasslands under existing management conditions are considered to be $C$ sink and sequester more $C$ than arable crops (Connan et al., 2001).

Therefore, the aim of this manuscript was to describe the amount of $C$ in both above- and below-ground components for the main cold temperate ecosystems in Southern Patagonia (Argentina). In particular, the aim was to quantify the $C$ storage in an age sequence and among crown classes for individual trees grown at different site qualities of deciduous $N$. antarctica forests in Southern Patagonia and under silvopastoral use, and to quantify the amount of $\mathrm{C}$ for main grassland steppe ecosystems including the effect of grazing.

\section{Carbon storage in main Patagonian ecosystems}

\subsection{Nothofagus antarctica native forest}

Above- and below-ground C pools were measured in pure even-aged stands of Nothofagus antarctica at different ages ( 5 to 220 years), crown (dominant, codominant, intermediate, suppressed) and site (site class III (SC III) where the mean total height of dominant mature tree $(\mathrm{H})$ reached $10.2 \mathrm{~m}$, site class IV (SC IV) where $\mathrm{H}$ reached $7.8 \mathrm{~m}$, and site class V (SC V) which represented a marginal site where $\mathrm{H}$ reached $5.3 \mathrm{~m}$ ) classes in the Patagonian region (Peri et al., 2010). Mean tissue C concentration varied from $46.3 \%$ in medium sized roots of dominant trees to $56.1 \%$ in rotten wood for trees grown in low quality sites. Total C concentration was in the order of: heartwood $>$ rotten wood $>$ sapwood $>$ bark $>$ small branches $>$ coarse roots $>$ leaves $>$ medium roots $>$ fine roots.

Sigmoid functions were fitted for total $C$ accumulation and $C$ root/shoot ratio of individual trees against age for each site class. The parameters are given in Peri et al. (2010). Total C accumulation over time followed the order: dominant $>$ codominant $>$ intermediate $>$ suppressed trees (Fig. 1a). For example, dominant trees growing on SC III had accumulated

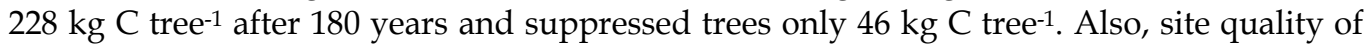


the stands had a strong impact on total $C$ accumulation over time. For example, while the mean total $\mathrm{C}$ accumulated for dominant trees grown in SC V at 150 years was $109 \mathrm{~kg} \mathrm{C}$ tree-

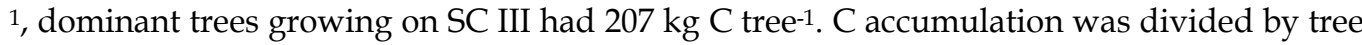
age to establish the average annual rate at which $\mathrm{C}$ was accumulated by trees. The rate of $\mathrm{C}$ accumulation showed a parabolic relationship with tree age and increased to reach a maximum and then declined as tree age increased further (Fig. 1b). Crown class also affected the maximum value and shape of this response. For example, maximum accumulation rate for dominant trees growing on SC III was $1.44 \mathrm{~kg} \mathrm{C}^{-1}$ tree$^{-1}$ year-1 at 116 years and then declined to $1.10 \mathrm{~kg} \mathrm{C}$ tree $^{-1}$ year- $^{-1}$ at 220 years (Fig. 1b). In contrast, maximum accumulation rate for suppressed trees was $0.26 \mathrm{~kg} \mathrm{C}$ tree $^{-1}$ year-1 at 139 years (Fig. 1b). Also, the site quality modified the maximum values and the shape of the rate of $C$ accumulation. The greater $C$ accumulation of dominant trees at any age compared to inferior crown classes was very closely related to the $C$ accumulation rates. This is consistent with Rötzer et al. (2009) who estimated that the amount of C storage in both above- and belowground components over time for a mixed beech stand changed with variations in site conditions, especially when precipitation decreased. Dominant trees and trees growing in better site qualities had larger crowns with more biomass of photosynthetic green leaves, and consequently had faster growth rates. In contrast, the leaves of suppressed trees located in the inferior stratum receive less available light for photosynthesis and these less active leaves may accumulate less $C$. For $N$. antarctica trees, there were no significant difference in the slope of the relationship between the $\mathrm{C}$ root/shoot ratio and age for different crown classes. Therefore, a single function was used for each site quality class. $\mathrm{C}$ root/shoot ratio decreased with age from a maximum value to a steady-state asymptote value. For example, $\mathrm{C}$ root/shoot ratio decreased from maximum values of 1.3 at 5 years to a steady-state asymptote of 0.3 beyond 60 years of age, for trees grown in SC III (Fig. 1c).Thus, root C accumulation was greater during the regeneration phase, and then the above-ground $\mathrm{C}$ accumulation of young and mature trees increased over time. The above-ground $C$ content for $N$. antarctica was lower than values reported by Hart et al. (2003) for an even-aged $N$. truncata old growth forest (root/shoot ratio of 0.28 ). At any time, the root $\mathrm{C}$ accumulation was greater for trees growing on the poorer sites (SC V) than for better site conditions. It has been demonstrated that $N$. antarctica has more root biomass to ensure establishment during stand replacement to improve water and nutrient uptake in dry environments and to provide better support in windy sites with shallow soils, compared to other Nothofagus species (Gargaglione et al., 2010).

In primary $N$. antarctica forest there were no significant differences in soil C pools for different age classes (data not shown). This is consistent with Davis et al. (2003) who reported that the sum of forest floor and mineral soil C in a New Zealand Nothofagus forest did not differ with age. However, total $\mathrm{C}$ content in the soil profile varied according to the

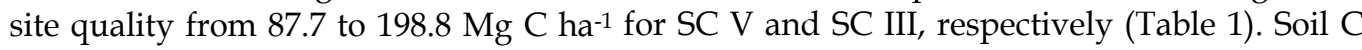
concentration increased from SC V to SC III thus influencing C content in organic and inorganic horizons (Table 1 ). The $C$ content of litter, organic-layer and inorganic soil layers were greater in the best site quality class stands. The $C$ in the soil pool (Table 1) represents between 52\% (optimal growth phase stand grown at SC IV) and 73\% (mature phase stand grown at SC III) of total ecosystem C. The soil C pool estimated in the present work was greater than those reported for other Nothofagus species (Tate et al., 1993; Hart et al., 2003) and similar to native cypress forests in Patagonia (Laclau, 2003). This highlights the importance to quantify the variability in soil $\mathrm{C}$ storage among forest types. 

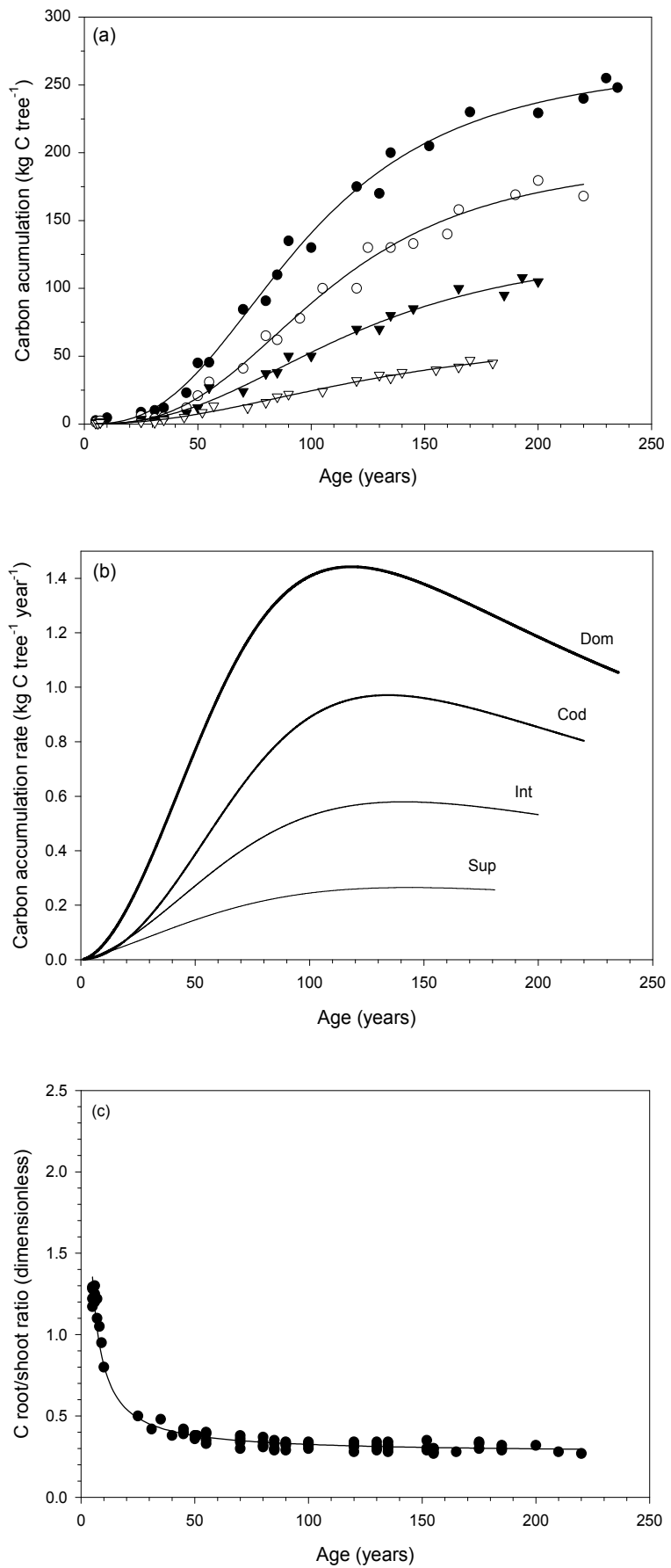

Fig. 1. Total carbon (C) accumulation (a), $\mathrm{C}$ accumulation rates (b) and $\mathrm{C}$ root/shoot ratio (c) against age for different crown classes of $N$. antarctica trees growing at Site Class III (mean total height of dominant mature tree $10.2 \mathrm{~m}$ ) in south Patagonia, Argentina (Peri et al., 2010). 
The equations for total $\mathrm{C}$ accumulation from individual trees were used to estimate the $\mathrm{C}$ storage at the stand level using forest inventory data. Total $\mathrm{C}$ storage in $\mathrm{N}$. antarctica forest ranged from $40.3 \mathrm{Mg} \mathrm{C}$ ha-1 for mature stands grown at SC V to $182.0 \mathrm{Mg} \mathrm{C}^{-1}$ for optimal growth stands at SC III (Table 1). In all studied site quality classes, total C accumulation was greater at the development stage of optimal growth (21-110 years). Similarly, Davis et al. (2003) estimated that stem $C$ storage in $N$. solandri var. cliffortiodes forest in a montane zone of New Zealand reached a maximum value (137 Mg C ha-1) at the pole development stage (120 years). In contrast, Laclau (2003) reported that C storage of native cypress forest in northwest Patagonia did not change significantly with stand age and precipitation (site quality). Sapwood contained more C in SC III (66.4 Mg C ha-1) than SC IV (32.5 Mg C ha-1), while medium roots contained more $\mathrm{C}$ in the SC V $\left(15.8 \mathrm{Mg} \mathrm{C}^{-1}\right)$ stands. In particular, roots accounted for $26 \%$ (regeneration phase grown at SC III) to $72 \%$ (mature phase grown at SC V) of total C in living trees of the stands (Table 1). In contrast, Hart et al. (2003) showed that mature $N$. truncata forest growing on a better site quality (dominant height of $21 \mathrm{~m}$ ) had greater amounts of $\mathrm{C}$ in the above- than the belowground components (166 vs. $\left.47 \mathrm{Mg} \mathrm{C} \mathrm{ha}^{-1}\right)$.

\begin{tabular}{|c|c|c|c|c|c|c|c|c|c|c|c|c|}
\hline \multirow[b]{2}{*}{ Soil horizons } & \multicolumn{4}{|c|}{$\begin{array}{c}\text { Site } \\
\text { Class III }\end{array}$} & \multicolumn{4}{|c|}{$\begin{array}{c}\text { Site Class } \\
\text { IV }\end{array}$} & \multicolumn{4}{|c|}{$\begin{array}{c}\text { Site Class } \\
V\end{array}$} \\
\hline & Litter & $\begin{array}{l}\text { Organic } \\
\text { Horizon }\end{array}$ & $\begin{array}{c}\text { Mineral } \\
\text { Horizon } \\
\mathrm{I}\end{array}$ & $\begin{array}{c}\text { Mineral } \\
\text { Horizon } \\
\text { II }\end{array}$ & Litter & $\begin{array}{l}\text { Organic } \\
\text { Horizon }\end{array}$ & $\begin{array}{c}\text { Mineral } \\
\text { Horizon I }\end{array}$ & $\begin{array}{c}\text { Mineral } \\
\text { Horizon II }\end{array}$ & Litter & $\begin{array}{l}\text { Organic } \\
\text { Horizon }\end{array}$ & $\begin{array}{c}\text { Mineral } \\
\text { Horizon I }\end{array}$ & $\begin{array}{c}\text { Mineral } \\
\text { Horizon II }\end{array}$ \\
\hline Depth $(\mathrm{cm})$ & $0-2$ & $2-6$ & $6-20$ & $20-60$ & $0-1$ & $1-5$ & $5-30$ & $30-60$ & $0-1$ & $1-4$ & $4-20$ & $20-50$ \\
\hline $\begin{array}{l}\text { Bulk density } \\
\left(\mathrm{g} \mathrm{cm}^{-3}\right)\end{array}$ & 0.07 & 0.47 & 0.79 & 1.04 & 0.10 & 0.39 & 1.14 & 1.29 & 0.09 & 0.63 & 0.97 & 1.05 \\
\hline $\begin{array}{l}\text { Carbon } \\
\text { concentration } \\
(\%)\end{array}$ & 47.2 & 16.0 & 6.0 & 2.3 & 50.8 & 14.2 & 2.1 & 0.4 & 49.1 & 9.4 & 3.2 & 0.5 \\
\hline $\begin{array}{l}\text { Carbon } \\
\text { content } \\
\left(\mathrm{Mg} \mathrm{ha}^{-1}\right)\end{array}$ & 6.6 & 30.1 & 66.4 & 95.7 & 5.8 & 22.1 & 59.8 & 15.5 & 4.4 & 17.8 & 49.7 & 15.8 \\
\hline Stand & \multicolumn{2}{|c|}{ Leaves } & $\begin{array}{c}\text { Small } \\
\text { branches }\end{array}$ & \multicolumn{2}{|c|}{ Sapwood } & Heartwood & Bark & $\begin{array}{c}\text { Rotten } \\
\text { wood }\end{array}$ & $\begin{array}{c}\text { Roots } \\
<2 \mathrm{~mm}\end{array}$ & $\begin{array}{c}\text { Roots } \\
<30 \mathrm{~mm}\end{array}$ & $\begin{array}{c}\text { Roots } \\
>30 \mathrm{~mm}\end{array}$ & Total \\
\hline \multicolumn{13}{|l|}{ Site Class III } \\
\hline Regeneration & \multicolumn{2}{|r|}{4.6} & 9.6 & \multicolumn{2}{|l|}{48.3} & 28.5 & 15.7 & 5.4 & 1.1 & 5.4 & 33.4 & 152.1 \\
\hline $\begin{array}{l}\text { Optimal } \\
\text { growth }\end{array}$ & \multicolumn{2}{|c|}{11.9} & 21.8 & \multicolumn{2}{|l|}{66.4} & 9.6 & 16.3 & 0.0 & 3.0 & 17.2 & 35.7 & 182.0 \\
\hline Mature & \multicolumn{2}{|r|}{4.5} & 13.9 & \multicolumn{2}{|l|}{12.0} & 0.0 & 3.2 & 0.0 & 1.7 & 26.4 & 13.5 & 75.1 \\
\hline \multicolumn{13}{|l|}{ Site Class IV } \\
\hline Regeneration & \multicolumn{2}{|r|}{0.8} & 2.0 & \multicolumn{2}{|l|}{13.4} & 14.6 & 7.2 & 1.0 & 0.3 & 2.6 & 14.2 & 56.2 \\
\hline $\begin{array}{l}\text { Optimal } \\
\text { growth }\end{array}$ & \multicolumn{2}{|r|}{3.6} & 7.3 & \multicolumn{2}{|l|}{32.5} & 5.9 & 9.3 & 0.0 & 0.9 & 8.9 & 19.4 & 87.9 \\
\hline Mature & \multicolumn{2}{|r|}{2.9} & 8.6 & \multicolumn{2}{|l|}{7.1} & 0.0 & 2.5 & 0.0 & 3.0 & 24.6 & 9.9 & 58.6 \\
\hline \multicolumn{13}{|l|}{ Site Class V } \\
\hline Regeneration & & 0.8 & 2.1 & \multicolumn{2}{|l|}{8.4} & 13.2 & 4.6 & 1.7 & 0.1 & 2.8 & 16.6 & 50.3 \\
\hline $\begin{array}{l}\text { Optimal } \\
\text { growth }\end{array}$ & & 1.9 & 5.7 & \multicolumn{2}{|l|}{13.1} & 3.0 & 4.6 & 0.5 & 1.5 & 8.0 & 15.8 & 54.0 \\
\hline Mature & & 1.1 & 5.2 & \multicolumn{2}{|l|}{4.1} & 0.0 & 1.9 & 0.0 & 3.4 & 16.5 & 8.2 & 40.3 \\
\hline
\end{tabular}

Table 1. Mean soil carbon content and predicted amount of carbon $\left(\mathrm{Mg} \mathrm{C}^{-1}\right)$ in sampled Nothofagus antarctica stands in Southern Patagonia (Peri et al., 2010). Site Class III: stands where the mean total height of dominant mature tree $(\mathrm{H})$ reach $10.2 \mathrm{~m}$, Site Class IV: $\mathrm{H}=7.8$ $\mathrm{m}$, Site Class V: $\mathrm{H}=5.3 \mathrm{~m}$

\subsection{Silvopastoral systems}

Deciduous $N$. antarctica forest has been usually used as silvopastoral systems (trees growing with natural pastures in the same unit of land to feed cattle and sheep). These forests are 
considered efficient carbon (C) sink ecosystems. Peri et al. (2009) reported the aboveground and belowground $\mathrm{C}$ sequestration for different components of trees and pasture (green and dead leaves, pseudostem and coarse and fine roots), and the $C$ storage in litter floor and different horizons of mineral soil (from 0 to $0.6 \mathrm{~m}$ depth) in a $N$. antarctica silvopastoral system grown in Southern Patagonia at a site class IV (SC IV) where H reached $7.8 \mathrm{~m}$. Mean stand density was 180 trees ha- $^{-1}(78 \%$ dominant trees and $22 \%$ codominant trees) in mature development stage (196 years). In this ecosystem, the $\mathrm{C}$ concentration was higher in the tree component of rot $(55.3 \%)$ and lower in the dead leaves component of pasture $(40.5 \%)$. The C concentration decreased from $46.9 \%$ in floor litter to $2.5 \%$ at $0.6 \mathrm{~m}$ mineral soil depth. At the silvopastoral stand level, the total C stored was $252 \mathrm{Mg} \mathrm{C}^{-1}$ distributed $86.7 \%$ in soil, $11.9 \%$ in trees and $1.4 \%$ in pasture (Table 2). Belowground biomass represented an important $\mathrm{C}$ storage pool in the ecosystem with mean values of 8.9 and $2.6 \mathrm{Mg} \mathrm{C}^{-1}$ for trees and pasture roots components, respectively. Total $\mathrm{C}$ accumulation in trees $(30.1 \mathrm{Mg} \mathrm{C}$ ha $^{-1}$ ) followed the order heartwood $>$ coarse roots $>$ sapwood $>$ bark $>$ small branches $>$ rot $>$ leaves $>$ fine roots. $\mathrm{C}$ storage in litter floor was $7.4 \mathrm{Mg} \mathrm{C} \mathrm{ha}^{-1}$, and in the mineral soil ranged from $13.6 \mathrm{Mg} \mathrm{C} \mathrm{ha-}^{-1}$ (horizon $0-0.03 \mathrm{~m}$ depth) to $98.6 \mathrm{Mg} \mathrm{C} \mathrm{ha}^{-1}$ (horizon $0.30-0.60 \mathrm{~m}$ depth). This is consistent with Dixon et al. (1994) who reported that the potential carbon storage with agroforestry systems in temperate zones ranges from 15 to $198 \mathrm{Mg} \mathrm{C} \mathrm{ha-1.}$ Sharrow \& Imail (2004) stated that silvopastoral system in Oregon (United Sates) were more efficient in $\mathrm{C}$ sequestration due to the higher biomass production and active nutrient cycling

\begin{tabular}{ll}
\hline System component & $\mathrm{Mg} \mathrm{Cha}-1$ \\
\hline Soil & 7.4 \\
Litter & 13.6 \\
Organic horizon $(0-03 \mathrm{~m})$ & 17.6 \\
Mineral horizon $(0.03-0.10 \mathrm{~m})$ & 81.3 \\
Mineral horizon $(0.10-0.30 \mathrm{~m})$ & 98.6 \\
Mineral horizon $(0.30-0.60 \mathrm{~m})$ & 218.5 \\
Total soil & \\
\hline Trees & 0.5 \\
Leaves & 1.0 \\
Small branches & 7.3 \\
Sapwood & 8.2 \\
Heartwood & 3.7 \\
Bark & 0.5 \\
Rot & 0.1 \\
Fine roots & 8.7 \\
Coarse roots & 30.1 \\
Total trees & \\
\hline Pasture & 0.5 \\
Green leaves & 0.1 \\
Dead leaves & 0.4 \\
Pseudostem & 2.5 \\
Roots & 3.5 \\
Total pasture & 252 \\
\hline Total silvopastoral system & \\
\hline
\end{tabular}

Table 2. Mean carbon storage of different components of a typical Nothofagus antarctica silvopastoral system in Southern Patagonia (Peri et al., 2009) 
patterns compared with tree plantations or pasture monocultures. This study improved the understanding about the potential of $\mathrm{C}$ sequestration of $N$. antarctica forests under silvopatoral management and highlights the importance of these forests as efficient carbon sink ecosystems.

\subsection{Shrubland}

In Santa Cruz province there is a "matorral" thicket area dominated mainly by Junellia tridens covering 2.8 million hectares among the grasslands of the Magellanic steppe and the steppe of the Central Plateau (Borrelli et al. 1997). These communities grow on sites with coarsertextured soils, are dominated by $60-70 \mathrm{~cm}$ tall shrubs. Water is the most important factor regulating primary production. Shrublands constitute significant and important parts of southern Patagonian landscapes providing a large number of important ecosystem services. Biogeochemical cycles in these ecosystems have gained little attention relative to forests and grassland systems. Our primary intent was to create dimensional relationships between two easily measured plant properties, crown area and height, and the total biomass and $C$ for the major shrub species. From this, significant differences were detected in total below- aboveground shrub $\mathrm{C}$, estimated by applying species specific models to the shrub dimensional data sets (Fig. 2). The relative proportion of $C$ has been constituted by the major species varied with stand age and J. tridens shrub cover. Total plant $C$ varied from 4.4 to $12.5 \mathrm{Mg} \mathrm{C}$ ha $^{-1}$ for 20 and $60 \%$ shrub cover, respectively (Fig. 2 ). In this ecosystem, the $C$ root/shoot ratio ranged between 0.17 and 0.30 . The soil carbon store $(0-30 \mathrm{~cm})$ dominates the carbon

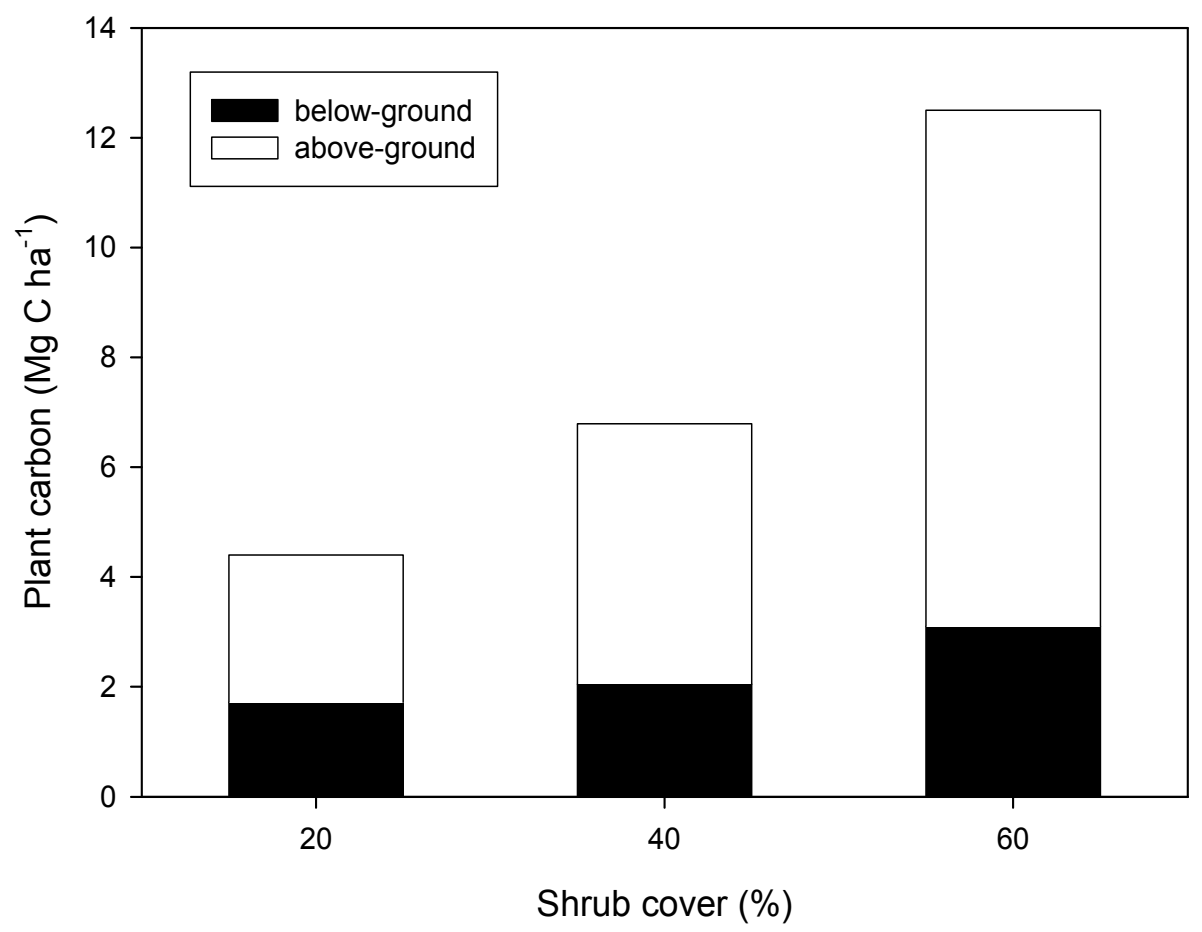

Fig. 2. Total plant carbon (C) accumulation for different shrub cover of "matorral" thicket area dominated mainly by Junellia tridens, Santa Cruz province 
budget at all $\mathrm{J}$. tridens shrubland sites and ranged from 70 (for 10-20\% shrub cover) to 160 $\mathrm{Mg} \mathrm{C}$ ha- $^{-1}$ (for $60-70 \%$ shrub cover) where soil C constitutes more than $90 \%$ of the total carbon in the ecosystem. This is consistent with Beier et al. (2009) who reported that soil C constitutes $95 \%$ of the total carbon in six shrublands along a climatic gradient across the European continent.

\subsection{Grasslands}

The Magellanic Patagonian steppe (southern Patagonia, Argentina) is a cold semiarid environment characterized by strong winds and high evaporation rates that cover 3 million hectares where grasses and shrubs are the dominated plant functional types with contrasting root systems. In this ecosystem Stipa chrysophylla and Festuca pallescens are dominant tussock species commonly associated with cool season Poa dusenii and Carex andina short grasses (Roig et al., 1985). There are antecedents related to biomass and C storage in the Patagonian steppe for main tussocks, short grasses and dwarf-shrub species (Peri \& Lasagno, 2006, 2008, 2009, 2010). In this ecosystem, C concentrations varied according to tissue components in all species studied, plant size and growing season being higher in coarse roots and green leaves. Total accumulation of $\mathrm{C}$ per hectare for three different grassland species composition and cover is presented in Table 3. Total carbon accumulated from grass plants ranged from 4.9 to $17.7 \mathrm{Mg} \mathrm{C}^{-1}$ depending on the main dominant species (Table 3). The greatest $\mathrm{C}$ accumulation of dominant F. pallescens grassland was mainly due to differences in biomass accumulation rates and to larger crowns with more biomass (Peri \& Lasagno, 2010). Carbon distribution between components varied according to the grassland composition. Thus, while dominant S. chrysophylla grassland accumulated more $\mathrm{C}$ in the senesced leaves component $(2.8 \mathrm{Mg} \mathrm{C} \mathrm{ha-1),} \mathrm{dominant} F$. pallescens grassland accumulated more carbon in fine roots $(5.2 \mathrm{Mg} \mathrm{C}$ ha- 1 ) and dominant $P$. dusenii in coarse roots (1.6 Mg C ha-1) (Table 3). Total C in roots ranged from $2.4 \mathrm{~kg} \mathrm{Mg} \mathrm{C} \mathrm{ha-}$ 1 for the $P$. dusenii grass steppe ecosystem to $8.7 \mathrm{Mg} \mathrm{C}^{-1}$ in the dominant grass riparian $F$. pallescens grassland, representing $49 \%$ of total $C$ sequestered by plants. The total $C$ stored in the studied grasslands ecosystems was $222.9 \mathrm{Mg} \mathrm{C}^{-1}$ distributed $88 \%$ in soil for grass riparian F. pallescens grassland and $83.9 \mathrm{Mg} \mathrm{C}^{-1}$ distributed $94 \%$ in soil. This is consistent with Hungate et al. (1997) who reported that up to $98 \%$ of C sequestration in grassland ecosystems occurred belowground and with Reeder \& Schuman (2002) who reported that the $80-90 \%$ of plant C short-grass steppe was stored belowground in the central Great Plains of USA.

The effect of long-term livestock grazing on C content of the plant-soil grassland system (to $30 \mathrm{~cm}$ ) of Dry Magellanic Grass Steppe and Sub-andean Grassland areas is presented in Figure 3. The vegetation of the steppe is dominated by grasses and sedges (Bromus, Carex, Festuca gracillima, Hordeum, Jarava, Poa, Rytidosperma virescens, Trisetum) with dwarf shrubs and herbs such as Nardophyllum, Perezia, Azorella, and Nassauvia admixed. The vegetation of the grass-shrub steppe is dominated by Agrostis, Festuca, Hordeum and Trisetum, however shrubs (Adesmia, Chuquiraga, Junellia, Mulinum, Senecio) are also frequent. The carrying capacity (ewe ha-1 $\mathrm{yr}^{-1}$ ) estimation is based on the biomass production of short grasses and forbs that grow in the space among tussocks of this ecological area and the requirements of $530 \mathrm{~kg} \mathrm{DM} \mathrm{yr}^{-1}$ for 1 Corriedale ewe of $49 \mathrm{~kg}$ of live weight. The baseline corresponds to an undisturbed vegetation area (non grazed areas). 
Pool

1. Grass steppe with $65 \%$ S. chrysophylla, 3\% P. dusenii, $1 \% \mathrm{~F}$. pallescens and $1 \% \mathrm{C}$. andina

\begin{tabular}{lc}
\hline Green leaves & 2.50 \\
Senesced leaves & 2.84 \\
Pseudostem & 1.48 \\
Fine roots & 2.38 \\
Coarse roots & 2.25 \\
Soil $(0-0.30 \mathrm{~m})$ & 86.1 \\
Total & 97.55
\end{tabular}

Green leaves

2. Grass riparian with $70 \%$ F. pallescens

Senesced leaves

2.92

Pseudostem

4.38

Fine roots

1.73

Coarse roots

Soil $(0-0.30 \mathrm{~m})$

3.49

Total

205.2

222.89

3. Grass steppe with $40 \%$ P. dusenii, $15 \%$ C. andina and $10 \%$ S. chrysophylla

Green leaves

0.81

Senesced leaves

0.76

Pseudostem

0.98

Fine roots

0.79

Coarse roots

1.63

Soil $(0-0.30 \mathrm{~m})$

Total

83.87

Table 3. Carbon amount at stand level $\left(\mathrm{Mg} \mathrm{C} \mathrm{ha}^{-1}\right)$ for different steppe grassland composition stands in southern Patagonia (Peri \& Lasagno, 2009)

On these extensively managed grasslands, grazing intensity was the main management practices that affected ecosystem $\mathrm{C}$ levels. This varied from $50 \mathrm{MgC} \mathrm{ha}^{-1}$ at a heavy stocking rate $\left(0.70\right.$ ewe ha $\left.\mathrm{yr}^{-1}\right)$ to $130 \mathrm{Mg} \mathrm{C}^{-1}$ under low grazing intensity $\left(0.10\right.$ ewe ha- $\left.\mathrm{yr}^{-1}\right)$ (Fig. 3). A slightly higher total $C$ content was detected in the low grazing intensity $(0.10$ ewe ha-1 $\mathrm{yr}^{-1}$ ) grassland compared with the non grazed areas (130 vs. $120 \mathrm{Mg} \mathrm{C} \mathrm{ha-1).} \mathrm{This} \mathrm{is}$ consistent with Reeder \& Schuman (2002) who reported that soil C content was highest in US mixed-grass and short-grass rangelands under grazing, while non-grazed enclosures caused immobilization of $\mathrm{C}$ in excessive above-ground plant litter. From a low grazing intensity of 0.10 ewe ha-1 $\mathrm{yr}^{-1}$, total grassland $\mathrm{C}$ declined as grazing intensity increased by reaching a value of $103 \mathrm{Mg} \mathrm{C} \mathrm{ha}^{-1}$ at a medium stocking rate of 0.35 ewe ha-1 $\mathrm{yr}^{-1}$ (Fig. 3). Then, total grassland ecosystem $\mathrm{C}$ was followed by a further decline to the lowest estimated $C$ value. For Dry Magellanic Grass Steppe grassland under sheep grazing, this response showed that 0.35 ewe ha-1 $\mathrm{yr}^{-1}$ stocking rate was a critical value below which ecosystem $\mathrm{C}$ was severely restricted. The effect of sheep on system $C$ arose from the influence of grazing 


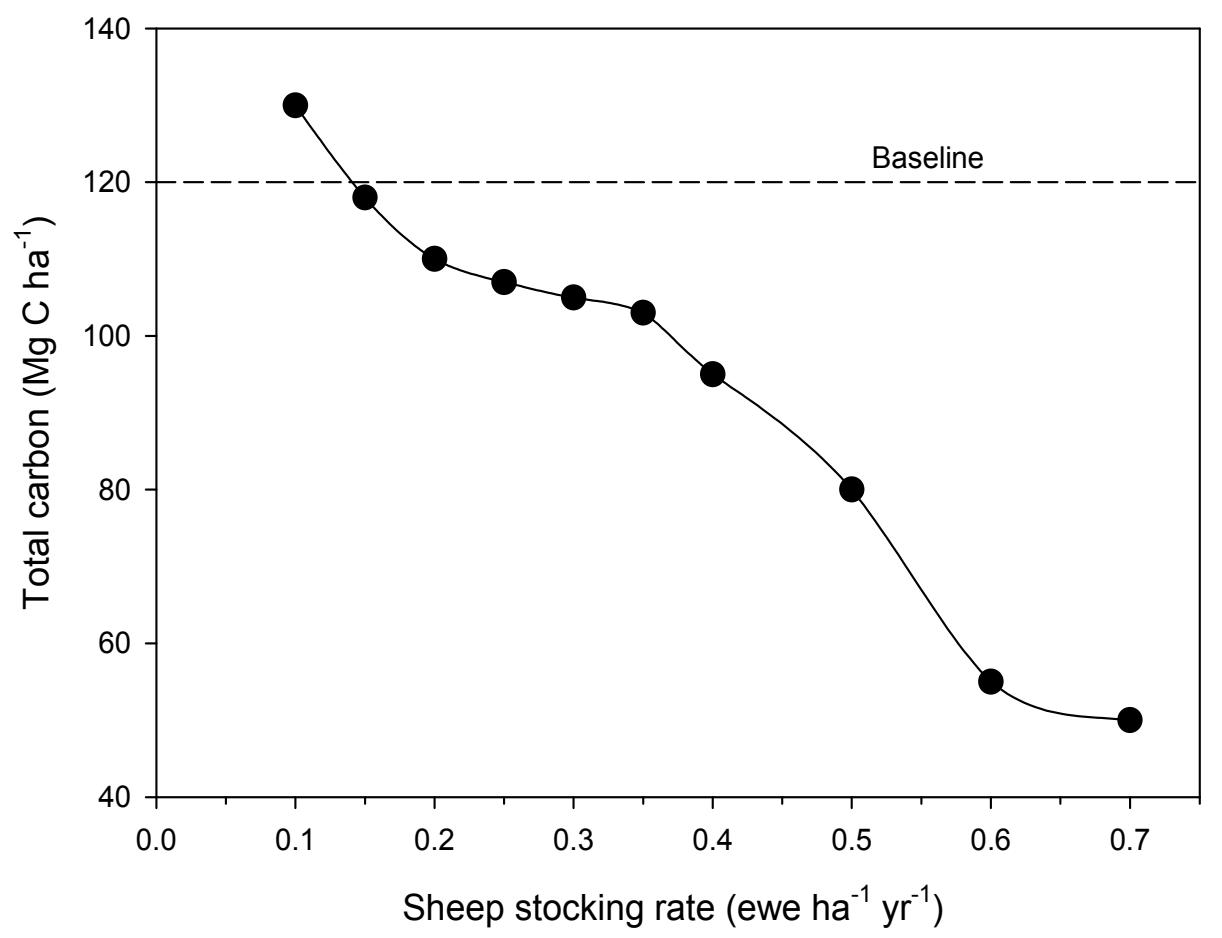

Fig. 3. Effect of long-term livestock grazing on $\mathrm{C}$ content of the plant-soil grassland system (to $30 \mathrm{~cm}$ ) of Dry Magellanic Grass Steppe and Sub-andean Grassland areas, Patagonia, Argentina. The baseline (dash line) corresponds to an undisturbed vegetation area (non grazed).

intensity on plant floristic composition. Thus, long-term grazing at heavy stocking rates has tended to decrease plant species diversity and plant cover, and consequently by increasing bare areas. However, the biggest impact on grassland $C$ ecosystem due to overgrazing was the $\mathrm{C}$ lost from soil (mainly the organic layer) as a consequence of soil erosion by strong winds.

\section{Conclusions}

Carbon storage has become an important issue in international negotiations on the management of greenhouse gas emissions, because increased carbon storage can be useful in offsetting emissions of carbon from fossil fuel burning and other sources. Estimates of native forest $C$ storage under different management practices are required for estimating regional and national greenhouse gas balance. The use of functions provide a valuable tool for understanding and estimating $\mathrm{C}$ accumulation of primary forests of $N$. antarctica using forest inventories data. Also, we improved the understanding about the potential of $\mathrm{C}$ sequestration of $N$. antarctica forests under silvopatoral management. Thinning in silvopastoral systems may change the distribution of $\mathrm{C}$ allocation within a stand, due to reduction in the number of trees and return of $C$ from litter. Stem-only harvesting rather than whole-tree removal, together with debarking the stem in situ, may reduce the loss of 
soil C pool from the forest ecosystem. Furthermore, root systems from removed trees remain in the system, and could provide $\mathrm{C}$ to soil through decomposition. Therefore, for any particular forest management system it is important to analyse the development of both above- and belowground $\mathrm{C}$ over the forest life cycle for different site qualities for accurate quantification of $C$ pools on regional scale.

$\mathrm{C}$ accumulation in grasslands and shrublands was strongly affected by plants composition, size and cover. In both ecosystems, it was critically important to quantify and understand belowground $\mathrm{C}$ allocation as well as soil $\mathrm{C}$ pools. Thus, quantification of roots $\mathrm{C}$ was important to improving our understanding of $\mathrm{C}$ cycles and storage in these ecosystems. In particular, long-term grazing intensity in grasslands was the main management practices that affected ecosystem $C$ levels where overgrazing determined $C$ lost mainly from soil as a consequence of soil erosion. Changes in grassland management that reverse the process of declining productivity can potentially lead to increased soil $\mathrm{C}$. Therefore, proper grassland management is important to carbon sequestration.

\section{Acknowledgment}

I want to thank to Romina Lasagno, Verónica Gargaglione, Martín Viola and Juan Ruiz for their invaluable help during sampling in the field and contribution with data analysis.

\section{References}

Beier, C.; Emmett, B.A.; Tietema, A.; Schmidt, I.K.; Peñuelas, J.; Láng, E.K.; Duce, P.; De Angelis, P.; Gorissen, A.; Estiarte, M.; de Dato, G.G.; Sowerby, A.; Kröel-Dulay, G.; Lellei-Kovács, E.; Kull, O.; Mand, P.; Petersen, J.; Gjelstrup, P. \& Spano, D. (2009). Carbon and nitrogen balances for six shrublands across Europe, Global Biogeochemical Cycles, Vol.23, (October 2009), pp. 13, ISSN 0886-6236

Borrelli, P.; Oliva, G.; Williams, M.; González, L.; Rial, P. \& Montes L. (1997). Sistema Regional de Soporte de Decisiones. Grupo interdisciplinario para el Sistema de Soporte de Decisiones - Santa Cruz y Tierra del Fuego. PRODESER (INTA-GTZ). EEA Santa Cruz, Argentina. $136 \mathrm{pp}$

Davis, M.R.; Allen, R.B. \& Clinton, P.W. (2003). Carbon storage along a stand development sequence in a New Zealand Nothofagus forest. Forest Ecology and Management, (April 2003) Vol.177, No.1-3, pp. 313-321, ISSN 0378-1127

Dixon, R.K.; Winjum, J.K.; Andrasko, K.J.; Lee, J.J. \& Schroeder, P.E. (1994). Integrated landuse systems: assessment of promising agroforest and alternative land-use practices to enhance carbon conservation and sequestration. Climatic Change, Vol.27, No.1, (May 1994), pp. 71-92, ISSN 0165-0009

Conant, R.T.; Paustian, K. \& Elliott, E.T. (2001). Grassland management and conversion into grasslands: effects on soil carbon. Ecological Applications, (April 2001), Vol.11, No.2, pp. 343-355, ISSN 1051-0761

Finér, L.; Mannerkoski, H.; Piirainen, S. \& Starr, M. (2003). Carbon and nitrogen pools in an old-growth, Norway spruce mixed forest in eastern Finland and changes associated with clear-cutting. Forest Ecology and Management, (February 2003), Vol.174, No.1-3, pp. 51-63, ISSN 0378-1127 
Gargaglione, V.; Peri, P.L. \& Rubio, G. (2010). Allometric relations for biomass partitioning of Nothofagus antarctica trees of different crown classes over a site quality gradient. Forest Ecology and Management, (March 2010), Vol. 259, No.6, pp. 1118-1126, ISSN 0378-1127

Golluscio, R.A.; Deregibus, V. \& Paruelo, J.M. (1998). Sustainability and range management in the Patagonian steppe. Ecología Austral, (December 1998), Vol.8, No.2, pp. 265284, ISSN 1667-7838

Hart, P.B.S.; Clinton, P.W.; Allen, R.B.; Nordmeyer, A.H. \& Evans, G. (2003). Biomass and macro- nutrients (above- and below-ground) in a New Zealand beech (Nothofagus) forest ecosystem: implications for storage and sustainable forest management. Forest Ecology and Management, (February 2003), Vol. 174, No.1-3, pp. 281-294, ISSN 0378-1127

Hungate, B.A.; Holland, E.A.; Jackson, R.B.; Chapin, F.S.; Mooney, H.A. \& Field, C.B. (1997). The fate of carbon in grasslands under carbon dioxide enrichment. Nature, Vol.388, (August 1997), pp. 576-579, ISSN: 0028-0836

IPCC (2001). Climate Change 2001: The Scientific Basis. Contribution of working group 1 to the third assessment report of the intergovernmental panel on climate change., J.T. Houghton; Y. Ding; D.J. Griggs; M. Noguer; P.J. van der Linden; X. Dai; K. Maskell \& C.A. Johnson (Eds.), Cambridge University Press, Cambridge, UK

Jobbágy, E.G. \& Sala, O.E. (2000). Controls of grass and shrub aboveground production in the Patagonian steppe. Ecological Applications, (April 2000), Vol.10, No.2, pp. 541549, ISSN 1051-0761

Laclau, P. (2003). Biomass and carbon sequestration of ponderosa pine plantations and native cypress forests in northwest Patagonia. Forest Ecology and Management, (July 2003), Vol.180, No.1-3, pp. 317-333, ISSN 0378-1127

Manabe, S. \& Wetherald, R.T. (1987). Large-scale changes of soil wetness induced by an increase in atmospheric carbon dioxide. Journal of Atmospheric Science, (April 1987), Vol.44, No.8, pp. 1211-1235, ISSN 0022-4928

Nosberger, J.; Blum, H. \& Fuhrer, J. (2000). Crop Ecosystem Responses to Climatic Change: Productive Grasslands, In: Climate Change and Global Crop Productivity, K.R. Reddy \& H.F. Hodges (Eds.), 271-291, CAB International, ISBN 0-85199-439-3, Wallingford, UK

Peri, P.L.; Viola, M. \& Martínez Pastur, G. (2004). Estimación de la fijación de carbono en bosques de Nothofagus antarctica. Proceedings II Reunión Binacional de Ecología, pp. 271, Mendoza, Argentina, 1-5 November, 2004

Peri, P.L.; Viola, M. \& Martínez Pastur, G. (2005). Estimación del contenido de carbono en bosques de ñire (Nothofagus antarctica) en Patagonia Sur. Proceedings III Congreso Forestal Argentino y Latinoamericano, pp. 9, ISSN 1669-6786, Corrientes, Argentina, 69 September, 2005

Peri, P.L. \& Lasagno, R. (2006). Eficiencia en la interceptación de la radiación y relaciones biomasa-nitrógeno de las principales especies de arbustos y subarbustos de la Estepa Magallánica. In: Desarrollo de un Sistema de Soporte de Decisiones para mejorar porcentajes de señalada de modo ecológicamente sustentable en establecimientos de la Estepa Magallánica (Patagonia), P.Pl. Peri, (Ed.), 51-59, Editorial Instituto Nacional de Tecnología Agropecuaria, ISBN-13: 978-987-521-212-1, Buenos Aires, Argentina 
Peri, P.L.; Gargaglione, V. \& Martínez Pastur, G. (2006). Dynamics of above- and belowground biomass and nutrient accumulation in an age sequence of Nothofagus antarctica forest of Southern Patagonia. Forest Ecology and Management, (September 2006), Vol.233, No. 1, pp. 85-99, ISSN 0378-1127

Peri, P.L.; Gargaglione, V. \& Martínez Pastur, G. (2008). Above- and belowground nutrients storage and biomass accumulation in marginal Nothofagus antarctica forests in Southern Patagonia. Forest Ecology and Management, (April 2008), Vol.255, No.7, pp. 2502-2511, ISSN 0378-1127

Peri, P.L. \& Lasagno, R. (2008). Secuestro de carbono en la estepa de Patagonia Sur. Proceedings XXIII Reunión Argentina de Ecología (ASAE), pp. 220, San Luis, Argentina, 25-28 November, 2008.

Peri, P.L. \& Lasagno, R. (2009). Acumulación de nutrientes y carbono para tres diferentes tipos de pastizal de estepa magallánica en Patagonia. Proceedings $V$ Congreso Nacional - II Congreso MERCOSUR - I Jornada Técnica de Productores Sobre Manejo de Pastizales Naturales, pp. 121-122, ISBN: 978-987-25275-0-1, Corrientes, Argentina, 1314 August, 2009

Peri, P.L.; Martínez Pastur, G.; Gargaglione, V. \& Lencinas, M.V. (2009). Aboveground and belowground carbon sequestration in a silvopastoral system of Nothofagus antarctica forests in Southern Patagonia, Argentina. Proceedings XIII World Forestry Congress, FAO. Thema: 1. Forests and biodiversity, Subtheme: 1.2 Deforestation and forest fragmentation, Buenos Aires, Argentina, 18-25 Octubre, 2009

Peri, P.L. \& Lasagno, R. (2010). Biomass, carbon and nutrient storage for dominant grasses of cold temperate steppe grasslands in southern Patagonia, Argentina. Journal of Arid Environments, (January 2010), Vol.74, No.1, pp. 23-34, ISSN 0140-1963

Peri, P.L.; Gargaglione, V.; Martínez Pastur, G. \& Lencinas, M.V. (2010). Carbon accumulation along a stand development sequence of Nothofagus antarctica forests across a gradient in site quality in Southern Patagonia. Forest Ecology and Management, (June 2010), Vol.260, No.2, pp. 229-237, ISSN 0378-1127

Reeder, J.D. \& Schuman, G.E. (2002). Influence of livestock grazing on C sequestration in semi-arid mixed-grass and short-grass rangelands. Environmental Pollution, (March 2002), Vol.116, No.3, pp. 457-463, ISSN 0269-7491

Roig, F.A.; Anchorena, J.; Dollenz O.; Faggi, A.M. \& Méndez, E. (1985). Las comunidades vegetales de la transecta botánica de la Patagonia Austral. In: Transecta Botánica de la Patagonia Austral, O. Boelcke, D.M. Moore \& F.A Roig (Eds.), Conicet-Instituto de la Patagonia-Royal Society, Buenos Aires, Argentina

Rötzer, T.; Seifert, T. \& Pretzsch, H. (2009). Modelling above and below ground carbon dynamics in a mixed beech and spruce stand influenced by climate. European Journal of Forest Research (March 2009), Vol.128, No.2, pp. 171-182, ISSN 1612-4669

Sharrow, S.H. \& Ismail, S. (2004). Carbon and nitrogen storage in agroforests, tree plantations, and pastures in western Oregon, USA. Agroforestry Systems, (March 2004), Vol.60, No.2, pp. 123-130, ISSN 0167-4366

Silvester, W.B. \& Orchard, T.A. (1999). The biology of kauri (Agathis australis) in New Zealand. 1. Production, biomass, carbon storage, and litter fall in four forest remnants. New Zealand Journal of Botany, (September 1999), Vol.37, No.3, pp. 553571, ISSN: 0028-825X 
Tate, K.R.; Ross, D.J.; O’Brien, B.J. \& Kelliher, F.M. (1993). Carbon storage and turnover, and respiratory activity, in the litter and soil of an old-growth southern beech (Nothofagus) forest. Soil Biology Biochemistry, (December 1993), Vol.25, No.12, pp. 1601-1612, ISSN 0038-0717

Veblen, T.T.; Donoso, C.; Kitzberger, T. \& Rebertus, A.J. (1996). Ecology of Southern Chilean and Argentinean Nothofagus Forests, In: The Ecology and Biogeography of Nothofagus Forests, T. Veblen, R. Hill \& J. Read, (Eds.), 293-353, Yale University Press, ISBN 0300-06423-3, New Haven 


\section{Part 4}

\section{Primary Productivity}





\title{
Long-Term UVR Effects Upon Phytoplankton Natural Communities of Patagonian Coastal Waters
}

\author{
Silvana R. Halac ${ }^{1,2}$, Virginia E. Villafañe1,3, \\ Rodrigo J. Gonçalves ${ }^{1,3}$ and E. Walter Helbling 1,3 \\ 1Estación de Fotobiología Playa Unión (EFPU), Chubut, \\ 2Instituto Nacional del Agua (INA), Córdoba, \\ ${ }^{3}$ Consejo Nacional de Investigaciones Científicas y Técnicas (CONICET),
}

Argentina

\section{Introduction}

Since the discovery of the ozone "hole" over the Antarctic continent and the concomitant increase in ultraviolet B radiation (UV-B, 280-315 nm) vast literature has been produced about the impact of these wavelengths on aquatic organisms. Nowadays it is widely accepted that ultraviolet radiation (UVR, 280-400 nm) acts as a stressor for both organisms and ecosystems, this being true not only for increased UVR but also for 'normal' levels (see review by Helbling and Zagarese 2003 and references therein). Many studies about the UVR impact on phytoplankton species and communities have reported negative effects on different cellular targets (e.g., photosystem II, DNA, proteins) which may affect several processes such as growth and photosynthesis (Vernet 2000; Villafañe et al. 2003). In particular, it has been found that UVR can significantly affect Photosynthesis versus Irradiance (P vs. E) parameters (Furgal and Smith 1997; Montecino et al. 2001; Villafañe et al. 2004c) thus remote sensing calculations of primary production based on them might be frequently overestimated.

On the other hand, some studies also documented positive effects of UVR, such as increased carbon uptake under UV-A (315-400 nm) exposure (Nilawati et al. 1997, Barbieri et al. 2002; Helbling et al. 2003). Exposure to UV-A can also induce the light-dependant enzymatic repair of the UVR-induced DNA damage (i.e., 'photorepair', Buma et al. 2003). Indirect effects of UVR such as the breakdown (photolysis / photodegradation) of dissolved organic matter (DOM) (Osburn and Morris 2003) can be either beneficial for organisms by means of increasing nutrient availability, or detrimental, by increasing water transparency so cells receive more irradiance (Cooke et al. 2006). It is also known that the interaction of UVR and other factors - e.g., nutrient availability, vertical mixing, changes in temperature, supersaturating oxygen concentrations or high $\mathrm{pH}$ values, may strongly condition the observed results (Forster and Schubert 2001; Neale et al. 2003; Beardall et al. 2009 and references therein) as compared to those obtained considering only UVR. This is due to the synergic or antagonistic nature of the interactions between UVR and those other factors (Dunne 2010). The evaluation of the combined effects of increased temperature and UVR is 
particularly interesting because these two variables are more affected in a global change scenario (Häder et al. 2011). In this regard, some studies have demonstrated that increased temperature under UVR exposure benefits photosynthetic performance of some diatoms species by enhancing repair rates (Sobrino and Neale 2007; Halac et al. 2010); however, in studies carried out with cyanobacteria, Fiorda Giordanino et al. (2011) found important inter-specific variability in responses (with some species benefiting from increased temperature whereas others were rather indifferent) and these variations were partially related to differences in morphology among the species.

In spite of the negative effects, there are several mechanisms that allow phytoplankton to cope with UVR over time periods of days / weeks: At the individual level, the most common strategy is the synthesis of protective compounds such as mycosporine-like amino acids - MAAs. As the maximum absorption of these compounds lies between 310 and 360 $\mathrm{nm}$, they have the potential of decreasing the energy of the most damaging portions of the solar spectrum (Banaszak 2003; Korbee et al. 2006). Pigments like carotenoids can also protect organisms by dissipating excessive energy as heat i.e., via non-photochemical quenching (Müller et al. 2001). Another common protective strategy for motile organisms is to avoid UVR by performing downward migration (Richter et al. 2007). Finally, some organisms have the ability to repair damage produced to the DNA molecule (Buma et al. 2003) or photosystem components, especially the D1 protein (Andersson and Barber 1996; Halac et al. 2009). All together, the net impact of UVR is the result of a trade-off between the sensitivity of individual / community and their acclimation capacity.

\section{Assessment of UVR effects upon phytoplankton over long-term periods}

Although extensive research has been carried out to address the short-term effects of UVR on phytoplankton (i.e., with experiments lasting less than one day, see review by Villafañe et al. 2003) the performance of communities over longer temporal scales (i.e., days / weeks) have been relatively less studied. Still, these studies are especially important because they reflect the result of a particular effect caused by UVR as well as potential photoacclimation i.e., short-term experiments frequently overestimate the impact of UVR. One way to evaluate UVR effects on aquatic autotrophic organisms on a long-term basis is by using an "enclosed ecosystem" as a model (named meso- or microcosms, depending on the volume of sample) in which a water parcel is isolated and incubated under conditions similar to those found in the natural environment (Wängberg et al. 1996). These setups make feasible to conduct controlled incubations of plankton communities while allowing the manipulation of UVR intensities (i.e., when working with artificial radiation sources) and spectral composition (by covering the containers with different filters / materials). On the other hand, natural conditions are not completely simulated in these cases, as for example water movements are restricted and larger organisms are usually excluded. In these experiments phytoplankton biomass tends to increase rapidly therefore, they often reproduce blooms conditions (Belzile et al. 2006 and references therein).

Studies devoted to evaluate the effects of UVR on phytoplankton communities over long periods of time have highlighted the high variability in responses. Some outdoor mesocosms studies showed little UVR effects on chlorophyll $a(\mathrm{Chl} a)$ content (Halac et al. 1997; Wängberg et al. 1999; Whitehead et al. 2000). On the other hand, Forster et al. (2001) working with phytoplankton of the Darss-Zingst estuary in the Baltic Sea found higher Chl $a$ concentration in samples that did not receive UVR, as also observed in the experiments 
carried out by Keller et al. (1997) with communities off Narragansett Bay. At the community level, UVR impact is frequently translated onto changes in the taxonomic composition towards more tolerant species or changes in size distribution. For example, studies carried out by Wängberg et al. (1999; 2008) found that small phytoplankton were favored by UV-B exposure, and Mousseau et al. (2000) reported a shift from diatoms to small naked flagellates that occurred more rapidly under enhanced UV-B than under its natural levels. UVR-mediated community structure shifts may result in an important impact for the whole aquatic system, either by altering the food web structure due to the differential sensitivity to UVR, or by affecting carbon allocation into different biomolecules which in turn is translated into changes of carbon and nutrient cycling in the ecosystem (Mostajir et al. 1999; Sommaruga 2003).

\section{Why studying UVR effects upon phytoplankton communities of Patagonia?}

The ecological effects of UVR were documented more intensively in the Antarctic region at beginning of the awareness of the Antarctic ozone 'hole'. Later studies pointed out that the influence of the Antarctic ozone depletion extends to mid latitudes (Atkinson et al. 1989) and that Southern mid latitudes may be even more affected (Seckmeyer and McKenzie 1992). Still, while many studies about the effects and impact of UVR on phytoplankton have been carried out in polar areas, relatively less is known about temperate regions (see review by Gonçalves et al. 2010) such as Patagonia. The Patagonia region is located at the southern tip of South America, includes part of Argentina and Chile (Fig. 1) and has unique characteristics that would warrant UVR studies for several reasons. First, the area is occasionally under the influence of ozone-depleted air masses from the Antarctic polar vortex, thus experiencing periods of enhanced UV-B (Villafañe et al. 2001; Helbling et al. 2005). Second, its great variability in cloudiness, from high cover over the Andes and subAntarctic regions to the relatively clear skies on the mid-latitude Atlantic coast, creates a range of environments with variable UVR climatology. Third, it presents a high variability in the nature and bio-optical characteristics of its water bodies (e.g. the upwelling deep waters in the Pacific and the shallow and very productive Atlantic waters). Finally, high wind speed and frequency, especially during spring and summer (Villafañe et al. 2004a; Helbling et al. 2005) strongly condition the depth of the upper mixed layer (UML) and hence the underwater radiation field to which organisms are exposed. In addition the assessment of the UVR impact on phytoplankton from Argentinean Patagonia is essential since these organisms are responsible for an important share of primary productivity in the Argentinean Sea (Lutz et al. 2010) and they constitute the base of a very rich food web that includes fishes (e.g. hake, anchovy) (Skewgar et al. 2007) and invertebrate species (e.g. shrimp and mussels) of great commercial value (Caille et al. 1997).

Taking into consideration these facts, in the next section we present our study case and a review of the current knowledge about UVR effects on phytoplankton communities mainly from Patagonia, and especially focusing on effects observed in a days/weeks timeframe.

\section{Study case: Long-term UVR effects on phytoplankton from Bahía Engaño, Patagonia, Argentina}

The study site (Bahía Engaño, Chubut, Argentina) is located at Northern coastal Patagonia (Fig. 1). Our research group had previously conducted several UVR studies with 


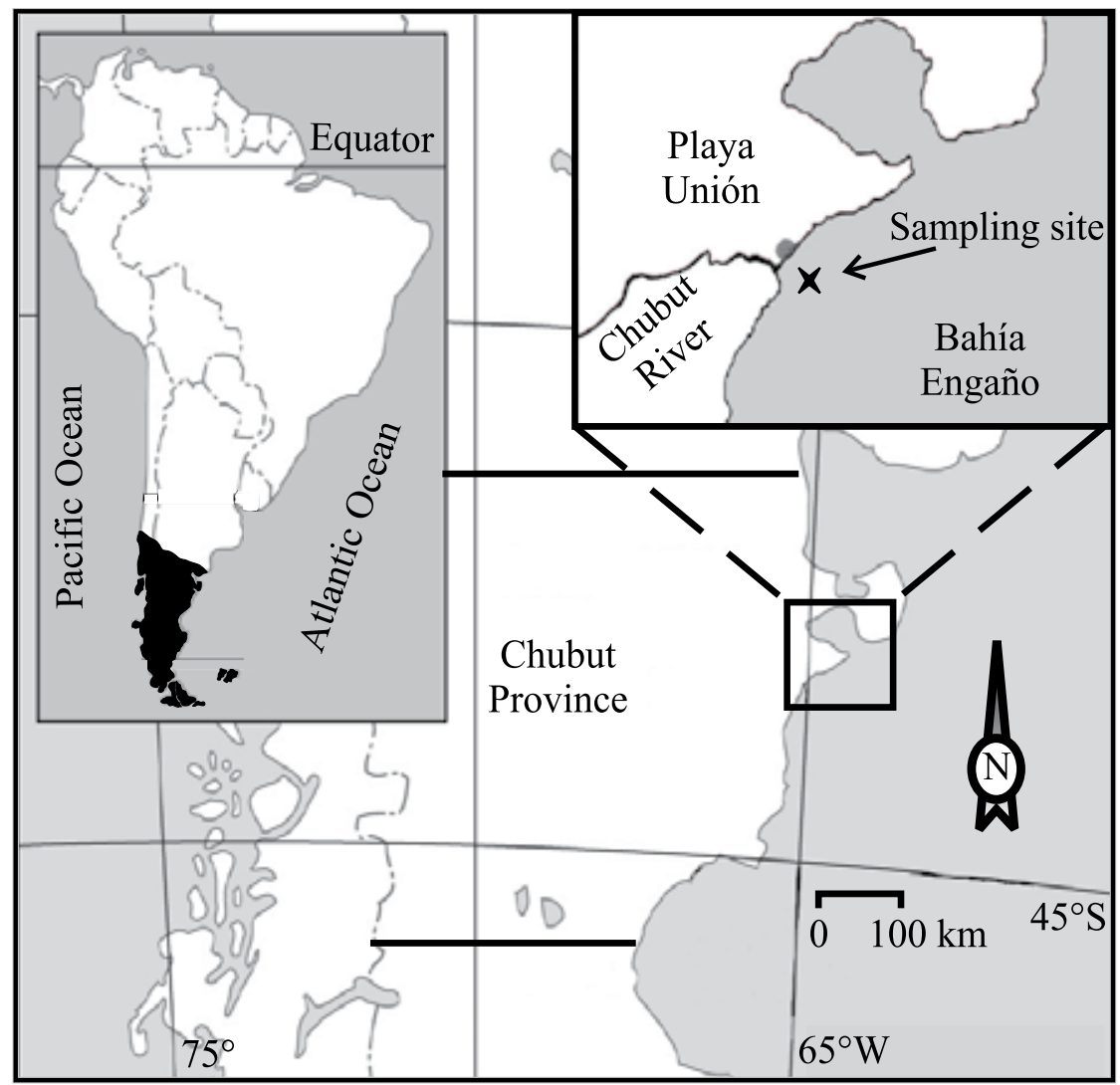

Fig. 1. Location of the study site, showing Patagonia (shaded area) and the relative position of the Chubut Province (Argentina) in South America. The inset shows the study area where microcosms experiments were done.

phytoplankton communities from this area, mostly determining short-term responses, particularly those related to inhibition of carbon fixation and photoinhibition (e.g., see Barbieri et al. 2002; Villafañe et al. 2004a; Villafañe et al. 2004b; Villafañe et al. 2008; Helbling et al. 2010), and relatively less studies to determine long-term responses to UVR in combination with nutrient addition (Helbling et al. 2005, Marcoval et al. 2008). Therefore, the results presented here aim to further elucidate aspects of UVR sensitivity and photoacclimation of phytoplankton from Patagonia occurring over longer periods of time, especially focusing on community properties such as global growth, abundance, taxonomic composition and size distribution.

An experimental approach was taken, in which natural phytoplankton samples were collected, and incubated under solar radiation during the austral summer of 2010. The experiments consisted in two microcosm incubations (hereafter MI and MII) which lasted between February 5 - 11 (MI) and February 15 - 21 (MII). The experimental setup consisted in exposing natural phytoplankton samples in 25-1, UVR-transparent bags (microcosms) under three different radiation conditions: a) PAB, 280-700 nm (samples receiving PAR+UVA+UV-B); b) PA, 320-700 nm (samples receiving PAR+UV-A) and c) P, 400-700 nm (samples receiving only PAR). The microcosms (duplicates per radiation treatment) were placed in a 
tank (3 m diameter, $1 \mathrm{~m}$ depth) with running water as temperature control and exposed to solar radiation at the surface for ca. 7 days. During the experiments, water samples from each microcosm bag was collected daily (early in the morning) for analyses of Chl $a$ and UVabsorbing compounds whereas samples for taxonomic composition and size distribution were taken every other day.

During the experiments, PAR and UVR irradiance conditions (Fig. 2) presented a typical pattern of relatively high values at noon and low ones during the morning and late
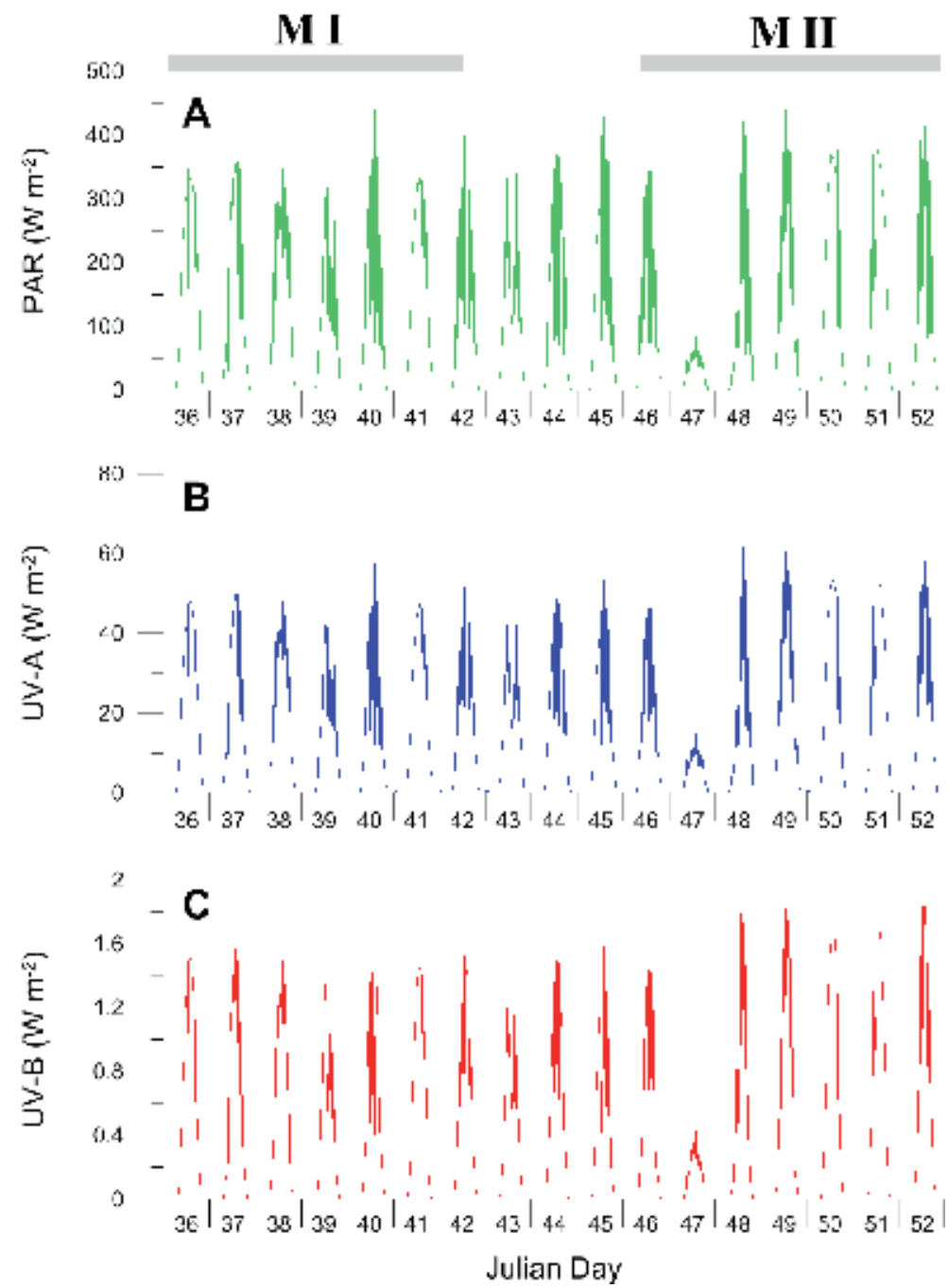

Fig. 2. Solar radiation reaching the Earth's surface at the study site during experiments carried out during February 5-11 (Julian days 36-42) (MI), and February 15-21 (Julian days 46-52), 2010 (MII). Irradiance is shown for: A) PAR, 400- $700 \mathrm{~nm}, \mathrm{~B})$ UV-A, 315-400 nm and, C) UV-B, $280-315 \mathrm{~nm}$. Solar radiation was continuously monitored using a broad-band filter radiometer (ELDONET, Real Time Computers, Möhrendorf, Germany, Häder et al. 2007) permanently installed on the roof of the Estación de Fotobiología Playa Unión. 
afternoon; also, the presence of clouds that resulted in high daily variability in solar irradiance is characteristic for the area during summer (Helbling et al. 2005). During our experiments, maximum PAR irradiance levels were rather similar $\left(\sim 440-460 \mathrm{~W} \mathrm{~m}^{-2}\right)$ (Fig. 2A) as also were UV-A $\left(\sim 60 \mathrm{~W} \mathrm{~m}^{-2}\right)$ and UV-B $\left(\sim 2 \mathrm{~W} \mathrm{~m}^{-2}\right)$ - except for the second day during MII where PAR and UVR values were very low (i.e., $\sim 100,17$, and $0.6 \mathrm{~W} \mathrm{~m}^{-2}$ for PAR, UV-A and UV-B, respectively; Figs. 2A-C). The high irradiance values in combination with long daylight periods result in high daily doses (Helbling et al. 2005) which are similar to those registered in tropical environments (Gao et al. 2007). Since phytoplankton in our experiments were exposed to these high irradiance conditions of solar radiation under a thin layer of water under, our results represent the 'worst-case scenario', i.e., as if cells were at the water surface, not allowed to move downward towards lower radiation levels.

Because the timing of our sampling (summer) that is considered a post-bloom condition for our study area (Villafañe et al. 2008), we added nutrients to each incubation bag (f/2 concentration (Guillard and Ryther 1962)) at the beginning of each experiment to avoid nutrient constraints while phytoplankton was growing. In both experiments, the phytoplankton assemblage showed an increase, as assessed by measurements of Chl $a$ (Fig. 3A), cellular abundance (Fig. 3B) and autotrophic carbon (Fig. 3C). Some general features were observed: Firstly, during both experiments the variables used to calculate growth had a typical exponential increase, similar to those occurring at bloom conditions, and thus an optimum cellular response. Secondly, the observed increase was similar for both experiments, although some differences appeared for some variables; and thirdly, no general UVR effects were observed (except in a few cases) within any experiment / variable measured.

As an overview of the increase of phytoplankton assemblages, Table 1 resumes the calculated growth rates $(\mu)$ during both experiments. The fast growth observed during the experiments were probably due to the addition of nutrients and the low turbulence inside the incubation bags, as previously observed in long-term studies with phytoplankton communities from the area (Helbling et al. 2005; Marcoval et al. 2008). As mentioned before, a common result of long-term incubations is the lack of UVR effects on growth and biomass, as also observed in our study (i.e., no-significant differences between radiation treatments as observed in Table 1 and Fig. 3). In fact, this lack of UVR effects on growth was also observed in other studies carried out in Patagonian waters: For example, Roy et al. (2006) working with phytoplankton communities from the Beagle Channel (Tierra del Fuego) observed minor changes in biomass due to UV-B (both normal and enhanced levels), even though the UV-B enhancement imposed to the samples was important (i.e., simulating $60 \%$ of ozone depletion). However, Hernando et al. (2006) found a significant effect of UVR on growth on these phytoplankton assemblages only when samples were exposed to solar radiation at fixed depths, in contrast to the mixed conditions imposed in the mesocosms described by Roy et al. (2006). In addition, Helbling et al. (2005) and Marcoval et al. (2008) determined variable UVR-induced inhibition of growth in natural communities off the Chubut coast under different conditions of nutrients availability, with nutrient-depleted samples being more sensitive to UVR than those in which nutrients had been added. Therefore, UVR alone is not an evident inhibitor of growth for phytoplankton off Patagonia waters, but it can have important effects when acting together with other stressors (e.g., nutrient availability, mixing conditions). 

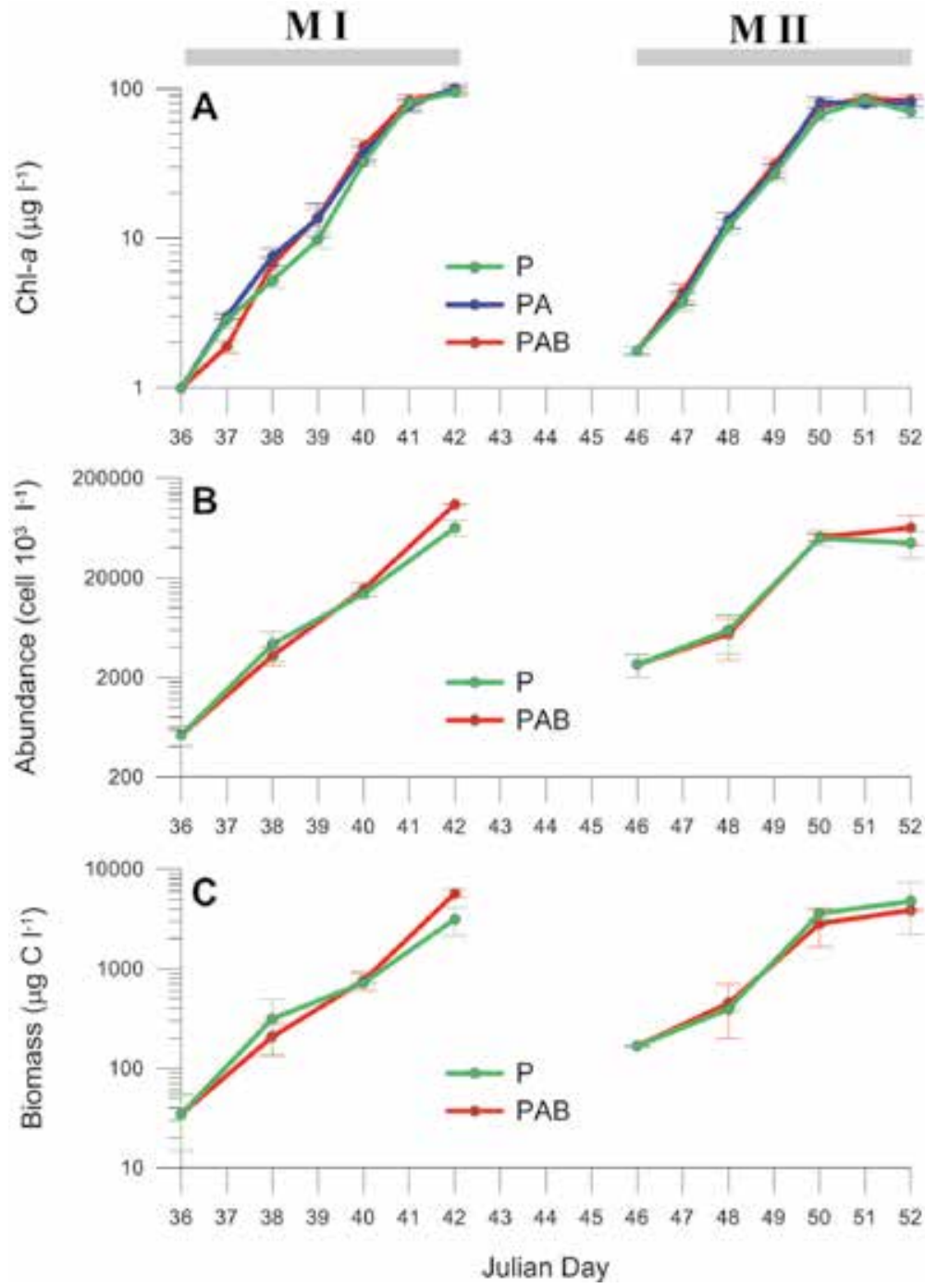

Fig. 3. Growth of the phytoplankton communities during MI and MII experiments evaluated as: A) Chlorophyll $a$ (Chl $a$ ) content (measured by fluorometric and spectrophotometric techniques, Holm-Hansen and Riemann 1978; Porra 2002); B) Cell concentration (obtained by microscopy; Villafañe and Reid 1995); and C) Autotrophic biomass (considering biovolumes according to Hillebrand et al. 1999 and posterior transformation to carbon content following Strathmann 1967). The different radiation treatments are shown in different colors. The vertical lines on the symbols indicate the half mean range. Note the different log scales for the variables presented.

Another observed pattern in the growth response was, at first sight, a similar trend among experiments which was due not only to the similar radiation conditions (Fig. 2) but also to the initial assemblages used in both experiments (i.e., similar starting taxonomic composition). In fact, at the beginning of experiments, the communities were numerically dominated by flagellates (e.g., chlorophytes and cryptophytes) and to a less extent by 


\begin{tabular}{|c|c|c|c|c|c|c|}
\hline \multicolumn{2}{|c|}{ Growth rates $\left(\boldsymbol{\mu} ; \mathbf{d}^{-1}\right)$} \\
\hline & PAB & P & PAB & P & PAB & P \\
\hline $\begin{array}{c}\text { Microcosm } \\
\text { I }\end{array}$ & $0.76 \pm 0.01$ & $0.76 \pm 0.06$ & $0.88 \pm 0.09$ & $0.79 \pm 0.04$ & $0.84 \pm 0.14$ & $0.75 \pm 0.15$ \\
\hline $\begin{array}{c}\text { Microcosm } \\
\text { II }\end{array}$ & $0.94 \pm 0.02$ & $0.90 \pm 0.03$ & $0.73 \pm 0.08$ & $0.73 \pm 0.11$ & $0.70 \pm 0.07$ & $0.76 \pm 0.03$ \\
\hline
\end{tabular}

Table 1. Growth rates $\left(\mu\right.$, in $\left.\mathrm{d}^{-1}\right)$ during MI and MII experiments, determined from measurements of Chl $a$, cellular abundance and estimations of autotrophic carbon.

diatoms (Thalassiosira spp., Nitzschia longissima); on the other hand, the abundance of dinoflagellates (e.g., Prorocentrum micans, unidentified naked species) was very low. This is in agreement with previous studies carried out in the area that demonstrated the conspicuous presence of flagellates during the summer (Villafañe et al. 2004a; Villafañe et al. 2008). However, it was also evident that there were some differences in the growth rates calculated from different variables as well as when comparing experiments. For example, during MI, Chl $a$-based $\mu$ were lower than those from cellular abundance and autotrophic carbon, while the opposite occurred in MII. The fact that Chl a concentration showed a slower (during MI) or faster (during MII) increase than the other two variables, suggests a differential acclimation of the assemblages as the experiments progressed. This could be due to different reasons: On the one hand, as the community grew the self-shading effect might become important and thus the $\mathrm{Chl}$ a concentration per cell would increase to keep efficiently capturing photons and maintain the exponential growth. This could be mediated by cell size, as smaller cells (i.e., higher surface-to-volume ratio) needs comparatively less Chl $a$ per cell as compared to larger cells (Falkowski 1981). On the other hand, an increase in cell size, with larger cells towards the end of the exponential growth phase, means a smaller surface-to-volume ratio and thus the need of higher $\mathrm{Chl} a$ content per cell. Indeed, a combination of both factors were observed in our experiments, as the $\mathrm{C}$ to $\mathrm{Chl} a$ ratio - an indicator of "light acclimation" - increased in MI and decreased in MII, while the Chl $a$ content per cell decreased in MI and increased in MII towards the end of the exponential phase (Table 2). In the following paragraphs we will discuss how changes in cell size, together with differential changes in species composition might have accounted for the observed patterns and variability among our experiments.

\begin{tabular}{|c|c|c|c|c|}
\hline \multirow{2}{*}{} & \multicolumn{2}{|c|}{ C / Chl $a$} & \multicolumn{2}{c|}{ Chl $a$ content per cell } \\
\cline { 2 - 5 } & PAB & P & PAB & P \\
\hline MI - $\mathrm{T}_{0}$ & $35 \pm 5$ & $35 \pm 5$ & $1.87 \pm 0.45$ & $1.87 \pm 0.45$ \\
\hline MI - $\mathrm{T}_{\mathrm{f}}$ & $58.8 \pm 3.1$ & 33.2 & $0.88 \pm 0.33$ & 1.48 \\
\hline \multicolumn{5}{|c|}{} \\
\hline MII - $\mathrm{T}_{0}$ & $94.6 \pm 0.9$ & $94.6 \pm 0.9$ & $0.65 \pm 0.18$ & $0.65 \pm 0.18$ \\
\hline MII - $\mathrm{T}_{\mathrm{f}}$ & $37 \pm 13$ & $53.8 \pm 15.7$ & $1.49 \pm 0.07$ & $1.33 \pm 0.02$ \\
\hline
\end{tabular}

Table 2. Mean (and half mean range) carbon to Chl $a$ ratio (in $\mu \mathrm{g} \mathrm{C} \mu \mathrm{g} \mathrm{Chl} a^{-1}$ ) and Chl $a$ content per cell (in pg) at the beginning $\left(\mathrm{T}_{0}\right)$ and at the end $\left(\mathrm{T}_{\mathrm{f}}\right)$ of the experiments. 
To study changes in the size spectra of each treatment, we recorded digital images of each sample and analyzed them to obtain the size (area) distribution of cells at the beginning of the incubation as well as at the end of the exponential growth. The size spectra data (Fig. 4) indicates that in both experiments most of the phytoplankton assemblages (> $60 \%)$ were dominated by small cells with an area $<100 \mu \mathrm{m}^{2}$ (Figs. 4A and C). A shift in the cumulative frequency of cell size in the range of $65-395 \mu \mathrm{m}^{2}$ was observed in all radiation treatments of MI (Fig 4B), being the P treatment the one with the higher change. On the other hand, during MII (Fig 4D) a slightly different response was observed, as the P treatment showed virtually no changes but the size distribution in the PAB treatment was slightly shifted towards larger areas in the range 85-395 $\mu \mathrm{m}^{2}$. It has been usually found in other studies that smaller cells tend to dominate the community after UVR-exposure (Mostajir et al. 1999), but in our results this might be strongly affected by the initial conditions of each microcosm. Also we can not rule out the effects of co-occurring predators (i.e., heterotrophic microplankton). Similarly to what we expressed about the lack of UVR-only effects on growth, we could speculate that UVR alone might not always show evident effects on size distribution, but depending on the starting taxonomic composition of the community, both PAR and UVR may have implications in the structure of the plankton community.
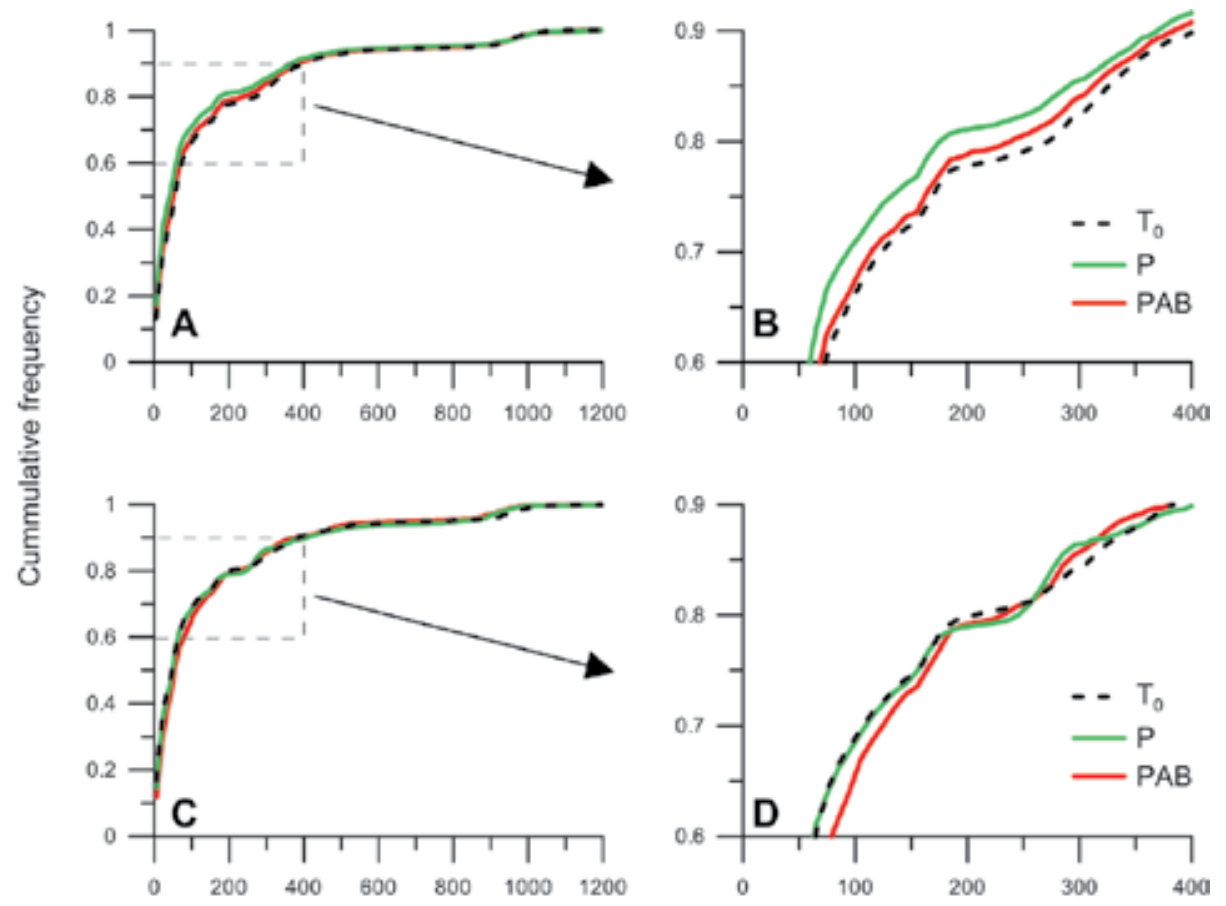

Size $\left(\mu m^{2}\right)$

Fig. 4. Cumulative frequency of size (in $\left.\mu \mathrm{m}^{2}\right)$ at the beginning $\left(\mathrm{T}_{0}\right)$ and at the end of the exponential growth phase for MI (A) MII (C). In B) and C) a detailed view within the size ranges of differences is shown. The radiation treatments are shown in different colors: $P$ (green), and PAB (red). Size distribution was evaluated in formalin-fixed samples from pictures taken under an inverted microscope; images were analyzed using Image J software (Abramoff et al. 2004). 
Microscopical analyses of the communities also supported changes in cell size throughout the experiments. For example, carbon allocated in the nanoplankton fraction (cells $<20 \mu \mathrm{m}$ in effective diameter) increased more rapidly than that of microplankton $(>20 \mu \mathrm{m})$ in MI (Fig. 5A), but the opposite occurred in MII (Fig. 5 B). Also, there was a general decrease in the microplankton biomass from $\mathrm{T}_{0}$ towards the end of the experiments (Fig $5 \mathrm{C}$ ) as was also expected from the shift towards smaller cells in MI (Fig 4B). However, the decrease was more pronounced in MI than in MII, therefore the overall result was that the relative contribution of microplankton to the total biomass in MII was higher than during MI (Fig 5C).
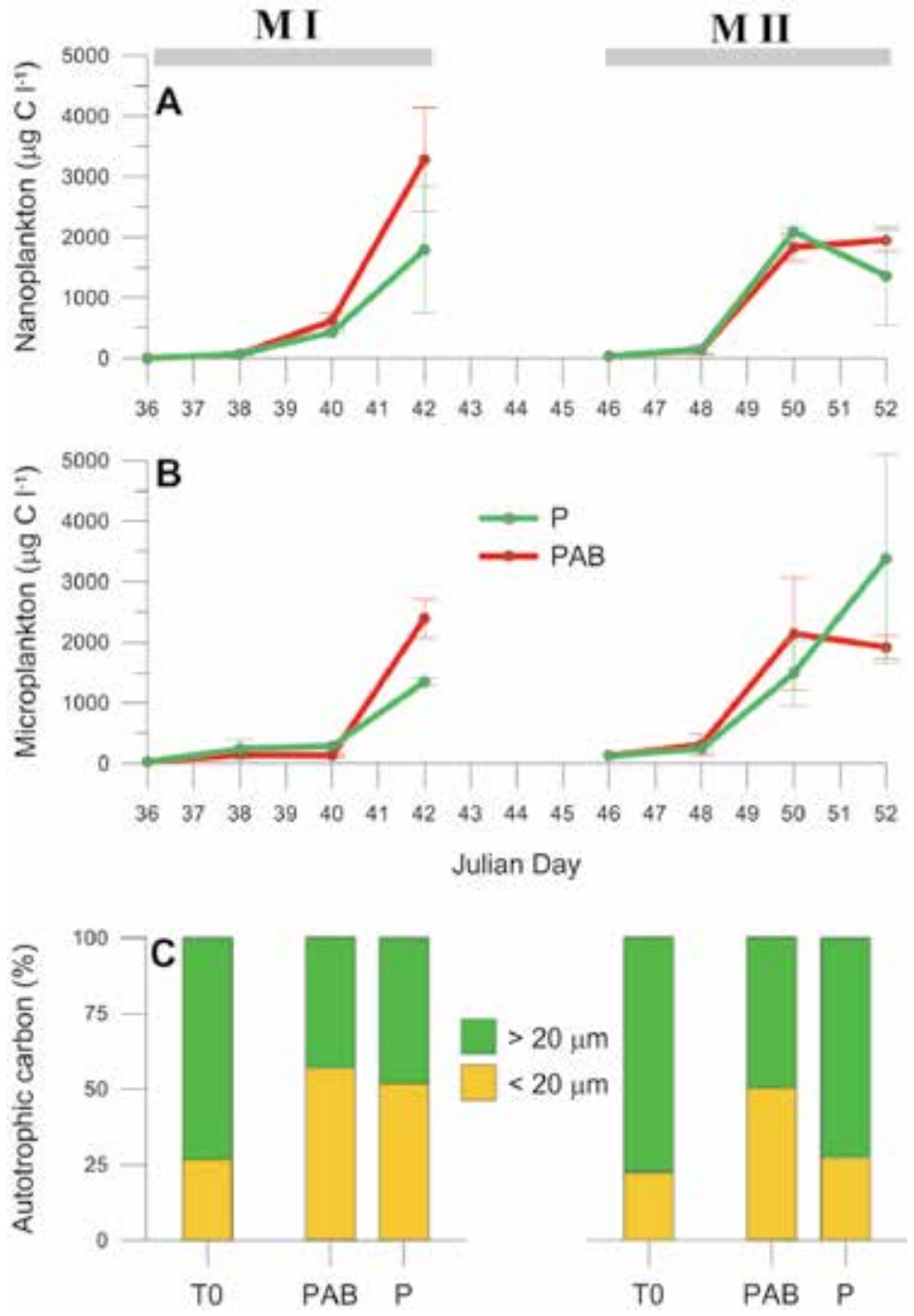

Fig. 5. Autotrophic carbon (in $\mu \mathrm{g} \mathrm{C}^{-1}$ ) of the phytoplankton size classes: A) Nanoplankton $(<20 \mu \mathrm{m})$ and, B) Microplankton $(\geq 20 \mu \mathrm{m})$. C) Relative contribution of nanoplankton and microplankton (\%) to the total autotrophic carbon at the beginning $\left(\mathrm{T}_{0}\right)$ and at the end of the MI and MII experiments. The radiation treatments / size fractions are shown in different colors: P (green) and PAB (red) / microplankton (green) and nanoplankton (orange). The vertical lines on the symbols indicate the half mean range. 
Any change in cell size and biomass allocation might occur within a particular species however they normally are associated to change in taxonomic composition towards the most resistant or acclimated groups. In fact, the most evident effect of UVR exposure (as compared to samples in which UVR was excluded) over long periods of time are the taxonomic changes produced in the community, which act as a photoacclimation mechanism. There are many studies that have reported this effect in long-term experiments (see review by Villafañe et al. 2003) but in particular, and for the Patagonia area, Hernando et al. (2006) working with the communities off the Beagle Channel observed changes from an assemblage co-dominated by phytoflagellates and diatoms at the beginning of the experiments to a progressive increase of euglenophytes, especially under static conditions of
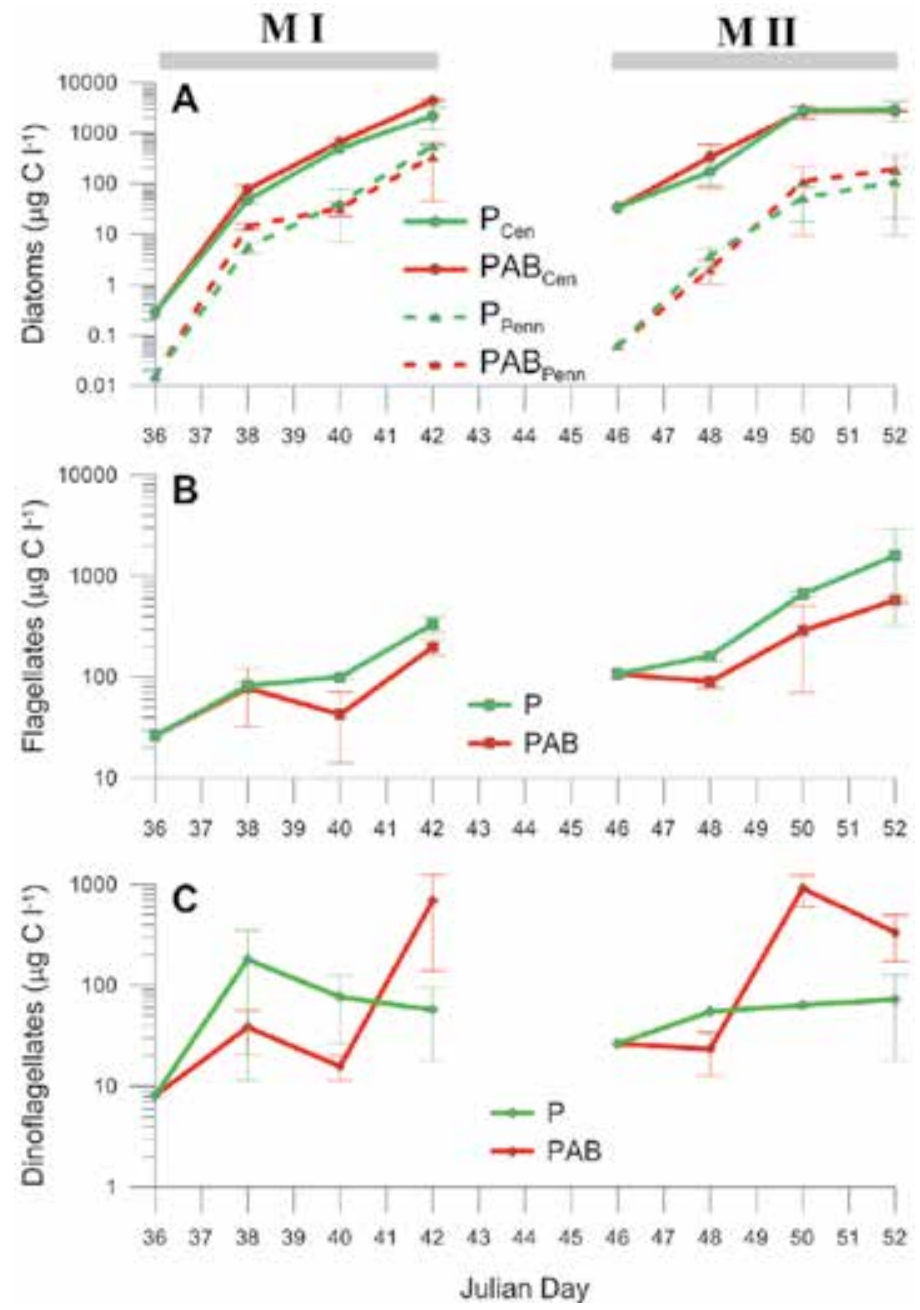

Fig. 6. Autotrophic carbon (in $\mu \mathrm{g} \mathrm{C}^{-1}$ ) of: A) Diatoms, B): Flagellates and, C) Dinoflagellates during the experiments $\mathrm{MI}$ and MII. The radiation treatments are shown in different colors: $\mathrm{P}$ (green), and PAB (red); different lines in panel A indicate the contribution to the total of centric (solid lines) and of pennate diatoms (dotted lines). The vertical lines on the symbols indicate the half mean range. 
the water column. In studies carried out with communities off the Chubut coast, Helbling et al. (2005) and Marcoval et al. (2008) also found that solar radiation played a fundamental role in shaping phytoplankton communities. In order to further explore these changes in species composition in our experiments, in Fig. 6 we show the contribution of the three main taxonomic groups - diatoms (centric and pennates), flagellates and dinoflagellates.

Overall, no UVR effects were observed in the diatoms in both experiments (Fig. 6A) while significant differences among radiation treatments became evident in flagellates (Fig. 6B) and in dinoflagellates (Fig. 6C). For example, autotrophic carbon in flagellates was negatively affected by UVR, resulting in significantly lower values in samples receiving UVR (PAB treatment) as compared to those that received only PAR (P treatment). On the contrary, autotrophic carbon in dinoflagellates was higher in samples receiving UVR. Previous studies (Hernando and San Román 1999; Hernando et al. 2005) have shown similar results about the sensitivity of flagellates. In the case of dinoflagellates, their response seems to be more related to the size as shown by Helbling et al. (2008) where larger species (i.e., Prorocentrum micans, $50 \mu \mathrm{m}$ mean diameter) were less sensitive than small ones such as Gymnodinium chlorophorum $(5 \mu \mathrm{m})$ and Heterocapsa triquetra $(20 \mu \mathrm{m})$.

However, the overall picture in our experiments shows a significantly higher increase of autotrophic carbon in diatoms (both centric and pennates) (Fig. 6A) with centric diatoms always accounting for the higher share at the end of the experiments, as compared to flagellates (Fig. 6B) and dinoflagellates (Fig. 6C). This differential increase in autotrophic carbon caused a shift in the community dominance from a flagellate-dominated community towards a diatom-dominated one (Fig. 7).
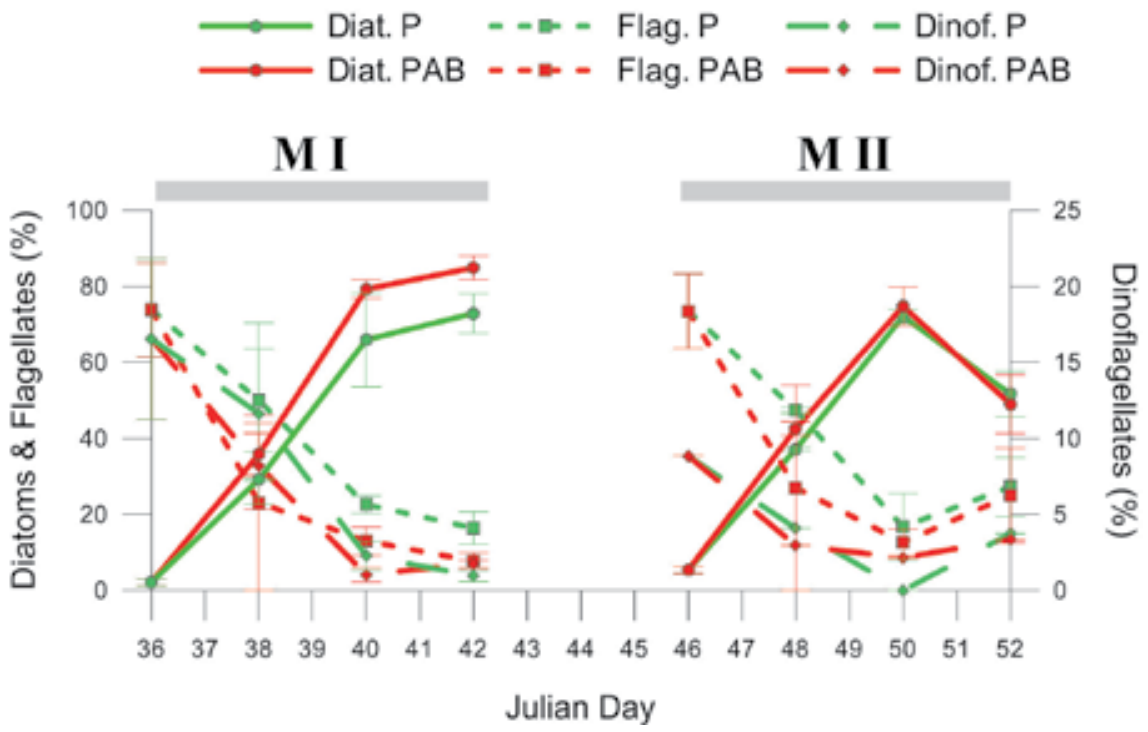

Fig. 7. Autotrophic carbon in diatoms, flagellates and dinoflagellates during the MI and MII experiments. The radiation treatments are shown in different colors: $\mathrm{P}$ (green), and PAB (red); filled lines: diatoms, dotted lines with squares: flagellates and dotted lines with diamonds: dinoflagellates. The vertical lines on the symbols indicate the half mean range. 
It should be noted that at the beginning of the experiments, the contribution of diatoms to the total abundance and biomass was very small (Figs. 6 and 7) and they were represented by Thalassiosira spp., Niztschia longissima, Skeletonema costatum, Asterionellopsis glacialis and unidentified pennates, among some others. However, by the end of the experiment, centric diatoms accounted for ca. $75 \%$ and $66 \%$ of the total autotrophic carbon for MI and MII, respectively. By the end of MI, and in both radiation treatments Thalassiossira spp. with a size range of 10-20 $\mu \mathrm{m}$ almost completely dominated the assemblages (Fig. 8). On the other hand, in MII there was a co- dominance of Thalassiossira spp. of 10-20 $\mu \mathrm{m}$ size and larger ones $(>20 \mu \mathrm{m})$.

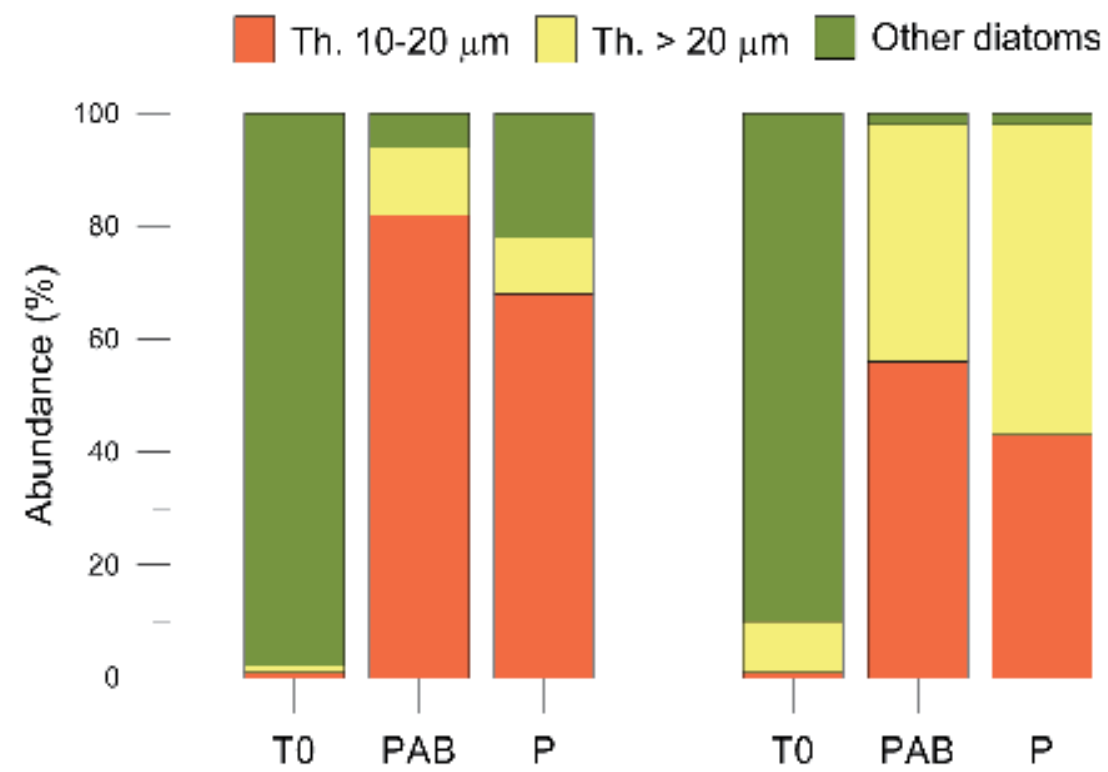

Fig. 8. Relative contribution of diatoms to the total autotrophic carbon at the beginning $\left(\mathrm{T}_{0}\right)$ and at the end of experiments. The size classes of Thalassiosira (Th.) are shown in different colors: > $20 \mu \mathrm{m}$ (yellow), 10-20 $\mu \mathrm{m}$ (red); other diatoms are represented in green.

So far, two main outcomes can be suggested from our data, one is related to changes in cell size (and consequently those on biomass, $\mathrm{Chl} a$ content per cell, etc.) and the other is that in species composition towards a diatom-dominated (mainly centric) assemblages. Although these are important acclimation mechanisms occurring over longer periods of time, there are also alternative ones to cope with UVR and excess of irradiance. One of such mechanism is, as previously mentioned, the synthesis of UV-absorbing compounds (mainly mycosporine like amino acids, MAAs). It has been found that even MAAs are generally very low in natural communities of Patagonia (Barbieri et al. 2002; Villafañe et al. 2004a; Villafañe et al. 2004c; Marcoval et al. 2008) but some species i.e., dinoflagellates such as Prorocentrum micans are able to synthesize them in high amounts after prolonged UVR exposure (Marcoval et al. 2007; Helbling et al. 2008); diatoms are also known to produce relatively high amounts (Lagunas et al., unpubl. data). It has also been shown that the synthesis of UV-absorbing compounds is more effective in large cells whereas in small species their synthesis would be too costly and osmotically disadvantageous (Garcia-Pichel 1994). In addition, previous 
studies (Helbling et al. 1996) showed that centric diatoms were able to synthesize significant amounts of UV-absorbing compounds after long-term exposure to UVR, whereas pennates did not. In our study case it is interesting to note that no significant changes in the concentration of UV-absorbing compounds were observed during MI (data not shown) probably due to the dominance of small diatom species during the experiment (Fig. 8). On the contrary, during MII there was a significant increase of UV-absorbing compounds (Fig 9). This increase, relative to the Chl $a$ content, was significant (Fig 9B) but there were no differences among radiation treatments, suggesting that all wavelengths of solar radiation triggered the synthesis of these compounds, as also observed for Antarctic diatoms (Helbling et al. 1996). A possible explanation is that high solar radiation in their natural environment will include PAR and UVR, therefore PAR as well as UVR may be capable of triggering the synthesis of MAAs so Thalassiossira spp. can obtain protection against solar UVR (Helbling et al. 1996). The presence of UV-absorbing compounds in MII probably reflects the higher proportion of large Thalassiossira species during this experiment (Fig 8) and also of dinoflagellates, although in lesser extent (Fig 6 C).

\section{II}
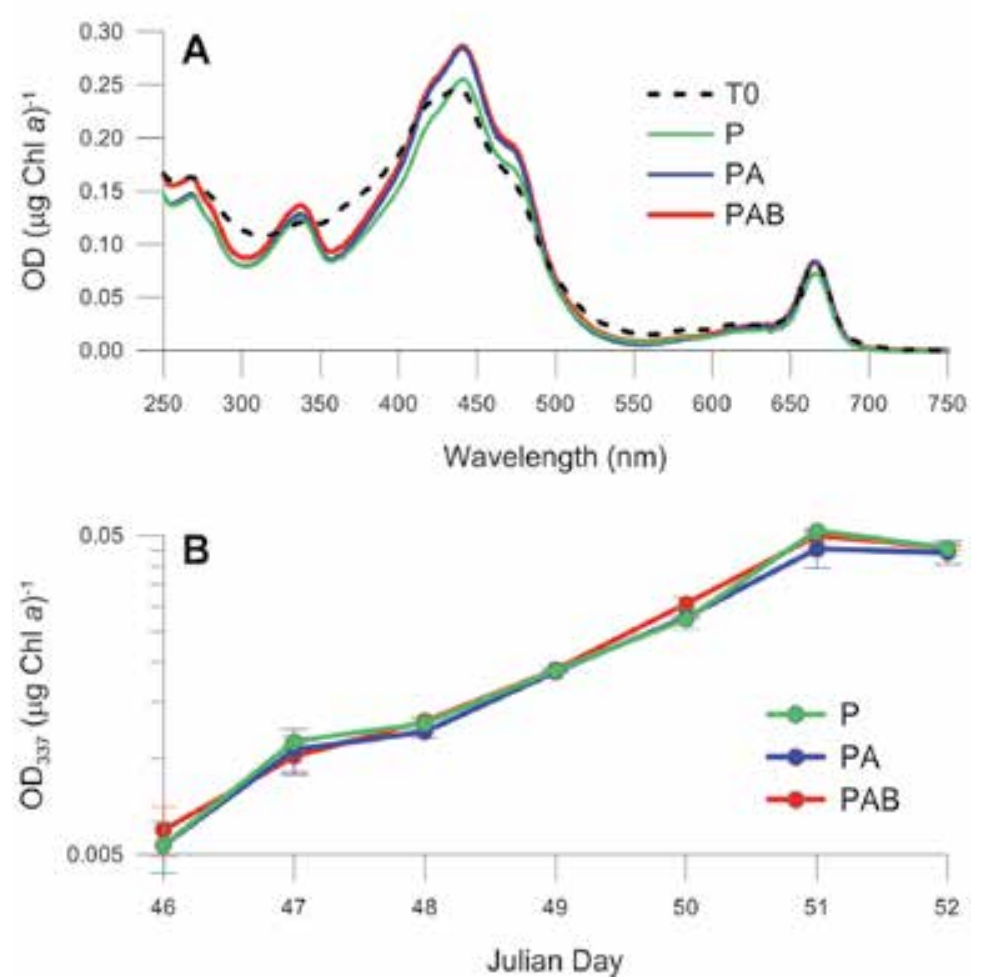

Fig. 9. A) Absorption spectra at the beginning $\left(\mathrm{T}_{0}\right)$ and at the end of the MII experiment: $\left.B\right)$ UV-absorbing compounds relative to $\mathrm{Chl} a$ content $\left(\mathrm{OD}_{337}\right.$ per $\left.\mu \mathrm{g} \mathrm{Chl} a^{-1}\right)$ throughout the experiment. UV-absorbing compounds were estimated as described in Dunlap et al. (1995) using the peak height at $337 \mathrm{~nm}$. The radiation treatments are shown in different colors: $\mathrm{P}$ (green), PA (blue) and PAB (red); dotted lines represent $\mathrm{T}_{0}$. 


\section{Ecological implications}

All together, this study indicates that within the experimental time frame, UVR effects are more evident in the taxonomic composition of the community than on algal growth / biomass. As stated above, the "starting point" of the studied community was very important in our incubations, therefore stressing the role of combined factors and preventing simple extrapolations. Also it suggests that it is not possible to generalize the solar radiation effects on diverse phytoplankton assemblages: Other factors such as previous light history, gradients of temperature and nutrient availability, in turn related to water turbulence and / or UML depth are very important to understand the observed responses. For example, even when both microcosms showed a sustained growth during several days, the final distribution of the autotrophic carbon was very different in each case. This may have important consequences for the available energy sources in the pelagic food web, as species and size distribution are two of the main factors affecting the chances of a phytoplankton cell being ingested by a predator. A community with a different carbon source will function and respond in a different way when exposed to UVR and other factors. It may be difficult to evaluate these scenarios with $\mathrm{Chl} a$ estimations obtained from remote sensing techniques, but additional in-situ research in this topic would help us to validate those estimations which proved to be useful for regional-global comparisons.

\section{Acknowledgments}

We thank V. Fiorda and E. Heimsch for their help during experiments. We are also grateful with personnel at Estación Marítima Comersonii at Puerto Rawson for sampling collection for our experiments. This work was supported by Agencia Nacional de Promoción Científica y Tecnológica (PICT2007-01651, Argentina), Consejo Nacional de Investigaciones Científicas y Técnicas (CONICET, Argentina) - Deutsche Forschungsgemeinschaft (DFG, Germany) (CONICET-DFG-2009), Ministerio de Ciencia, Tecnología e Innovación Productiva (MINCyT, Argentina) - Consejo Nacional de Ciencia y Tecnología (CONACYT, Mexico) (Project $\mathrm{N}^{\circ} \mathrm{MX} / 09 / 13$ ) and Fundación Playa Unión. This work is in partial fulfillment of the Ph.D. thesis of SRH, supported by a scholarship from Agencia Nacional de Ciencia and Instituto Nacional del Agua (Argentina). This is Contribution N ${ }^{\circ} 124$ of Estación de Fotobiología Playa Unión.

\section{References}

Abramoff MD, Magelhaes PJ, Ram SJ (2004). Image processing with ImageJ. Biophotonics International, 11, 36-42

Andersson B, Barber J (1996). Mechanisms of photodamage and protein degradation during photoinhibition of photosystem II. In: Photosynthesis and the environment, Baker NJ (ed) pp 101-121, Kluwer Academic Publishers, Boston

Atkinson RJ, Matthews WA, Newman PA, Plumb RA (1989). Evidence of the mid-latitude impact of Antarctic ozone depletion. Nature, 340, 290-294

Banaszak AT (2003). Photoprotective physiological and biochemical responses of aquatic organisms. In: UV effects in aquatic organisms and ecosystems, Helbling EW, Zagarese HE (eds), pp 329-356, The Royal Society of Chemistry, Cambridge 
Barbieri ES, Villafañe VE, Helbling EW (2002). Experimental assessment of UV effects upon temperate marine phytoplankton when exposed to variable radiation regimes. Limnology and Oceanography, 47, 1648-1655

Beardall J, Sobrino C, Stojkovic S (2009). Interactions between the impacts of ultraviolet radiation, elevated $\mathrm{CO}_{2}$, and nutrient limitation on marine primary producers. Photochemical and Photobiological Sciences, 8, 1257-1265

Belzile C, Demers S, Ferreyra GA, Schloss I, Nozais C, Lacoste K, Mostajir B, Roy S, Gosselin M, Pelletier E, Gianesella SMF, Vernet M (2006). UV Effects on marine planktonic food webs: A synthesis of results from mesocosm studies. Photochemistry and Photobiology, 82, 850-856

Buma AGJ, Boelen P, Jeffrey WH (2003). UVR-induced DNA damage in aquatic organisms. In: UV effects in aquatic organisms and ecosystems, Helbling EW, Zagarese HE (eds), pp 291-327, The Royal Society of Chemistry, Cambridge

Caille G, Gonzalez R, Gostonyi A, Ciocco NF (1997) Especies capturadas por las flotas de pesca costera en Patagonia, Informes Técnicos. Plan Manejo Integrado Zona Costera Patagónica, 27, 1-21.

Cooke SL, Williamson CE, Hargreaves BR, Morris DP (2006). Beneficial and detrimental interactive effects of dissolved organic matter and ultraviolet radiation on zooplankton in a transparent lake. Hydrobiologia, 568, 15-28

Dunlap WC, Rae GA, Helbling EW, Villafañe VE, Holm-Hansen O (1995). Ultravioletabsorbing compounds in natural assemblages of Antarctic phytoplankton. Antarctic Journal of the United States, 30, 323-326

Dunne RP (2010). Synergy or antagonism-interactions between stressors on coral reefs. Coral Reefs, 29, 145-152

Falkowski PG (1981). Light shade adaptation and assimilation numbers. Journal of Plankton Research, 3, 203-216

Fiorda Giordanino MV, Strauch SM, Villafañe VE, Helbling EW (2011). Influence of temperature and UVR on photosynthesis and morphology of four species of cyanobacteria. Journal of Photochemistry and Photobiology B: Biology, 103, 68-77

Forster R, Schubert H (2001). The effects of ultraviolet radiation on the planktonic community of a shallow, eutrophic estuary: Results of mesocosm experiments. Helgoland Marine Research, 55, 23-34

Furgal JA, Smith REH (1997). Ultraviolet radiation and photosynthesis by Georgian Bay phytoplankton of varying nutrient and photoadaptive status. Canadian Journal of Fisheries and Aquatic Sciences, 54, 1659-1667

Gao K, Li G, Helbling EW, Villafañe VE (2007). Variability of UVR effects on photosynthesis of summer phytoplankton assemblages from a tropical coastal area of the South China Sea. Photochemistry and Photobiology, 83, 802-809

Garcia-Pichel F (1994). A model for internal self-shading in planktonic organisms and its implications for the usefulness of ultraviolet sunscreens. Limnology and Oceanography, 39, 1704-1717

Gonçalves RJ, Souza MS, Aigo J, Modenutti B, Balseiro E, Villafañe VE, Cussac V, Helbling EW (2010). Responses of plankton and fish from temperate zones to UVR and temperature in a context of gobal change. Ecología Austral, 20, 129-153 
Guillard RRL, Ryther JH (1962). Studies of marine planktonic diatoms. I. Cyclotella nana Hustedt, and Detonula confervacea (Cleve) Gran. Canadian Journal of Microbiology, 8, 229-239

Häder D-P, Helbling EW, Williamson CE, Worrest RC (2011). Effects of UV radiation on aquatic ecosystems and interactions with climate change. Photochemical and Photobiological Sciences, 10, 242-260

Häder D-P, Lebert M, Schuster M, del Ciampo L, Helbling EW, McKenzie R (2007). ELDONET - A decade of monitoring solar radiation on five continents. Photochemistry and Photobiology, 83, 1384-1357

Halac SR, Felip M, Camarero L, Sommaruga-Wögrath S, Psenner R, Catalan J, Sommaruga R (1997). An in situ enclosure experiment to test the solar UVB impact on plankton in a high-altitude mountain lake. I. Lack of effect on phytoplankton species composition and growth. Journal of Plankton Research, 19, 1671-1686

Halac SR, García-Mendoza E, Banaszak AT (2009). Ultraviolet radiation reduces the photoprotective capacity of the marine diatom Phaeodactylum tricornutum (Bacillariophyceae, Heterokontophyta). Photochemistry and Photobiology, 85, 807-815

Halac SR, Villafañe VE, Helbling EW (2010). Temperature benefits the photosynthetic performance of the diatoms Chaetoceros gracilis and Thalassiosira weissflogii when exposed to UVR. Journal of Photochemistry and Photobiology, B: Biology, 101, 196-205

Helbling EW, Barbieri ES, Marcoval MA, Gonçalves RJ, Villafañe VE (2005). Impact of solar ultraviolet radiation on marine phytoplankton of Patagonia, Argentina. Photochemistry and Photobiology, 81, 807-818

Helbling EW, Buma AGJ, Van de Poll W, Fernández Zenoff MV, Villafañe VE (2008). UVRinduced photosynthetic inhibition dominates over DNA damage in marine dinoflagellates exposed to fluctuating solar radiation regimes. Journal of Experimental Marine Biology and Ecology, 365, 96-102

Helbling EW, Chalker BE, Dunlap WC, Holm-Hansen O, Villafañe VE (1996). Photoacclimation of antarctic marine diatoms to solar ultraviolet radiation. Journal of Experimental Marine Biology and Ecology, 204, 85-101

Helbling EW, Gao K, Gonçalves RJ, Wu H, Villafañe VE (2003). Utilization of solar UV radiation by coastal phytoplankton assemblages off SE China when exposed to fast mixing. Marine Ecology Progress Series, 259, 59-66

Helbling EW, Pérez DE, Medina CD, Lagunas MG, Villafañe VE (2010). Phytoplankton distribution and photosynthesis dynamics in the Chubut River estuary (Patagonia, Argentina) throughout tidal cycles Limnology and Oceanography, 55, 55-65

Helbling EW, Zagarese HE (2003). UV effects in aquatic organisms and ecosystems. The Royal Society of Chemistry, Cambridge

Hernando MP, Schloss I, Roy S, Ferreyra G (2006). Photoacclimation to long-term ultraviolet radiation exposure of natural sub-Antarctic phytoplankton communities: Fixed surface incubations versus mixed mesocosms. Photochemistry and Photobiology, 82, 923-935

Hernando MP, Malanga G, Ferreyra GA (2005). Oxidative stress and antioxidant defenses generated by solar UV in a sub-Antarctic marine phytoflagellate. Scientia Marina, 68, 287-295 
Hernando MP, San Román N (1999). Preliminary data on chronic effects of ultraviolet radiation on the growth of some phytoplankton species of the Beagle Channel, Argentina. Scientia Marina, 63, 81-88

Hillebrand H, Dürselen CD, Kirschtel D, Pollingher U, Zohary T (1999). Biovolume calculation for pelagic and benthic microalgae. Journal of Phycology, 35, 403-424

Holm-Hansen O, Riemann B (1978). Chlorophyll a determination: improvements in methodology. Oikos, 30, 438-447

Keller AA, Hargraves P, Jeon H, Klein-Macphee G, Klos E, Oviatt C, Zhang J (1997). Ultraviolet-B radiation enhancement does not affect marine trophic levels during a winter-spring bloom. Ecoscience, 4, 129-139

Korbee N, Figueroa FL, Aguilera J (2006). Acumulación de aminoácidos tipo micosporina (MAAs): Biosíntesis, fotocontrol y funciones ecofisiológicas. Revista Chilena de Historia Natural, 79, 119-132

Lutz VA, Segura V, Dogliotti AI, Gagliardini DA, Bianchi AA, Balestrini CF (2010). Primary production in the Argentine Sea during spring estimated by field and satellite models. Journal of Plankton Research, 32, 181-195

Marcoval MA, Villafañe VE, Helbling EW (2007). Interactive effects of ultraviolet radiation and nutrient addition on growth and photosynthesis performance of four species of marine phytoplankton. Journal of Photochemistry and Photobiology, B: Biology, 89, 7887

Marcoval MA, Villafañe VE, Helbling EW (2008). Combined effects of solar ultraviolet radiation and nutrients addition on growth, biomass and taxonomic composition of coastal marine phytoplankton communities of Patagonia. Journal of Photochemistry and Photobiology, B: Biology, 91, 157-166

Montecino V, Molina X, Martínez G, Olmedo MI, Retamal L, Hannach G, Orellana MV (2001). Ecophysiological strategies in response to UV-B radiation stress in cultures of temperate microalgae isolated from the Pacific coast of South America. Revista Chilena de Historia Natural, 74, 293-311

Mostajir B, Demers S, de Mora S, Belzile C, Chanut J-P, Gosselin M, Roy S, Villegas PZ, Fauchot J, Bouchard JN, Bird D, Monfort P, Levasseur M (1999). Experimental test of the effect of ultraviolet-B radiation in a planktonic community. Limnology and Oceanography, 44, 586-596

Mousseau L, Gosselin M, Levasseur M, Demers S, Fauchot J, Roy S, Villegas PZ, Mostajir B (2000). Effects of ultraviolet-B radiation on simultaneous carbon and nitrogen transport rates by estuarine phytoplankton during a week-long mesocosm study. Marine Ecology Progress Series, 199, 69-81

Müller P, Li X-P, Niyogi KK (2001). Non-photochemical quenching. A response to excess light energy. Plant Physiology, 125, 1558-1566

Neale PJ, Helbling EW, Zagarese HE (2003). Modulation of UVR exposure and effects by vertical mixing and advection. In: UV effects in aquatic organisms and ecosystems, Helbling EW, Zagarese HE (eds), pp 108-134, Royal Society of Chemistry

Nilawati J, Greenberg BM, Smith REH (1997). Influence of ultraviolet radiation on growth and photosynthesis of two cold ocean diatoms. Journal of Phycology, 33, 215-224

Osburn CL, Morris DP (2003). Photochemistry of chromophoric dissolved organic matter in natural waters. In: UV effects in aquatic organisms and ecosystems, Helbling EW, Zagarese H (eds), pp 185-217, The Royal Society of Chemistry, Cambridge 
Porra RJ (2002). The chequered history of the development and use of simultaneous equations for the accurate determination of chlorophylls a and b. Photosynthesis Research, 73, 149-156

Richter PR, Häder D-P, Goncalves RJ, Marcoval MA, Villafañe VE, Helbling EW (2007). Vertical migration and motility responses in three marine phytoplankton species exposed to solar radiation. Photochemistry and Photobiology, 83, 810-817

Roy S, Mohovic B, Gianesella SMF, Schloss IR, Ferrario ME, Demers S (2006). Effects of enhanced UV-B on pigment-based phytoplankton biomass and composition of mesocosm-enclosed natural marine communities from three latitudes. Photochemistry and Photobiology, 82, 909-922

Seckmeyer G, McKenzie RL (1992). Increased ultraviolet radiation in New Zealand (45 $\left.{ }^{\circ} \mathrm{S}\right)$ relative to Germany $\left(48^{\circ} \mathrm{N}\right)$. Nature, $359,135-137$

Skewgar E, Boersma PD, Harris G, Caille G (2007). Sustainability: Anchovy fishery threat to Patagonian ecosystem. Science, 315, 45

Sobrino C, Neale PJ (2007). Short-term and long-term effects of temperature on photosynthesis in the diatom Thalassiosira pseudonana under UVR exposures. Journal of Phycology, 43, 426-436

Sommaruga R (2003). UVR and its effects on species interactions. In: UV effects in aquatic organisms and ecosystems, Helbling EW, Zagarese H (eds), pp 485-508, The Royal Society of Chemistry, Cambridge

Strathmann RR (1967). Estimating the organic carbon content of phytoplankton from cell volume or plasma volume. Limnology and Oceanography, 12, 411-418

Vernet M (2000). Effects of UV radiation on the physiology and ecology of marine phytoplankton. In: The effects of $U V$ radiation in the marine environment, de Mora S, Demers S, Vernet M (eds), pp 237-278, Cambridge University Press, Cambridge

Villafañe VE, Barbieri ES, Helbling EW (2004a). Annual patterns of ultraviolet radiation effects on temperate marine phytoplankton off Patagonia, Argentina. Journal of Plankton Research, 26, 167-174

Villafañe VE, Buma AGJ, Boelen P, Helbling EW (2004b). Solar UVR-induced DNA damage and inhibition of photosynthesis in phytoplankton from Andean lakes of Argentina. Archiv für Hydrobiologie, 161, 245-266

Villafañe VE, Helbling EW, Zagarese HE (2001). Solar ultraviolet radiation and its impact on aquatic systems of Patagonia, South America. Ambio, 30, 112-117

Villafañe VE, Janknegt PJ, de Graaff M, Visser RJW, van de Poll WH, Buma AGJ, Helbling EW (2008). UVR-induced photoinhibition of summer marine phytoplankton communities from Patagonia. Marine Biology, 154, 1021-1029

Villafañe VE, Marcoval MA, Helbling EW (2004c). Photosynthesis versus irradiance characteristics in phytoplankton assemblages off Patagonia (Argentina): Temporal variability and solar UVR effects. Marine Ecology Progress Series, 284, 23-34

Villafañe VE, Reid FMH (1995). Métodos de microscopía para la cuantificación del fitoplancton. In: Manual de Métodos Ficológicos, Alveal K, Ferrario ME, Oliveira EC, Sar E (eds), pp 169-185, Universidad de Concepción, Concepción, Chile

Villafañe VE, Sundbäck K, Figueroa FL, Helbling EW (2003). Photosynthesis in the aquatic environment as affected by UVR. In: UV effects in aquatic organisms and ecosystems, Helbling EW, Zagarese HE (eds), pp 357-397, Royal Society of Chemistry 
Wängberg S-A, Andreasson KIM, Gustavson K, Reinthaler T, Henriksen P (2008). UV-B effects on microplankton communities in Kongsfjord, Svalbard - A mesocosm experiment. Journal of Experimental Marine Biology and Ecology, 365, 156-163

Wängberg S- $\AA$, Garde K, Gustavson K, Selmer J-S (1999). Effects of UVB radiation on marine phytoplankton communities. Journal of Plankton Research, 21, 147-166

Wängberg SA, Selmer JA, Gustavson K (1996). Effects of UV-B radiation on biomass and composition in marine phytoplankton communities. Scientia Marina, 60, 81-88

Whitehead RF, de Mora S, Demers S, Gosselin M, Monfort P, Mostajir B (2000). Interactions of ultraviolet-B radiation, mixing, and biological activity on photobleaching of natural chromophoric dissolved organic matter: A mesocosm study. Limnology and Oceanography, 45, 278-291 


\title{
In Situ Primary Production Measurements as an Analytical Support to Remote Sensing - An Experimental Approach to Standardize the ${ }^{14} \mathrm{C}$ Incorporation Technique
}

\author{
Tamara Cibic and Damiano Virgilio* \\ Dipartimento di Oceanografia Biologica, \\ Istituto Nazionale di Oceanografia e Geofisica Sperimentale (OGS), Trieste, \\ ${ }^{*}$ Current address: Regional Environmental Protection Agency-FVG, Palmanova,
}

Italy

\section{Introduction}

Primary production measurement in marine waters is one of the most important tools to understand the ecosystem functioning and the transport of inorganic/organic matter through the food web. Direct measurement of the driving process, that is photosynthesis, in this dynamic system was first achieved using the Winkler technique for estimating dissolved oxygen concentrations, introduced by Gaarder and Gran in 1927 (Williams et al., 2002). Nowadays the light-dark bottle oxygen technique is considered not sensitive enough and the rate had poor accuracy and precision (Marra, 2002).

The introduction of the ${ }^{14} \mathrm{C}$ technique changed the study of productivity (Marra, 2002). The year 1952 marked the end of a century-long struggle to develop a method to determine oceanic primary productivity with precision, accuracy and efficiency (Barber \& Hilting, 2002). Thousands of measurements of marine phytoplankton productivity have been made at discrete locations throughout the world's oceans since the introduction of the radiolabelled carbon uptake method in 1952 (Steemann-Nielsen, 1952). Although numerous, these discrete primary productivity measurements only provide information for infinitesimally small points over the oceans' surfaces. Scaling these discrete measurements to global projections by means of satellite-based estimates requires mathematical models. Clearly, although much of the discrepancy between modelled and measured production results from limitations of the models, some of the disagreement is also due to methodological differences in ${ }^{14} \mathrm{C}$ measurements and errors in the ${ }^{14} \mathrm{C}$ data (Behrenfeld \& Falkowski, 1997). To compare modelled primary production with that obtained in situ, a high quality database of ${ }^{14} \mathrm{C}$ measurements is required. Calculating accurate primary production estimates over large areas is a primary step for ecosystem models charged with the task of assessing trophic dynamics. Reliable estimates of primary production are also necessary for multiple other applications, including quantifying the flux of carbon dioxide, assessing export production and estimating production of climate-active gases such as dimethyl sulphide. Estimating accurate primary production on global scales is also essential to understanding the consequences of climate change on phytoplankton growth (Friedrichs et al., 2009). 
The ${ }^{14} \mathrm{C}$ method is relatively simple. A known amount of ${ }^{14} \mathrm{C}-\mathrm{CO}_{2}$ is added to bottles containing the water samples and after an incubation time the organic carbon is frequently separated from the remaining inorganic carbon by filtration (Peterson, 1980). Several debates have arisen from the comparison of the results obtained with the ${ }^{14} \mathrm{C}$ method and the Winkler method, the latter largely used for primary production estimates before 1952 (Peterson, 1980). In 1972 Schindler and co-workers modified the ${ }^{14} \mathrm{C}$ method proposed 20 years earlier by Steemann-Nielsen. The authors described a method in which the samples were not filtered, in order to avoid the rupture of cells during filtration and loss during drying of filters that can still cause underestimation of primary production (Theodórsson \& Bjarnason, 1975). The problems encountered in filtering and the somewhat arbitrary nature of the separation between dissolved and particulate matter led to the development of the acidification and bubbling procedure (Peterson, 1980). Unfortunately, this technique does not permit to assess the two fractions of primary production labelled with ${ }^{14} \mathrm{C}_{-} \mathrm{CO}_{2}$ : $\mathrm{POC}$ (Particulate Organic Carbon, corresponding to the ${ }^{14} \mathrm{C}$ retained in the autotrophic cells) and DOC (Dissolved Organic Carbon, released from the autotrophic cells). Therefore this technique is not useful to understand the transformation of the organic matter along the trophic levels, in particular the link between autotrophic production and other levels of the marine food web. In most of the references regarding primary production in the water column, the method usually applied to stop the process and remove the excess labelled ${ }^{14} \mathrm{C}$ was filtration and subsequent acidification with $\mathrm{HCl}$ (Table 1).

\begin{tabular}{|c|c|c|}
\hline $\mathrm{HCl}$ & sample volume & reference \\
\hline filters wetted with $1 \mathrm{~N}$ & $50 \mathrm{ml}$ (filter) & Babin et al., 1994 \\
\hline concentrated acid fumes & $75 \mathrm{ml}$ (filter for POC production) & \multirow{2}{*}{ Cermeño et al., 2006} \\
\hline $100 \mu \mathrm{l}$ of $18.5 \%$ acid & $5 \mathrm{ml}$ (filtrated for DOC production) & \\
\hline filters rinsed twice with $1 \mathrm{~N}$ & $50 \mathrm{ml}$ (filter) & Hewson et al., 2001 \\
\hline $\begin{array}{c}1 \mathrm{ml}, 2 \mathrm{M} \text { (filters stored for } 2-3 \\
\text { days at }-20^{\circ} \mathrm{C} \text { before acidification } \\
\text { and counting) }\end{array}$ & $\begin{array}{l}100-500 \mathrm{ml} \text { (filter) for primary production } \\
\text { estimate }\end{array}$ & Karl et al., 1998 \\
\hline $0.5 \mathrm{ml}, 6 \mathrm{~N}$ & $1 \mathrm{ml}$ (total sample) & Lewis \& Smith, 1983 \\
\hline $200 \mu \mathrm{l}, 0.1 \mathrm{~N}$ & $50 \mathrm{ml}$ (filter) & Mangoni et al,. 2008 \\
\hline concentrated acid fumes & $5 \mathrm{ml}$ (filter for POC production) & \multirow{3}{*}{ Marañón et al., 2004} \\
\hline $100 \mu \mathrm{l}$ of $50 \%$ acid & $5 \mathrm{ml}$ (filtrated for DOC production) & \\
\hline $100 \mu \mathrm{l}$ of $50 \%$ acid & $5 \mathrm{ml}$ (total sample for TOC production) & \\
\hline $500 \mu \mathrm{l}, 0.5 \mathrm{~N}$ & 320 (?) $\mathrm{ml}$ (filter) & Moutin \& Raimbault, 2002 \\
\hline 2 drops of $5 \mathrm{~N}$ & not available & O'Donohue \& Dennison, 1997 \\
\hline $0.5 \mathrm{ml}, 6 \mathrm{~N}$ & $5 \mathrm{ml}$ (filtrated for extracellular release) & \multirow{2}{*}{ Pugnetti et al., 2005} \\
\hline $0.5 \mathrm{ml}, 6 \mathrm{~N}$ & $5 \mathrm{ml}$ (total primary productivity) & \\
\hline fumes of concentrated acid & $75 \mathrm{ml}$ (filter) & Teira et al., 2005 \\
\hline
\end{tabular}

Table 1. Summary of currently in use primary production filtration and acidification methods. $\mathrm{POC}=$ particulate organic carbon; $\mathrm{DOC}=$ dissolved organic carbon .

Many authors use filters to estimate primary production, without considering the filtrated fraction, which corresponds to the exudate release, nor the total sample. Moreover, different $\mathrm{HCl}$ concentrations are used in the reported papers. When samples are filtered, filters can be wetted or rinsed with acid (Babin et al., 1994; Hewson et al., 2001) or, in more recent studies, exposed to concentrated acid fumes (Cermeño et al., 2006; Marañón et al., 2004; Teira et al., 2005). The added $\mathrm{HCl}$ concentration ranged from $0.1 \mathrm{~N}$ (Mangoni et al., 2008) to $6 \mathrm{~N}$ (Lewis \& Smith, 1983; Pugnetti et al., 2005). Considering different acid volumes added to different 
sample volumes also the final acid concentrations were very diverse among the studies. Although the ${ }^{14} \mathrm{C}$ technique has now been used in more than 35000 oceanographic experiments (del Giorgio \& Williams, 2005), from the review of the earlier and recent literature, we evidenced that different methods are still used to stop the photosynthetic activity, and that highly variable concentrations of $\mathrm{HCl}$ are added to remove the excess labelled bicarbonate which was not assimilated by the microalgae. In order to standardize this step of the ${ }^{14} \mathrm{C}$ method, we designed a series of experiments, using both water samples and a mix culture of microalgal taxa which represent a coastal phytoplankton community. The first aim of our study was to define which $\mathrm{HCl}$ concentration, with an equal volume, among $0.1 \mathrm{~N}, 0.2 \mathrm{~N}, 0.5 \mathrm{~N}, 1 \mathrm{~N}, 2 \mathrm{~N}$ and $5 \mathrm{~N}$ was sufficient both to remove the excess labelled bicarbonate and to kill the cells but without damaging their structures with a consequent loss of assimilated ${ }^{14} \mathrm{C}$. Secondly, using both chlorophyll $a$ red autofluorescence and motility of flagellates and diatoms as proxies of microalgal viability, we tested if different acid concentrations were sufficient to stop the microalgal photosynthetic activity.

\section{Materials and methods}

\subsection{Water sampling}

On 18th October 2006, 29th January 2007 and $4^{\text {th }}$ September 2008 five litres of seawater was collected at $5 \mathrm{~m}$ depth by a Niskin bottle about $10 \mathrm{~km}$ far from the coast in the Gulf of Trieste (northern Adriatic Sea, Italy). In each cruise seawater temperature and chlorophyll $a$ (chl $a$ ) were recorded by a Multiparameter Probe Ocean Seven 316 Idronaut. In laboratory the sampled water was immediately transferred to translucent polycarbonate carboy (Nalgene) and kept at in situ temperature $\left(20^{\circ} \mathrm{C}\right.$ in October, $10^{\circ} \mathrm{C}$ in January, $20^{\circ} \mathrm{C}$ in September) and light conditions ranging from 100 to $200 \mu \mathrm{mol}$ photons $\mathrm{s}^{-1} \mathrm{~m}^{-2}$, according to the sampling day. Flushing by an air pump kept the water at oxygen saturation. Water was exposed to a 14:10 h light:dark cycle.

\subsection{Experimental design}

The next morning (10.00-11.00 a.m.) 1.3201 of sampled seawater was transferred to an Erlenmeyer flask and kept in the darkness for 30 minutes to reduce the photosynthetic activity. Subsequently, $99 \mu \mathrm{Ci}$ (3.66 MBq) of $\mathrm{NaH}^{14} \mathrm{CO}_{3}$ (DHI, Denmark) was added into the flask. The sample was gently stirred and then 6 subsamples of $220 \mathrm{ml}$ were transferred to six Erlenmeyer flasks. Three of these were incubated at in situ conditions, while the other three were wrapped up in aluminium foils to maintain them in darkness and incubated together with the light ones at in situ temperature for 2 hours. Inoculum and subsampling were performed at very low light to avoid the beginning of the photosynthetic activity before incubation. After incubation each $220 \mathrm{ml}$ replicate was stored in dark and cold conditions (ice was used to keep temperature close to $0^{\circ} \mathrm{C}$ ) until filtration. From each of $220 \mathrm{ml}$ replicates, 6 aliquots of $25 \mathrm{ml}$ were filtered using a Millipore vacuum filtration manifold (with 12 wells) through polycarbonate $0.2 \mu \mathrm{m}$ filters applying a low vacuum pressure in order to avoid cell damage. The 6 filters were put into $6 \mathrm{ml}$ plastic scintillation vials (Perkin Elmer); $5 \mathrm{ml}$ of the 6 filtrated samples was collected and put into $20 \mathrm{ml}$ glass scintillation vials (Perkin Elmer) to assess the rate of phytoplankton exudate release. Finally, six $5 \mathrm{ml}$ aliquots of the total sample, drawn from the $220 \mathrm{ml}$ replicate, were directly put into $20 \mathrm{ml}$ glass scintillation vials. To each final sample series $(6$ filters +6 filtrated samples +6 total samples) obtained from the $220 \mathrm{ml}$ replicate, $200 \mu \mathrm{l}$ of $\mathrm{HCl}$ at progressively higher 
concentrations $(0.1 \mathrm{~N}-0.2 \mathrm{~N}-0.5 \mathrm{~N}-1 \mathrm{~N}-2 \mathrm{~N}-5 \mathrm{~N}$ which correspond to final $\mathrm{HCl}$ concentrations of $0.004 \mathrm{~N}-0.008 \mathrm{~N}-0.02 \mathrm{~N}-0.04 \mathrm{~N}-0.08 \mathrm{~N}-0.2 \mathrm{~N}$, respectively, for filtrated and total samples) was added and left under hood overnight to remove the labelled bicarbonate which was not assimilated by the microalgae. $5 \mathrm{ml}$ of Filter Count scintillation cocktail (Perkin Elmer) was added to filters, while $10 \mathrm{ml}$ of Ultima Gold XR (Perkin Elmer) was added both to filtrated and not filtrated samples. Disintegrations per minute (DPM) were measured twice by a QuantaSmart TRI-CARB 2900 TR Liquid Scintillation Analyzer (Packard BioScience, USA) including quenching correction, obtained using internal standards.

\subsection{Statistical analysis}

Student's t-test was applied to test for significant differences between pairs of experiments considering different acid normalities for filters, filtrated and total samples. Only data obtained from the first reading was used for the t-test.

\subsection{Effects of $\mathrm{HCl}$ on the planktonic microalgal community}

In order to test if the added acid concentrations were sufficient to stop the microalgal photosynthetic activity, another experiment was carried out. A mix of six microalgae, representing the local phytoplankton community, was prepared, simulating the proportion among the groups which is characteristic of a resuspended coastal water mass. We chose: Chaetoceros socialis as a typical planktonic diatom, Cylindrotheca fusiformis as a tychopelagic diatom, Paralia sulcata as a common benthic diatom, Gymnodinium sp. representing naked dinoflagellates, Lingulodinium polyedrum representing thecate dinoflagellates and an undetermined Cryptophycea as a typical small phytoflagellate (Table 2). We stored the mix culture for $24 \mathrm{~h}$ at $15^{\circ} \mathrm{C}$ and 12:12 light:dark photoperiod (50 $\mu \mathrm{mol}$ photons s $\mathrm{m}^{-2}$ ). The next day 7 aliquots of $5 \mathrm{ml}$ were transferred into $20 \mathrm{ml}$ scintillation glass vials. The following protocol was performed: one replicate was used as a control, while to the other six $200 \mu \mathrm{l}$ of $\mathrm{HCl}$ at increasing concentrations (the same of the previous experiments) was added. Then, we performed a litmus test (Merck), estimating the $\mathrm{pH}$ in each sample. We left the samples under hood overnight to simulate the primary production protocol as described above. The next day a few drops of each sample were observed under an inverted microscope (Leica DMI 3000B) using both phase contrast and epifluorescence, under a blue filter set (BP450-490 nm) at different magnifications (from 200 to 400X). As proxies of viability we considered both chlorophyll $a$ red autofluorescence and motility of flagellates and of the tychopelagic diatom. The motility of planktonic (Chaetoceros socialis) and benthic (Paralia sulcata) diatoms was not taken into account because these two taxa do not have specific structures allowing movement.

\begin{tabular}{|c|c|c|}
\hline Taxon & Representing group & Presence \\
\hline Chaetoceros socialis & Planktonic diatom & abundant \\
Cylindrotheca fusiformis & Tychopelagic diatom & abundant \\
Paralia sulcata & Benthic diatom & rare \\
Gymnodinium sp. & Naked dinoflagellate & rare \\
Lingoludinium polyedrum & Thecate dinoflagellate & rare \\
undet. Cryptophycea & Small phytoflagellate & the most abundant \\
\hline
\end{tabular}

Table 2. Composition of the mix culture artificially created in the laboratory to simulate a natural phytoplankton community of coastal waters. 


\subsection{Recovery experiment}

During microscopic observations we observed several shades of red autofluorescence. Since we could not be sure that a pale orange colour was a sign of a not viable cell, we carried out another test. We believed that some cells could be still viable after a mild acid treatment and thus able to photosynthesize, especially during the period elapsing between the addition of the acid and the addition of the scintillation liquid. We tried to demonstrate that after a mild acid treatment some microalgae were still photosynthetically active. Consequently, we restored their maintenance conditions looking at the microalgal growth after two weeks. Therefore, the residual aliquots $(>4 \mathrm{ml})$ of a few selected treatments (without acid, $0.1 \mathrm{~N}$, $0.2 \mathrm{~N}$ and $5 \mathrm{~N}$ ) from the first experiment (mix culture) were transferred into $100 \mathrm{ml}$ Erlenmeyer flasks which were filled with F/2 medium to a final volume of $50 \mathrm{ml}$. The four flasks were kept at $15^{\circ} \mathrm{C}$ and 12:12 light:dark photoperiod until microscopic observations.

\section{Results and discussion}

\subsection{In situ primary production as an analytical support to remote sensing}

Frequently the problem with the model efficiency is data limited by the amount of representative in situ measurements. As more in situ data become available they can be exploited within most of the existing complex formulations. When asked what is needed to improve model performance, all model developers coincide in requesting more data (Carr et al., 2006). When comparing primary production measurements with those from different studies, it is difficult to decipher whether differences are due to inter-annual changes, the spatial location of the stations sampled in each region, the frequency over which the measurements were taken or the measurement protocol used (Tilstone et al., 2009). Often in situ primary production data are associated with a level of uncertainty and need to be regarded as ranges rather than as exact values (Friedrichs et al., 2009). Another problem with in situ measurements is that ship resources cannot solve low-frequency spatial and temporal variability, much less make direct observations of mesoscale variability beyond isolated snapshots. The chronic undersampling of ship-based estimates of global primary production requires significant extrapolations, making it essentially impossible to quantify basin-scale variability from in situ measurements (Carr et al., 2006). Fortunately, satellite provide a solution. Sensors that measure ocean colour are presently used to estimate chlorophyll concentration in the upper ocean (Carr et al., 2006). The simplest models estimate time and depth-integrated production as a function of surface chlorophyll. However, surface chlorophyll explains only $30-40 \%$ of the variance in primary production at the scale of a single station (Hyde et al., 2008). To go from biomass, a pool, to photosynthesis, a rate, a time dependent variable is needed (Carr et al., 2006). Recently, a series of round-robin experiments were carried out to evaluate and compare models which estimate primary productivity from ocean colour (Campbell et al., 2002, as cited in Tilstone et al., 2009). In these experiments, in situ measurements of carbon uptake were used to predict depth-integrated primary production based on information accessible via remote sensing. According to the authors, there is no way to quantify model performance without comparing the output to in situ data (Carr et al., 2006). For any model, a vital element of model skill is the ability to reproduce in situ observations; in the case of primary production models, measurements of primary production. If observations are representative and the data have undergone careful quality control, firm conclusions can be reached regarding the environmental conditions that challenge model skill. These challenging conditions, in turn, 
can be taken into account by model developers and end-users to improve model formulation and/or application. As a consequence, improving primary production estimates will increase the skill of global models (Friedrichs et al., 2009).

\subsection{Different fixatives and $\mathrm{HCl}$ concentrations in phytoplankton primary production}

Results of the phytoplankton primary production experiments are presented in separate figures as filter, filtrated and total fractions. In the graphs each bar represents one biological replicate, while standard deviations result from 2 scintillation counts (from the QuantaSmart scintillation analyzer). In Figure 1 are shown filter DPM values of the three experiments. In the second experiment some problems took place during filtration, i.e. the process occurred too quickly probably due to not proper positioning of the following filters: $1 \mathrm{~L} 0.1 \mathrm{~N}, 2 \mathrm{~L} 0.1 \mathrm{~N}, 2 \mathrm{~L} 0.5 \mathrm{~N}, 1 \mathrm{~L} 1 \mathrm{~N}, 2 \mathrm{~L} 1 \mathrm{~N}, 1 \mathrm{~L} 5 \mathrm{~N}$ and $2 \mathrm{~L} 5 \mathrm{~N}$, therefore leading to an underestimate of DPM values.
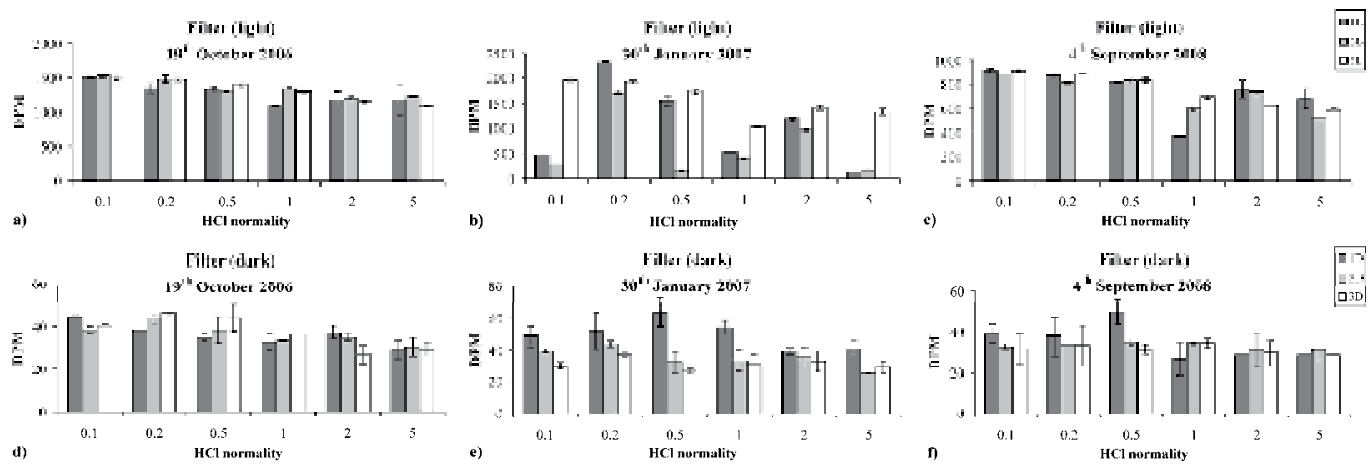

Fig. 1. Filter DPM values of light and dark replicates resulted from the three experiments. Each bar represents the mean of 2 scintillation counts for each biological replicate. For each experiment a different $y$-axis scale was applied to better highlight the difference between acid treatments.

In the same experiment we observed that DPM values of the first dark replicate were higher than those of the second dark replicate, which were in turn higher than the third one (except for the $5 \mathrm{~N}$ treatment). Not considering the above mentioned replicates, we noted that both light and dark DPM values of the second experiment were higher than those of the first and third ones. Higher values were probably due to a higher chl $a$ content $\left(2.62 \mu \mathrm{g} \mathrm{l}^{-1}\right)$ measured at $5 \mathrm{~m}$ depth on $30^{\text {th }}$ January 2007 if compared to the chl $a$ content estimated on the other two sampling dates ( 0.88 and $0.52 \mu \mathrm{g} \mathrm{l}^{-1}$ in 2006 and 2008, respectively). Focusing only on the first and last experiments, we observed a decrease in DPM values going from $0.1 \mathrm{~N}$ to $5 \mathrm{~N}$ treatment, both in dark, but especially in light replicates. Considering the average of the three light biological replicates, there was a consistent reduction in DPM values in correspondence with progressively stronger acid treatments. In detail, the DPM decrease between $0.1 \mathrm{~N}$ and $0.2 \mathrm{~N}$ treatments, expressed as percentage, was very similar: $5.99 \%$ and $5.33 \%$ in the first and last experiment, respectively. This percentage of difference was higher comparing the $0.1 \mathrm{~N}$ acid treatment to the $2 \mathrm{~N}$ one: $19.18 \%$ and $20.02 \%$ in the first and last experiment, respectively. Finally, the percentage decrease between $0.1 \mathrm{~N}$ and $5 \mathrm{~N}$ treatments reached $31.17 \%$ in the third experiment. 
In Figure 2a-f are shown DPM values of filtrated samples of the three experiments. In the second experiment higher DPM values were registered due to the previously reported filtration issue. We infer that some of the labelled phytoplankton ended up in the vial placed underneath the corresponding filter without being retained by the filter. In fact there is a relationship between high DPM values of the filtrated samples and low DPM values of the corresponding filters $(1 \mathrm{~L} 0.1 \mathrm{~N}, 2 \mathrm{~L} 0.1 \mathrm{~N}, 2 \mathrm{~L} 0.5 \mathrm{~N}, 1 \mathrm{~L} 1 \mathrm{~N}, 2 \mathrm{~L} 1 \mathrm{~N}, 1 \mathrm{~L} 5 \mathrm{~N}$ and $2 \mathrm{~L} 5 \mathrm{~N})$. Unlike the filters, where light values were 1 or 2 orders of magnitude higher than dark values, in the filtrated samples their difference was markedly lower. Since the volume of the filtrated sample was 5 times lower than that of the filter sample, DPM values obtained from the filtrated samples were generally 1 or 2 orders of magnitude lower than those obtained from the filters. When DPM values are very low, the biological variability among replicates is amplified. This variability was noted particularly in light and dark samples of the first experiment.
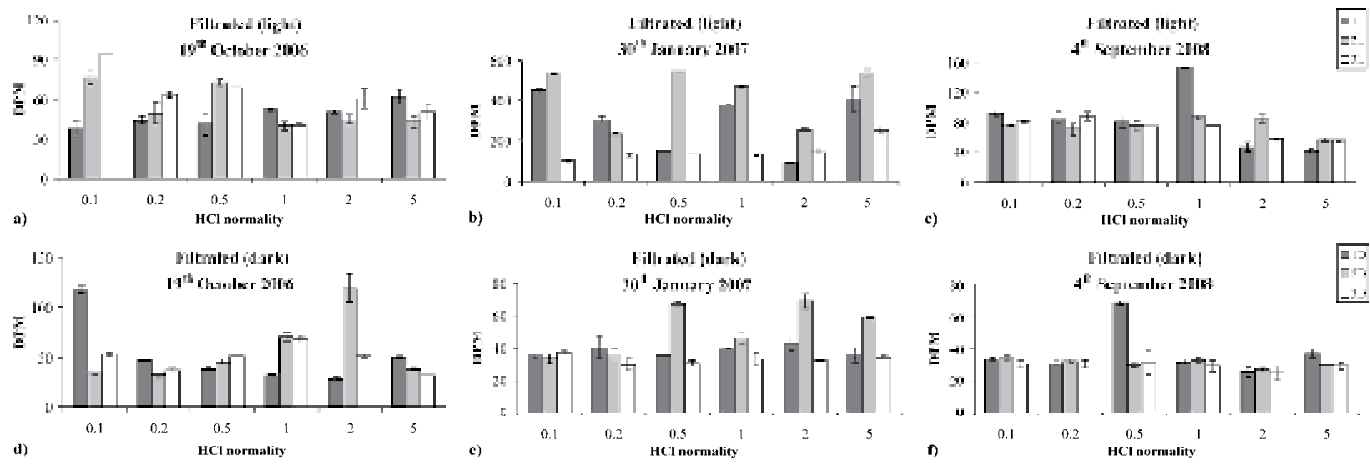

Fig. 2. DPM of light and dark filtrated fractions resulted from the three experiments. Each bar represents the mean of 2 scintillation counts for each biological replicate. For each experiment a different y-axis scale was applied to better highlight the difference between acid treatments.
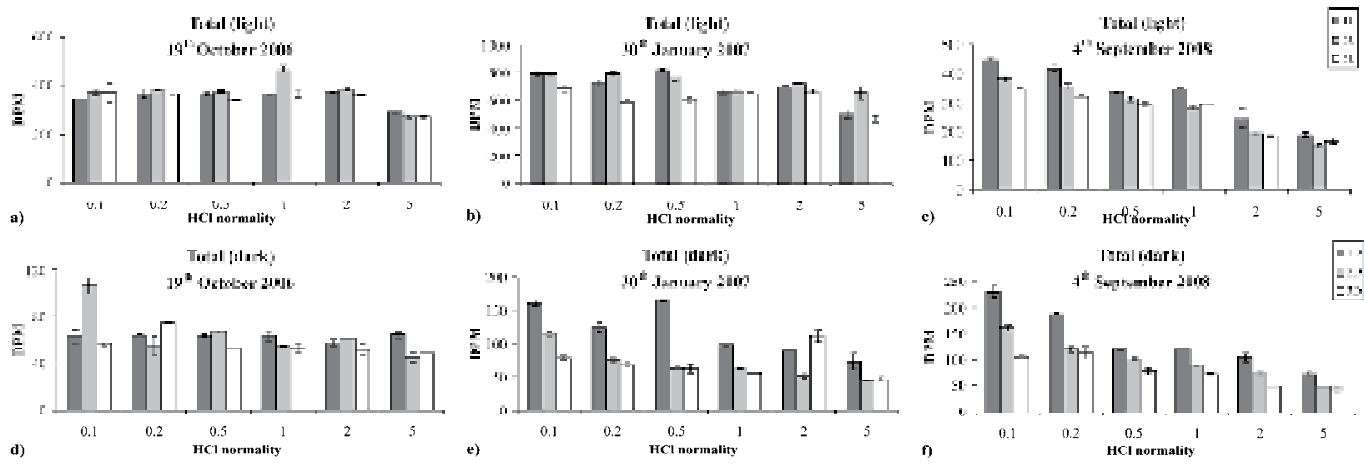

d)

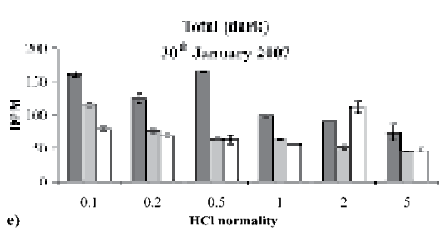

Fig. 3. DPM of light and dark total samples resulted from the three experiments. Each bar represents the mean of 2 scintillation counts for each biological replicate. For each experiment a different $y$-axis scale was applied to better highlight the difference between acid treatments. 
In Figure 3a-f are shown DPM values from total samples of the three experiments. Due to higher chl $a$ content DPM light values from the second experiment were twice as high than those obtained in the other two experiments. On the contrary, DPM dark values, which were always lower than the corresponding DPM light values, were progressively higher from the first to the last experiment. However, the decrease in DPM values, going from $0.1 \mathrm{~N}$ to $5 \mathrm{~N}$ treatment, was mostly evident in the third experiment, both for light and dark replicates.

While the average reduction of light DPM values between the $0.1 \mathrm{~N}$ and $0.2 \mathrm{~N}$ treatments was identical in the second and third experiments $(6.62 \%$ and $6.61 \%$, respectively), the percentage decrease in other pairs of treatments $(0.1 \mathrm{~N}$ vs $0.5 \mathrm{~N} ; 0.1 \mathrm{~N}$ vs $1 \mathrm{~N} ; 0.1 \mathrm{~N}$ vs $2 \mathrm{~N} ; 0.1 \mathrm{~N}$ vs $5 \mathrm{~N}$ ) was much higher in the last experiment, reaching even $56.4 \%$ when the $0.1 \mathrm{~N}$ and $5 \mathrm{~N}$ treatments were compared.

\subsection{Statistical analysis}

The t-test applied to dark samples of the three experiments highlighted only a few statistically significant differences between pairs of the tested acid normalities, e. g. for filters in the first experiment and the filtrated fraction in the last one, probably because DPM values were comparable to the background noise of the instrument. Except for the last experiment, performed in September 2008, the t-test did not show any differences between pairs of the tested acid normalities when performed on filtrated fractions, either (Table 3). In detail, in the first light-experiment the $2 \mathrm{~N}$ acid treatment on filters was significantly different from the $0.1 \mathrm{~N}, 0.2 \mathrm{~N}$ and $0.5 \mathrm{~N}$ ones, while the $5 \mathrm{~N}$ treatment of the total light fraction was significantly diverse from almost all the other treatments. Similarly, in the same dark-experiments only the $5 \mathrm{~N}$ acid treatment performed on filters was significantly different from the $0.1 \mathrm{~N}, 0.2 \mathrm{~N}$ and $0.5 \mathrm{~N}$ ones. The most significant differences between pairs of acid treatments were obtained in the last experiment for the total light fraction.

\begin{tabular}{|c|c|c|c|c|c|c|c|c|c|c|c|c|c|c|c|c|c|c|}
\hline & \multicolumn{3}{|c|}{$1^{\text {st }}$ experiment (light) } & \multicolumn{3}{|c|}{$1^{\text {st }}$ experiment (dark) } & \multicolumn{3}{|c|}{$2^{\text {nd }}$ experiment (light) } & \multicolumn{3}{|c|}{$2^{\text {nd }}$ experiment (dark) } & \multicolumn{3}{|c|}{$3^{\text {rd }}$ experiment (light) } & \multicolumn{3}{|c|}{$3^{\text {rd }}$ experiment (dark) } \\
\hline & filters & filtrated & total & filters & filtrated & total & filters & filtrated & total & filters & filtrated & total & filters & filtrated & total & filters & filtrated & total \\
\hline $0.1 \mathrm{~N}$ vs $0.2 \mathrm{~N}$ & n.s. & n.s. & n.s. & n.s. & n.s. & n.s. & n.s. & n.s. & n.s. & n.s. & n.s. & n.s. & n.s. & n.s. & n.s. & n.s. & n.s. & n.s. \\
\hline $0.1 \mathrm{~N}$ os $0.5 \mathrm{~N}$ & n.s. & n.s. & n.s. & n.s. & n.s. & n.s. & n.s. & n.s. & n.s. & n.s. & n.s. & n.s. & $4.49^{\star}$ & n.s. & n.s. & n.s. & n.s. & n.s. \\
\hline $0.1 \mathrm{~N}$ os $1 \mathrm{~N}$ & n.s. & n.s. & n.s. & n.s. & n.s. & n.s. & n.s. & n.s. & n.s. & n.s. & n.s. & n.s. & n.s. & n.s. & n.s. & n.s. & n.s. & n.s. \\
\hline $0.1 \mathrm{~N}$ os $2 \mathrm{~N}$ & $7.90^{* *}$ & n.s. & n.s. & n.s. & n.s. & n.s. & n.s. & n.s. & n.s. & n.s. & n.s. & n.s. & n.s. & n.s. & $5.36^{* *}$ & n.s. & $5.09^{*}$ & n.s. \\
\hline $0.1 \mathrm{~N}$ os $5 \mathrm{~N}$ & n.s. & n.s. & $5.50^{*}$ & $4.14^{*}$ & n.s. & n.s. & n.s. & n.s. & n.s. & n.s. & n.s. & n.s. & $4.19^{*}$ & $4.51^{*}$ & $7.27^{* *}$ & n.s. & n.s. & n.s. \\
\hline $0.2 \mathrm{~N}$ os $0.5 \mathrm{~N}$ & n.s. & n.s. & n.s. & n.s. & n.s. & n.s. & n.s. & n.s. & n.s. & n.s. & n.s. & n.s. & n.s. & n.s. & n.s. & n.s. & n.s. & n.s. \\
\hline $0.2 \mathrm{~N} v s 1 \mathrm{~N}$ & n.s. & n.s. & n.s. & n.s. & n.s. & n.s. & $5.03^{* *}$ & n.s. & n.s. & n.s. & n.s. & n.s. & n.s. & n.s. & n.s. & n.s. & n.s. & n.s. \\
\hline $0.2 \mathrm{~N} v s 2 \mathrm{~N}$ & $3.13^{*}$ & n.s. & n.s. & n.s. & n.s. & n.s. & $3.79^{*}$ & n.s. & n.s. & n.s. & n.s. & n.s. & n.s. & n.s. & $4.72^{*}$ & n.s. & $4.75^{*}$ & n.s. \\
\hline $0.2 \mathrm{~N}$ vs $5 \mathrm{~N}$ & n.s. & n.s. & $11.87^{\star \star *}$ & $4.61^{*}$ & n.s. & n.s. & $3.44^{*}$ & n.s. & n.s. & n.s. & n.s. & n.s. & n.s. & $3.17^{*}$ & $6.63^{*}$ & n.s. & n.s. & n.s. \\
\hline $0.5 \mathrm{~N}$ os $1 \mathrm{~N}$ & n.s. & n.s. & n.s. & n.s. & n.s. & n.s. & n.s. & n.s. & n.s. & n.s. & n.s. & n.s. & n.s. & n.s. & n.s. & n.s. & n.s. & n.s. \\
\hline $0.5 \mathrm{~N}$ vs $2 \mathrm{~N}$ & $3.04^{*}$ & n.s. & n.s. & n.s. & n.s. & n.s. & n.s. & n.s. & n.s. & n.s. & n.s. & n.s. & n.s. & n.s. & $4.77^{\star}$ & n.s. & n.s. & n.s. \\
\hline $0.5 \mathrm{~N}$ os $5 \mathrm{~N}$ & n.s. & n.s. & $6.48^{* *}$ & $3.26^{*}$ & n.s. & n.s. & n.s. & n.s. & n.s. & n.s. & n.s. & n.s. & n.s. & $4.68^{*}$ & $8.98^{* * *}$ & n.s. & n.s. & $2.90^{*}$ \\
\hline $1 \mathrm{~N}$ os $2 \mathrm{~N}$ & n.s. & n.s. & n.s. & n.s. & n.s. & n.s. & n.s. & n.s. & n.s. & n.s. & n.s. & n.s. & n.s. & n.s. & $3.61^{*}$ & n.s. & $4.85^{*}$ & n.s. \\
\hline $1 \mathrm{~N}$ os $5 \mathrm{~N}$ & n.s. & n.s. & n.s. & n.s. & n.s. & n.s. & n.s. & n.s. & n.s. & n.s. & n.s. & n.s. & n.s. & n.s. & $6.03^{* *}$ & n.s. & n.s. & n.s. \\
\hline $2 \mathrm{~N}$ os $5 \mathrm{~N}$ & n.s. & n.s. & $10.65^{\star * *}$ & n.s. & n.s. & n.s. & n.s. & n.s. & n.s. & n.s. & n.s. & n.s. & n.s. & n.s. & n.s. & n.s. & $-3.12^{*}$ & n.s. \\
\hline
\end{tabular}

Table 3. Student's t-test applied to pairs of treatments (acid normalities); n.s. = not significant; ${ }^{* * *} \mathrm{p} \leq 0.001 ;{ }^{* *} \mathrm{p} \leq 0.01 ;{ }^{*} \mathrm{p} \leq 0.05$

\subsection{Effects of $\mathrm{HCl}$ on the planktonic microalgal community}

The litmus test performed on the planktonic community revealed that the addition of $200 \mu \mathrm{l}$ of $\mathrm{HCl} 0.1 \mathrm{~N}$ was sufficient to decrease the $\mathrm{pH}$ value from 8 to 4 (Table 4, Fig. 4). 


\begin{tabular}{|c|c|c|c|c|c|c|}
\hline \multicolumn{8}{|c|}{$\mathrm{pH}$ value } \\
\hline Without acid & $\mathbf{0 . 1 N}$ & $\mathbf{0 . 2 N}$ & $\mathbf{0 . 5 N}$ & $\mathbf{1 N}$ & $\mathbf{2 N}$ & $\mathbf{5 N}$ \\
\hline 8 & 4 & $2-3$ & 2 & $1-2$ & 1 & $0-1$ \\
\hline
\end{tabular}

Table 4. Litmus test performed on the mix culture $(5 \mathrm{ml})$ in order to test the $\mathrm{pH}$ value at increasing acid normalities.

The further increase of $\mathrm{HCl}$ normality gradually lowered the $\mathrm{pH}$ value down to zero. Since $\mathrm{HCl}$ is added to remove the excess labelled $\mathrm{C}$, it is important to know the $\mathrm{pH}$ of the acidified sample. In fact, if $\mathrm{HCl}$ is not sufficiently concentrated, $\mathrm{pH}$ will not reach the value which is necessary to shift the equilibrium towards the $\mathrm{CO}_{2}$ fraction and consequently the removal of the labelled bicarbonate from the system. Only a $\mathrm{pH}<5$ ensures a complete shift towards the $\mathrm{CO}_{2}$ fraction (Libes, 1992). In water samples the $0.1 \mathrm{~N} \mathrm{HCl}$ treatment was enough to lower $\mathrm{pH}$ below this value. On the other hand, if the acid is too aggressive it can damage the cell membrane, causing the loss of an undetermined quantity of assimilated ${ }^{14} \mathrm{C}$ and therefore leading to an underestimate of DPM values.

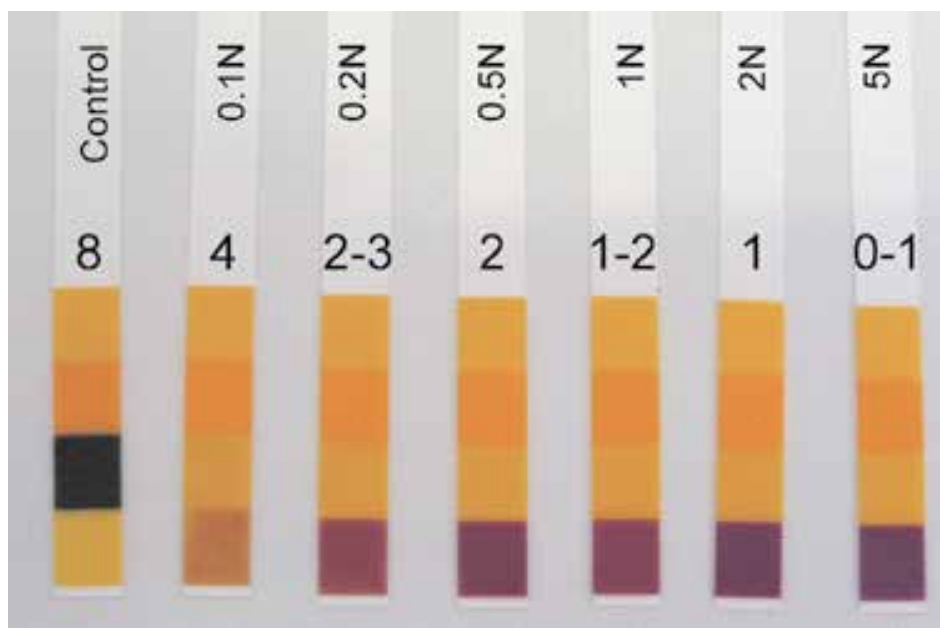

Fig. 4. Litmus test performed on the mix culture $(5 \mathrm{ml})$ in order to test the $\mathrm{pH}$ value at increasing acid normalities.

The macroscopic observation of the acidified mix culture samples revealed that while the control was brownish red coloured (mostly due to diatom pigments), $0.1 \mathrm{~N}, 0.2 \mathrm{~N}$ and $0.5 \mathrm{~N}$ treatments were greenish. We hypothesize that in the first three mild treatments $\mathrm{HCl}$ degraded the accessory pigments, i.e. fucoxanthin, typical of diatoms and responsible for the brownish red colouring, but not chlorophyll $a$. Samples treated with an acid concentration from $1 \mathrm{~N}$ up to $5 \mathrm{~N}$ lost their colouring.

Another experiment on the planktonic community was performed where both motility of flagellates and of the tychopelagic diatom and chlorophyll $a$ fluorescence were used as proxies of cell viability. Motility was observed only in the control, since from the $0.1 \mathrm{~N}$ treatment onward all cells were motionless (Table 5). From the microscopic observations in contrast phase we noticed that from the $0.1 \mathrm{~N}$ treatment onward some frustules of Cylindrotheca fusiformis appeared deformed and thinner than in the control (Fig. 5). In the same samples, all Gymnodinium sp. cells showed detachment of their thecal membranes. 


\begin{tabular}{|c|c|c|c|c|c|c|c|c|c|c|c|c|c|c|}
\hline & \multicolumn{7}{|c|}{ Chlorophyll $a$ status } & \multicolumn{7}{|c|}{ Motility } \\
\hline & not acidified & $0.1 \mathrm{~N}$ & $0.2 \mathrm{~N}$ & $0.5 \mathrm{~N}$ & $1 \mathrm{~N}$ & $2 \mathrm{~N}$ & $5 \mathrm{~N}$ & not acidified & $0.1 \mathrm{~N}$ & $0.2 \mathrm{~N}$ & $0.5 \mathrm{~N}$ & $1 \mathrm{~N}$ & $2 \mathrm{~N}$ & $5 \mathrm{~N}$ \\
\hline Planktonic diatoms & $\overline{+++}$ & + & $\overline{0}$ & $\overline{0}$ & $\overline{0}$ & $\overline{0}$ & $\overline{0}$ & - & - & - & - & - & - & - \\
\hline Benthic (centric) diatoms & +++ & +++ & $+++/++$ & ++ & ++ & ++ & $++/+$ & 一 & - & - & - & - & - & - \\
\hline Tychopelagic diatoms & +++ & $+++/+\left(^{*}\right)$ & + & + & $+/ 0$ & 0 & 0 & ++ & 0 & 0 & 0 & 0 & 0 & 0 \\
\hline Naked dinoflagellates & +++ & + & + & 0 & 0 & 0 & 0 & + & 0 & 0 & 0 & 0 & 0 & 0 \\
\hline Thecate dinoflagellates & +++ & +++ & +++ & +++ & +++ & $++/+$ & + & + & 0 & 0 & 0 & 0 & 0 & 0 \\
\hline Phytoflagellates & +++ & + & 0 & 0 & 0 & 0 & 0 & ++ & 0 & 0 & 0 & 0 & 0 & 0 \\
\hline
\end{tabular}

Table 5. Viability test on the mix culture at increasing acid normalities using both cell motility and chl $a$ fluorescence as proxies. Chl $a$ status: +++ , intense red; ++, orange; + pink; 0 , not fluorescent. Motility: ++ , good motility; + , reduced motility; - , naturally not motile; 0 , induced non-motility by the acid. $\left(^{*}\right)$ half of the cells with viable chl $a$, the other half with degraded chl $a$.

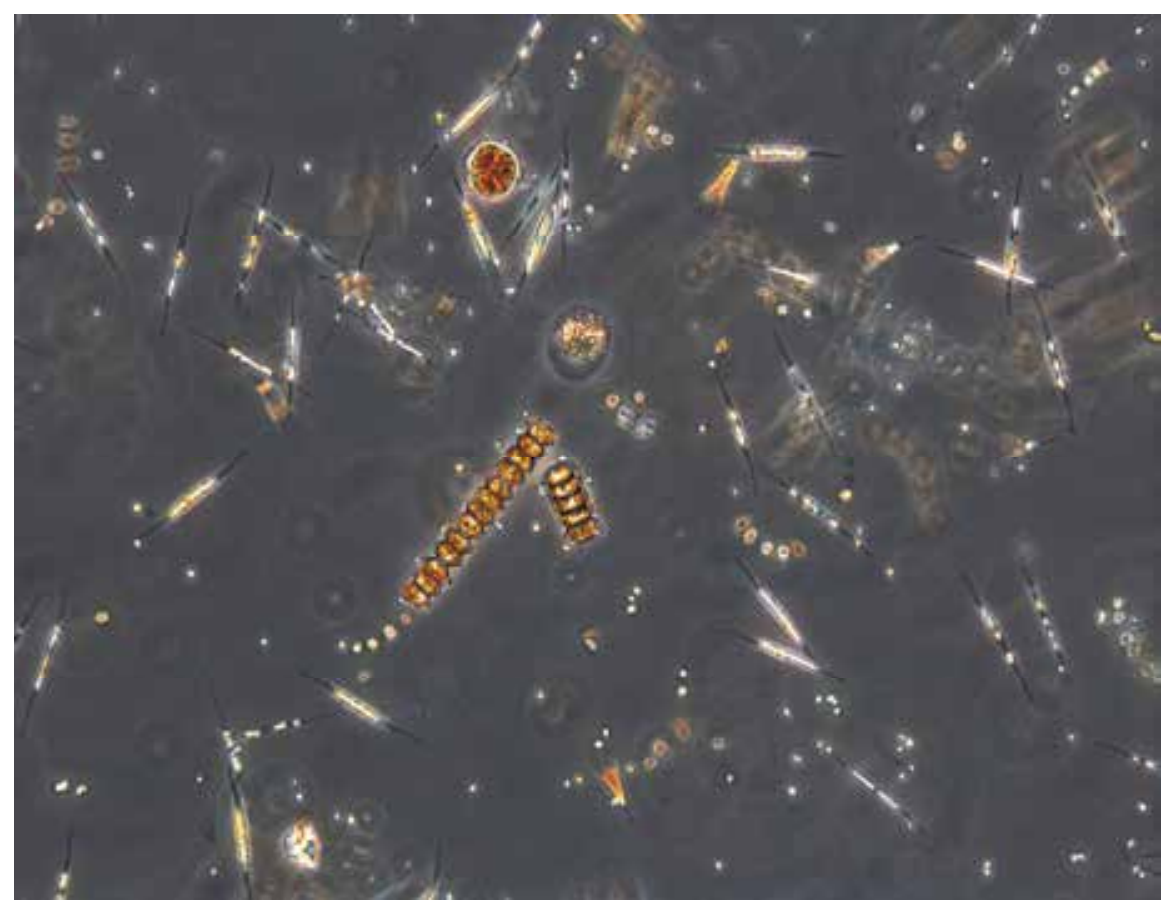

Fig. 5. Micrograph of the mix culture treated with $0.1 \mathrm{~N} \mathrm{HCl}$ observed under an inverted microscope at 200X magnification using phase contrast.

Analysing samples in epifluorescence, we noticed that in the control all cells appeared red coloured. In the $0.1 \mathrm{~N}$ treatment a different response was observed according to the taxon: the planktonic diatom, the naked dinoflagellate and the small phytoflagellate showed a less intense pigmentation (with respect to the control); half of the observed tychopelagic diatom cells was still red coloured, while the other half became faded. Only the benthic diatom and the thecate dinoflagellate were still bright red (Fig. 6).

In the $0.2 \mathrm{~N}$ treatment the planktonic diatom and the small phytoflagellate did not show fluorescence any more, whereas the tychopelagic diatom and the naked dinoflagellate emitted a faint fluorescence. 


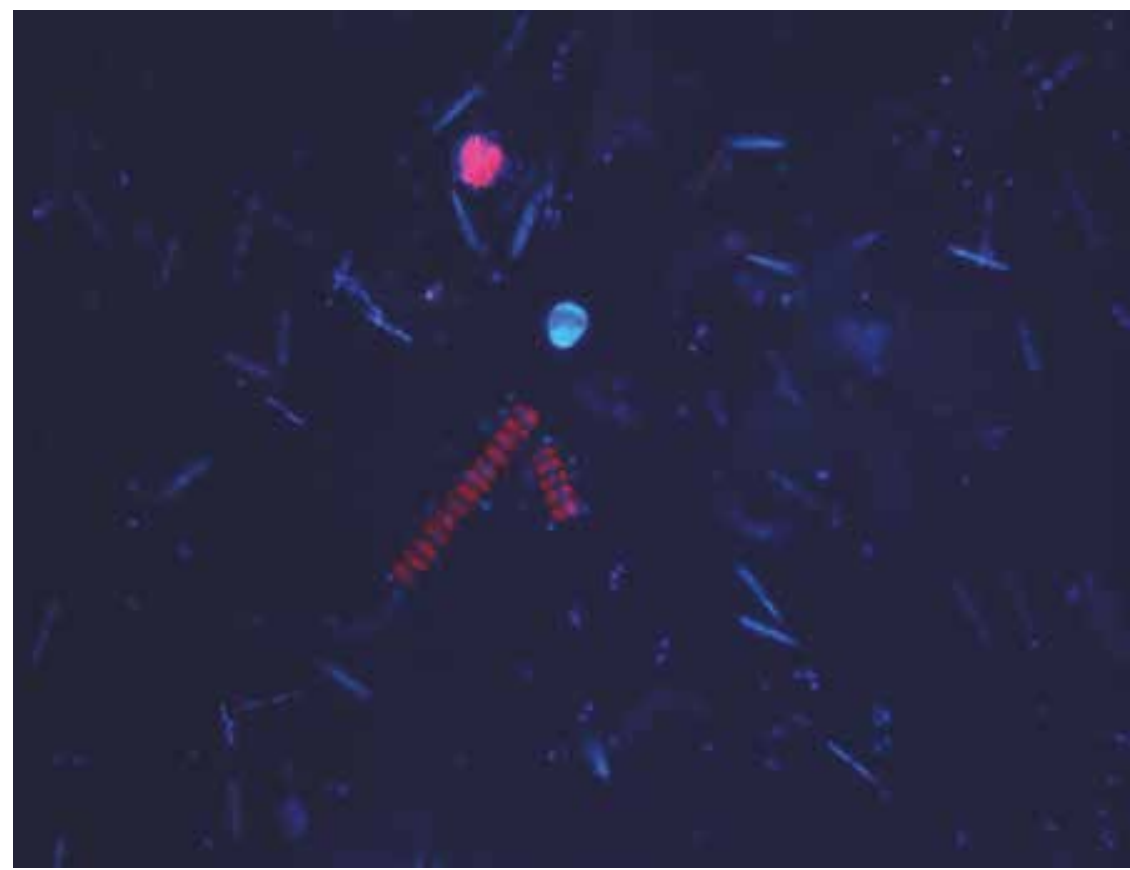

Fig. 6. Micrograph of the mix culture treated with $0.1 \mathrm{~N} \mathrm{HCl}$ observed under an inverted microscope at 200X magnification using epifluorescence.

Most of benthic diatom cells turned from red to orange, while only thecate dinoflagellate cells kept a bright red colour. Unlike the $0.2 \mathrm{~N}$ treatment, the $0.5 \mathrm{~N}$ sample presented naked dinoflagellate cells which lost their fluorescence and benthic diatom cells which were definitively orange. The only alteration in the next treatment $(1 \mathrm{~N})$ was represented by tychopelagic diatoms which became pale. In the $2 \mathrm{~N}$ treatment tychopelagic diatoms were not fluorescent any more, while thecate dinoflagellate cells turned their fluorescence from intense red to faded orange. In the last treatment $(5 \mathrm{~N})$ benthic diatoms turned to faded orange, whereas thecate dinoflagellates emitted a faint fluorescence.

The microscopic observation of the recovered mix culture of the not acidified treatment revealed that some taxa were still alive and motile. The undetermined Cryptophycea was very active and abundant. Cylindrotheca fusiformis completely colonized the bottom of the flask, whereas Lingulodinium polyedrum was still motile but not abundant. We believe that both Gymnodinium sp. and Chaetoceros sp. did not grow due to interspecific competition, while Paralia sulcata was probably inhibited by the high temperature and irradiance since this species prefers low temperature and dim light (McQuoid \& Nordberg, 2003). The recovered culture of the $0.1 \mathrm{~N}$ treatment showed a similar scenario with the exception of the undetermined Cryptophycea which disappeared from the flask, confirming its immediate reaction to acid addition. In the recovered culture of the $0.2 \mathrm{~N}$ treatment we observed the empty frustules of Cylindrotheca fusiformis as well as completely pale and not motile Lingulodinium cells. In this treatment a Paralia sulcata colony (15 cells ca.) was encountered; most of the cells were still pigmented. In the recovered culture of the $5 \mathrm{~N}$ treatment none of the microalgae was observed.

Considering the results of the litmus test and the microalgal viability test together, some considerations can be made. If the $\mathrm{pH}$ value is not sufficiently low, the inorganic ${ }^{14} \mathrm{C}$ cannot 
be completely removed from the system and the cells remain still metabolically active. Consequently, the microalgae are able to continue both to uptake inorganic carbon and to consume the assimilated ${ }^{14} \mathrm{C}$ during the period elapsing between the addition of the acid and the addition of the scintillation liquid. Moreover, if the $\mathrm{pH}$ value is sufficiently low to completely remove the inorganic ${ }^{14} \mathrm{C}$, but not to kill all the cells, primary production could be underestimated. In fact, with a complete depletion of inorganic carbon $(\mathrm{pH}<5)$, the cells cannot uptake it any more, but they could continue to consume the already assimilated ${ }^{14} \mathrm{C}$. This could occur treating the not filtered water samples with a mild acid.

Therefore we reckon that the acid concentration is crucial: only a sufficiently strong acid allows the complete removal of the inorganic carbon and at the same time the killing of all microalgal cells. In fact, when mild acid treatments were used, some taxa seemed to be not affected by the acid, as demonstrated by both our viability test and our recovery experiment. For example, the benthic diatom Paralia sulcata maintained a bright autofluorescence at lower $\mathrm{pH}$ values than other taxa. Benthic microalgae have a thicker and more silicified frustule compared to planktonic forms, which probably prevents the acid from penetrating into the cell. This can be of particular interest when the phytoplankton community is characterized by the presence of benthic diatoms; those communities are typical of shallow coastal water masses rather than deeper waters.

\section{Conclusion}

The aim of this study was to define which $\mathrm{HCl}$ concentration, with an equal volume, among $0.1 \mathrm{~N}, 0.2 \mathrm{~N}, 0.5 \mathrm{~N}, 1 \mathrm{~N}, 2 \mathrm{~N}$ and $5 \mathrm{~N}$ (which correspond to final $\mathrm{HCl}$ concentrations of $0.004 \mathrm{~N}$ $0.008 \mathrm{~N}-0.02 \mathrm{~N}-0.04 \mathrm{~N}-0.08 \mathrm{~N}-0.2 \mathrm{~N}$, respectively, for $5 \mathrm{ml}$ filtrated and total samples) was sufficient both to remove the excess labelled bicarbonate and to kill the cells but without damaging their structures and therefore leading to loss of assimilated ${ }^{14} \mathrm{C}$. The litmus test demonstrated that the use of a mild acid $(0.1 \mathrm{~N})$ does decrease the $\mathrm{pH}$ from 8 to 4 . However, the results obtained from our viability test and recovery experiment suggest that some microalgal taxa in the not filtrated samples could remain still photosynthetically active after a too mild acid treatment. Therefore, the use of a slightly more concentrated acid $(0.2 \mathrm{~N})$ is recommended. In our experiments this acid concentration led to on average $6 \%$ lower DPM values if compared to the $0.1 \mathrm{~N}$ treatment, both for filters and total samples. Nevertheless, we believe that this small loss is acceptable in exchange for greater sureness of having killed the majority of the microalgal cells. In contrast, it is very likely that the $5 \mathrm{~N}$ treatment damages the cell membrane with the consequent loss of assimilated ${ }^{14} \mathrm{C}$, leading to an underestimate of DPM values up to $31 \%$ for filters and $56 \%$ for total samples if compared to the mildest acid treatment. Our experiments were carried out using oligotrophic water (Fonda Umani et al., 2004) from the Gulf of Trieste. In the next future we are going to carry out another set of experiments on mesotrophic and eutrophic waters, applying the same chloridric acid concentrations, to test if similar results are achieved.

\section{Acknowledgment}

We thank Daniela Fornasaro and Benedetta Guardiani for helping us during the experiments. We are also grateful to Oriana Blasutto for water sampling and Massimo Celio for multiparameter probe data. Additional thanks go to Marina Cabrini and Paola Del Negro for the help they have provided in relation to this work. Finally, we thank Alfred Beran for providing us with microalgal cultures. 


\section{References}

Babin, M.; Morel, A. \& Gagnon, R. (1994). An incubator designed for extensive and sensitive measurements of phytoplankton photosynthetic parameters. Limnology and Oceanography, Vol.39, No.3, pp. 694-702

Barber, R.T. \& Hilting, A.K. (2002). Carbon Assimilation in Marine and Freshwater Ecosystems, In: Phytoplankton Productivity, P.J. le B. Williams; D.N. Thomas \& C.S. Reynolds, (Eds.), 16-43, Blackwell Science, ISBN0-632-05711-4, Oxford, UK

Behrenfeld, M.J. \& Falkowski, P.G. (1997). Photosynthetic rates derived from satellite-based chlorophyll concentration. Limnology and Oceanography, Vol.42, No.1, pp. 1-20

Carr, M,E.; Friedrichs, M.A.M.; Schmeltz, M.; Aita, M.N.; Antoine, D.; Arrigo, K.R.; Asanuma, I.; Aumont, O.; Barber, R.; Behrenfeld, M. et al. (2006). A comparison of global estimates of marine primary production from ocean color. Deep-Sea Research II, Vol.53, pp. 741-770

Cermeño, P.; Marañón, E.; Pérez, V.; Serret, P.; Fernández, E. \& Castro, C.G. (2006). Phytoplankton size structure and primary production in a highly dynamic coastal ecosystem (Ría de Vigo, NW-Spain): Seasonal and short-time scale variability. Estuarine Coastal and Shelf Science, Vol.67, pp. 251-266

Fonda Umani, S.; Beran, A.; Parlato, S.; Virgilio, D.; Zollet, T.; De Olazabal, A.; Lazzarini, B. \& Cabrini, M. (2004). Noctiluca scintillans MACARTNEY in the Northern Adriatic Sea: long-term dynamics, relationships with temperature and eutrophication, and role in the food web. Journal of Plankton Research, Vol.26, pp. 545-561

Friedrichs, M.A.M.; Carr, M.E.; Barber, R.T.; Scardi, M.; Antoine, D.; Armstrong, R.A.; Asanuma, I.; Behrenfeld, M.J.; Buitenhuis, E.T.; Chai, F. et al. (2009). Assessing the uncertainties of model estimates of primary productivity in the tropical Pacific Ocean. Journal of Marine Systems, Vol.76, pp. 113-133

del Giorgio, P.A. \& Williams, P.J. le B. (2005). Respiration in Aquatic Ecosystems, Oxford University Press, ISBN 0-19-852709-8, Oxford, UK

Hewson, I.; O'Neil, J.M.; Heil, C.A.; Bratbak, G. \& Dennison, W. C. (2001) Effects of concentrated viral communities on photosynthesis and community composition of co-occurring benthic microalgae and phytoplankton. Aquatic Microbial Ecology, Vol.25, pp. 1-10

Hyde, K.J.W.; O'Reilly, J.E. \& Oviatt, C.A. (2008). Evaluation and application of satellite primary production models in Massachusetts Bay. Continental Shelf Research, Vol.28, pp. 1340-1351

Karl, D.M.; Hebel, D.V. \& Björkman, K. (1998). The role of dissolved organic matter release in the productivity of the oligotrophic North Pacific Ocean. Limnology and Oceanography, Vol.43, pp. 1270-1286

Lewis, M.R. \& Smith, J.C. (1983). A small volume, short-incubation-time method for measurement of photosynthesis as a function of incident irradiance. Marine Ecology Progress Series, Vol.13, pp. 99-102

Libes, S. M. (1992). An Introduction to Marine Biogeochemistry. Wiley \& Sons, Inc. ISBN 978-012-088530-5, New York, U.S.A.

Mangoni, O.; Modigh, M.; Mozetič, P.; Bergamasco, A.; Rivaro, P. \& Saggiomo, V. (2008). Structure and photosynthetic properties of phytoplankton assemblages in a highly dynamic system, the Northern Adriatic Sea. Estuarine Coastal and Shelf Science, Vol.77, No.4, pp. 633-644 
Marañón, E.; Cermeño, P.; Fernández, E.; Rodríguez, J. \& Zabala, L. (2004). Significance and mechanisms of photosynthetic production of dissolved organic carbon in a coastal eutrophic system. Limnology and Oceanography, Vol.49, pp. 1652-1666

Marra, J. (2002). Approaches to the Measurement of Plankton Production, In: Phytoplankton Productivity, P.J. le B. Williams; D.N. Thomas \& C.S. Reynolds, (Eds.), 78-108, Blackwell Science, ISBN0-632-05711-4, Oxford, UK

McQuoid, M.R. \& Nordberg, K. (2003). The diatom Paralia sulcata as an environmental indicator species in coastal sediments. Estuarine Coastal and Shelf Science, Vol.56, pp. 339-354

Moutin, T. \& Raimbault, P. (2002). Primary production, carbon export and nutrients availability in western and eastern Mediterranean Sea in early summer 1996 (MINOS cruise). Journal of Marine Systems, Vol. 33-34, pp. 273-288

O'Donohue, M.J.H. \& Dennison, W.C. (1997). Phytoplankton productivity response to nutrient concentrations, light availability and temperature along an Australian estuarine gradient. Estuaries, Vol.20, No.3, pp. 521-533

Peterson, B.J. (1980). Aquatic primary productivity and the ${ }^{14} \mathrm{C}-\mathrm{CO}_{2}$ method: A history of the productivity problem. Annual Review of Ecology and Systematics, Vol.11, pp. 359-385

Pugnetti, A.; Armeni, M.; Camatti, E.; Crevatin, E.; Dell'Anno, A.; Del Negro, P.; Milandri, A.; Socal, G.; Fonda Umani, S. \& Danovaro, R. (2005). Imbalance between phytoplankton production and bacterial carbon demand in relation to mucilage formation in the Northern Adriatic Sea. Science of the Total Environment, Vol.353, pp. $162-177$

Steemann-Nielsen, E. (1952). The use of radioactive carbon (14C) for measuring organic production in the sea. Journal du Conseil Permanent International pour l'Exploration de la Mer., Vol.16, pp. 117-140

Teira, E.; Mouriño, B.; Marañón, E.; Pérez, V.; Pazó, M. J.; Serret, P.; de Armas, D.; Escánez, J.; Woodwaard, E.M.S. \& Fernández, E. (2005). Variability of chlorophyll and primary production in the Eastern North Atlantic Subtropical Gyre: potential factors affecting phytoplankton activity. Deep-Sea Research Part I, Vol.52, pp. 569-588

Theodórsson, P. \& Bjarnason, J.O. (1975). The acid-bubbling method for primary productivity measurements modified and tested. Limnology and Oceanography, Vol.20, pp. 1018-1019

Tilstone, G.; Smyth, T.; Poulton, A. \& Huston, R. (2009). Measured and remotely sensed estimates of primary production in the Atlantic Ocean from 1998 to 2005. Deep-Sea Research II, Vol.56, pp. 918-930

Williams, P.J. le B.; Thomas, D.N. \& Reynolds, C.S. (2002). Phytoplankton Productivity, Blackwell Science, ISBN0-632-05711-4, Oxford, UK 

